Prepared in cooperation with the National Park Service, Bureau of Land Management, U.S. Fish and Wildlife Service, and U.S. Forest Service

\title{
Evaluating Connection of Aquifers to Springs and Streams, Eastern Part of Great Basin National Park and Vicinity, Nevada
}

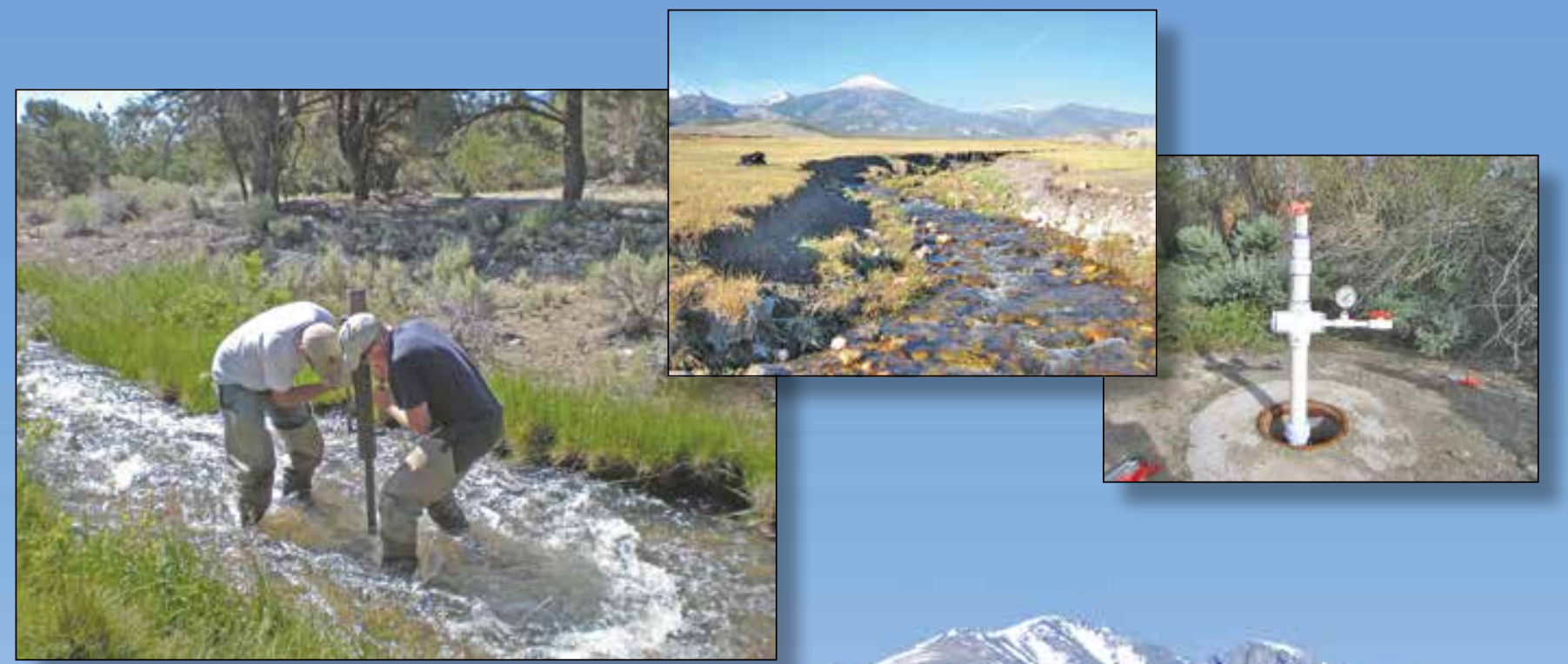

Professional Paper 1819

U.S. Department of the Interior U.S. Geological Survey

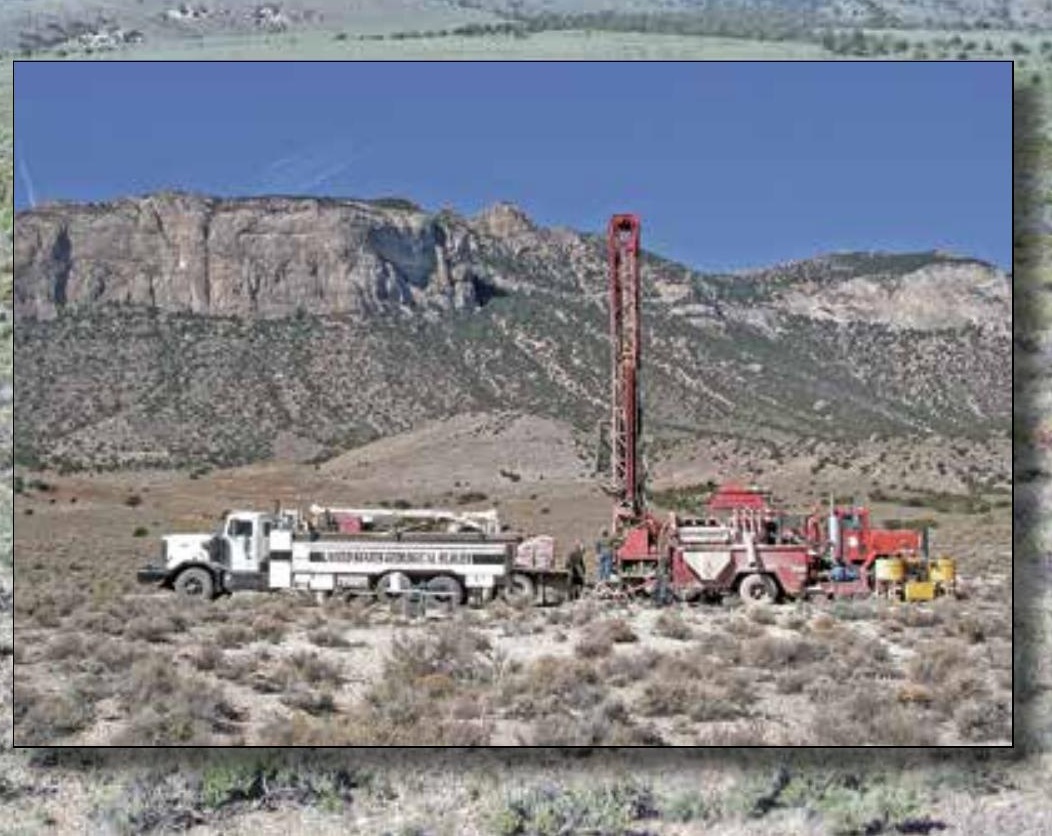




\section{Cover images:}

Upper left: Installation of piezometer PL3 on Lehman Creek by Mark Pepper and Jon Reynolds, National Park Service. Photograph taken by Christine Hatch, University of Nevada, Reno, July, 2009.

Upper right: Snake 5 deep well, Snake Creek. Photograph taken by Christine Hatch, University of Nevada, Reno, June, 2011.

Upper center: Piezometer PL2 on Lehman Creek. Photograph taken by Christine Hatch, University of Nevada, Reno, November, 2011.

Lower right: Big Springs Northwest well. Photograph taken by Donald Sweetkind, U.S. Geological Survey, October 8, 2009.

Background: Wheeler Peak, southern part of Snake Range, Nevada. Photograph taken by Donald Sweetkind, May 29, 2009. 


\section{Evaluating Connection of Aquifers to Springs and Streams, Eastern Part of Great Basin National Park and Vicinity, Nevada}

By David E. Prudic, Donald S. Sweetkind, Tracie R. Jackson, K. Elaine Dotson,

Russell W. Plume, Christine E. Hatch, and Keith J. Halford

Prepared in cooperation with the National Park Service, Bureau of Land Management, U.S. Fish and Wildlife Service, and U.S. Forest Service

Professional Paper 1819 


\title{
U.S. Department of the Interior SALLY JEWELL, Secretary
}

\section{U.S. Geological Survey Suzette M. Kimball, Acting Director}

\author{
U.S. Geological Survey, Reston, Virginia: 2015
}

For more information on the USGS - the Federal source for science about the Earth, its natural and living resources, natural hazards, and the environment—visit http://Www.usgs.gov or call 1-888-ASK-USGS.

For an overview of USGS information products, including maps, imagery, and publications, visit http://www.usgs.gov/pubprod/.

Any use of trade, firm, or product names is for descriptive purposes only and does not imply endorsement by the U.S. Government.

Although this information product, for the most part, is in the public domain, it also may contain copyrighted materials as noted in the text. Permission to reproduce copyrighted items must be secured from the copyright owner.

Suggested citation:

Prudic, D.E, Sweetkind, D.S., Jackson, T.R., Dotson, K.E., Plume, R.W., Hatch, C.E., and Halford, K.J. 2015, Evaluating connection of aquifers to springs and streams, Great Basin National Park and vicinity, Nevada: U.S. Geological Survey Professional Paper 1819, 188 p., http://dx.doi.org/10.3133/pp1819.

ISSN 2330-7102 (online) 


\section{Acknowledgments}

The study was developed cooperatively among the National Park Service, Bureau of Land Management, U.S. Fish and Wildlife Services, the U.S. Forest Service, the U.S. Geological Survey, and the University of Nevada, Reno. The National Park Service, as the lead agency, prepared and submitted a proposal for funding through the Southern Nevada Public Lands Management Act Round 8-Conservation Initiatives category for White Pine County.

Many people assisted with the design, oversight, management, data collection, and data verification for this project. First and foremost, we wish to acknowledge the numerous contributions of William P. (Bill) Van Liew, Hydrologist from the National Park Service, Water Resources Division, for his ongoing efforts to understand the hydraulic connection of groundwater in the Great Basin National Park with the groundwater in Snake and Spring Valleys and how pumping in the valleys might affect surface and groundwater resources in the park. Bill also was assigned the task of oversight and project management. Robert Boyd, of the U.S. Bureau of Land Management, and James Prieur, of Southern Nevada Water Authority, spent many hours in the design of the project and in coordination with ongoing data collection by other agencies. Gary Karst, Hydrologist at Lake Mead National Recreation Area, spent many hours in the removal of fiber-optic cable from Lehman Creek and assisting in the oversight of the drilling of test wells at two places: one next to Snake Creek and the other next to Baker Creek.

Andrew Ferguson, former Great Basin National Park Superintendent, oversaw support of the project. This included providing personnel for helping with the permits, providing logistical support for the semi-annual public meetings, obtaining previously collected data, and assisting with data collection. Acknowledgements are extended to park personnel Gretchen Baker (Ecologist) and Benjamin Roberts (Chief of Natural Resources) for their guidance and help in obtaining permits, providing documents on caves and previously collected data; Gretchen also spent many hours collecting water samples and making discharge measurements as part of this study. Laura Belica (Fisheries Biologist at the park) helped install temperature cables in Lehman Creek and assisted in discharge measurements along Snake Creek. Mark Pepper (Fisheries Biologist) and Jonathan Reynolds (Fisheries Technician) provided much needed help and enthusiasm in driving steel well points into the boulder and cobble streambeds of Baker, Lehman, and Snake Creeks and in the installation of cable along Lehman Creek. Also, Carol Ferguson, park volunteer, kindly assisted in the installation and removal of fiber-optic temperature cable along sections of Lehman Creek during the summer and fall of 2009 and again in May 2010.

Graduate students Michaela Wörndl and Wes Hanson, both from University of Nevada, Reno, and Lauren Shumaker, University of California-Santa Cruz, assisted with various hydrologic and geologic field-data collection during the summer of 2009. George (Buck) Douglass, Jr., Nevada Department of Wildlife, assisted in the installation and removal of fiber-optic temperature cable along a section of Snake Creek, in the collection of water samples at Spring Creek Spring, and in the aquifer test of the supply well at the Spring Creek fish-rearing station.

Wendy Hayes (environmental scientist, San Francisco Bay area) and Jim Reynolds (University of Alaska, Fairbanks, emeritus) helped with stream discharge measurements and temperature cable installation.

Special thanks are extended to the land owners for access to reaches of Baker, Lehman, and Snake Creeks that crossed their properties. These include Craig, Tom, David, and Dean Baker of the Baker Ranches; Ray Okelberry of Big Springs Ranch; Don and Veronica Duff; Donald and Susan Geary; Gordon and Marcella Swallow; and Andrew and Carol Ferguson. We also thank William Dearden for allowing access to the Utah Department of Transportation yard in Garrison to temporarily store equipment and supplies. 
Robert N. Pennington, James L. Wood, Alan Priessler, and Carl Thodal (U.S. Geological Survey, Carson City, Nevada) helped with field data collection. Toby Welborn (U.S. Geological Survey, Carson City, Nevada) compiled information on mean annual precipitation and acreage of altitude intervals for selected drainage basins in the southern Snake Range and assisted in the collection of geophysical data. Alan Wallace (retired, U.S. Geological Survey) helped in the collection of geologic information and provided many insightful discussions about the geology of the study area. Special thanks are extended to the drilling crew of the U.S. Geological Survey Western Region Drilling Program. Finally, researchers David A. Stonestrom and Mark Huebner at the U.S. Geological Survey in Menlo Park, California, graciously analyzed backup water samples from selected sites for dissolved anions that were originally collected for stable isotopes of water. 


\section{Contents}

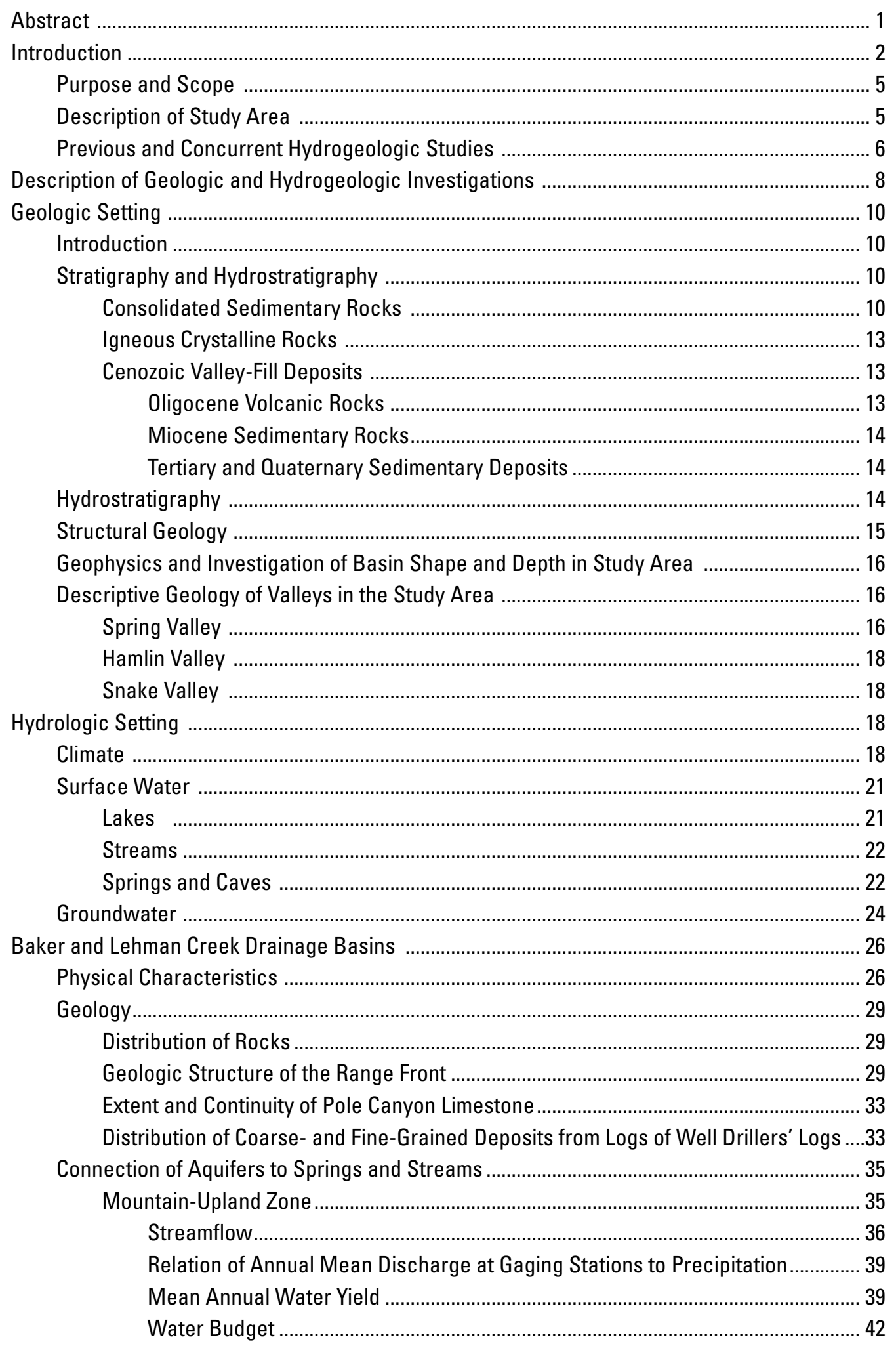


Selected Water Chemistry to Evaluate Water-Budget Estimates ......................... 45

Estimating Mean Age of Water with Tritium ................................................ 45

Stable Isotope Concentrations of Water for Evaluating Evaporation ........... 46

Dissolved Chloride and Chloride-Mass Balance ............................................ 46

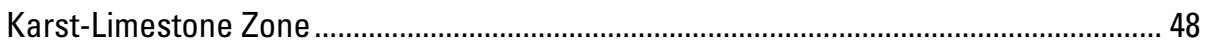

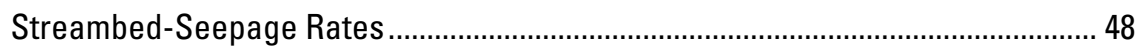

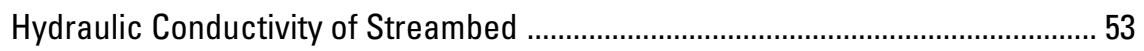

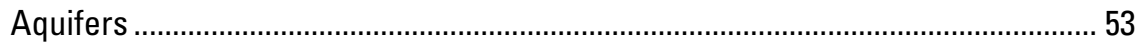

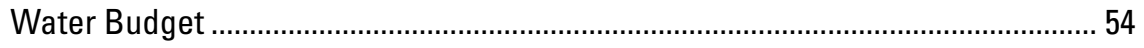

Bulk Transmissivity of Limestone ...................................................................... 55

Rowland Spring and Evidence for Groundwater Flow between Baker and Lehman Drainage basins ......................................................................... 55

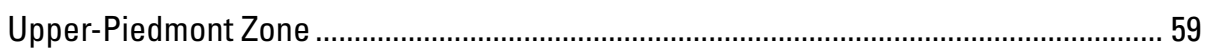

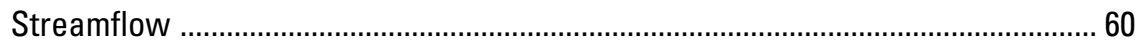

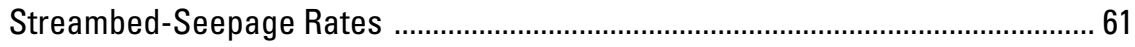

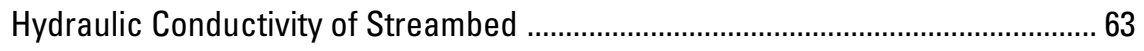

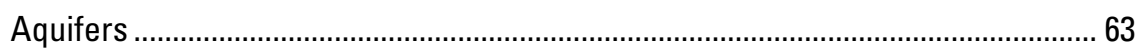

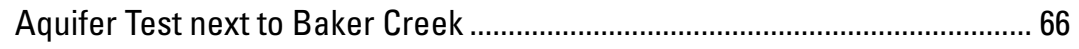

Estimates of Transmissivity from Specific-Capacity Data ............................... 68

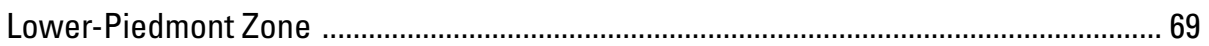

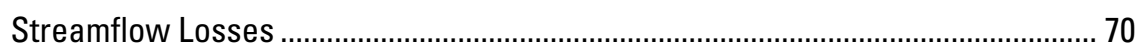

Vertical Hydraulic Conductivity of Streambed .................................................... 71

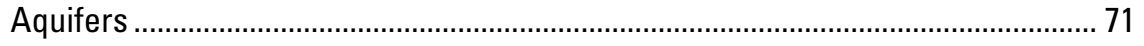

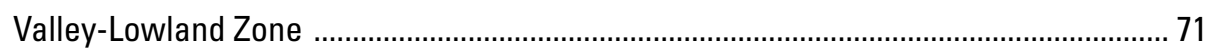

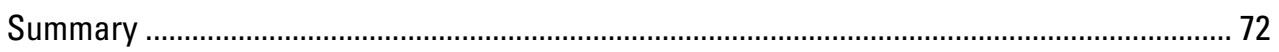

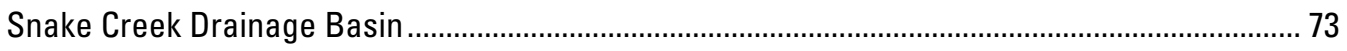

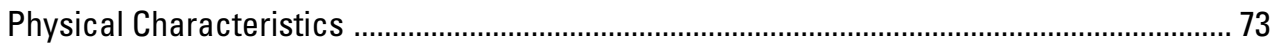

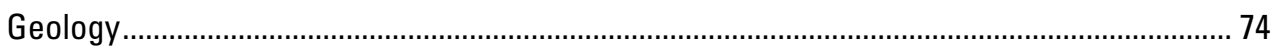

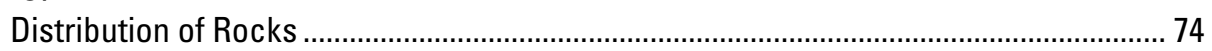

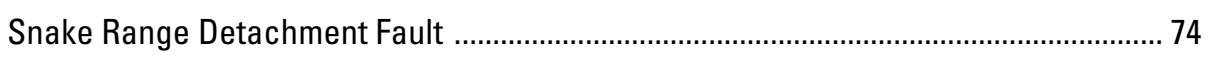

Extent of Miocene Deposits and Faults near Snake Creek ........................................... 76

Quaternary Fault and Thickness of Quaternary Alluvium ................................................. 77

Distribution of Coarse- and Fine-Grained Sediments from Well-Drillers' Logs ............ 77

Connection of Aquifers to Springs and Streams ........................................................... 77

Mountain-Upland Zone ...................................................................................... 78

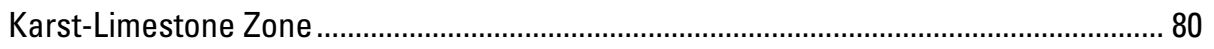

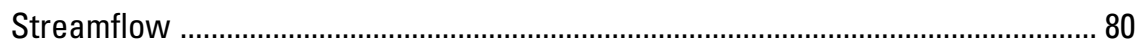

Net Streamflow Gain and Loss ........................................................................ 81

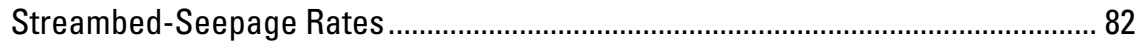

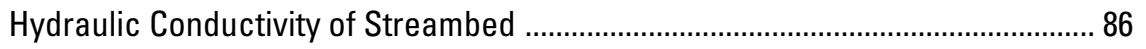

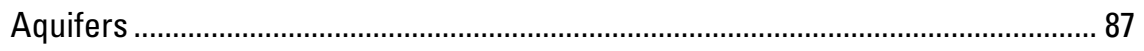

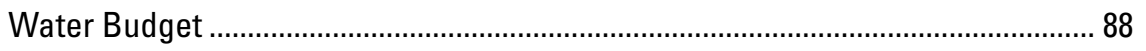

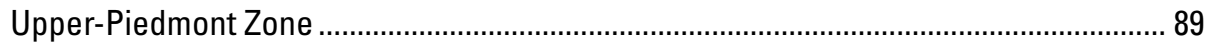

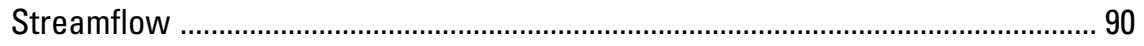

Streambed-Seepage Rates ............................................................................ 90

Hydraulic Conductivity of Streambed .................................................................. 96 
Calcite Precipitation as a Mechanism for Clogging Streambed ........................... 96

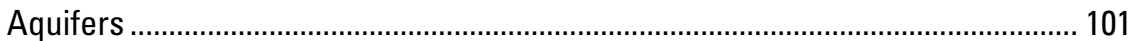

Hydraulic Properties of Deposits and Rocks ................................................ 102

Geochemical Evidence for Flow through Carbonate Rocks ........................ 103

Water-Level Trend in Fractured Limestone ..................................................... 104

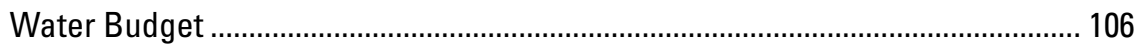

Lower-Piedmont and Valley-Lowland Zones ................................................................. 106

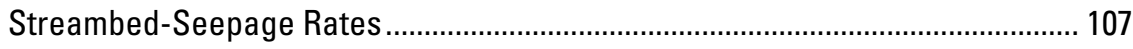

Hydraulic Conductivity of Streambed .................................................................. 107

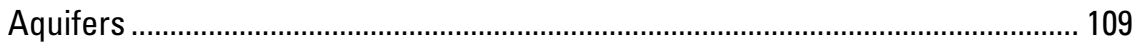

Water-Level Trends in Basin-Fill Deposits .................................................... 109

Hydraulic Properties of Deposits and Rocks ............................................. 111

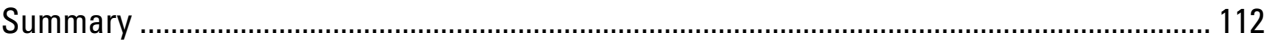

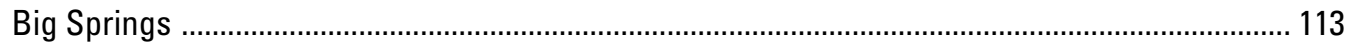

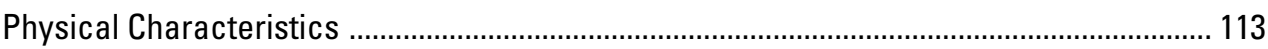

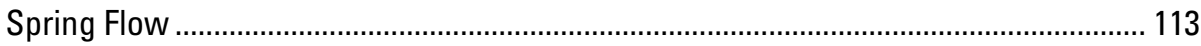

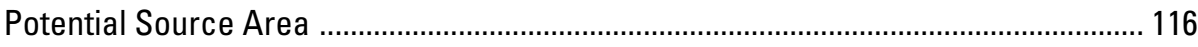

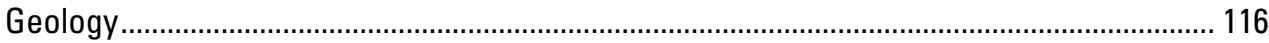

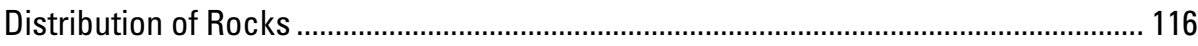

Subsurface Geology of Southern Snake and Northern Hamlin Valleys ....................... 117

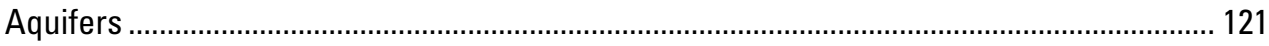

Distribution of Coarse- and Fine-Grained Deposits from Well-Drillers' Logs.............. 122

Hydraulic Properties of Basin-Fill Deposits ................................................................. 124

Hydraulic Properties of Carbonate Rocks ................................................................... 125

Petroleum Exploration Wells in Carbonate Rocks ...................................................... 126

Groundwater Flow Beneath the Limestone Hills ............................................................. 127

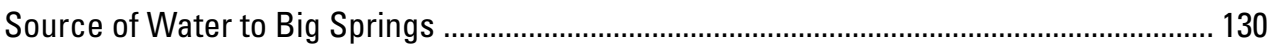

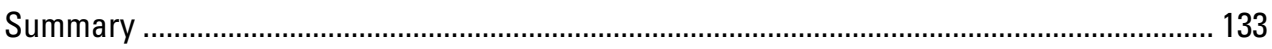

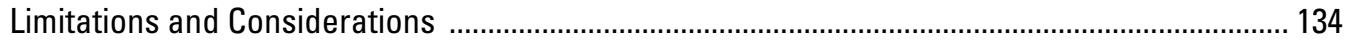

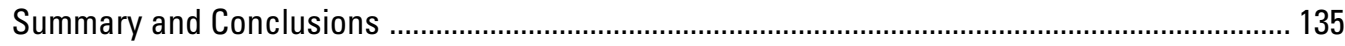

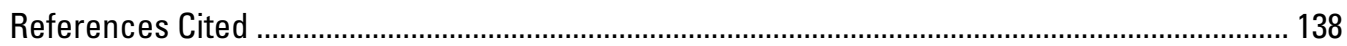

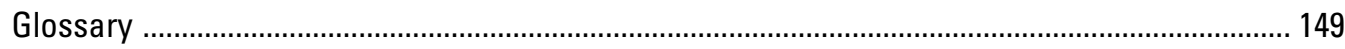

Appendix 1. Geologic and Geophysical Data for Test Wells Drilled September 2009-

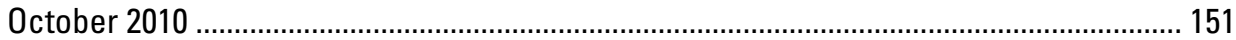

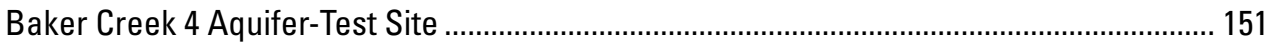

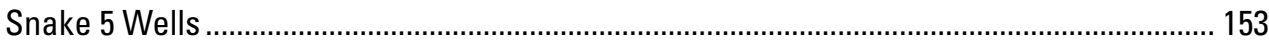

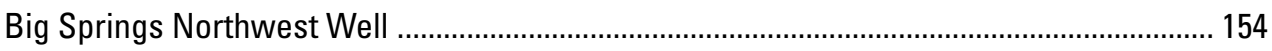

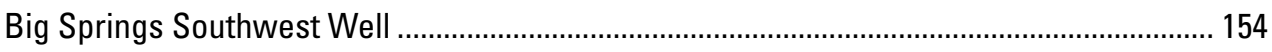

References Cited .................................................................................................................... 154

Appendix 2. Records at Bulk-Precipitation Stations on Mount Washington, Unnamed

Peak Northwest of Mount Mariah, and Cave Mountain, White Pine County, Nevada for Water Years 1984-2011 ................................................................................. 159

Reports with Bulk Precipitation at Stations in Nevada ..................................................... 159

Appendix 3. Discharge Measurements in and near Great Basin National Park, White Pine County, Nevada, Water Years 2009-11 ...................................................... 161

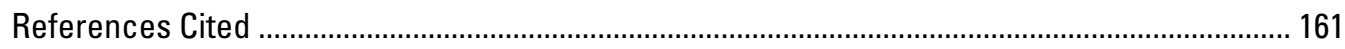


Appendix 4. Daily-Mean Discharge at Temporary Gaging Stations in and near Great

Basin National Park, White Pine County, Nevada, Water Years 2005-11 163

Appendix 5. Daily Mean Water Level and Temperature in Monitoring Wells at Baker 4 Aquifer-Test Site and Stage in Baker Creek, near Great Basin National Park, White Pine County, Nevada, Water Years 2009-11 165

Appendix 6. Daily Mean Water Levels in the Shallow and Deep Wells at Snake 5, near Great Basin National Park, White Pine County, Nevada, Water Years 2010-11 166

Appendix 7. Daily Mean Depth to Water in Wells Northwest and Southwest of Big Springs, Southern Part of Snake Valley, White Pine County, Nevada, Water Years 2010-12

Appendix 8. Baker Creek Stage, Groundwater Levels, Water Temperatures, and Pumping Rates Measured before, during, and after a 92-Hour Aquifer Test at Baker 4 Aquifer-Test Site, near Great Basin National Park, White Pine County, Nevada, October 2009

Appendix 9. Temperature, Depth to Water, and Drawdown in Nevada Department of Wildlife Well next to Snake Creek during and following a 5-Hour Aquifer Test on June 23, 2009, White Pine County, Nevada

Appendix 10. Depth to Water and Drawdown in Northwest and Southwest Big Springs

Well before, during, and after Aquifer Tests, South End of Snake Valley, White

Pine County, Nevada, October and November 2010

Appendix 11. Slug-Test Data at Snake 5 Deep Well, Southern Part of Snake Range, White

Pine County, Nevada, June 2011

References Cited

Appendix 12. Depth to Groundwater in Southern Spring Valley MX Wells and Pumping

Rates before, during, and after a Step-Drawdown and Two Constant-Rate Tests,

South End of Spring Valley, Lincoln County, Nevada, September 1980.

References Cited

Appendix 13. Description of Piezometer Installation, Stream Stage, and Water Levels in Shallow Piezometers and Hydraulic Gradients at Selected Sites on Baker, Lehman, and Snake Creeks, near Great Basin National Park, White Pine County, Nevada

References Cited 177

Appendix 14. Description of Water-Temperatures in Streambed Piezometers Used for Determining Streambed-Seepage Rates and Vertical Hydraulic Conductivity at Selected Sites on Baker, Lehman, and Snake Creeks, near Great Basin National Park, White Pine County, Nevada 178

References Cited

Appendix 15. Description of Placement and Measurement of Stream Water Temperature Using Fiber-Optic Cables and a Distributed Temperature Sensing Method near Great Basin National Park, White Pine County, Nevada

References Cited

Appendix 16. Summary of Water-Quality Data at Selected Stream Sites, Springs, and Wells, Great Basin National Park and Vicinity, White Pine County, Nevada, September 2007-January 2010 184

References Cited 


\section{Figures}

1. Map showing location of Great Basin National Park in the Snake Range and selected features in eastern Nevada and western Utah

2. Map showing location of Great Basin National Park and surrounding area in eastern White Pine and northern Lincoln Counties, Nevada

3. Map showing simplified geologic map of southern Snake Range and vicinity, eastern Nevada and western Utah

4. Stratigraphic columnar sections, southern Snake Range and vicinity, White Pine County, Nevada

5. Map showing thickness of Cenozoic basin fill for the study area, eastern Nevada and western Utah

6. Map showing mean precipitation rates from 1971 to 2000, Great Basin National Park and vicinity, eastern Nevada and western Utah

7. Graph showing variation in mean summer and winter precipitation rates for 1985-2011 at lower altitude weather stations at Eskdale, Utah, and in Great Basin National Park near Lehman Caves Visitor Center and at bulk-precipitation stations northwest of Mount Moriah, on the west slope of Mount Washington, and on Cave Mountain in the Schell Creek Range, White Pine County, Nevada

8. Graph showing annual variation in snow-water equivalent at end of March or beginning of April from 1942 to 2011 at the middle Baker Creek snow course and in winter precipitation from 1949 to 2011 at the weather station near Lehman Caves Visitor Center, Great Basin National Park, White Pine County, Nevada

9. Map showing potentiometric surface of groundwater for southern Snake and Spring Valleys and northern Hamlin Valley, Nevada and Utah, for late winter and early spring 2010

10. Map showing Baker and Lehman Creek drainage basins in the southern Snake Range and Great Basin National Park, White Pine County, Nevada

11. Graphs showing precipitation and temperature means relative to land-surface altitudes from Baker, Nevada, to Wheeler Peak, for 1971-2000, and annual values at the weather station near Lehman Caves Visitor Center, Great Basin National Park, White Pine County, Nevada, for water years 1938-2011

12. Map showing geology of the Baker and Lehman Creek drainage basins, Great Basin National Park, White Pine County, Nevada

13. Diagrams showing interpretive geologic cross sections in the Baker and Lehman Creek drainage basins, White Pine County, Nevada

14. Map showing distribution of clasts in alluvial deposits in the Baker and Lehman Creek drainage basins, White Pine County, Nevada, between the mountain front and valley floor

15. Idealized cross section showing streamflow and groundwater flow along Baker and Lehman Creeks in the mountain-upland zone, Great Basin National Park, White Pine County, Nevada

16. Graphs showing measured discharge on selected dates between September 1992 and August 2011, Great Basin National Park, White Pine County, Nevada

17. Graphs showing mean, median, minimum and maximum daily mean discharges, Great Basin National Park, White Pine County, Nevada, for water years 1948-55, 1993-97, and 2002-10

18. Graph showing annual runoff at gaging stations on Baker and Lehman Creeks, Great Basin National Park, White Pine County, Nevada, for water years 1948-55, 1993-97, and 2003-10

19. Graphs showing relation of annual mean discharge at gaging stations on Baker and Lehman Creeks, Great Basin National Park, White Pine County, Nevada 
20. Graph showing estimated mean annual runoff from mountain-upland zone and calculated mean annual water yield compared with total mean annual precipitation for six drainage basins in the southern Snake Range, Great Basin National Park, White Pine County, Nevada

21. Map showing locations of discharge-measurement sites, streambed piezometers, and wells in the karst-limestone and upper-piedmont zones of the Baker and Lehman Creek drainage basins between June 2009 and August 2011, Great Basin National Park, White Pine County, Nevada

22. Diagram showing relation of deuterium and oxygen-18 in water samples collected from Baker and Lehman Creeks, Pole Canyon, and Cave and Marmot Springs in the mountain-upland zone as well as in the volume-weighted mean annual, mean-winter, and mean-summer precipitation collected in vicinity of Great Basin National Park, White Pine County, Nevada

23. Idealized cross section showing streamflow and groundwater flow along Baker and Lehman Creeks in the karst-limestone zone, Great Basin National Park, White Pine County, Nevada

24. Graphs showing streambed temperatures from piezometers in karst-limestone zone of Lehman Creek, Great Basin National Park, White Pine County, Nevada

25. Graphs showing daily mean stream stage and groundwater head above streambed and daily mean and measured hydraulic gradient for piezometers in Lehman Creek at lower end of karst-limestone zone, Great Basin National Park, White Pine County, Nevada

26. Graphs showing discharge measurements taken between July 20, 2010, and August 18, 2011, in the karst-limestone zone, Great Basin National Park, White Pine County, Nevada

27. Graphs showing constituent concentrations in water samples collected from Baker Creek upstream of the Narrows, Lehman Creek near lower Lehman campground, and Rowland Spring between July 2010 and August 2011, Great Basin National Park, White Pine County, Nevada

28. Idealized cross section showing streamflow and groundwater flow along Baker and Lehman Creeks in the upper-piedmont zone, downstream of Great Basin National Park, White Pine County, Nevada

29. Graphs showing measured discharge for selected dates between September 1992 and March 2010 in the upper-piedmont zone, Great Basin National Park, White Pine County, Nevada

30. Map and graphs, Great Basin National Park, White Pine County, Nevada

31. Graphs showing streambed temperatures in four piezometers in the upper-piedmont zone of Baker and Lehman Creeks, Great Basin National Park, White Pine County, Nevada

32. Graphs showing daily mean stream stage, piezometer head above streambed, and hydraulic gradient in the upper-piedmont zone, Great Basin National Park, White Pine County, Nevada

33. Graphs showing results of 94 -hour aquifer test and 10 days following test, September 26 to 0 ctober 23, 2009, in monitoring wells at Baker 4 aquifer-test site downstream from Great Basin National Park, White Pine County, Nevada

34. Idealized cross section showing streamflow and groundwater flow along Baker and Lehman Creeks in the lower-piedmont and valley-lowland zones, downstream of Great Basin National Park, White Pine County, Nevada

35. Map showing Snake Creek drainage basin in the southern Snake Range and Great Basin National Park, White Pine County, Nevada

36. Map showing geology of the Snake Creek drainage basin, Great Basin National Park, White Pine County, Nevada

37. Diagram showing interpretive geologic cross section along Snake Creek from mountain front to Nevada-Utah state line 
38. Idealized cross section showing flow along Snake Creek in the mountain-upland and karst-limestone zones along Snake Creek, Great Basin National Park, White Pine County, Nevada

39. Graph showing the runoff rate of Snake Creek at the gaging station at the eastern boundary of Great Basin National Park in relation to the winter and annual precipitation rates at the bulk-precipitation station on Mount Washington for water-years 2003-09, White Pine County, Nevada

40. Graph showing daily mean discharge in Snake Creek at a gaging station at the eastern boundary of Great Basin National Park for water-years 2003-09, White Pine County, Nevada

41. Graph showing discharge data from four gaging stations on Snake Creek from October 1, 2002, to September 30, 2004, Great Basin National Park, White Pine County, Nevada

42. Map showing monitoring locations in Snake Creek drainage basin from 1 mile inside Great Basin National Park to the Nevada-Utah state line, White Pine County, Nevada ....... 83

43. Graph showing discharge measurements in Snake Creek for six dates between September 1992 and February 2010, Great Basin National Park, White Pine County, Nevada

44. Graphs showing creek and streambed temperatures in two piezometers in karstlimestone zone on Snake Creek for selected 2-week periods Great Basin National Park, White Pine County, Nevada

45. Graphs showing daily mean stream stage, piezometer head above streambed, and daily mean and measured hydraulic gradient at piezometers in Snake Creek, at the lower end of karst-limestone zone, between May 2009 and February 2010, Great Basin National Park, White Pine County, Nevada

46. Idealized cross section showing flow along Snake Creek in the upper-piedmont zone, downstream of Great Basin National Park, White Pine County, Nevada

47. Map and graphs showing distributed-temperature sensing measurements every 3.28 feet Great Basin National Park, White Pine County, Nevada

48. Graphs showing streambed temperatures in four piezometers in the upper-piedmont zone of Snake Creek for September 2-15, 2009, Great Basin National Park, White Pine County, Nevada

49. Graphs showing streambed temperatures at two piezometers PS7 and PS5 during two selected 2-week periods in upper-piedmont zone of Snake Creek downstream from Great Basin National Park, White Pine County, Nevada

50. Graphs showing daily mean stream stage and piezometer head above streambed and daily mean and measured hydraulic gradient at piezometers in Snake Creek in the upper-piedmont zone between May 2009 and February 2010, downstream from Great Basin National Park, White Pine County, Nevada

51. Diagrams showing water levels in near-surface deposits next to Snake Creek on July 3, 2009, and September 7, 2009, downstream from Great Basin National Park, White Pine County, Nevada

52. Graph showing selected dissolved constituents and ratio of oxygen-18 to oxygen-16 relative to dissolved-chloride concentration in Snake Creek, piezometer PS11 and Spring Creek Spring downstream from Great Basin National Park, White Pine County, Nevada, during January 16-17, 2010

53. Graph showing calcium concentrations relative to the percentage of dissolved carbon dioxide volume in water samples collected along Snake Creek, Nevada, during January 16-18, 2010

54. Graph showing saturation index for calcium relative to temperature for surface-water and groundwater samples collected along Snake Creek, Nevada, during January 16-18, 2010

55. Graph showing daily mean depth to water in the Snake 5 wells in relation to daily mean discharge of Snake Creek near the boundary between the upper-piedmont and lowerpiedmont zones and Spring Creek Spring, January 2010-September 2011, White Pine County, Nevada 
56. Idealized cross section showing flow along Snake Creek in the lower-piedmont and valley-lowland zones, White Pine County, Nevada and Millard County, Utah

57. Graph showing streambed temperatures at piezometers PS10 and PS9 in upperpiedmont zone of Snake Creek, downstream of Great Basin National Park, White Pine County, Nevada

58. Graphs showing daily mean stream stage, piezometer head above streambed, and daily mean and measured hydraulic gradient at piezometers in Snake Creek in the lowerpiedmont zone, downstream of Great Basin National Park, White Pine County, Nevada .... 109

59. Graphs showing daily mean depth to water in Utah Geological Survey monitoring wells in lower-piedmont and valley-lowland zones of Snake Creek drainage basin near Garrison, Millard County, Utah, 2009-11

60. Graphs showing well data from fractured limestone in upper-piedmont zone through basin-fill deposits in lower-piedmont and valley-lowland zones in the Snake Creek drainage to fractured limestone in the Burbank Hills, White Pine County, Nevada and Millard County, Utah

61. Map showing location of Big Springs in southern Snake Valley, Big Spring Wash at the south end of the Snake Range in northern Hamlin Valley, Limestone Hills that divide southern Spring Valley from northern Hamlin Valley, and water level contours that depict a groundwater divide in southern Spring Valley, south of Baking Powder Flat, Lincoln and White Pine Counties, Nevada .....

62. Graph showing daily mean discharge in the north and south channels and combined daily mean discharge of Big Springs for water years 2006-11, southern Snake Valley, White Pine County, Nevada

63. Map showing geology of the Big Springs area in southern Snake Valley, including the south end of the Snake Range, northern Hamlin Valley, and southern Spring Valley in Lincoln and White Pine Counties, Nevada

64. Perspective view showing the subsurface geology of southern Snake Valley, northern Hamlin Valley, and southern Spring Valley, as interpreted from well data, seismicreflection profiles, and modeled gravity data

65. Map and diagrams showing location and two-dimensional resistivity profiles of lowfrequency magnetotelluric (MT) data collected in the vicinity of the Limestone Hills in northern Hamlin Valley and southern Spring Valley, Lincoln County, Nevada

66. Maps showing location of wells with subsurface lithologic data in the vicinity of Big Springs, Lincoln and White Pine Counties, Nevada

67. Graphs showing distribution of groundwater pumping and comparison of measured and simulated drawdown during September 1980 for the MX test wells in southern Spring Valley, Lincoln County, Nevada

68. Map showing distribution of basin-fill deposits and carbonate rocks and depth to groundwater in southern Spring Valley, northern Hamlin Valley, and southern Snake Valley, Lincoln and White Pine Counties, Nevada

69. Map showing conceptualization of groundwater flow to southern Snake Valley from source areas in the south end of the Snake Range, southern Spring Valley, and northern Hamlin Valley, Lincoln and White Pine Counties, Nevada

1-1. Map showing location of completed and planned wells near Great Basin National Park, White Pine County, Nevada

1-2. Map showing location of Baker Creek 4 aquifer-test site, near Great Basin National Park, White Pine County, Nevada

1-3. Diagram showing lithologic and geophysical logs for the Snake 5 well 155

1-4. Diagram showing lithologic and geophysical logs for the Big Springs northwest well 156

1-5. Diagram showing lithologic and geophysical logs for the Big Springs southwest well 157 


\section{Tables}

1. Index of gaging stations in the southern part of Snake Range and Snake Valley, Great Basin National Park, and Cleve Creek in nearby Schell Creek Range, White Pine County, Nevada

2. Lithologic classes in drill holes in the vicinity of Baker and Lehman Creeks, White Pine County, Nevada

3. Mean annual precipitation volume and water yield from the mountain-upland zone in the Baker and Lehman Creek drainage basins and from four nearby drainage basins, Great Basin National Park, White Pine County, Nevada

4. Water budgets for the mountain-upland and karst-limestone zones in the combined drainage basins of Baker and Lehman Creek, Great Basin National Park, White Pine County, Nevada

5. Selected water chemistry of creeks and springs near the contact between mountainupland and karst-limestone zones, at Model Cave in karst-limestone zone, and at Rowland Spring near contact between karst-limestone and upper-piedmont zones, Great Basin National Park, White Pine County, Nevada, 1990-2011

6. Discharge measurements, streamflow loss or gain, streambed width and length, and net streambed-seepage rates for selected reaches on Baker Creek, Great Basin National Park, White Pine County, Nevada, July 2009 to August 2011

7. Discharge measurements, streamflow loss or gain, streambed width and length, and net streambed-seepage rates for selected reaches on Lehman Creek, Great Basin National Park, White Pine County, Nevada, July 2010 to August 2011

8. Streambed-seepage rates, hydraulic gradients, and hydraulic conductivities at six piezometers driven into Baker and Lehman Creeks, Great Basin National Park, White Pine County, Nevada, June 2009 to November 2010

9. Summary of hydraulic properties of the younger alluvial and older basin-fill deposits estimated from an aquifer test from 0 ctober 9, 2009, to 0ctober 13, 2009, at the Baker 4 aquifer-test site downstream of Great Basin National Park, White Pine County, Nevada

10. Summary of transmissivity estimates derived from specific capacities reported in welldrillers' logs for Baker and Lehman Creek drainage basins, vicinity of Great Basin National Park, White Pine County, Nevada

11. Water budgets for the mountain-upland, karst-limestone, and upper-piedmont zones in the Snake Creek drainage basin, Great Basin National Park, White Pine County, Nevada

12. Net streambed-seepage rates from stream-discharge measurements along selected reaches on Snake Creek, Great Basin National Park, White Pine County, Nevada, July 2009 through February 2010

13. Streambed-seepage rates and hydraulic conductivities of the streambed at 10 piezometers driven into Snake Creek, Great Basin National Park, White Pine County, Nevada, May 2009 through February 2010

14. Saturation indices of calcite and the partial pressure of carbon dioxide for water samples collected January 16-18, 2010, from Snake Creek, springs, and wells, Great Basin National Park, White Pine County, Nevada

15. Geochemical modeling results of mineral-phase mass transfer for each of four segments along Snake Creek from water samples collected January 16-17, 2010, Great Basin National Park, White Pine County, Nevada

16. Summary of transmissivity estimates from specific capacities reported in well-drillers' logs and from two aquifer tests for wells in the Snake Creek and Big Wash drainage basins, vicinity of Great Basin National Park, White Pine County, Nevada

17. Geochemical modeling results of mineral-phase mass transfer for flow paths to the Snake 5 deep well from spring and well-water samples collected January 16-18, 2010, Great Basin National Park, White Pine County, Nevada 
18. Summary of transmissivity estimates from specific capacities reported in well-drillers' logs and from aquifer tests for wells in southern Snake, northern Hamlin, and southern Spring Valleys, vicinity of Big Springs, White Pine and Lincoln Counties, Nevada

19. Summary of transmissivity from aquifer tests for wells in southern Snake, northern Hamlin, and southern Spring valleys, vicinity of Big Springs, White Pine and Lincoln Counties, Nevada

20. Mean annual precipitation volume and groundwater recharge in southern Spring Valley, Big Spring Wash drainage basin in northern Hamlin Valley, and eastern slope of southern Snake Range in southern Snake Valley, Lincoln and White Pine Counties, Nevada

21. Selected water-quality constituents in water for wells and springs in southern Spring Valley, northern Hamlin Valley, and southern Snake Valley sampled between October 2010 and May 2011, Lincoln and White Pine Counties, Nevada

22. Selected water-quality constituents in water from Big Springs and test wells northwest and southwest of the springs in southern Snake Valley sampled in October and November 2010, White Pine and Lincoln counties, Nevada

1-1. Monitoring wells drilled near Great Basin National Park, White Pine County, Nevada, as part of this study, 2009-2010

1-2. Lithologic description of down hole intervals, Snake Creek 5 monitoring wells, Great Basin National Park, White Pine County, Nevada

1-3. Lithologic description of down hole intervals, Big Springs Northwest well, southern part of the Snake Range, White Pine County, Nevada

1-4. Lithologic description of down hole intervals, Big Springs Southwest well, south end of the Snake Range, White Pine County, Nevada 158

2-1. Description of bulk-precipitation stations in and near Great Basin National Park, White Pine County, Nevada

2-2. Record of bulk precipitation at station on Mount Washington, southern part of the Snake Range, Great Basin National Park, White Pine County, Nevada, 1984-2011

2-3. Record of bulk precipitation at station on unnamed peak northwest of Mount Moriah, northern part of the Snake Range, White Pine County, Nevada, 1984-2011

2-4. Record of bulk precipitation at station on Cave Mountain, Schell Creek Range, White Pine County, Nevada, 1985-2011

3-1. Location and description of discharge measurements at selected sites in the Baker, Lehman, and Snake Creek drainage basins, Great Basin National Park, White Pine County, Nevada, water years 2009-11

3-2. Discharge measurements at selected sites in the Baker Creek drainage basin, Great Basin National Park, White Pine County, Nevada, water years 2009-11

3-3. Discharge measurements at selected sites in the Lehman Creek drainage basin, Great Basin National Park, White Pine County, Nevada, water years 2009-11

3-4. Discharge measurements at selected sites in the Snake Creek drainage basin, Great Basin National Park, White Pine County, Nevada, water years 2009-11

3-5. Discharge measurements at selected sites on Big Springs Creek, Great Basin National Park, White Pine County, Nevada, water years 2009-11

4-1. Location and description of National Park Service and University of Nevada, Reno, gaging stations in the Baker, Lehman, and Snake Creek drainage basins in and near Great Basin National Park, White Pine County, Nevada, water years 2005-11

4-2. Daily mean discharge at National Park Service gaging station on Baker Creek at Narrows near Baker, Nevada (station 10243240), water years 2005-10

4-3. Daily mean discharge at National Park Service gaging station on Rowland Spring at Great Basin National Park boundary near Baker, Nevada (station 10243265), water years 2005-10

4-4. Daily mean discharge at National Park Service gaging station on Snake Creek at Great Basin National Park boundary near Baker, Nevada (station 10243232), water years 2005-09 
4-5. Daily mean discharge at University of Nevada, Reno, temporary gaging station on Pole Canyon upstream of Pioche Shale outcrop near Baker, Nevada (siteidentification number 385858114131901), water year 2011

4-6. Daily mean discharge at University of Nevada, Reno, temporary gaging station on Pole Canyon near confluence with Baker Creek near Baker, Nevada (siteidentification number 3859221141251), water year 2011

4-7. Daily mean discharge at University of Nevada, Reno, temporary gaging station on Model Cave resurgent spring near Baker, Nevada (site-identification number 385922114123701), water year 2011

4-8. Daily mean discharge at University of Nevada, Reno temporary gaging station on Rosethorn spring near Baker, Nevada (site-identification number 385948114114401), water years 2010-11

4-9. Daily mean discharge at University of Nevada, Reno, temporary gaging station on Spring Creek Spring, Nevada Department of Wildlife Spring Creek fish-rearing station, near Garrison, Utah (site-identification number 385434114063901), water years $2009-11$

4-10. Daily mean water temperature at University of Nevada, Reno, temporary gaging station on Pole Canyon upstream of Pioche Shale outcrop near Baker, Nevada (site-identification number 385858114131901), water year 2011

4-11. Daily mean water temperature at University of Nevada, Reno, temporary gaging station on Pole Canyon near confluence with Baker Creek near Baker, Nevada (site-identification number 3859221141251), water year 2011

4-12. Daily mean water temperature at University of Nevada, Reno, temporary gaging station on Model Cave resurgent spring near Baker, Nevada (site-identification number 385922114123701), water year 2011

4-13. Daily mean water temperature at University of Nevada, Reno, temporary gaging station on Rosethorn spring near Baker, Nevada (site-identification number 385948114114401), water years 2010-11

4-14. Daily mean temperature at University of Nevada, Reno, temporary gaging station on Spring Creek Spring, Nevada Department of Wildlife Spring Creek fish-rearing station, near Garrison, Utah (site-identification 385434114063901), water years 2009-11

5-1. Daily mean depth to water in 6-inch diameter monitoring well at Baker 4 aquifertest site next to Baker Creek near Baker, Nevada (site-identification number 385947114113201), water years 2009-11

5-2. Daily mean depth to water in shallow monitoring well at Baker 4 aquifer-test site about 37 feet southeast of 6 -inch well next to Baker Creek near Baker, Nevada (site-identification number 385947114113202), water years 2009-11

5-3. Daily mean depth to water in deeper monitoring well at Baker 4 aquifer-test site about 37 feet southeast of 6 -inch well next to Baker Creek near Baker, Nevada (site-identification number 385947114113203), water years 2009-11

5-4. Daily mean depth to water in shallow monitoring well at Baker 4 aquifer-test site about 50 feet south of 6 -inch well next to Baker Creek near Baker, Nevada (siteidentification number 385947114113204), water years 2009-11

5-5. Daily mean depth to water in deeper monitoring well at Baker 4 aquifer-test site about 50 feet south of 6-inch well next to Baker Creek near Baker, Nevada (siteidentification number 385947114113205), water years 2009-11

5-6. Daily mean stage in Baker Creek at site 2 near upstream monitoring wells at Baker 4 aquifer-test site (site-identification number 385946114113301), water years 2009-11

5-7. Daily mean water temperature in 6-inch diameter monitoring well at Baker 4 aquifertest site next to Baker Creek near Baker, Nevada (site-identification number 385947114113201), water years 2009-11

5-8. Daily mean water temperature in shallow monitoring well at Baker 4 aquifer-test site about 37 feet southeast of 6-inch well next to Baker Creek near Baker, Nevada (site-identification number 385947114113202), water years 2009-11 
5-9. Daily mean water temperature in deeper monitoring well at Baker 4 aquifer-test site about 37 feet southeast of 6 -inch well next to Baker Creek near Baker, Nevada (site-identification number 385947114113203), water years 2009-11

5-10. Daily mean water temperature in shallow monitoring well at Baker 4 aquifer-test site about 50 feet south of 6 -inch well next to Baker Creek near Baker, Nevada (siteidentification number 385947114113204), water years 2009-11

5-11. Daily mean water temperature in deeper monitoring well at Baker 4 aquifer-test site about 50 feet south of 6 -inch well next to Baker Creek near Baker, Nevada (site-identification number 385947114113205), water years 2009-11

5-12. Daily mean temperature in Baker Creek at site 2 near upstream monitoring wells at Baker 4 aquifer-test site (site-identification number 385946114113301), water years 2009-11 165

6-1. Daily mean depth to water in Snake 5 shallow well next to Snake Creek near Garrison, Utah (site-identification number 385524114045602), water years 2010-11 166

6-2. Daily mean depth to water in Snake 5 deep well next to Snake Creek near Garrison, Utah (site-identification number 385524114045601), water years 2010-11

7-1. Daily mean depth to water in northwest Big Springs well before, during, and after 48-hour aquifer test at well (site-identification number 384227114082701), south end of Snake Valley, White Pine County, Nevada, water years 2010-12

7-2. Daily mean depth to water in southwest Big Springs well before, during and after 48-hour aquifer test at well (site-identification number 384112114091101), south end of Snake Valley, White Pine County, Nevada, water years 2010-11

8-1. Names and locations of monitoring wells at Baker Creek 4 aquifer-test site and temporary gaging stations in Baker Creek near Great Basin National Park, White Pine County, Nevada

8-2. Temperature, depth to water, drawdown, and pumping rate in 6 -inch diameter well at Baker 4 aquifer-test site (site-identification number 385947114113201), October 2009

8-3. Temperature, depth to water, and drawdown in shallow 2-inch monitoring well about 37 feet southeast (downstream) of pumped well at Baker 4 aquifer-test site (site-identification number 385947114113202), October 2009

8-4. Temperature, depth to water, and drawdown in deeper 2-inch monitoring well about 37 feet southeast (downstream) of pumped well at Baker 4 aquifer-test site (site-identification number 385947114113203), October 2009

8-5. Temperature, depth to water, and drawdown in shallow 2 -inch monitoring well about 50 feet south (upstream) of pumped well at Baker 4 aquifer-test site (site-identification number 385947114113204), October 2009

8-6. Temperature, depth to water, and drawdown in deeper 2-inch monitoring well about 50 feet south (upstream) of 6 -inch pumped well at Baker 4 aquifer-test site (site-identification number 385947114113205), October 2009

8-7. Hourly mean temperature and stage for pressure transducers in Baker Creek near Baker 4 aquifer-test site, 0ctober 2009

9-1. Temperature, depth to water, and drawdown in Nevada Department of Wildlife well next to Snake Creek during and following 5-hour aquifer test on June 23, and June 24, 2009, Spring Creek fish-rearing station, White Pine County, Nevada

10-1. Depth to water and drawdown in northwest Big Springs well before, during, and after 42-hour aquifer test at well (site-identification number 384227114082701), south end of Snake Valley, White Pine County, Nevada, October 4-10, 2010

10-2. Depth to water and drawdown in southwest Big Springs well before, during, and after 47.25-hour aquifer test at well (site-identification number 384112114091101), south end of Snake Valley, White Pine County, Nevada, November 2-4, 2010

11-1. Slug-test data for test 1 at Snake 5 deep well on June 1, 2011, Great Basin National Park, White Pine County, Nevada ...

11-2. Slug-test data for test 2 at Snake 5 deep well on June 1, 2011, Great Basin National Park, White Pine County, Nevada 
11-3. Slug-test data for test 3 at Snake 5 deep well on June 1, 2011, Great Basin National Park, White Pine County, Nevada

12-1. Site-identification number, location, well diameter, casing depth, and depth to top and bottom of screened interval of pumped and observation wells in southern Spring Valley used for aquifer tests as part of U.S. Air Force MX missile-siting investigation, White Pine County, Nevada, September 1-21, 1980

12-2. Depth to water and drawdown in the 10-inch diameter pumped well before, during, and after one step-drawdown and two constant-rate aquifer tests as part of U.S. Air Force MX missile-siting investigation (site-identification number 383704114225001), south end of Spring Valley, White Pine County, Nevada, September 1-21, 1980

12-3. Depth to water and drawdown in the 2-inch diameter observation well before, during, and after the two constant-rate aquifer tests as part of U.S. Air Force Missile siting program (site-identification number 385947114113203), south end of Spring Valley, White Pine County, Nevada, September 10-21, 1980

13-1. Location, land-surface altitude, depths, screen length, and dates of installation and removal of piezometers driven into the streambed or near streambed of Baker, Lehman, and Snake Creeks, Great Basin National Park, White Pine County, Nevada

13-2. Daily mean stream stage, groundwater head relative to streambed, and hydraulic gradient from pressure-transducer data and manual measurements in piezometer PB1 driven into the streambed of Baker Creek, Great Basin National Park, White Pine County, Nevada, 2009-10

13-3. Daily mean stream stage, groundwater head relative to streambed, and hydraulic gradient from pressure-transducer data and manual measurements in piezometer PB2 driven into the streambed of Baker Creek, Great Basin National Park, White Pine County, Nevada, 2009-10

13-4. Daily mean stream stage, groundwater head relative to streambed, and hydraulic gradient from pressure-transducer data and manual measurements in piezometer PL1 driven into the streambed of Lehman Creek, Great Basin National Park, White Pine County, Nevada, 2009-10

13-5. Daily mean stream stage, groundwater head relative to streambed, and hydraulic gradient from pressure-transducer data and manual measurements piezometer PL2 driven into the streambed of Lehman Creek, Great Basin National Park, White Pine County, Nevada, 2009-10

13-6. Daily mean stream stage, groundwater head relative to streambed, and hydraulic gradient from pressure-transducer data and manual measurements piezometer PL3 driven into the streambed of Lehman Creek, Great Basin National Park, White Pine County, Nevada, 2009-10

13-7. Daily mean stream stage, groundwater head relative to streambed, and hydraulic gradient from pressure-transducer data and manual measurements piezometer PL4 driven into the streambed of Lehman Creek, Great Basin National Park, White Pine County, Nevada, 2009-10

13-8. Daily mean stream stage, groundwater head relative to streambed, and hydraulic gradient from pressure-transducer data and manual measurements in piezometer PS1 driven into the streambed of Snake Creek, Great Basin National Park, White Pine County, Nevada, 2009-10

13-9. Daily mean stream stage, groundwater head relative to streambed, and hydraulic gradient from pressure-transducer data and manual measurements in piezometer PS2 driven into the streambed of Snake Creek, Great Basin National Park, White Pine County, Nevada, 2009-13

13-10. Daily mean stream stage, groundwater head relative to streambed, and hydraulic gradient from pressure-transducer data and manual measurements in piezometer PS3 driven into the streambed of Snake Creek, Great Basin National Park, White Pine County, Nevada, 2009-10 
13-11. Daily mean stream stage, groundwater head relative to streambed, and hydraulic gradient from pressure-transducer data and manual measurements in piezometer PS4 driven into the streambed of Snake Creek, Great Basin National Park, White Pine County, Nevada, 2009-13

13-12. Daily mean stream stage, groundwater head relative to streambed, and hydraulic gradient from pressure-transducer data and manual measurements in piezometer PS5 driven into the streambed of Snake Creek, Great Basin National Park, White Pine County, Nevada, 2009-10

13-13. Daily mean stream stage, groundwater head relative to streambed, and hydraulic gradient from pressure-transducer data and manual measurements in piezometer PS6 driven into the streambed of Snake Creek, Great Basin National Park, White Pine County, Nevada, 2009-10

13-14. Daily mean stream stage, groundwater head relative to streambed, and hydraulic gradient from pressure-transducer data and manual measurements in piezometer PS7 driven into the streambed of Snake Creek, Great Basin National Park, White Pine County, Nevada, 2009-10

13-15. Daily mean stream stage, groundwater head relative to streambed, and hydraulic gradient from pressure-transducer data and manual measurements in piezometer PS8 driven into the streambed of Snake Creek, Great Basin National Park, White Pine County, Nevada, 2009-10

13-16. Daily mean stream stage, groundwater water head relative to streambed, and hydraulic gradient from pressure-transducer data and manual measurements in piezometer PS9 driven into the streambed of Snake Creek, Great Basin National Park, White Pine County, Nevada, 2009-10

13-17. Daily mean stream stage, groundwater water head relative to streambed, and hydraulic gradient from pressure-transducer data and manual measurements in piezometer PS10 driven into the streambed of Snake Creek, Great Basin National Park, White Pine County, Nevada, 2009-10

13-18. Daily mean stream stage, groundwater head relative to streambed, and hydraulic gradient from pressure-transducer data and manual measurements in piezometer PS11 driven into the streambed of Snake Creek, Great Basin National Park, White Pine County, Nevada, 2009-10

13-19. Daily mean stream stage, groundwater head relative to streambed, and hydraulic gradient from pressure-transducer data and manual measurements in piezometer PS12 driven into the streambed of Snake Creek, Great Basin National Park, White Pine County, Nevada, 2009-13

13-20. Daily mean groundwater head relative to land surface and temperature from pressuretransducer data and manual measurements in piezometer PS4_sb1 driven into ground 14 feet south of piezometer PS4 in Snake Creek, Great Basin National Park, White Pine County, Nevada, 2009-13

13-21. Daily mean groundwater head relative to land surface and temperature from pressuretransducer data and manual measurements in piezometer PS4_sb2 driven into ground 45 feet south of piezometer PS4 in Snake Creek, Great Basin National Park, White Pine County, Nevada, 2009-13

13-22. Estimates of lateral hydraulic conductivity from slug tests in piezometers driven into the streambed of Baker, Lehman, and Snake Creeks, Great Basin National Park, White Pine County, Nevada, 2009-2013

14-1. Hydraulic and thermal properties used to estimate streambed-seepage rates and vertical hydraulic conductivity at piezometers driven into the streambeds at selected locations along Baker, Lehman, and Snake Creeks near Great Basin National Park, White Pine County, Nevada

14-2. Hourly temperature and water level at selected depths in piezometer PB1, driven into the streambed of Baker Creek, Great Basin National Park, White Pine County, Nevada, 2010 
14-3. Hourly temperature and water level at selected depths in piezometer PB2, driven into the streambed of Baker Creek, Great Basin National Park, White Pine County, Nevada, 2009-10

14-4. Hourly temperatures and water levels in creek and at selected depths in piezometer PL1, driven into the streambed of Lehman Creek, Great Basin National Park, White Pine County, Nevada, 2009-10

14-5. Hourly temperatures and water levels in creek and at selected depths in piezometer PL2, driven into the streambed of Lehman Creek, Great Basin National Park, White Pine County, Nevada, 2010

14-6. Hourly temperatures and water levels in creek and at selected depths in piezometer PL3, driven into the streambed of Lehman Creek, Great Basin National Park, White Pine County, Nevada, 2010

14-7. Hourly temperatures and water levels in creek and at selected depths in piezometer PL4, driven into the streambed of Lehman Creek, Great Basin National Park, White Pine County, Nevada, 2009-10

14-8. Hourly temperatures and water levels in creek and at bottom of piezometer PS1, driven into the streambed of Snake Creek, Great Basin National Park, White Pine County, Nevada, 2009

14-9. Hourly temperatures and water levels in creek and at bottom of piezometer PS2, driven into the streambed of Snake Creek, Great Basin National Park, White Pine County, Nevada, 2009

14-10. Hourly temperatures and water levels in creek and at selected depths in piezometer PS3, driven into the streambed of Snake Creek, Great Basin National Park, White Pine County, Nevada, 2009

14-11. Hourly temperatures and water levels in creek and at selected depths in piezometer PS4, driven into the streambed of Snake Creek, Great Basin National Park, White Pine County, Nevada, 2009-10

14-12. Hourly temperatures and water levels in creek and at bottom of piezometer PS5, driven into the streambed of Snake Creek, Great Basin National Park, White Pine County, Nevada, 2009-10

14-13. Hourly temperatures and water levels in creek and at selected depths in piezometer PS7, driven into the streambed of Snake Creek, Great Basin National Park, White Pine County, Nevada, 2009-10

14-14. Hourly temperatures and water levels in creek and at selected depths in piezometer PS9, driven into the streambed of Snake Creek, Great Basin National Park, White Pine County, Nevada, 2009-10

14-15. Hourly temperatures and water levels in creek and near bottom of piezometer PS10, driven into the streambed of Snake Creek, Great Basin National Park, White Pine County, Nevada, 2009

14-16. Hourly temperatures at selected depths in piezometer PS11, driven into the streambed of Snake Creek, Great Basin National Park, White Pine County, Nevada, 2009-10 180

14-17. Hourly temperature and water level at selected depths in piezometer PS12, driven into the streambed of Snake Creek, Great Basin National Park, White Pine County, Nevada, 2009-10

15-1. Distributed temperature sensing measurements from selected reaches of Lehman and Snake Creeks in and near Great Basin National Park, White Pine County, Nevada, 2009-10

16-1. Sampling locations for water chemistry from creeks, springs, caves, and wells in and near Great Basin National Park, southern Snake Valley, Nevada

16-2. Field parameters at selected surface-water sites for water chemistry in and near Great Basin National Park, White Pine County, Nevada, 2009-11

16-3. Dissolved major-ion concentrations at selected surface-water sites in and near Great Basin National Park, White Pine County, Nevada, 2009-11 
16-4. Dissolved trace-element concentrations at selected surface-water sites in and near Great Basin National Park, White Pine County, Nevada, 2009-11

16-5. Nutrient concentrations at selected surface-water sites in and near Great Basin National Park, White Pine County, Nevada, 2009-11 186

16-6. Stable- and radioactive-isotope chemistry at selected surface-water sites in and near Great Basin National Park, White Pine County, Nevada, 2009-11

16-7. Field parameters at selected caves, springs, and groundwater sites for water chemistry in and near Great Basin National Park, White Pine County, Nevada, 2009-11

16-8. Dissolved major-ion concentrations at selected caves, springs, and groundwater sites in and near Great Basin National Park, White Pine County, Nevada, 2009-11 186

16-9. Dissolved trace-element concentrations at selected caves, springs, and groundwater sites in and near Great Basin National Park, White Pine County, Nevada, 2009-11 186

16-10. Nutrient concentrations at selected caves, springs, and groundwater sites in and near Great Basin National Park, White Pine County, Nevada, 2009-11 186

16-11. Stable- and radioactive-isotope chemistry at selected caves, springs, and groundwater sites in and near Great Basin National Park, White Pine County, Nevada, 2009-11 186

16-12. Dissolved chlorofluorocarbon and gas concentrations at groundwater sites in and near Great Basin National Park, White Pine County, Nevada, 2009-11 


\section{Conversion Factors, Datums, and Water-Quality Units}

Inch/Pound to SI

\begin{tabular}{|c|c|c|}
\hline Multiply & By & To obtain \\
\hline \multicolumn{3}{|c|}{ Length } \\
\hline inch (in.) & 2.54 & centimeter $(\mathrm{cm})$ \\
\hline inch (in.) & 25.4 & millimeter (mm) \\
\hline foot $(\mathrm{ft})$ & 0.3048 & meter $(\mathrm{m})$ \\
\hline mile (mi) & 1.609 & kilometer $(\mathrm{km})$ \\
\hline \multicolumn{3}{|c|}{ Area } \\
\hline acre & 4,047 & square meter $\left(\mathrm{m}^{2}\right)$ \\
\hline acre & 0.4047 & hectare (ha) \\
\hline acre & 0.4047 & square hectometer $\left(\mathrm{hm}^{2}\right)$ \\
\hline acre & 0.004047 & square kilometer $\left(\mathrm{km}^{2}\right)$ \\
\hline square foot $\left(\mathrm{ft}^{2}\right)$ & 929.0 & square centimeter $\left(\mathrm{cm}^{2}\right)$ \\
\hline square foot $\left(\mathrm{ft}^{2}\right)$ & 0.09290 & square meter $\left(\mathrm{m}^{2}\right)$ \\
\hline square mile $\left(\mathrm{mi}^{2}\right)$ & 259.0 & hectare (ha) \\
\hline square mile $\left(\mathrm{mi}^{2}\right)$ & .590 & square kilometer $\left(\mathrm{km}^{2}\right)$ \\
\hline \multicolumn{3}{|c|}{ Volume } \\
\hline cubic mile $\left(\mathrm{mi}^{3}\right)$ & 4.168 & cubic kilometer $\left(\mathrm{km}^{3}\right)$ \\
\hline acre-foot (acre-ft) & 1,233 & cubic meter $\left(\mathrm{m}^{3}\right)$ \\
\hline acre-foot (acre-ft) & 0.001233 & cubic hectometer $\left(\mathrm{hm}^{3}\right)$ \\
\hline \multicolumn{3}{|c|}{ Flow rate } \\
\hline acre-foot per year (acre-ft/yr) & 1,233 & cubic meter per year $\left(\mathrm{m}^{3} / \mathrm{yr}\right)$ \\
\hline acre-foot per year (acre-ft/yr) & 0.001233 & cubic hectometer per year $\left(\mathrm{hm}^{3} / \mathrm{yr}\right)$ \\
\hline foot per day (ft/d) & 0.3048 & meter per day $(\mathrm{m} / \mathrm{d})$ \\
\hline foot per year (ft/yr) & 0.3048 & meter per year $(\mathrm{m} / \mathrm{yr})$ \\
\hline cubic foot per second $\left(\mathrm{ft}^{3} / \mathrm{s}\right)$ & 0.02832 & cubic meter per second $\left(\mathrm{m}^{3} / \mathrm{s}\right)$ \\
\hline $\begin{array}{l}\text { cubic foot per second per square } \\
\text { mile }\left[\left(\mathrm{ft}^{3} / \mathrm{s}\right) / \mathrm{mi}^{2}\right]\end{array}$ & 0.01093 & $\begin{array}{l}\text { cubic meter per second per square } \\
\text { kilometer }\left[\left(\mathrm{m}^{3} / \mathrm{s}\right) / \mathrm{km}^{2}\right]\end{array}$ \\
\hline cubic foot per day $\left(\mathrm{ft}^{3} / \mathrm{d}\right)$ & 0.02832 & cubic meter per day $\left(\mathrm{m}^{3} / \mathrm{d}\right)$ \\
\hline gallon per minute (gal/min) & 0.06309 & liter per second $(\mathrm{L} / \mathrm{s})$ \\
\hline inch per year (in/yr) & 25.4 & millimeter per year $(\mathrm{mm} / \mathrm{yr})$ \\
\hline \multicolumn{3}{|c|}{ Radioactivity } \\
\hline picocurie per liter $(\mathrm{pCi} / \mathrm{L})$ & 0.037 & becquerel per liter $(\mathrm{Bq} / \mathrm{L})$ \\
\hline \multicolumn{3}{|c|}{ Hydraulic conductivity } \\
\hline foot per day (ft/d) & 0.3048 & meter per day $(\mathrm{m} / \mathrm{d})$ \\
\hline \multicolumn{3}{|c|}{ Hydraulic gradient } \\
\hline foot per mile (ft/mi) & 0.1894 & meter per kilometer $(\mathrm{m} / \mathrm{km})$ \\
\hline \multicolumn{3}{|c|}{ Transmissivity } \\
\hline foot squared per day $\left(\mathrm{ft}^{2} / \mathrm{d}\right)$ & 0.09290 & meter squared per day $\left(\mathrm{m}^{2} / \mathrm{d}\right)$ \\
\hline
\end{tabular}

Temperature in degrees Celsius $\left({ }^{\circ} \mathrm{C}\right)$ may be converted to degrees Fahrenheit $\left({ }^{\circ} \mathrm{F}\right)$ as follows:

${ }^{\circ} \mathrm{F}=\left(1.8 x^{\circ} \mathrm{C}\right)+32$

Vertical coordinate information is referenced to the North American Vertical Datum of 1988 (NAVD 88), unless otherwise specified.

Horizontal coordinate information is referenced to the North American Datum of 1983 (NAD 83), unless otherwise specified. 
Altitude, as used in this report, refers to distance above the vertical datum.

*Transmissivity: The standard unit for transmissivity is cubic foot per day per square foot times foot of aquifer thickness $\left[\left(\mathrm{ft}^{3} / \mathrm{d}\right) / \mathrm{ft}^{2}\right] \mathrm{ft}$. In this report, the mathematically reduced form, foot squared per day $\left(\mathrm{ft}^{2} / \mathrm{d}\right)$, is used for convenience.

Specific conductance is given in microsiemens per centimeter at 25 degrees Celsius $\left(\mu \mathrm{S} / \mathrm{cm}\right.$ at $\left.25^{\circ} \mathrm{C}\right)$.

Concentrations of chemical constituents in water are given either in milligrams per liter (mg/L) or micrograms per liter $(\mu \mathrm{g} / \mathrm{L})$.

Concentrations of radioactive tritium (hydrogen-3 or ${ }^{3} \mathrm{H}$ ) are given in picocuries per liter (pCi/L) and carbon-14 $\left({ }^{14} \mathrm{C}\right)$ is given as a percentage of modern carbon-14.

Concentrations of of deuterium (hydrogen-2 or ${ }^{2} \mathrm{H}$ ), oxygen-18 $\left({ }^{18} \mathrm{O}\right)$, and carbon-13 $\left({ }^{13} \mathrm{C}\right)$ are given in delta

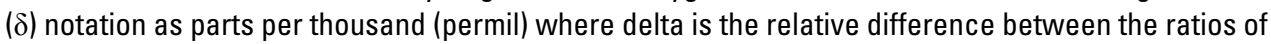
deuterium to protium (hydrogen-1 or ${ }^{1} \mathrm{H}$ ) or oxygen-18 to oxygen-16 $\left({ }^{16} \mathrm{O}\right)$ in water samples to the respective ratios in Vienna Standard Mean Ocean Water (VSMOW; Giofiantini, 1978), and carbon-13 to carbon-12 ( $\left.{ }^{12} \mathrm{C}\right)$ in water to that in a sample from the Pee Dee Formation of South Carolina (PDB; Craig, 1957). A negative value represents water with less deuterium relative to protium or oxygen-18 relative to oxygen- 16 than VSMOW and less carbon- 13 relative to carbon- 12 than PDB.

\section{Abbreviations and Acronyms}

$\begin{array}{ll}\text { AMT } & \text { Audiomagnetotelluric } \\ \text { BS-NW } & \text { Big Springs northwest well } \\ \text { BS-SW } & \text { Big Springs southwest well } \\ \text { CFC } & \text { chlorofluorocarbon } \\ \text { CSAMT } & \text { controlled-source audio-magnetotelluric } \\ \text { DTS } & \text { distributed temperature sensing } \\ \text { GBNP } & \text { Great Basin National Park } \\ \text { HSU } & \text { hydro stratigraphic unit } \\ \text { LVVWD } & \text { Las Vegas Valley Water District } \\ \text { Ma } & \text { million years ago } \\ \text { MT } & \text { magnetotelluric } \\ \text { NDOW } & \text { Nevada Department of Wildlife } \\ \text { PVC } & \text { polyvinyl chloride } \\ \text { SNWA } & \text { Southern Nevada Water Authority } \\ \text { UGS } & \text { Utah Geological survey } \\ \text { UNR } & \text { University of Nevada, Reno } \\ \text { USGS } & \text { U.S. Geological Survey }\end{array}$




\title{
Evaluating Connection of Aquifers to Springs and Streams, Eastern Part of Great Basin National Park and Vicinity, Nevada
}

\author{
By David E. Prudic ${ }^{1,3}$, Donald S. Sweetkind ${ }^{2}$, Tracie R. Jackson' ${ }^{1}$, K. Elaine Dotson', Russell W. Plume ${ }^{3}$, Christine \\ E. Hatch', and Keith J. Halford ${ }^{3}$
}

\section{Abstract}

Federal agencies that oversee land management for much of the Snake Range in eastern Nevada, including the management of Great Basin National Park by the National Park Service, need to understand the potential extent of adverse effects to federally managed lands from nearby groundwater development. As a result, this study was developed (1) to attain a better understanding of aquifers controlling groundwater flow on the eastern side of the southern part of the Snake Range and their connection with aquifers in the valleys, (2) to evaluate the relation between surface water and groundwater along the piedmont slopes, (3) to evaluate sources for Big Springs and Rowland Spring, and (4) to assess groundwater flow from southern Spring Valley into northern Hamlin Valley. The study focused on two areas - the first, a northern area along the east side of Great Basin National Park that included Baker, Lehman, and Snake Creeks, and a second southern area that is the potential source area for Big Springs. Data collected specifically for this study included the following: (1) geologic field mapping; (2) drilling, testing, and water quality sampling from 7 test wells; (3) measuring discharge and water chemistry of selected creeks and springs; (4) measuring streambed hydraulic gradients and seepage rates from 18 shallow piezometers installed into the creeks; and (5) monitoring stream temperature along selected reaches to identify places of groundwater inflow.

The Snake Range was formed by a generally normalfaulted uplift, where late Proterozoic and Cambrian siliciclastic rocks and metamorphic rocks are present at the highest altitudes and younger Paleozoic carbonate rocks are exposed along the flanks. The consolidated rocks are intruded by Jurassic to Tertiary age plutons, which are most common between the Lehman and Snake Creek drainage basins. Older Cenozoic rocks, including Oligocene volcanic rocks and Miocene sedimentary rocks, crop out locally and fill the basins that underlie Snake, Spring, and Hamlin Valleys. Younger Tertiary and Quaternary sedimentary (basin-fill) deposits overlie the older Cenozoic rocks.

${ }^{1}$ University of Nevada, Reno, Department of Geological Sciences and Engineering, Reno, Nevada ${ }^{2}$, U.S. Geological Survey, Geosciences and Environmental Change Science Center, Denver, Colorado 3 , U.S. Geological Survey, Nevada Water Science Center, Carson City, Nevada.
The rocks and deposits can be divided into three distinct aquifers. These aquifers include (1) basin-fill aquifers that consist of the permeable parts of the Cenozoic basin fill and some fractured or jointed Cenozoic volcanic rocks, (2) an upper carbonate-rock aquifer that consists of upper Paleozoic carbonate rocks overlying a regionally extensive middle Paleozoic siliciclastic confining unit, and (3) a lower carbonate-rock aquifer that consists of lower Paleozoic carbonate rocks. Secondary openings created by faults, shear zones, fractures, and, in the carbonate rocks, karst solution features, largely determine the water-transmitting properties of the volcanic- and carbonaterock aquifers. The basin-fill aquifers are composed of a wide variety of rock types and have highly variable hydraulic properties. The three aquifers are stratigraphically and structurally heterogeneous, causing large variations in the ability to store and transmit water. The aquifers are separated by confining units in some areas and are in contact with each other in other areas, yet function as a single, composite aquifer system. Basin-fill aquifers most often overlie or adjoin the lower and upper carbonate-rock aquifers.

Baker, Lehman and Snake Creek drainage basins were divided into five hydrologic zones on the basis of climate, geology, and topography. The five zones, from highest to lowest altitudes, are the mountain-upland, karst-limestone, upper-piedmont, lower-piedmont, and valley-lowland zones. The primary hydrologic connection between the mountainupland and the valley-lowland zones is streamflow. Much of the streamflow from the mountain-upland zone is generated above tree line.

Groundwater flow increases in the karst-limestone zone because of increased permeability caused by dissolution, which results in increased streamflow losses. Most of the increased groundwater flow is to springs near faults that form the boundary with the upper-piedmont zone. Thus, groundwater flow from the karst-limestone zone to the upper-piedmont zone was only 10 percent of the combined flow of streams and springs that exit the karst-limestone zone. About 60 percent of the water flowing from Rowland Spring in the Lehman Creek drainage basin was from streamflow losses along Baker Creek. The remaining flow from Rowland Spring comes from local recharge in the karst-limestone zone. 
In the upper-piedmont zone, the water table by Baker, Lehman and Snake Creeks was near the water level in the creeks for several hundred feet downstream from the karstlimestone zone. Water levels in piezometers along Snake Creek downstream from its confluence with Spring Creek were far below the streambed, indicating gravity drainage beneath this section of the creek. Estimated vertical hydraulic conductivity along a 3-mile reach of Snake Creek downstream of this confluence was 0.5 foot per day, which was an order of magnitude less than that estimated for Baker and Lehman Creeks. The low vertical hydraulic conductivity in the streambed along the lower reaches of Snake Creek results from chemical precipitation of calcite caused by off-gassing of carbon dioxide derived from springs at the end of the karstlimestone zone.

The younger alluvial deposits thicken rapidly across faults that form the upper boundary of the lower-piedmont zone. The absence of springs or groundwater flow to the creeks upstream of these faults indicates they are not a complete barrier to groundwater flow. The water table was shallow in the valleylowland zone in the Baker and Lehman Creek drainage basins, whereas the water table was more than 50 feet below land surface in the Snake Creek drainage basin. In contrast to thick basin fill in the valley-lowland zone in the Baker and Lehman Creek drainage basins, fractured and karst limestone underlie basin fill at relatively shallow depths in Snake Creek drainage basin. The underlying limestone acts as a drain for groundwater in the basin fill beneath Snake Creek.

A groundwater divide in southern Spring Valley south of Baking Powder Flat separates groundwater flow to the flat from southeastward flow into northern Hamlin Valley. Groundwater flow from southern Spring Valley south of the groundwater divide into northern Hamlin Valley was estimated to range from 6,000 to 11,000 acre-feet per year. This groundwater does not flow to Big Springs in southern Snake Valley; rather, the source of water to Big Springs is groundwater recharge in the Big Spring Wash drainage basin and in nearby smaller drainage basins at the south end of the Snake Range.

Groundwater flow from southern Spring Valley continues through the western side of Hamlin Valley before being directed northeast toward the south end of Snake Valley. This flow is constrained by southward-flowing groundwater from Big Spring Wash and northward-flowing groundwater beneath central Hamlin Valley. The redirection to the northeast corresponds to a narrowing of the width of flow in southern Snake Valley caused by a constriction formed by a steeply dipping middle Paleozoic siliciclastic confining unit exposed in the flanks of the mountains and hills on the east side of southern Snake Valley and shallowly buried beneath basin fill in the valley. The narrowing of groundwater flow could be responsible for the large area where groundwater flows to springs or is lost to evapotranspiration between Big Springs in Nevada and Pruess Lake in Utah.

\section{Introduction}

Great Basin National Park (GBNP) is in eastern Nevada near the border of Utah and includes about 125 square miles $\left(\mathrm{mi}^{2}\right)$ of the highest altitudes in the southern part of the Snake Range (fig. 1). The lands within the GBNP are the head-water area for streams and an important recharge area for groundwater in Snake and Spring Valleys. Streamflow generated in GBNP and groundwater in Snake and Spring Valleys are primarily used for agriculture. Large quantities of groundwater are stored in the basin-fill deposits beneath the valleys (Welch and others, 2007, p. 41). Groundwater also supports substantial areas of evapotranspiration in Snake and Spring Valleys (Welch and others, 2007; Gardner and others, 2011). The principal recharge areas for groundwater in the valleys next to GBNP are the Snake Range between Snake and Spring Valleys and the Schell Creek Range on the west side of Spring Valley (fig. 1). Estimated groundwater recharge to these valleys exceeds current water use for irrigation, stock watering, mining activities, and public and domestic supplies (Laczniak and others, 2007, p. 44, 64). Nevada and Utah share Snake Valley and its water resources. With increasing demand for water in Nevada and Utah, several proposals have been made to use the groundwater in Snake and Spring Valleys.

The National Park Service began discussions with the U.S. Geological Survey (USGS) in May 2000 about how to evaluate potential effects of groundwater pumping in Snake and Spring Valleys on water resources in GBNP. These discussions led to a USGS study to characterize surface-water resources in GBNP and to evaluate the susceptibility of those resources to groundwater pumping in Snake and Spring Valleys (Elliott and others, 2006). The initial assessment was designed to characterize the surface-water resources in GBNP first and then assess areas that were likely to be susceptible or potentially susceptible to depletions from groundwater pumping. Areas were identified in and near GBNP on the basis of geology and from water gain and loss studies along selected creeks in and near GBNP. The study began in September 2002, and data collection continued until September 30, 2004.

Results from the initial assessment identified three drainage basins on the east side of GBNP where surface-water resources potentially could be affected by groundwater pumping in Snake Valley (fig. 2). Other streams and springs were identified both east and west of GBNP on public lands managed by the Bureau of Land Management and on privately owned lands near the valley margins of Spring and Snake Valley or on the valley floors (fig. 2).

Hood and Rush (1965, p. 35) listed five suggestions for future studies during the water-resources reconnaissance study of Snake Valley that provided guidance for this study: (1) a comprehensive inventory of the water resources, including data on all existing wells, springs, and streams, both in the valleys and mountain uplands; (2) a systematic geologic study of the basin fill to evaluate the aquifer framework and its relation to the carbonate-rock aquifer; (3) the drilling of several test holes at selected sites to evaluate the relation between the 


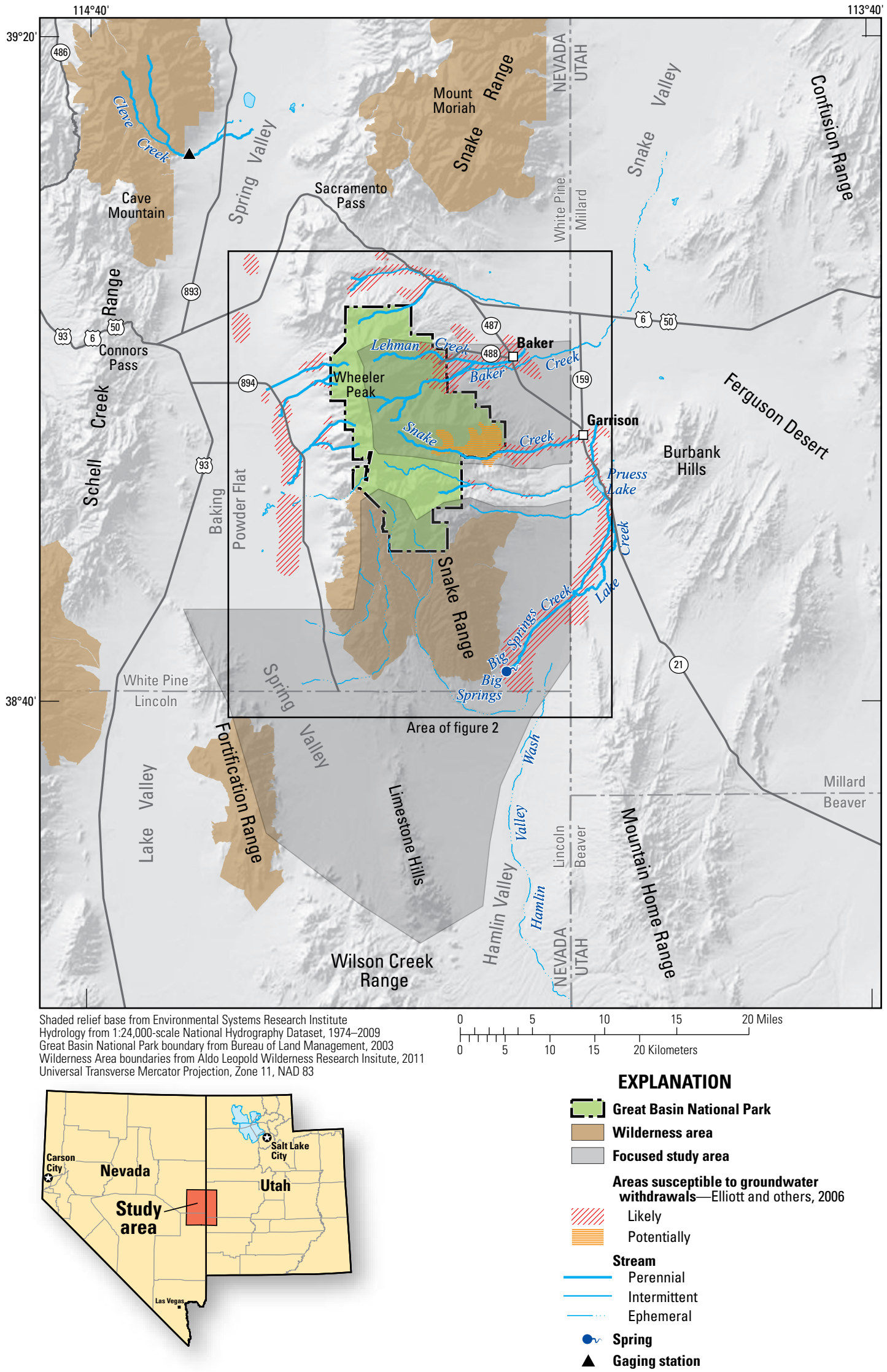

Figure 1. Location of Great Basin National Park in the Snake Range and selected features in eastern Nevada and western Utah. 


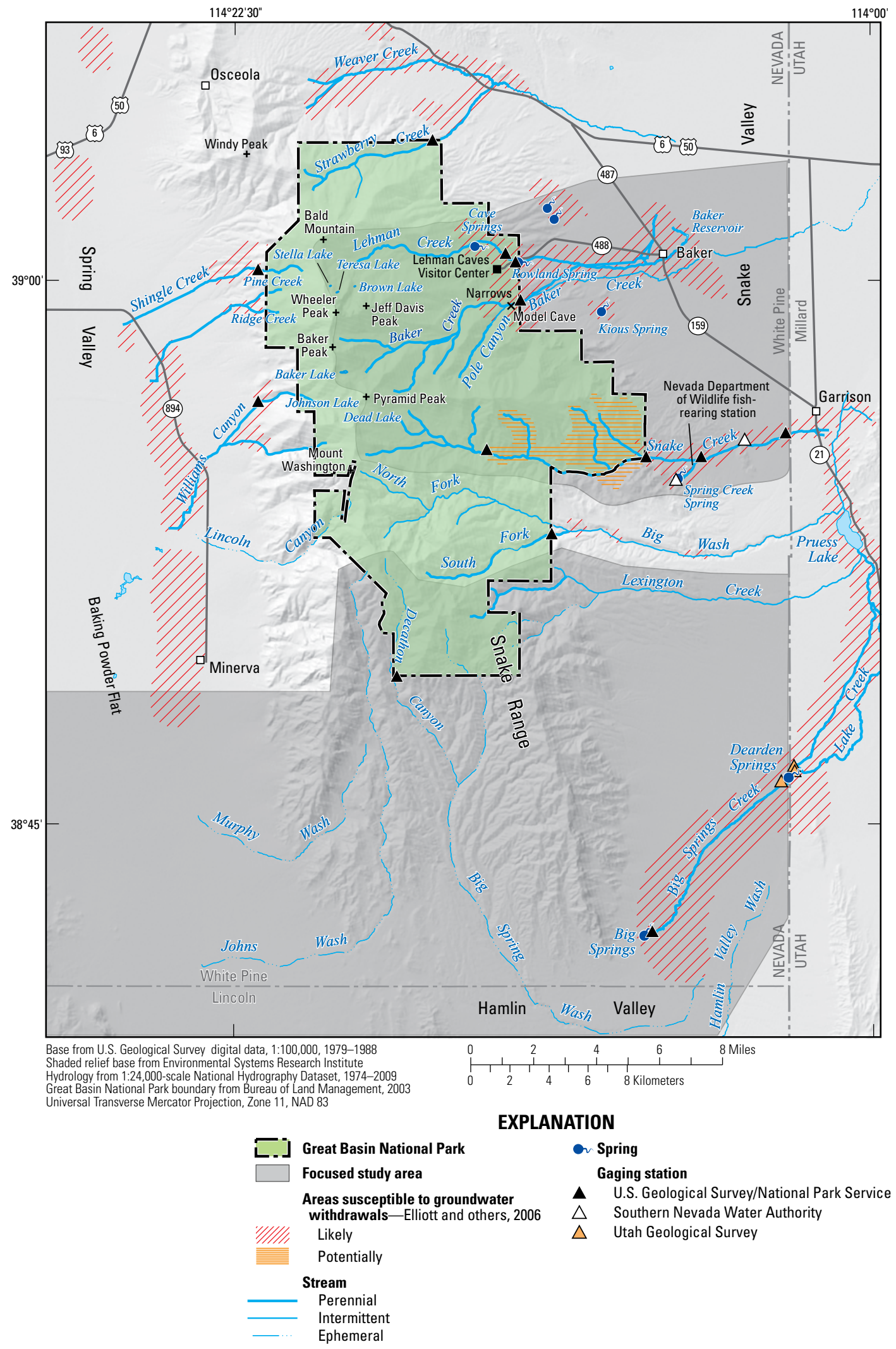

Figure 2. Location of Great Basin National Park and surrounding area in eastern White Pine and northern Lincoln Counties, Nevada. 
basin-fill and carbonate-rock aquifers; (4) the continued use of existing gaging stations and adding temporary gaging stations selected for systematic observations; and (5) continued waterlevel measurements in selected observation wells.

\section{Purpose and Scope}

Results from the Elliot and others (2006) study, and the suggestions for future studies by Hood and Rush (1965), were used to develop this study of selected areas along the eastern and southern slopes of the southern part of the Snake Range (southern Snake Range). The 4-year study that is the subject of this report began in August 2008. The purposes of this study were to gain a better understanding (1) of the distribution of aquifers that control groundwater flow on federal lands on the eastern side and south end of the Snake Range in White Pine County, Nevada; (2) of the connection between aquifers and surface water, because of the importance of ecologically sensitive areas along streams and at springs; (3) of the source areas for Big Springs and Rowland Spring; and (4) of groundwater flow from southern Spring Valley into northern Hamlin Valley (fig. 2). Results from the initial assessment by Elliot and others (2006) helped develop focused studies in two areas (fig. 2). The first area extended southward from the Lehman Creek drainage basin to the Snake Creek drainage basin and was further subdivided into two parts for the purposes of the report: a northern part that includes the water resources in the Baker and Lehman Creek drainage basins and a southern part that includes the water resources of the Snake Creek drainage basin. The second area was south of GBNP and included the south end of the Snake Range, the south end of Spring Valley (southern Spring Valley), the north end of Hamlin Valley (northern Hamlin Valley), and Big Springs in the south end of Snake Valley (southern Snake Valley; fig. 2).

The study was divided into four study elements (U.S. Geological Survey, 2008). Study element one was an assessment of the geometry and hydraulic properties of Cenozoic sedimentary rocks and coarse- and fine-grained basin-fill deposits. This element included an inventory of existing wells, the distribution of coarse- and fine-grained deposits in well drillers' logs, and aquifer testing of selected wells that were drilled for this study. Study element two was an evaluation of the streambed properties along selected reaches of Baker, Lehman, and Snake Creeks and of the interaction between surface water and groundwater. This element included analysis of streamflow losses and gains by (1) assessing differences between discharge measurements along selected reaches; (2) installing and monitoring shallow piezometers at selected locations in the streambed; (3) drilling a series of wells, and doing an aquifer test next to Baker Creek outside GBNP; and (4) monitoring stream temperature along selected reaches of Lehman and Snake Creeks. Study element three was to determine the source areas for Rowland Spring and Big Springs. Rowland Spring is near the eastern boundary of GBNP and is the largest perennial spring within GBNP. Big Springs has the most flow of the springs studied and forms the headwaters to Big Springs
Creek, which flows northeast into Utah. This element included (1) analysis of streamflow losses where alluvium along Baker and Lehman Creeks overlie limestone, (2) drilling of monitoring wells northwest and southwest of Big Springs, and (3) collection and analysis of water samples for evaluating source areas to the springs. Study element four was to assess the groundwater flow from southern Spring Valley into northern Hamlin Valley because it is a potential source of water to Big Springs (Hershey and others, 2007). This element included (1) the delineation of the groundwater divide in southern Spring Valley, (2) analyses of the geology from southern Spring Valley to southern Snake Valley, (3) analyses of coarse- and fine-grained basin-fill deposits, (4) estimates of the hydraulic gradient and aquifer properties of rocks and basin fill, and (5) geochemical analysis of water-quality samples from selected wells and springs.

This report is divided into four main sections. The first section includes the introduction, a summary of the types of geologic and hydrogeologic investigations used for this study, and a description of the regional geologic and hydrologic setting that provides a basis for the subsequent detailed studies. The second and third sections describe, respectively, detailed studies in the Baker and Lehman Creek drainage basins and in the Snake Creek drainage basin and include selected data from previously published reports. In each of these sections, the range-front hydrology is divided into five distinct hydrogeologic zones on the basis of topography, geology, climate, streamflow, and groundwater, in which the connection of aquifers to springs and streams vary. The fourth section describes the geology and hydrology in the vicinity of Big Springs and in a broader southern study area that includes potential source areas to Big Springs from southern Spring Valley eastward across the southern Snake Range and Limestone Hills to southern Snake Valley. Much of the data collected during this study, along with selected data previously collected by other state and federal agencies, are presented in the appendixes. Each appendix is briefly described at the end of the report; data associated with the appendixes are presented in tables. These tables are available for download at the persistent URL where this report is archived, http://dx.doi.org/10.3133/ pp1819.

\section{Description of Study Area}

The study area included southern Snake and Spring Valleys; northern Hamlin Valley; the southern Snake Range, which forms the topographic divide between Spring and Snake Valleys; and the Limestone Hills, which form the topographic divide between southern Spring and northern Hamlin Valleys (fig. 1). Two smaller areas were the focus of this study. These two areas included (1) the Baker, Lehman, and Snake Creek drainage basins in the GBNP to the Nevada-Utah state line and (2) an area extending from southern Spring Valley eastward across the southern Snake Range and Limestone Hills to southern Snake Valley, where Big Springs, at the margin of the valley floor, is the headwater to Big Springs Creek (fig. 1). 
The study area is sparsely populated, and the land in the valleys is used primarily for grazing cattle and sheep and for growing alfalfa, along with some corn, wheat, and oats. Besides individual ranches that are scattered along the valley floors, most people reside in three small communities in southern Snake Valley. These hamlets include (1) Baker, Nevada, which lies at the toe of the alluvial fans of Baker and Lehman Creeks; (2) Garrison, Utah, which lies at the toe of the alluvial fan of Snake Creek; and (3) a small housing development named Lehman Creek Estates, which lies next to the eastern boundary of the GBNP along the Lehman Creek drainage basin (fig. 2). The population of Baker, the largest community, was estimated at 68 in 2010 (Nevada Demographer, 2011).

Land-surface altitude in the study area ranges from 13,063 feet (ft) above mean sea level at the top of Wheeler Peak to 5,750 ft on Baking Powder Flat, in southern Spring Valley, and to 5,100 ft near where Baker Creek crosses the border between Nevada and Utah (fig. 2).

Perennial streams are mostly in the northern half of the southern Snake Range. Baker, Lehman, and Snake Creeks have the greatest streamflow and generally drain eastward into Snake Valley. Perennial streams on the west side of the range include Pine, Ridge, and Shingle Creeks, and Williams Canyon. Because the northern half of the southern Snake Range is steeper on its west side than its east side, perennial streams draining eastward to Snake Valley have longer stream lengths and larger drainage basins than those draining westward to Spring Valley.

Where the perennial streams on both sides of the southern Snake Range flow onto the alluvial fans, many have been diverted into pipelines or concrete-lined ditches. The water is then diverted to ranches on the valley floors, where the water is used for irrigation of crops. Snake Creek is the only creek that is diverted in GBNP. A pipeline diverts as much as 3 cubic feet per second $\left(\mathrm{ft}^{3} / \mathrm{s}\right)$ where the creek flows across permeable bedrock in GBNP. Although Snake Creek is intermittent along the section where water is diverted into the pipeline and along a second section near the eastern boundary of GBNP, the creek is perennial at the Nevada-Utah state line. Snake Creek and Spring Creek Spring are used to supply water to the Nevada Department of Wildlife's (NDOW) Spring Creek fish-rearing station, which lies just east of GBNP and south of Snake Creek, and the combined flow in the creek is used to irrigate crops near Garrison, Utah.

Streams in the southern half of the southern Snake Range are either intermittent or ephemeral. Intermittent or ephemeral streams that drain into Snake Valley or northern Hamlin Valley include Big Wash and Big Spring Wash. Ephemeral streams that drain into southern Spring Valley are Johns and Murphy Washes and Lincoln Canyon (fig. 2).

The largest springs in the study area are the group associated with Big Springs, which is at the south end of Snake Valley (fig. 2). Flow from these springs, along with several nearby smaller springs, forms Big Springs Creek, which flows northeast to the Nevada-Utah state line, where the creek's name changes to Lake Creek (fig. 2). Another series of springs, called Dearden Springs or Stateline Springs, add flow to the creek at the state line. Big Springs and Lake Creek are used to irrigate native pasture along their lengths. Lake Creek flows into Pruess Lake, which was dammed in the late 1800s (Meinzer, 1911). Because of leakage through the dam into underlying carbonate rocks, the lake never reached its expected size. Water from Pruess Lake and Snake Creek is used for irrigation of crops near Garrison, Utah.

\section{Previous and Concurrent Hydrogeologic Studies}

Prior to this study, information and data had been collected in the area since the late 1800s. Initial surveys, known as the Wheeler Surveys, U.S. Army, Engineer Department (Wheeler and Lockwood, 1875; Wheeler, 1875), described the geography, geology, water, plants, and animals for the region west of the 100th meridian. Reports by the USGS that focus on the water resources of the area began with an initial study of the Utah part of Snake Valley in the early 1900s (Meinzer, 1911). The first valley-wide water-resource appraisals were done in the mid-1960s (Hood and Rush, 1965; Rush and Kazmi, 1965). These reports were followed by regional studies of groundwater resources in Nevada and Utah, some of which included groundwater-flow models (Mifflin, 1968; Eakin and others, 1976; Gates, 1984; Carlton, 1985; Bedinger and others, 1990; Dettinger and others, 1995; Prudic and others, 1995; Harrill and Prudic, 1998). More recent studies, as discussed in subsequent paragraphs, have focused on data collection to provide a better understanding of the quantities of surface water and groundwater.

Water-resource appraisals of Snake and Spring Valleys by Hood and Rush (1965) and Rush and Kazmi (1965), respectively, evaluated the surface-water and groundwater resources of each respective valley and produced the first valley-wide water budgets. Rush and Kazmi (p. 24) estimated about 4,000 acre-feet (acre-ft) of groundwater from the southeastern part of Spring Valley flowed annually across the Limestone Hills into northern Hamlin Valley (fig. 1), principally from the south end of the Snake Range, and that groundwater development in the "southern part of [Spring] Valley might reduce this outflow somewhat" (p. 29). Hood and Rush (1965) concluded that about 60 percent of the groundwater recharge in Snake Valley was generated from the Nevada side (mostly from the southern Snake Range) and that "groundwater development could affect some of the springs in Snake Valley, depending on the location and extent of development" (p. 35).

Additional data collection and analysis of water resources were done for the U.S. Department of Defense as part of an MX missile-siting investigation from the mid-1970s to the early 1980s (Ertec Western, 1981a-d). During this study, numerous small-diameter borings, ranging in depth from about 90 to $200 \mathrm{ft}$, were drilled in eastern Nevada and western Utah as part of the siting investigation. Data collected from these borings were used in the design of the MX missile-basing system and to select locations to drill larger diameter test wells 
(Mason and others, 1985). The larger diameter test wells were drilled to depths between 300 and 1,400 ft and were designed to determine well yields and estimate effects of planned withdrawals. More than 70 shallow wells were drilled in Spring, Hamlin, and Snake Valleys. One larger-diameter test well was drilled in southern Spring Valley, and another was drilled east of the Limestone Hills in northern Hamlin Valley. Data collected from these test wells provided important information about the aquifer properties of the basin-fill deposits. All data collected from these studies and all test wells were given to the USGS, and most of the wells have been used for long-term monitoring (Bunch and Harrill, 1984; Mason and others, 1985; Tumbusch and Schaefer, 1996).

Since the initial application for rights to pump groundwater from Snake and Spring Valleys by the Las Vegas Valley Water District (LVVWD) in 1989, several studies have been completed, and several more are ongoing, that describe the water resources of the two valleys. Although the initial applications were filed by the LVVWD, the LVVWD became a member of the Southern Nevada Water Authority (SNWA) in 1991, along with six other agencies, for regional management of the water needs in southern Nevada. The initial applications were transferred to the SNWA in December 2003 (Southern Nevada Water Authority, 2009a). Many of the water-resource studies since 1990, particularly in Spring Valley, were funded by the LVVWD and, later, by the SNWA (Dixon and others, 2007; Southern Nevada Water Authority and U.S. Bureau of Land Management, 2008). Additional funds for specific studies also have been provided by the National Park Service, Bureau of Land Management, USGS, State of Utah (Utah Geological Survey), and Utah counties that include parts of Snake and Hamlin Valleys.

Studies by the LVVWD included an analysis of steadystate groundwater flow, streamflow, and groundwater flow (Brothers and others, 1993; Brothers and others, 1994; Broadbent and others, 1995; Katzer and Donovan, 2003). In 2005, the SNWA began an intensive geologic and hydrologic study of Spring Valley that included the drilling of several test wells and analyzing aquifer-test results (Eastman and Muller, 2009a-d; Muller and others, 2009; Prieur and others, 2009, 2010a-b; Mace and Muller, 2010a-d).

Prior to a September 2006 water rights hearing by the Nevada State Engineer's Office on the SNWA's groundwater applications filed in 1989 by LVVWD in Spring Valley, a "Stipulation" was "made and entered into between the SNWA and the United States Department of the Interior on behalf of the Bureau of Indian Affairs, the Bureau of Land Management, the National Park Service, and the Fish and Wildlife Service (collectively, the 'DOI Bureaus')" (U.S. Department of the Interior and Southern Nevada Water Authority, 2006). The Stipulation required that the SNWA implement a systematic monitoring plan in coordination with the DOI Bureaus in Spring Valley, northern Hamlin Valley, and southern Snake Valley. As of 2012, the SNWA had implemented most of the plan in Spring Valley and had produced annual status and data reports on the results of monitoring of groundwater levels, streamflows, spring flows, and water chemistry (Southern Nevada Water Authority, 2008, 2009b, 2010, 2011, and 2012). Also included in the plan was the long-term monitoring of flow at Big Springs in southern Snake Valley by the USGS and the drilling of six monitoring wells in an area near the topographic divide between Spring and Hamlin Valleys along the Limestone Hills eastward to the Nevada-Utah state line (figs. 1, 2). The monitoring of flow at Big Springs is ongoing. An exploratory well in southern Spring Valley in this area that previously had been drilled by the SNWA was selected as one of the six proposed monitoring wells. The other five drilling sites were identified in the fall of 2007 and had not been drilled as of August 2013.

Hydrogeologic studies of Snake Valley area by the SNWA were published in a Utah Geological Association Guidebook in 2009. The studies included the characterization of streams and springs (Kistinger and others, 2009), water chemistry (Acheampong and others, 2009), and characterization of the geology and hydrogeology (McPhee and others, 2009; Rowley and others, 2009).

A federal study began in 2005, following the passing of legislation (Section 301(e) of the Lincoln County Conservation, Recreation, and Development Act of 2004: PL 108-424), that directed the Secretary of Interior to study the water resources of the basin-fill and carbonate-rock aquifers in White Pine County and nearby smaller areas in surrounding counties in Nevada and Utah. This study was done cooperatively by the USGS, the Desert Research Institute, and the State of Utah (Welch, and others, 2007). The study was named BARCAS for $\boldsymbol{B}$ asin $\boldsymbol{a}$ nd $\boldsymbol{R}$ ange $\boldsymbol{c}$ arbonate-rock $\boldsymbol{a}$ quifer system. The study evaluated the (1) extent, thickness, and hydrologic properties of aquifers; (2) volume and quality of water stored in aquifers; (3) subsurface geologic structures controlling groundwater flow; (4) groundwater-flow directions and gradients; and (5) distributions and rates of groundwater flow. This study led to a greater understanding of the thickness and extent of basin-fill and carbonate-rock aquifers and to improved methods for estimating groundwater discharge from evapotranspiration. Estimates of groundwater evapotranspiration for Snake Valley greatly exceeded previous estimates and exceeded estimates of groundwater recharge. Because their analysis included multiple basins, excess water in other basins (such as Spring Valley) was balanced by assuming much of this excess water moved through permeable regions, such as the Limestone Hills between Spring and Hamlin Valleys, into Snake Valley (Laczniak and others, 2007, p. 71).

The Utah Geological Survey (UGS) began an assessment of groundwater resources in western Utah in 2005. The purpose was to evaluate potential effects from proposed groundwater pumping in eastern Nevada (Kirby and Hurlow, 2005). The assessment was completed in 2014 (Hurlow, 2014). As part of the assessment, UGS developed a groundwatermonitoring network in Utah's western deserts that included northern Hamlin and Snake Valleys (Utah Geological Survey, 2011). The monitoring network required drilling of new monitoring wells on the east side of Snake Valley in Utah, the 
establishment of gaging stations to measure spring flow, and the installation of shallow piezometers in wetlands as part of a habitat inventory. This long-term monitoring network was requested by the Utah State Legislature in response to proposed water-development projects in east-central Nevada and southwestern Utah. Objectives of the monitoring program included (1) drilling of monitoring wells near planned pumping wells to assess potential effects on groundwater resources in Utah, (2) collecting data to assess water-level and chemical trends, (3) the monitoring of flow from selected springs, (4) using aquifer tests to assess the capacity of aquifers to transmit and store groundwater, and (5) evaluating regional groundwater-flow patterns. Data from this network can be obtained from the UGS website: http://apps.geology.utah.gov/groundwater/ map.php?proj_id $=1$.

In 2007, the USGS began a federally funded water-availability study of the Great Basin carbonate and alluvial aquifer system in western Utah and eastern Nevada. The study was part of a groundwater-availability program that assesses water availability in the Nation's major aquifer systems. Specific objectives of the study included quantifying current groundwater resources, evaluating how those resources have changed over time, and developing tools to assess system responses to stresses from future human uses and climate variability (Heilweil and Brooks, 2011; Brooks and others, 2014). Although regional in scope, the study included the carbonate-rock and basin-fill aquifers in Snake and Spring Valleys; selected data collected for the study were incorporated into the analyses presented in this report.

The National Park Service has funded several studies related to the potential effects of groundwater pumping in the valleys next to the GBNP. A geophysical seismic-refraction near Lehman Creek downstream of the GBNP was completed in 2004 (David L. Berger, U.S. Geological Survey, Carson City, Nev., written commun., 2004). A geochemical assessment of the source water for Cave Springs and its relation to the carbonate-rock aquifer was done in the fall of 2007 (Prudic and Glancy, 2009). Beginning in 2009, five other studies were done. The first comprised a series of seismic-refraction surveys along Baker Creek from the eastern boundary of GBNP upstream to the Narrows (Allander and Berger, 2009). The second involved the collection of water-quality samples from Baker and Snake Creeks and, in each of their drainage basins, from selected caves and springs in February 2009 (Paul and others, 2014). The third was an audio-magnetotelluric geophysical survey along and near Baker Creek for the purpose of characterizing the range-front faults (Asch and Sweetkind, 2010, 2011). The fourth analyzed pumping effects on groundwater levels, groundwater loss to phreatophytes, and spring flows in Snake and Spring Valleys by using a numerical groundwater-flow model (Halford and Plume, 2011). The fifth was a study between September 2011 and April 2012 to determine the connection of Baker Creek and Pole Canyon with water in caves and at springs in the Baker and Lehman Creek drainage basins by placing fluorescent dyes in the creeks upstream of the limestone outcrops (Thomas Aley,
Ozark Underground Laboratory, Inc., Protem, Missouri, written commun., 2013).

Finally, several counties in Utah, funded a study of Snake Valley that began in 2010 (U.S. Geological Survey, 2011; Masbruch and others, 2014). Project objectives were (1) to improve the understanding of groundwater flow in the basin-fill and carbonate aquifers, of connections between the aquifers, and of sources of water to springs and wells in Snake Valley and (2) to constrain estimates of interbasin groundwater flow.

\section{Description of Geologic and Hydrogeologic Investigations}

Several geologic and hydrogeologic investigations were done to fulfill the objectives of this study. Descriptions of these investigations are provided in this section, including the methods used and links to data presented in the appendixes. The data and their interpretation are discussed in detail in subsequent sections of this report. Geologic investigations included (1) field mapping and evaluation of structures in the southern Snake Range and the Limestone Hills; (2) mapping of Miocene stratigraphic units along the east side of the southern Snake Range; (3) compilation and geologic interpretation of well-drillers' logs obtained from the Nevada Division of Water Resources well-log database (Nevada Division of Water Resources, 2008) for southern Spring Valley, northern Hamlin Valley, and southern Snake Valley; and (4) drilling of monitoring wells at selected sites near Baker Creek (Baker 4 aquifertest site), Snake Creek (Snake 5 wells), and Big Springs (Big Springs NW and SW wells). Well location, drilling methods, lithologic descriptions, geophysical logs, and well-completion data for each of the completed sites are summarized in appendix 1.

Precipitation and temperature records were compiled for this study. These data were obtained from the Western Regional Climate Center (2011, 2012a, 2012b) for cooperative stations near Lehman Caves; Eskdale, Utah; and Garrison, Utah. Snowpack data from the Baker Creek snow course were obtained from the Natural Resources Conservation Service (2011). Bulk-precipitation stations at high altitudes in the Snake Range and in the nearby Schell Creek Range were compiled from data published in the USGS annual water-data reports for Nevada (http://waterdata.usgs.gov/nv/nwis/); data for water years 1985-2011 are in appendix 2 along with references to annual water-data reports available in printed form.

During the study, discharge was measured at 14 sites in the Baker Creek drainage basin, at 9 sites in the Lehman Creek drainage basin, at 15 sites in the Snake Creek drainage basin between June 2009 and September 2011, and at 3 places along Big Springs Creek in November 2009. The measurements were made in an effort to quantify gains and losses along each creek. Measurements were made by personnel from the U.S. 
Geological Survey, the National Park Service, and University of Nevada, Reno. Measurements by the National Park Service were in support of this study. Discharge measurements of creeks and springs were made by using a pygmy or standard AA meter attached to a wading rod according to procedures described by Rantz and others (1982, chapter 5) and Nolan and others (2000). Measurement sites were selected on the basis of access to the creeks, the distribution of flow across the channel, and geology. These discharge measurements are summarized in appendix 3 .

Three gaging stations have been operated by the National Park Service at Rowland Spring (USGS station number 10243265), Baker Creek (USGS station number 10243240), and Snake Creek at boundary of GBNP (USGS station number 10243230) since October 1, 2004. Data collected at Rowland Spring and Baker Creek gaging stations during water years 2005-10, and at Snake Creek during water years 2005-09, were analyzed by this study to determine daily mean discharge. Daily mean discharges at these gaging stations are listed in appendix 4 along with data from four temporary gaging stations in the Baker Creek drainage basin (two on Pole Canyon, one at Model Cave resurgent spring, and one at Rosethorn spring) and one temporary gaging station at Spring Creek Spring in the Snake Creek drainage basin that were established as part of this study and operated for selected periods between June 2009 and September 2011.

Groundwater investigations included (1) the measurement of groundwater levels in many existing wells in southern Spring Valley, northern Hamlin Valley, and the Nevada part of southern Snake Valley during the spring and fall of 2009; (2) the estimation of transmissivity from 32 specific-capacities reported in well-drillers' logs; (3) 2 aquifer tests at wells completed near Big Springs during fall 2010 and 1 next to Baker Creek in October 2009; (4) an aquifer test of a domestic-supply well at the NDOW Spring Creek fish-rearing station during June 2009; (5) a slug test of a well completed in carbonate rock next to Snake Creek in June 2010; and (6) the installation of 18 piezometers in the streambed at selected locations along Baker, Lehman, and Snake Creeks and 2 streambank piezometers next to Snake Creek during summer of 2009. Groundwater measurements of wells in southern Spring Valley, northern Hamlin Valley, and southern Snake Valley were coordinated with measurements made by SNWA, the USGS Water Science Center in Utah, and the UGS. The measurements were used to develop a new groundwater potentiometric surface contour map that included all water-level measurements in the study area (Gardner and others, 2011).

Pressure transducers were used to record water level and temperature every 15 minutes in the five monitoring wells at the Baker 4 aquifer-test site next to Baker Creek between September 2009 and September 2011. Daily mean data are summarized in appendix 5. Water-level and temperature data were recorded hourly in the Snake 5 deep well next to Snake Creek between January 2010 and September 2011 and in the shallow well between June and August 2011, after water was first measured in the shallow well. Only daily mean depth to water data in the Snake 5 wells are summarized in appendix 6 because water temperature in the deep well was constant at 10.9 degrees Celsius $\left({ }^{\circ} \mathrm{C}\right)$, and water in the shallow well was only present for a few weeks. Pressure transducers also were used to record water levels hourly in the two monitoring wells near Big Springs. Daily mean water levels in the well northwest of Big Springs between November 2009 and January 2012 and in the well southwest of Big Springs between September 2010 and June 2011 are summarized in appendix 7. The data from the four aquifer tests are listed in appendixes $8-10$. Data for three slug tests at the Snake 5 deep well are listed in appendix 11. Data from an aquifer test at a monitoring well in southern Spring Valley done as part of the MX missile-siting investigation in Nevada and Utah were found in the USGS files, but no analysis of the data was ever published (Bunch and Harrill, 1984). The test data are listed in appendix 12 and were analyzed as part of this study.

Two shallow piezometers were driven at selected locations into the streambed of Baker Creek, four were driven into the streambed of Lehman Creek, and twelve were driven into streambed of Snake Creek to measure the hydraulic gradient between the creek and shallow groundwater and to estimate the streambed-seepage rate. The methods for piezometer installation and data collection used to determine the hydraulic gradient of the streambed at each piezometer, and for slug tests used to evaluate the connection of the piezometer to sediments beneath the streambed, are given in appendix 13. Methods for determining streambed-seepage rates and vertical hydraulic conductivity of the streambed are described in appendix 14, and the hourly temperature data collected at each piezometer are provided as well.

Groundwater flow to selected reaches of Lehman and Snake Creeks was evaluated by using distributed temperature sensing (DTS). DTS measures temperature by using Ramanspectra backscattered light along a fiber-optic cable (Selker and others, 2006; Tyler and others, 2009). Temperatures were measured along one 2,800-ft reach on Snake Creek immediately downstream of the eastern boundary of GBNP during the summer of 2009 and along two adjoining reaches (totaling $5,300 \mathrm{ft}$ ) from the Lehman Creek gaging station past the eastern boundary of GBNP beginning in October 2009 and ending in May 2010. Details of the installation of the fiber-optic cable in the selected reaches of Lehman and Snake Creeks are provided in appendix 15 .

Lastly, a total of 34 surface-water samples were collected from 13 sites along Baker, Lehman, and Snake Creeks between February 2009 and August 2011, and a total of 31 groundwater samples were collected from 17 springs and wells. Four surface water samples and seven groundwater samples collected in the Baker and Snake Creek drainage basins during February 2009 were for a related, but separate, study (Paul, 2014), and groundwater samples collected from Rowland Spring in the Lehman Creek drainage basin, from Marmot Spring in the Baker Creek drainage basin, and from Outhouse and Spring Creek Springs in the Snake Creek drainage basin during May 2010, as well as a sample from the 
Snake Creek 5 deep well in June 2010, were collected by the Utah Water Science Center of the USGS as part of a separate study (Philip Gardner, U.S. Geological Survey, written commun., 2011). The water samples were analyzed for different constituents, depending on the purpose of each collected sample. The samples were used to evaluate the connection of streams with aquifers and to evaluate source areas to Rowland Spring and Big Springs. Description of sample collection methods, laboratories used for the chemical analyses, the collecting agency, and the constituents analyzed at each sampling site are provided in appendix 16.

\section{Geologic Setting}

\section{Introduction}

The history of the study area is preserved in a geologic setting of rocks and geologic structures that span more than a billion years. This geology ranges from Late Proterozoic sedimentary rocks to widespread Quaternary alluvial deposits and active faults (Stewart, 1980; Hintze and Kowallis, 2009). The geologic framework strongly affects groundwater flow. Any water-resources assessment of the area can benefit from considering the complex geologic history and understanding the distribution of the diverse rock types and geologic environments.

The Snake Range is a generally north-trending normal fault-bounded uplift, where late Proterozoic and Cambrian siliciclastic rocks or metamorphic rocks are present at or near the surface (fig. 3). These rocks form the lowest parts of the consolidated rock stratigraphic section, yet are at the highest altitudes in the range, including Mount Moriah in the northern Snake Range and Wheeler Peak in the southern Snake Range (fig. 3). In contrast, outcrops of Pennsylvanian- and Permianaged carbonate rocks, some of the highest consolidated rocks stratigraphically, are widely exposed in the southern part of the Schell Creek Range to the west, and in the Burbank Hills and Confusion Range to the east, of the study area (fig. 3). These ranges feature regional-scale synclines that preserve the entire thickness of the Paleozoic consolidated-rock section (Gans and Miller, 1983). Snake Valley separates the structurally complex Snake Range from the relatively simple structure and stratigraphy of the Confusion Range to the east (fig. 3). Volcanic rocks dominate to the south of the study area where voluminous ash-flow tuffs were erupted from large volcanic calderas of the Indian Peak caldera complex. These volcanic rocks are exposed in outcrops south of the Limestone Hills, in the Fortification Range, in the Mountain Home Range (fig. 3), and in the subsurface in Spring and Hamlin Valleys (Sweetkind and du Bray, 2008).

The structural geologic setting of the study area is complex, exhibiting several ages and styles of deformation. The study area was affected by two general phases of deformation: a Late Devonian to Eocene compressional deformation characterized by regional folding and overthrusting and a subsequent Neogene extension characterized by at least two periods of normal faulting. Locally, Miocene calderas and transverse and strike-slip faults are important structural elements. Miocene-aged low-angle normal faults dominate the northern Snake Range, the northern half of the southern Snake Range, and parts of the Schell Creek Range (Gans and Miller, 1983; Bartley and Wernicke, 1984; fig. 3). Arcuate normal faults that involve Miocene sedimentary rocks and are interpreted to connect with the low-angle normal faults at depth are present to the east of Sacramento Pass and in the Snake Creek drainage basin (Grier, 1984; Miller and others, 1999; fig. 3). Young, moderate- to high-angle normal faults bound the eastern side of the Schell Creek Range, the western side of the Snake Range and the Limestone Hills, and the western side of the Mountain Home Range and are present along the eastern flank of the southern Snake Range south of Lexington Creek (fig. 3).

\section{Stratigraphy and Hydrostratigraphy}

Stratigraphic units in the study area (fig. 4) span from late Precambrian through Triassic consolidated sedimentary rocks and their metamorphic equivalents, igneous crystalline rocks that range in age from Jurassic to Tertiary, various types of Oligocene volcanic rocks, Miocene and younger semi-consolidated basin fill, and poorly consolidated to unconsolidated Tertiary and Quaternary basin-fill.

\section{Consolidated Sedimentary Rocks}

East-central Nevada and western Utah were in a region with relatively continuous deposition of predominantly marine sediments on the subsiding western continental shelf of North America from the late Precambrian through Triassic periods (Stewart and Poole, 1974; Poole and others, 1992). Where not disturbed by structural complications, this stratigraphic sequence is up to $30,000 \mathrm{ft}$-thick (fig. 4). In the vicinity of the Snake Range, most stratigraphic sections are incomplete as a result of faulting, uplift, and subsequent erosion, but can be confidently correlated with more complete sections to the west of the study area in the Egan Range (Kellogg, 1963) and to the east in the House Range, Mountain Home Range, and Confusion Range (Hintze and Davis, 2002a, 2003). Formational designations, thicknesses, and regional facies variations have been described by Langenheim and Larson (1973), Stewart (1980), Poole and others (1992), and Hintze and Kowallis (2009).

The lowest part of the stratigraphic section consists of a late Proterozoic to Middle Cambrian section of quartzite and shale, including the McCoy Creek Group, Prospect Mountain Quartzite, and Pioche Shale (fig. 4). This basal siliciclastic section is over $6,000 \mathrm{ft}$ thick, and its base is not exposed. The overlying Middle Cambrian through Devonian section consists of a Middle Cambrian to Lower Ordovician limestone section 


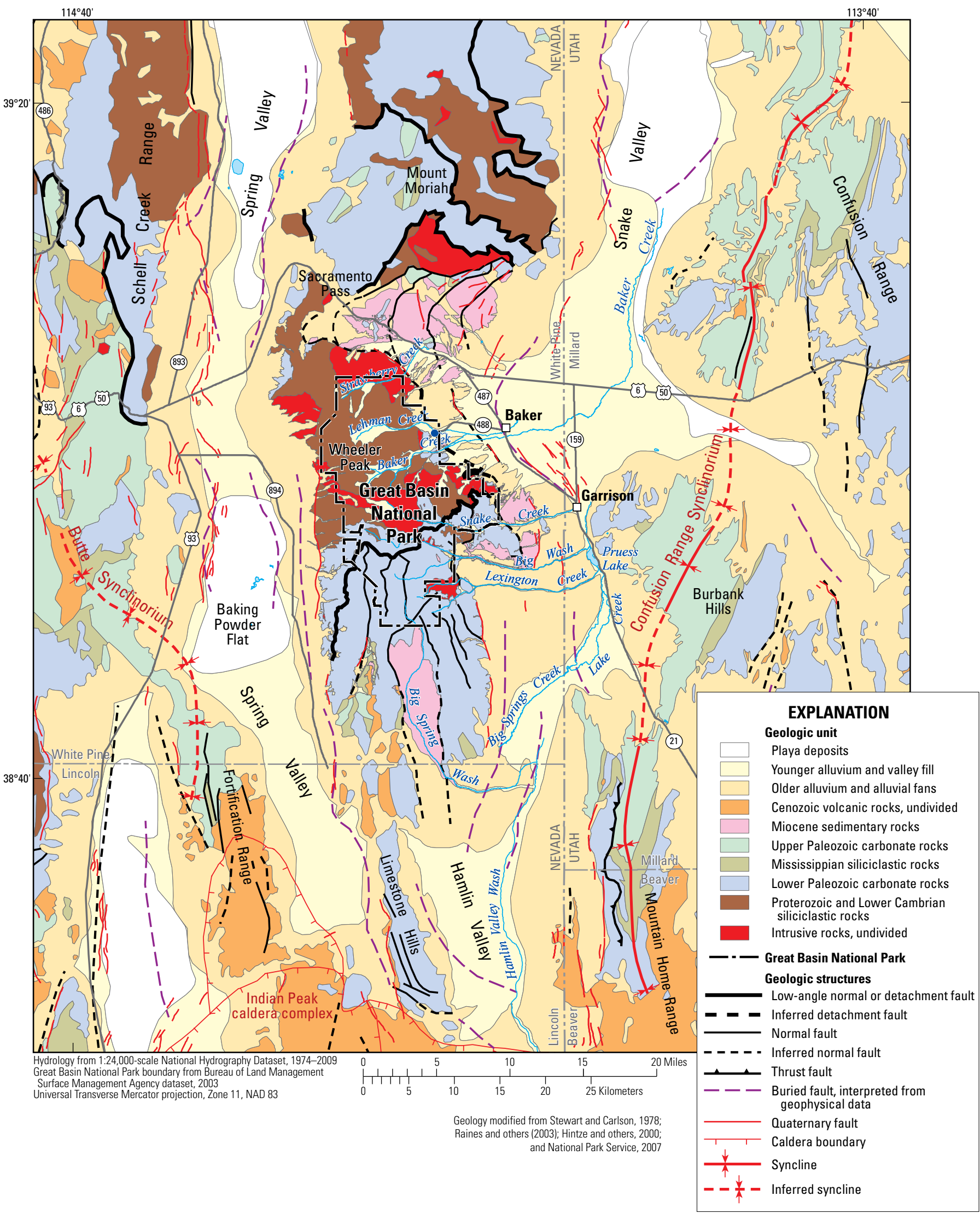

Figure 3. Simplified geologic map of southern Snake Range and vicinity, eastern Nevada and western Utah. 
Stratigraphic section, north end of southern Snake Range

\section{Stratigraphic section, south end of southern Snake Range and vicnity}

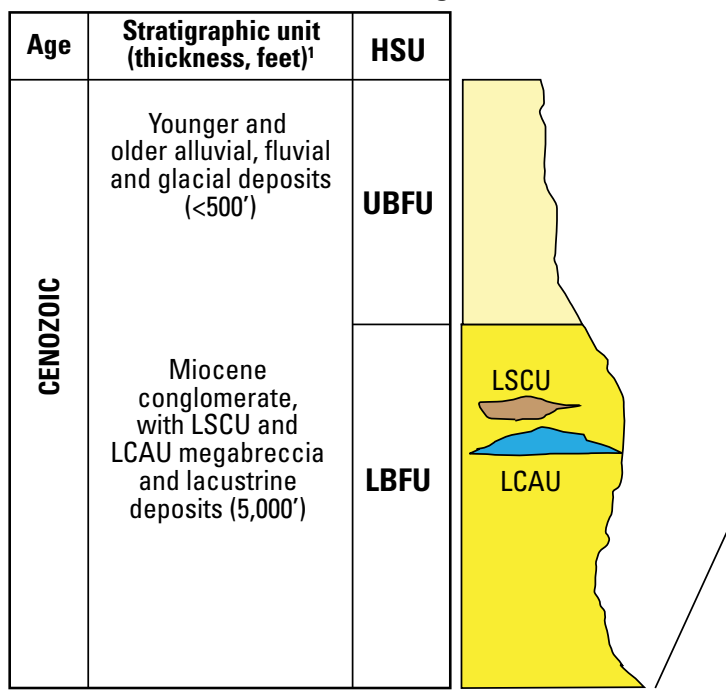

Middle Cambrian and Ordovician carbonate rocks occur as local

faulted blocks. Odrovician through Permian rocks have been removed

by faulting and are not exposed, but are possibly present in subsurface

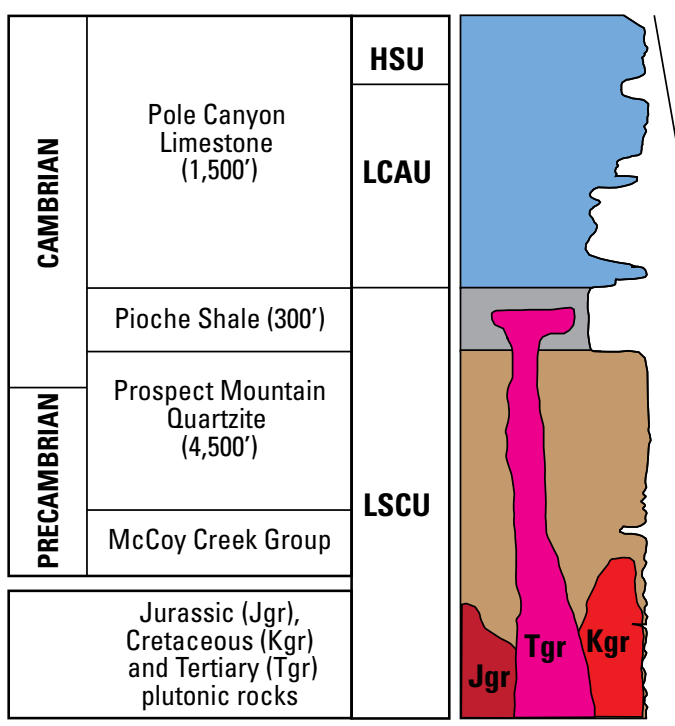

\begin{tabular}{|c|c|c|}
\hline Age & $\begin{array}{c}\text { Stratigraphic unit } \\
\text { (thickness, feet) }\end{array}$ & HSU \\
\hline \multirow{3}{*}{$\begin{array}{c}\text { Younger and older } \\
\text { alluvial and fluvial } \\
\text { deposits }\left(<500^{\prime}\right)\end{array}$} & UBFU \\
\cline { 1 - 3 } & $\begin{array}{c}\text { Miocene and Pliocene } \\
\text { basin-fill deposits }\left(5,000^{\prime}\right)\end{array}$ & LBFU \\
\cline { 2 - 3 } & Oligocene volcanic rocks & VU
\end{tabular} \mid

${ }^{1}$ Generalized unit thickness after Miller and others, 1995a.

\begin{tabular}{|c|c|c|}
\hline PERM. & Arcturus Formation $\left(2,500^{\prime}\right)$ & \multirow{2}{*}{ UCAU } \\
\hline PENN. & Ely Limestone $\left(2,500^{\prime}\right)$ & \\
\hline \multirow{3}{*}{$\begin{array}{l}z \\
\frac{z}{\alpha} \\
\frac{\alpha}{\infty} \\
\frac{\mathscr{s}}{\bar{s}} \\
\frac{\mathscr{s}}{\Sigma}\end{array}$} & Chainman Shale $\left(1,800^{\prime}\right)$ & USCU \\
\hline & Joanna Limestone $\left(500^{\prime}\right)$ & \multirow{9}{*}{ LCAU } \\
\hline & Pilot Shale $\left(500^{\prime}\right)$ & \\
\hline \multirow{3}{*}{$\frac{z}{\text { z }}$} & $\begin{array}{l}\text { Guilmette Formation } \\
\qquad\left(3,500^{\prime}\right)\end{array}$ & \\
\hline & Simonson Dolomite $\left(650^{\prime}\right)$ & \\
\hline & Sevy Dolomite $\left(1,300^{\prime}\right)$ & \\
\hline SIL. & Laketown Dolomite $\left(1,500^{\prime}\right)$ & \\
\hline \multirow{3}{*}{ 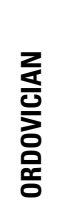 } & Ely Springs Dolomite (350') & \\
\hline & Eureka Quartzite $\left(500^{\prime}\right)$ & \\
\hline & Pogonip Group $\left(1,600^{\prime}\right)$ & \\
\hline
\end{tabular}

${ }^{2}$ Generalized unit thickness after Hintze and Davis, 2003

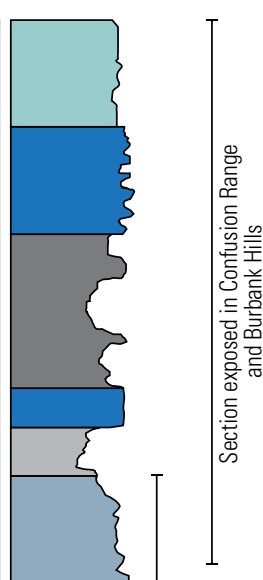

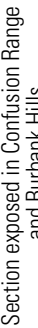

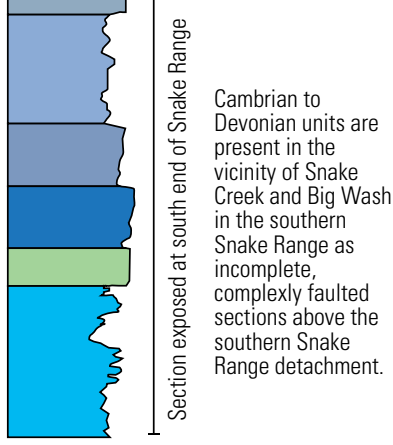

Precambrian and Cambrian units are not exposed in Confusion Range but inferred to exist at depth.

\section{Notes}

SIL., Silurian; PENN., Pennsylvanian; PERM., Permian

HSU, Hydrostratigraphic unit

UBFU, Upper basin-fill unit; LBFU, Lower basin-fill unit; VU, volcanic-rock unit

UCAU, Upper carbonate-rock aquifer unit; USCU, Upper silastic-rock confining unit

LCAU, Lower carbonate-rock aquifer unit; LSCU, Lower silastic-rock confining unit

Figure 4. Stratigraphic columnar sections, southern Snake Range and vicinity, White Pine County, Nevada. 
(including the Pole Canyon Limestone, Lincoln Peak Formation, Johns Wash Limestone, Corset Spring Shale, Notch Peak Limestone, and Pogonip Group), a distinctive Middle Ordovician quartzite (the Eureka Quartzite), and an Upper Ordovician to Middle Devonian dolomite section (including the Fish Haven and Laketown Dolomites, Sevy Dolomite, and Guilmette Formation) (Whitebread, 1969; Hose and Blake, 1976; fig. 4). Late Proterozoic to Middle Cambrian siliciclastic rocks and local exposures of Middle Cambrian carbonate rocks form most of the sedimentary rock exposed in the northern part of the southern Snake Range near Wheeler Peak (fig. 3). The Ordovician through Devonian section is present in fault-disrupted sections near Snake Creek and as an intact stratigraphic section at the south end of the range and in the Limestone Hills (figs. 3, 4).

The thick lower Paleozoic carbonate section is overlain by a Mississippian-aged mudstone, siltstone, and sandstone that represent the siliciclastic influx associated with thrust-fault uplift of the Antler orogenic event in central Nevada (Poole and Sandberg, 1977; Miller and others, 1992). This interval, which includes the Mississippian Chainman Shale and other siliciclastic rocks, is widely distributed across eastern Nevada and western Utah and, where not structurally thinned, generally ranges in thickness from 1,000 to greater than 3,000 ft (Hose and Blake, 1976; fig. 4). Chainman Shale is only present at the south end of the Snake Range as isolated, fault-bounded blocks, but it forms continuous relatively thick sections in the Confusion Range, Burbank Hills, and Mountain Home Range in western Utah (Hintze and Davis, 2002a, 2003).

The stratigraphically highest consolidated sedimentary rocks are thick, widespread Pennsylvanian and Permian carbonate-rock units that include up to 5,000 ft of Ely Limestone and Arcturus Group limestones and silty limestones (Hose and Blake, 1976; fig. 4). The only Mesozoic rocks present in the study area are minor exposures of Triassic rocks preserved in the downfolded core of the regional-scale Confusion Range syncline to the northeast of the study area (fig. 3).

\section{Igneous Crystalline Rocks}

The consolidated rocks of the Snake Range were intruded by plutons of Jurassic (from 155 to 160 million years ago, or $\mathrm{Ma}$ ), Cretaceous (from 90 to $110 \mathrm{Ma}$ ), and Tertiary (from 36 to $28 \mathrm{Ma}$ ) ages (Lee and Van Loenen, 1971; Lee and others, 1981; Miller and others, 1989). Intrusive rocks are most common in the northern half of the southern Snake Range (fig. 3), such as near Strawberry Creek and in the area between the Lehman and Snake Creeks (Whitebread, 1969; McGrew and others, 1995; National Park Service, 2007). The Prospect Mountain Quartzite, Pioche Shale, and Pole Canyon Limestone are all in intrusive contact with these plutons (fig. 3). In some instances, plutons intrude along the Pioche Shale, separating the Pole Canyon Limestone and the Prospect Mountain Quartzite (Whitebread, 1969; Miller and others, 1995b; National Park Service, 2007).

\section{Cenozoic Valley-Fill Deposits}

Older Cenozoic rocks crop out locally in the study area and underlie the alluvial basins of Spring, Snake, and Hamlin Valleys. These rocks include Oligocene volcanic rocks and Miocene sedimentary rocks. Younger Pliocene and Quaternary sedimentary deposits overlie the older Cenozoic rocks (fig. 4).

\section{Oligocene Volcanic Rocks}

The middle Tertiary geologic evolution of east-central Nevada was dominated by volcanic events that produced many ash-flow tuffs deposited during caldera-forming eruptions (Best and others, 2013). Fractured Cenozoic volcanic rocks near the major volcanic fields are locally thick enough to be important subregional aquifers that could contribute groundwater to regional flow systems in the underlying Paleozoic carbonate rocks, where the two rock types are in contact (Harrill and others, 1988; Dettinger and others, 1995). Eruption dynamics caused ash-flow sheets to be distributed as far as tens of miles from their sources, to pond in topographic lows, and to mantle topography. Near their volcanic sources, individual ash-flow sheets can be up to several hundred $\mathrm{ft}$ thick, and the aggregate thickness of the outflow deposits that erupted from multiple calderas in east-central Nevada can be thousands of $\mathrm{ft}$ thick (Sweetkind and du Bray, 2008).

The Indian Peak caldera complex, to the south of the study area at the south end of the Limestone Hills (fig. 3), erupted about 2,400 cubic miles $\left(\mathrm{mi}^{3}\right)$ of volcanic rock between about 32 and $27 \mathrm{Ma}$ (Best and others, 1989a, 2013). At least four major calderas have been identified in this complex on the basis of thick intracaldera tuff sequences and collapse breccias; two other calderas were inferred from the presence of regionally extensive ash-flow sheets (Best and Grant, 1987; Best and others, 1989a, 2013; Loucks and others, 1989; Williams and others, 1997). Best and others (1989a) estimated that ash-flow tuffs erupted from the Indian Peak caldera complex alone cover about 21,000 $\mathrm{mi}^{2}$ in east-central Nevada. Within the study area, many of the ash-flow tuffs erupted relatively early in the extensional history of the area (Axen and others, 1993). As a consequence, regionally distributed ash-flow tuffs typically are preserved deep in the stratigraphy of the downfaulted basins and often covered by thick intervals of younger sedimentary deposits. On the basis of the reported thickness of volcanic-rock outcrops in the White Rock Mountains and the Mountain Home Range, Sweetkind and du Bray (2008) estimated that volcanic rocks could be 6,000 ft thick or more in the southern part of Hamlin Valley. Seismic data in the north-central part of Hamlin Valley indicated that volcanic rocks could be about 3,000 ft thick (Shah Alam, 1990). Local outcrops of volcanic rocks are present at the north end of the Limestone Hills (fig. 3), which are a high-standing horst block that was not involved in the downfaulting that created the basins beneath Snake and Spring Valleys. 


\section{Miocene Sedimentary Rocks}

Semi-consolidated Miocene strata are present along the east flank of the southern Snake Range in the vicinity of Sacramento Pass, Snake Creek, and the south end of the range in Big Spring Wash (fig. 3). The area east of Sacramento Pass is underlain by a $5,000-10,000 \mathrm{ft}$-thick section of generally nonresistant Cenozoic strata that were deposited in a faultbounded depression between and east of the northern and southern parts of the range (Miller and others, 1995b). The section includes relatively thin Oligocene volcanic rocks at the base overlain by Miocene-aged, fine-grained, locally ash-rich lacustrine sedimentary rocks that have substantial quantities of limestone clasts, which are, in turn, overlain by coarse-grained, commonly conglomeratic, moderately to wellcemented conglomerates and other alluvial sediments (Grier, 1984; Miller and others, 1995b; National Park Service, 2007). Incorporated within the Tertiary section are coherent megablocks of Paleozoic strata and extensive lenses of monolithologic breccia that have been interpreted as landslide deposits derived from the rapidly uplifting Snake Range during major Miocene extension and uplift. Megablocks and megabreccia lenses in this section range in size from a few tens of feet to more than 1,000 ft long (Grier, 1984; Miller and others, 1995a; National Park Service, 2007). The sediments that compose the Miocene section were shed from and deposited along the flanks of the range during uplift.

\section{Tertiary and Quaternary Sedimentary Deposits}

Late Tertiary and Quaternary unconsolidated sediments blanket at least half of the study area, filling the broad, intermontane basins that formed during late Tertiary and Quaternary crustal extension. Included in these young sedimentary sequences are fine-grained sediments deposited in localized lakes in the Pliocene and Pleistocene (Reheis, 1999). Intermontane basins are typically filled with poorly sorted, stream and alluvial fan deposits of sands and gravels along the basin margins and with playa silts and clays along the basin axes.

Older alluvium, which is Quaternary and possibly Pliocene in age, tends to cap ridges and form high-standing alluvial surfaces. The younger Quaternary alluvium, which includes some glacial outwash deposits, occupies active channels and fans (Miller and others, 1995a; National Park Service, 2007).

\section{Hydrostratigraphy}

The diverse geologic units of the study area can be grouped into hydrostratigraphic units (HSUs) to help conceptualize the aquifer system. HSUs have considerable lateral extent, and each HSU includes geologic units that have similar physical characteristics in terms of their capacity to store and transmit water. Similar to hydrostratigraphic groupings used in previous studies in the Great Basin region (Winograd and Thordarson, 1975; Belcher, 2004; Welch and others, 2007; Gardner and others, 2011; Heilweil and Brooks, 2011), the consolidated pre-Cenozoic and igneous rocks of the study area can subdivided into four consolidated-rock HSUs: (1) a lower siliciclastic confining unit (fig. 4), representing lowpermeability Precambrian and Lower Cambrian siliciclastic formations and also including intrusive igneous rocks of all ages; (2) a lower carbonate aquifer unit (fig. 4), representing high-permeability Middle Cambrian through Devonian limestone and dolomite; (3) an upper siliciclastic confining unit, representing low-permeability Mississippian shale; and (4) an upper carbonate aquifer unit (fig. 4), representing highpermeability Pennsylvanian and Permian carbonate rocks. The basin-filling Cenozoic units can be generally subdivided to include three HSUs: (1) a volcanic unit (fig. 4), representing areas of volcanic rocks with highly variable permeability; (2) a lower basin-fill unit (fig. 4), representing the lower, relatively less permeable part of the Cenozoic basin fill; and (3) an upper basin-fill unit (fig. 4), representing the upper, more permeable part of the Cenozoic basin fill that includes the most recent alluvial deposits.

The hydrostratigraphic units in the study area form three distinct aquifer systems: a basin-fill system that includes permeable parts of the upper and lower basin-fill HSUs, and some Cenozoic volcanic rocks in the volcanic unit, and two consolidated-rock carbonate aquifer systems consisting of the lower and upper carbonate aquifer HSUs. Matrix permeability, which defines the rock's primary permeability, is low both for the consolidated carbonate-rock aquifers (Winograd and Thordarson, 1975) and for the welded parts of ash-flow tuff volcanic-rock aquifers (Blankennagel and Weir, 1973). Secondary openings created by faults, shear zones, fractures, and, in the carbonate rocks, karst solution features, largely determine the water-transmitting properties of these consolidated rocks. The HSUs that correspond to the Cenozoic basin-fill aquifer units include a wide variety of rock types and can have highly variable hydraulic properties. Grain size, sorting, compaction, and cementation are important influences on hydraulic conductivity of the basin-fill HSUs (Belcher and others, 2001). Each of these units can include one or more water-bearing zones, but are stratigraphically and structurally heterogeneous, resulting in a highly variable ability to store and transmit water.

In parts of the study area, the three aquifer systems can be separated by less permeable rock units, such as consolidated siliciclastic rock HSUs or low-permeability zones in the Cenozoic units. In some places, two or more of the aquifer systems can be in contact with each other and function as a single composite aquifer. The Paleozoic carbonate rocks of the lower carbonate aquifer unit are underlain at depth by the lower permeability siliciclastic and crystalline rocks of the lower siliciclastic confining unit. Where not structurally disrupted, the upper and lower carbonate-rock aquifer HSUs are separated by the intervening low-permeability upper siliciclastic confining unit HSU. This succession is present in the ranges to the east of Snake Valley and can be inferred at depth beneath parts of Snake Valley. In the Snake Range itself, the upper part of the Paleozoic section is missing, and the lower siliciclastic and lower carbonate HSUs are exposed at the surface. Throughout most of the study area, basin-fill aquifers most often overlie or adjoin the lower and upper carbonate aquifer HSUs. 


\section{Structural Geology}

The oldest structural features in the study area are compressional folds and thrust faults. From the Late Jurassic through the early Tertiary periods, the entire width of northern Nevada was compressed in a general west to east direction. During this time, western Utah and eastern Nevada were strongly affected by a major east-directed thrust fault system; the deformational event in this area has been called the Sevier orogeny (Armstrong, 1968). In the study area, regional folds in the carbonate-rock section are the main manifestation of this deformational belt. Two regional synclines are present in the study area, the Butte and Confusion synclinoriums (Hose, 1977). These structures have broadly sinuous, but generally north-trending, fold axes, and they preserve rocks as young as Triassic in the core of the fold and have the entire Paleozoic carbonate-rock section present beneath (fig. 3). A small thrust related to the Sevier deformation is exposed in the Mountain Home Range; Mesozoic-age structures are not evident in the southern Snake Range itself.

Cenozoic deformation of the region is characterized by a variety of structural patterns that overlap in space and time and include the following: (1) local extreme extension along detachment faults associated with the development of metamorphic core complexes and the development of greatly extended zones (Wernicke, 1992); (2) generally younger basin-range extension along steeply dipping faults; (3) development of discrete strike-slip faults and transverse structures that accommodate slip between adjacent normal fault domains; and (4) Cenozoic volcanism that preceded and was contemporaneous with regional extension, creating huge caldera complexes and depositing voluminous material into the evolving basins.

Prior to regional extension and block faulting that created much of the present Basin and Range physiography, large-magnitude extension in localized highly deformed and extended areas created metamorphic core complexes (Coney, 1980; Armstrong, 1982; Wernicke, 1992, 2013). Largemagnitude extension in the study area was along a gently to moderately dipping extensional fault (Cooper, 2008; Cooper and others, 2010) that has been called the Snake Range décollement by Miller and others $(1983,1999)$, but is here referred to as a detachment fault, as these features are often called (Armstrong, 1982; Wernicke, 1992, 2013). In the northern Snake Range, the gently dipping detachment fault generally separates ductilely deformed and metamorphosed Neoproterozoic and Cambrian rocks that lie beneath the fault from the highly faulted, brittle, deformed, non-metamorphosed Paleozoic rocks above it (Miller and others, 1983; Cooper and others, 2010). In the southern and central parts of the northern Snake Range, the detachment fault generally follows the top of the Lower Cambrian Pioche Shale (Miller and others, 1983), but in the northern part of the range, the fault cuts upsection, and the Middle Cambrian Pole Canyon Limestone is present beneath the detachment fault (Cooper and others, 2010). On the basis of seismic reflection data, the moderately dipping detachment fault was interpreted to dip beneath Snake Valley and the Confusion Range to the east of the northern and southern Snake Range (Allmendinger and others, 1983).

The magnitude of extension and intensity of lower-plate deformation decrease to the south in the southern Snake Range (Miller and others, 1999), but the detachment fault can be mapped to the south end of the Snake Range (McGrew and others, 1995; Miller and others, 1999; National Park Service, 2007). The southern Snake Range detachment fault approximately parallels the northeastern boundary of the GBNP from Strawberry Creek southward to about 2 miles north of Snake Creek and then trends southwest across the crest of the range (fig. 3). In the southern Snake Range, rocks beneath the detachment fault include the Neoproterozoic and Lower Cambrian Prospect Mountain Quartzite, the Lower Cambrian Pioche Shale, the Middle Cambrian Pole Canyon Limestone, and intrusive rocks of various ages (McGrew and others, 1995; Miller and others, 1999; National Park Service, 2007). These rocks exhibit low-grade metamorphism and brittle-toductile fabrics. Above the detachment, Lower Paleozoic rocks are brittle, deformed, and complexly faulted, particularly in the vicinity of Snake Creek and Big Wash (McGrew, 1993; McGrew and others, 1995; fig. 3).

Thick sections of partly consolidated to consolidated Miocene sedimentary rocks are exposed to the north of the Lehman Creek, in the vicinity of Sacramento Pass along U.S. Highways 6 and 50, and to the south along Snake Creek and Big Wash (fig. 3). These thick, west-tilted sections of middle Miocene rocks overlie the southern Snake Range detachment fault and were derived from the Snake Range during middle Miocene faulting and related uplift (McGrew, 1993; McGrew and others, 1995; Miller and others, 1999). The stratigraphy and structure of the Miocene section in the vicinity of Sacramento Pass have been described in detail (Gans and Miller, 1983; Grier; 1984; Miller and others 1995b); these exposures provide insight into the history of faulting that led to the uplift of rocks in the northern and southern Snake Range and the development of the topography of this region. The Sacramento Pass section is tilted moderately to the west and is repeated by three major down-to-the-east listric normal faults (Grier, 1984; Miller and others, 1995b; National Park Service, 2007). Geologic maps portray these faults as arcuate in shape and merging with the Snake Range detachment fault to the north and the range-front fault to the south (Grier, 1984; Miller and others, 1995b). In cross section, these normal faults are scoop-shaped, in the hanging wall of the detachment fault, and are interpreted to merge with the detachment fault at shallow depth (Grier, 1984; Miller and others, 1995b). Tilted Tertiary strata are in fault contact with bedrock of the southern and northern Snake Range along the Snake Range detachment fault, which is inferred to have been responsible for the uplift of the range and is the dominant structural feature on the east side of the range (Gans and Miller, 1983; Grier; 1984; Miller and others, 1999; Cooper, 2008; fig. 3). East of the northern Snake Range, seismic data have been interpreted to indicate that the detachment fault dips gently eastward beneath Snake 
Valley and continues with minimal offset beneath the western part of the Confusion Range (Allmendinger and others, 1983; McCarthy, 1986).

Generally, the Basin and Range physiography of eastcentral Nevada is the result of Miocene through Holocene extension that created steeply dipping, range-bounding faults and intervening downfaulted basins (Zoback and others, 1981; Stewart, 1998). These faults have produced elongate mountain ranges and intervening Neogene basins. Moderately-dipping, listric to planar, extensional faults, with several thousands of feet of displacement, separate basins from ranges on one, or in most cases, both sides (Dohrenwend and others, 1996). Most of the range-bounding faults strike north and are relatively straight or gently arcuate. Locally, ranges are bounded by multiple en-echelon fault segments, rather than a single fault (Kleinhampl and Ziony, 1985). Some basins have a half-graben form in which the basin fill and basin floor are tilted toward a master fault on one side of the basin; this fault accommodates much of the extensional deformation and subsidence, producing a tilted, asymmetric basin (Stewart, 1998). More commonly, basins have the form of a symmetric graben, with major faults bounding both sides of the basin (Stewart, 1998; Watt and Ponce, 2007).

\section{Geophysics and Investigation of Basin Shape and Depth in Study Area}

Regional gravity investigations and models have played a critical role in defining major basin-bounding and intrabasin faults, the thickness of Cenozoic geologic units, and the subsurface three-dimensional geometry of pre-Cenozoic rocks (Saltus and Jachens, 1995; Blakely and Ponce, 2001; Mankinen and others, 2006; Watt and Ponce, 2007; Mankinen and McKee, 2009). The pre-Cenozoic basement rocks are much denser than the overlying Cenozoic volcanic rocks and sedimentary basin fill, which can be used to estimate the depth-to-basement in Cenozoic basins (Saltus and Jachens, 1995). Gravity measurements are mathematically inverted to produce a map of regional-scale thickness of Cenozoic deposits (fig. 5), also referred to as "depth to pre-Cenozoic basement" (Watt and Ponce, 2007). The inversion process to determine the thickness of Cenozoic deposits is subject to a number of limitations, including the following: (1) gravity data coverage, especially for stations on basement outcrops; (2) accuracy of the density-depth function; (3) accuracy or scale of geologic mapping; and (4) simplifying assumptions regarding concealed geology (Watt and Ponce, 2007). A more detailed discussion of the accuracy and limitations of the inversion method are provided by Jachens and Moring (1990). Because of the regional depth-to-basement process, limitations mentioned previously, and the inherent ambiguity in the gravity method, caution needs to be exercised when thicknesses less than 1,500 ft are interpolated (Watt and Ponce, 2007).

Gravity data revealed that most of the valleys are underlain by basins in which the long axes run north-south (fig. 5) and that contain one or more elongate sub-basins (Watt and Ponce, 2007; Mankinen and McKee, 2009). According to estimates based on the inversion of regional gravity data, most basins reach depths to pre-Cenozoic basement of about $5,000 \mathrm{ft}$; some exceed 10,000 ft in depth, and the deepest basins are in northern Lake and Spring Valleys and in localized areas in Snake and Hamlin Valleys (fig. 5). Some of the valleys outside of the study area are underlain by basins with a half-graben structure and a dominant range-front fault on one side of the basin (Watt and Ponce, 2007). Some valleys are more symmetric and have a graben beneath the valley axis with shallow pediments on either side (Watt and Ponce, 2007; Mankinen and McKee, 2009). The valleys that flank the southern Snake Range have several sub-basins with different extensional dynamics. In between these sub-basins, transfer zones have developed to accommodate differential extension. A number of basins have several sub-basins (fig. 5) separated by buried, structurally controlled, intrabasin highs (Watt and Ponce, 2007; Mankinen and McKee, 2009).

\section{Descriptive Geology of Valleys in the Study Area}

\section{Spring Valley}

Spring Valley is bordered by the Schell Creek Range to the west and the Snake Range to the east; the southernmost part of Spring Valley is bounded by the Fortification Range to the west and the Limestone Hills to the east (fig. 1). The valley is a graben with large, high-angle, basin-range faults (fig. 3) bounding both sides of the valley (Mankinen and others, 2006; Dixon and others, 2007; Watt and Ponce, 2007). Pleistocene, if not Holocene, fault scarps follow the western side of the valley, and Holocene scarps are present farther to the east, away from the range front (Dohrenwend and others, 1996). Late Pleistocene faults follow the western base of the southern Snake Range. Spring Valley is covered by Quaternary sediments, and a late Pleistocene lake covered most of the valley (Reheis, 1999). Lacustrine sediments are at and near land surface in much of the valley.

Gravity data indicated that the Cenozoic section throughout most of Spring Valley is less than 3,000 ft deep (fig. 5) and that the basin is segmented into local sub-basins separated by buried bedrock highs (Mankinen and others, 2006; Watt and Ponce, 2007). In the north-central part of the basin, an east-dipping normal fault at the eastern base of the Schell Creek Range has displaced Tertiary and Quaternary rocks to a depth of at least $6,000 \mathrm{ft}$ (Gans and others, 1985). This deep northern basin is separated from the southern half of Spring Valley by an east-west trending structural high that, at least partly, is composed of Tertiary volcanic rocks (Mankinen and others, 2006). A central sub-basin is present south of where U.S. Highway 6 and 50 crosses the valley (fig. 5). Cenozoic basin fill in this sub-basin, which underlies Baking Powder Flat, is mostly less than 3,000 ft thick (fig. 5), except for a 


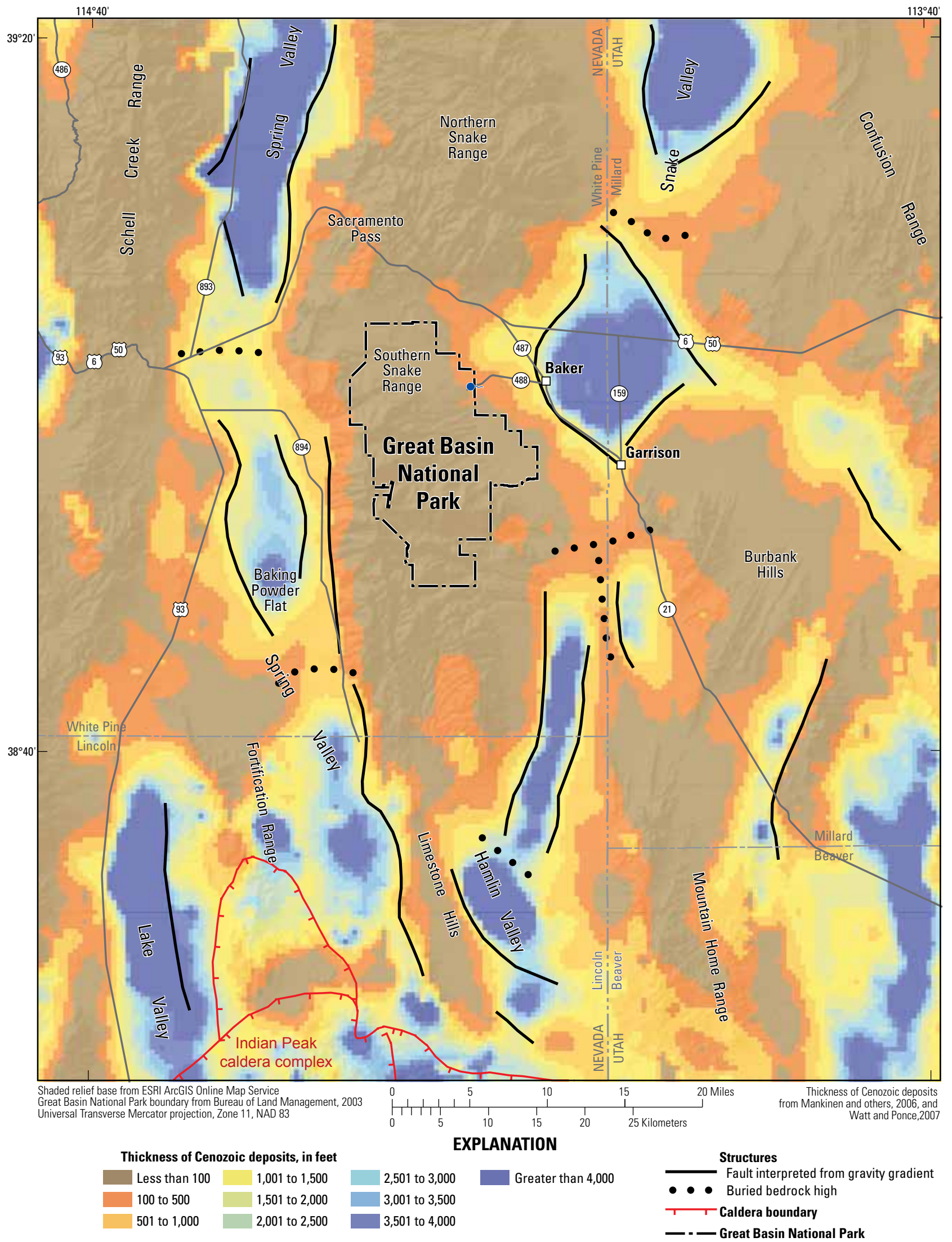

Figure 5. Thickness of Cenozoic basin fill for the study area, eastern Nevada and western Utah. 
small circular area at its south end (Mankinen and others, 2006; Watt and Ponce, 2007). The southernmost sub-basin in Spring Valley is separated from the northern parts of the valley by a northeast-southwest trending basement high visible in the gravity data (fig. 5). Density variations in the pre-Cenozoic basement rocks in the vicinity of this buried high (Watt and Ponce, 2007) indicated that the basement rocks are Paleozoic carbonate rocks. The southern sub-basin, between the Fortification Range and the Limestone Hills, is up to 5,000 ft deep in places and was shown by audio-magnetotelluric data to be internally faulted (McPhee and others, 2006, 2008).

\section{Hamlin Valley}

Hamlin Valley is graben, bounded on the west by the Limestone Hills (fig. 3), which contain east- to southeast-dipping lower Paleozoic carbonate rocks (Rowley and others, 2009). Carbonate rocks on the east side of the valley in the Mountain Home Range are mostly upper Paleozoic rocks. These rocks are folded into a tight anticline-syncline pair and disrupted by a small thrust fault on the west side of the range (Hintze and Davis, 2002a). The northern margin of the Indian Peak caldera complex underlies southern Hamlin Valley (fig. 3). Ash-flow tuff erupted from the caldera complex is exposed in the Mountain Home Range and, on the basis of geophysical and well data, is known to occur in the subsurface in Hamlin Valley (Best and others, 2013). The middle of the valley is covered by Quaternary and Tertiary alluvium.

The configuration of the Cenozoic section beneath Hamlin Valley is known through gravity (Watt and Ponce, 2007), seismic (Shah Alam, 1990), and drill-hole data (Hess and others, 2004). These data, discussed in a subsequent section of the report, indicated Hamlin Valley is made up of three sub-basins separated by buried bedrock highs (fig. 5).

\section{Snake Valley}

Snake Valley is bordered on the west by the Snake Range, Deep Creek Range, and the Kern Mountains and on the east by the Confusion Range and the Burbank Hills (fig. 1). The north end of the valley merges into the Great Salt Lake Desert.

West-dipping, faulted Miocene orogenic sediments are exposed east of Sacramento Pass; data from an oil and gas exploration hole to the east of Baker, Nevada (Hess and others, 2004), showed that these sediments extend in the subsurface beneath the main part of the valley. Similar Miocene sediments are exposed farther north, between the northern Snake and Kern Mountains. Volcanic rocks are thin and only locally present in Snake Valley and the flanking ranges (Hintze and Davis, 2002a, 2002b). Lake Bonneville extended south into the valley to about 3 miles (mi) north of Garrison, Utah (Hintze and Davis, 2002a, 2002b); lithologic data from shallow water wells indicated that lacustrine sediments are present in the shallow subsurface.

The Cenozoic section in Snake Valley is generally less than 3,000 ft thick (fig. 5) and, in many places, is less than
1,600 ft thick (Watt and Ponce, 2007). Thicker Cenozoic basin fill, probably mostly middle Miocene sediments, is east of Big Springs, east of Sacramento Pass, east of the Kern Mountains, and east of the Deep Creek Range. Gravity data indicated that these areas have the greatest depths to basement in Snake Valley (fig. 5), reaching at least 6,000 ft thick and locally more than 9,000 ft thick (Mankinen and others, 2006; Watt and Ponce, 2007; Mankinen and McKee, 2009).

\section{Hydrologic Setting}

The quantity and location of surface water and groundwater in the vicinity of the GBNP are dependent on the topography, geology, soil, and climate of the area. Topography is, in a large part, controlled by the geologic forces that formed the numerous mountains and valleys in the Great Basin region of Nevada and Utah. The variation in topography is critical to local climatic variability between mountains and valleys throughout the Great Basin (Houghton and others, 1975). Surface water is prevalent in mountain areas where exposed bedrock is not permeable and less prevalent where bedrock is permeable or where thick unconsolidated deposits or soils cover consolidated rocks in the mountains or valleys (Prudic and others, 1995, p. D9). In contrast, groundwater is prevalent in mountain areas where bedrock is permeable and in the valleys where thick, unconsolidated deposits cover consolidated rocks. Most groundwater in the Great Basin is pumped from unconsolidated deposits on or next to the valley floors (Harrill and Prudic, 1998).

\section{Climate}

The climate at and near the GBNP is similar in character to the rest of the Great Basin in Nevada and Utah, where the generally cooler mountains receive more precipitation than the generally warmer valleys. The most common storms form as low-pressure systems in the Pacific, dropping much of their water on the west slopes of the Sierra Nevada, the Cascade Range, and the coastal ranges south of the Sierra Nevada, prior to moving across the Great Basin (Houghton and others, 1975). These storms are most prevalent from November to April and typically result in snow accumulations in the mountain ranges of the Great Basin, but can occasionally produce heavy snowfall in the valleys as well. Continental storms are a second type of storm that result when low-pressure systems build over Nevada and Utah along cold fronts from polar-air masses brought southward by northerly winds. A third type of storm is the convective thunderstorm that results from moist air moving north from the Gulf of California and the Gulf of Mexico, which can bring intense rainfall from August to October (Houghton and others, 1975).

Mean precipitation rates range from less than 8 inches per year (in/yr) on the valley floor of southern Snake Valley to more than $32 \mathrm{in} / \mathrm{yr}$ on top of the highest peaks in GBNP (fig. 6). Mean precipitation rates for the period of record 


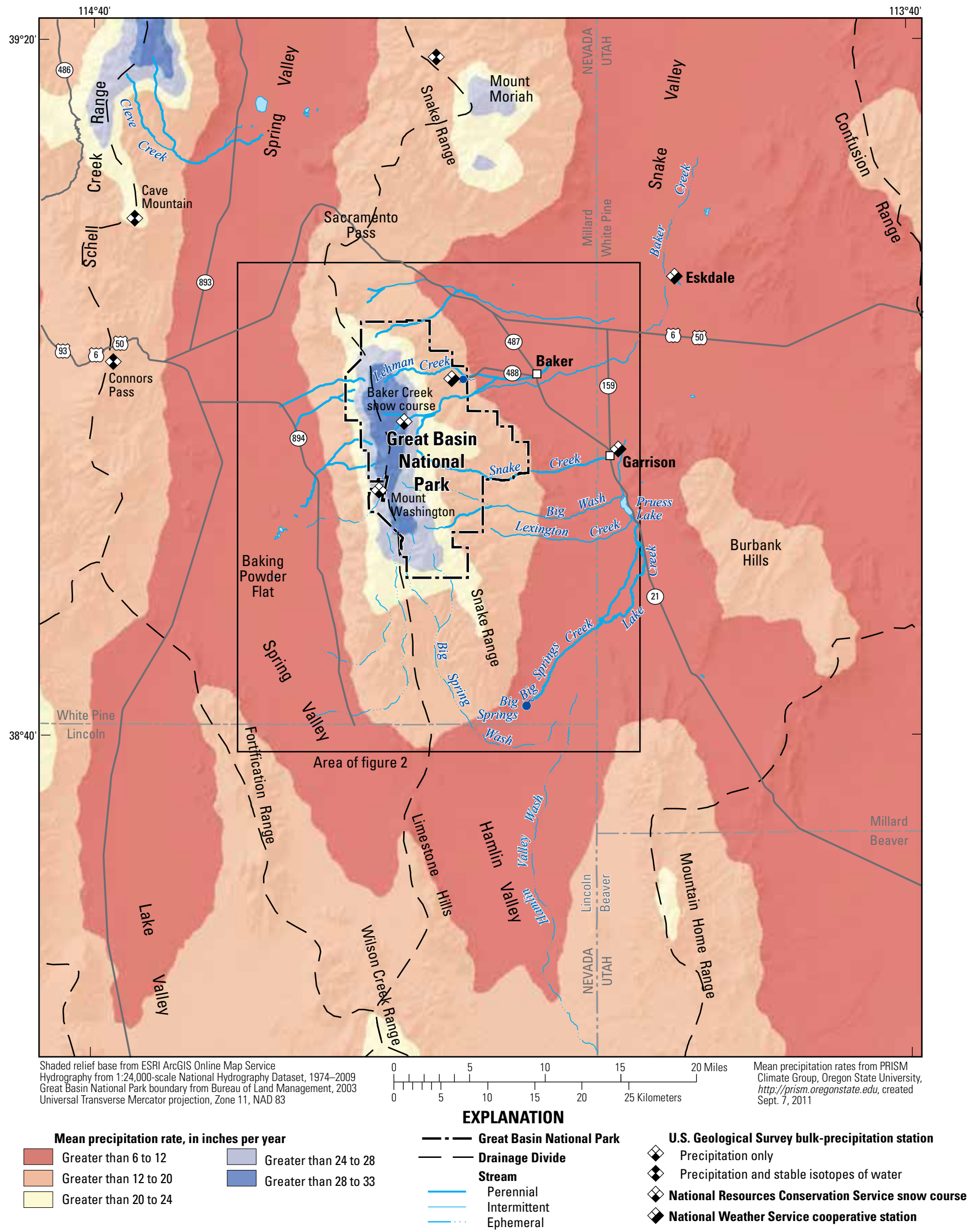

Figure 6. Mean precipitation rates from 1971 to 2000, Great Basin National Park and vicinity, eastern Nevada and western Utah. 
were $6.3 \mathrm{in} / \mathrm{yr}$ at the Eskdale weather station (water years 1967-2011), $13.2 \mathrm{in} / \mathrm{yr}$ at the weather station near Lehman Caves Visitor Center (water years 1938-1947, 1949, and 1951-2011), $18.2 \mathrm{in} / \mathrm{yr}$ at the bulk-precipitation station on top of an unnamed peak northwest of Mt. Moriah (water years 1985-2011), and 25.6 in/yr at the bulk-precipitation station on Mt. Washington (water years 1985-2011); mean precipitation rates at the various stations corresponded well to the contoured mean precipitation rates from the PRISM Climate Group shown in figure 6.

Bulk precipitation data at gaging stations was collected twice yearly, typically in May or June and again in October or November (appendix 2), but the dates varied depending on weather and snow conditions. Mean precipitation rates at the bulk-precipitation stations were divided into summer (JuneOctober) and winter (November-May) periods and compared with comparable periods for weather stations at Eskdale, Utah, and near Lehman Caves Visitor Center (fig. 7). Mean precipitation rates for water years 1985-2011 ranged widely, from 2.9 in. per winter at Eskdale, Utah, to 20.4 in. per winter at Mount Washington, whereas summer precipitation rates varied little between the two locations.
Mean annual temperature generally ranged from $10.4{ }^{\circ} \mathrm{C}$ at the weather station near Eskdale, Utah, to $9.0^{\circ} \mathrm{C}$ at the weather station near Lehman Caves (Western Regional Climate Center, 2012). Although no long-term temperature data have been collected at the highest altitudes in GBNP, the mean temperature at the top of Wheeler Peak in 2009 was $-4{ }^{\circ} \mathrm{C}$ (Reinemann and others, 2011). During 2007-09, the mean winter lapse rate between the valley floor near Baker and Wheeler Peak was $1.34{ }^{\circ} \mathrm{C}$ per $1,000 \mathrm{ft}\left(2.41^{\circ} \mathrm{F}\right.$ per $\left.1,000 \mathrm{ft}\right)$, and the mean summer lapse rate was greater than in winter at $2.15^{\circ} \mathrm{C}$ per $1,000 \mathrm{ft}\left(3.87^{\circ} \mathrm{F}\right.$ per $1,000 \mathrm{ft}$; Reinemann and others, 2011).

Variations in precipitation and temperature between Snake Valley and the southern Snake Range create a range of vegetation and habitat zones (National Park Service, 2012a). The climate in southern Snake and Spring Valleys is mid-latitude steppe and is characterized by mean precipitation rates less than $10 \mathrm{in} / \mathrm{yr}$ (semiarid to arid), cold winters, and hot summers (Houghton and others, 1975). Sagebrush (Artemisia L.) is the dominant vegetation. The climate in the higher parts of the southern Snake Range is humid continental and is characterized by mean precipitation rates in excess of $20 \mathrm{in} / \mathrm{yr}$, cold winters, and mild summers (Houghton and others, 1975).

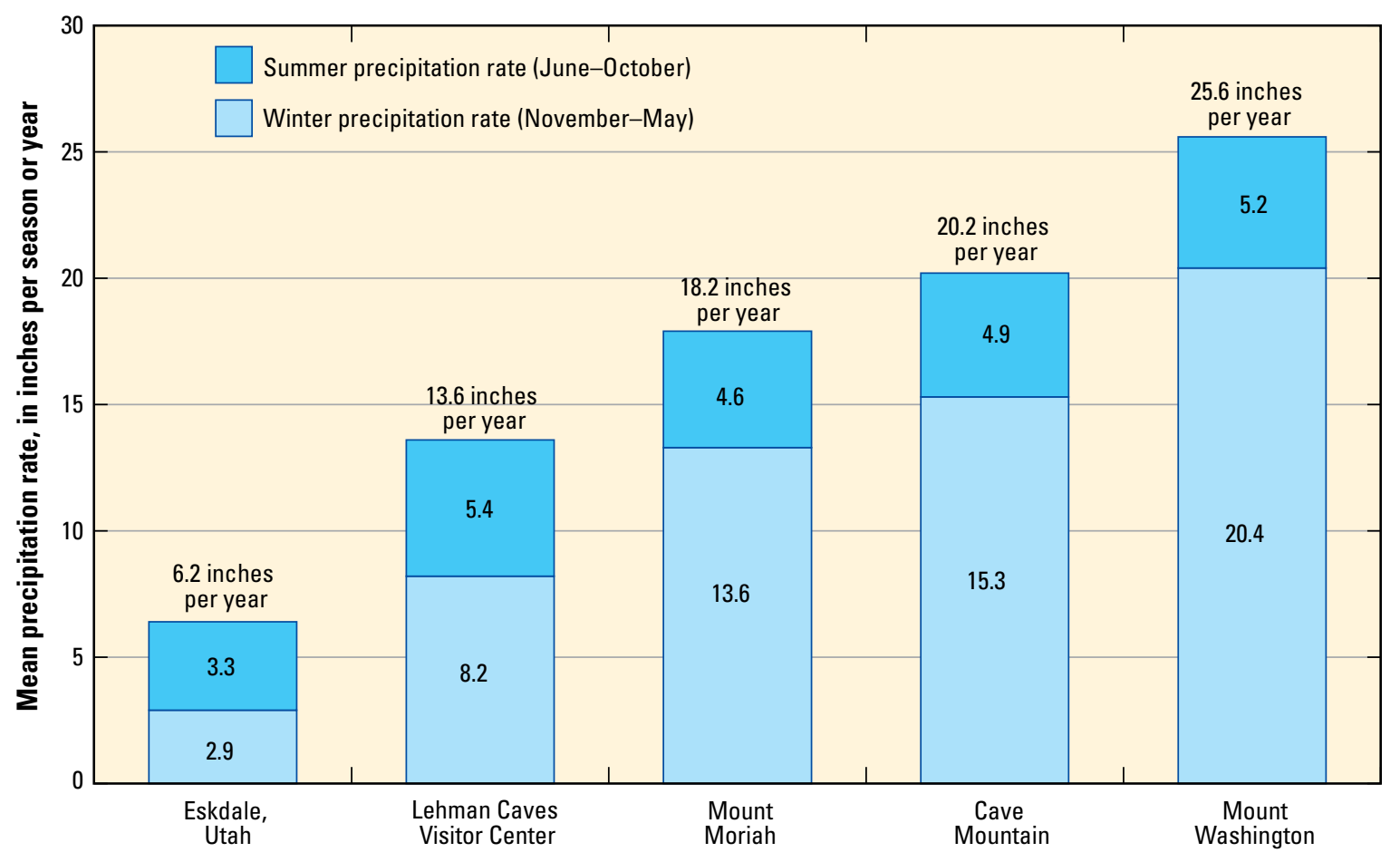

Figure 7. Variation in mean summer and winter precipitation rates for 1985-2011 at lower altitude weather stations at Eskdale, Utah, and in Great Basin National Park near Lehman Caves Visitor Center and at bulk-precipitation stations northwest of Mount Moriah, on the west slope of Mount Washington, and on Cave Mountain in the Schell Creek Range, White Pine County, Nevada. 
Pinyon (Pinus monophylla)-juniper (Juniperus L.) woodlands prevail on the lower slopes of the mountains, and aspen (Populus tremuloides)-conifer forests prevail on the higher slopes, except at the highest altitudes, where alpine tundra is dominant (U.S. Department of the Interior, 1992; Orndorff and others, 2001; Elliott and others, 2006).

Much of the precipitation in the higher parts of the mountains falls as snow beginning in October or November and continuing through March. Three snow courses in the Baker Creek drainage basin have been used to estimate the annual snowpack since the winter of 1942 (Natural Resources Conservation Service, 2011). The water content of the snowpack (snow-water equivalent, in inches) is routinely measured at the end of March or beginning of April. The data from the middle snow course are shown in figure 8 . Snowmelt usually begins in April and continues into summer, with snow at the highest altitudes melting last. Snow can remain in some protected, high-altitude areas throughout the year; an example is a small glacier that remains in the cirque, a depression carved by glacial ice, on the north side of Wheeler Peak (Osborn and Bevis, 2001).

\section{Surface Water}

Annual precipitation in the southern Snake Range, particularly at altitudes greater than $11,000 \mathrm{ft}$, generally exceeds annual evapotranspiration, so the presence of streams and lakes is largely a function of the permeability of rocks that are exposed at the surface. At lower altitudes in Snake Valley, the presence of streams is mostly dependent on streamflow from the mountains or springs near the margins of the valley. Some streams have been altered in their lower reaches by human activity to prevent or reduce water infiltration or uptake by vegetation and to allow the water to reach areas of crop production. Stream alteration includes confinement in a man-made pipe or ditch, channel straightening, and vegetation removal.

\section{Lakes}

Six small (about 3 acres or less in size) and shallow (about $20 \mathrm{ft}$ or less deep) lakes are found in depressions in the southern Snake Range, and all are in GBNP (National

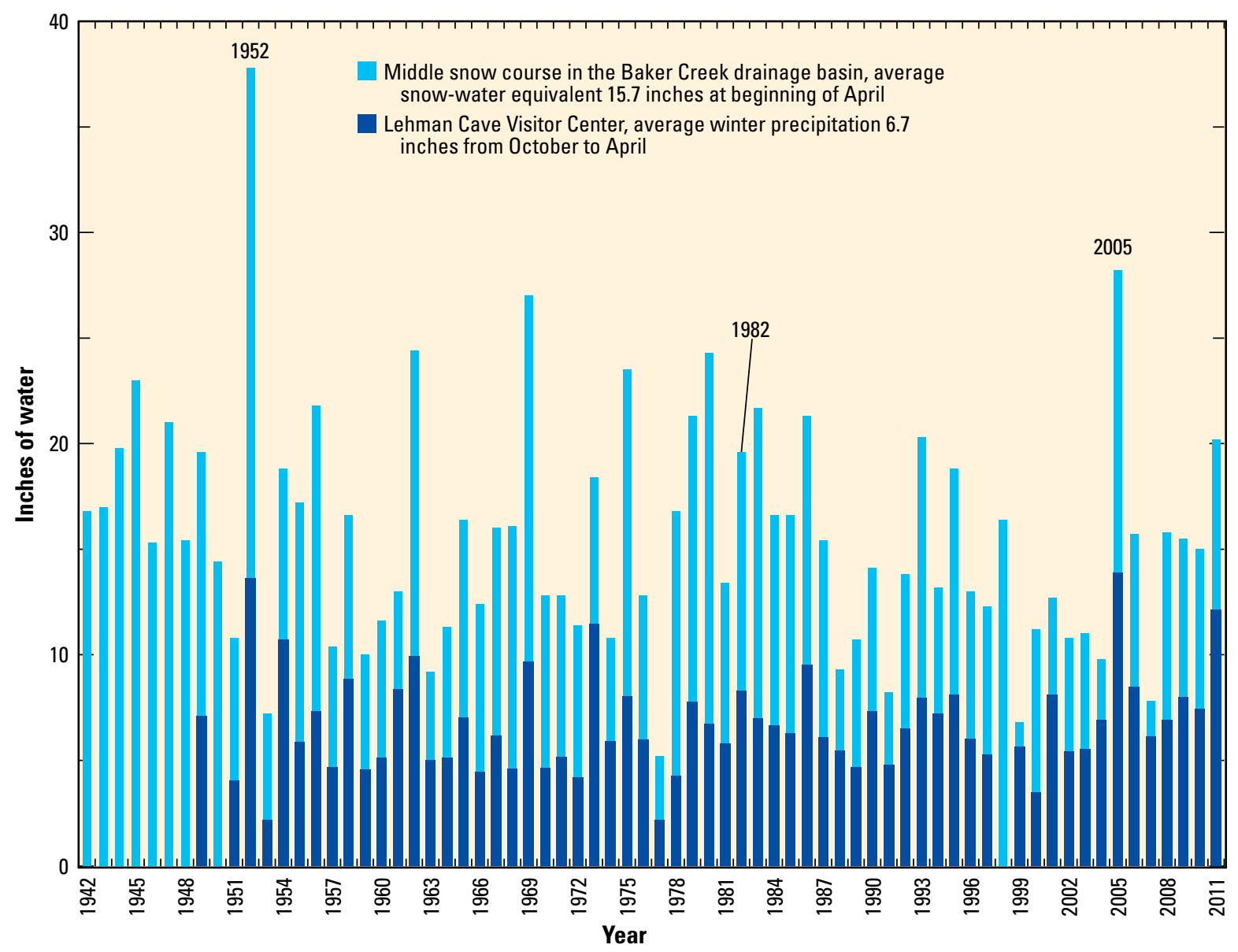

Figure 8. Annual variation in snow-water equivalent at end of March or beginning of April from 1942 to 2011 at the middle Baker Creek snow course and in winter precipitation (October-March) from 1949 to 2011 at the weather station near Lehman Caves Visitor Center, Great Basin National Park, White Pine County, Nevada. 
Evaluating Connection of Aquifers to Springs and Streams, Eastern Part of Great Basin National Park and Vicinity, Nevada

Park Service, 2012b). Stella and Teresa Lakes in the Lehman Creek drainage basin, Baker Lake in the Baker Creek drainage basin, and Johnson Lake in the Snake Creek drainage basin are cirque lakes (National Park Service, 2012b). Brown Lake in the Lehman Creek drainage basin and Dead Lake in the Snake Creek drainage basin are in depressions formed behind moraines (National Park Service, 2012b). Teresa Lake is fed by a spring at the base of a talus deposit below Wheeler Peak. Johnson Lake is also fed by a spring, but the other lakes are fed by snowmelt or from groundwater flow through glacial deposits. Surface water flows out of the cirque lakes only during snowmelt in years with abundant precipitation. No surface water flows out of Brown and Dead Lakes.

Lakes are absent in areas where Paleozoic limestone and dolomite are exposed in the southern Snake Range. A few beaver ponds and man-made ponds are present in the Big Wash and Weaver Creek drainage basins. Pruess Lake, south of Garrison, Utah, is the only natural lake on the valley floor. The lake is in a shallow depression partly blocked by Paleozoic limestone. The lake receives inflow from Lake Creek and, during high-water years, from Lexington Creek and Big Wash. A small dam was built to enlarge the lake in the late 1800s (Meinzer, 1911), but leakage through the limestone limits its storage capacity. The lake is used for irrigation of agriculture in Garrison, Utah.

\section{Streams}

Perennial streams are common in drainage basins in the northern half of GBNP where exposed rocks are Precambrian to Cambrian quartzite and Mesozoic to Cenozoic granite. Perennial streams that have headwaters in GBNP and drain into Snake Valley include Baker, Lehman, Snake, and Strawberry Creeks and the upper section of South Fork Big Wash (fig. 2). Only Baker, Lehman, Snake, and Strawberry Creeks routinely supply water to the valley floor and are used for irrigation in Snake Valley. Baker, Lehman, and Strawberry Creeks have been diverted into pipelines or concrete-lined ditches that, even during low flows, convey water across the alluvial fans. Snake Creek has a pipeline that diverts low flow (up to $3 \mathrm{ft}^{3} / \mathrm{s}$ ) around a section of Pole Canyon Limestone in GBNP (Elliott and others, 2006, p. 37). This diversion, however, is only partly effective; the creek is intermittent at the eastern boundary of GBNP during most years because of losses from infiltration into Paleozoic limestone. Baker, Lehman, Snake, and Strawberry Creeks are first- and secondorder headwater streams, and each has flow contributions from springs (National Park Service, 2012b).

Gaging stations were operated near the boundary of GBNP on Baker, Lehman, Snake, and Strawberry Creeks, and the South Fork of Big Wash from October 2002 to September 2004 (Elliott and others, 2006, p. 8). The Lehman Creek gaging station has been operated by the USGS periodically from 1947 to 2012 on Lehman Creek (table 1), and the data are available from the National Water Information System database (http://waterdata.usgs.gov/nwis). GBNP has continued to operate the gaging stations near the eastern boundary of GBNP on Baker and Snake Creeks (Gretchen Baker, National Park Service, Great Basin National Park, Baker, Nev., written commun., 2010). Snake Creek has the largest drainage area in GBNP, whereas Baker Creek has the greatest mean annual runoff (table 1).

\section{Springs and Caves}

Springs are common in GBNP and along the mountain front. Springs also are present where the toe of alluvial fans meet the valley floor. Personnel at GBNP documented more than 425 springs in GBNP between 2003 and 2004 (relatively dry years), of which 150 were in the Baker Creek drainage basin (National Park Service, 2012b). In drainage basins south of Snake Creek, underlain by limestone and dolomite, noticeably fewer springs were found.

Most of the springs in GBNP are small (discharges less than $0.1 \mathrm{ft}^{3} / \mathrm{s}$ - less than 40 gallons per minute) and are in glacial deposits that overlie low-permeability rocks (mostly quartzite and granite). The spring at the base of a large talus pile below Wheeler Peak that flows into Teresa Lake discharges at a rate greater than $0.1 \mathrm{ft}^{3} / \mathrm{s}$. Two other springs with relatively large discharges are in the South Fork of Big Wash drainage basin. The largest spring in GBNP is Rowland Spring, which is in the Lehman Creek drainage basin; the mean discharge of the spring was $2.7 \mathrm{ft}^{3} / \mathrm{s}$ in water years 2002-10 (table 1). Several other springs (discharges greater than $0.1 \mathrm{ft}^{3} / \mathrm{s}$ ) are along faults on the northeastern flank of the southern Snake Range from Weaver Creek, just north of U.S. Highway 6 and 50, south to Spring Creek Spring along the south side of the Snake Creek drainage basin (fig. 2). The mean discharge of Spring Creek Spring from June 2010 to August 2011 was $1.8 \mathrm{ft}^{3} / \mathrm{s}$ (table 1).

The gaging station on Rowland Spring has been operated since October 2002, first, by the USGS, through September 2004 (Elliott and others, 2006), then by the National Park Service (Gretchen Baker, National Park Service, Great Basin National Park, Baker, Nev., 2010, written commun.; table 1). Daily mean discharge of this spring ranged from $0.8 \mathrm{ft}^{3} / \mathrm{s}$, on January 29, 2003 (Elliott and others, 2006, p. 80), to $4.8 \mathrm{ft}^{3} / \mathrm{s}$, on July 24, 2005 (appendix table 4-2). A gaging station on Spring Creek Spring, which is a tributary to Snake Creek, has been operated by SNWA since June 24, 2009, and the daily mean discharge ranged from about $0.9 \mathrm{ft}^{3} / \mathrm{s}$, on several dates in February 2010, to $3 \mathrm{ft}^{3} / \mathrm{s}$, on several dates between July 22, and August 4, 2011 (Gavin Kistinger, Southern Nevada Water Authority, Las Vegas, Nev., written commun., 2011). Daily mean discharge also was estimated from data collected by the University of Nevada, Reno at a 9-inch Parshall flume (appendix table 4-5).

The largest spring along the eastern and southern sides of the southern Snake Range is Big Springs near the valley floor at the south end of Snake Valley (fig. 2). Big Springs has several orifices that combine to form a north and south channel. Both channels have gaging stations that have been operated 
Table 1. Index of gaging stations in the southern part of Snake Range and Snake Valley, Great Basin National Park, and Cleve Creek in nearby Schell Creek Range, White Pine County, Nevada.

[Station number and name are from source agency. USGS, U.S. Geological Survey; NPS, National Park Service; SNWA, Southern Nevada Water Authority; UGS, Utah Geologica Survey. Data can be obtained from source agency. Horizontal coordinate information is referenced to the North American Datum of 1983 . Land-surface altitude is referenced to the North American Vertical Datum of 1988. Estimated mean annual runoff corrected to 41.9-year mean at the Cleve Creek gaging station (June 1914 through September 2011) in the Schell Creek Range except Spring Creek Spring and Big Springs north and south channel gaging stations were estimated on basis of mean precipitation during period of record to long-term mean precipitation at the Great Basin National Park weather station. Mean annual precipitation volume estimated from 1971-2000 from rates obtained from the PRISM Climate Group, Oregon State University, http://prism.oregonstate.edu. Abbreviation: mm, two digit month; yyyy, four digit year. Symbol: <, less than; -, not determined]

\begin{tabular}{|c|c|c|c|c|c|c|c|c|c|c|}
\hline \multirow[b]{2}{*}{$\begin{array}{l}\text { Gaging } \\
\text { station } \\
\text { number }\end{array}$} & \multirow[b]{2}{*}{ Gaging station name } & \multirow{2}{*}{\multicolumn{2}{|c|}{ Decimal degrees }} & \multirow{2}{*}{$\begin{array}{l}\text { Land- } \\
\text { surface } \\
\text { altitude } \\
\text { (feet above } \\
\text { vertical } \\
\text { datum) }\end{array}$} & \multirow[b]{2}{*}{$\begin{array}{l}\text { Drainage } \\
\text { area } \\
\text { (square } \\
\text { miles) }\end{array}$} & \multirow{2}{*}{$\begin{array}{c}\text { Mean } \\
\text { discharge } \\
\text { for period } \\
\text { of record } \\
\text { (cubic feet } \\
\text { per second) }\end{array}$} & \multirow{2}{*}{$\begin{array}{l}\text { Estimated } \\
\text { mean } \\
\text { annual } \\
\text { runoff } \\
\text { (acre-feet) }\end{array}$} & \multirow{2}{*}{$\begin{array}{l}\text { Total mean } \\
\text { annual } \\
\text { precipita- } \\
\text { tion volume } \\
\text { (acre-feet) }\end{array}$} & \multirow[b]{2}{*}{$\begin{array}{l}\text { Period of record at } \\
\text { gaging station } \\
\text { (mm/yyvy) }\end{array}$} & \multirow[b]{2}{*}{$\begin{array}{l}\text { Source } \\
\text { agency }\end{array}$} \\
\hline & & & & & & & & & & \\
\hline 10243700 & Cleve Creek near Ely, Nevada & 39.217 & 114.530 & 6,140 & 31.8 & 10.9 & 7,900 & - & $\begin{array}{l}06 / 1914-12 / 1916 \\
10 / 1959-09 / 1967 \\
10 / 1976-09 / 1981 \\
12 / 1982-09 / 1987 \\
03 / 1990-09 / 2011\end{array}$ & USGS \\
\hline 10243280 & $\begin{array}{l}\text { Strawberry Creek above Great } \\
\text { Basin National Park boundary near } \\
\text { Baker, Nevada }\end{array}$ & 39.064 & 114.259 & 6,840 & 7.59 & 0.58 & 630 & 8,500 & $10 / 2002-09 / 2004$ & USGS \\
\hline 10243640 & $\begin{array}{l}\text { Shingle Creek near Great Basin } \\
\text { National Park boundary near } \\
\text { Osceola, Nevada }\end{array}$ & 39.005 & 114.360 & 7,860 & 1.98 & 0.84 & 930 & 2,800 & $10 / 2002-09 / 2004$ & USGS \\
\hline 10243260 & Lehman Creek near Baker, Nevada & 39.012 & 114.214 & 6,700 & 9.01 & 5.3 & 4,100 & 12,000 & $\begin{array}{l}12 / 1947-09 / 1955 \\
10 / 1992-09 / 1997 \\
10 / 2002-09 / 2011\end{array}$ & $\begin{array}{l}\text { USGS } \\
\text { USGS } \\
\text { USGS }\end{array}$ \\
\hline 10243265 & $\begin{array}{l}\text { Rowland Spring at Great Basin } \\
\text { National Park near Baker, Nevada }\end{array}$ & 39.010 & 114.208 & 6,580 & - & 2.7 & 2,100 & - & $\begin{array}{l}10 / 2002-09 / 2004 \\
10 / 2004-09 / 2010\end{array}$ & $\begin{array}{l}\text { USGS } \\
\text { NPS }\end{array}$ \\
\hline 10243240 & $\begin{array}{l}\text { Baker Creek at Narrows near } \\
\text { Baker, Nevada }\end{array}$ & 38.991 & 114.207 & 6,730 & 16.6 & 9.5 & 7,300 & 21,000 & $\begin{array}{l}12 / 1947-09 / 1955 \\
10 / 1992-09 / 1997 \\
10 / 2002-09 / 2004 \\
09 / 2004-09 / 2010\end{array}$ & $\begin{array}{l}\text { USGS } \\
\text { USGS } \\
\text { USGS } \\
\text { NPS }\end{array}$ \\
\hline 10243230 & $\begin{array}{l}\text { Snake Creek above pipeline near } \\
\text { Baker, Nevada }\end{array}$ & 38.922 & 114.224 & 7,620 & 9.32 & 2.7 & 3,000 & 12,000 & $10 / 2002-09 / 2004$ & USGS \\
\hline 10243232 & $\begin{array}{l}\text { Snake Creek at Great Basin } \\
\text { National Park boundary near Baker, } \\
\text { Nevada }\end{array}$ & 38.919 & 114.133 & 6,190 & 22.6 & 3.9 & 2,900 & 23,000 & $\begin{array}{l}10 / 2002-09 / 2004 \\
09 / 2004-09 / 2009\end{array}$ & $\begin{array}{l}\text { USGS } \\
\text { NPS }\end{array}$ \\
\hline 1951510 & $\begin{array}{l}\text { Spring Creek Spring near Garrison, } \\
\text { Utah }\end{array}$ & 38.909 & 114.113 & 6,125 & - & 1.8 & 1,200 & - & $06 / 2009-09 / 2011$ & SNWA \\
\hline 10243233 & $\begin{array}{l}\text { Snake Creek below Spring Creek } \\
\text { near Garrison, Utah }\end{array}$ & 38.919 & 114.101 & 5,815 & 25.8 & 4.1 & 4,500 & 25,000 & $01 / 2003-09 / 2004$ & USGS \\
\hline 1951508 & Snake Creek near Garrison, Utah & 38.926 & 114.076 & 5,576 & 28.4 & 4.7 & 4,400 & 26,000 & $05 / 2008-09 / 2011$ & SNWA \\
\hline 10243233 & $\begin{array}{l}\text { Snake Creek at Nevada-Utah state } \\
\text { line near Garrison, Utah }\end{array}$ & 38.930 & 114.049 & 5,350 & 32.7 & 3.4 & 4,000 & 29,000 & $01 / 2003-09 / 2004$ & USGS \\
\hline 10243228 & $\begin{array}{l}\text { South Fork Big Wash above Great } \\
\text { Basin National Park boundary near } \\
\text { Baker, Nevada }\end{array}$ & 38.884 & 114.188 & 6,880 & 6.62 & 0.53 & 580 & 7,440 & $10 / 2002-09 / 2004$ & USGS \\
\hline 10243630 & $\begin{array}{l}\text { Williams Canyon above aqueduct } \\
\text { near Minerva, Nevada }\end{array}$ & 38.945 & 114.359 & 7,320 & 2.58 & 1.13 & 1,250 & 3,470 & $10 / 2002-09 / 2004$ & USGS \\
\hline 10243228 & $\begin{array}{l}\text { Decathon Canyon below Great } \\
\text { Basin National Park boundary near } \\
\text { Minerva, Nevada }\end{array}$ & 38.816 & 114.281 & 8,410 & 5.11 & 0.0 & $<10$ & 7,200 & $10 / 2002-09 / 2004$ & USGS \\
\hline 102432241 & $\begin{array}{l}\text { Big Springs Creek north channel } \\
\text { near Baker, Nevada }\end{array}$ & 38.699 & 114.131 & 5,570 & - & 3.8 & 2,400 & - & $10 / 2005-09 / 2011$ & USGS \\
\hline 10243224 & $\begin{array}{l}\text { Big Springs Creek south channel } \\
\text { near Baker Nevada }\end{array}$ & 38.699 & 114.131 & 5,570 & - & 6.1 & 3,800 & - & $05 / 2005-09 / 2011$ & USGS \\
\hline 68040311 & $\begin{array}{l}\text { Big Springs Creek above Deardon } \\
\text { Springs }\end{array}$ & 38.772 & 114.047 & 5,445 & - & 8.8 & - & - & 10/2009-09/2011 & UGS \\
\hline 67789745 & $\begin{array}{l}\text { East middle ditch below Deardon } \\
\text { Springs }\end{array}$ & 38.777 & 114.048 & 5,430 & - & 9.3 & - & - & $10 / 2009-09 / 2011$ & UGS \\
\hline 67948638 & $\begin{array}{l}\text { West middle ditch below Deardon } \\
\text { Springs }\end{array}$ & 38.778 & 114.043 & 5,430 & - & 6.4 & - & - & $10 / 2009-09 / 2011$ & UGS \\
\hline
\end{tabular}


by the USGS, in cooperation with SNWA, since October 1, 2005. The daily mean discharge of the combined flow at the springs ranged from $8.7 \mathrm{ft}^{3} / \mathrm{s}$, for several days in October 2005, to $12.3 \mathrm{ft}^{3} / \mathrm{s}$, on April 23, 2007 (data are from USGS, National Water Information System, http://waterdata.usgs. gov/nwis). The second largest springs are at Dearden Springs, also known as Stateline Springs, in southern Snake Valley along Big Springs Creek and Lake Creek at the Nevada-Utah state line (fig. 2). The estimated mean discharge from these springs, from October 1, 2009, to September 30, 2011, was $6.9 \mathrm{ft}^{3} / \mathrm{s}$. The discharge was estimated by using monthly totals from three gaging stations (one upstream on Big Springs Creek and two on ditches downstream of Dearden Springs) that are operated by the UGS (Utah Geological Survey, data accessed, August 20, 2013, at http://files.geology.utah.gov/esp/ snake_valley_project/sv_surface_data.htm).

The GBNP contains over 40 known caves in limestone and dolomite (National Park Service, 2012b). These caves are clustered in four geographically distinct groups in GBNP: the Lehman Hill cave system, the Baker Creek cave system, four widely scattered caves in the Snake Creek drainage basin, and alpine caves in high-altitude areas. The Lehman Hill cave system is near the Lehman Caves Visitor Center (fig. 2). The close proximity and similar orientation of the passages in the cave system indicate that these caves could have formed from a single, evolving, subsurface drainage network between Lehman Hill and Rowland Spring (National Park Service, 2012b).

The Baker Creek cave system comprises 15 known limestone caves that underlie Baker Creek (National Park Service, 2012b). Six of these caves are hydrologically interconnected, forming the cave system (Bridgemon, 1965). Lange (1958) hypothesized that all the caves were continuous at one time, and that the Narrows, which is about $500 \mathrm{ft}$ long and no more than 125 wide and $100 \mathrm{ft}$ deep, represents an area where part of the cave system collapsed. Collapse of the Narrows diverted Baker Creek, which had previously flowed northeast to Lehman Creek, into the Pole Canyon drainage basin (Lange, 1958; Bridgemon, 1965; Pease and others, 1969). Some of the caves have active underground streams that are supplied by excess water leaving Baker Creek's channel during seasonal overflow, which normally takes place from mid-June to August (Lange, 1958; Pease and others, 1969). Part of the streamflow lost to the Baker Creek cave system during spring snowmelt re-enters Baker Creek after it reemerges from Model Cave downstream of the Narrows.

\section{Groundwater}

Groundwater exists throughout the study area at varying depths and in rocks with varying ability to transmit and store water. Most groundwater in Nevada is pumped from basinfill aquifers in the valleys next to mountains because (1) the majority of people live in the valleys, (2) groundwater typically is at shallow depths, and (3) wells drilled into sand and gravel in the basin fill readily yield water (Harrill and Prudic, 1998, p. A7). The study area is no exception. In addition, the study area lies in the middle of the carbonate-rock province of eastern Nevada and western Utah (Harrill and Prudic, 1998, p. A16). This area is characterized by thick sequences of Paleozoic carbonate (limestone and dolomite) rocks in the mountain ranges that underlie basin-fill deposits at depth beneath the valleys and form a regional consolidated-rock aquifer (Harrill and others, 1988; Harrill and Prudic, 1998). Eocene and Oligocene volcanic aquifers, less than $500 \mathrm{ft}$ thick, locally overlie the carbonate rocks, where not removed by erosion.

In the mountain regions of the study area, groundwater is in thin aquifers (tens of feet thick) of unconsolidated coarsegrained alluvial and glacial deposits or in thick carbonate-rock aquifers (hundreds to thousands of feet thick). These aquifers allow for the movement of groundwater from the mountains toward the valleys. In the valleys, groundwater is in unconsolidated sand and gravel basin-fill aquifers that are hundreds to thousands of $\mathrm{ft}$ thick. Basin-fill aquifers beneath the valleys are interbedded with fine-grained silts and clays that act to confine deeper sand and gravel aquifers.

The carbonate-rock aquifers can be hydraulically connected to the basin-fill aquifers in the mountains and valleys where the carbonate-rock aquifers are overlain or can abut permeable sand and gravel. Older basin-fill deposits of Miocene age can function locally as a confining unit between the two types of aquifers either because they are well-cemented fanglomerates or they consist of thick and impermeable sequences of weathered clay, lacustrine deposits, or anhydrite.

Groundwater fills the pore spaces between individual grains in the coarse, clastic basin-fill aquifers as well as the shallow alluvial and glacial deposits in the mountains. Groundwater in the basin-fill aquifers flows through interconnected pores between individual grains, whereas groundwater in the carbonate-rock aquifers flows mostly along bedding planes, through fractures or through tubular openings caused by dissolution of the rocks by water (Davis and DeWeist, 1966). The volume of pore space in the sand and gravel parts of the unconsolidated basin-fill aquifers typically ranges between 26 and 53 percent (Morris and Johnson, 1967 , p. D20). The percentage of space from fractures and tubular openings in the total volume occupied by rock in the carbonate-rock aquifers of eastern Nevada and western Utah is much less than that, and the porosity of the carbonate-rock aquifers - although highly variable - typically ranges from less than 0.01 percent to about 10 percent, as estimated from core samples and borehole geophysical logs (Plume, 1996, p. 41-58; Harrill and Prudic, 1998, p. A15; Halford and Plume, 2011). These porosities were reported for discrete zones that are a small fraction of the total volume of the carbonate-rock thickness.

Water levels from alluvial wells and carbonate-rock wells in Snake Valley were contoured together because basin-fill and carbonate-rock aquifers have been interpreted to be hydraulically connected and to function as a single system (Gardner and others, 2011). Groundwater in the study area generally flows from higher potentiometric-surface contours in and next to the mountains to lower potentiometric-surface contours near the valley floor (fig. 9). In southern Spring Valley, groundwater 


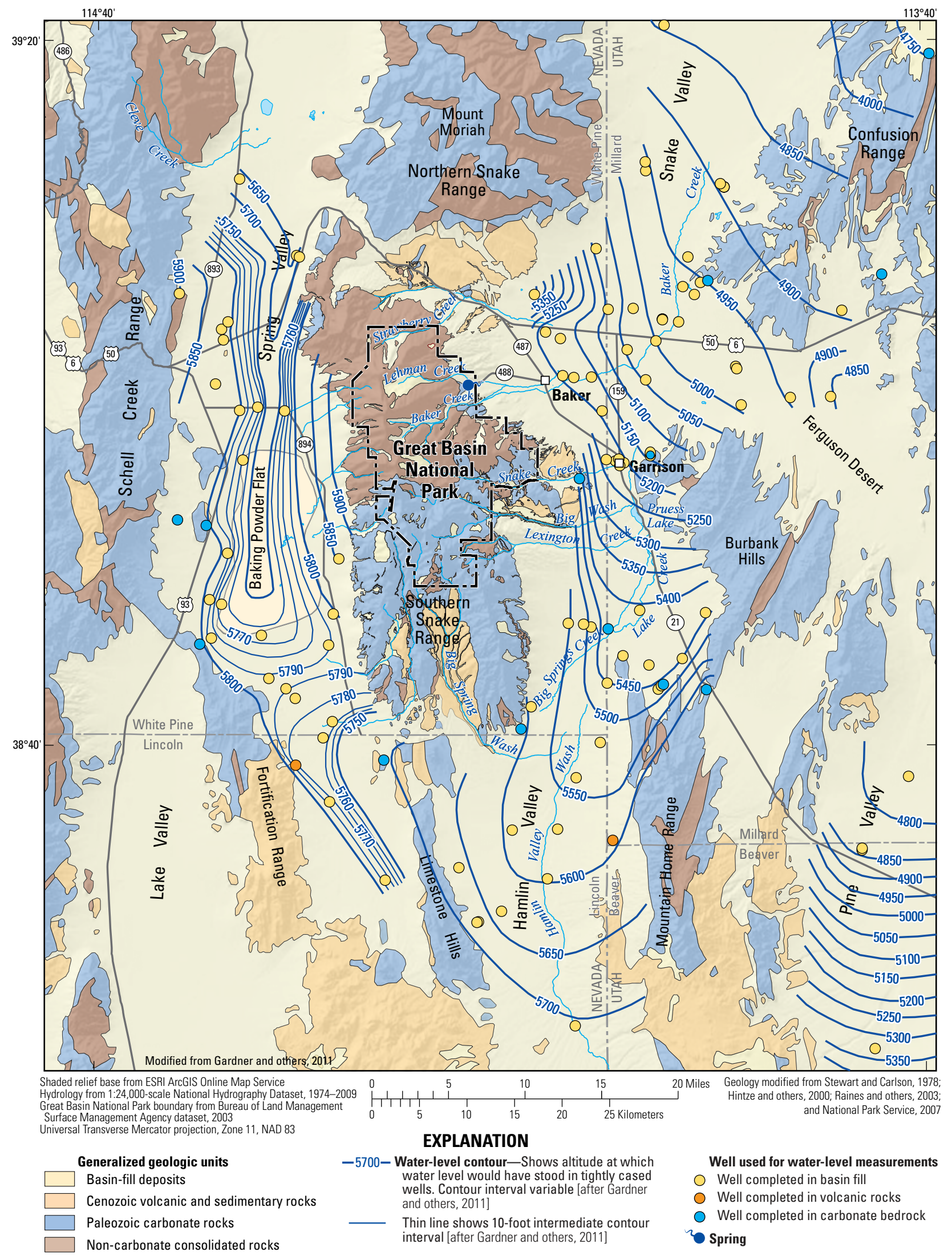

Figure 9. Potentiometric surface of groundwater for southern Snake and Spring Valleys and northern Hamlin Valley, Nevada and Utah, for late winter and early spring 2010. 
flows west from the southern Snake Range and east from the Schell Creek Range toward Baking Powder Flat, where it is the source for springs or is lost to evapotranspiration. The 5,790-foot potentiometric contours in southern Spring Valley define a groundwater divide that separates northwestward flow to Baking Powder Flat from southeastward flow toward the northern Limestone Hills (fig. 9; also, see figure 5-3 in Southern Nevada Water Authority, 2008). The location of this divide is similar to the one originally defined by Rush and Kazmi (1965, p. 20).

In southern Snake Valley, the potentiometric-surface contours indicated that groundwater flows from the southern Snake Range east to Snake Valley (fig. 9), where some of the groundwater is lost to evapotranspiration on the valley floor (Laczniak and others, 2007). Water sources on the valley floor are a combination of precipitation along with streamflow and groundwater flow from the southern Snake Range. Beneath the southernmost part of the valley floor, groundwater flows generally northeast along the valley axis.

Groundwater flow is through basin-fill aquifers in much of the Snake Valley as well as through the lower carbonate-rock aquifer beneath the western side of the valley and through the upper and lower carbonate-rock aquifers beneath the east side of the valley and the Burbank Hills. Groundwater flow is generally to the northeast, and on the basis of the potentiometric-surface contours (fig. 9), groundwater is interpreted to move from the basin-fill aquifer in Snake Valley into the carbonate-rock aquifer in the Burbank Hills and the Confusion Range (Gardner and others, 2011). Fault offset on the western sides of these ranges is minimal (Hintze and Davis, 2002a; $2002 \mathrm{~b}$ ), and the shape of the contours indicates that flow is not impeded along the western edge of these ranges. In northern Hamlin Valley and southern Snake Valley, westward flow into Pine Valley appears to be restricted by the presence of steeply dipping, low-permeability Chainman Shale on the east side of the Confusion Range synclinorium (fig. 3; also Welch and others, 2007, p. 16, plate 1; Gardner and others, 2011). Farther north, groundwater flow to the east is unrestricted in the Ferguson Desert, where carbonate-rock aquifers are buried by $300 \mathrm{ft}$ to more than 1,000 ft of basin-fill deposits (Gardner and others, 2011), and in the Confusion Range, where the Chainman Shale is structurally disrupted and favorably oriented structures allow flow into Tule Valley.

\section{Baker and Lehman Creek Drainage Basins}

\section{Physical Characteristics}

Baker and Lehman Creek drainage basins are on the eastern side of the topographic divide between Snake and Spring Valleys in the southern Snake Range (fig. 10). Baker Creek drains the southern side of Wheeler and Jeff Davis Peaks, and Lehman Creek drains the north side. Both creeks flow eastward into Snake Valley, where the water is used for irrigation near the town of Baker, Nevada. Altitudes range from about 5,330 ft at Baker, Nevada, to 13,063 ft at Wheeler Peak.

The Baker and Lehman Creek drainage basins include four small high-mountain lakes: Baker Lake in the Baker Creek drainage basin and Stella, Teresa, and Brown Lakes in the Lehman Creek drainage basin. The drainage basin area of Baker Creek upstream of the gaging station at the GBNP boundary is $16.6 \mathrm{mi}^{2}$, and the drainage basin area of Lehman Creek upstream of the gaging station is $9.0 \mathrm{mi}^{2}$ (Toby Welborn, U.S. Geological Survey, Carson City, Nev., written commun., 2011). Stream lengths upstream of the gaging stations are $6.8 \mathrm{mi}$ for Baker Creek and $5.5 \mathrm{mi}$ for Lehman Creek (Elliott and others, 2006, p. 8). Streams lengths at Baker, Nevada, are $11.8 \mathrm{mi}$ for Baker Creek (measured along the natural channel) and $11.2 \mathrm{mi}$ for Lehman Creek (Toby Welborn, U.S. Geological Survey, Carson City, Nev., written commun., 2009).

Baker and Lehman Creeks have similar streambed slopes. Slope of the streambeds exceeds 12 percent in the mountain areas. The slope decreases to 8 percent through the Narrows of Baker Creek and between lower Lehman Creek campground and the gaging station. The natural streambed slope decreases to about 6 percent downstream of GBNP. Baker Creek was diverted from its natural channel in the early 1900s about $0.9 \mathrm{mi}$ downstream of the gaging station (fig. 10). The natural channel downstream of the diversion has a grove of trees and once had numerous beaver ponds. Occasionally, the melting of large accumulations of snow causes streamflow to overtop the diversion and flow down the natural channel. The combined drainage area down to the confluence of the diverted Baker Creek with Lehman Creek is $33.4 \mathrm{mi}^{2}$. About $0.1 \mathrm{mi}$ downstream of this confluence is a concrete-lined ditch that diverts as much as $26 \mathrm{ft}^{3} / \mathrm{s}$ (Craig Baker, Baker Ranches, Inc., Baker, Nev., written commun., 2010) and is able to accommodate the combined streamflow in Baker and Lehman Creeks most of the time. Occasionally, the combined streamflow exceeds the capacity of the ditch, and excess water enters an overflow channel next to the ditch or, in high water years, spreads across multiple channels. The concrete ditch extends $1.6 \mathrm{mi}$ down the slope of alluvial deposits and ends about $1.2 \mathrm{mi}$ upstream of the town of Baker. The slope along the 1.6-mi long concrete ditch is 5 percent, and downstream of the ditch, the slope gradually decreases to 3 percent at Baker. The natural channel of Baker Creek has a slope similar to that of the concrete ditch, and it gradually decreases to 3 percent south of Baker as well.

The patterns of precipitation and streamflow in the Baker and Lehman Creek drainage basins are typical of mountain drainage basins in the Great Basin that have formed over low-permeability rocks. Precipitation and temperature, which control streamflow, vary in relation to altitude and to annual and seasonal climate patterns. Mean precipitation rates (1971-2000) in the two drainage basins ranged from about $8 \mathrm{in} / \mathrm{yr}$ at Baker, Nevada, to slightly more than $32 \mathrm{in} / \mathrm{yr}$ on Wheeler Peak; mean temperatures ranged from about $10{ }^{\circ} \mathrm{C}$ 


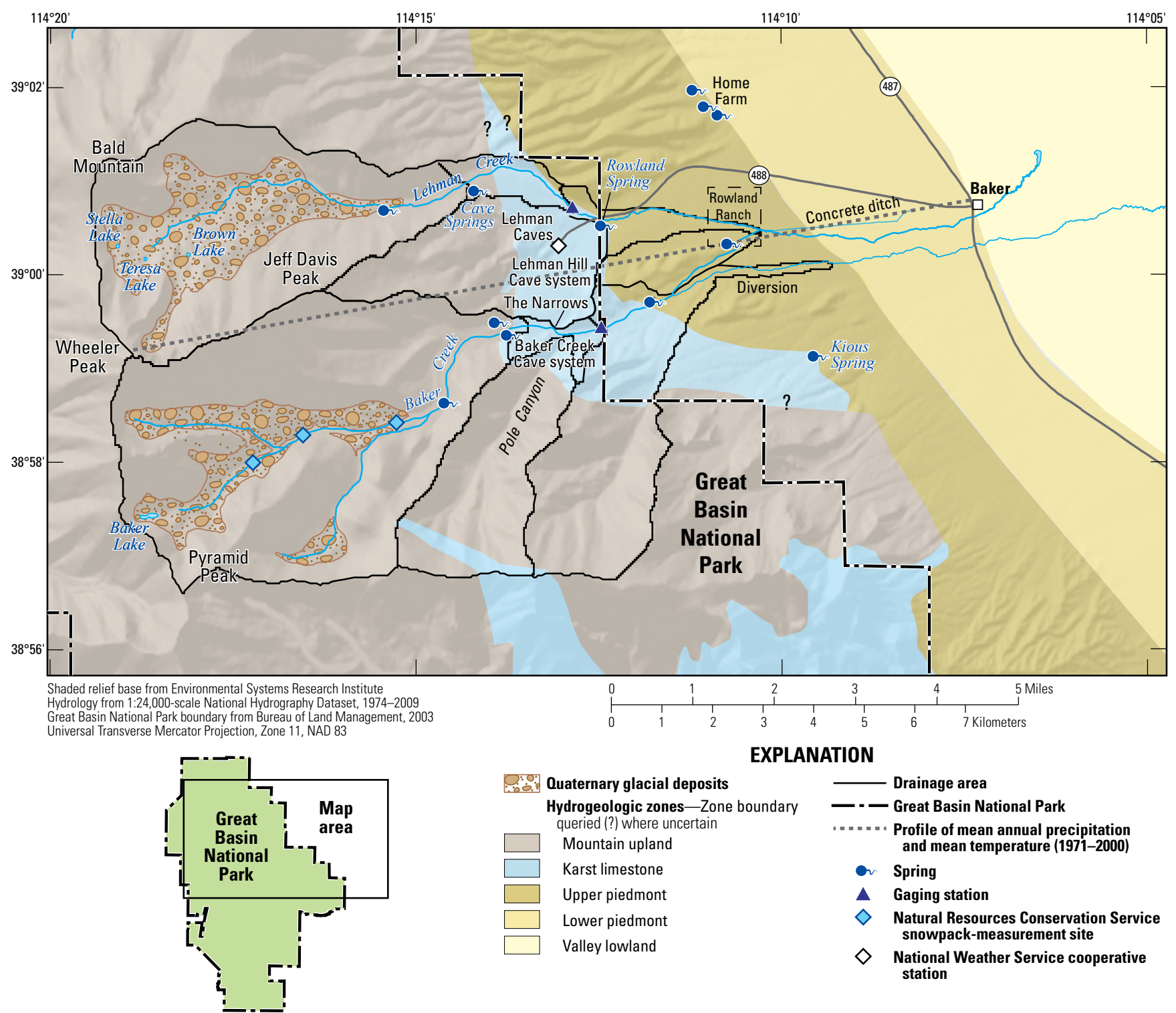

Figure 10. Baker and Lehman Creek drainage basins in the southern Snake Range and Great Basin National Park, White Pine County, Nevada.

at Baker to less than $1{ }^{\circ} \mathrm{C}$ on Wheeler Peak (fig. 11A). About 80 percent of the precipitation at higher altitudes accumulated as snow during the cold winter months (fig. 7). The melting of this snowpack results in a large increase in streamflow in Baker and Lehman Creeks, where streamflow typically peaks in May and June.

A weather station has been in operation at or near Lehman Caves Visitor Center since October 1937 (fig. 11B). Some years have months when no precipitation data were collected, which resulted in no estimates of annual precipitation for water years 1948 and 1950 and no annual mean temperature estimates for water years 1938-1950, 1997, and 1998. Precipitation rates at the weather station near Lehman Caves
Visitor Center ranged from a low of $5.3 \mathrm{in} / \mathrm{yr}$, for water year 1953 , to $22.3 \mathrm{in} / \mathrm{yr}$, in water years 1982 and 2005. Annual mean temperature at the Lehman Caves weather station ranged from $7.0^{\circ} \mathrm{C}$ in 1992 to $1{ }^{\circ} \mathrm{C}$ in 1996 . This small difference in annual mean temperature $\left(4^{\circ} \mathrm{C}\right)$ corresponds to a change in land-surface altitude of more than 3,000 ft. The inter-annual variations in precipitation and temperature result in interannual variability in annual runoff at the gaging stations. 

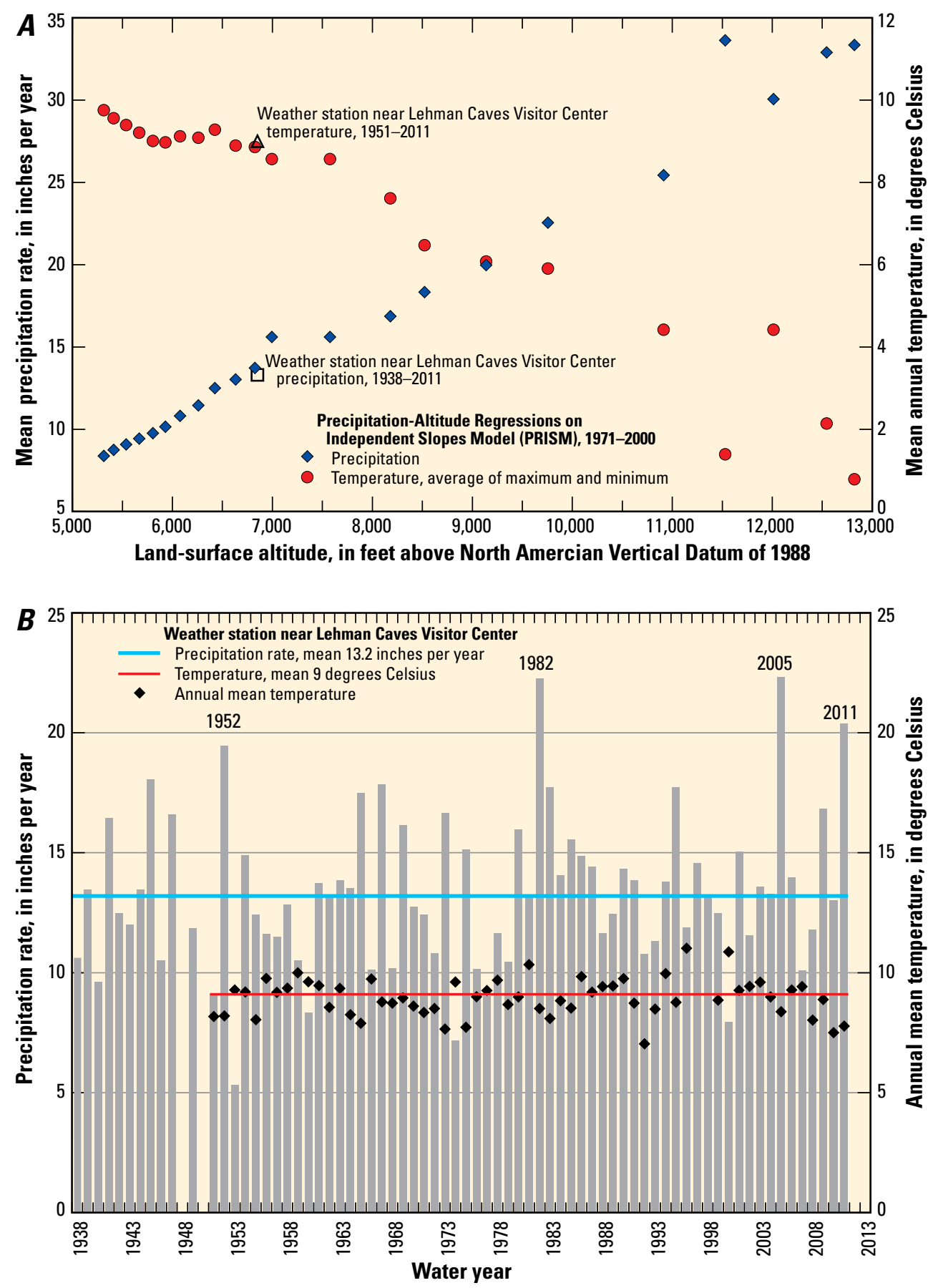

Figure 11. Precipitation and temperature $A$, means relative to land-surface altitudes from Baker, Nevada, to Wheeler Peak, for 1971-2000, and $B$, annual values at the weather station near Lehman Caves Visitor Center, Great Basin National Park, While Pine County, Nevada, for water years 1938-2011. 


\section{Geology}

\section{Distribution of Rocks}

The surface geology of the Baker and Lehman Creek drainage basins is shown in figure 12 and is based on a 1:24,000-scale digital geologic map of GBNP (Brown and Davila, 1995; National Park Service, 2007) that was modified according to geologic mapping during this study. The bedrock geology consists of a thick section of Neoproterozoic and Lower Cambrian quartzite that is successively overlain by relatively thin Lower Cambrian shale and Middle Cambrian limestone (Whitebread, 1969; McGrew and others, 1995; National Park Service, 2007). Up to 5,000-ft thick Neoproterozoic and Lower Cambrian Prospect Mountain Quartzite underlies Wheeler Peak and the upland headwaters of Baker and Lehman Creeks. The lower part of this formation consists of thickly bedded (1-5 ft), coarse-grained quartzite, which grades upward to thinner-bedded quartzite with occasional interbeds of silty quartzite and siltstone. Conformably overlying the quartzite is the Lower Cambrian Pioche Shale, which has a maximum thickness of about $300 \mathrm{ft}$. The Pioche Shale consists of thin-bedded dark siltstone and shale that is recessive-weathering, forming valleys or low points on ridges near Cave Springs and in the vicinity of Pole Canyon (fig. 12).

Overlying the Pioche Shale is the Middle Cambrian Pole Canyon Limestone, a 1,500-1,800-ft-thick, mostly massive limestone. The Pole Canyon Limestone forms the hill in which the Lehman Hill cave system has developed and also underlies prominent hills along Baker Creek and the lower reaches of Pole Canyon (fig. 12). The Pole Canyon Limestone, where highly fractured or where dissolution has enlarged the fractures and bedding planes, can transmit large quantities of water. The Pole Canyon Limestone is inferred to exist in the subsurface in the area between the Narrows of Baker Creek and Rowland Spring (fig. 13A). The Lehman Hill (including Lehman Caves) and the Baker Creek cave systems were formed in this limestone (Bridgemon, 1965). The Baker Creek cave system includes a western part near the Narrows of Baker Creek, and Model Cave is the eastern part (fig. 12). The western part of the Baker Creek cave system includes several caves, including Ice, Sink, Crevasse, Wheelers Deep, Dynamite, and Systems Key Caves, which form a 9,000-ft long compact, overlapping-maze system of hydrologically interconnected small passageways (Bridgemon, 1965; Pease and others, 1969). Model Cave is about $0.3 \mathrm{mi}$ to the east and is $4,000-\mathrm{ft}$ long. The cave is a simple passage tubular in shape and large, with a perennial stream in its lower part. Model, Systems Key, and Dynamite Caves are connected to Ice, Crevasse, and Wheelers Deep Caves (Bridgemon, 1965).

The Cretaceous Pole Canyon granitic pluton intrudes the Prospect Mountain quartzite in upper Pole Canyon (Lee and others, 1981; McGrew and others, 1995). Most other outcrops of granitic rocks in the Baker and Lehman Creek drainage basins belong to the Tertiary Young Canyon pluton (Miller and others, 1989; Miller and others, 1995a), a medium-grained, equigranular granite. Upper parts of this pluton invade the Pioche Shale as sill-like intrusive bodies, such as to the west of Lehman Caves (Miller and others, 1995b), or form small isolated exposures, such as along Baker Creek to the east of the Narrows (McGrew and others, 1995; fig. 12).

Bedrock units are concealed beneath older and younger Quaternary alluvium and glacial deposits to the east of the mountain front (fig. 13). Material mapped as older alluvium is Quaternary and possibly Pliocene in age (fig. 12) and tends to cap ridges and form high-standing alluvial surfaces (Miller and others, 1995b). These deposits are exposed in low hills of unconsolidated to partly consolidated clay, silt, sand, and gravel deposited as alluvial material and glacial outwash. The glacial deposits consist mostly of ground moraine in the upper reaches of Baker and Lehman Creeks, but also include a prominent outwash deposit that forms the ridge on the north side of Lehman Creek (fig. 12). The younger Quaternary deposits include glacial outwash and younger stream deposits. These deposits are in active channels and fans and are typically unconsolidated, consisting of a heterogeneous mix of clay, silt, sand, and gravel as well (McGrew and others, 1995; Miller and others, 1995a, 1995b).

\section{Geologic Structure of the Range Front}

The southern Snake Range detachment fault and associated hanging-wall normal faults, which cut and tilted the Miocene units in the Sacramento Pass section, project south toward the entrance to GBNP and along the east side of the Snake Range (Miller and others, 1995b). The location of the range-bounding fault in the vicinity of Baker and Lehman Creeks is not easily determined, however, because of the presence of extensive young sedimentary cover and overall geologic complexity.

The inferred location of the detachment fault in the vicinity of the creeks is based on the following types of geologic and geophysical data: (1) mapped exposures of the detachment fault nearby, (2) presence of Miocene conglomeratic deposits and megabreccia, (3) well control, and (4) results from electrical geophysical profiles. The detachment fault is exposed on a low ridge to the south of Kious Spring (fig. 12), where steeply west-dipping Cambrian and Ordovician carbonate rocks overlie the subplanar, gently east-dipping detachment fault surface that projects into Snake Valley without apparent interruption. Beneath the detachment fault is sheared, cataclastically deformed, and chlorite-altered granitic rocks of the Young Canyon pluton (Lee and Christiansen, 1983; Miller and others, 1995b). Near Strawberry Creek, to the north of Baker and Lehman Creeks, a moderately north- and northeastdipping fault along the range front separates Jurassic granite from Tertiary conglomerate of the Sacramento Pass section, which dips to the southwest toward the fault (Miller and others, 1995a, 1995b).

Although not well exposed in the Baker and Lehman Creek drainage basins, Miocene sediments can be inferred to exist in the subsurface beneath Quaternary cover. Tertiary 


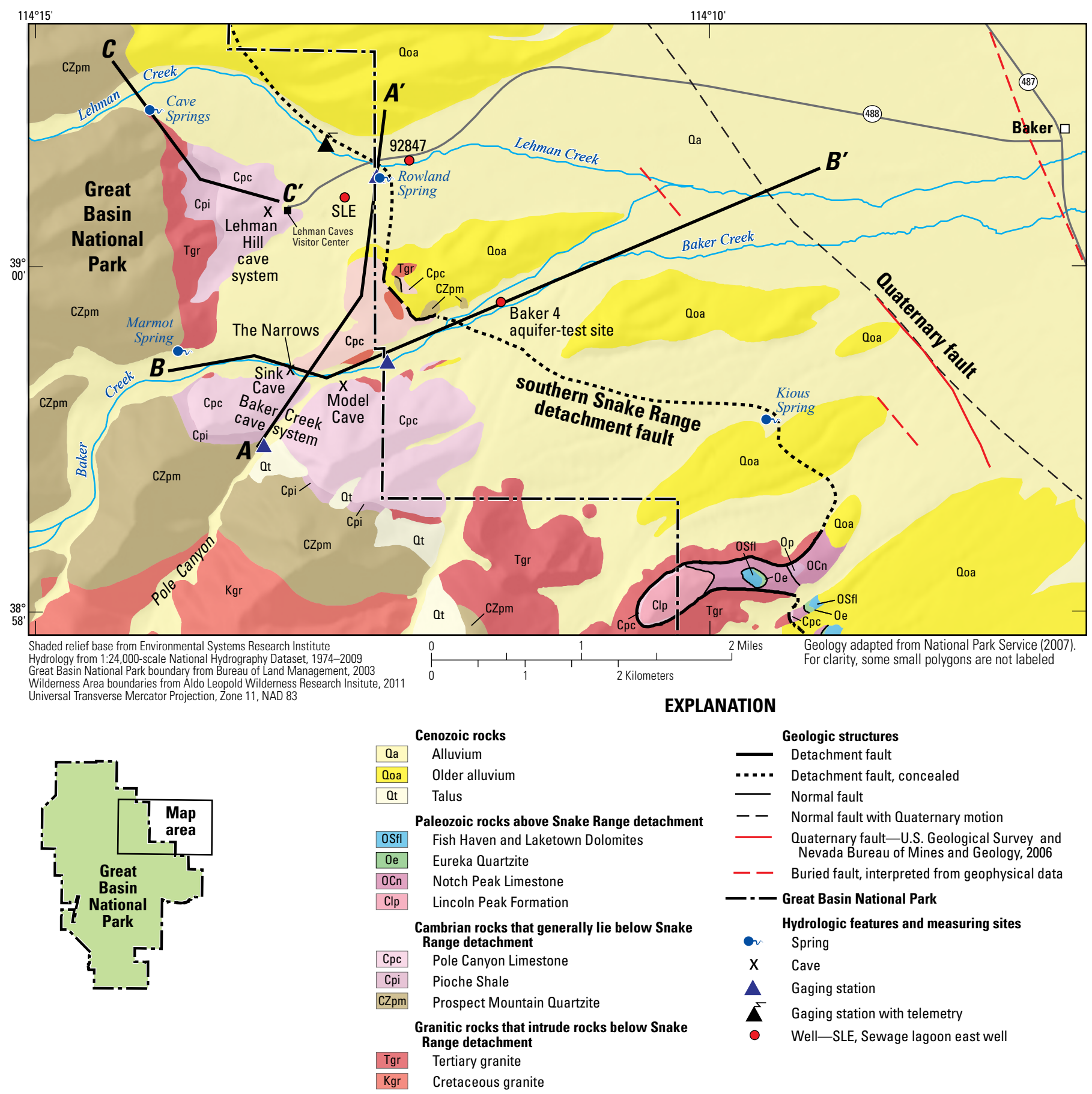

Figure 12. Geology of the Baker and Lehman Creek drainage basins, Great Basin National Park, White Pine County, Nevada. 

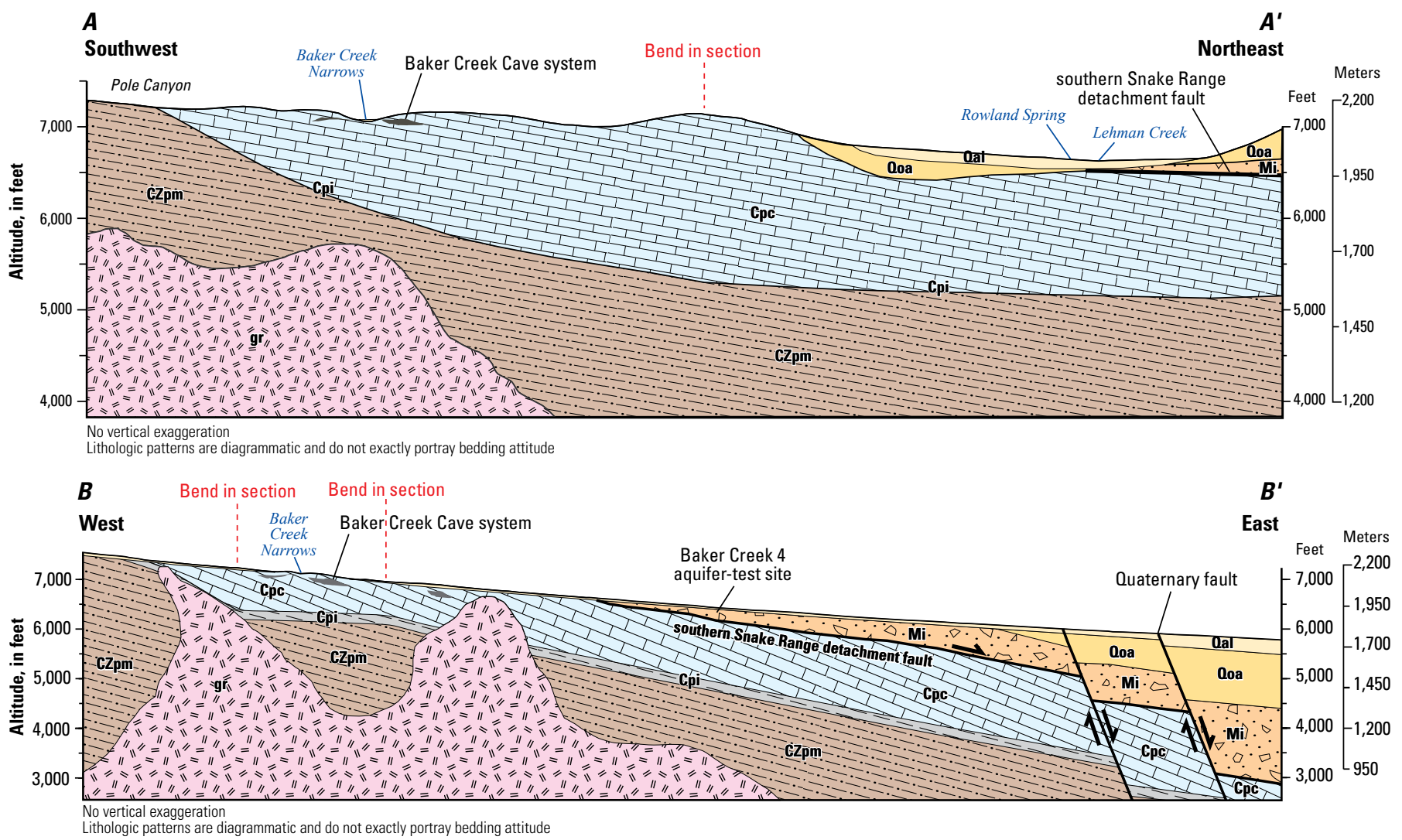

C
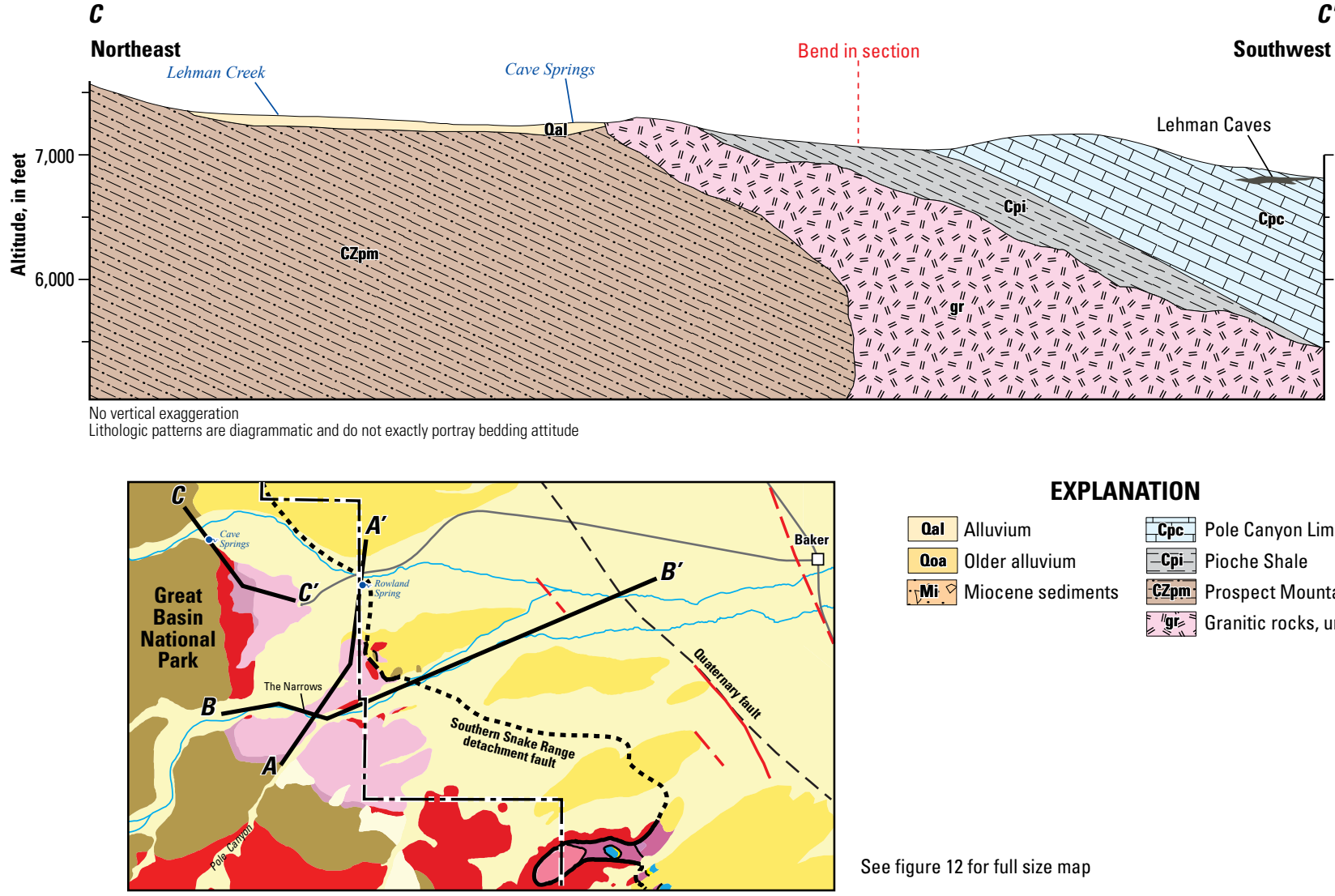

See figure 12 for full size map

Figure 13. Interpretive geologic cross sections in the Baker and Lehman Creek drainage basins, White Pine County, Nevada: $A$, Section A-A', Pole Canyon to Rowland Spring; B, Section B-B', Baker Creek; and C, Section C-C', Cave Springs to Lehman Caves. 
conglomerates near Strawberry Creek can be traced to the southeast, where they are buried by younger deposits (Miller and others, 1995a, 1995b). Elevated rolling topography north of the Lehman Creek drainage basin indicates that the Tertiary conglomeratic section exists in the shallow subsurface, buried beneath a pediment surface of older alluvium and glacial outwash (Miller and others, 1995b; National Park Service, 2007). Isolated exposures of carbonate, granitic, and siliciclastic rocks were mapped by McGrew and others (1995) on the low ridge that separates the Baker and Lehman Creek drainage basins. Geologic mapping done for this study indicated that these outcrops are Miocene conglomerates and megabreccia blocks that lie above the detachment fault and are locally exposed in outcrop under thin alluvial cover (fig. 12). On the basis of map relations, Miocene deposits were inferred to underlie the entire ridge north of Baker Creek to the east of bedrock outcrops of the Pole Canyon Limestone. Map relations showed that the contact between these conglomeratic deposits and Pole Canyon Limestone exposed at the west end of this ridge dips moderately to the east (Miller and others, 1995b).

At the Baker 4 aquifer-test site (fig. 12), the deepest monitoring well first penetrated a block of Pioche Shale at $35 \mathrm{ft}$ below land surface and bottomed in this shale at a depth of $60.5 \mathrm{ft}$ (appendix table 1-1). This shale block was interpreted to be a megabreccia block in the Miocene conglomeratic section, similar to exposures on the hillside immediately north of the well site. A well drilled north of Lehman Creek and $1,300 \mathrm{ft}$ east of the GBNP boundary (fig. 12, well 92847) first encountered unconsolidated alluvial deposits, then consolidated sediments, prior to intercepting Paleozoic limestone at $150 \mathrm{ft}$ below land surface (Nevada Division of Water Resources well-drillers' log 92847, http://water.nv.gov/data/ welllog/index.(fm), indicating the continuity of limestone beneath younger and older alluvium.

Two controlled-source audio-magnetotelluric (CSAMT) geophysical profiles were collected on the eastern flank of the southern Snake Range along Baker Creek and in the vicinity of Kious Spring to investigate the location and geometry of faults along the range front (Asch and Sweetkind, 2010; Asch and Sweetkind, 2011). The two CSAMT lines were similar in their electrical response and were interpreted to show generally similar subsurface geologic conditions to depths of 2,000-2,500 ft, which consisted of three distinct domains on the basis of the electrical response (Asch and Sweetkind, 2010, 2011). The first was a shallow 300-600 ft-deep domain that was interpreted to be the result of a heterogeneous assemblage of Miocene conglomerate and incorporated megabreccia blocks overlying the shallowly eastward-dipping southern Snake Range detachment fault. The second domain was a greater-than-800-ft deep region of generally higher resistivity that was interpreted to be Paleozoic sedimentary rocks and Mesozoic and Cenozoic plutonic rocks beneath the detachment surface. Of note, the resistivity boundaries at depth had no counterparts in the shallow section, which was evidence of the low-angle nature of the southern Snake Range detachment fault (fig. 13B). A third, eastern electrical response domain was interpreted to be a section of Miocene strata overlain by Quaternary alluvial fill. These deposits lie east of a subvertical to steeply east-dipping normal fault that cuts all units and the detachment fault and has as much as $1,300 \mathrm{ft}$ of east-sidedown offset. These results indicated a two-stage history of faulting, where an older Miocene period of low-angle faulting, probably associated with large-magnitude normal offset, was followed by much younger basin-range faulting removed from the mountain range front (Asch and Sweetkind, 2010; Asch and Sweetkind, 2011).

Geologic mapping, well data, and the CSAMT data were used to define the southern Snake Range detachment fault along the eastern flank of the Snake Range, where the fault is mostly covered and difficult to locate using surface geologic mapping (fig. 12). Hydrologic evidence, discussed in a later section, indicated that the covered trace of the detachment fault could pass to the east of both Rowland and Kious springs. These data and models helped define the subsurface geometry of faults and geologic units, but the degree of subsurface hydraulic connection is dependent on the relative permeability of the geologic units and the faults, information that cannot be obtained from this application of CSAMT alone. Kistinger and others (2009) suggested that Rowland Spring (figs. 12, 13A) was along a north-northwest-trending basin-range fault that continued west to Cave Springs with about $300 \mathrm{ft}$ of down-to-the-east offset. Paleozoic limestone was encountered at similar depths in wells drilled $1,700 \mathrm{ft}$ southwest (well SLE, fig. 12) and $600 \mathrm{ft}$ east of Rowland Spring (well 92847, fig. 12), however, so little, if any, offset of the Paleozoic limestone is possible. Irregular topography near the spring orifice is likely the result of alluvial incision and historic changes in the course of Lehman Creek, rather than from fault offset of Quaternary sediments.

Young Quaternary faults are mapped or interpreted to the east of the present range front (U.S. Geological Survey and Nevada Bureau of Mines and Geology, 2006; Rowley and others, 2009). One such fault, locally mapped about $3 \mathrm{mi}$ east of the eastern boundary of GBNP (fig. 12), was selected as the boundary between the upper and lower piedmont hydrogeologic zones and is discussed in a following section. Additional Quaternary faults are mapped farther to the east, near Baker, Nevada; they coincide with gravity gradients that indicate thickness of the Miocene and younger basin fill increasing from less than 1,600 ft on the west to greater than 3,200 ft thick on the east (Watt and Ponce, 2007). Quaternary scarps are not well developed and appear as local gentle swales that affect the alluvial surfaces. Because these faults are far from the topographic range front, they were not responsible for the formation of the range front itself, unlike many other basin and range settings, where the majority of the uplift was late Miocene (about $10 \mathrm{Ma}$ ) and younger, and the faulting was at the range front. 


\section{Extent and Continuity of Pole Canyon Limestone}

In the covered interval between the limestone outcrops in GBNP and the town of Baker, the subsurface extent and continuity of the Pole Canyon Limestone is not known with certainty. Pole Canyon Limestone was inferred in the subsurface as far east as Rowland Spring on the basis of limestone outcrops on nearby hills, presence of limestone at the bottom of well SLE (fig. 12) drilled to the northwest of Rowland Spring (Prudic, 2012a; also Nevada Division of Water Resources well-drillers' $\log 115321$, http://water.nv.gov/data/ welllog/index.cfm), and inferences based on the characteristics of Rowland Spring (Elliott and others; 2006). To the east of Rowland Spring, limestone was found at a depth of about $150 \mathrm{ft}$ in well 92847 (fig. 12), which was drilled south of the main entrance road to GBNP and about a quarter of a mile downstream of GBNP (Nevada Division of Water Resources well drillers' $\log 92847$, http://water.nv.gov/data/welllog/ index.cfm). A USGS seismic-refraction survey was completed about $1 \mathrm{mi}$ east of the test hole on the western end of Rowland Ranch (fig. 10). Results from this survey indicated high-velocity material, interpreted as Paleozoic limestone, at depths of $250 \mathrm{ft}$ to $280 \mathrm{ft}$ below land surface (David L. Berger, U.S. Geological Survey, Carson City, Nev., written commun., 2004). Pole Canyon Limestone was interpreted at depth beneath Baker Creek and to the south of Kious Spring on the basis of characteristically high resistivity values measured at depth along the two CSAMT geophysical profiles (Asch and Sweetkind, 2010; Asch and Sweetkind, 2011). The oil-exploration well Baker Creek 12-1, 3 mi east of the town of Baker, is the only deep well to penetrate the Paleozoic section beneath basin fill east of the Quaternary fault (fig. 14; Hess and others, 2004). This well was drilled through 4,610 ft of Cenozoic basin fill before it penetrated the top of the Ordovician Eureka Quartzite. Given the deformed nature of surface outcrops of Paleozoic rocks to the east in the Confusion Range (fig. 3), the Eureka Quartzite is unlikely to be horizontal and widespread beneath the Cenozoic basin fill; rather, the quartzite is likely tilted and interbedded with Paleozoic carbonate rocks that lie both above and below it.

\section{Distribution of Coarse- and Fine-Grained Deposits from Logs of Well Drillers' Logs}

Water wells in the vicinity of Baker, Nevada, are mostly less than $300 \mathrm{ft}$ deep and penetrate various mixtures of sand and gravel and fine sand, silt, and clay deposits interpreted to be younger alluvium (Nevada Division of Water Resources, accessed July 2009, at http://water.nv.gov/data/welllog/index. cfm). Some wells penetrate cemented intervals that could be equivalent to the older alluvium observed in outcrops. Welldrillers' descriptions of down-hole intervals from lithologic logs were assigned to one of four general lithologic classescobbles, gravel, sand, or clay - to facilitate comparison of grain size and sorting characteristics among the lithologic logs (table 2). A single lithologic class tended to be dominant in any given well; for example, wells that contained intervals of cobble-sized particles tended to be dominated by cobbles. Only six wells could be described as mixed, with sub-equal percentages of all four general lithologic classes. All wells were symbolized by dominant lithologic class and plotted in map view to evaluate the spatial distribution of lithology classes (fig. 14). Cobble-sized deposits could be confined to the active, high-energy stream channels, based on the results from wells along Lehman Creek near the GBNP boundary. Gravel-dominated deposits are more widely distributed along the range front and probably represent coalescing alluvial fans. Wells at the distal ends of these fans, just to the east of the town of Baker and Nevada State Highway 487, display a heterogeneous mixture of lithologic classes. All of the mixed classification wells are in this area, and gravel-dominated wells are next to clay-dominated wells (fig. 14). Lithologic variability probably results from differences in stream energy and in depositional environment as the fans interfingered with fine-grained deposits in the basin axis (fig. 14).

The Baker Creek 12-1 oil exploration well, 3 mi east of the town of Baker (fig. 14), is the only deep well in the area. Between the start of logging at $560 \mathrm{ft}$ below land surface and a depth of 1,400 ft, this well penetrated interlayered gravel, sand, and clay before entering a thick section of heterogeneous, clay-rich material that is probably the Miocene

Table 2. Lithologic classes in drill holes in the vicinity of Baker and Lehman Creeks, White Pine County, Nevada.

[Lithologic classes defined as follows: cobbles include all intervals described as containing cobbles; gravel includes all intervals described as conglomerate, gravel, or gravel and sand; sand includes all intervals described as sandstone or sand; clay includes all intervals described as clay, sandy clay, or clay and gravel; mixed includes interbedded layers of the other lithologic classes in nearly equal proportions. Lithologic descriptors not considered in lithologic class assignment include hard layer, limestone, granite, soil, and intervals without a lithologic description]

\begin{tabular}{|c|c|c|c|c|c|c|}
\hline \multirow{2}{*}{ Dominant lithologic class } & \multirow{2}{*}{ Number of drill holes } & \multirow{2}{*}{ Total footage drilled } & \multicolumn{4}{|c|}{$\begin{array}{l}\text { Footage of lithologic class divided by total footage drilled in each class } \\
\text { (percentage of total footage drilled) }\end{array}$} \\
\hline & & & Cobbles & Gravel & Sand & Clay \\
\hline Cobbles & 8 & 205 & 76 & 16 & 3 & 6 \\
\hline Gravel & 24 & 1,431 & 4 & 76 & 6 & 14 \\
\hline Sand & 4 & 163 & 6 & 0 & 85 & 8 \\
\hline Clay & 30 & 1,506 & 3 & 15 & 5 & 77 \\
\hline Mixed & 6 & 398 & 17 & 29 & 16 & 38 \\
\hline
\end{tabular}


sedimentary section (Hess and others, 2004). Lithologic descriptions, drilling rate, and geophysical logs indicated local intervals of quartzite and limestone in this section that could represent megabreccia blocks. The altitude of the top of this inferred Miocene section is consistent with the interpreted altitude of the down-dropped Miocene section on the east end of the CSAMT geophysical profile collected along Baker Creek west of Baker (Asch and Sweetkind, 2010; Asch and Sweetkind, 2011).

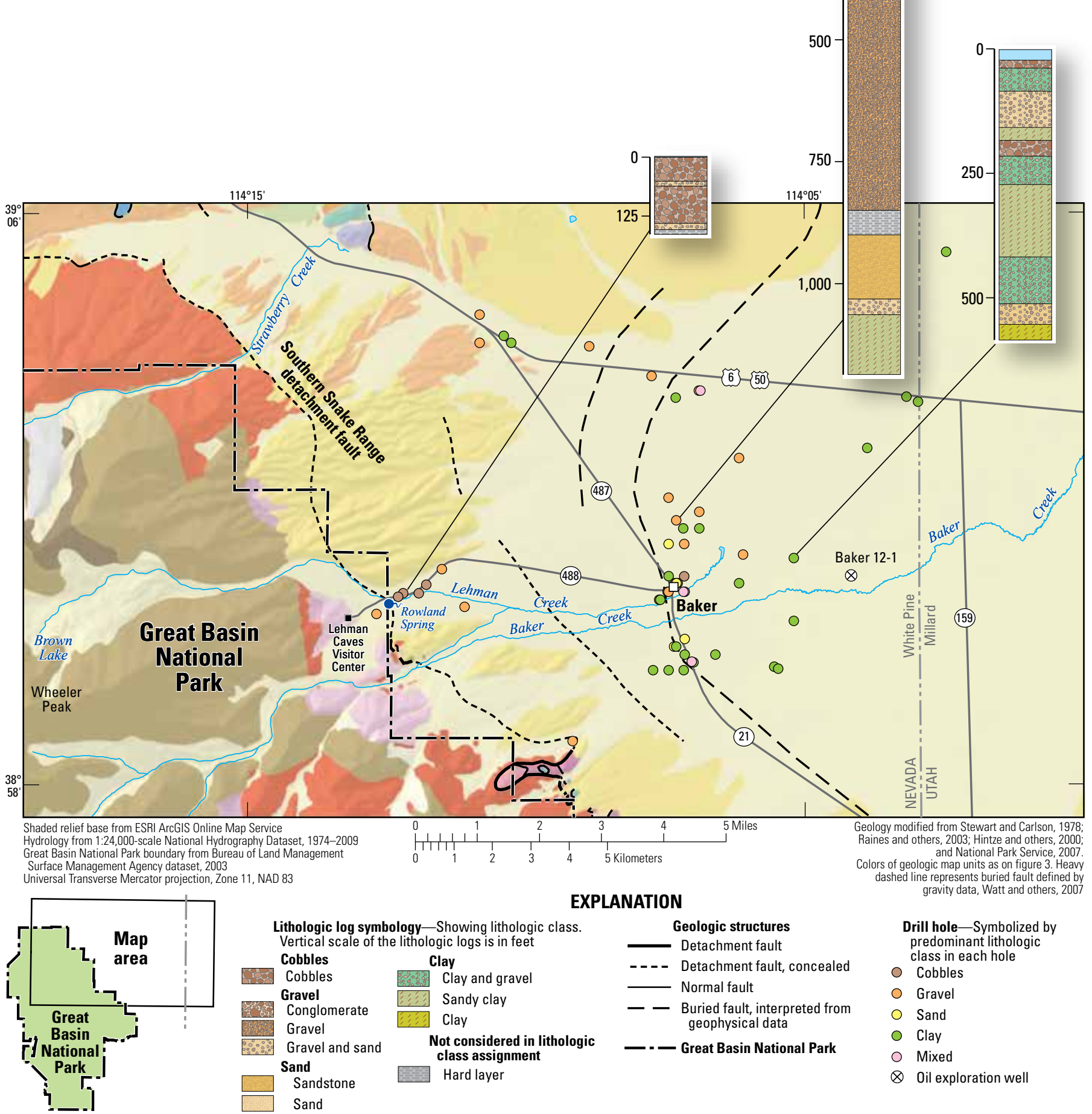

Figure 14. Distribution of clasts in alluvial deposits in the Baker and Lehman Creek drainage basins, White Pine County, Nevada, between the mountain front and valley floor. 


\section{Connection of Aquifers to Springs and Streams}

Streamflow in Baker and Lehman Creeks and its connection with groundwater are directly related to the geology in the drainage basins. The headwaters of Baker Creek are underlain primarily by Prospect Mountain Quartzite (fig. 12). Outcrops of Tertiary granite are on both sides of the creek about half a mile west of the Narrows. The granite is inferred to have a tabular, sill-like geometry on the basis of its coincidence with the Pioche Shale horizon, and it probably underlies the streambed alluvium in this area (fig. 13B). Baker Creek cuts through northeast-dipping Pole Canyon Limestone at the Narrows (fig. 13B ). East of GBNP, the stream flows over alluvial and glacial deposits, inferred to be underlain by Miocene sedimentary rocks (fig. 13B).

The headwaters of Lehman Creek originate from glacial cirques on the north side of Wheeler Peak and from the south side of Bald Mountain (fig. 10). The creek in this area flows over thin alluvial and glacial deposits that overlie Prospect Mountain Quartzite. Cave Springs, about 1 mi upstream of Lehman Caves, is used for the GBNP's water supply. The springs flow from alluvial and glacial deposits near the contact between Proterozoic Prospect Mountain Quartzite and Tertiary granite (Prudic and Glancy, 2009). To the east of Cave Springs, intrusive rocks (fig. 12) are exposed on the south side of Lehman Creek and could continue northward beneath the alluvial and glacial deposits. East of the granite outcrops, a small north-south trending valley is underlain by Pioche Shale that has been partially invaded by the granite (fig. 13C). East-dipping Pole Canyon Limestone forms the eastern end of the ridge south of Lehman Creek in the vicinity of the Lehman Caves Visitor Center (fig. 13C). Map relations indicated a continuous east-dipping stratigraphic section, with no evidence for the presence of a range-front normal fault in the vicinity of Cave Springs. Pole Canyon Limestone was inferred to underlie the alluvial and glacial deposits beneath Lehman Creek downstream of Cave Springs, although a well drilled east of the sewage lagoons in 2012 indicated that the limestone could be thin to nonexistent because granite intruded into the limestone (Prudic, 2012a).

Rowland Spring flows from young alluvial and glacial deposits south of Lehman Creek. Elliott and others (2006) interpreted Rowland Spring to be sustained by deeper groundwater flow through carbonate rocks of the Pole Canyon Limestone on the basis of flow and elevated temperatures. The inferred buried trace of the southern Snake Range detachment fault is likely to be east of Rowland Spring, allowing groundwater flow in carbonate bedrock to the west of the fault trace and providing a local permeability contrast that diverts water upward. East of GBNP, Lehman Creek and water from Rowland Spring flow over alluvial and glacial deposits inferred to be underlain by Miocene sedimentary rocks.

Conceptually, the Baker and Lehman Creek drainage basins can be separated into five distinct hydrogeologic zones on the basis of topography, geology, climate, streamflow, and groundwater flow in which the connection of aquifers to springs and streams vary. The five zones are named (1) mountain upland, (2) karst limestone, (3) upper piedmont, (4) lower piedmont, and (5) valley lowland (fig. 10). These zones are defined by multiple features and are used here to describe differences in the types of aquifers and their connection to springs and streams. A series of conceptualized diagrams were used to illustrate the relation among geology, streamflow, and groundwater flow in and between zones. The conceptual diagrams portray a generalized version of the subsurface hydrogeology roughly along an east-west profile parallel to Baker and Lehman Creeks; these profile diagrams do not exactly correspond to the geologic section B-B' (fig. 13), although many geologic relations are similar.

\section{Mountain-Upland Zone}

The mountain-upland zone includes the upper parts of Baker and Lehman Creeks and Pole Canyon in Great Basin National Park upstream of the limestone outcrops (figs. 10, 12). Distinct features of the mountain-upland zone are (1) high-altitude terrain with steep slopes and thin soils; (2) a wet and cold climate; (3) active erosion with relatively thin talus, glacial, and alluvial deposits overlying poorly-permeable quartzite, granite, and shale; (4) a high percentage of streamflow relative to precipitation; and (5) shallow groundwater circulation that contributes to streamflow along the creeks.

The mountain-upland zone lies at altitudes greater than $7,000 \mathrm{ft}$, and the climate is colder and wetter than the other zones (fig. 11A). Between the altitudes of 7,000 and 11,000 ft, this zone is densely covered with a coniferous forest, above which is bare rock and tundra (Houghton and others, 1975). The only source of water to this zone is precipitation, a large fraction of the which is lost to evapotranspiration, particularly in the forested areas; most of remaining water exits the zone as streamflow. Groundwater flow in this zone is limited to relatively shallow, short flow paths from the mountain ridges and slopes to deeply incised stream channels.

Groundwater flow is mostly through large pores in glacial deposits and through smaller pores in thin colluvium and alluvial deposits that mantle the generally less permeable quartzite. No wells are present in this zone, and information regarding groundwater flow is limited to streamflow gains along the stream channels and at springs that form where the glacial deposits end or along the contact between quartzite and granite or shale. Surface exposures of the quartzite show abundant relic-bedding planes and bedding-parallel fractures. Slightly longer and deeper groundwater-flow paths can go through the quartzite, although flow is still relatively shallow because of steep topographic slopes and because granite underlies the quartzite at relatively shallow depth (fig. 15). Much of what little groundwater flow there is in the mountain upland is lost to evapotranspiration or flows to creeks and springs or as subsurface outflow through thin glacial and alluvial deposits and, perhaps, through fractures in the shale and granite. 


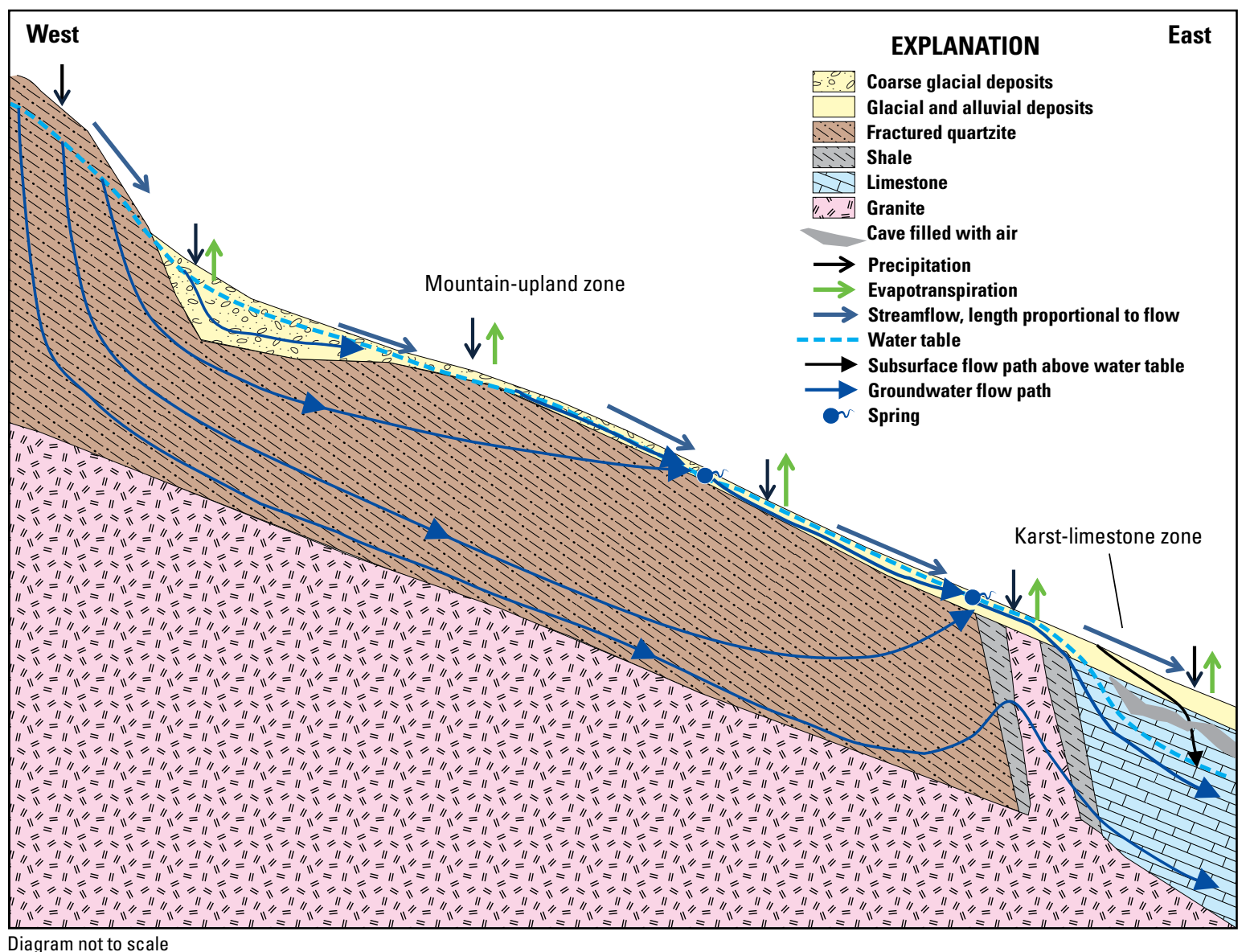

Figure 15. Idealized cross section showing streamflow and groundwater flow along Baker and Lehman Creeks in the mountain-upland zone, Great Basin National Park, White Pine County, Nevada.

\section{Streamflow}

Gaging stations have been operated periodically since 1947 at one site each on Baker and Lehman Creeks near the eastern boundary of GBNP (table 1; fig. 10). Both these gaging stations are downstream of the mountain-upland zone, and most of the streamflow at the two gaging stations is from the mountain-upland zone. The streamflow recorded at the gaging stations integrated snowmelt, groundwater flow to the creeks (from springs and diffuse flow along the streambed) and streamflow loss to groundwater, upstream of the gaging stations. Repeated discharge measurements upstream of the gaging stations between 2009 and 2011 showed net losses along the creeks in the karst-limestone zone (fig. 16). Thus, mean annual discharge (in cubic feet per second) from the mountainupland zone in both creeks was greater than the mean annual discharge at the gaging stations.

The mean of daily mean discharge measured at the gaging stations on Baker and Lehman Creeks were similar in both creeks during the period of record for water years 1947-55, 1993-97, and 2002-10 (fig. 17). In both creeks, the mean of the daily mean discharge was dominated by snowmelt, which resulted in high flows from May through July. Because of a lack of streamflow during the winter months, the minimum daily mean discharge was between December and February.
Maximum and minimum daily mean discharges in Lehman Creek differed less than those in Baker Creek. The ratio of maximum to minimum daily mean discharges for Lehman Creek ranged from about 2 in February to as much as 50 in late May and early June, whereas the ratio for Baker Creek ranged from about 3 in October to more than 200 in January. The same ratio for Baker Creek during snowmelt in late May to early June ranged from 40 to 98 . The largest ratios of maximum to minimum daily mean discharges were during January in Baker Creek and reflected a large variation for any day because, during some years, much of the water in the creek near and upstream of the gaging station was frozen.

The mean and median of the daily mean discharges at the gaging stations on both creeks were the same during low flow, but the means were greater than the median during high flow. The latter reflected large accumulations of snow during a few winters that resulted in much greater daily mean discharge during snowmelt than in most other years.

Daily mean discharge at the gaging stations on Baker and Lehman Creeks were totaled to get annual runoff in acre-feet. The annual runoff at the Baker Creek gaging station exceeded the mean annual runoff only 5 years, and the annual runoff at the Lehman Creek gaging station exceeded the mean annual runoff 7 years (fig. 18). 

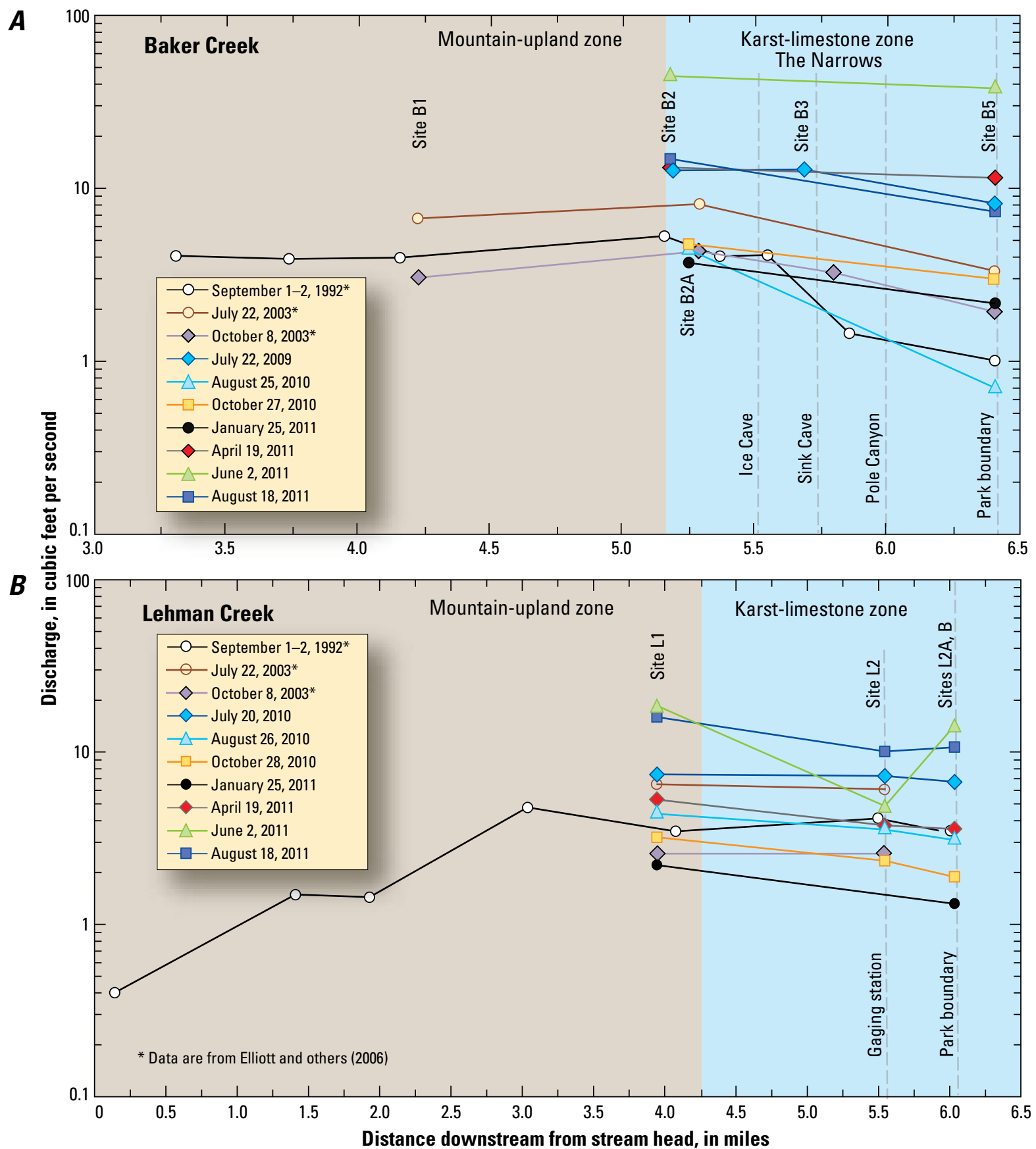

Figure 16. Measured discharge on selected dates between September 1992 and August 2011, Great Basin National Park, White Pine County, Nevada, for $A$, Baker Creek, and $B$, Lehman Creek. 


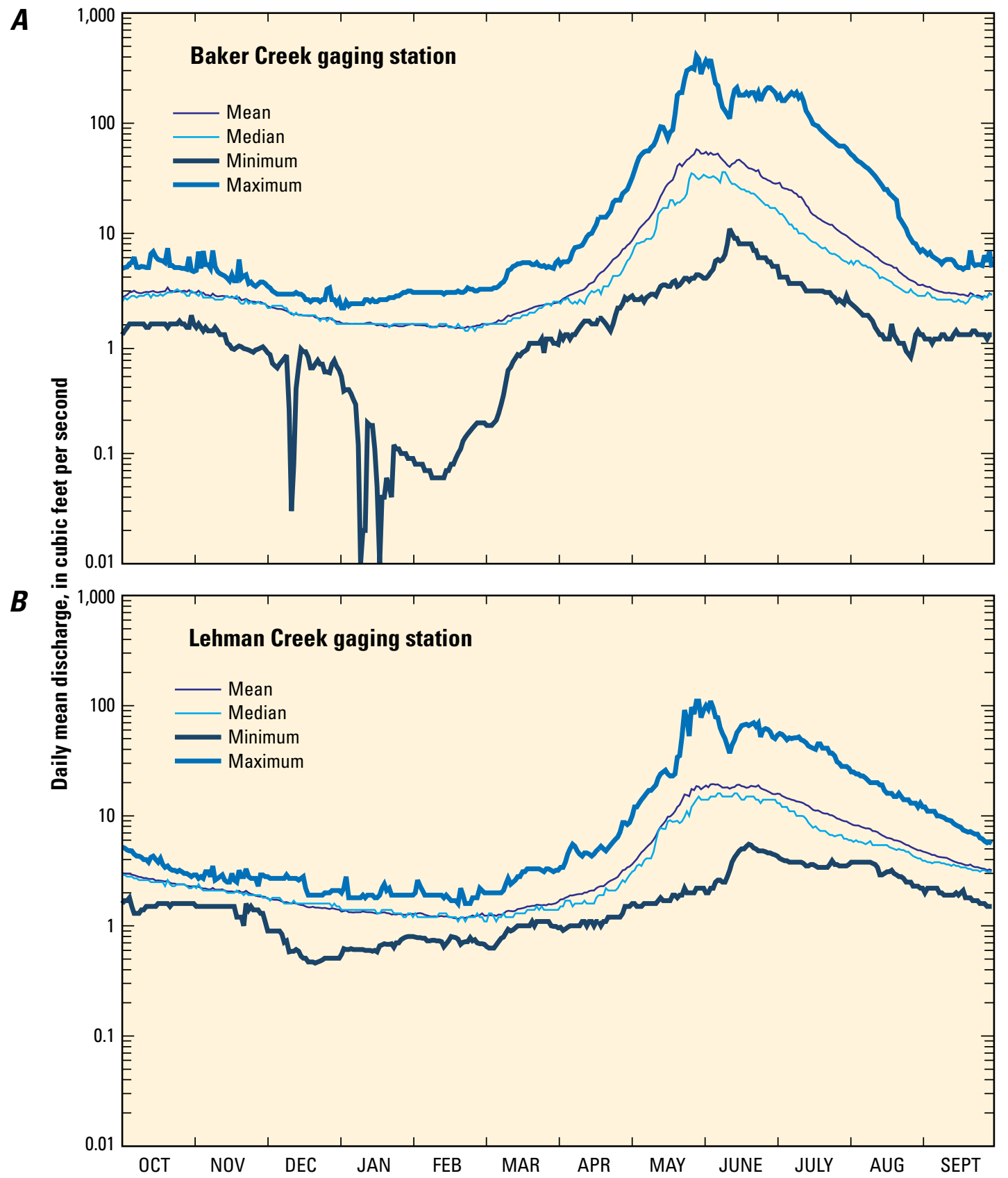

Figure 17. Mean, median, minimum and maximum daily mean discharges, Great Basin National Park, White Pine County, Nevada, for water years 1948-55, 1993-97, and 2002-10, at gaging stations on $A$, Baker Creek (station number 10243260), and $B$, Lehman Creek (station number 10243240). 


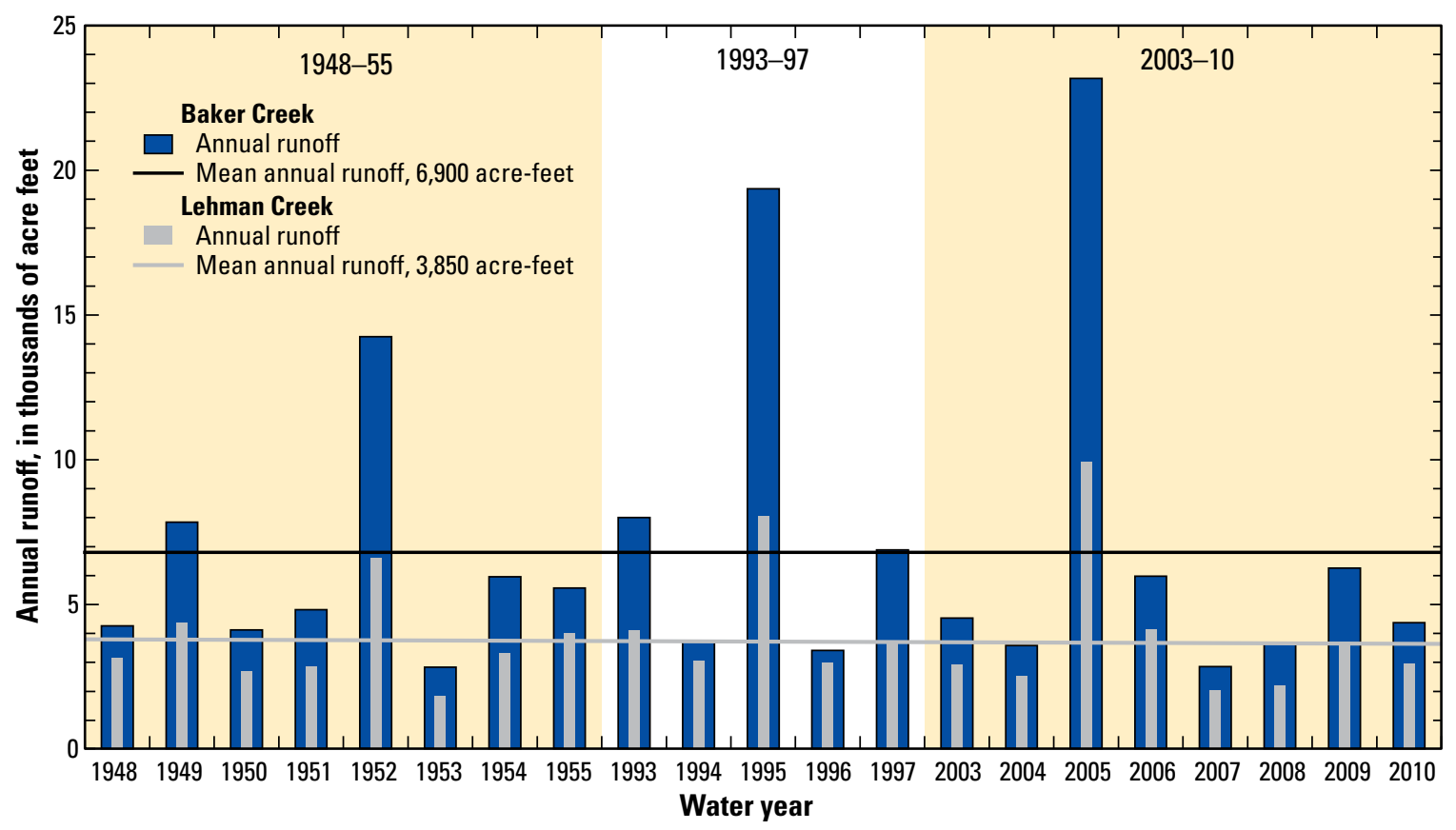

Figure 18. Annual runoff at gaging stations on Baker and Lehman Creeks, Great Basin National Park, White Pine County, Nevada, for water years 1948-55, 1993-97, and 2003-10.

\section{Relation of Annual Mean Discharge at Gaging Stations to Precipitation}

Annual mean discharge (in cubic feet per second) at the gaging stations on Baker and Lehman Creeks correlated with the snow-water equivalent on or about April 1 from the middle snow course in the Baker Creek drainage basin (fig. 19A) and with the water-year precipitation rate at the weather station near Lehman Caves Visitor Center (fig. 19B). The best correlations used an exponential equation, with water years 1952, 1995, and 2005 producing more annual mean discharge relative to the snow-water equivalent and annual precipitation rate. At least three factors could explain the exponential equations (fig. 19B). The first could be that evapotranspiration was water limited during most years, and once precipitation exceeded this limit, the proportion that became streamflow was increased. The second could be that proportionately more snow accumulated at higher altitudes in the drainage basins than at the snow course and the weather station during years of well above-average precipitation. The third could be that cooler temperatures during the wet years reduced evapotranspiration, allowing for a greater fraction of snowmelt to become streamflow.

\section{Mean Annual Water Yield}

Mean annual water yield (runoff plus groundwater flow) from the mountain-upland zone in the southern Snake Range was estimated assuming water not consumed by evapotranspiration exited the zone primarily as runoff in seven drainages basins that included Baker, Lehman, and Snake Creeks and the four nearby basins of Strawberry Creek, Shingle Creek,
Williams Canyon, and Pole Canyon. In mountainous areas of the Great Basin, mean annual water yield from a drainage basin was less dependent on drainage area than on the magnitude of precipitation and evapotranspiration, which change substantially with altitude (Riggs and Moore, 1965, p. 199).

The method for estimating water yield is a function of the magnitude of precipitation in each drainage basin. Precipitation in each drainage basin was divided into two to four areas with varying mean precipitation rates. Coefficients that represented the fraction of precipitation in each area that became water yield were adjusted until the computed mean annual water yield approximated the mean annual runoff (groundwater flow assumed minor) best in the six drainage basins that excluded Pole Canyon because it did not have an estimate of mean annual runoff from a gaging station. A mean precipitation was estimated for each of the drainage basins by multiplying an area with the mean precipitation rate in each area. Mean precipitation rates from 1971 to 2000 were obtained from the PRISM Climate Group, Oregon State University (http://prism.oregonstate.edu, September 7, 2011); mean precipitation for selected areas, with a range in annual precipitation rates, and a total mean precipitation for each of the drainage basins are listed in table 3 .

Mean annual runoff for the six drainage basins excluding Pole Canyon was estimated from gaging stations and was assumed equal to water yield. Gaging stations were operated near the end of the mountain-upland zone on Snake, Strawberry, and Shingle Creeks and Williams Canyon between October 2002 and September 2004 (Elliott and others, 2006). Gaging stations on Baker and Lehman Creeks have a longer record (table 1) but are downstream of the mountain-upland 


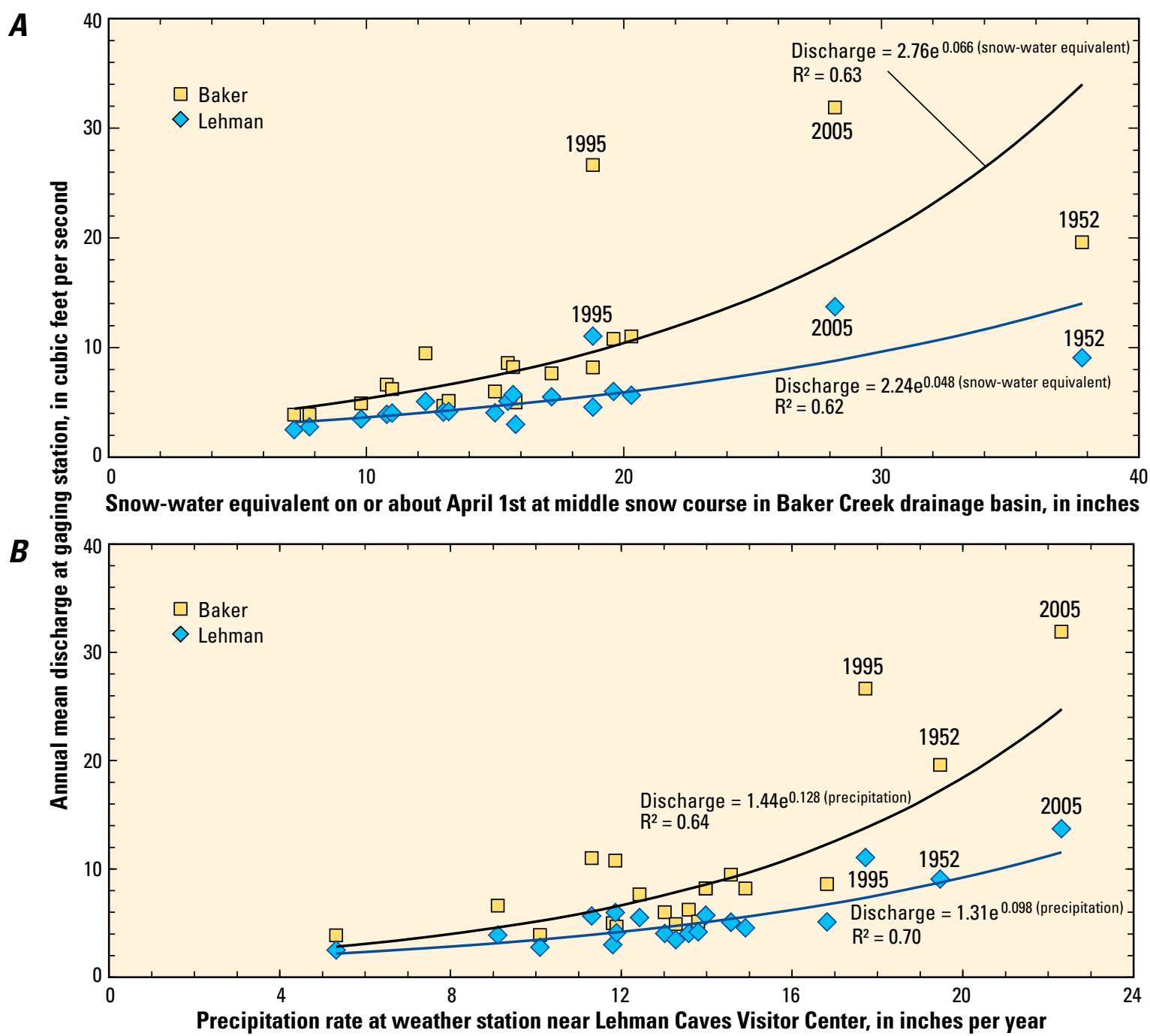

Figure 19. Relation of annual mean discharge at gaging stations on Baker and Lehman Creeks, Great Basin National Park, White Pine County, Nevada, $A$, to the snow-water equivalent for the middle snow course in the Baker Creek drainage basin on or near April 1, and $B$, to water-year precipitation rates (October-September) at the weather station near Lehman Caves Visitor Center.

Table 3. Mean annual precipitation volume and water yield from the mountain-upland zone in the Baker and Lehman Creek drainage basins and from four nearby drainage basins, Great Basin National Park, White Pine County, Nevada.

[Mean annual water yield estimated from discharge measurements in all drainage basins except Pole Canyon, which was estimated from equation 1. Mean chloride concentrations of streamflow are flow-weighted for Baker Creek, Lehman Creek, and Pole Canyon. Mean precipitation rates from 1971-2000 (PRISM Climate Group, Oregon State University, http://prism.oregonstate.edu, created 7 Sept. 2011). Symbol: —, not determined; >, greater than]

\begin{tabular}{|c|c|c|c|c|c|c|c|c|c|c|c|}
\hline \multirow{3}{*}{ Drainage basin } & \multirow{3}{*}{$\begin{array}{l}\text { Drainage } \\
\text { area } \\
\text { (square } \\
\text { miles) }\end{array}$} & \multirow{2}{*}{\multicolumn{2}{|c|}{$\begin{array}{l}\text { Mean annual water yield } \\
\text { (acre-feet) }\end{array}$}} & \multirow{3}{*}{$\begin{array}{c}\text { Total } \\
\text { mean } \\
\text { annual } \\
\text { precipitation } \\
\text { volume } \\
\text { (acre-feet) }\end{array}$} & \multirow{2}{*}{\multicolumn{5}{|c|}{$\begin{array}{c}\text { Mean annual precipitation volumes (acre-feet) } \\
\text { Range in mean precipitation rates (inches per year) }\end{array}$}} & \multirow{2}{*}{\multicolumn{2}{|c|}{$\begin{array}{l}\text { Mean chloride } \\
\text { concentration of } \\
\text { streamflow }\end{array}$}} \\
\hline & & & & & & & & & & & \\
\hline & & $\begin{array}{l}\text { Estimated from } \\
\text { discharge } \\
\text { measurements }\end{array}$ & $\begin{array}{l}\text { Computed from } \\
\text { equation } 1\end{array}$ & & $>12-16$ & $>16-20$ & $>20-24$ & $>24-28$ & $>28$ & $\begin{array}{l}\text { (milligrams } \\
\text { per liter) }\end{array}$ & $\begin{array}{c}\text { (number of } \\
\text { samples) }\end{array}$ \\
\hline Baker Creek & 12.7 & 9,320 & 7,630 & 17,400 & 22 & 2,220 & 3,730 & 3,220 & 8,230 & 1.2 & 14 \\
\hline Lehman Creek & 8.38 & 4,650 & 5,580 & 11,800 & 57 & 689 & 2,080 & 2,930 & 6,000 & 1.1 & 12 \\
\hline Strawberry Creek & 7.79 & 850 & 1,050 & 8,650 & 735 & 2,220 & 3,290 & 2,200 & 206 & 4.2 & 4 \\
\hline Shingle Creek & 1.98 & 930 & 820 & 2,670 & 0 & 0 & 483 & 1,650 & 536 & 1.0 & 4 \\
\hline Williams Canyon & 2.58 & 1,250 & 2,130 & 4,580 & 0 & 230 & 904 & 1,190 & 2,260 & 1.0 & 2 \\
\hline $\begin{array}{l}\text { Snake Creek upstream } \\
\text { of pipeline }\end{array}$ & 9.33 & 2,980 & 2,980 & 11,800 & 0 & 1,100 & 5,660 & 2,540 & 2,460 & 1.2 & 5 \\
\hline Pole Canyon & 3.34 & - & 250 & 3,540 & 0 & 1,540 & 2,000 & 0 & 0 & 6.7 & 8 \\
\hline
\end{tabular}


zone. Mean annual runoff from the six drainage basins was adjusted to the long-term mean at the gaging station on Cleve Creek in the Schell Creek Range on the west side of Spring Valley (table 1). Gaging stations on Baker and Lehman Creeks were downstream of the mountain-upland zone, and each creek had losing stream reaches in the karst-limestone zone. Consequently, the mean annual runoff listed in table 1 for the gaging stations on Baker and Lehman Creeks is less than the mean annual runoff that exited the mountain-upland zone in the two drainage basins and the mean annual runoff on Strawberry Creek is more than at the gaging station because of additional inflow during snowmelt. Mean annual runoff from the mountain-upland zone for Baker and Lehman Creeks was adjusted further on the basis of periodic discharge measurements, recorded between 2009 and 2011 near the end of the mountain-upland zone, by using a method presented by Moore (1968). Similarly, Strawberry Creek was adjusted using periodic discharge measurements at the end of the mountainupland zone in 2003 (Elliott and others, 2006, p. 19).

The method for estimating water yield in the seven drainage basins was similar to that used by Riggs and Moore (1965) and Moore (1968), except their empirical equations for mean annual runoff were based on land-surface altitudes in a drainage basin. The relation between mean annual water yield and precipitation was done to determine (1) the principal areas that contribute runoff from the mountain-upland zone and (2) the quantity of groundwater recharge in the karst-limestone zone assuming that water not lost to evapotranspiration either becomes streamflow in the mountain-upland zone or groundwater recharge in the karst-limestone zone.

The calculation of mean annual water yield for each of the drainage basins assumed no long-term change in storage (snowpack, lake levels, or in groundwater). Because the mountain-upland zone is underlain by thin glacial and alluvial deposits that overlie quartzite or granite of low permeability, little or no groundwater was assumed to exit the zone; rather, nearly all shallow groundwater returns to stream channels in the mountain-upland zone. The continued, slow melting of a permanent ice field at the foot of Wheeler Peak in the Lehman Creek drainage basin during the past 50 years could result in a greater estimate of water yield for that drainage basin. No other permanent ice fields exist in the other five drainage basins, however, so the overall effect of the melting ice field on the mean annual water yield is slight.

The six lakes in the Baker, Lehman, and Snake Creek drainage basins are small and have no documented mean change in water levels during the past 50 years. Thus, given the assumptions that the drainage basins are in dynamic equilibrium and that groundwater flow out of the mountain-upland zone is minor, the difference between mean annual precipitation and water yield for each selected area can be assumed to be equal to the mean annual evapotranspiration for those areas (Ward and Trimble, 2004, p. 94).

Two empirical equations were developed that produced similar estimates of mean annual water yield. Total mean precipitation in the first equation was divided into four areas with different mean precipitation rates that resulted in the following equation, which had a root-mean error of 870 acre-ft and produced 195 acre-ft more overall than the combined estimated mean annual runoff from all six drainage basins excluding Pole Canyon:

$$
\widehat{Y l d}=0.03 \times \overline{P P T_{>12-16}}+0.07 \times \overline{P P T_{>16-24}}+0.22 \times \overline{P P T_{>24-28}}+0.79 \times \overline{P P T_{>28}}
$$

where

$\widehat{Y l d}$ is the calculated mean annual water yield, in acre- $\mathrm{ft}$;

$\overline{P P T_{>12-16}}$ is the mean precipitation for rates greater than 12 to 16 inches per year, in acre-ft;

$\overline{P P T_{>16-24}}$ is the mean precipitation for rates greater than 16 to 24 inches per year, in acre-ft;

$\overline{P P T_{24-28}}$ is the mean precipitation for rates greater than 24 to 28 inches per year, in acre-ft; and

$\overline{P P T_{>28}} \quad$ is the mean precipitation for rates greater than 28 inches per year, in acre-ft.

The second equation produced a similar result as the first equation; however, when the total mean precipitation was divided into two areas having different precipitation rates (from greater than 12 to $28 \mathrm{in} / \mathrm{yr}$ and greater than $28 \mathrm{in} / \mathrm{yr}$ ), as shown in the following equation, it had a root-mean error of 830 acre-ft and produced 85 acre-feet more overall than the combined estimated mean annual runoff from all six drainage basins excluding Pole Canyon:

$$
\widehat{Y l d}=0.10 \times \overline{P P T_{>12-28}}+0.83 \times \overline{P P T_{>28}}
$$

where

$\overline{P P T_{>12-28}}$ is the mean precipitation for rates greater than 12 to 28 inches per year, in acre-ft, and

$\overline{P P T_{>28}}$ is the mean precipitation for rates greater than 28 inches per year, in acre-ft.

These two empirical equations are limited to the total mean precipitation determined for each of the seven drainage basins listed in table 3. Results from the four-rate equation indicated that most of the water yield was generated in areas where mean precipitation rates exceeded $28 \mathrm{in} / \mathrm{yr}$, and only 3 percent was generated in areas where mean precipitation rates ranged from greater than 12 to $16 \mathrm{in} / \mathrm{yr}$. This indicated that 21 percent of the mean precipitation (or about 6 in.) was lost to evapotranspiration in areas where mean precipitation rates exceeded $28 \mathrm{in} / \mathrm{yr}$, and 97 percent of the mean precipitation (or about 13.6 in.) was lost to evapotranspiration in areas where mean precipitation rates ranged from greater than 12 to $16 \mathrm{in} / \mathrm{yr}$. Decreasing evapotranspiration with increasing altitudes in the southern Snake Range is consistent with lower temperatures at higher altitudes. A similar pattern was determined for the two-interval equation, except that 90 percent of the mean annual precipitation was lost in areas where mean precipitation rates ranged from greater than 12 to $28 \mathrm{in} / \mathrm{yr}$. The greater fraction of water yield for mean precipitation rates greater than $28 \mathrm{in} / \mathrm{yr}$ in both equations was related to land-surface altitudes greater than $11,000 \mathrm{ft}$ and generally corresponded to areas 
above treeline, where vegetation was sparse and mean annual temperatures were less than $4^{\circ} \mathrm{C}$.

Even though two equations produced nearly the same overall mean annual water yield as the combined mean annual runoff from the six drainage basins excluding Pole Canyon, they consistently underestimated the mean annual water yield in the Baker and Shingle Creek drainage basins and overestimated the mean annual water yield in the Lehman Creek and Williams Canyon drainage basins (fig. 20). The likely reason for the variation in the estimated mean annual water yield relative to the estimated mean annual runoff is that the areas of mean precipitation rates in excess of $28 \mathrm{in} / \mathrm{yr}$ were underestimated for the Baker Creek and Shingle Creek drainage basins and overestimated for Lehman Creek and Williams Canyon (no weather stations collected data in places where the mean precipitation rate was greater than $28 \mathrm{in} / \mathrm{yr}$ ). Even with the variation between predicted and estimated mean annual water yields among the six drainage basins, the dependence on mean precipitation rates greater than $28 \mathrm{in} / \mathrm{yr}$ in each of the drainage basins resulted in different quantities of mean annual water yield relative to total mean annual precipitation in the mountain-upland zone of each of the six drainage basins (fig. 20). Strawberry Creek had more total mean precipitation than Shingle Creek and Williams Canyon, yet the mean annual water yield was about the same because a greater fraction of the drainage areas for Shingle Creek and Williams Canyon had mean precipitation rates greater than $28 \mathrm{in} / \mathrm{yr}$ (table 3). Similarly, total mean annual precipitation in the mountain-upland zone of Snake Creek was greater than that of Lehman Creek, yet the mean annual water yield in Lehman Creek exceeded that of Snake Creek; again, this was caused by Lehman Creek having a larger area with mean precipitation rates greater than $28 \mathrm{in} / \mathrm{yr}$. Baker Creek had the greatest total mean annual precipitation and mean annual water yield from the mountainupland zone because nearly half of the total mean annual precipitation in its drainage basin was from areas where mean precipitation rates exceeded $28 \mathrm{in} / \mathrm{yr}$.

\section{Water Budget}

A mean annual water budget for the mountain-upland zone for the combined Baker and Lehman Creek drainage basins was used to determine the relative importance of the various outflow components and to estimate inflow to the karstlimestone zone, where groundwater flow increases because of streamflow losses. The total mean annual precipitation for the combined drainage area that lies in mountain-upland zones in both drainage basins was 34,000 acre-ft (table 4) and included the mountain-upland zone in Pole Canyon. The uncertainty for this estimate was 20 percent, even though 15 percent

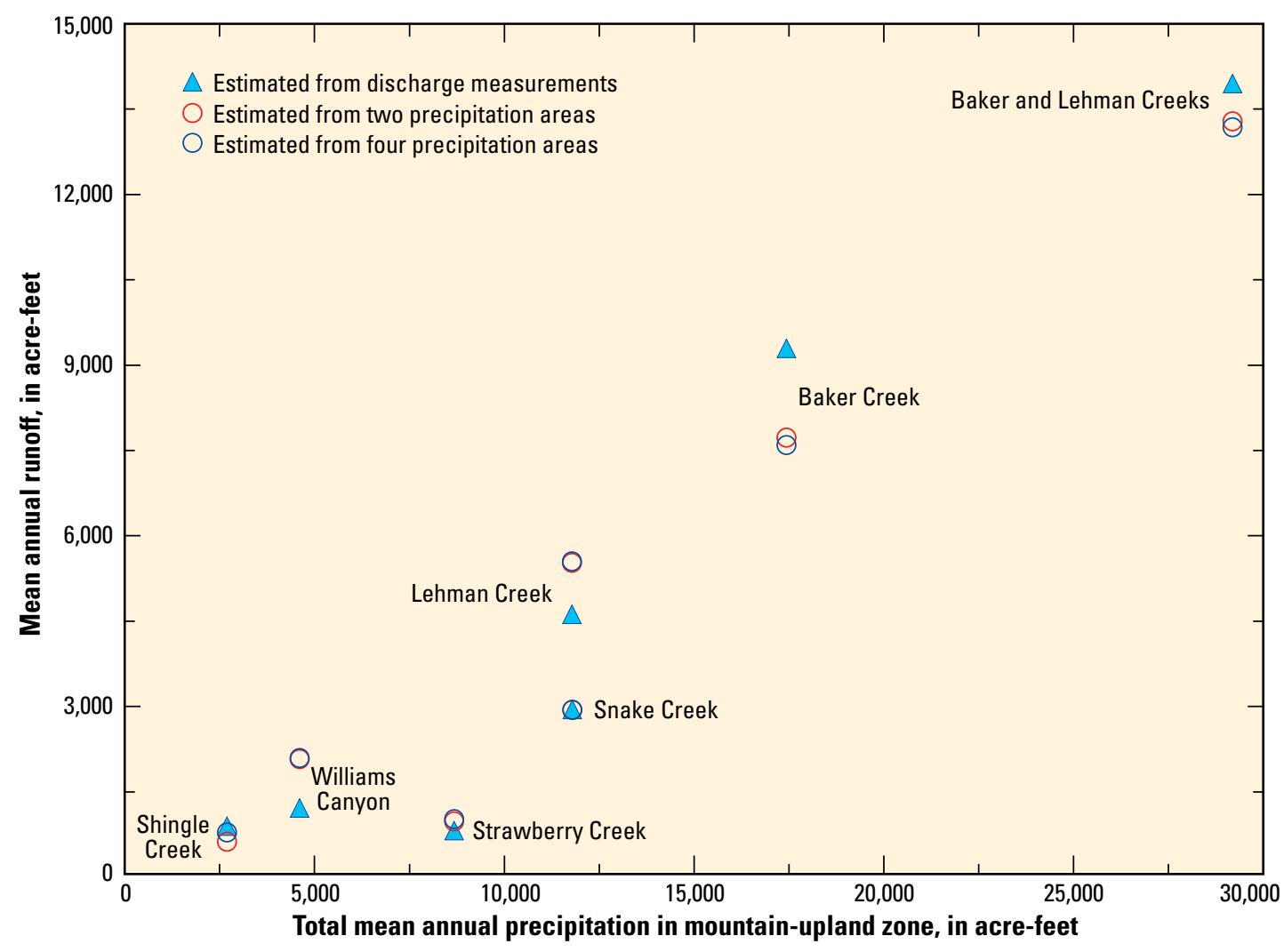

Figure 20. Estimated mean annual runoff from mountain-upland zone and calculated mean annual water yield compared with total mean annual precipitation for six drainage basins in the southern Snake Range, Great Basin National Park, White Pine County, Nevada. 
uncertainty of the mean annual precipitation from the PRISM Climate Group, Oregon State University was estimated at weather stations by Jeton and others (2005).

The mean annual runoff from the mountain-upland zone in table 4 is the sum of runoff for Baker Creek, Lehman Creek and Pole Canyon listed in table 3 plus an estimate of mean annual runoff of 160 acre-ft from an unnamed tributary in the Lehman Creek drainage basin west of Lehman Caves. Pole Canyon was included because it is a tributary to Baker Creek and contributes water to the karst-limestone zone in the combined Baker and Lehman Creek drainage basins. The mean annual runoff from the mountain-upland zone was 14,400 acre-ft (table 4), with uncertainty approximated at 15 percent for Baker and Lehman Creeks and 40 percent for the Pole Canyon and the unnamed tributary to Lehman Creek. Mean annual runoff from the mountain-upland zone for Baker and Lehman Creeks was estimated from discharge measurements near the end of the mountain-upland zone, corrected to the long-term mean annual runoff at the respective gaging stations. The estimate of mean annual runoff for Pole Canyon and the unnamed tributary was from equation 1, which resulted in a greater estimated uncertainty compared to the other estimates.

Groundwater flow from the mountain-upland zone into the karst-limestone zone was estimated by using Darcy's Law. The estimated cross-sectional area of flow through shallow alluvial deposits that overlie granite-shale was 20,000 square feet $\left(\mathrm{ft}^{2}\right)$ for Baker Creek (width of $400 \mathrm{ft}$ and depth of $50 \mathrm{ft}$ ), 10,000 $\mathrm{ft}^{2}$ for Lehman Creek (width of $200 \mathrm{ft}$ and depth of $50 \mathrm{ft}$ ), and $1,000 \mathrm{ft}^{2}$ for Pole Canyon (width of $100 \mathrm{ft}$ and depth of $10 \mathrm{ft}$ ). The estimated cross-sectional area of flow through the graniteshale was estimated at 5,400,000 $\mathrm{ft}^{2}$ (width of 18,000 ft and depth of $300 \mathrm{ft}$ ). The lateral hydraulic conductivity of the shallow alluvial deposits was estimated at 20 feet per day $(\mathrm{ft} / \mathrm{d})$ on the basis of an aquifer test in alluvial deposits along Baker Creek, and the lateral hydraulic conductivity of the graniteshale was assumed to be $0.001 \mathrm{ft} / \mathrm{d}$. The hydraulic gradient for the shallow alluvial deposits was assumed to be equal to the streambed slope of 0.08 feet per foot $(\mathrm{ft} / \mathrm{ft})$, and the hydraulic gradient for the granite and shale was assumed to be $0.8 \mathrm{ft} / \mathrm{ft}$ because of its low hydraulic conductivity. The estimated mean annual flow through the shallow alluvial deposits beneath Baker and Lehman Creeks and Pole Canyon was 400 acre-ft, whereas the estimated mean annual flow through the granite and shale was 40 acre-ft (table 4). The estimated uncertainty of groundwater flow was 50 percent.

The total mean annual flow of springs along the contact between the mountain-upland and karst-limestone zone was estimated to be 150 acre-ft. This includes the combined annual flow from Cave and Marmot Springs (fig. 21) of about 90 acre-ft (Gretchen Baker, National Park Service, Great Basin National Park, Baker, Nev., written commun., 2009)

Table 4. Water budgets for the mountain-upland and karst-limestone zones in the combined drainage basins of Baker and Lehman Creek, Great Basin National Park, White Pine County, Nevada.

[PRISM is from the 1971-2000 mean annual precipitation obtained from the PRISM Climate Group, Oregon State University, http://prism.oregonstate.edu; tables 1 and 3 are from this report; measurements are a combination of records from gaging stations listed in appendix 4, from periodic discharge measurements listed in appendix 3 , and from other available information on the flow of small springs; Darcy's Law are calculations of groundwater flow assuming a cross-sectional area, a lateral hydraulic conductivity, and a hydraulic gradient; calculation is the difference in the total inflow less all other outflows in a zone; and sum is the total of either all inflows or outflows assuming no change in storage. Symbol: - , not determined]

\begin{tabular}{|c|c|c|c|c|c|}
\hline \multirow{3}{*}{ Water budget component } & \multicolumn{2}{|c|}{$\begin{array}{c}\text { Mountain upland } \\
\text { drainage area } 25.4 \text { square miles }\end{array}$} & \multicolumn{2}{|c|}{$\begin{array}{c}\text { Karst limestone } \\
\text { drainage area } 4.2 \text { square miles }\end{array}$} & \multirow{3}{*}{$\begin{array}{l}\text { Source of } \\
\text { estimates }\end{array}$} \\
\hline & Mean annual volume & Estimated uncertainty & Mean annual volume & Estimated uncertainty & \\
\hline & \multicolumn{4}{|c|}{ Acre-feet } & \\
\hline \multicolumn{6}{|c|}{ Inflow } \\
\hline Precipitation & 33,000 & 6,600 & 3,200 & 600 & PRISM \\
\hline Runoff & 0 & - & 14,400 & 2,300 & Tables 1 and 3 \\
\hline Spring flow & 0 & - & 150 & 75 & Measurements \\
\hline \multicolumn{6}{|l|}{ Groundwater } \\
\hline Younger alluvial deposits & 0 & - & 400 & 200 & Darcy's Law \\
\hline Older alluvial deposits/consolidated rocks & 0 & - & 40 & 20 & Darcy's Law \\
\hline Total & 33,000 & 6,600 & 18,200 & 3,200 & Sum \\
\hline \multicolumn{6}{|c|}{ Outflow } \\
\hline Evapotranspiration & 18,000 & 9,000 & 2,800 & 800 & Calculation \\
\hline Runoff & 14,400 & 2,300 & 11,400 & 1,100 & Tables 1 and 3 \\
\hline Spring flow & 150 & 75 & 2,700 & 300 & Measurements \\
\hline \multicolumn{6}{|l|}{ Groundwater } \\
\hline Younger alluvial deposits & 400 & 200 & 500 & 300 & Darcy's Law \\
\hline Older alluvial deposits/consolidated rocks & 40 & 20 & 800 & 400 & Darcy's Law \\
\hline Total & 33,000 & 11,600 & 18,200 & 2,900 & Sum \\
\hline
\end{tabular}


and about 60 acre-ft from minor springs between Baker and Lehman Creeks. The estimated uncertainty in the total mean annual flow of springs was 50 percent (table 4).

The mean annual evapotranspiration for the mountainupland zone was estimated to be 19,000 acre-ft by subtracting estimates of mean annual runoff from mean annual precipitation. Uncertainty of 50 percent was determined by subtracting the sum of the minimum estimates of all outflows except evapotranspiration from the difference in the maximum estimate of precipitation minus mean evapotranspiration. The water budget for the mountain-upland zone indicated that about 56 percent of mean annual precipitation was lost to evapotranspiration, whereas 42 percent was runoff and 2 percent was groundwater flow to springs and to the karstlimestone zone. Thus, the estimated water yield from the mountain-upland zone was about 44 percent of the mean annual precipitation. This water yield was more than that of 35 percent determined for the Ash Canyon drainage basin on the east slope of the Carson Range near Carson City, Nevada (mean annual precipitation of 29.6 inches; Maurer and Berger, 1997, p. 34), and less than the 56 percent water yield for the upper Kings River on the western slope of the Sierra Nevada

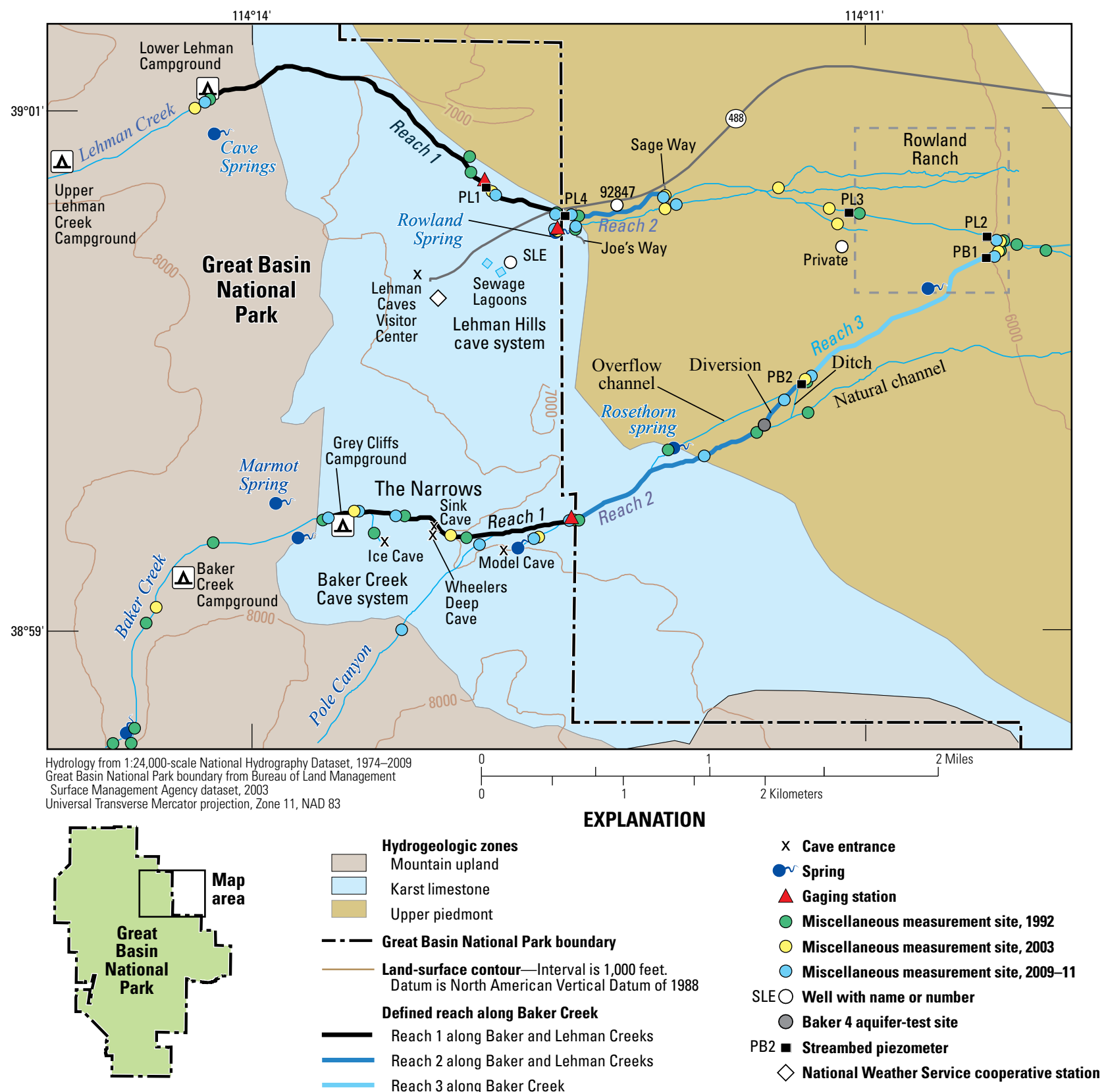

Figure 21. Locations of discharge-measurement sites, streambed piezometers, and wells in the karst-limestone and upper-piedmont zones of the Baker and Lehman Creek drainage basins between June 2009 and August 2011, Great Basin National Park, White Pine County, Nevada. 
(mean precipitation of 38.7 inches; Goulden and others, 2012). Goulden and others (2012) found evapotranspiration decreased at altitudes above $7,900 \mathrm{ft}$ because of colder temperatures. Typically, in mountain drainage basins underlain by low-permeability rocks, the percentage of water yield to precipitation increased with increasing precipitation (Maurer and Berger, 1997, p. 35; Hunsaker and others, 2012, p. 669).

\section{Selected Water Chemistry to Evaluate Water- Budget Estimates}

Radioactive tritium concentrations, stable isotopes of water, and dissolved chloride concentrations were used to evaluate the mean age of water in the mountain-upland zone and the relation between evaporation (which enriches stable isotope concentrations of water) and transpiration (which increases dissolved chloride concentrations, Clark and Fritz, 1997 , p. 80, 92). The selected water chemistry was assessed for samples from Baker and Lehman Creeks, Pole Canyon, and Cave and Marmot Springs, in the mountain-upland zone, and from Model Cave and Rowland Spring, in the karst-limestone zone (table 5). The data were compiled from analyses of samples that were a composite of samples collected during this study, from previous data available in the National Water Information System Database, and from analyses of samples collected by the National Park Service (Gretchen Baker, National Park Service, Great Basin National Park, Baker, Nev., written commun., 2010) and reported by Acheampong (1992). Averages listed in table 5 for the creeks, Rowland Spring, and Model Cave are flow weighted. Simple averages were used for Cave and Marmot Springs. The water chemistry of samples collected during this study is summarized in appendix 16. Daily mean discharge measurements for Rowland Spring, Baker Creek, Pole Canyon, and Model Cave resurgent spring not available in the National Information System Database are listed in appendix tables 4-2, 4-3, 4-7, 4-8, and 4-9.

\section{Estimating Mean Age of Water with Tritium}

Tritium is used to estimate the mean age of water less than 60 years old and was used to evaluate the age of water in Baker and Lehman Creeks and from Marmot Spring and Rowland Spring. Tritium is a radioactive isotope of hydrogen that forms naturally in the upper atmosphere and quickly combines to form tritiated water (Farmer and others, 1998). Over time, tritium is converted to helium by the release of a beta particle (Clark and Fritz, 1997, p. 174). The half-life of tritium is about 12.3 years (Lucas and Unterweger, 2000; Eaton and others, 2005), which means that tritium is not present in water that has not been exposed to the atmosphere since the 1940s. Tritium concentrations are increased in the atmosphere by nuclear testing and nuclear power plants. Nuclear testing caused tritium concentrations in precipitation at Salt Lake City, Utah, to peak at about 25,000 picocuries per liter ( $\mathrm{pCi} / \mathrm{L}$, or 8,000 tritium units, where 1 tritium unit equals $3.24 \mathrm{pCi} / \mathrm{L}$ ) during the spring of 1963 (Plummer and others, 2000, p. 270). If tritiated water entered groundwater in 1963, and was not mixed with any other water, the maximum concentration of that water in 2011 would be about 1,700 pCi/L (Clark and Fritz, 1997, p. 181).

The tritium concentration in precipitation at Salt Lake City decreased rapidly following its peak and, by the mid-1990s, was estimated to range between 30 and $45 \mathrm{pCi} / \mathrm{L}$. Measurements of precipitation during 1995-97 in Las Vegas, Nevada, showed seasonal variation from about $16 \mathrm{pCi} / \mathrm{L}$ in the fall and winter to about $40 \mathrm{pCi} / \mathrm{L}$ during the spring and summer (Farmer and others, 1998, p. 105). Although precipitation near the Lehman Caves in GBNP is not analyzed routinely for tritium, tritium concentrations from two samples collected in 2010 from Baker and Lehman Creeks (table 5) were similar to the tritium concentration of precipitation measured during 1995-97 at Las Vegas, Nevada, and to that estimated for the mid 1990s for Salt Lake City, Utah, which indicated a recent water source. A water sample from Marmot Spring collected

Table 5. Selected water chemistry of creeks and springs near the contact between mountain-upland and karst-limestone zones, at Model Cave in karst-limestone zone, and at Rowland Spring near contact between karst-limestone and upper-piedmont zones, Great Basin National Park, White Pine County, Nevada, 1990-2011.

[Site locations are shown in figure 21. Flow-weighted averages for Baker Creek, Lehman Creek, Pole Canyon, Rowland Spring and Model Cave; means for Cave and Marmot Springs from available analyses. Stable-isotope ratios reported in delta $(\delta)$ notation as parts per thousand (permil). Delta is the relative difference between the ratios of hydrogen-2 (deuterium) to hydrogen-1 $\left({ }^{2} \mathrm{H} /{ }^{1} \mathrm{H}\right)$ or oxygen-18 to oxygen-16 $\left({ }^{18} \mathrm{O} /{ }^{16} \mathrm{O}\right)$ in water samples to the respective ratios in Vienna Standard Mean Ocean Water (VSMOW; Giofiantini, 1978). A negative value represents water with less ${ }^{2} \mathrm{H}$ relative to ${ }^{1} \mathrm{H}$ or ${ }^{18} \mathrm{O}$ relative to ${ }^{16} \mathrm{O}$ than VSMOW. Standard error at 95 -percent confidence level is 2 permil for $\delta$ D and 0.2 permil for $\delta^{18} \mathrm{O}$. Symbol: -, not analyzed]

\begin{tabular}{|c|c|c|c|c|c|c|c|c|c|}
\hline \multirow{3}{*}{ Site location } & \multicolumn{2}{|c|}{ Tritium } & \multicolumn{3}{|c|}{ Stable-isotope ratios in delta notation } & \multicolumn{2}{|c|}{ Specific conductance } & \multicolumn{2}{|c|}{ Dissolved chloride } \\
\hline & \multirow{2}{*}{$\begin{array}{l}\text { Picocuries } \\
\text { per liter }\end{array}$} & \multirow{2}{*}{$\begin{array}{l}\text { Number of } \\
\text { samples }\end{array}$} & Deuterium & Oxygen-18 & \multirow{2}{*}{$\begin{array}{l}\text { Number of } \\
\text { samples }\end{array}$} & \multirow{2}{*}{$\begin{array}{l}\text { Microsiemens per } \\
\text { centimeter at } 25 \\
\text { degrees Celsius }\end{array}$} & \multirow{2}{*}{$\begin{array}{l}\text { Number of } \\
\text { samples }\end{array}$} & \multirow{2}{*}{$\begin{array}{l}\text { Milligrams } \\
\text { per liter }\end{array}$} & \multirow{2}{*}{$\begin{array}{l}\text { Number of } \\
\text { samples }\end{array}$} \\
\hline & & & & & & & & & \\
\hline $\begin{array}{l}\text { Baker Creek upstream of narrows in Grey } \\
\text { Cliffs group campground }\end{array}$ & 24.8 & 2 & -112 & -15.3 & 10 & 42 & 12 & 1.2 & 14 \\
\hline $\begin{array}{l}\text { Lehman Creek at campsite } 5 \text { in lower } \\
\text { Lehman campground }\end{array}$ & 26.9 & 2 & -114 & -15.5 & 9 & 41 & 12 & 1.1 & 11 \\
\hline Pole Canyon at shale contact & - & 0 & -114 & -15.2 & 4 & 240 & 8 & 6.8 & 8 \\
\hline Cave Springs & - & 0 & -115 & -15.6 & 17 & 120 & 4 & 5.1 & 7 \\
\hline Marmot Spring & 26.2 & 1 & -113 & -15.3 & 2 & 95 & 6 & 3.9 & 6 \\
\hline Model Cave & - & 0 & -114 & -15.3 & 4 & 110 & 8 & 2.5 & 8 \\
\hline Rowland Spring & 19.7 & 2 & -112 & -15.1 & 11 & 120 & 19 & 3.4 & 17 \\
\hline
\end{tabular}


in May 2010 had a tritium concentration similar to that of Baker and Lehman Creeks. Using the variation of tritium concentrations in precipitation between winter and summer measured near Las Vegas, Nevada, and proportioning those concentrations according to the seasonal percentages of mean precipitation rates resulted in a range of $21 \mathrm{pCi} / \mathrm{L}$ for altitudes higher than $11,000 \mathrm{ft}$ to $29 \mathrm{pCi} / \mathrm{L}$ for altitudes near Lehman Caves. Because the average tritium concentration in the two samples from Lehman Creek was $27 \mathrm{pCi} / \mathrm{L}$ (table 5), the value from Lehman Creek was used in place of modern precipitation in the drainage basins. These data indicated a short residence time for streamflow and water flowing from Marmot Spring due to relatively shallow groundwater circulation in the mountain-upland zone.

\section{Stable Isotope Concentrations of Water for Evaluating Evaporation}

The flow-weighted average ratios of the stable isotopes of hydrogen and oxygen relative to sea water (table 5) were similar to the volume-averaged ratios in precipitation of -113 parts per thousand (permil) for delta deuterium and -15.3 permil for delta oxygen-18 that were determined from 5 years of data from three nearby bulk-precipitation stations (fig. 6; Friedman and others, 2002) and from 1 year of data from Baker and Lehman Creek drainage basins (Acheampong, 1992, p. 29). The similarity of these ratios to those in precipitation indicated minimal evaporation prior to becoming streamflow or groundwater recharge (Craig, 1961a; Clark and Fritz, 1997, p. 80). Transpiration by plants does not affect the stable-isotope ratios in water because fractionation takes place at the leaf surface and not at root uptake. Consequently, the stable isotopes of water in the mountain-upland zone indicated that much of the water lost to evapotranspiration was not from evaporation.

The seasonal variation in deuterium and oxygen-18 ratios for water in the creeks and from Cave and Marmot Springs was close to the volume-weighted mean annual deuterium and oxygen-18 ratios in precipitation and differed less than the volume-weighted mean annual winter- and summer-precipitation ratios (fig. 22). The lack of pronounced seasonal variation in the ratios indicated mixing of winter and summer precipitation, perhaps through shallow-groundwater circulation.

\section{Dissolved Chloride and Chloride-Mass Balance}

Dissolved-chloride concentrations in water from Baker and Lehman Creeks and the springs were greater than would be

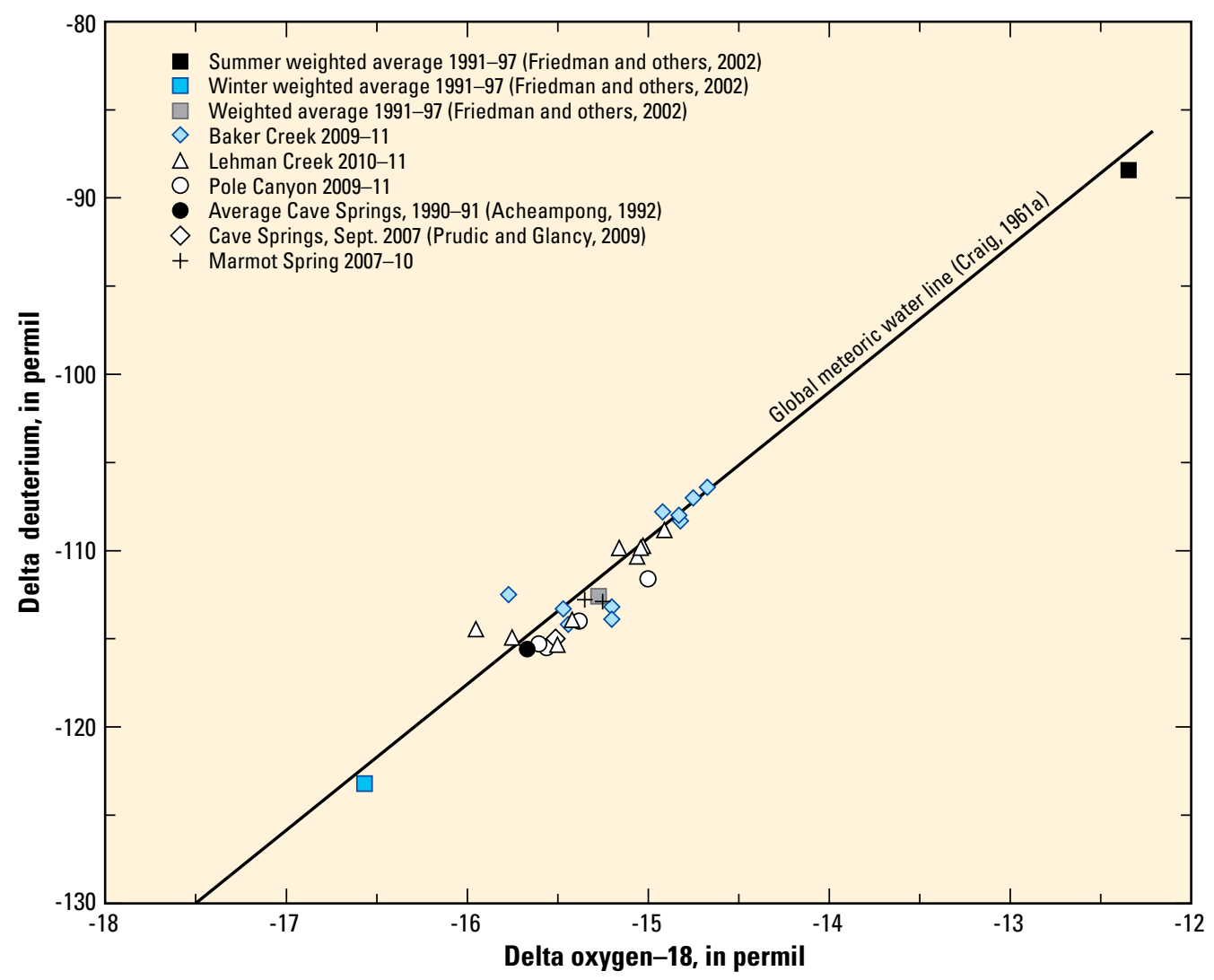

Figure 22. Relation of deuterium and oxygen-18 in water samples collected from Baker and Lehman Creeks, Pole Canyon, and Cave and Marmot Springs in the mountain-upland zone as well as in the volume-weighted mean annual, mean-winter, and mean-summer precipitation collected in vicinity of Great Basin National Park, White Pine County, Nevada. 
expected from atmospheric deposition of salts in the mountain-upland zone (table 5). The dissolved chloride concentration of precipitation has been monitored at the GBNP since January 1985 as part of a national network for monitoring the chemistry of precipitation (National Atmospheric Deposition Program, 2011). The mean volume-weighted concentration of chloride in precipitation was 0.16 milligrams per liter $(\mathrm{mg} / \mathrm{L})$. This concentration did not include chloride deposited by dust between periods of precipitation. The chemical composition of dust (dry fall) has been collected in the GBNP since May 1995 as part of the national program for monitoring water chemistry in precipitation; however, chloride is not part of the analyses (National Atmospheric Deposition Program, 2011).

Assuming chloride was only introduced by precipitation, the mean concentration of chloride in surface water and groundwater in the drainage basins would be equal to the mass of chloride deposited on the land surface from precipitation or to the concentration multiplied by precipitation minus water lost through evapotranspiration. Given an estimated evapotranspiration of 56 percent of total mean annual precipitation for the combined drainage basins (table 4), the mean concentration of dissolved chloride in surface water and groundwater would not be more than $0.36 \mathrm{mg} / \mathrm{L}$, if atmospheric chloride deposition was $0.16 \mathrm{mg} / \mathrm{L}$. The flow-weighted mean chloride concentration was $1.2 \mathrm{mg} / \mathrm{L}$ for Baker Creek and $1 \mathrm{mg} / \mathrm{L}$ for Lehman Creek, however, and chloride concentrations were higher in water from Pole Canyon and from Cave and Marmot Springs (table 5). Four explanations for this are (1) mean annual runoff was less than a third of that estimated, (2) mean annual precipitation and evapotranspiration were more than estimated, (3) chloride salts are present in measureable quantities in the rocks, and (4) chloride attached to dust (dry fall, Dettinger, 1989) was deposited in sufficient quantities to account for the chloride in the creeks and springs.
Assuming the mean annual runoff at the gaging stations was the same as that from the mountain-upland zone and the flow-weighted mean chloride concentrations, the mean annual precipitation and evapotranspiration in the mountainupland zone would need to be at least three times greater than was estimated, but such large quantities of precipitation and evapotranspiration are unreasonable. Minerals in the rocks do not contain enough chloride to account for the chloride concentrations in the creeks (Lee and Van Loenen, 1971), and chemical precipitation of salts (particularly chloride) from the actively eroding mountains with moderate precipitation would be unlikely. Thus, only chloride salts on dust deposited from the atmosphere could account for the chloride concentrations in the water in creeks and springs.

Chloride mass balance is useful for estimating groundwater recharge in drainage basins (or parts of drainage basins) underlain by permeable rocks (Dettinger, 1989), but it requires an estimate of total atmospheric chloride deposition. To estimate groundwater recharge for the karst-limestone zone in the Baker and Lehman Creek drainage basins, for the karst-limestone and upper-piedmont zones in the Snake Creek drainage basin, and for drainage basins at the south end of the Snake Range that potentially contribute flow to Big Springs, the water-budget components listed in table 4 and the dissolved-chloride concentrations in table 5 were used to estimate the mean annual dissolved-chloride concentration from atmospheric deposition (in precipitation and from dust) in the mountain-upland zone of Baker and Lehman Creeks and Pole Canyon by using the chloride-mass balance method (Dettinger, 1989). The method assumes no dissolution of chloride from the rocks and that the annual chloride mass from precipitation and dust is balanced by outflow of the same chloride mass, or no annual change in chloride mass in the mountain-upland zones. The chloride mass-balance equation was rewritten as follows:

where

$$
C_{p p t}=\frac{\left(C_{B} V_{B}\right)+\left(C_{L} V_{L}\right)+\left(C_{P} V_{P}\right)+\left(C_{g w B} V_{g w B}\right)+\left(C_{g w L} V_{g w L}\right)+\left(C_{g w P} V_{g w P}\right)+\left(C_{s p} V_{s p}\right)}{V_{p p t}}
$$

\footnotetext{
$C_{p p t}$ is mean chloride concentration from precipitation and dry fall, in $\mathrm{mg} / \mathrm{L}$;

$C_{B}$ is mean chloride concentration of water in Baker Creek, in $\mathrm{mg} / \mathrm{L}$;

$C_{L}$ is mean chloride concentration of water in Lehman Creek, in $\mathrm{mg} / \mathrm{L}$;

$C_{P}$ is mean chloride concentration of water in Pole Canyon, in $\mathrm{mg} / \mathrm{L}$;

$C_{g w B}$ is mean chloride concentration of groundwater beneath Baker Creek, in $\mathrm{mg} / \mathrm{L}$;

$C_{g w L}$ is mean chloride concentration of groundwater beneath Lehman Creek, in mg/L;

$C_{g w P}$ is mean chloride concentration of groundwater beneath Pole Canyon, in $\mathrm{mg} / \mathrm{L}$;

$C_{s p} \quad$ is mean chloride concentration of spring water, in $\mathrm{mg} / \mathrm{L}$;

$V_{p p t}$ is mean annual precipitation, in acre-ft;

$V_{B}$ is mean annual runoff in Baker Creek, in acre-ft;

$V_{L}$ is mean annual runoff in Lehman Creek, in acre-ft;

$V_{P}$ is mean annual runoff in Pole Canyon, in acre-ft;

$V_{g w B}$ is mean annual groundwater flow beneath Baker Creek, in acre-ft;

$V_{g w L}$ is mean annual groundwater flow beneath Lehman Creek, in acre-ft;

$V_{g w P}$ is mean annual groundwater flow beneath Pole Canyon, in acre-ft; and

$V_{s p}$ is mean annual spring flow, in acre-ft.
} 
The mean chloride concentration in the shallow alluvium beneath the creeks was assumed to be the same as the mean chloride concentration in the creek water. A water sample from the Baker Creek test-well downstream of GBNP had a chloride concentration of $1 \mathrm{mg} / \mathrm{L}$ in October 2009, which was similar to the concentration in water from Baker Creek. The mean chloride concentrations in water from Cave and Marmot Springs were averaged. A range in the inflows and outflows were used to account for uncertainty in the mean annual precipitation, runoff, groundwater flow, and spring flow listed in table 4 . This resulted in an estimated mean annual chloride concentration of $0.6 \mathrm{mg} / \mathrm{L}$, with an uncertainty of $0.2 \mathrm{mg} / \mathrm{L}$ (a range of 0.4-0.8 mg/L). Dettinger (1989, p. 62) also reported a chloride concentration of $0.6 \mathrm{mg} / \mathrm{L}$ from atmospheric deposition that included dry fall for Nevada.

An estimate of mean chloride concentrations from atmospheric deposition also was calculated by using the total mean annual precipitation for each of the seven drainage basins listed in table 3 along with the estimated mean annual runoff and mean chloride concentrations for each creek. The mean chloride concentrations in water from Baker and Lehman Creeks and Pole Canyon were flow-weighted means, whereas only a simple average of the $2-5$ samples collected from the other creeks near the end of the mountain-upland zone was used for the other drainage basins.

The resulting mean precipitation-weighted chloride concentration was $0.5 \mathrm{mg} / \mathrm{L}$ and ranged from $0.35 \mathrm{mg} / \mathrm{L}$ in Snake Creek to $0.6 \mathrm{mg} / \mathrm{L}$ in Baker Creek. The estimated mean chloride concentrations of atmospheric deposition for the two drainage basins on the west side of the southern Snake Range (Williams Canyon and Shingle Creek) and Snake Creek to the south of Baker Creek were less than the overall mean, whereas the concentrations for Strawberry and Lehman Creeks to the north and Pole Canyon to the east were near the mean of $0.5 \mathrm{mg} / \mathrm{L}$. The lower concentrations in Snake, Shingle, and Williams Canyon drainage basins could be an artifact of using a non-flow weighted average from the limited number of chloride analyses or could indicate less atmospheric chloride deposition in those drainage basins. The mean chloride concentration for atmospheric deposition of $0.6 \mathrm{mg} / \mathrm{L}$ used in this study resulted in somewhat greater estimates of mean annual runoff and groundwater water recharge compared with those obtained by using an estimate of $0.5 \mathrm{mg} / \mathrm{L}$.

\section{Karst-Limestone Zone}

The karst-limestone zone in the Baker and Lehman Creek drainage basins (shown on fig. 21) begins where Middle Cambrian Pole Canyon Limestone outcrops on the lower slopes in the mountain part of the drainage basins or lies at shallow depth beneath thin glacial and alluvial deposits. Distinctive features of this zone are as follows: (1) moderate-altitude terrain with steep to moderate slopes between ridges and stream channels and thin soils; (2) a moist and cool climate; (3) active erosion with thin, young, glacial and alluvial deposits along stream channels that overlie karst and permeable limestone;
(4) losing stream reaches; and (5) shallow-groundwater circulation. The limestone in this zone has become more permeable from dissolution by shallow circulating groundwater, which has created numerous caves and large tubular openings, some of which are above the groundwater table (fig. 23).

Water losses along Baker and Lehman Creeks contribute to flow through the karst limestone either as percolation through alluvial deposits above the limestone or as flow directly into caves. Both creeks consistently lost flow in the karst-limestone zone. Much of the loss was along Baker Creek in the Narrows, even though during the spring and summer of 2011, flow from Pole Canyon and from a resurgent spring near Model Cave entered Baker Creek. Some streamflow in Baker Creek typically is lost to Ice and Sink Caves. Ice Cave is near the entrance to the Narrows, and Sink Caves is about midway between Ice Cave and the confluence with Pole Canyon (fig. 21).

\section{Streambed-Seepage Rates}

Net streambed-seepage rates were estimated for Baker and Lehman Creeks in the karst-limestone zone by taking discharge measurements at different locations along a creek on a single day and then dividing the streamflow loss (or gain) between two measurements by the estimated area of the streambed between them. Values are reported in $\mathrm{ft} / \mathrm{d}$ (for $\mathrm{ft}^{3} / \mathrm{d} / \mathrm{ft}^{2}$ ) so that they can be compared directly with estimates of streambed-seepage rates from streambed piezometers. Net streambed-seepage rates for Lehman Creek also were estimated by measuring the temperature of the streambed in two shallow piezometers, PL1 and PL4, every 15 minutes, as the temperature changed during the day. Piezometer PL1 was about $20 \mathrm{ft}$ downstream of the gaging station, and piezometer PL4 was immediately downstream of GBNP. The methods used to estimate streambed-seepage rates from temperature and water-level data in streambed piezometers are described in appendix 14.

Net streambed-seepage rates estimated from differences between discharge measurements at selected locations along Baker and Lehman Creeks are summarized in tables 6 and 7, respectively. The tables include net streambed-seepage rates for both creeks at selected locations in the upper-piedmont zone. The reach in the karst-limestone zone (reach 1) extended from upstream of the Narrows to the eastern boundary of GBNP on Baker Creek and from the lower Lehman Creek campground to just upstream of the eastern boundary of GBNP on Lehman Creek (fig. 21). Net streambed-seepage rates ranged from -1.1 to $-8.6 \mathrm{ft} / \mathrm{d}$, where negative values represent streamflow losses, for reach 1 on Baker Creek (table 6) and from -0.8 to $-3.5 \mathrm{ft} / \mathrm{d}$ on Lehman Creek (table 7), and streamflow loss was greater as discharge measurements increased. Much of the loss on Baker Creek was actually from flow into Ice and Sink Caves; thus, the streamflow losses estimated for Baker Creek, particularly at higher discharge rates, could be exaggerated. No direct losses to caves were observed along Lehman Creek; thus, streamflow losses were diffused along the streambed. The greater streamflow losses along 


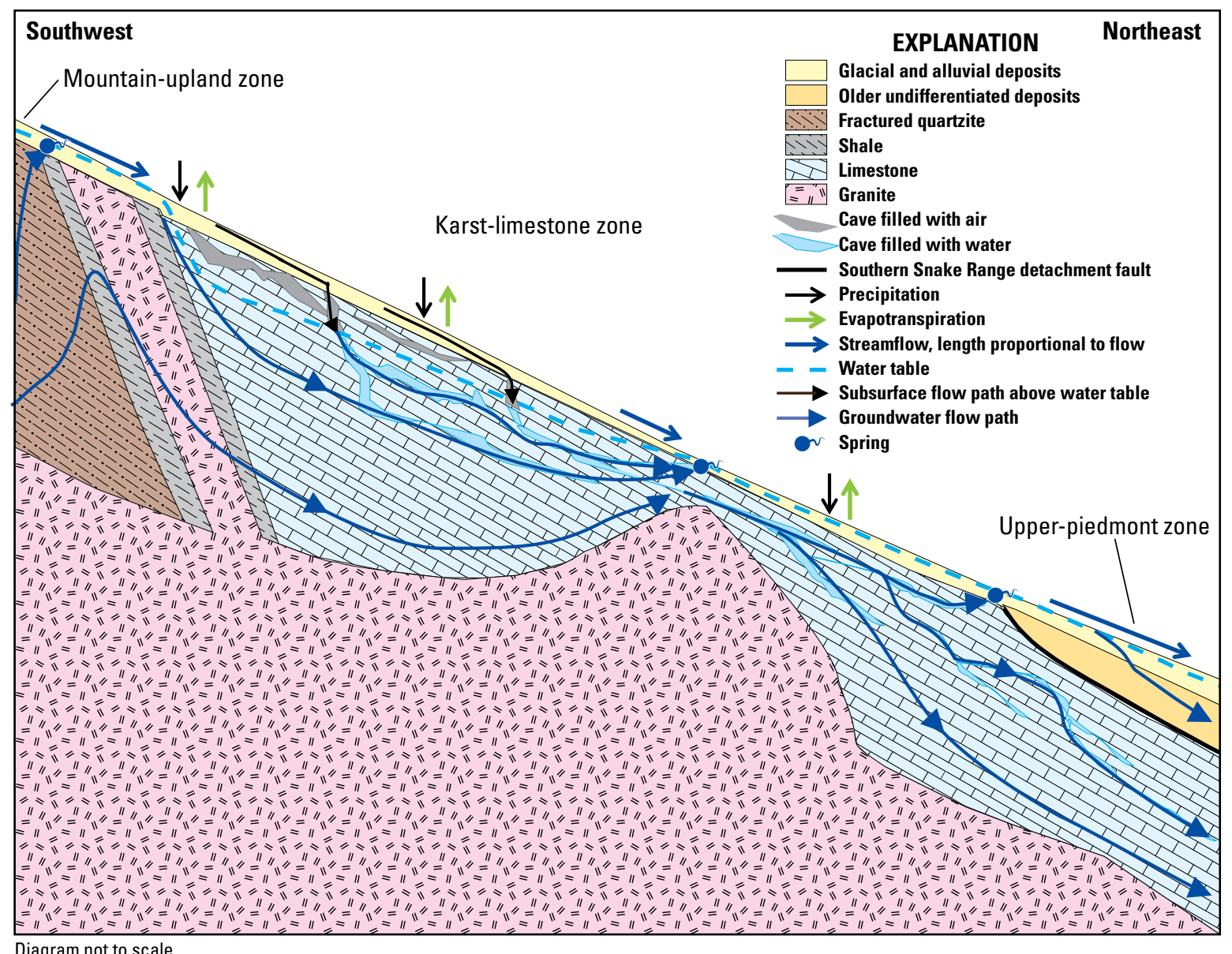

Figure 23. Idealized cross section showing streamflow and groundwater flow along Baker and Lehman Creeks in the karst-limestone zone, Great Basin National Park, White Pine County, Nevada.

Table 6. Discharge measurements, streamflow loss or gain, streambed width and length, and net streambed-seepage rates for selected reaches on Baker Creek, Great Basin National Park, White Pine County, Nevada, July 2009 to August 2011.

[Reach 1 is between measurements at Grey Cliff group campground and park boundary; reach 2 is between park boundary and trail crossing diverted Baker Creek downstream of spring inflow (spring inflow subtracted from discharge at downstream end); reach 3 is between trail crossing diverted Baker Creek and confluence with Lehman Creek. Gain is positive; loss is negative. Discharge and gain or loss rounded to three significant figures; uncertainty and net streambed-seepage rate rounded to two significant figures. Abbreviation: $\mathrm{mm}$, two digit month; dd, two digit day; yyyy, four digit year; e, estimated with uncertainty assumed at 25 percent. Symbol: —, net streambed-seepage rate less than uncertainty]

\begin{tabular}{|c|c|c|c|c|c|c|c|c|c|}
\hline $\begin{array}{c}\text { Date } \\
\mathrm{mm} / \mathrm{dd} / \mathrm{yyyy}\end{array}$ & $\begin{array}{c}\text { Reach } \\
\text { number }\end{array}$ & $\begin{array}{c}\text { Upstream } \\
\text { discharge } \\
\text { measurement } \\
\text { (cubic feet per } \\
\text { second) }\end{array}$ & $\begin{array}{c}\text { Downstream } \\
\text { discharge } \\
\text { measurement } \\
\text { (cubic feet per } \\
\text { second) }\end{array}$ & $\begin{array}{l}\text { Gain or loss } \\
\text { (cubic feet per } \\
\text { second) }\end{array}$ & Gain or loss & $\begin{array}{l}\text { Estimated } \\
\text { uncertainty } \\
\text { (cubic feet per } \\
\text { second) }\end{array}$ & $\begin{array}{l}\text { Estimated } \\
\text { stream } \\
\text { length } \\
\text { (feet) }\end{array}$ & $\begin{array}{c}\text { Estimated } \\
\text { average } \\
\text { stream width } \\
\text { (feet) }\end{array}$ & $\begin{array}{c}\text { Net streambed } \\
\text { seepage rate } \\
\text { (feet per day) }\end{array}$ \\
\hline $7 / 20 / 2010$ & 1 & e11.0 & 6.52 & $\mathrm{e}-4.5$ & Loss & 3.3 & 6,100 & 13 & -4.9 \\
\hline $8 / 25 / 2010$ & 1 & 4.43 & 0.70 & -3.73 & Loss & 0.41 & 6,100 & 12 & -4.4 \\
\hline $12 / 08 / 2010$ & 1 & 3.66 & 2.77 & -0.89 & Loss & 0.51 & 6,100 & 12 & -1.1 \\
\hline $1 / 25 / 2011$ & 1 & 3.71 & 2.16 & -1.55 & Loss & 0.47 & 6,100 & 12 & -1.8 \\
\hline 4/19/2011 & 1 & 13.2 & 7.50 & -5.70 & Loss & 1.7 & 6,500 & 12 & -6.3 \\
\hline $6 / 02 / 2011$ & 1 & 44.7 & 32.9 & -11.7 & Loss & 6.2 & 6,500 & 18 & -8.6 \\
\hline
\end{tabular}


Table 7. Discharge measurements, streamflow loss or gain, streambed width and length, and net streambed-seepage rates for selected reaches on Lehman Creek, Great Basin National Park, White Pine County, Nevada, July 2010 to August 2011.

[Reach 1 is between measurements at lower Lehman campground and downstream of park entrance road; reach 2 is between park boundary and upstream side of Sage Way road crossing. Gain is positive; loss is negative. Discharge and gain or loss rounded to three significant figures; uncertainty and net streambed-seepage rate rounded to two significant figures. Abbreviation: mm, two digit month; dd, two digit day; yyyy, four digit year. Symbol: —, net streambed-seepage rate less than uncertainty]

\begin{tabular}{|c|c|c|c|c|c|c|c|c|c|}
\hline $\begin{array}{c}\text { Date } \\
\mathrm{mm} / \mathrm{dd} / \mathrm{yyyy}\end{array}$ & $\begin{array}{l}\text { Reach } \\
\text { number }\end{array}$ & $\begin{array}{l}\text { Upstream } \\
\text { discharge } \\
\text { (cubic feet per } \\
\text { second) }\end{array}$ & $\begin{array}{l}\text { Downstream } \\
\text { discharge } \\
\text { (cubic feet per } \\
\text { second) }\end{array}$ & $\begin{array}{l}\text { Gain or loss } \\
\text { (cubic feet per } \\
\text { second) }\end{array}$ & Gain or loss & $\begin{array}{l}\text { Estimated } \\
\text { uncertainty } \\
\text { (cubic feet per } \\
\text { second) }\end{array}$ & $\begin{array}{c}\text { Estimated } \\
\text { stream length } \\
\text { (feet) }\end{array}$ & $\begin{array}{l}\text { Estimated } \\
\text { average } \\
\text { stream width } \\
\text { (feet) }\end{array}$ & $\begin{array}{c}\text { Net streambed- } \\
\text { seepage rate } \\
\text { (feet per day) }\end{array}$ \\
\hline $7 / 20 / 2010$ & 1 & 7.35 & 6.64 & -0.71 & Neutral & 1.1 & 11,000 & 9 & - \\
\hline $8 / 26 / 2010$ & 1 & 4.32 & 3.04 & -1.28 & Loss & 0.59 & 11,000 & 9 & -1.1 \\
\hline $9 / 28 / 2010$ & 1 & 2.78 & 1.6 & -1.18 & Loss & 0.35 & 11,000 & 9 & -1.0 \\
\hline $10 / 28 / 2010$ & 1 & 3.15 & 1.85 & -1.30 & Loss & 0.40 & 11,000 & 9 & -1.1 \\
\hline $12 / 07 / 2010$ & 1 & 2.08 & 0.96 & -1.12 & Loss & 0.24 & 11,000 & 9 & -1.0 \\
\hline $1 / 25 / 2010$ & 1 & 2.17 & 1.29 & -.88 & Loss & 0.28 & 11,000 & 9 & -0.8 \\
\hline $4 / 19 / 2011$ & 1 & 5.24 & 3.53 & -1.71 & Loss & 0.70 & 11,000 & 9 & -1.5 \\
\hline $6 / 02 / 2011$ & 1 & 18.5 & 14.2 & -4.30 & Loss & 2.6 & 11,000 & 12 & -2.8 \\
\hline $8 / 18 / 2011$ & 1 & 15.9 & 10.6 & -5.30 & Loss & 2.1 & 11,000 & 12 & -3.5 \\
\hline $11 / 07 / 2009$ & 2 & 1.82 & 2.11 & 0.29 & Neutral & 0.31 & 1,800 & 6 & - \\
\hline $2 / 24 / 2010$ & 2 & 1.05 & 1.18 & 0.13 & Neutral & 0.18 & 1,800 & 6 & - \\
\hline $3 / 23 / 2010$ & 2 & 1.06 & 1.21 & 0.15 & Neutral & 0.18 & 1,800 & 6 & - \\
\hline
\end{tabular}

Table 8. Streambed-seepage rates, hydraulic gradients, and hydraulic conductivities at six piezometers driven into Baker and Lehman Creeks, Great Basin National Park, White Pine County, Nevada, June 2009 to November 2010.

\begin{tabular}{|c|c|c|c|c|c|c|c|}
\hline \multirow{2}{*}{$\begin{array}{l}\text { Streambed } \\
\text { piezometer }\end{array}$} & \multirow{2}{*}{$\begin{array}{l}\text { Measurement period } \\
\mathrm{mm} / \mathrm{dd} / \mathrm{yyyy}\end{array}$} & \multicolumn{2}{|c|}{$\begin{array}{l}\text { Streambed-seepage rate } \\
\text { (feet per day) }\end{array}$} & \multicolumn{2}{|c|}{$\begin{array}{l}\text { Hydraulic gradient } \\
\text { (foot per foot) }\end{array}$} & \multicolumn{2}{|c|}{$\begin{array}{l}\text { Hydraulic conductivity } \\
\text { (feet per day) }\end{array}$} \\
\hline & & Mean & Range & Mean & Range & Vertical & Lateral \\
\hline \multicolumn{8}{|c|}{ Karst-limestone zone-Lehman Creek } \\
\hline \multirow{2}{*}{ PL1-0 } & $6 / 14 / 2009$ to $9 / 04 / 2009$ & -0.53 & -0.59 to -0.43 & -0.36 & -0.39 to -0.32 & 2 & $>100$ \\
\hline & $3 / 24 / 2010$ to $8 / 25 / 2010$ & -0.88 & -1.0 to -0.44 & -0.33 & -0.42 to -0.18 & 4 & $>100$ \\
\hline PL4-0.44 & $3 / 24 / 2010$ to $5 / 20 / 2010$ & -2.0 & -3.1 to -1.4 & -0.03 & -0.04 to -0.02 & 90 & 100 \\
\hline \multicolumn{8}{|c|}{ Upper-piedmont zone-Baker Creek } \\
\hline PB2-1.48 & $9 / 05 / 2009$ to $3 / 23 / 2010$ & -0.08 & -3.0 to 3.0 & -0.08 & -0.40 to 0.40 & 10 & - \\
\hline PB1-2.29 & $3 / 26 / 2010$ to $11 / 03 / 2010$ & -0.08 & -0.80 to 0.20 & -0.03 & -0.30 to 0.10 & 3 & $>100$ \\
\hline \multicolumn{8}{|c|}{ Upper-piedmont zone-Lehman Creek } \\
\hline PL3-1.60 & $3 / 24 / 2010$ to $8 / 25 / 2010$ & -0.62 & -1.4 to -0.37 & -1.1 & -1.3 to -0.45 & 1 & 100 \\
\hline PL2-2.42 & $3 / 24 / 2010$ to $11 / 03 / 2010$ & -0.15 & -0.24 to 0.04 & -0.18 & -0.29 to 0.05 & 1 & $>100$ \\
\hline
\end{tabular}

Lehman Creek in 2011 compared with 2010 were caused, in part, by overbank flows to distributary channels. If the mean streambed-seepage rate of $-1 \mathrm{ft} / \mathrm{d}$ estimated during low flow was assumed for the higher flows, then the area of streamflow would need to be about three times greater to account for the measured streamflow losses.

No piezometers were driven into the streambed of Baker Creek in the karst-limestone zone because of large quartzite boulders in the channel. Mean, maximum, and minimum of daily streambed-seepage rates for Lehman Creek at piezometers PL1 and PL4 in the karst-limestone zone are listed in table 8 and were estimated by using methods described in appendix 14. Piezometer PL1 was driven into the streambed on May 30, 2009, and, in early June 2009, temperatures were similar at all depths (fig. 24). This yielded a streambedseepage rate of $-3.5 \mathrm{ft} / \mathrm{d}$ on June 4, 2009, whereas, in August and early September 2009, greater differences in temperature with depth yielded a rate of about $-0.5 \mathrm{ft} / \mathrm{d}$. Differences in 
$\boldsymbol{A}$
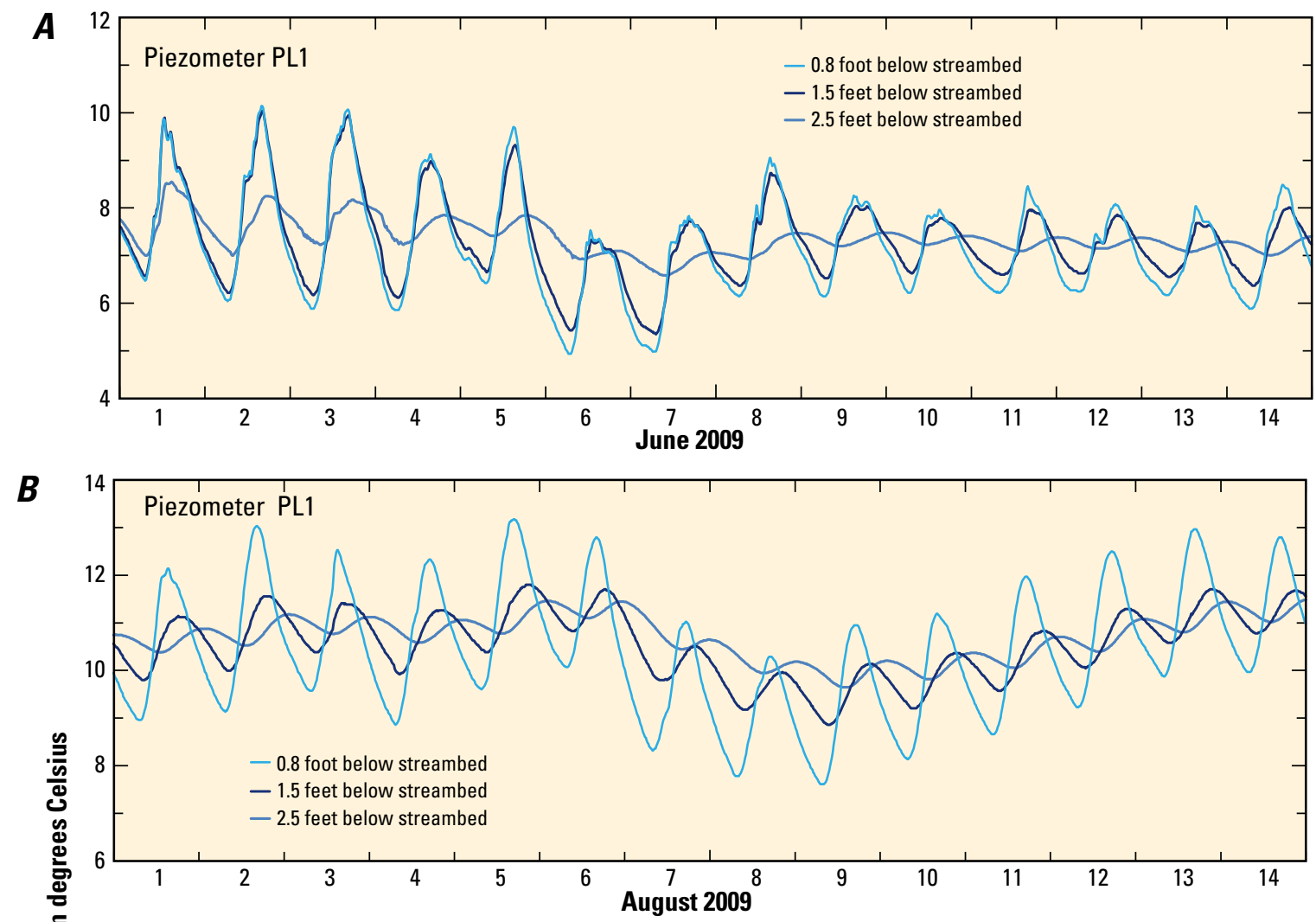

C

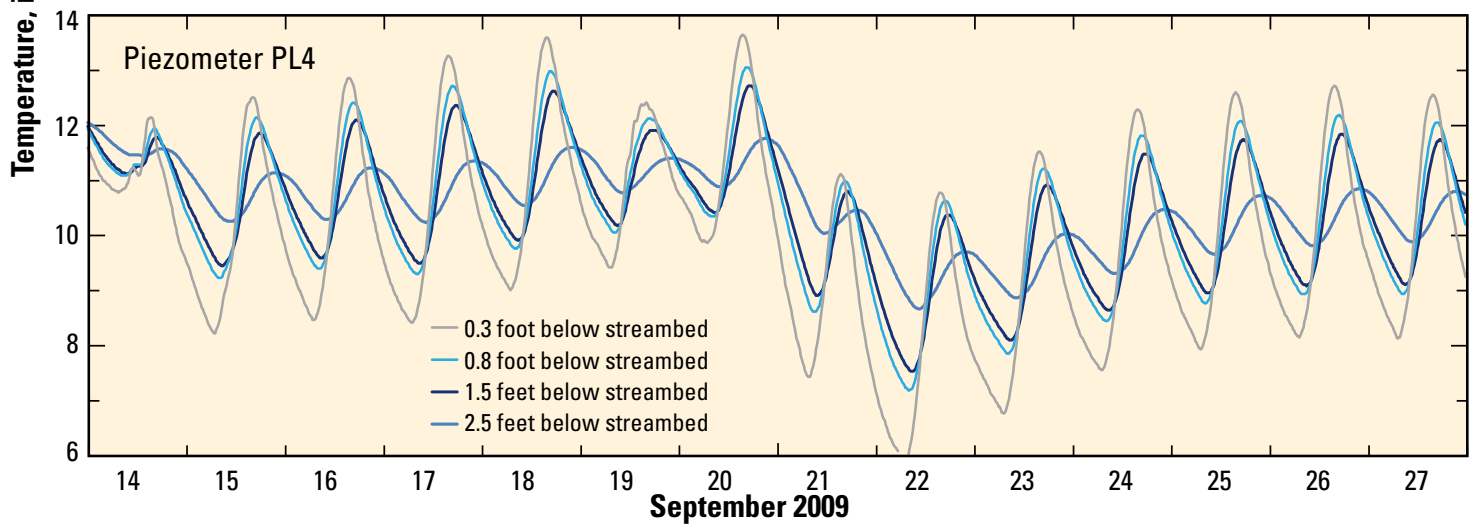

D

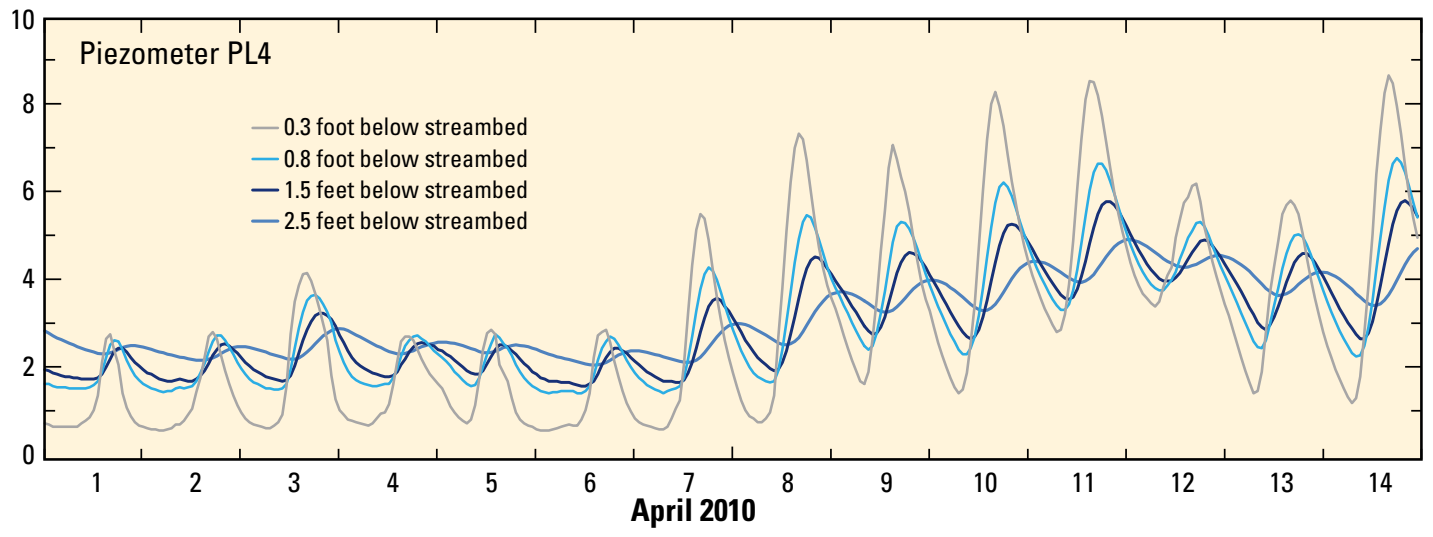

Figure 24. Streambed temperatures from piezometers in karst-limestone zone of Lehman Creek, Great Basin National Park, White Pine County, Nevada, for selected 2-week periods: $A$, piezometer PL1, June 1-14, 2009; $B$, piezometer PL1, August 1-14, 2009; $C$, piezometer PL4, September 14-27, 2009; and D, piezometer PL4, April 1-14, 2010. 
temperature with depth measured in June 2010 were similar to those from August and late September 2009, and yielded streambed-seepage rates of about $-0.9 \mathrm{ft} / \mathrm{d}$.

The greatest rates of loss (most negative streambed-seepage rates) from the streambed in Lehman Creek at PL1 were measured in early June 2009, reflecting disturbance at the site from driving the piezometer into the streambed. Within a few weeks, however, the streambed-seepage rates had become nearly constant at $-0.5 \mathrm{ft} / \mathrm{d}$. During the same period, the hydraulic gradient of the streambed at PL1 became more negative, indicating that the head in the piezometer was declining more rapidly than it was in the creek (fig. 25). This indicated that the area around the piezometer that was disturbed during installation became sealed with fine-grained sediments within a month. The lowest streambed-seepage rate of $-0.4 \mathrm{ft} / \mathrm{d}$ was measured from August 12 to 18, 2009, when streambed hydraulic gradients were nearly stable at $-0.37 \mathrm{ft} / \mathrm{ft}$ (fig. 25 ).

Streambed temperatures at piezometer PL4 showed the greatest diurnal changes at the shallowest depths; temperature changes dampened and lagged with increasing depth beneath the streambed during September 14-27, 2009 (fig. 24C). The hydraulic gradient of the streambed at PL4 was only slightly negative (fig. 25). The September temperature data were consistent with downward flow from the creek into the streambed, but the large diurnal fluctuations indicated that the vertical hydraulic conductivity was greater than it was at PL1. From September 12, 2009, to March 24, 2010, daily mean stream stage at PL4 was estimated by adjusting the stage at the gaging station near PL1 to the stream stage measured on specific dates at the piezometer. A pressure transducer was placed in the creek next to the piezometer on March 24, 2010, and stage data were recorded until August 26, 2010, when the pressure transducer and temperature logger were removed. The pressure transducer in the piezometer failed on May 20, 2010.

From September 12, 2009, to May 12, 2010, the hydraulic gradient varied little; the head in the piezometer closely matched that in the creek, indicating groundwater flow at piezometer PL4 paralleled flow in the creek (fig. 25). The slightly positive hydraulic gradients estimated for some days from late January 2010 until the pressure transducer was installed on March 24, 2010, were the result of estimating the stage at the gaging station near PL1 because of ice. Consequently, streambed-seepage rates were estimated only for March 24-May 20, 2010, during which time pressure transducers in the creek and piezometer were working, and the daily hydraulic gradients varied little from $-0.03 \mathrm{ft} / \mathrm{ft}$.

Streambed temperatures at piezometer PL4 showed similar diurnal fluctuations during April 1-14, 2010, as those in September 2009 (fig. 24D), and the hydraulic gradients in September 2009 were similar to those between March and May 2010. Even though the hydraulic gradients were low at PL4, and groundwater flow could parallel the stream, the diurnal-temperature fluctuations from late summer to fall 2009 and in spring 2010 indicated that some water from the creek infiltrated the shallow groundwater either at the piezometer or nearby. The estimated streambed-seepage rates at PL4 averaged $-2 \mathrm{ft} / \mathrm{d}$ and ranged from -3.1 to $-1.4 \mathrm{ft} / \mathrm{d}$. Nevertheless, the estimated streambed-seepage rates at the two piezometers were similar to the net streambed-seepage rates estimated from discharge measurements in reach 1 of Lehman Creek (table 7).

A fiber-optic cable was placed in Lehman Creek between PL1 and PL4 to measure water temperature every 3.28 feet (1 meter) along with a distributed temperature sensing (DTS) instrument (appendix 15). This method is useful for

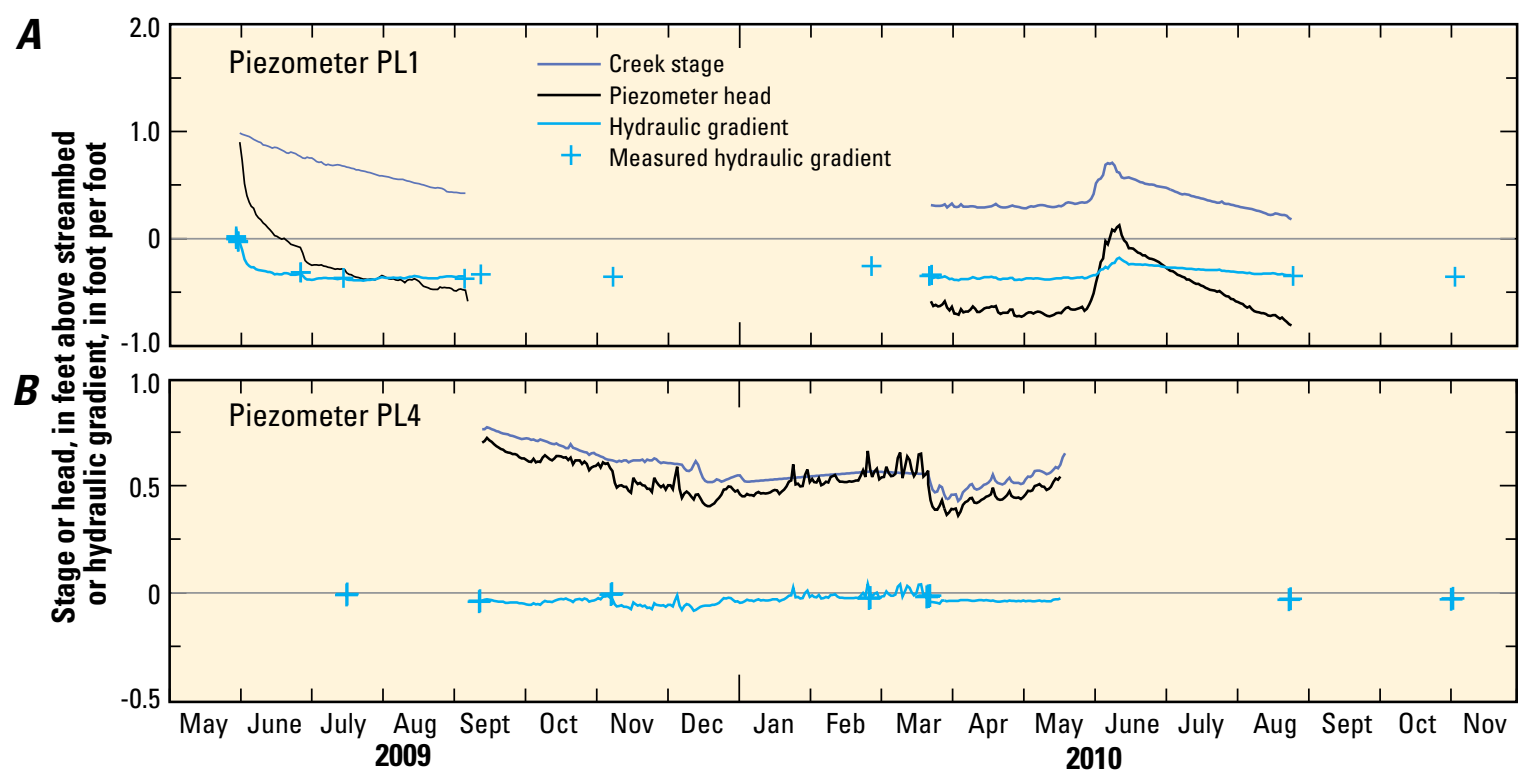

Figure 25. Daily mean stream stage and groundwater head above streambed and daily mean and measured hydraulic gradient for piezometers in Lehman Creek at lower end of karst-limestone zone, Great Basin National Park, White Pine County, Nevada, between May 2009 and November 2010, for $A$, piezometer PL1, and B, piezometer PL4. 
identifying areas of groundwater flow when groundwater temperatures are higher than those in the creek. Temperatures in Lehman Creek were measured three times between October 2009 and February 2010. During the early morning, prior to solar heating of water in the creek, water temperatures indicated no place in the channel where cooler or warmer groundwater entered the creek upstream of piezometer PL4. The lack of temperature differences along the creek indicated either that the temperature of shallow groundwater beneath the creek was similar to that in the creek or that deeper groundwater, as represented by the temperature of water flowing from Rowland Spring, did not flow to Lehman Creek between piezometers PL1 and PL4 in any great quantity. The temperature of Rowland Spring varied little from October 2001 to September 2010 (Elliot and others, 2006, p. 114-119; Gretchen Baker, National Park Service, Great Basin National Park, Baker, Nev., written commun., 2011), with daily means between $8{ }^{\circ} \mathrm{C}$ and $10^{\circ} \mathrm{C}$. Piezometer PL4 and the downstream end of the cable were east and at a slightly lower altitude than Rowland Spring.

\section{Hydraulic Conductivity of Streambed}

Slug tests were done when the piezometers were driven into the streambed to evaluate the connection of the screened interval with the streambed sediments. Hydraulic conductivity from these tests was evaluated and is summarized in appendix table 13-22. Results from the slug tests represented the most permeable materials and were assumed to represent the lateral hydraulic conductivity of sediments that parallel the streambeds. Vertical hydraulic conductivity of the streambed was estimated from the diurnal temperature changes used to estimate streambed-seepage rates at the piezometers. Estimated lateral and vertical hydraulic conductivities are listed in table 8 . Some estimates of lateral hydraulic conductivity from slug tests exceeded $100 \mathrm{ft} / \mathrm{d}$; because of uncertainty about how water was poured into the piezometers, estimates greater than $100 \mathrm{ft} / \mathrm{d}$ were simply listed as greater than $100 \mathrm{ft} / \mathrm{d}$.

Estimates of vertical hydraulic conductivity at PL1 ranged from 2 to $4 \mathrm{ft} / \mathrm{d}$ during periods in the summer of 2009 and in spring and summer of 2010 (table 8). This vertical hydraulic conductivity was about 25 times less than the lateral hydraulic conductivity estimated from slug tests and was slightly greater than the vertical hydraulic conductivity of $2 \mathrm{ft} / \mathrm{d}$ estimated along the alluvial fan of Trout Creek in north central Nevada (Prudic and others, 2007, p. 332) and the $1.6 \mathrm{ft} / \mathrm{d}$ estimated from the aquifer test next to Baker Creek in October 2009 (Jackson, 2010). The vertical and lateral hydraulic conductivities differed because the streambed was lined with large cobbles and boulders, and the pores were clogged with clay, silt and sand (Ronan and others, 1998; Prudic and others, 2007, p. 332). Clogging of the streambed with fine sediments reduces the area of infiltration, which results in a vertical hydraulic conductivity, when averaged over an area of the streambed, much less than the lateral hydraulic conductivity of the shallow sediments beneath the streambed (Schälchli, 1992; Rehg and others, 2005). Because of this, lateral hydraulic conductivities estimated from slug tests in the piezometers were not reliable for estimating streambed-seepage rates.

The vertical hydraulic conductivity estimated from streambed-seepage rates at PL4 was greater than that at PL1 (table 8), mostly, because the hydraulic gradient was near zero, and the diurnal temperature changes penetrated deeply in the streambed (fig. 24). Conduction of heat, alone, was insufficient to explain the diurnal temperature fluctuations measured at depths of 0.8 and $1.5 \mathrm{ft}$ below the streambed. Model calibration to these intermediate temperatures required a vertical hydraulic conductivity of $90 \mathrm{ft} / \mathrm{d}$ (nearly the same as the lateral hydraulic conductivity from slug tests in PL4).

The reason the vertical hydraulic conductivity of the streambed at piezometer PL4 near the contact between the karst-limestone zone and upper-piedmont zone was the same as the lateral hydraulic conductivity is unknown. Perhaps fine-grained sediments did not filter into the streambed at this site because of the low vertical hydraulic gradient (averaged $-0.035 \mathrm{ft} / \mathrm{ft}$ ). Additionally, the piezometer was just to the northeast of Rowland Spring where a seismic refraction study indicated the young alluvial deposits are less than $10-\mathrm{ft}$ thick (Benjamin Roberts, National Park Service, Great Basin National Park, Baker, Nev., written commun., 2012). Water flowing from the creek to the piezometer was inferred because water temperatures in the piezometer during April 2010 (fig. 24D) were much colder than water from Rowland Spring (daily means between 8 and $10{ }^{\circ} \mathrm{C}$ ), indicating that the large diurnal temperature fluctuations measured at different depths in PL4 could result from shallow lateral flow parallel to the creek.

\section{Aquifers}

Groundwater flow through aquifers in the karst-limestone zone is primarily through shallow alluvial deposits and deeper, but still shallow, circulation through fractures and tubular openings (caves) in the Pole Canyon Limestone. Inflow to the aquifers is primarily from streamflow losses in the karst-limestone zone. A small quantity of groundwater enters through the thin glacial and alluvial deposits beneath and next to creeks from the mountain-upland zone. Much of the shallow groundwater that enters the karst-limestone zone along these creeks infiltrates the underlying limestone, so the shallow glacial and alluvial deposits are unsaturated beneath Baker Creek upstream of the Narrows (Allander and Berger, 2009) or, at least, perched above a deeper water table in the limestone (fig. 23).

The depth of groundwater flow through the karst-limestone zone was limited by the depth of karst features and fractures in the limestone and by the relatively shallow depth to the underlying granite or shale. A considerable quantity of groundwater flows from the limestone back to the shallow glacial and alluvial deposits and to springs upstream of the southern Snake Range detachment fault that forms the boundary between the karst-limestone and upper-piedmont zones (fig. 23). 


\section{Evaluating Connection of Aquifers to Springs and Streams, Eastern Part of Great Basin National Park and Vicinity, Nevada}

The numerous caves and tubular openings that both follow and cut across the bedding planes at shallow angles form conduits that create a complex pattern of rapid groundwater flow from outcrop areas at higher altitudes on the west and south sides of the zone to lower altitudes on the east and north sides (fig. 23). Caves near the west and south sides of the zone were unsaturated. The most visited of these caves are Lehman Caves, although many more caves have been explored in the Baker Creek Cave System both north and south of the Narrows (Bridgemon, 1965; Pease and others, 1969). Seismicrefraction surveys at selected locations along the north side of Baker Creek at the upstream end of the Narrows indicated that the depth to groundwater was about $100 \mathrm{ft}$ beneath Baker Creek (Allander and Berger, 2009). This relatively great depth to water was also indicated by a dry cave passage in Systems Key Cave trending north to northeast about $60 \mathrm{ft}$ beneath Baker Creek near the upstream end of the Narrows (Benjamin Roberts, National Park Service, Great Basin National Park, Baker, Nev., oral commun., 2009).

Granite is surrounded by limestone at the surface on both sides of Baker Creek downstream of the confluence with Pole Canyon and downstream of an intermittent spring that flows from Model Cave during spring snowmelt. Model Cave was first described during a speological expedition in 1952 (DeSaussure and others, 1953). The relation of Model Cave to other caves in the Baker Creek Cave system was described by Lange (1958), who noted that large seasonal fluctuations of the water level in Model Cave were caused by streamflow of Baker Creek into Ice and Dynamite Caves (the article did not mention Sink Cave in the channel of Baker Creek). During the winter months, a permanent stream in Model Cave has a flow of about 0.2 to $0.3 \mathrm{ft}^{3} / \mathrm{s}$ and does not resurface downstream (Lange, 1958). At least as much flow continues through fractures and tubular openings in the limestone that surrounds the intruded granite in the Baker Creek drainage basin (illustrated as underflow beneath the highest spring in fig. 23). Farther downstream, groundwater flowing through fractures and tubular openings in the limestone resurfaces near the detachment fault in Baker and Lehman Creek drainage basins, of which, Rowland Spring has the largest perennial flow.

\section{Water Budget}

Total mean annual inflow to the karst-limestone zone was about 18,000 acre-ft, of which, 14,400 acre-ft, or 79 percent, was runoff from the mountain-upland zone (table 4). Precipitation on this zone was only 3,200 acre-ft, or 18 percent. Inflow from the springs at the end of the mountain-upland zone was only 150 acre-ft, and another 440 acre-ft was groundwater flow, mostly through shallow glacial and alluvial deposits associated with Baker and Lehman Creeks. Estimates of groundwater flow from the mountain-upland zone to the karstlimestone zone are discussed in the "Mountain-Upland Zone" section of this report.

Outflow from the karst-limestone zone to the upperpiedmont zone is through one of three modes. The first and largest component of outflow is runoff in the stream channels and from springs at the end of the karst-limestone zone. The second is groundwater flow through relatively thin (less than $100 \mathrm{ft}$ thick), younger glacial and alluvial deposits that underlie Baker and Lehman Creek drainage basins. The third is deeper groundwater flow through older basin-fill deposits, fractures, and tubular openings in limestone of the karstlimestone zone that enters older basin-fill deposits or fractured limestone beneath the upper-piedmont zone.

Total mean annual outflow from the karst-limestone zone was assumed to be equal to the total mean annual inflow because changes in storage were assumed to be negligible. The mean annual runoff in Baker and Lehman Creeks leaving the karst-limestone zone was estimated by using the mean annual runoff at the gaging stations listed in table 1 . The mean annual runoff for Baker and Lehman Creeks totaled 11,400 acre-ft, or 63 percent of the total outflow. Rowland Spring and several minor springs in the vicinity of the spring are about $400 \mathrm{ft}$ south of where Lehman Creek crosses over the southern Snake Range detachment fault. Smaller springs are present near the detachment fault in the Baker Creek drainage basin. The estimated mean annual groundwater flow to springs at the end karst-limestone zone, marked by the southern Snake Range detachment fault, totaled 2,700 acre-ft, or 15 percent of the total outflow from this zone. Spring flow included estimated mean annual runoff of 2,100 acre-ft for Rowland Spring from water years 2002 to 2010 (table 1) plus an additional 400 acrefeet to account for the gain in flow between the spring and about $400 \mathrm{ft}$ downstream, which was estimated from periodic discharge measurements taken between July 2010 and August 2011 (appendix table 3-2, site L3A). A small spring also adds to the outflow in the Baker Creek drainage basin near the end of the karst-limestone zone. The mean annual flow of this spring, called "Rosethorn" spring in this report, was 200 acre$\mathrm{ft}$ and was estimated from periodic discharge measurements taken (appendix table 3-3, site B5C) as well as from daily mean discharge at a temporary gaging station between July 2009 and August 2011 (appendix table 4-6) and adjusted to the mean precipitation rate at the weather station near Lehman Caves Visitor Center.

Evapotranspiration in the karst-limestone zone was estimated by using chloride-mass balance with a ratio of 0.12 between atmospheric deposition $(0.6 \mathrm{mg} / \mathrm{L})$ and mean chloride concentrations for Pole Canyon and Cave and Marmot Springs (about $5 \mathrm{mg} / \mathrm{L}$, table 5). This ratio was multiplied by the mean annual precipitation to estimate groundwater recharge in the karst-limestone zone. Two dissolved-chloride samples were collected from a test well drilled in May 2012, east of the sewage lagoons, and the chloride concentration in groundwater was $5 \mathrm{mg} / \mathrm{L}$ (Prudic, 2012a). The estimated annual groundwater recharge from precipitation in the karst-limestone zone was about 400 acre-ft, which means at least 2,800 acre-ft was lost to evapotranspiration annually. The uncertainty of evapotranspiration was estimated by using the maximum and minimum estimates of groundwater recharge derived from the minimum and maximum atmospheric deposition estimates of 0.4 and $0.8 \mathrm{mg} / \mathrm{L}$, the maximum and minimum mean annual 
precipitation estimated to range from 3,800 and 2,600 acre-ft, and the maximum and minimum dissolved chloride concentration in groundwater estimated to range from $7 \mathrm{mg} / \mathrm{L}$ (Pole Canyon) to $3 \mathrm{mg} / \mathrm{L}$ (Rowland Spring). The estimate of mean annual evapotranspiration assumed little evapotranspiration of surface water in the creeks. Subtracting the total of all outflows, except for groundwater, from the total inflow to the karst-limestone zone resulted in an estimate of total mean annual groundwater flow from the karst-limestone zone to the upper-piedmont zone of 1,300 acre-ft.

Groundwater outflow from the karst-limestone zone was estimated for three units: shallow alluvial deposits, older basin-fill deposits, and consolidated rocks (table 4). The shallow alluvial deposits included younger glacial and alluvial deposits. The thickness of younger glacial and alluvial deposits at the end of the karst-limestone zone near Lehman Creek and Rowland Spring was estimated to be about $10 \mathrm{ft}$ on the basis of shallow seismic refraction lines done as part of the design for the sewage lagoons (Benjamin Roberts, National Park Service, Great Basin National Park, Baker, Nev., written commun., 2012). A test well drilled in May 2012, east of the southern sewage lagoon, encountered $146 \mathrm{ft}$ of younger and older basin-fill deposits (Prudic, 2012a), which was similar to that encountered in a private well drilled about a quarter of a mile downstream of the eastern boundary of GBNP and north of Lehman Creek. The younger deposits were about $20 \mathrm{ft}$ deep at the test well and about $100 \mathrm{ft}$ thick at the private well. The older deposits ranged from about 50 to $100 \mathrm{ft}$ thick. Thin intervals of permeable sand and gravel were encountered in the older deposits, indicating some groundwater could exit the karst-limestone zone through them.

The estimated groundwater outflow through the younger alluvial deposits in the Lehman Creek drainage basin was about 150 acre-ft per year (acre-ft/yr). This estimate assumed a lateral hydraulic conductivity of $90 \mathrm{ft} / \mathrm{d}$ (piezometer PL4, table 8 ), a hydraulic gradient of $0.05 \mathrm{ft} / \mathrm{ft}$, a saturated thickness of $10 \mathrm{ft}$, and a width of $400 \mathrm{ft}$. The estimated groundwater flow through the younger alluvial deposits next to Baker Creek was 350 acre-ft/yr based on a numerical groundwater-flow model used to evaluate aquifer properties near the Baker Creek aquifer-test site (Jackson, 2010). The mean annual groundwater outflow through younger glacial and alluvial deposits in the Baker and Lehman Creek drainage basins was about 500 acre-ft (table 4).

The remaining 800 acre-ft/yr of groundwater outflow to the upper-piedmont zone was a combination of flow through older basin-fill deposits and through fractured limestone (table 4). The older deposits included those that underlie glacial deposits, and they bound the drainage divide on the northern side of Lehman Creek (fig. 12). The glacial deposits along the northern drainage divide divert Lehman Creek southward at the upstream end of the karst-limestone zone. The springs at Home Farm could be fed by flow either through older buried alluvial deposits or through the underlying Pole Canyon Limestone. The mean annual flow of the Home Farm springs was estimated at about $400 \mathrm{acre}-\mathrm{ft} / \mathrm{yr}$, so at least half of the estimated $800 \mathrm{acre}-\mathrm{ft} / \mathrm{yr}$ of groundwater flow through the older basin-fill deposits and fractured limestone flowed to the surface at Home Farm.

\section{Bulk Transmissivity of Limestone}

A bulk transmissivity for the limestone was estimated on the basis of a total mean annual flow of 4,200 acre-ft moving through fractures and solution openings in the limestone. This total mean annual flow included flow from Rowland Spring, lesser springs near Rowland Spring, and Rosethorn spring (total annual of 2,700 acre-ft); groundwater flow through the older basin-fill deposits and fractured limestone (800 acre-ft); and flow from the Model Cave resurgent spring (700 acre-ft). A mean hydraulic gradient of $0.05 \mathrm{ft} / \mathrm{ft}$ was assumed and was the same as the streambed gradient of Lehman Creek. Bulk transmissivity is dependent on the width of flow used. If the width of flow included the total width of fractures, solution openings, and limestone, then it would be about $3 \mathrm{mi}$., because a straight line projected from where the upper-piedmont zone crosses the eastern boundary of GBNP north of Lehman Creek to where it crosses the southern drainage divide of Baker Creek is about $3 \mathrm{mi}$. The estimated bulk transmissivity was about 600 square feet per day $\left(\mathrm{ft}^{2} / \mathrm{d}\right)$. This estimate is $50-70$ percent of the range for the transmissivity of younger alluvial deposits estimated from an aquifer test along Baker Creek (Jackson, 2010; http://nevada.usgs.gov/water/AquiferTests/ snake_valley_baker.cfm? studyname $=$ snake_valley_baker). The bulk transmissivity of the fractured limestone is increased when the total width is replaced by an effective width of flow through fractures and solution openings. When the effective width of flow was reduced to 5 percent of the total width (5 percent porosity), the effective transmissivity of the fractures and solution openings was $13,000 \mathrm{ft}^{2} / \mathrm{d}$. Thus, the range in transmissivity of the karst limestone can be large, even when the total mean annual flow is the same; the range in transmissivity varies with the width of flow used in the calculation.

\section{Rowland Spring and Evidence for Groundwater Flow between Baker and Lehman Drainage basins}

Rowland Spring has a mean annual runoff of 2,100 acre-ft, (table 1), which was unusually high, relative to the mean annual precipitation of 3,200 acre- $\mathrm{ft}$ in the karst-limestone zone, table 4). The only other sources for flow to Rowland Spring included streamflow losses along creeks and losses from springs that enter the karst-limestone zone from the mountain-upland zone and groundwater flow through alluvial deposits that cross over the boundary between the mountainupland and karst-limestone zone and through low-permeability consolidated rocks. Elliott and others (2006, p. 32, 35) considered Baker Creek to be the likely source of flow at Rowland Spring. They concluded this because of streamflow losses to the Pole Canyon Limestone in the Narrows, the northeast dip of the limestone between Baker Creek and Rowland Spring, and a higher land-surface altitude for Baker Creek in the Narrows than the altitude of Rowland Spring. Furthermore, the 
outcrop of Tertiary granite immediately downstream of Model Cave could restrict eastward groundwater flow through the limestone beneath the Baker Creek drainage basin.

A direct connection between streamflow losses in the karst-limestone zone along Baker Creek and Pole Canyon with Rowland Spring was determined by adding different fluorescent dyes to the two creeks at the end of the mountainupland zone on September 27, 2011, and then measuring the concentration of those dyes in Rowland Spring (Thomas Aley, Ozark Underground Laboratory, Inc., Protem, Missouri, written commun., 2013). The travel time from the introduction of a dye to the peak concentration at Rowland Spring was 2.75 days for the dye added to Baker Creek and 47.8 days for the dye added to Pole Canyon, although the total mass of each dye at Rowland Spring was only a fraction of that added to the creeks. Thus, at least some of the streamflow losses along Baker Creek and Pole Canyon in the karst-limestone zone flows to Rowland Spring and flow from Baker Creek to Rowland Spring is relatively rapid.

Discharge measurements taken on nine dates between July 2010 and August 2011 routinely showed streamflow losses in the karst-limestone zone on Baker and Lehman Creeks (fig. 26A, B). Water samples collected from the upstream discharge-measurement sites on both creeks and at Rowland Spring were analyzed for selected water chemistry. The purpose of these measurements and water sample analyses was to determine if the creeks were the only source of water to Rowland Spring or if an additional source was required. Although losses along Lehman Creek probably flow through older deposits and limestone to the springs at Home Farm, evaluation of the streamflow losses along Lehman Creek was included. Water samples were analyzed for the stable-isotope ratios of hydrogen and oxygen (appendix table 16-6) and dissolved concentrations of chloride, sulfate, fluoride, bromide, nitrate, and phosphate (appendix table 16-3). Additionally, two sets of water samples were collected following peak flow in July 2010 and during low flow in December 2010 for detailed water chemistry analyses. Losses along Baker Creek included flow directly into Ice and Sink Caves.

The streamflow loss in the karst-limestone zone along Baker Creek ranged from $0.9 \mathrm{ft}^{3} / \mathrm{s}$ on December 8, 2010, to about $15 \mathrm{ft}^{3} / \mathrm{s}$ on June 2, 2011 (fig. 26C), and averaged $4.1 \mathrm{ft}^{3} / \mathrm{s}$. Inflow to Baker Creek from Pole Canyon and from the resurgent spring below Model Cave was measured on three dates between April and August 2011 when discharge also was measured on Baker Creek (appendix table 3-2, sites BC4 and PC2), and those discharges were added to the discharge measurement of Baker Creek upstream of the Narrows prior to subtracting the measured discharge at the gaging station to obtain the net streamflow loss for the measurement dates. Some of the flow from the resurgent spring could have been lost along its channel prior to reaching Baker Creek because flow from the resurgent spring was measured at a site about $400 \mathrm{ft}$ upstream of the confluence. The streamflow loss along Lehman Creek ranged from $0.7 \mathrm{ft}^{3} / \mathrm{s}$ on July 20, 2010, to $5.3 \mathrm{ft}^{3} / \mathrm{s}$ on August 18, 2011 (fig. 26C), and averaged $2 \mathrm{ft}^{3} / \mathrm{s}$.
Lehman Creek had no tributary inflows. Discharge measured about $400 \mathrm{ft}$ downstream of Rowland Spring ranged from $3.28 \mathrm{ft}^{3} / \mathrm{s}$ on December 7, 2010, to $5.3 \mathrm{ft}^{3} / \mathrm{s}$ on July 20, 2010 (fig. 26C), and averaged $4.2 \mathrm{ft}^{3} / \mathrm{s}$. Because the average streamflow loss of Baker Creek was about the same as the average discharge measured about $400 \mathrm{ft}$ downstream of Rowland Spring, it could account for most of the flow at Rowland Spring. Discharge measured about $400 \mathrm{ft}$ downstream of Rowland Spring exceeded the combined streamflow loss from Baker and Lehman Creeks in the karst-limestone zone on four dates between September 28, 2010, and January 25, 2011, however, indicating that a source of water to the spring other than rapid flow through limestone fractures and solution openings is needed to explain the fall and winter flows. Additional sources of water for Rowland Spring include local recharge, recharge from streamflow losses in the karst-limestone zone from Pole Canyon in the Baker Creek drainage basin, recharge from streamflow losses in the karst-limestone zone along a small creek that enters a northeast-trending valley west of Lehman Caves in the Lehman Creek drainage basin, and recharge from springs at the end of the mountain-upland zone.

Tritium concentrations in water from Rowland Spring were less than those in Baker and Lehman Creeks (table 5). The mean age of water for Baker Creek and Rowland Spring relative to that of Lehman Creek (assuming the tritium concentration in Lehman Creek was representative of recent precipitation) was estimated using a radioactive half-life for tritium of 12.3 years (Lucas and Unteweger, 2000) and the equation from Clark and Fritz (1997, p. 181). The mean age of water in Baker Creek relative to that of Lehman Creek was 1.5 years and to that of Rowland Spring was 5.6 years. The older mean age of water from Rowland Spring relative to Lehman Creek indicated either a longer residence time for water in the limestone compared with water in Baker and Lehman Creeks or that water from Rowland Spring was a mixture of young water from the creeks along with older water that had moved more slowly through the glacial and alluvial deposits and through small fractures in the limestone.

If the residence time for all water in the limestone was 5.6 years, then the stable-isotope ratio of deuterium to hydrogen at Rowland Spring would not vary as much as the deuterium ratios in the creeks, which was not the pattern that was determined from samples between July 2010 and August 2011 (fig. 27A). One standard deviation for the deuterium ratios is \pm 1 permil; thus, deuterium ratios for any date among the three sampling locations did not differ significantly, but the ratios changed from more negative ratios between April and July (depleted by winter precipitation) to less negative ratios between September and January (enriched by evaporation), indicating that some fraction of the flow at Rowland Spring was rapid flow from one or both creeks through limestone to the spring.

Dissolved-chloride concentrations in the creeks were lowest in July 2010, then increased during the fall and winter, and peaked at the start of snowmelt in April 2011 (fig. 27B). The dissolved-chloride concentrations in Rowland Spring were about three times greater than those in the creeks, even though 

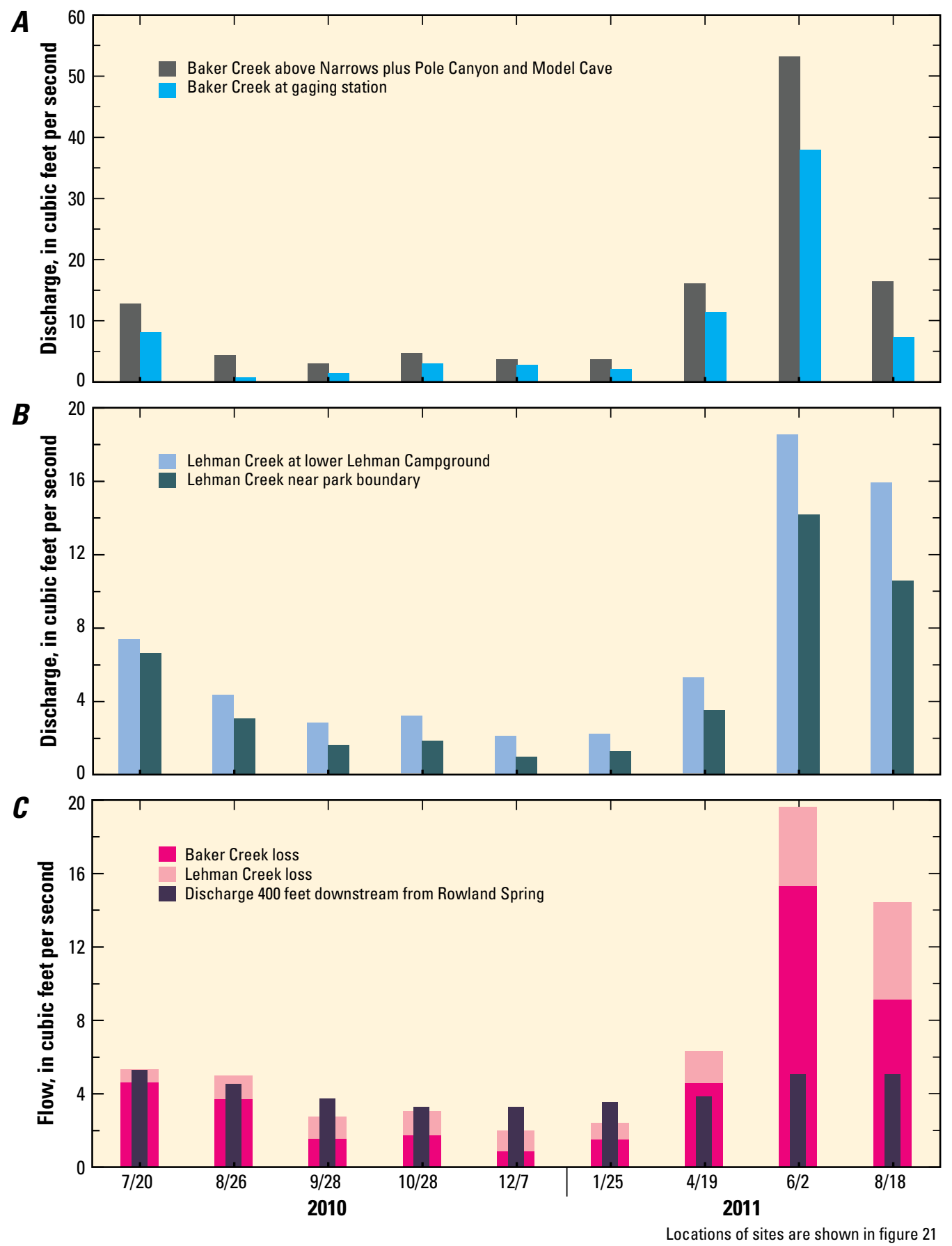

Figure 26. Discharge measurements taken between July 20, 2010, and August 18, 2011, in the karst-limestone zone, Great Basin National Park, White Pine County, Nevada, $A$, at upstream and downstream sites on Baker Creek; $B$, at upstream and downstream sites on Lehman Creek; and $C$, streamflow loss between discharge-measurement sites on Baker and Lehman Creeks and discharge measured 400 feet downstream of Rowland Spring. 

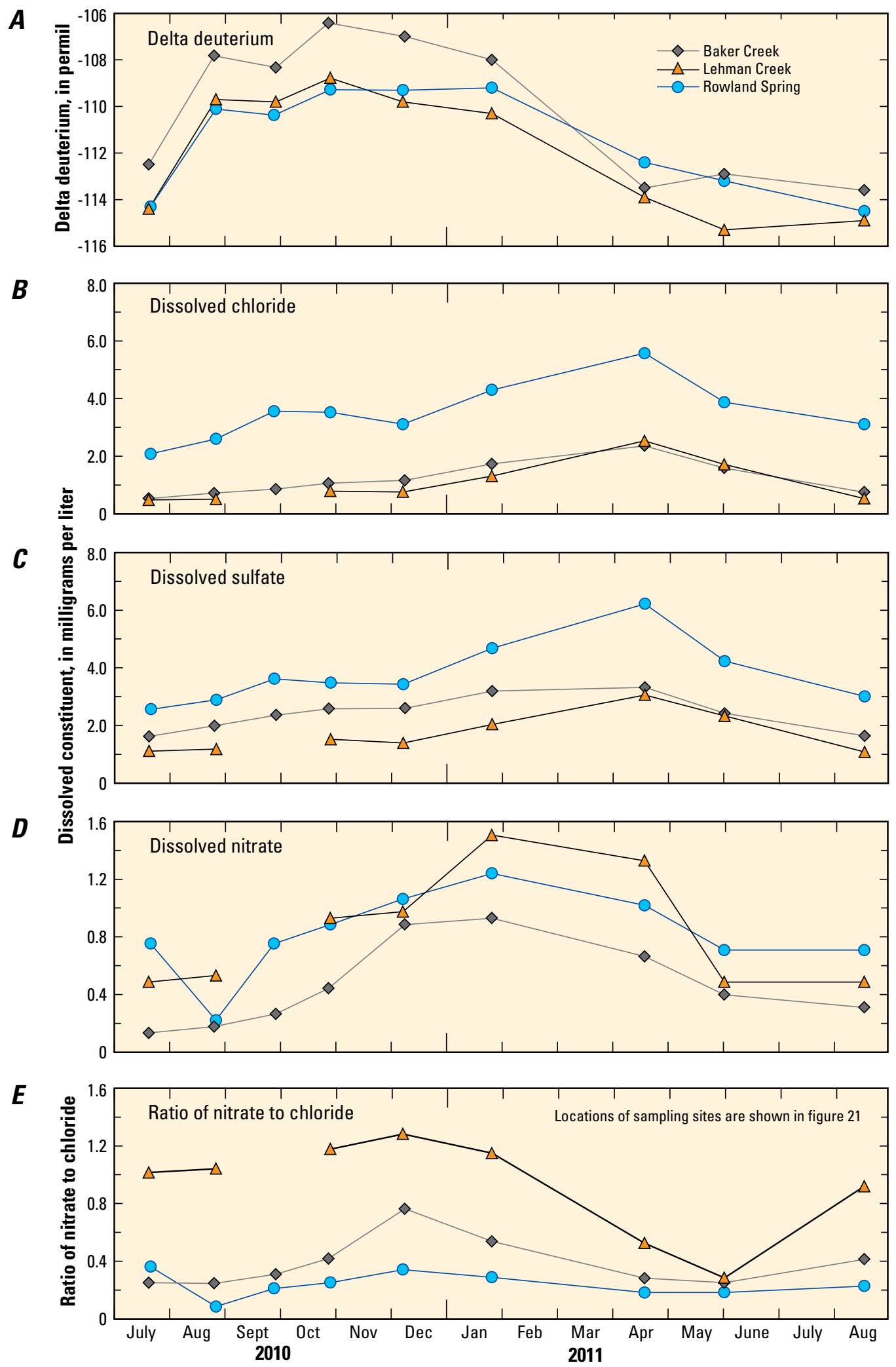

Figure 27. Constituent concentrations in water samples collected from Baker Creek upstream of the Narrows, Lehman Creek near lower Lehman campground, and Rowland Spring between July 2010 and August 2011, Great Basin National Park, White Pine County, Nevada, for $A$, delta deuterium; $B$, dissolved chloride; $C$, dissolved sulfate; $D$, dissolved nitrate; and $E$, ratio of dissolved nitrate to dissolved chloride. 
the seasonal pattern was nearly the same. Because Pole Canyon Limestone only contains trace concentrations of chloride (Lee and Van Loenen, 1971, p. 9), the most likely explanation for the higher chloride concentration at Rowland Spring is that it represents a mixture of water from the creeks and from diffuse recharge, where the chloride in precipitation had been concentrated through evapotranspiration. Another potential source of dissolved-chloride in flow at Rowland Spring is leakage from the sewage lagoons.

Dissolved-sulfate concentrations in water were also higher in Rowland Spring than in the creeks, but all showed a peak concentration at the start of snowmelt in April 2011 (fig. 27C). The mean volume-weighted sulfate concentration in precipitation at the weather station near Lehman Caves Visitor Center during 1985-2010 was four times greater than the chloride concentration (National Atmospheric Deposition Program, 2011). The mean flow-weighted ratio of sulfate to chloride in Baker and Lehman Creeks was 2, whereas the ratio at Rowland Spring was 1.1. The ratio of sulfate to chloride in water decreases from precipitation to streamflow, and then to groundwater, largely as a result of adsorption or biological incorporation, consumption, or transformation (Williams and Melack, 1997, p. 126).

The temporal differences in dissolved-nitrate concentrations in water from Rowland Spring and the creeks differed from those of chloride and sulfate in that highest nitrate concentrations were measured in January 2011, and dissolved-nitrate concentrations at Rowland Spring generally were higher than those in Baker Creek (fig. 27D). The mean volume-weighted nitrate concentration in precipitation at the weather station near Lehman Caves during 1985-2010 was six times greater than that of chloride (National Atmospheric Deposition Program, 2011). The ratio of dissolved nitrate to dissolved chloride in the creeks and Rowland Spring (fig. 27E) was much less than that in precipitation, and the lowest mean ratio was at Rowland Spring. The low dissolved-nitrate concentrations in Rowland Spring relative to dissolved-chloride concentrations indicated little leakage from the lined sewage lagoons. The sewage lagoons are large lined ponds that have little biological activity to remove nitrate from the water, and leakage through cracks in the lining of the ponds would infiltrate quickly through the underlying glacial and alluvial deposits. Leakage from the lagoons would increase nitrate and chloride concentrations as well as the ratio of nitrate to chloride compared with the ratios in water from Baker and Lehman Creeks. Consequently, the most reasonable explanation for increased chloride concentrations in water from Rowland Spring compared with the creeks is that creek water mixed with diffuse recharge containing greater dissolvedchloride concentrations, similar to the chloride concentrations measured in water from Pole Canyon and Cave and Marmot Springs.

The percentage of local groundwater in water at Rowland Spring and nearby smaller springs not associated with rapid flow from streamflow losses directly to the karst limestone along Baker Creek was estimated by assuming (1) a range in mean dissolved-chloride concentration in local groundwater from 5 to $7 \mathrm{mg} / \mathrm{L}$, (2) a mean dissolved-chloride concentration in water from Baker Creek of $1.2 \mathrm{mg} / \mathrm{L}$, and (3) an estimated mean annual flow from Rowland Spring and minor springs that contribute flow downstream of 2,500 acre-ft. The total mean annual contribution of water from Baker Creek, and perhaps Lehman Creek, to Rowland Spring and nearby smaller springs was estimated to range from 1,300 to 1,600 acre-ft, and the remaining 900-1,200 acre-ft was estimated to come from groundwater. Total mean annual groundwater flow to the karst-limestone zone, not including losses along Baker and Lehman Creeks, was about 1,400 acre-ft and included recharge from direct precipitation in the karst-limestone zone (400 acre-ft), groundwater flow from the mountain-upland zone (440 acre-ft), streamflow losses along Pole Canyon and an unnamed creek west of Lehman Caves (400 acre-ft), and recharge of water from Cave and Marmot Springs (150 acre-ft). The difference in mean annual chloride concentrations between Baker Creek and Rowland Spring indicated that between 50 and 60 percent of the flow from Rowland Spring and smaller nearby springs was from Baker Creek or a combination of water from Baker and Lehman Creeks. The losses along Lehman Creek could actually flow to the springs at Home Farm; thus, the majority of the flow at Rowland Spring derived from surface water was probably from Baker Creek.

\section{Upper-Piedmont Zone}

The upper-piedmont zone (fig. 21) begins where the southern Snake Range detachment fault overlies the limestone and intersects land surface or is buried at shallow depth beneath younger alluvial and glacial deposits. Distinct features of this zone are as follows: (1) moderate slopes with relatively minor relief between ridges and stream channels; (2) a relatively moist and warm climate; (3) a combination of erosion and deposition, with thin soils on top of young glacial and alluvial deposits that overlie older basin-fill deposits and limestone; (4) slightly losing to slightly gaining stream reaches in generally close contact with shallow groundwater; and (5) relatively shallow groundwater circulation through younger and older deposits, and deeper, but still relatively shallow, groundwater circulation through fractures in limestone. The fractured limestone in this zone is overlain by the detachment fault that is in turn overlain by older and younger deposits (fig. 28).

A water budget was not estimated for the upper-piedmont zone for three reasons. First, the quantity of flow and loss down the natural channel of Baker Creek during peak flow was unknown. Flow down the natural channel is limited to periods of peak flow. The original wooden diversion structure was buried by cobbles and boulders, and streamflow in the original channel varied irregularly depending on the channel geometry at the diversion structure (Craig Baker, Baker Ranches, Inc., Baker, Nev., written commun., 2012). Second, insufficient discharge measurements were made near the confluence of the two creeks to evaluate increases or decreases 


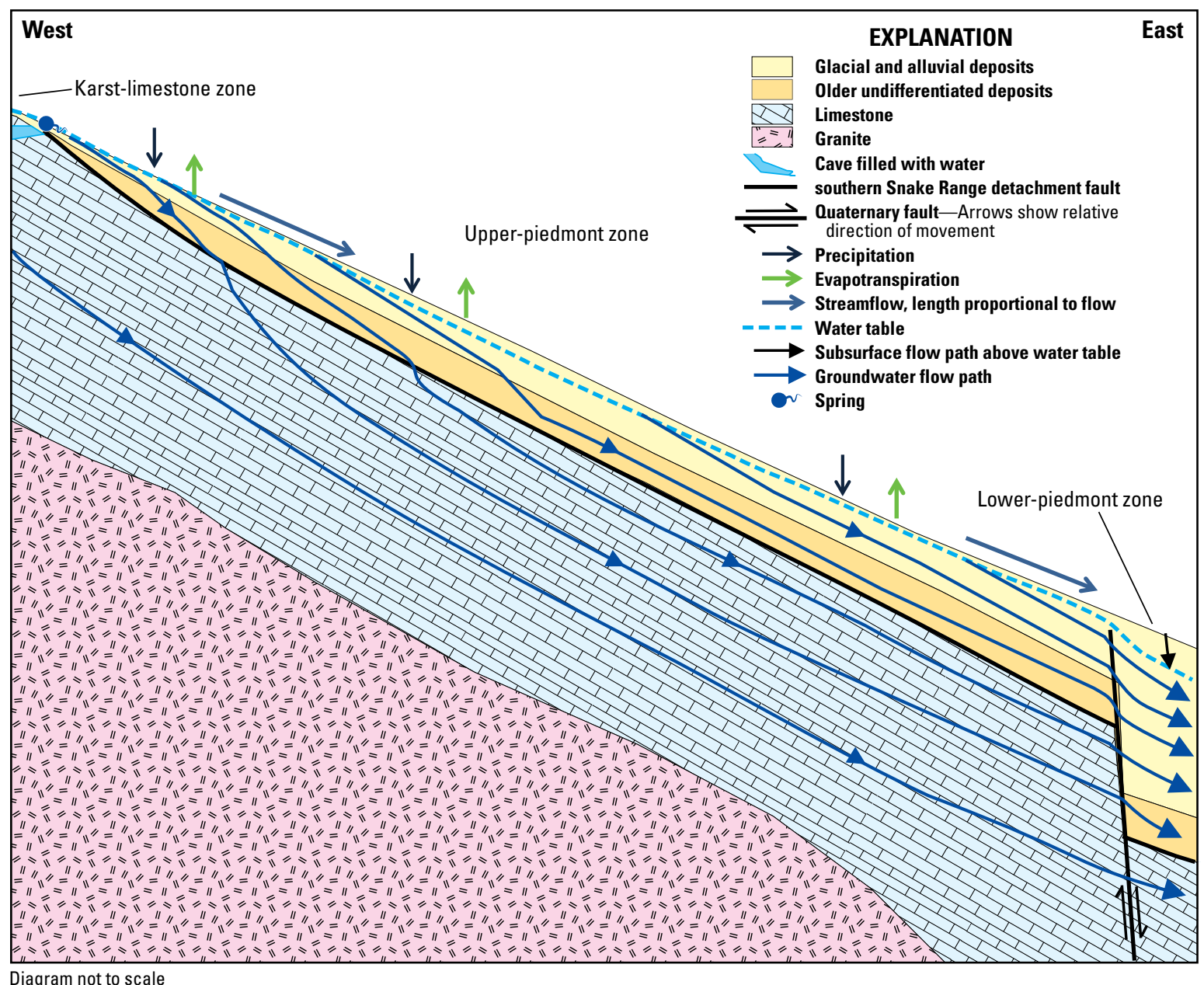

Figure 28. Idealized cross section showing streamflow and groundwater flow along Baker and Lehman Creeks in the upper-piedmont zone, downstream of Great Basin National Park, White Pine County, Nevada.

in streamflow at the downstream end of the upper-piedmont zone. Third, no estimates of evapotranspiration or water use were done for Rowland Ranch or for the riparian corridor along the natural channel of Baker Creek.

\section{Streamflow}

Streamflow along Baker and Lehman Creeks generally increases at the beginning of the upper-piedmont zone because of springs along the detachment fault. Downstream of the GBNP boundary, Baker Creek had a net gain in flow or was neutral in the upper-piedmont zone to its confluence with Lehman Creek for the two measurements in 1992 and 2003, but increased about $2 \mathrm{ft}^{3} / \mathrm{s}$ during a period of high flow on July 22, 2009 (fig. 29), indicating that shallow groundwater in the alluvial deposits was adding flow to the creek during that time. Downstream of GBNP, Baker Creek is diverted to the north side of its alluvial plain (fig. 21) and crosses over older basin-fill deposits that are exposed along the divide between the Baker and Lehman Creeks. Sources of gain included inflow from small springs north of the creek, an intermittent tributary spring, and a series of small springs that add flow to the abandoned natural channel south of the diverted channel. The flow from the small springs along the abandoned natural channel is added to the diverted channel downstream of the aquifer-test site along Baker Creek.

Evaluating streamflow along Lehman Creek was more difficult because Rowland Spring forms a parallel channel about $400 \mathrm{ft}$ south of Lehman Creek (fig. 21). Because this channel is at a slightly higher altitude than Lehman Creek, some water flows northward through small, channel-like depressions and joins with Lehman Creek. Additionally, water from Rowland Spring is used as a domestic supply for homes between the channels. The flow in both channels can be diverted to multiple channels to irrigate Rowland Ranch, which complicates the evaluation of streamflow gains and losses downstream of Sage Way. Consequently, in figure 29, the discharge measured from Rowland Spring was added to the discharge measured in Lehman Creek. Finally, water from excess irrigation on Rowland Ranch can return to Lehman Creek or Baker Creek near their confluence or to small channels north of Lehman Creek that do not return back to the main channels, which complicates assessment of streamflow gains and losses in Lehman Creek by the ranch. 


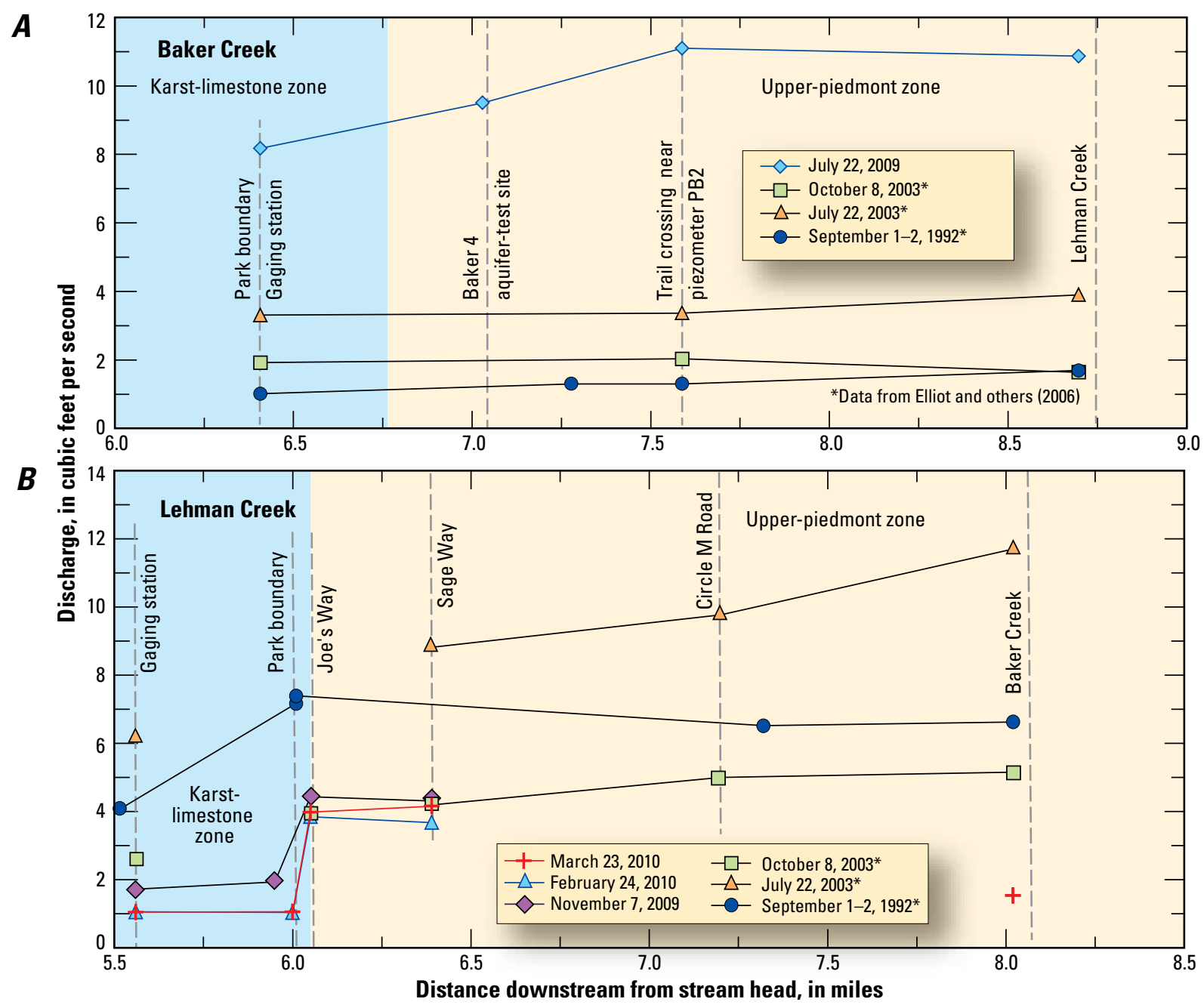

Figure 29. Measured discharge for selected dates between September 1992 and March 2010 in the upper-piedmont zone, Great Basin National Park, White Pine County, Nevada, in $A$, Baker Creek, and B, Lehman Creek.

\section{Streambed-Seepage Rates}

Net streambed-seepage rates were estimated by comparing discharge measurements in the upper-piedmont zone along Baker Creek on July 22, 2009 (table 6). Streamflow in Baker Creek was less than its peak flow, but greater than low flow during the fall and winter. The difference in discharge measurements between the GBNP boundary and about midway to the confluence with Lehman Creek (reach 2), not including contributions from springs, indicated streamflow gains of about $2.6 \mathrm{ft}^{3} / \mathrm{s}$ and resulted in a positive streambed-seepage rate of $3 \mathrm{ft} / \mathrm{d}$. The difference between discharge measurements in the lower reach (reach 3), from the end of reach 2 to just upstream of the confluence with Lehman Creek, was less than the uncertainty; thus, the net streambed-seepage rate was near zero.

Differences between discharge measurements on Lehman Creek from downstream of the GBNP boundary to near Sage Way in the upstream section of the upper-piedmont zone were all less than the uncertainty, although discharge measurements between November 2009 and March 2010 indicated a slight streamflow gain at the downstream site near Sage Way (table 7). If the slight streamflow gain was correct, the net streambed-seepage rate ranged from 1 to $2 \mathrm{ft} / \mathrm{d}$. The slight streamflow gain was consistent with results from distributed temperature sensing (DTS) measurements along two fiberoptic temperature cables placed in Lehman Creek from the gaging station on Lehman Creek to downstream of Sage Way (appendix table 15-1).

Stream temperatures were averaged between 8:00 and 9:00 a.m. pacific standard time (PST) on November 7, 2009, for each 3.28 -ft distance (1 meter) along the two fiber-optic cables (figs. $30 A, B$ ). An increase of about $0.5^{\circ} \mathrm{C}$ between the end of the first cable, near piezometer PL4, and the beginning of the second cable, just upstream of Joe's Way, indicated groundwater seepage to the creek between the two cables and for another $300 \mathrm{ft}$ downstream of Joe's Way. Recording thermistors in the creek at the end of the upper cable and at the beginning of the lower cable also showed an increase in temperature. This increase in stream temperature is near where the detachment fault crosses Lehman Creek (fig. 12) and where 
wet meadows are present along the north side of the creek, indicating some groundwater was diffusely added to the creek.

Water temperature increased about $0.4{ }^{\circ} \mathrm{C}$ at $3,700 \mathrm{ft}$ downstream of the gaging station, as measured along the creek during the morning on November 7,2009 ; about $0.1{ }^{\circ} \mathrm{C}$ at $4,130 \mathrm{ft}$ downstream; and about $0.3{ }^{\circ} \mathrm{C}$ at $4,650 \mathrm{ft}$ downstream (fig. 30B). The point source at $3,700 \mathrm{ft}$ was by a wet meadow that borders the north side of the creek just upstream of where Lehman Creek splits into two channels and near a depressionlike channel (possibly an abandoned channel) that potentially connects water from Rowland Spring creek to Lehman Creek (fig. 30A). The middle source was associated with an upward shift in a downward temperature slope and to another depression-like channel between Rowland Spring creek and Lehman Creek (fig. 30B). The farthest downstream source was near a sharp bend in the creek, but with no observable connection between water from Rowland Spring creek and Lehman Creek.

On February 25, 2010, the greatest temperature increase in the creek was $4,130 \mathrm{ft}$ downstream of the gaging station
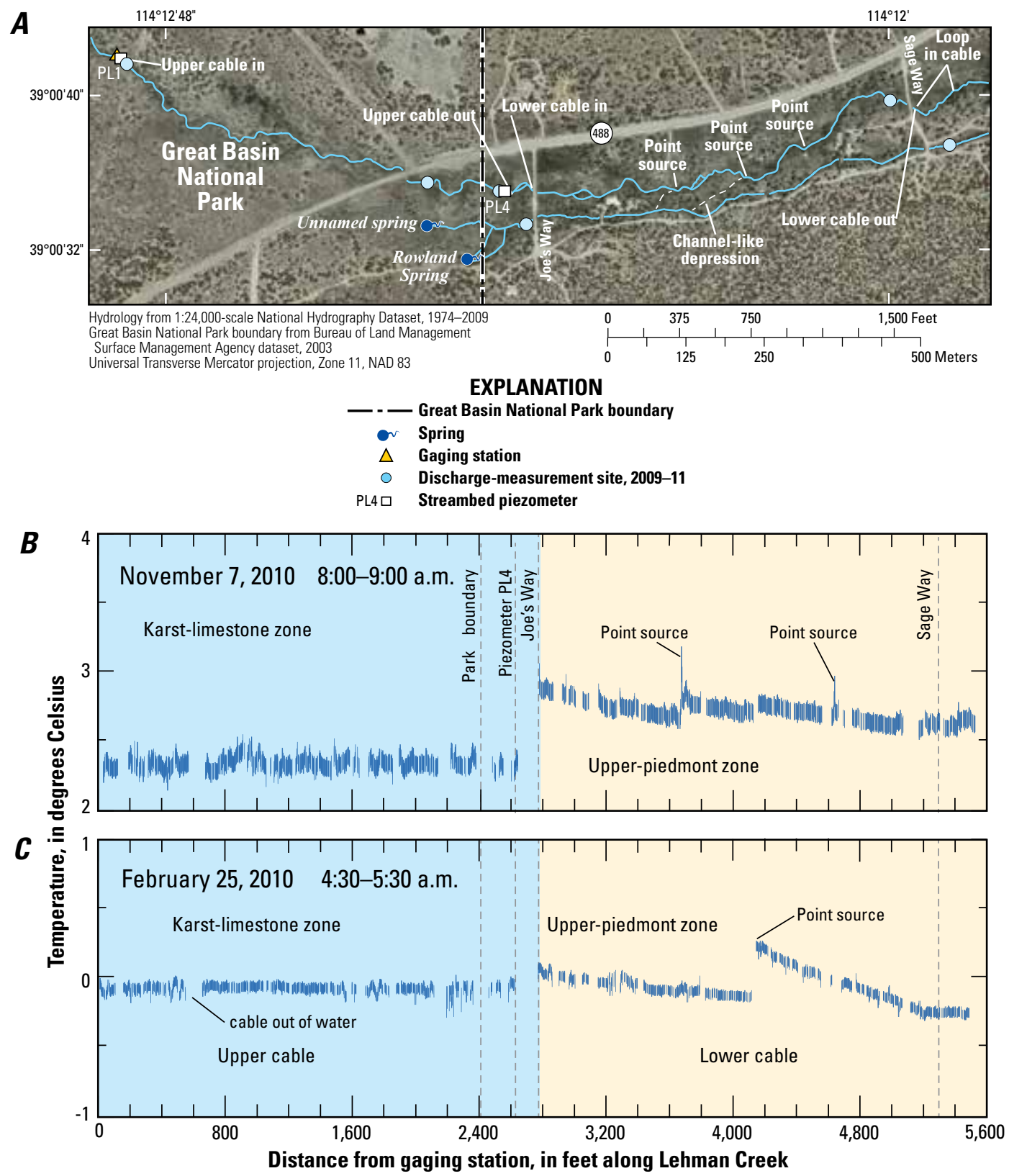

Figure 30. Great Basin National Park, White Pine County, Nevada, showing $A$, location of two fiber-optic cables placed in Lehman Creek from the gaging station to 1.04 miles downstream; $B$, averaged stream temperatures from distributed-temperature sensor measurements every 3.28 feet (1 meter) for November 7, 2009, from 8:00 to 9:00 a.m.; and $C$, averaged stream temperatures from distributed-temperature sensor measurements every 3.28 feet (1 meter) for February 25, 2010, from 4:30 to 5:30 a.m. 
(fig. 30C), where the slightest temperature increase was noted previously. Throughout the night and early morning, temperatures at this location were 0.5 to $0.8^{\circ} \mathrm{C}$ warmer than at the downstream end of the cable and up to $0.4{ }^{\circ} \mathrm{C}$ warmer than the water temperature at the gaging station. Because nighttime air temperatures in February were about $-10{ }^{\circ} \mathrm{C}$, the increase in water temperature could only be caused by groundwater flow to the creek. Cooler temperatures downstream indicated no additional groundwater seepage to the creek. Elsewhere along the creek, no temperature increases were measured, indicating groundwater seepage along reach 2 of Lehman Creek from near the GBNP boundary to Sage Way were not large, which was consistent with discharge measurements (table 7).

Streambed-seepage rates were estimated by using temperature loggers placed inside four piezometers at selected depths using methods described in appendix 14; two piezometers were driven into each streambed in the upper-piedmont zone of Baker and Lehman Creeks. The two sites on Baker Creek were along the diversion downstream of the aquifer-test site (fig. 21). Results of streambed-seepage rates and vertical hydraulic conductivity are listed in table 8 . Temperature data from each of the four piezometers for selected 2-week periods are shown in figure 31. A general decrease in amplitude diurnally and an increasing lag in peak temperatures with greater depth indicated downward flow through the streambed.

Mean streambed-seepage rates indicated that, on average, water was lost from the creek to the streambed (table 8). The largest range in streambed-seepage rates was from -3 to $3 \mathrm{ft} / \mathrm{d}$ between September 5, 2009, and March 23, 2010, at piezometer PB2. The greatest mean loss in this zone was estimated at piezometer PL3 on Lehman Creek, downstream of GBNP and upstream of Rowland Ranch (fig. 21), where the vertical hydraulic gradient was generally $-1.1 \mathrm{ft} / \mathrm{d}$, except during peak flow during end of March to April 2010, indicating gravity drainage most of the time beneath the streambed (fig. 32).

The daily mean hydraulic gradient was determined by calculating the difference between the daily mean stage of the creek at each piezometer with the daily mean water level in each piezometer on the dates in table 8 . The difference was divided by the distance from the top of the streambed to the midpoint of the piezometer to obtain the daily mean hydraulic gradient. The hydraulic gradients at the four piezometers indicated active surface-water interactions with shallow groundwater in the alluvial deposits in the creeks. The greatest depth to groundwater beneath the creek was at piezometer PL3. The water level in piezometer PL3 increased from late March to early April 2010 (fig. 32C), likely as the result of local recharge caused by snowmelt in the upper-piedmont zone, because stream stage was nearly constant during that period. Similar, but lesser, rises in water level were measured at piezometers PL2 and PB1 that resulted in brief periods of positive hydraulic gradients at both piezometers, indicating groundwater seepage to the creek.

The daily mean hydraulic gradient also was estimated at the Baker 4 aquifer-test well nearest to Baker Creek. The altitude of the well and the pressure transducer in the creek next to the well were surveyed to the nearest $0.05 \mathrm{ft}$, and the water level in the well was consistently lower than the stage of Baker Creek (fig. 32E). The hydraulic gradient ranged from $-0.15 \mathrm{ft} / \mathrm{ft}$, during peak stream stage in early June 2010, to about $-0.4 \mathrm{ft} / \mathrm{ft}$, during lowest stream stage in January 2010. The aquifer test caused the hydraulic gradient to change from $-0.3 \mathrm{ft} / \mathrm{ft}$, before the test on October 8, 2009, to nearly $-0.5 \mathrm{ft} / \mathrm{ft}$, during most of the test from October 8 to 11,2009 . Thus, although the data indicated generally lower water levels beneath and next to both creeks in the upper-piedmont zone, the hydraulic gradient of the streambeds were near the water level in the creek, except at streambed piezometer PL3, which indicated a direct connection between the creeks and shallow groundwater.

\section{Hydraulic Conductivity of Streambed}

In the upper-piedmont zone, the vertical hydraulic conductivity of the streambed ranged from $1 \mathrm{ft} / \mathrm{d}$, at the two piezometers on Lehman Creek, to $10 \mathrm{ft} / \mathrm{d}$ at piezometer PB2, downstream of the aquifer-test site on Baker Creek; the greatest vertical hydraulic conductivity was estimated at the end of the karst-limestone zone in Lehman Creek at piezometer PL4 (table 8). The vertical hydraulic conductivities were much less than the lateral hydraulic conductivities estimated from slug tests (table 8), except for those at piezometer PL4. Estimates of vertical hydraulic conductivity for piezometers PL1, PL2, PL3, and PB1 were only slightly greater than the vertical hydraulic conductivity of $1.6 \mathrm{ft} / \mathrm{d}$ estimated for the Baker Creek streambed from an aquifer test during October 2009 (Jackson, 2010; results available at http://nevada.usgs.gov/water/AquiferTests/snake_valley_baker. cfm?studyname $=$ snake_valley_baker).

Greater lateral to vertical hydraulic conductivity is typical of stratified alluvial deposits (Freeze and Cherry, 1979, p. 147-148). Streambeds can have a pronounced decrease in vertical hydraulic conductivity and porosity near the interface in losing reaches of a stream resulting from clogging of the streambed by fine sediments. The vertical hydraulic conductivity at PL4 was the same as the lateral hydraulic conductivity, and, although the water level at PL4 was slightly below the water level in the creek, the hydraulic gradient was near zero and near an area of groundwater flow to Lehman Creek, which was consistent with a previous study that found greater vertical hydraulic conductivities in areas where groundwater flow was to the stream compared with areas losing flow to groundwater (Rosenberry and Pitlick, 2009).

\section{Aquifers}

The two main aquifers in the upper-piedmont zone are the younger alluvial deposits and the underlying Pole Canyon Limestone. Groundwater flow is relatively shallow, and much of the flow to upper-piedmont zone from the karst-limestone zone is through the younger glacial and alluvial deposits that lie beneath and next to Baker and Lehman Creeks, and somewhat deeper flow is through less permeable older basin-fill 
$\boldsymbol{A}$

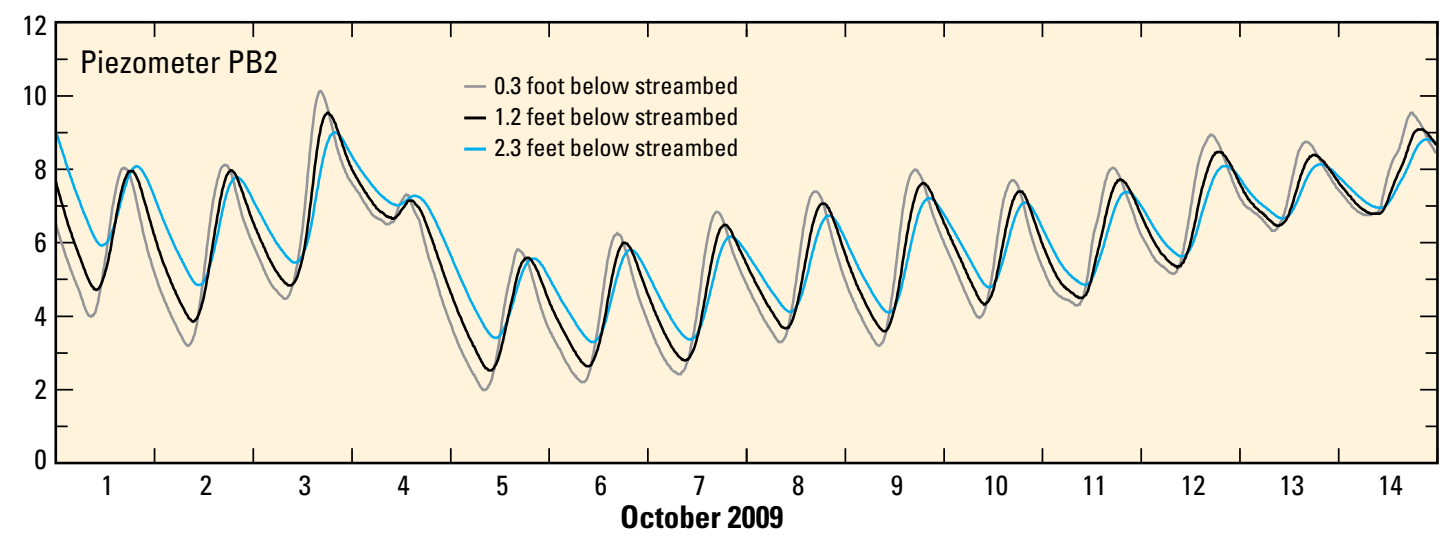

B

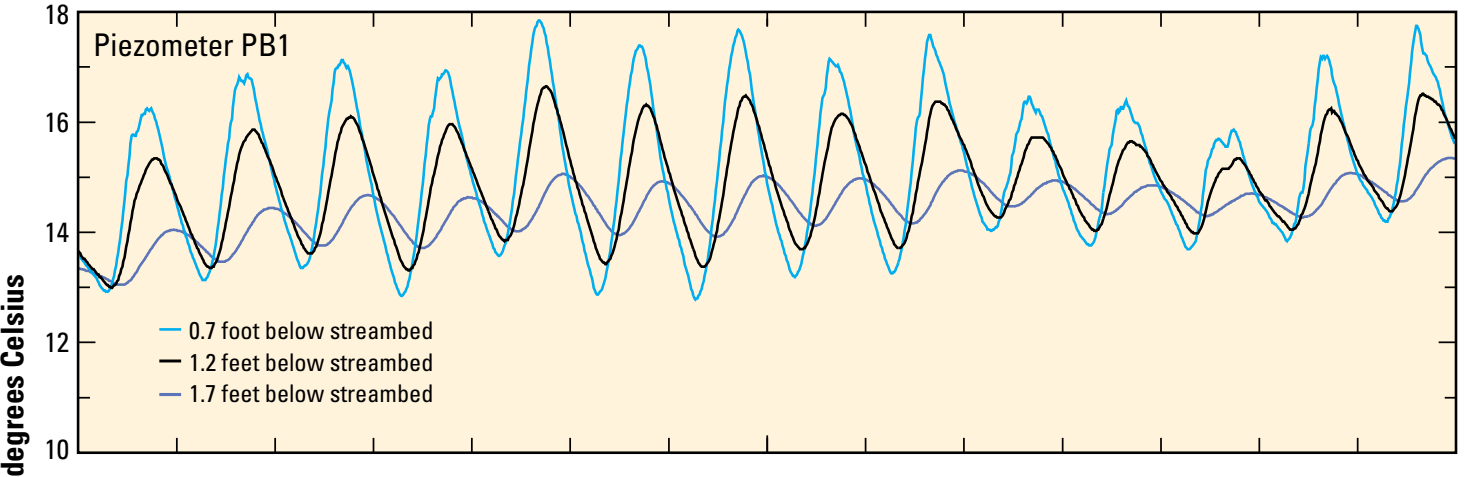

C

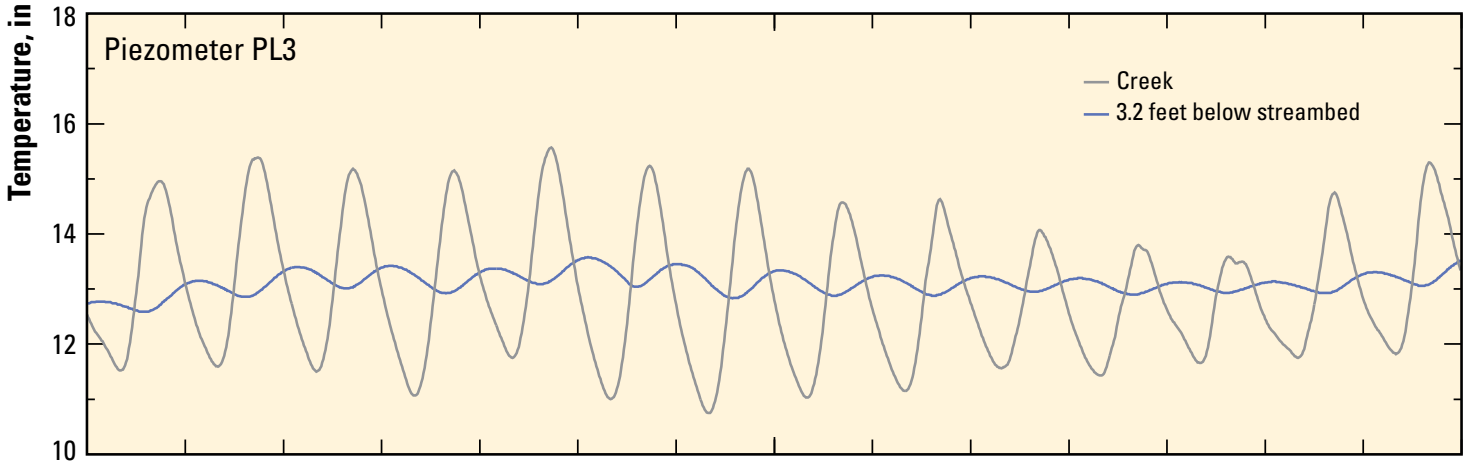

D

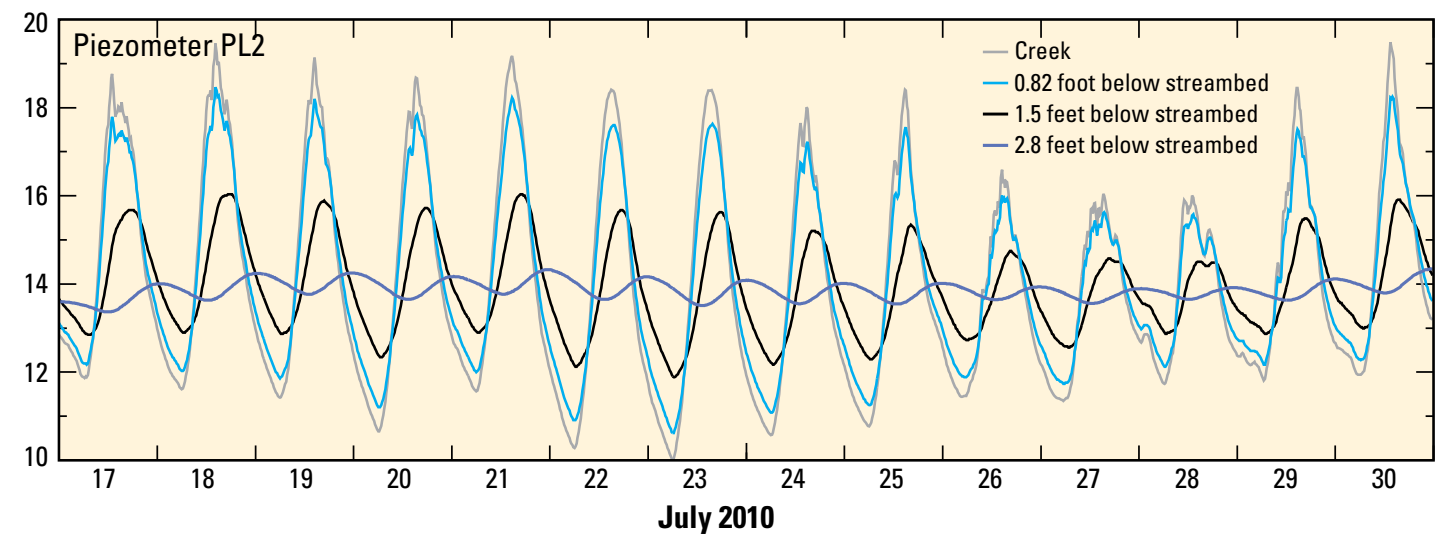

Figure 31. Streambed temperatures in four piezometers in the upper-piedmont zone of Baker and Lehman Creeks, Great Basin National Park, White Pine County, Nevada, during selected 2-week periods: $A$, October 1-14, 2009, at piezometer PB2, near aquifer-test site on Baker Creek; $B$, July 17-31, 2010, at piezometer PB1, upstream of confluence of Baker Creek diversion with Lehman Creek; $C$, July 17-31, 2010, at piezometer PL3, upstream of Rowland Ranch on Lehman Creek; and D, July 17-31, 2010, at piezometer PL2, upstream of confluence of Lehman Creek with Baker Creek diversion. 

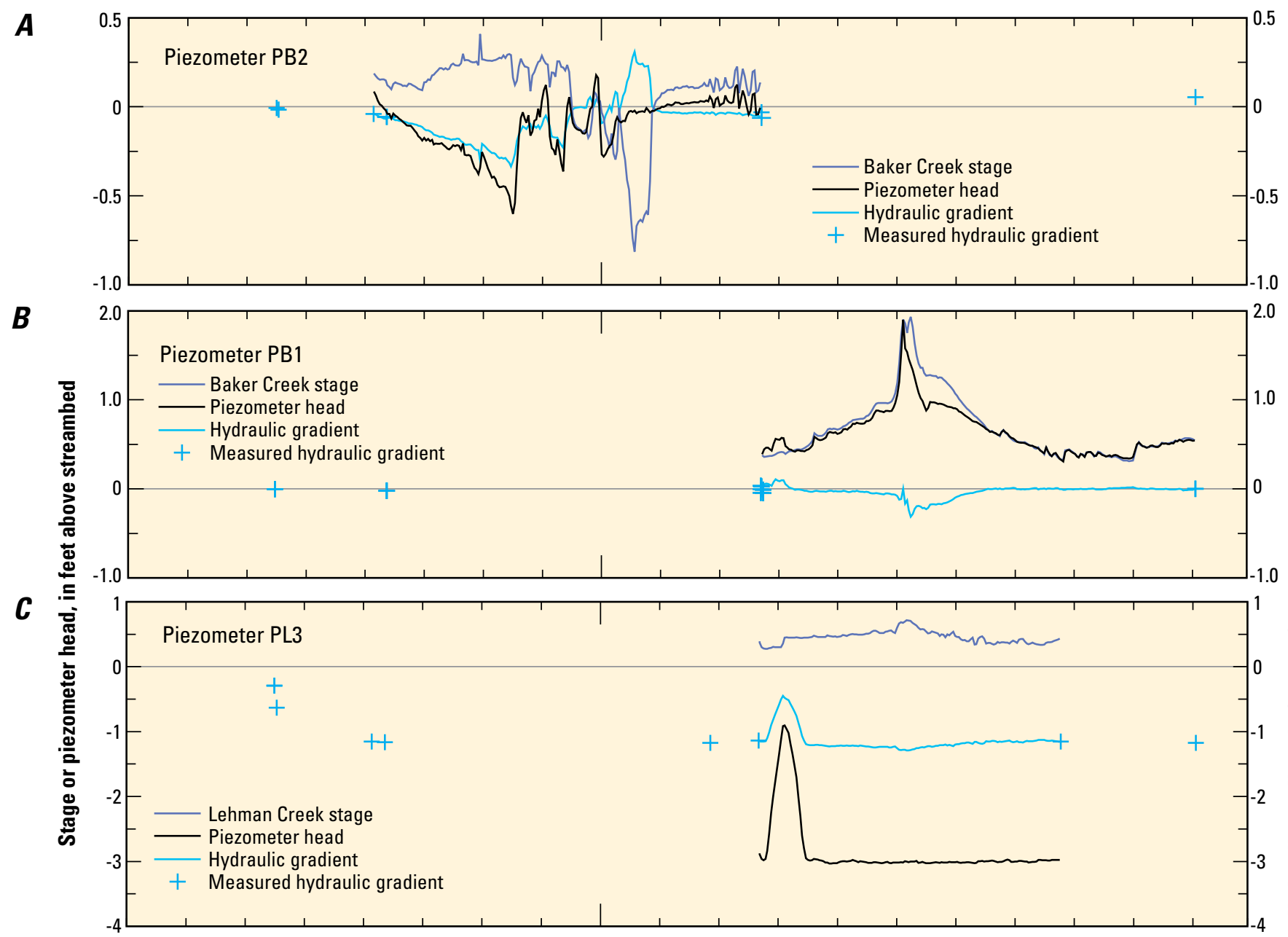

D
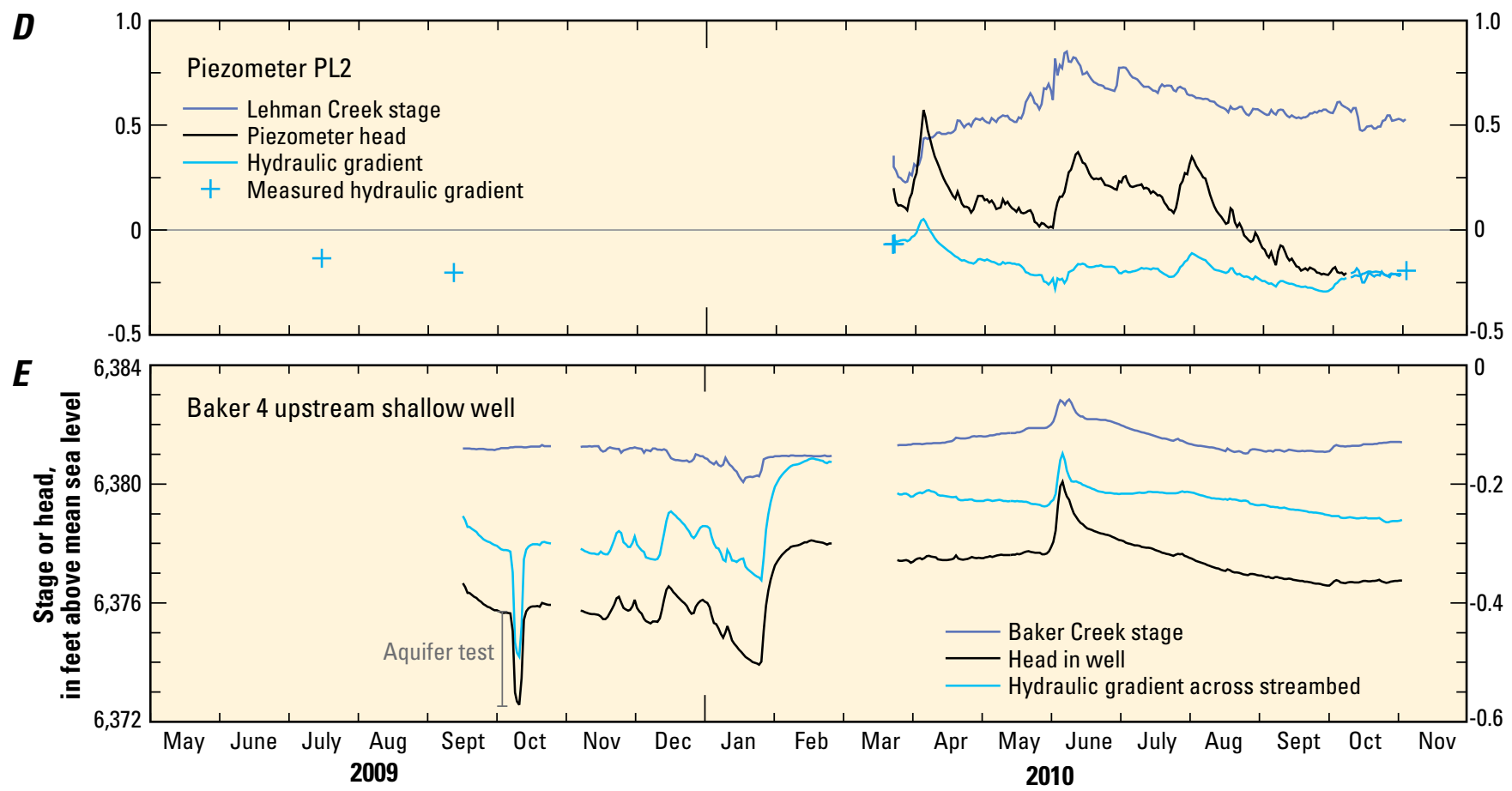

Figure 32. Daily mean stream stage, piezometer head above streambed, and hydraulic gradient in the upper-piedmont zone, Great Basin National Park, White Pine County, Nevada, between May 2009 and November 2010, for $A$, piezometer PB2 in Baker Creek; $B$, piezometer PB1 in Baker Creek; $C$, piezometer PL3 in Lehman Creek; $D$, piezometer PL2 in Lehman Creek; and $E$, the upstream shallow well at Baker 4 aquifer-test site. 
deposits (some of which could be consolidated and fractured) and the fractured limestone beneath the older basin-fill deposits (fig. 28). Unfractured consolidated older deposits (including fault breccia consisting of cemented quartzite cobbles and boulders) and unfractured limestone both act as confining units that restrict the vertical movement of groundwater and effectively confine lateral groundwater flow to the fractures in the limestone.

Fractured marble was encountered at a depth of $146 \mathrm{ft}$, in a well east of the sewage lagoons in GBNP (well SLE; fig. 21), and limestone was encountered at a depth of $150 \mathrm{ft}$, in another well 1,300 ft east of GBNP (well 92847; fig. 21. This indicated little offset of the younger and older deposits across the detachment fault that separates the karst-limestone zone from the upper-piedmont zone. Depth to bedrock (presumably limestone) increased to $250 \mathrm{ft}$ along the seismic-refraction line on the west side of Rowland Ranch (David L. Berger, U.S. Geological Survey, Carson City, Nev., written commun., 2004); the greater depth was consistent with the dip of the limestone. A geophysical survey along the north side of Baker Creek also showed a gradual increase in the thickness of younger and older deposits underlain by limestone (Asch and Sweetkind, 2010, 2011).

Beneath the upper-piedmont zone, the confined groundwater in the fractured limestone was not in contact with atmospheric carbon dioxide, making it a "closed system" (Drever, 1988, p. 67-68). The lack of a continuous supply of carbon dioxide from the atmosphere limits continued dissolution of fractures in the limestone. Thus, groundwater flow through the limestone in the upper-piedmont zone is conceptualized as flow through gradually decreasing tubular openings, where, eventually, groundwater flow is limited to small fractures and bedding planes as the water becomes saturated with respect to calcite. This gradual decrease in the number and size of tubular openings in the limestone could result in an overall decrease in the porosity and transmissivity of the limestone in the upper-piedmont zone.

Limited domestic-well data in the Lehman Creek drainage basin indicated deeper water levels in wells farther away from the creek and at deeper depths. Results from a seismic-refraction survey on the western side of Rowland Ranch indicated that the average depth to groundwater was about $24 \mathrm{ft}$ below land surface (D.L. Berger, U.S. Geological Survey, Carson City, Nev., written commun., 2004), but a well drilled to a depth of $150 \mathrm{ft}$ slightly west of the south end of Rowland Ranch had an initial depth to water of $42 \mathrm{ft}$ in 1993. In the Baker Creek drainage basin, the water level in nested wells drilled next to Baker Creek as part of an aquifer test was deeper than in the creek and had the same pattern of greater depths to water in the deeper well relative to the shallower well in the same test hole (Jackson, 2010). All of these data indicated that groundwater flowed downward from the creek to the shallow alluvial deposits and then to the older, deeper, fractured, consolidated alluvial deposits, which is shown in figure 28. Downward flow through the alluvial deposits can be explained, in part, by an increase in the thickness of the younger and older deposits to the east. The quantity of downward flow is limited by the hydraulic gradient and vertical hydraulic conductivity of the deposits and limestone.

\section{Aquifer Test next to Baker Creek}

An aquifer test was done in October 2009 at the Baker 4 aquifer-test site (fig. 21) in the upper-piedmont zone, where three test holes were drilled next to Baker Creek (appendix 1; Jackson, 2010; http://nevada.usgs.gov/water/AquiferTests/ snake_valley_baker.cfm? studyname=snake_valley_baker). The wells were drilled in a riparian corridor about $0.8 \mathrm{mi}$ downstream of GBNP and just downstream of where Baker Creek is diverted and routed northeast along the northern boundary between younger and older deposits. The test was started on October 7, 2009, at 14:39 PDT, and ended on October 11, 2009, at 12:31 PDT. The 6-in. diameter well $54 \mathrm{ft}$ north of Baker Creek, and screened from 20 to $40 \mathrm{ft}$ below land surface, was pumped at a constant rate of $26 \mathrm{gal} / \mathrm{min}$ for 94 hours. Pressure transducers were placed in the pumping well and in the four 2-in. diameter monitoring wells, as well as at four locations along Baker Creek - two upstream and two downstream (appendix 1). Data collected from the aquifer test are summarized in appendix 5.

Analytical methods for evaluating hydraulic properties could not replicate measured water-level declines (drawdown) in the monitoring wells (Jackson, 2010, p. 87). Consequently, a three-dimensional finite-difference model was developed and used to estimate the hydraulic properties of the alluvial deposits in the vicinity of the aquifer test (Jackson, 2010, p. 97-151; http://nevada.usgs.gov/water/AquiferTests/snake_valley_baker.cfm? studyname=snake_valley_baker). Model simulated water-level declines and recovery following the test are shown in figure $33 \mathrm{~A}$. The upstream deep well was screened in a megablock of Pioche Shale in older basin-fill deposits, and its drawdown was much less than the drawdown in the other wells, which were screened in younger deposits.

The younger deposits are heterogeneous, and lateral hydraulic conductivity parallel to the natural channel of Baker Creek ranged from 0.3 to $37 \mathrm{ft} / \mathrm{d}$, whereas the vertical hydraulic conductivity ranged from 0.2 to $3 \mathrm{ft} / \mathrm{d}$, and the vertical hydraulic conductivity of the streambed was $1.6 \mathrm{ft} / \mathrm{d}$ (table 9). This heterogeneity reflects the high-energy environment in which the sediments were deposited. The sediments in the younger deposits consist of a poorly sorted mixture of silt, sand, gravel, cobbles, and boulders deposited by glaciofluvial and fluvial processes. In the numerical model, the older deposits were represented with a simplified geometry in the vicinity of the aquifer test (Jackson, 2010, p. 97-151), because only one monitoring well was completed in the older deposits, and the results reported by Asch and Sweetkind (2010) were not sufficient to increase the geologic complexity.

The reported transmissivity of the younger alluvial deposits was $900 \mathrm{ft}^{2} / \mathrm{d}$ (http://nevada.usgs.gov/water/AquiferTests/ snake_valley_baker.cfm? studyname=snake_valley_baker), assuming the lateral hydraulic conductivity perpendicular to the natural Baker Creek channel was the same as that parallel 
A
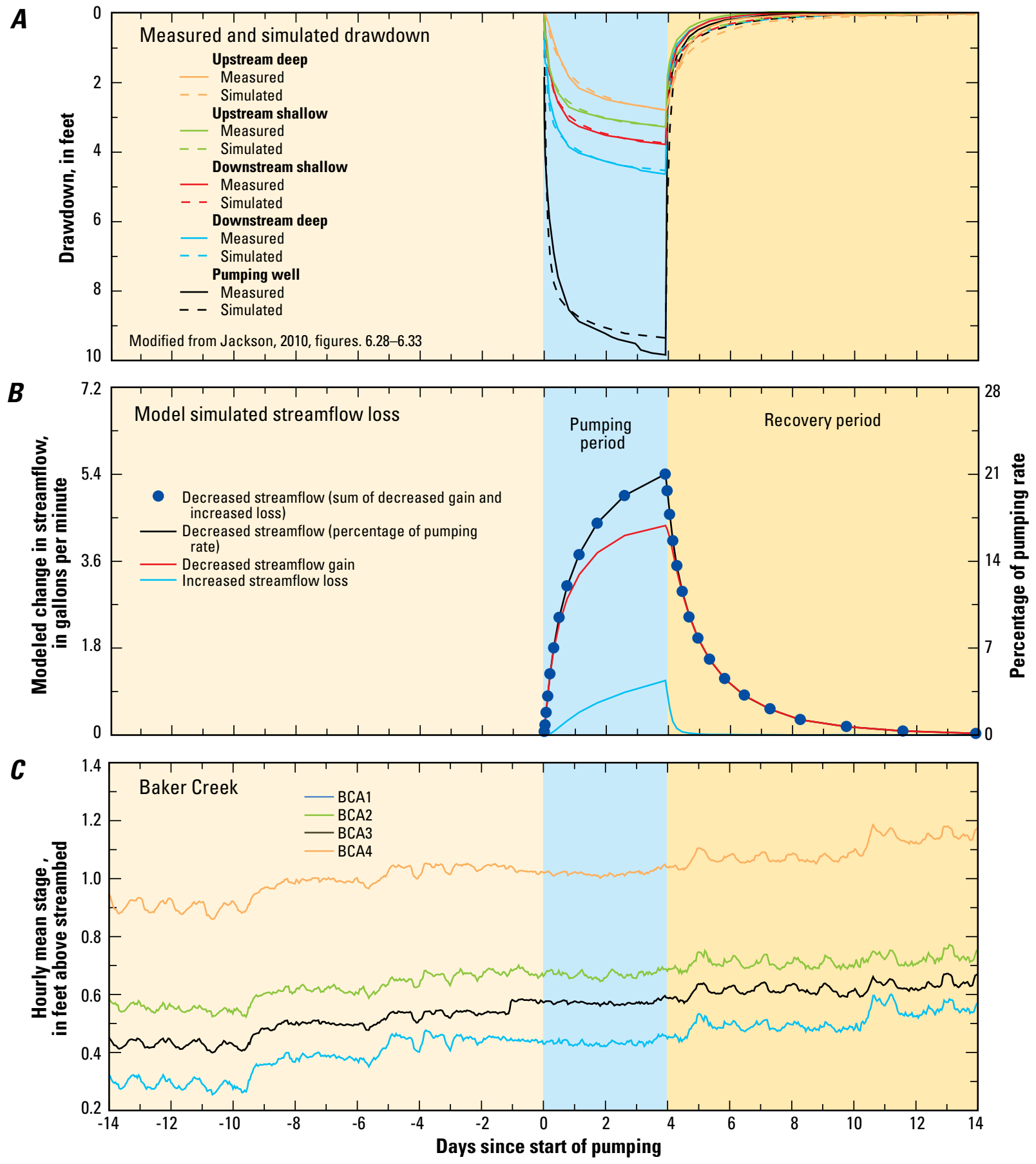

Figure 33. Results of 94-hour aquifer test and 10 days following test, September 26 to 0ctober 23, 2009, in monitoring wells at Baker 4 aquifer-test site downstream from Great Basin National Park, White Pine County, Nevada: $A$, comparison of model-simulated and measured drawdown; $B$, model-simulated changes in streamflow along Baker Creek; and $C$, stream stage recorded from four pressure transducers in Baker Creek. 
Table 9. Summary of hydraulic properties of the younger alluvial and older basin-fill deposits estimated from an aquifer test from October 9, 2009, to October 13, 2009, at the Baker 4 aquifer-test site downstream of Great Basin National Park, White Pine County, Nevada.

[Younger alluvial deposits were divided into 5 units with unit 1 the shallowest and unit 5 the deepest (Jackson, 2010, p. 134). Symbol: - , not determined]

\begin{tabular}{|c|c|c|c|c|c|c|c|}
\hline \multirow{2}{*}{ Hydraulic property } & \multirow{2}{*}{$\begin{array}{l}\text { Baker Creek } \\
\text { streambed }\end{array}$} & \multicolumn{5}{|c|}{ Younger alluvial deposits } & \multirow{2}{*}{$\begin{array}{l}\text { Older basin-fill } \\
\text { deposits }\end{array}$} \\
\hline & & Unit 1 & Unit 2 & Unit 3 & Unit 4 & Unit 5 & \\
\hline Thickness (feet) & 3.28 & 3.28 & 13.1 & 3.28 & 13.1 & 26.2 & $3.28-59.0$ \\
\hline Lateral hydraulic conductivity (feet per day) & - & 3.28 & 12.1 & 0.59 & 33.5 & 37.7 & 0.02 \\
\hline Vertical hydraulic conductivity (feet per day) & 1.64 & 1.64 & 1.0 & 0.33 & 3.0 & 0.8 & 0.02 \\
\hline Lateral anisotropy ratio (dimensionless) & - & 0.60 & 0.6 & 1.00 & 1.0 & 1.0 & 1.00 \\
\hline $\begin{array}{l}\text { Lateral to vertical hydraulic conductivity ratio } \\
\text { (dimensionless) }\end{array}$ & - & 2.00 & 12.1 & 1.79 & 11.3 & 44.2 & 1.15 \\
\hline Storage coefficient (dimensionless) & - & $1.0 \mathrm{E}-2$ & $1.5 \mathrm{E}-6$ & $1.5 \mathrm{E}-6$ & $1.5 \mathrm{E}-5$ & $1.1 \mathrm{E}-5$ & $2.5 \mathrm{E}-5$ \\
\hline
\end{tabular}

to the channel. This contrasts with an average transmissivity of the younger deposits parallel to the Baker Creek of 1,300 $\mathrm{ft}^{2} / \mathrm{d}$. This value was determined by dividing the modeled inflow along the upstream boundary of 41,700 cubic feet per day $\left(\mathrm{ft}^{3} / \mathrm{d}\right)$, prior to pumping, with the product of the mean width of $550 \mathrm{ft}$ and the mean hydraulic gradient of $0.06 \mathrm{ft} / \mathrm{ft}$. The somewhat greater estimate of transmissivity parallel to the natural channel of Baker Creek was reasonable because the model had a lateral anisotropy of 0.6 perpendicular to the natural channel in the upper $16 \mathrm{ft}$ of younger deposits.

The connection between the younger glacial and alluvial deposits and Baker Creek was evaluated with the numerical model (fig. 33B), because the pumping rate in the 6-in. diameter well was insufficient to measure a change in flow or stage along Baker Creek. Model simulated vertical hydraulic conductivity of the streambed (table 9) was less than vertical hydraulic conductivities estimated from shallow piezometers in the upper-piedmont zone along Baker and Lehman Creeks (table 8). Drawdown in the shallow wells near Baker Creek was sensitive to the vertical hydraulic conductivity of the streambed. Increasing the vertical hydraulic conductivity of the streambed in the model resulted in too little drawdown in the nearby shallow wells and required decreasing the vertical hydraulic conductivity between model layers. Even with the vertical hydraulic conductivity of the streambed at $1.6 \mathrm{ft} / \mathrm{d}$, model simulations resulted in an increase in streamflow loss, as well as a decrease in streamflow gain, from groundwater flow to Baker Creek downstream of the aquifer-test site (fig. 33B). The model simulated a reduction in groundwater flow to the diverted channel of Baker Creek, downstream of the aquifer-test site. Simulated streamflow loss at the end of the 94-hour (hr) test was about 21 percent of the pumping rate. This simulated decrease in streamflow could not be evaluated against the differences in discharges estimated from the temporary gaging stations upstream and downstream of the aquifer-test site, because the uncertainty in the discharge at the temporary gaging stations exceeded the maximum potential decrease of $0.05 \mathrm{ft}^{3} / \mathrm{s}$ from pumping.
The hourly mean stage at the four pressure-transducer locations showed slowly rising water levels in the creek up to 10 days before the test, but, during the test, the stage in the creek was steady (fig. 33C). The stage began rising again near the end of the 94-hr test, which could have caused the quick water-level recoveries in the monitoring wells. Three discharge measurements were made before the test at the upstream and downstream transducers in Baker Creek (BCA1 and BCA4, respectfully). The first measurement, on September 5, 2009, indicated no difference in measured discharge between sites, whereas later measurements indicated a slight increase in measured discharge between sites, from 1.51 to $1.71 \mathrm{ft}^{3} / \mathrm{s}$, on September 17, 2009, and from 1.77 to $2.09 \mathrm{ft}^{3} / \mathrm{s}$, on October 8, 2009. The measured increases were about the same as the estimated error of the measurements.

\section{Estimates of Transmissivity from Specific-Capacity Data}

Well-drillers' logs obtained from the Nevada Division of Water Resources (Nevada Division of Water Resources, 2008) were used to estimate transmissivity from the specific capacity reported in the logs. Transmissivity was calculated from specific capacity by using the method described by Theis and others (1963, p. 331-345). Their equation 1 was modified to convert to units used in this study as follows:

$$
T=-15.32\left(\frac{Q}{s}\right)\left(0.577 \log _{e}\left[\frac{r^{2} S}{4 T t}\right]\right)
$$

where

$\left(\frac{Q}{s}\right)$ is the specific capacity of a pumped well, in gallons per minute per foot of drawdown;

$r$ is the effective radius of pumped well, in $\mathrm{ft}$;

$S$ is the storage coefficient, dimensionless;

$t$ is the time, in days; and

$T$ is the transmissivity, in $\mathrm{ft}^{2} / \mathrm{d}$.

The equation requires an estimate of the range in storage coefficient, an initial guess of transmissivity, and repeated iteration to replace the initial guess with a new estimate until the right-side transmissivity equals the left-side transmissivity 
(Prudic, 1991). The storage coefficient used in the calculations ranged from a specific yield of 5 percent to a minimum value estimated by multiplying the thickness of the well screen with a specific storage of $1 \times 10^{-6}$ per $\mathrm{ft}$ (Lohman, 1972).

Four well-drillers' logs in the upper-piedmont zone had sufficient information to estimate transmissivity (table 10). All wells were drilled in the Lehman Creek drainage basin between GBNP and Rowland Ranch. The estimated range in transmissivity for the three wells screened or perforated in younger deposits was $700-3,000 \mathrm{ft}^{2} / \mathrm{d}$. The estimated transmissivity from specific-capacity data at the aquifer-test site next to Baker Creek was $900 \mathrm{ft}^{2} / \mathrm{d}$, assuming a storage coefficient of 0.00002 . The estimate was in the lower range of transmissivity estimates from the aquifer test because the analysis using specific-capacity data did not include turbulent well losses or any boundary effects caused by lower permeability of the older deposits or leakage of Baker Creek. Transmissivities estimated from specific capacity of a pumping well are typically less when compared with estimates of transmissivity from aquifer tests determined from one or more observation wells (Prudic, 1991). Still, the range of estimated transmissivities for the younger deposits was consistent with the transmissivity of $1,300 \mathrm{ft}^{2} / \mathrm{d}$ determined from the $94-\mathrm{hr}$ test at the aquifer-test site (Jackson, 2010). The transmissivity estimated for the well screened in the fractured, older deposits had a range of $200-300 \mathrm{ft}^{2} / \mathrm{d}$, which is consistent with the older deposits being less permeable than the younger deposits. The actual transmissivity at each well could be greater than that estimated from the specific-capacity data, although one comparison between specific-capacity data and that estimated from an aquifer-test in observation wells next to Baker Creek was 70 percent of the greatest estimate of transmissivity from the numerical model.

The estimated range in hydraulic conductivity was about $3 \mathrm{ft} / \mathrm{d}$ for the fractured, consolidated older deposits and $10-300 \mathrm{ft} / \mathrm{d}$ for the younger deposits, when assuming a thickness of only the screened or perforated interval. Although the range in hydraulic conductivity for the younger deposits was indicative of reasonably permeable materials, the transmissivity of these deposits in the upper-piedmont zone is limited because the deposits have little saturated thickness.

\section{Lower-Piedmont Zone}

The boundary between the upper-piedmont and lowerpiedmont zones coincides with one or more Quaternary faults associated a rapid thickening of younger deposits on the downthrown side of the fault, with an offset of $1,300 \mathrm{ft}$ (Asch and Sweetkind, 2011, p. B4-B6). This results in an increase in transmissivity that causes the depth to water to increase across the fault (fig. 34). Features of this zone are the following: (1) decreasing streambed slopes, with little relief

Table 10. Summary of transmissivity estimates derived from specific capacities reported in well-drillers' logs for Baker and Lehman Creek drainage basins, vicinity of Great Basin National Park, White Pine County, Nevada.

[Nevada well-log number and data obtained from Nevada Division of Water Resources. Assumed well for well-log number 74561 was pumped for 6 hours. Transmissivity rounded to one significant figure. Symbol: $<$, less than]

\begin{tabular}{|c|c|c|c|c|c|c|c|c|}
\hline $\begin{array}{l}\text { Nevada } \\
\text { well-log } \\
\text { number }\end{array}$ & $\begin{array}{c}\text { Hole } \\
\text { diameter } \\
\text { (inches) }\end{array}$ & $\begin{array}{c}\text { Screened } \\
\text { interval } \\
\text { (feet below } \\
\text { land surface) }\end{array}$ & Geologic Unit & $\begin{array}{l}\text { Pump rate } \\
\text { (gallons per } \\
\text { minute) }\end{array}$ & $\begin{array}{c}\text { Drawdown } \\
\text { (feet) }\end{array}$ & $\begin{array}{l}\text { Hours well } \\
\text { pumped }\end{array}$ & $\begin{array}{l}\text { Range in } \\
\text { storage } \\
\text { coefficient }\end{array}$ & $\begin{array}{c}\text { Estimated } \\
\text { transmissivity } \\
\text { (feet squared } \\
\text { per day) }\end{array}$ \\
\hline \multicolumn{9}{|c|}{ Upper-piedmont zone } \\
\hline 9421 & 11 & $60-70$ & Sand and gravel & 70 & 6 & 0.5 & $5 E-2-1 E-5$ & $1,000-3,000$ \\
\hline 22314 & 10 & $50-151$ & Cobble, sand and gravel & 20 & 2 & 2 & $5 E-2-1 E-4$ & $2,000-3,000$ \\
\hline 22315 & 10 & $50-129$ & Cobble, sand and gravel & 20 & 4 & 2 & $5 E-2-7 E-5$ & $700-1,000$ \\
\hline 92847 & 12 & $105-145$ & Fractured rock & 80 & 80 & 18.5 & $4 E-4-4 E-5$ & $200-300$ \\
\hline \multicolumn{9}{|c|}{ Lower-piedmont zone } \\
\hline 22316 & 10 & $51-151$ & Sand and gravel & 20 & 10 & 3 & $1 E-1-1 E-4$ & $300-400$ \\
\hline 22317 & 10 & $50-156$ & Sand and gravel & 20 & 10 & 3 & $1 E-1-1 E-4$ & $300-400$ \\
\hline 25197 & 7 & $126-146$ & Sand & 20 & 70 & 2 & $1 E-2-2 E-5$ & $40-70$ \\
\hline 33372 & 9 & $130-158$ & Sand and gravel & 8 & 105 & 24 & $1 E-2-3 E-5$ & $10-20$ \\
\hline 650 & 9 & $70-132$ & Sand and gravel & 30 & $<1$ & 2 & $1 E-1-6 E-5$ & $5,000-9,000$ \\
\hline 43528 & 15 & $75-245$ & Sand and gravel & 450 & 1 & 8 & $3 \mathrm{E}-1-2 \mathrm{E}-1$ & $90,000-100,000$ \\
\hline \multicolumn{9}{|c|}{ Valley-lowland zone } \\
\hline 33373 & 16 & $145-240$ & Clay, sand and gravel & 150 & 135 & 8 & $1 E-3-2 E-4$ & $200-300$ \\
\hline 34161 & 22 & $65-410$ & Clay, sand and gravel & 600 & 100 & 8 & $1 E-1-3 E-4$ & $1,000-2,000$ \\
\hline 40151 & 16 & $55-500$ & Clay, sand and gravel & 440 & 105 & 6 & $1 E-1-4 E-4$ & $600-900$ \\
\hline 74561 & 16 & $33-347$ & Clay, sand and gravel & 372 & 62 & 6 & $1 E-1-3 E-4$ & $800-1,000$ \\
\hline 94995 & 24 & $50-560$ & Clay, sand and gravel & 1,200 & 113 & 2 & $1 E-1-3 E-4$ & $1,000-2,000$ \\
\hline
\end{tabular}


between channels and greater soil development compared with zones higher in the drainage basins; (2) a dry climate with relatively cold winters and warm summers; (3) a combination of erosion and deposition, with migrating stream channels overlying thickening alluvial and basin-fill deposits; (4) little to no streamflow generated from precipitation in the zone; (5) relatively large streamflow losses, except where water is diverted into a concrete-lined ditch; (6) groundwater circulation through younger and older deposits, where an intervening unsaturated zone separates losses along channels from underlying groundwater; and (7) inferred deeper groundwater circulation through fractured limestone.

\section{Streamflow Losses}

The greater thickness of an unsaturated zone associated with the rapid thickening of younger alluvial deposits (fig. 34) results in increased streamflow losses in the lowerpiedmont zone. The natural streamflow losses that recharged groundwater in the lower-piedmont zone diminished after Baker Creek was diverted to Lehman Creek in the early 1900s and the combined flow of the two creeks was diverted to a concrete ditch in 1962 or 1963 (fig. 34; Craig Baker, Baker Ranches, Inc., Baker, Nevada, written commun., 2012). Streamflow that enters the lower-piedmont zone along the old channel of Baker Creek is unknown. The concrete ditch has a capacity of $26 \mathrm{ft}^{3} / \mathrm{s}$ (Craig Baker, Baker Ranches, Inc., Baker, Nev., written commun., 2012), which, when exceeded, causes the excess flow to continue down along natural channels next to the ditch. Assuming little streamflow loss between the gaging stations on the two creeks and along the channel downstream of Rowland Spring during water years 2002-10, the combined daily mean discharge at the gaging stations on the two creeks and at Rowland Spring exceeded the capacity of the ditch 14 percent of the time.

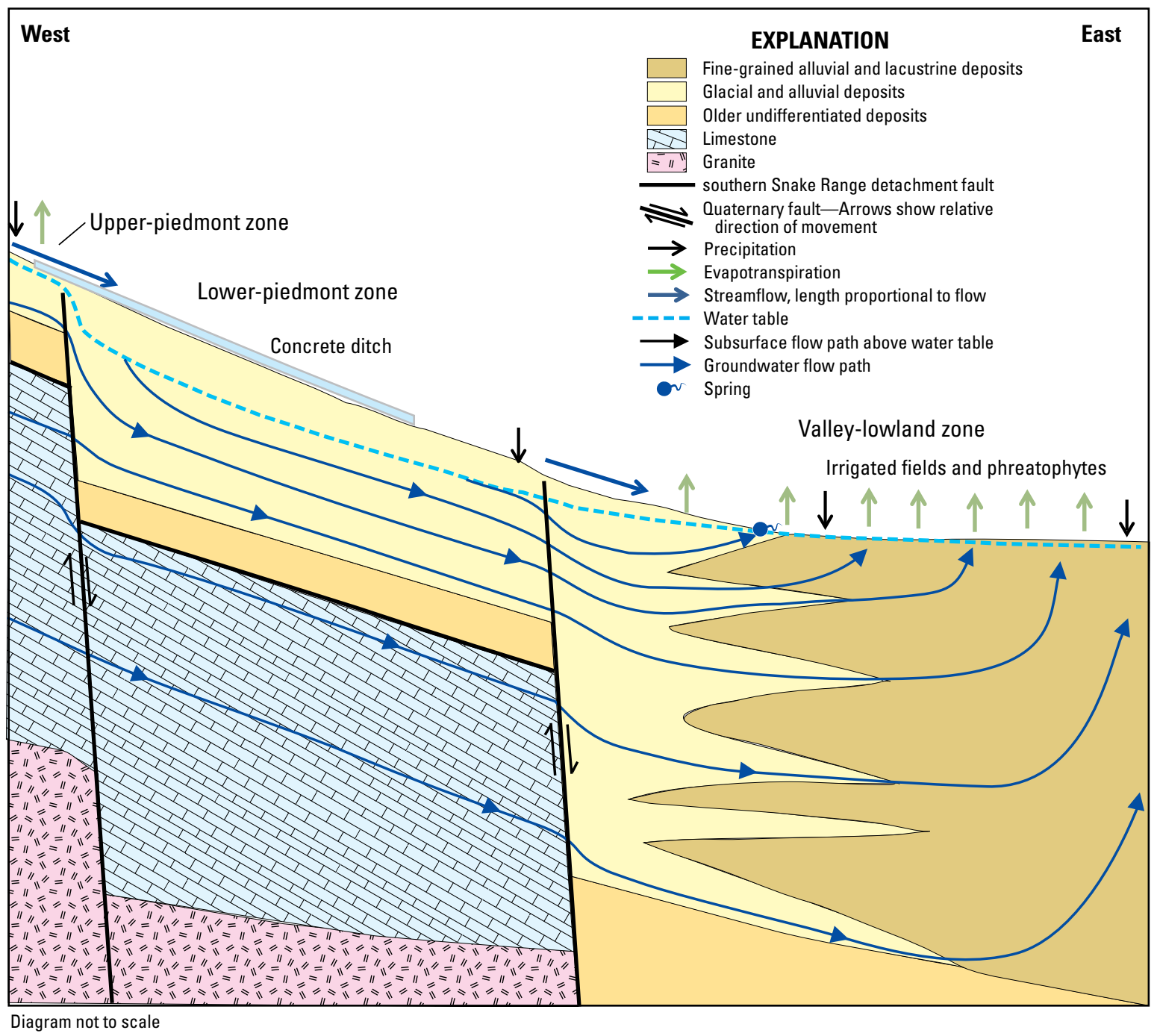

Figure 34. Idealized cross section showing streamflow and groundwater flow along Baker and Lehman Creeks in the lower-piedmont and valley-lowland zones, downstream of Great Basin National Park, White Pine County, Nevada. 
From the confluence of Baker and Lehman Creeks to the valley-lowland zone, the estimated streamflow loss during low flow, prior to the construction of a concrete ditch, was about $4 \mathrm{ft}^{3} / \mathrm{s}$ (Dean Baker, Baker Ranches, Inc., Baker, Nev., oral commun., 2009). During a study in September 2, 1992, discharge measurements immediately upstream of the ditch and at three locations downstream of the ditch, near Baker (Elliott and others, 2006, p. 17), yielded a net streamflow loss that ranged from 0 to $1.4 \mathrm{ft}^{3} / \mathrm{s}$, depending on which downstream measurement was used. Thus, before the concrete ditch was constructed, much of the streamflow loss took place in the approximately $2 \mathrm{mi}$. of natural channel that was replaced by the ditch. The average loss rate per mile of channel was $2 \mathrm{ft}^{3} / \mathrm{s}$ when flow was around $4 \mathrm{ft}^{3} / \mathrm{s}$ or less, with gravity drainage beneath the streambed. Greater streamflow losses are likely during high flow because of increased channel width and higher stream stage.

\section{Vertical Hydraulic Conductivity of Streambed}

The vertical hydraulic conductivity of the streambed along Lehman Creek in the lower-piedmont zone was estimated at $3 \mathrm{ft} / \mathrm{d}$, assuming that $4 \mathrm{ft}^{3} / \mathrm{s}$ was lost along the natural channel (prior to construction of the concrete ditch) before reaching the valley-lowland zone at Baker. This estimate also assumed the natural channel was 10-12 ft wide and that gravity drainage was controlled by a vertical hydraulic gradient of $-1 \mathrm{ft} / \mathrm{ft}$ in the streambed. This estimate was similar to the estimated range of 1.6 to $4 \mathrm{ft} / \mathrm{d}$ for vertical hydraulic conductivity in the streambed in the upper-piedmont zone (tables 8, 9).

\section{Aquifers}

The most productive aquifer in the lower-piedmont zone is the relatively thick, shallow, coarse-grained, younger alluvial deposits. The older basin-fill deposits and the fractured limestone could allow some additional and deeper groundwater flow through the zone. Groundwater flow to the lowerpiedmont zone is limited to groundwater flow that can pass through the Quaternary fault in younger deposits, in older basin-fill deposits, and in fractured limestone (fig. 34). The mean annual precipitation in lower-piedmont zones is insufficient to produce appreciable groundwater recharge. Except for springs along the Quaternary fault at the Home Farm, the faults in this area are sufficiently permeable by Baker and Lehman Creeks to allow for most of the groundwater flow beneath the creeks to pass from the upper-piedmont zone to the lower-piedmont zone.

Specific-capacity data were available from six welldrillers' logs in the lower part of the lower-piedmont zone (table 10). Four wells in Baker, Nev. (well-logs 22316, 22317, 25197, and 33372), were drilled for domestic supply. The other two wells (well-logs 650 and 43528) were drilled to the south near the natural channel of Baker Creek for irrigation (well-log 650) and municipal supply (well-log 43528). The wells generally were drilled into sand and gravel that had lenses of clay. Estimated transmissivities ranged from 10 to $100,000 \mathrm{ft}^{2} / \mathrm{d}$, with the greater values in wells farther west and south that encountered coarser-grained sediments (well-logs 650 and 43528). Both those wells had reported drawdowns of $1 \mathrm{ft}$ or less.

Nearly half the wells with specific-capacity data had estimated transmissivities that exceeded estimates from wells drilled in the upper-piedmont and valley-lowland zones, indicating that the alluvial deposits in this zone have intervals that are more permeable than elsewhere in the Baker and Lehman Creek drainage basins. Dividing the estimated transmissivity by the screened interval yielded a range in hydraulic conductivity from 0.5 to $600 \mathrm{ft} / \mathrm{d}$. The lesser values were similar to those in the older basin-fill deposits in the upper-piedmont zone, and the greater values exceeded all estimates of hydraulic conductivity in the younger alluvial deposits in the upperpiedmont zone, yet were consistent with hydraulic conductivities estimated for sand and gravel along the Humboldt River near Winnemucca, Nev. (Cohen and others, 1965), and for sand and gravel along the West and East Forks of the Carson River in Carson Valley, Nev., and in California (Maurer, 1986, p. 30).

The lower-piedmont zone generally provides an ideal location for deposition of well-sorted sand and gravel because most of the large cobbles have been dropped farther up the drainage basins, and the silt and clay are carried farther onto the valley floor (fig. 14; Zones, 1961, p. 35-39). Typically, areas with the greatest transmissivities are near the toe of alluvial fans associated with perennial mountain streams, such as Baker and Lehman Creeks (Zones, 1961, Bredehoeft, 1963, Bredehoeft and Farvolden, 1963). Even though the lowerpiedmont zone is generally more permeable than the other zones, groundwater flow through it is limited by groundwater flow from the upper-piedmont zone and streamflow losses in the zone, which are less since diversion of Baker Creek to Lehman Creek and the construction of a 2-mi-long concrete ditch in the upper section of the lower-piedmont zone (fig. 34).

\section{Valley-Lowland Zone}

The boundary between the lower-piedmont and valleylowland zones coincides with one or more Quaternary faults (fig. 34; U.S. Geological Survey and Nevada Bureau of Mines and Geology, 2006; Rowley and others, 2009). The valleylowland zone is separated from the lower-piedmont zone by a decrease in the coarseness of the alluvial and basin-fill deposits, which is generally coincident with a large-offset normal fault, as defined by gravity data, that increased the thickness of basin-fill deposits in the valley-lowland zone. Features of this zone are as follows: (1) shallow land-surface slopes with thick soil development; (2) an arid climate with cold winters and hot summers; (3) deposition of sediments mostly eroded from higher in the drainage basins; (4) a thick sequence of interbedded coarse and fine-grained younger and older basin-fill deposits; (5) streamflow diverted for irrigation and groundwater pumping from relatively shallow depths; and (6) inferred, deep groundwater circulation through limestone that underlies fine-grained and cemented Miocene sedimentary rocks. 


\section{Evaluating Connection of Aquifers to Springs and Streams, Eastern Part of Great Basin National Park and Vicinity, Nevada}

Groundwater in the valley-lowland zone is characterized by flow through lenses of sand and gravel near the lowerpiedmont zone that progressively thin and grade to finergrained deposits of sand, silt, and clay. Groundwater levels in this zone are typically near land surface, and the general direction of flow changes to lateral and upward, where much of the shallow groundwater is lost to evapotranspiration (fig. 34). Streamflow that reaches the valley-lowland zone is used for irrigation of crops and, during periods of excessive flow, some streamflow can pond in shallow depressions, where it is lost to evapotranspiration or slowly infiltrates to shallow groundwater.

Several wells have been drilled in the valley-lowland zone, and some are used for supplemental irrigation of crops before the spring snowmelt or during years when snowmelt is insufficient to provide the water necessary for irrigation. Five well-drillers' logs for this zone had sufficient information to estimate transmissivity (table 10). The wells were drilled for irrigation in younger alluvial deposits of alternating layers of clay, sand, and gravel. Estimated transmissivities ranged from 200 to $2,000 \mathrm{ft}^{2} / \mathrm{d}$. Because of the greater thickness of the deposits, these transmissivities were similar to those estimated in the upper-piedmont zone. Dividing the estimated transmissivity by the screened interval yielded a range in hydraulic conductivity from 1 to $5 \mathrm{ft} / \mathrm{d}$. These deposits were generally less permeable than the coarser sediments of the upper- and lower-piedmont zones.

\section{Summary}

Much of the mean annual runoff in the mountain-upland zone is generated in areas that exceed $11,000 \mathrm{ft}$ above mean sea level, where an estimated 80 percent of the mean annual precipitation becomes runoff because, in the mountain-upland zone, low-permeability quartzite and granite bedrock is covered by thin soil or by thin glacial and alluvial deposits, which limit groundwater flow and storage. Inflow to the mountainupland zone is precipitation, and outflow is mostly by evapotranspiration in the zone and runoff to the karst-limestone zone. Evapotranspiration in the mountain-upland zone was estimated at about 56 percent of the mean annual precipitation, and mean annual runoff was estimated at 42 percent.

Runoff from the mountain-upland zone is the dominant inflow to the karst-limestone zone, accounting for 79 percent of the total inflow; precipitation in the zone accounts for another 18 percent, and the remaining 3 percent is from groundwater inflow. Groundwater flow increases in the karstlimestone zone relative to the mountain-upland zone primarily because of the presence of the Pole Canyon Limestone and increased permeability caused by dissolution along bedding planes and fractures. This results in net streamflow losses along Baker and Lehman Creeks and Pole Canyon of about 3,300 acre-ft annually, which is about a 23 percent decrease in the mean annual runoff that enters from the mountain-upland zone. Most of the groundwater flow in the karst-limestone zone is through large tubular openings and supplies springs near the low-angle, southern Snake Range detachment fault or to an intermittent resurgent spring from Model Cave along Baker Creek. This spring is just upstream of granite outcrops and a decrease in the thickness of the limestone, which force flow to the surface. Rowland Spring accounts for about 80 percent of the spring flow along the detachment fault. Chloride mass-balance calculations indicated that about 60 percent of the flow to Rowland Spring was from streamflow loss in the Narrows of Baker Creek. The source of springs at the Home Farm north of Lehman Creek drainage basin is probably from streamflow loss along Lehman Creek because the Pole Canyon Limestone dips to the northeast. Outflow from the karst-limestone zone to the upper-piedmont zone is mostly runoff and flow from springs near the detachment fault.

The groundwater connection between the karst-limestone zone at the eastern edge of GBNP and the valley-lowland zone near Baker, Nev., is through three aquifers. The shallowest and most used aquifer is the younger glacial and alluvial deposits. This aquifer is thin and in direct contact with Baker and Lehman Creeks in the upper-piedmont zone. The creeks generally lose small quantities of flow to the younger deposits in this zone. These losses are limited, however, by the low vertical hydraulic conductivity of the streambeds (generally $2-4 \mathrm{ft} / \mathrm{d}$ ). The younger deposits thicken rapidly across one or more Quaternary faults (Asch and Sweetkind, 2011) that define the boundary between the upper- and lower-piedmont zones. The thickening of the younger deposits corresponds to an increase in the transmissivity and greater depth to the water table. Streamflow losses along Baker and Lehman Creek increase in the lower-piedmont zone because streamflow loss through the streambed is controlled by gravity drainage. At least $4 \mathrm{ft}^{3} / \mathrm{s}$ was needed for streamflow to reach Baker, Nev., prior to the construction of a 2-mile long concrete ditch in the zone during the early 1960s (Craig Baker, Baker Ranches, Inc., Baker, Nevada, written commun., 2012). Construction of the concrete-lined ditch reduced streamflow losses and, subsequently, decreased groundwater recharge in the lowerpiedmont zone.

The second aquifer consists of permeable zones in the older basin-fill deposits, but overall, this aquifer is less permeable than the overlying shallow aquifer. Flow through this aquifer is limited to inflow from shallow groundwater in the karst-limestone zone and to vertical flow from the overlying shallow aquifer.

The third aquifer is the fractured limestone that underlies the older basin-fill deposits in the upper- and lower-piedmont zones. The hydraulic conductivity of the fractured limestone beneath the older basin fill is probably less than that in the karst-limestone zone because dissolution of fractures in the limestone beneath the older basin-fill deposits is limited by carbon dioxide that enters with groundwater from the karstlimestone zone. Furthermore, if large tubular openings from dissolution of the limestone were continuous beneath the older basin-fill, then springs near the end of the karst-limestone zone would not exist. Depth to the fractured limestone in the lowerpiedmont zone exceeds 2,000 ft (Asch and Sweetkind, 2011, p. B5), and groundwater from fractured limestone beneath the 
upper-piedmont zone could move to the thicker younger alluvial deposits in the lower-piedmont zone, with little groundwater flow through the deeper, fault-offset fractured limestone. The younger alluvial deposits thicken rapidly again across another Quaternary fault that forms the boundary between the lower-piedmont slope and valley lowland. Groundwater in the valley lowland flows predominately through the younger deposits, and this zone is generally an area where groundwater is lost to evapotranspiration on the valley floor.

\section{Snake Creek Drainage Basin}

\section{Physical Characteristics}

The Snake Creek drainage basin lies on the eastern side of the crest along the southern Snake Range (fig. 35). The drainage basin is between the Baker Creek drainage basin to the north and the Big Wash drainage basin to the south. Snake Creek flows eastward to Snake Valley, where it is used for irrigation near the town of Garrison, Utah. Land-surface altitudes range from about 5,280 $\mathrm{ft}$ at Garrison, Utah, to $11,926 \mathrm{ft}$ at Pyramid Peak (fig. 35). The drainage basin includes two small high-altitude lakes, Johnson and Dead.

In the GBNP, the drainage area is $22.6 \mathrm{mi}^{2}$, and the stream has a length of $9.9 \mathrm{mi}$ (table 1; Elliot and others, 2006, p. 8). Snake Creek has the largest drainage area in the GBNP. The drainage area at the Nevada-Utah state line is $32.7 \mathrm{mi}^{2}$, and the stream length is $15 \mathrm{mi}$ (table 1; Elliot and others, 2006, p. 8). In the GBNP, Snake Creek has a streambed slope of more than 13 percent along its uppermost $3.3 \mathrm{mi}$, which abruptly decreases to an average 5 percent slope for the last 6.6 mi to the GBNP boundary. Spring Creek joins Snake Creek

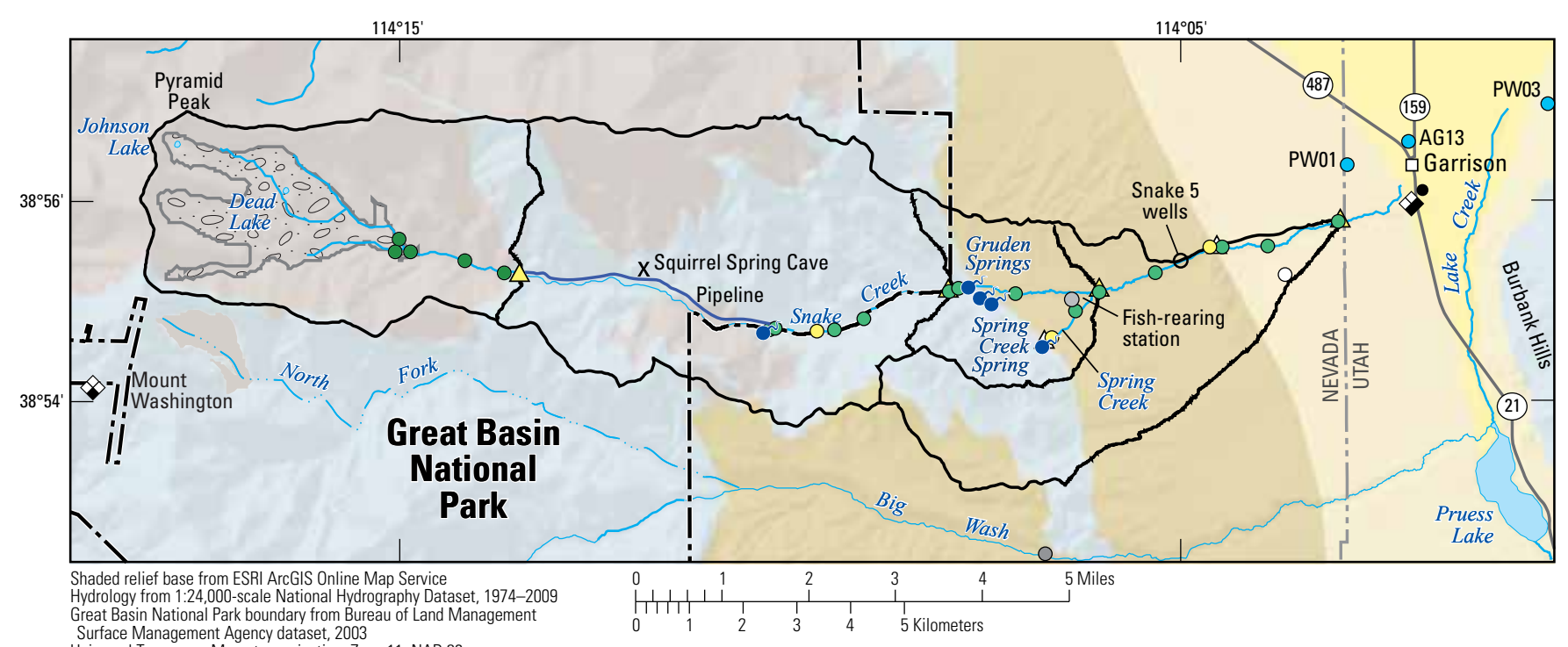

Great Basin National Park boundary from Bureau of Land Management

Univace Management Agency dataset, 2003
Universanerse Mercator projection, Zone 11, NAD 83
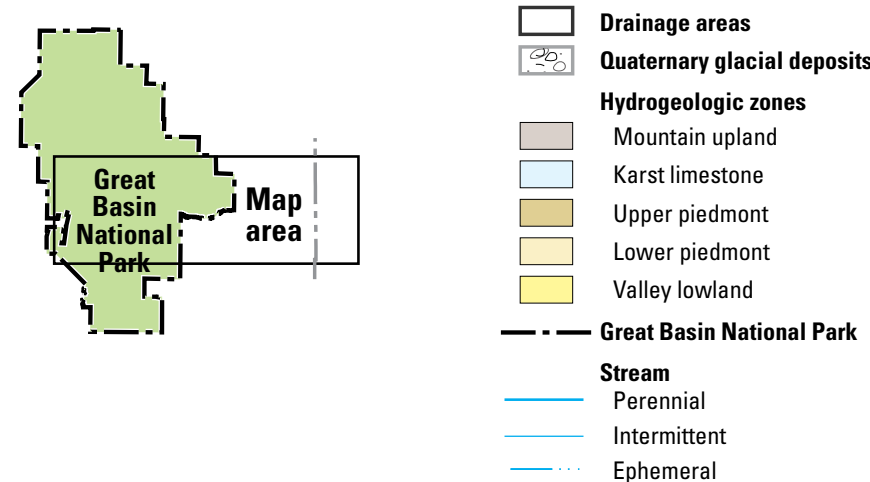

\section{EXPLANATION}

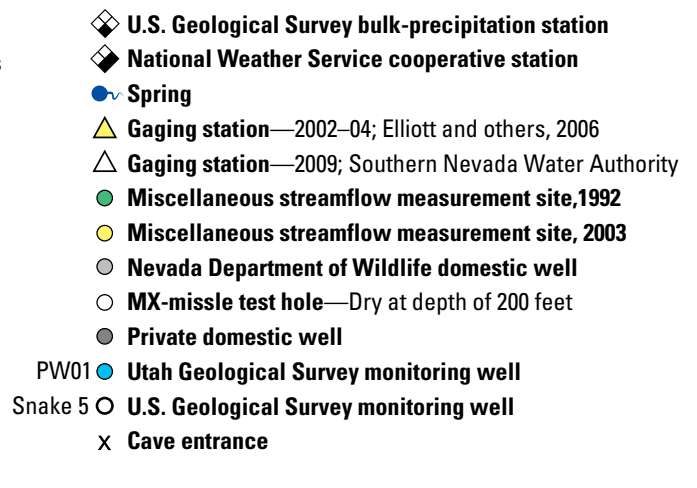

Figure 35. Snake Creek drainage basin in the southern Snake Range and Great Basin National Park, White Pine County, Nevada. 
about $3.4 \mathrm{mi}$ upstream of the Nevada-Utah state line or $3.2 \mathrm{mi}$ downstream of GBNP after first filling ponds for the NDOW Spring Creek fish-rearing station (fig. 35). The average streambed slope is 3 percent from GBNP to the Nevada-Utah state line (Toby Welborn, U.S. Geological Survey, Carson City, Nev., written commun., 2010).

Precipitation and evapotranspiration vary in relation to altitude in the drainage basin and in relation to annual and seasonal climate variations. Mean precipitation rates ranged from less than 8 in./yr at Garrison, Utah (Western Regional Climate Center, 2011), to more than $30 \mathrm{in} . / \mathrm{yr}$ in the highest parts of the drainage basin (fig. 6). Mean annual temperature ranged from about $10.3^{\circ} \mathrm{C}$ at Garrison, Utah, to less than $3{ }^{\circ} \mathrm{C}$ at the highest altitudes. The bulk-precipitation station on Mount Washington is southwest of the Snake Creek drainage basin, and about 80 percent of the precipitation at higher altitudes accumulated as snow during the winter months (fig. 7).

\section{Geology}

The surface geology of the Snake Creek drainage basin is shown in figure 36 and is based on a 1:24,000-scale digital geologic map of GBNP (Brown and Davila, 1995; National Park Service, 2007), which was modified for this study with geologic mapping. The area around Snake Creek is characterized by complexly faulted bedrock uplands, flanked to the east by extensive, partly buried, Miocene conglomeratic deposits that are overlain and flanked to the east by younger Quaternary deposits in the vicinity of the Nevada-Utah state line (fig. 36). The southern Snake Range detachment fault (McGrew, 1993; Miller and others, 1999) is the dominant structural feature in the drainage basin; the development of this fault affected the exposure and configuration of most of the consolidated and partly consolidated rocks in this area.

\section{Distribution of Rocks}

Consolidated rocks that lie above the southern Snake Range detachment fault consist of a mosaic of normal-fault bounded blocks of various non-metamorphosed lower Paleozoic sedimentary rocks that are predominantly carbonate, but include locally important exposures of Ordovician Eureka Quartzite (fig. 36). These fault blocks are brittlely deformed, exhibit variable dip and direction, and possess incomplete fragments of the known regional stratigraphy (McGrew, 1993; Miller and others, 1999). Consolidated rocks that lie below the detachment fault surface have greater lateral continuity, but are, in part, ductilely deformed and weakly metamorphosed and consist of a structurally thinned, but coherent, stratigraphy of the Pole Canyon Limestone and Prospect Mountain Quartzite intruded by Tertiary and older granitic rocks (figs. 36, 37; McGrew, 1993; McGrew and others, 1995).

Just to the east of GBNP, Paleozoic rocks are juxtaposed against a thick section of Miocene conglomeratic rocks across an east-dipping, down-to-the-east fault (Tertiary fault in fig. 36). This conglomeratic section also is exposed in the Big Wash drainage basin, where it is unconformably overlain by older alluvium. A horst block of the Devonian Guilmette Formation limestone is present along the east edge of these conglomeratic exposures to the north and south of Snake Creek. The east side of this block is bounded by another down-to-the-east fault that separates all exposures of Miocene conglomeratic rocks on the west from older and younger basin-fill deposits on the east (fig. 36). Basin-fill deposits occupy an area about $4 \mathrm{mi}$ wide in this part of Snake Valley, where Devonian Guilmette Formation limestone crops out just to the east of Garrison (fig. 3).

\section{Snake Range Detachment Fault}

The southern Snake Range detachment fault lies along the eastern front of the range between Baker Creek and Snake Creek. Just north of the Snake Creek drainage basin, the map trace of the fault swings southwestward into the main part of the range between Snake Creek and Big Wash (fig. 36; McGrew and others, 1995; National Park Service, 2007). The fault surface has gentle, map-scale warps and corrugations that trend approximately east-west; the complexly faulted Paleozoic rocks in the Snake Creek area are preserved in a shallow downwarp of the detachment fault surface to the south of the Young Canyon pluton (McGrew and others, 1995). The Paleozoic section above the detachment fault is broken into a mosaic of fault blocks of varying stratal dip and dip direction. The low-angle faults that disrupt the carbonate rocks above the detachment fault are hanging-wall normal faults that merge with the main detachment fault in the shallow subsurface (fig. 37; McGrew, 1993; McGrew and others, 1995).

On average, the detachment fault dips 10 to 15 degrees to the southeast and projects eastward beneath Snake Valley (fig. 37; McGrew and others, 1995; fig. 37). Miller and others (1999) analyzed the thermal history of footwall and hanging wall rocks and documented rapid slip and major fault-related uplift on this portion of the detachment fault during the Miocene (about $17 \mathrm{Ma}$ ). On the basis of a distinct reflector on regional seismic lines, the detachment fault was interpreted in the subsurface to the north of Garrison, Utah (Allmendinger and others, 1983), where it is observed to plunge beneath Snake Valley and the Confusion Range with little modification by post-Miocene, high-angle, normal faults. The detachment fault also was interpreted from seismic reflection data collected during oil and gas exploration of Snake and Hamlin Valleys as a distinct reflector plunging to the south and southeast (Shah Alam, 1990). Complexly faulted and tilted blocks of Paleozoic bedrock have been inferred to exist beneath Miocene and younger sedimentary cover east of GBNP (fig. 37). The configuration of fault blocks is unknown, but the altitude at the top of the Paleozoic section is consistent with the results of an audiomagnetotelluric survey along an east-west traverse about 2 mi south of Snake Creek (McPhee and others, 2009). Similar to surface exposures to the west, these fault blocks were inferred to lie above the east-dipping detachment fault and merge with it at depth (fig. 37; McGrew, 1993; McGrew and others, 1995). The buried faults were depicted as dying out upward in the Miocene sedimentary section because they 


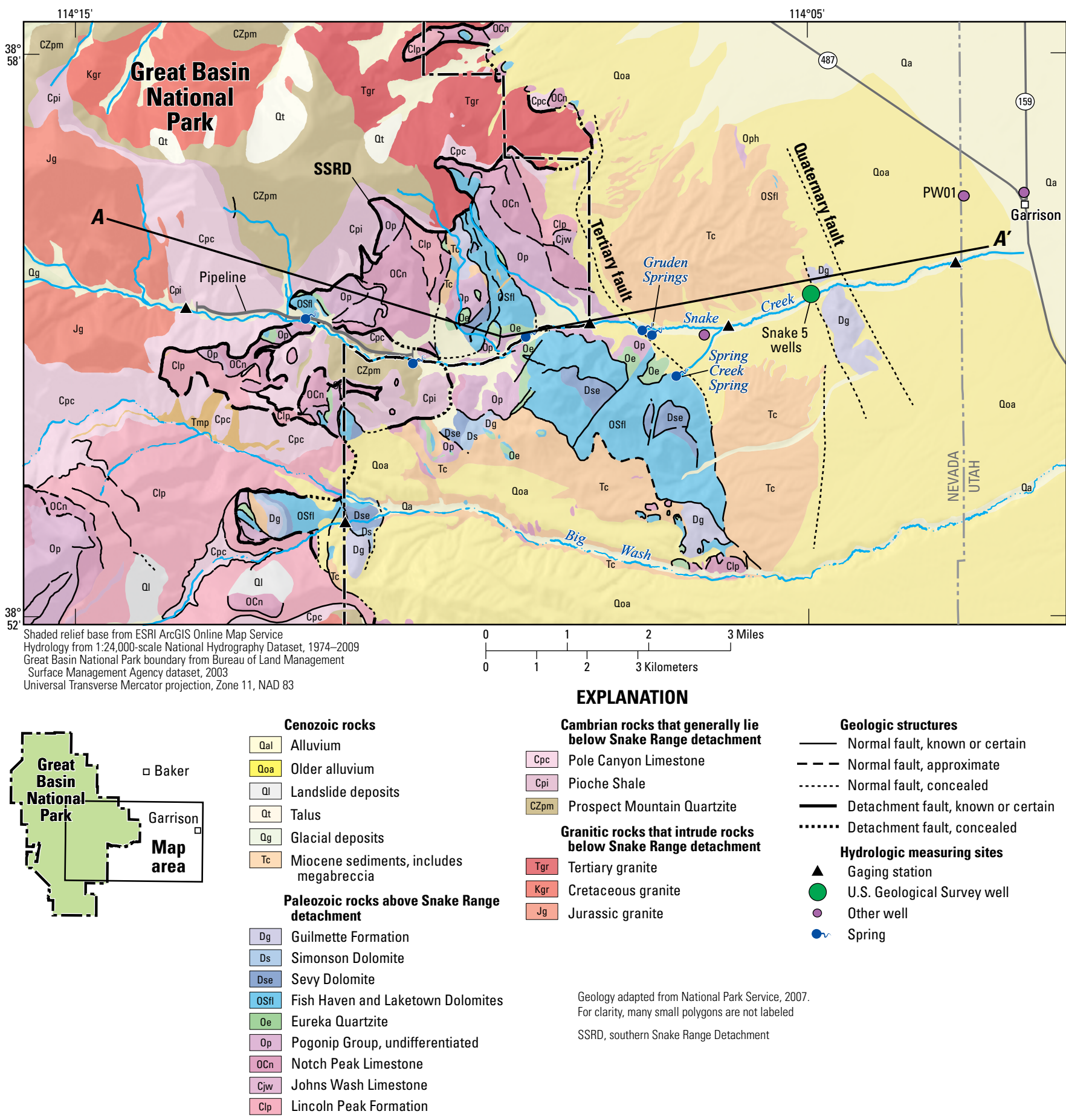

Figure 36. Geology of the Snake Creek drainage basin, Great Basin National Park, White Pine County, Nevada. 

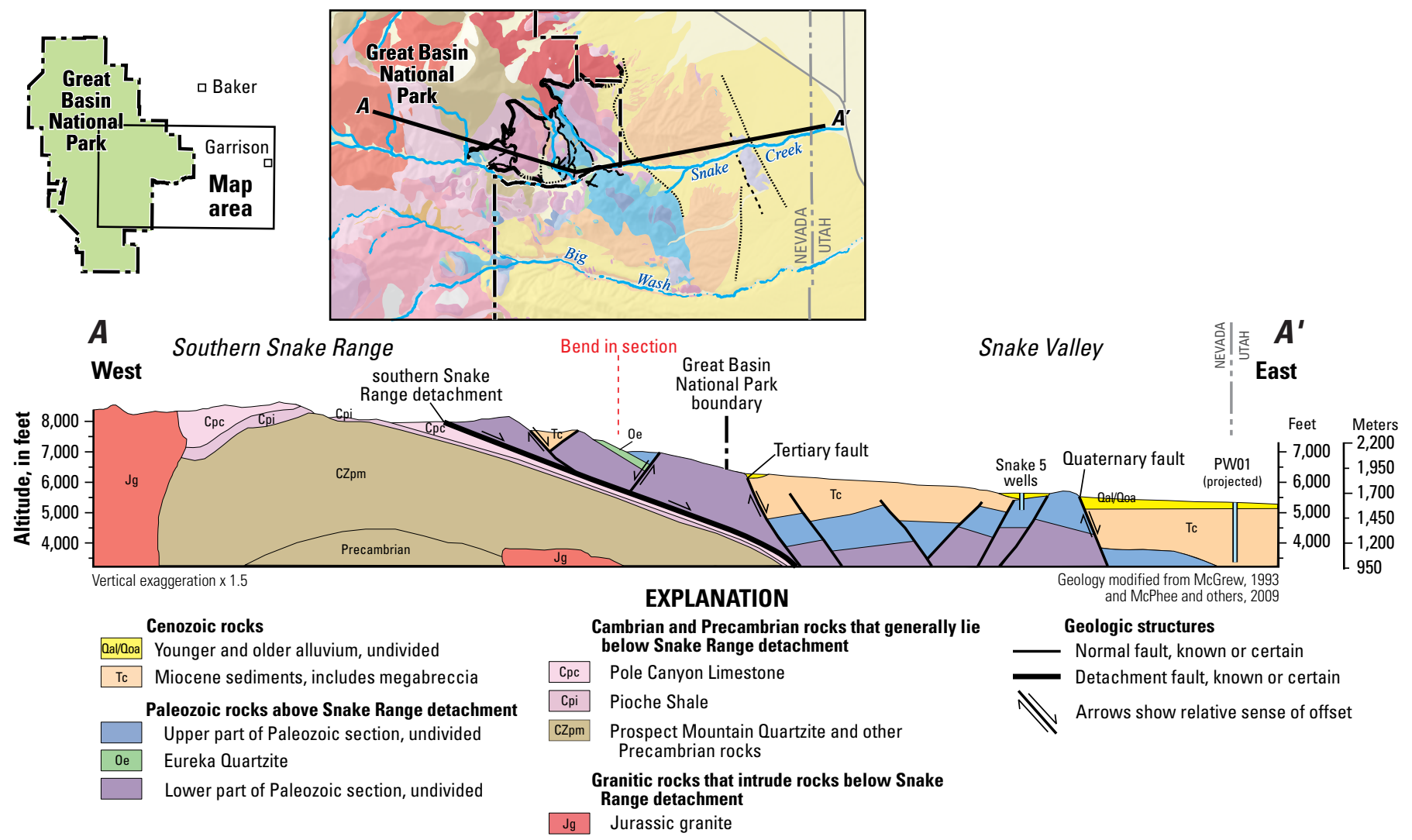

Figure 37. Interpretive geologic cross section along Snake Creek from mountain front to Nevada-Utah state line.

were interpreted to have had predominantly Miocene motion and then were buried by latest Miocene conglomerates derived from erosion of the uplifted range. These faults are not shown on the geologic map (fig. 36) because they are buried and do not cut the rocks and deposits exposed on the surface.

\section{Extent of Miocene Deposits and Faults near Snake Creek}

Along the mountain front, where Snake Creek emerges from the canyon in consolidated rocks, the Paleozoic section is juxtaposed against a west-tilted conglomeratic sedimentary section across an east-dipping, down-to-the-east fault (Tertiary fault in figs. 36, 37). Faulted, west-tilted conglomerate and other semi-consolidated alluvial deposits are well-exposed along the eastern parts of Snake Creek drainage basin and in the Big Wash drainage basin (fig. 36) and were inferred to underlie Quaternary deposits in the near subsurface in the vicinity of Garrison, Utah (fig. 37). These semi-consolidated deposits are lithologically diverse, including partly cemented to cemented alluvial-fan conglomerate, gravel, and sand, with lesser amounts of marl and tuff (McGrew and others, 1995). Included in these deposits are blocks of internally brecciated Paleozoic strata that range in dimension from tens to hundreds of feet. Like the Sacramento Pass section farther to the north, these coarse-grained sediments and included megabreccia blocks were interpreted to be synorogenic sediments deposited following rapid Miocene uplift of the range front (McGrew, 1993; Miller and others, 1999). Lithologic heterogeneity and lack of continuous markers within the Miocene section make delineation of true stratigraphic thickness difficult to define. However, outcrop relations clearly indicate that the section thickens westward toward the range front, where the section could be as thick as 1,500 ft (fig. 37). In Big Wash, the section is uniformly southwest dipping, nearly unfaulted, and 4,400 ft thick (McGrew and others, 1995). Audiomagnetotelluric (AMT) data along an east-west traverse about 2 mi south of Snake Creek estimated the Tertiary sediments to be about 4,000 ft thick near the range front, shallowing and thinning eastward to a fault or pinch out against the upfaulted Paleozoic horst block (McPhee and others, 2009). The Snake 5 wells (appendix 1), near the upfaulted Paleozoic block, penetrated $78 \mathrm{ft}$ of Cenozoic section, a thickness generally consistent with results from the AMT line to the south.

The age of the conglomeratic sedimentary section is less than about $16 \mathrm{Ma}$ based on fission-track ages on granitic boulder clasts from these deposits (Miller and others, 1999). Bedded, reworked ash deposits in this section have been correlated on the basis of major, minor, and trace-element chemistry with volcanic eruptions from the Snake River Plain, Idaho, that took place around 11.6 Ma (Mike Perkins, University of Utah, Salt Lake City, Utah, written commun., May 2010). These ages, the presence in these deposits of clasts eroded from granite below the detachment, and the relatively intact nature 
of the section, in contrast to the complexly faulted mosaic of Paleozoic rocks exposed to the west, all indicated that these Cenozoic sediments are younger than most, if not all, of the faulting associated with the detachment fault (McGrew, 1993; Miller and others, 1999). The west-dipping, conglomeratic sedimentary section is overlain by undated, nearly flat-lying, older alluvial-fan deposits (fig. 36). The angular unconformity between older alluvial-fan deposits and Miocene sediments is well exposed in the Big Wash drainage basin.

The fault (Tertiary fault, fig. 36) that separates the Paleozoic rocks from the conglomeratic sedimentary section appears to have had predominantly Tertiary (Miocene) motion based on the units it offsets and its relation to the detachment fault. The conglomeratic sedimentary section generally dips moderately (up to 40 degrees) to the west-southwest toward this fault, thickens against it, and is offset by it, indicating that this fault was active during and shortly after deposition of the sediments. Older alluvial-fan deposits (fig. 36) show little to no offset across this fault. The fault is curved in map view and appears to merge northward with the surface trace of the detachment fault (McGrew and others, 1995). Also, the fault has listric geometry based on AMT data (McPhee and others, 2009) and map relations and likely merges with the detachment fault at depth. McGrew (1993) suggests that geologic relations are not conclusive, however, and that this fault could cut the detachment fault in the subsurface.

\section{Quaternary Fault and Thickness of Quaternary Alluvium}

Flat-lying to gently tilted, unconsolidated to consolidated alluvial-fan, sand and gravel deposits underlie pediment surfaces along the eastern flank of the southern Snake Range. The well data and gravity-based models of the thickness of Cenozoic basin fill (Watt and Ponce, 2007) indicated that these younger basin-fill deposits thicken rapidly to the east of the limestone horst block that outcrops east of the Snake 5 wells (fig. 36). The east side of this block is bounded by one or more down-to-the-east faults that offset Quaternary deposits. This fault, east of the limestone horst block, is labeled as the "Quaternary fault" for purposes of discussion in subsequent sections.

Wells to the east of the Nevada-Utah state line and west of Garrison, Utah, penetrate as much as $820 \mathrm{ft}$ of coarse-grained basin-fill deposits that are likely to be Quaternary in age. A monitoring well, drilled by the UGS, close to the state line and north of the Snake Creek drainage basin (PW01, fig. 36) penetrated $1,837 \mathrm{ft}$ of basin-filling sediments without penetrating underlying bedrock.

\section{Distribution of Coarse- and Fine-Grained Sediments from Well-Drillers' Logs}

Only four wells exist in the Snake Creek drainage basin between the Tertiary fault and the floor of Snake Valley at the Nevada-Utah state line: the Snake 5 wells, two wells on the NDOW property near the confluence of Spring Creek and Snake Creek, and a well on private property west of the NDOW wells. Depth to bedrock is generally shallow at these locations. The Snake 5 wells, drilled near the horst of Devonian carbonate rock (fig. 36), penetrated $40 \mathrm{ft}$ of mostly coarse-grained alluvial material and another $38 \mathrm{ft}$ of weathered clay before encountering carbonate rock. One of the NDOW wells penetrated about $20 \mathrm{ft}$ of alluvium before encountering what the driller labeled "granite bedrock;" the second NDOW well penetrated about $30 \mathrm{ft}$ of sand and gravel. The fourth well, upstream from the NDOW wells, was drilled to a depth of about $104 \mathrm{ft}$ through sandy clay with layers of more coarse material before encountering carbonate rock.

The limited lithologic data along this part of Snake Creek did not permit a spatial analysis of the distribution of lithology, but some general observations could be made. First, a channel of extremely coarse alluvial material, such as was observed in the Baker and Lehman Creek drainage basins, is not evident from the available well-log data. Each of the four wells has some gravel beds, but layers of clay and sandy clay were also observed. Near the Tertiary fault in the vicinity of Gruden Springs, surficial material on the banks of the creek is generally fine-grained. The next closest available lithologic data in the area were from wells east of the Nevada-Utah state line near Garrison, Utah. Several of these wells encountered thick intervals of cobbles and gravel interbedded with sand and gravel, sand, and finer-grained material.

\section{Connection of Aquifers to Springs and Streams}

The connection of aquifers to springs and Snake Creek was evaluated on the basis of the same five hydrogeologic zones used to describe the water resources of the Baker and Lehman Creek drainage basins (fig. 35). Similar to Baker and Lehman Creek drainage basins, streamflow in Snake Creek and its connection with groundwater are directly related to the geology. The headwaters to Snake Creek are in relatively impermeable Prospect Mountain Quartzite and intrusive units, where the detachment fault has been eroded away (fig. 36). Downstream, in the karst-limestone zone, but still beneath the detachment fault, the creek crosses the Pole Canyon Limestone and is diverted to a pipeline in this section to prevent streamflow losses. Between the east end of the pipeline and the eastern GBNP boundary and in the karst-limestone zone, the creek flows over complexly faulted blocks of the upper plate, which are dominated by carbonate rocks (fig. 36). Before Snake Creek leaves the karst-limestone zone, the creek crosses the base of the southwest-dipping fault block, which includes Ordovician Eureka Quartzite (fig. 36). The Eureka Quartzite in this locality is dense, massive, and highly cemented and creates a partial impediment to groundwater flow (Elliott and others, 2006, p. 39). Downstream of this fault block, Snake Creek flows over highly fractured rocks of the Cambrian and Ordovician Pogonip Group (Whitebread, 1969; McGrew and others, 1995). The creek then crosses a fault with large offset and over Cenozoic sedimentary rocks (fig. 36). Gruden Springs, along Snake Creek, issue from the alluvial deposits and underlying 
Cenozoic section near this fault. Spring Creek originates from a spring that issues from the undifferentiated Laketown and Fish Haven Dolomites along the same fault contact south of Snake Creek (fig. 36).

\section{Mountain-Upland Zone}

The mountain-upland zone includes the headwater area in Great Basin National Park at altitudes between 7,600 and 11,926 ft, which are upstream of Paleozoic limestone in an area underlain mostly by granitic rocks (fig. 35). Most of the zone is covered by coniferous forest (Houghton and others, 1975), because only a fraction lies above an altitude of $11,000 \mathrm{ft}$. Consequently, more precipitation is lost to evapotranspiration, and less contributes to runoff, than in the mountain-upland zone in the Baker and Lehman Creek drainage basins (table 3 ).

Groundwater flows mostly through large pores in glacial deposits and through smaller pores in thin colluvium and alluvial deposits that mantle the, generally, less permeable granite. The shallow groundwater helps maintain perennial flow in Snake Creek near the end of this zone. No wells were present, and only one set of discharge measurements taken on September 3, 1992, were available to evaluate changes in streamflow in the mountain-upland zone (Elliot and others, 2006, p. 18). Discharge measurements on that date indicated Snake Creek lost about $0.8 \pm 0.3 \mathrm{ft}^{3} / \mathrm{s}$ between the end of the glacial deposits and the first gaging station that is at the end of the mountain-upland zone (fig. 35). Much of this loss infiltrated the alluvial deposits next to the stream and was either used to replenish groundwater or exited the mountainupland zone as shallow groundwater flow mostly through the alluvial deposits (fig. 38). Slightly longer and deeper groundwater could flow through fractures in the granite, but because unweathered granite generally has low permeability, such flow would be a fraction of the flow through either the alluvial aquifers or streamflow to the karst-limestone zone. Consequently, unweathered granite that underlies much of the

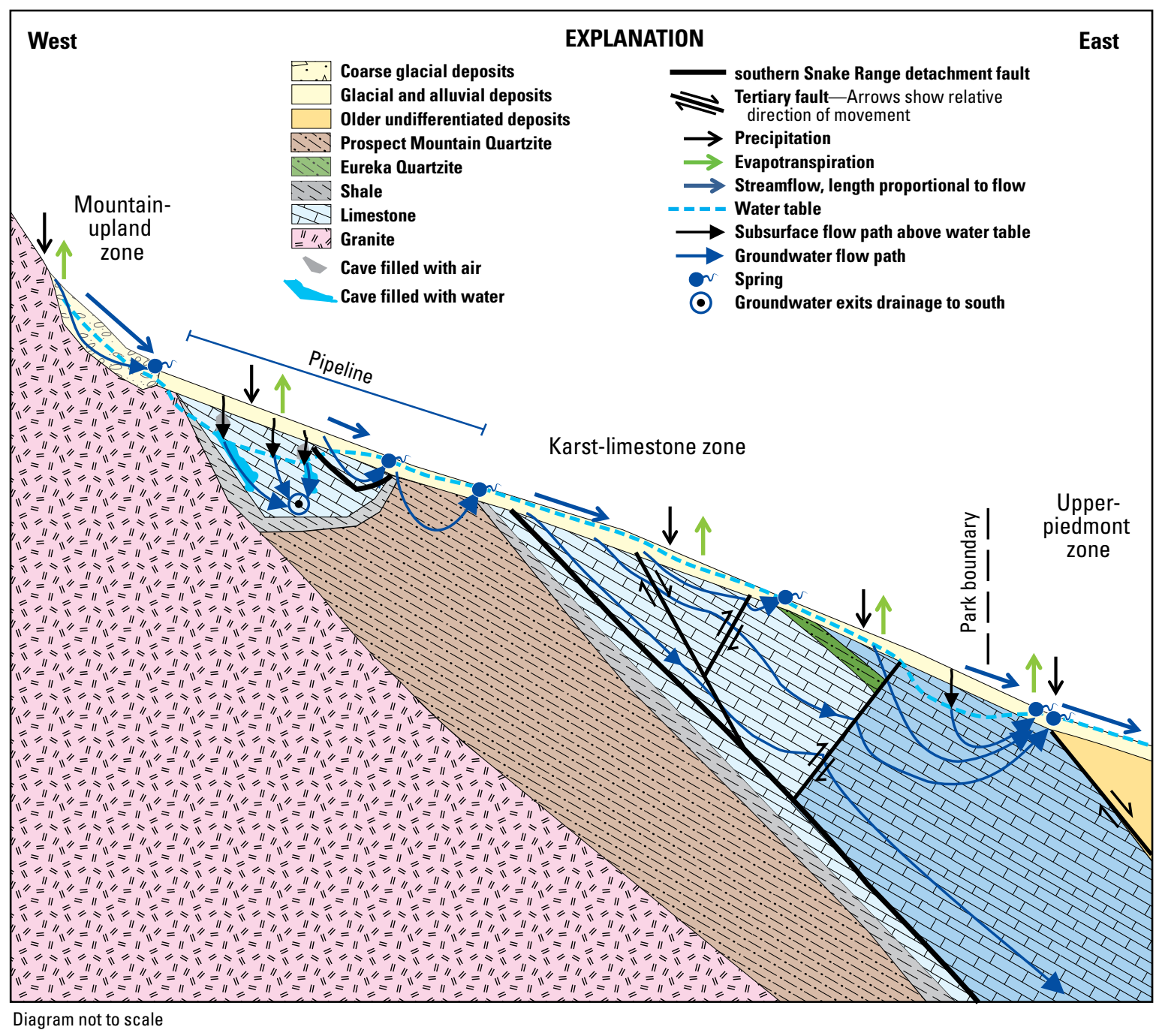

Figure 38. Idealized cross section showing flow along Snake Creek in the mountain-upland and karst-limestone zones along Snake Creek, Great Basin National Park, White Pine County, Nevada. 
northern Snake Range was assumed to be an effective barrier to deep groundwater flow, so much of the groundwater in this zone flows through shallow glacial and alluvial deposits that overlie the granite.

A mean annual water budget of the mountain-upland zone was used to determine the relative importance of the processes contributing to water loss and to estimate mean annual flows to the karst-limestone zone (table 11). Mean annual precipitation in the mountain-upland zone was estimated to be 12,000 acre-ft, and the uncertainty was estimated to be 20 percent. At the uppermost gaging station, which was operated from 2002 to 2004 near the end of the mountainupland zone, the mean annual runoff was 3,000 acre-ft, with uncertainty approximated at 10 percent (table 11). By using Darcy's Law, an estimated cross-sectional area of flow through shallow alluvial deposits of 4,000 $\mathrm{ft}^{2}$, a hydraulic conductivity of $50 \mathrm{ft} / \mathrm{d}$, and a hydraulic gradient equal to the streambed gradient of $0.06 \mathrm{ft} / \mathrm{ft}$, the mean annual groundwater flow out of the mountain-upland zone was approximated as 100 acre-ft (table 11), with an estimated uncertainty of 50 percent.
Evapotranspiration was estimated by subtracting runoff and groundwater flow from precipitation, and the estimated uncertainty of evapotranspiration was determined by subtracting the minimum estimated runoff and groundwater flow estimates derived from the uncertainty for those estimates from the maximum precipitation estimate.

About 75 percent of the mean annual precipitation was estimated to be lost to evapotranspiration, and 25 percent exited the zone as runoff. Evapotranspiration was greater than in the Baker and Lehman Creek drainage basins because most of the precipitation fell in the area where altitudes were below $11,000 \mathrm{ft}$, where trees are present (mean precipitation rate is less than $28 \mathrm{in} / \mathrm{yr}$ ). The average chloride concentration of Snake Creek near the mountain-upland zone was $1.2 \mathrm{mg} / \mathrm{L}$ based on five samples (table 3). This indicated that the mean annual chloride concentration in precipitation (wet and dry fall) in the mountain-upland zone was about $0.3 \mathrm{mg} / \mathrm{L}$, which was about half of the $0.6 \mathrm{mg} / \mathrm{L}$ estimated for precipitation in the Baker and Lehman Creek drainage basins.

Table 11. Water budgets for the mountain-upland, karst-limestone, and upper-piedmont zones in the Snake Creek drainage basin, Great Basin National Park, White Pine County, Nevada.

[PRISM is from the 1971-2000 mean precipitation rates obtained from the PRISM Climate Group, Oregon State University, http://prism.oregonstate.edu; table 1 is in this report; measurements are a combination of records from gaging stations listed in appendix 4, from periodic discharge measurements listed in appendix 3 , and from other available information on the flow of small springs; Darcy's Law are calculations of groundwater flow assuming a cross-sectional area, a lateral hydraulic conductivity, and a hydraulic gradient; calculation of evapotranspiration for mountain-upland and upper-piedmont zones is the difference between inflow and all other outflows; equation 1 used to estimate evapotranspiration for karstlimestone zone because inflow from Big Wash was calculated from the difference in inflow less all other outflows. Symbol: - , not determined ; <, less than]

\begin{tabular}{|c|c|c|c|c|c|c|c|}
\hline \multirow{3}{*}{ Water budget component } & \multicolumn{2}{|c|}{$\begin{array}{l}\text { Mountain upland } \\
\text { drainage area } 9.3 \text { square miles }\end{array}$} & \multicolumn{2}{|c|}{$\begin{array}{l}\text { Karst limestone } \\
\text { drainage area } 16.1 \text { square miles }\end{array}$} & \multicolumn{2}{|c|}{$\begin{array}{c}\text { Upper piedmont } \\
\text { drainage area } 5.5 \text { square miles }\end{array}$} & \multirow{3}{*}{ Source of estimates } \\
\hline & $\begin{array}{l}\text { Mean annual } \\
\text { volume }\end{array}$ & $\begin{array}{l}\text { Estimated } \\
\text { uncertainty }\end{array}$ & $\begin{array}{l}\text { Mean annual } \\
\text { volume }\end{array}$ & $\begin{array}{c}\text { Estimated } \\
\text { uncertainty }\end{array}$ & $\begin{array}{l}\text { Mean annual } \\
\text { volume }\end{array}$ & $\begin{array}{l}\text { Estimated } \\
\text { uncertainty }\end{array}$ & \\
\hline & \multicolumn{6}{|c|}{ Acre-feet } & \\
\hline \multicolumn{8}{|c|}{ Inflow } \\
\hline Precipitation & 12,000 & 2,400 & 13,000 & 2,600 & 2,600 & 500 & PRISM \\
\hline Runoff & 0 & - & 3,000 & 300 & 2,900 & 300 & Table 1 \\
\hline Spring flow & 0 & - & 0 & - & 2,200 & 600 & Measurements \\
\hline \multicolumn{8}{|l|}{ Groundwater } \\
\hline Younger alluvial deposits & 0 & - & 100 & 50 & $<10$ & - & Darcy's Law \\
\hline Older alluvial deposits & 0 & - & 0 & - & 0 & - & Darcy's Law \\
\hline Consolidated rocks & 0 & - & $<10$ & - & 400 & 200 & Darcy’s Law \\
\hline Big Wash drainage & 0 & - & 1,700 & 800 & 0 & - & Difference between inflow and outflow \\
\hline Total & 12,000 & 2,400 & 17,800 & 3,750 & 8,100 & 1,600 & Sum \\
\hline \multicolumn{8}{|c|}{ Outflow } \\
\hline Evapotranspiration & 8,900 & 3,000 & 12,000 & 4,000 & 3,300 & 2,000 & Calculation or equation 1 or 2 \\
\hline Runoff & 3,000 & 300 & 2,900 & 300 & 4,400 & 400 & Table 1 \\
\hline Spring flow & 0 & - & 2,200 & 600 & 0 & - & Measurements \\
\hline \multicolumn{8}{|l|}{ Groundwater } \\
\hline Younger alluvial deposits & 100 & 50 & $<10$ & - & $<10$ & - & Darcy’s Law \\
\hline Older alluvial deposits & 0 & - & 0 & - & $<10$ & - & Darcy’s Law \\
\hline Consolidated rocks & $<10$ & - & 400 & 200 & 400 & 200 & Darcy’s Law \\
\hline Big Wash drainage & - & - & 300 & 200 & 0 & - & Calculation \\
\hline Total & 12,000 & 3,350 & 17,800 & 5,300 & 8,100 & 2,400 & Sum \\
\hline
\end{tabular}


The mean annual precipitation estimated for the mountainupland zone was slightly more than that estimated for the Lehman Creek drainage basin, which was consistent with its larger drainage basin area (table 3 ). The mean annual runoff in Snake Creek was 60 percent of that estimated for Lehman Creek, however. Less runoff in Snake Creek corresponded to less mean annual precipitation in areas with mean precipitation rates greater than $28 \mathrm{in} / \mathrm{yr}$. Groundwater flow from the mountain-upland zone could be more than was estimated, but this seems unlikely, because granite is not typically permeable and would require a large percentage of fractures to accommodate much groundwater flow.

\section{Karst-Limestone Zone}

The karst-limestone zone makes up a greater fraction of the drainage basin area of Snake Creek compared with those of the Baker and Lehman Creek drainage basins. This zone has similar topographic and hydrologic features as those in the Baker and Lehman Creek drainage basins, but differs geologically, because many large tilted fault blocks of Paleozoic carbonate rocks are present above the southern Snake Range detachment fault (fig. 37). Flow through this zone near Snake Creek is shown conceptually in figure 38. Some water is lost along Snake Creek to limestone where the creek exits the mountain-upland zone and where the detachment fault has been eroded away. However, most of the flow through the karst-limestone zone is streamflow in Snake Creek, with relatively shallow circulation of groundwater in faulted blocks above the detachment fault or in shallow alluvium associated with Snake Creek.

\section{Streamflow}

Streamflow in Snake Creek varied along its length. Two types of measurements along Snake Creek were presented by Elliott and others (2006, p. 38, p. 83-90): (1) multiple discharge measurements from a single day at different locations along Snake Creek and (2) continuous records at four gaging stations from October 2002 to September 2004. Analyses of these data are presented in this report.

The GBNP has operated the gaging station on Snake Creek at its boundary (station number 10243232) since October 2004 (Gretchen Baker, National Park Service, Great Basin National Park, Baker, Nev., written commun., 2011). From October 1, 2002 to September 30, 2009, the mean discharge was $3.9 \mathrm{ft}^{3} / \mathrm{s}$. When adjusted to the 41-yr mean of Cleve Creek, the mean annual runoff was 2,900 acre-ft (table 1).

Snake Creek is intermittent at the eastern boundary of GBNP. Melting of the winter snowpack increases the daily mean discharge from May to July each year. Snake Creek ceases to flow between early August and September in most years, but not during water-year 2005 (fig. 39). Peak daily mean discharge in 2005 was 10 times more than in 2004, and the creek remained perennial through water-year 2006, then ceased flowing in September 2007.

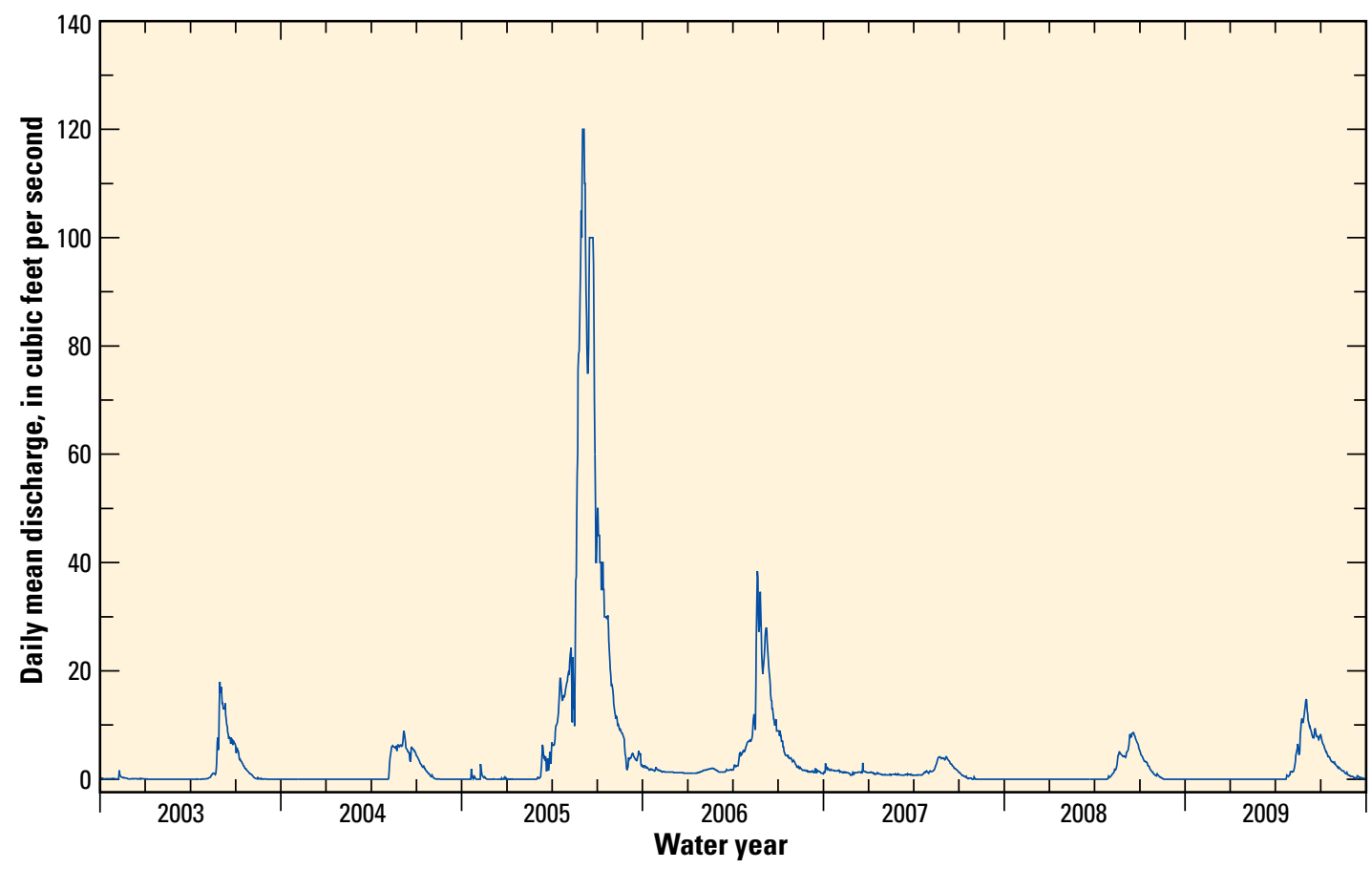

Figure 39. Runoff rate of Snake Creek at the gaging station at the eastern boundary of Great Basin National Park in relation to the winter and annual precipitation rates at the bulk-precipitation station on Mount Washington for water-years 2003-09, White Pine County, Nevada. 
The runoff rate is the annual runoff in acre-feet divided by the drainage area upstream of the gaging station in acres and converted to inches per year. The runoff rate at the gaging station at the eastern boundary of GBNP was used to compare with winter and annual precipitation rates at the bulk-precipitation station on Mountain Washington (fig. 40). Typically, the runoff rate was less than 5 percent of the winter precipitation rate recorded at bulk-precipitation station on Mount Washington, except for water years 2005 and 2006 following a large accumulation of winter precipitation from November 2004 to April 2005. Summer precipitation, indicated by the difference between winter and annual precipitation rates, did not appear to affect the runoff rate as much as the winter precipitation rate, because, during water-year 2009 , the annual precipitation rate was almost as much as during 2005, but the runoff rate was much less. The runoff rate in 2009 was nearly the same as that in 2003, which had a similar winter precipitation rate (fig. 40). The percentage of the runoff rate to winter precipitation rate increased to 28 percent during water year 2005, which was more than five times that of most years, and indicated both increased runoff from precipitation as well as an increase in the area that contributes water to Snake Creek in the drainage basin. This increased percentage of the runoff rate to winter precipitation rate continued through 2006, when the winter precipitation rate at the bulk-precipitation station on Mount Washington was only slightly more than in 2003, yet the percentage of the runoff rate to the winter precipitation rate, at 16 percent, remained greater than that of most years. This indicated that water entered groundwater storage in the karst-limestone zone in 2006 and continued to supply water to Snake Creek at the eastern boundary of GBNP, as indicated by continued daily mean discharge throughout the fall and winter of 2006 and 2007 (fig. 39).

\section{Net Streamflow Gain and Loss}

The change in daily mean discharge from one gaging station to the next for four gaging stations along Snake Creek that were in operation during water-years 2003 and 2004 (Elliott and others, 2006) were used to estimate the daily net streamflow gains and losses between the gaging stations (Dotson, 2010). These gaging stations, which were all in continuous operation from January 9, 2003, to September 30, 2004, included gaging stations near the end of the mountain-upland zone, a gaging station at the eastern boundary of GBNP, a gaging station downstream of the confluence with Spring Creek, and a gaging station at the Nevada-Utah state line (fig. 35). During the 21-month period, the reach through most of the karst-limestone zone lost flow on 99 percent of the days at an average rate of $1.6 \mathrm{ft}^{3} / \mathrm{s}$ (fig. 41). This reach included a pipeline that can convey up to $3 \mathrm{ft}^{3} / \mathrm{s}$ across an outcrop of Pole Canyon Limestone (Elliott and others, 2006, p. 37). When upstream flows exceeded $3 \mathrm{ft}^{3} / \mathrm{s}$, some of the flow in the natural channel overlying the limestone was lost.

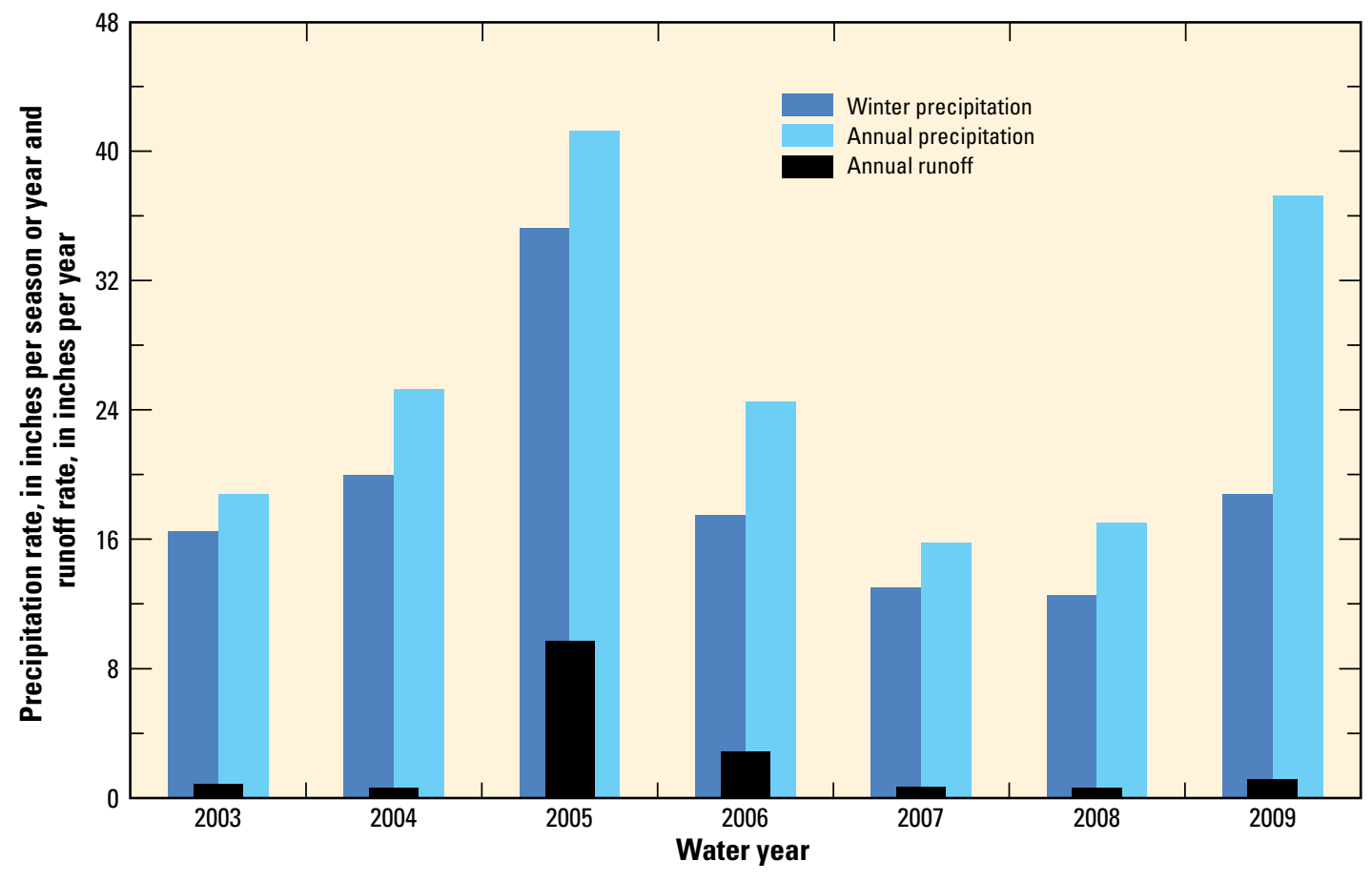

Figure 40. Daily mean discharge in Snake Creek at a gaging station at the eastern boundary of Great Basin National Park for wateryears 2003-09, White Pine County, Nevada. 
The pipeline was constructed in the early 1960s along a 2-mi long section where Snake Creek first flowed over the Pole Canyon Limestone, then crossed the detachment fault, and flowed over an isolated block of Prospect Mountain Quartzite above the detachment fault (fig. 36). Measured and estimated streamflow losses prior to construction of the pipeline ranged from 2 to $5 \mathrm{ft}^{3} / \mathrm{s}$ along the 2-mi section, beginning where Snake Creek crossed onto the Pole Canyon Limestone, with most of the streamflow loss in the first mile (Craig Baker, Baker Ranches, Inc., Baker, Nev., 2013, written commun.). Because the Pole Canyon Limestone dips to the southeast, much of the streamflow lost to the Pole Canyon Limestone in this section could exit the drainage basin to the south (Elliott and others, 2006, p. 37). This water did not resurface in the karst-limestone zone of Big Wash, because the North Fork of Big Wash is ephemeral, and a perennial reach on the South Fork is maintained by a spring at the base of a large block of carbonate rocks above the southern Snake Range detachment fault.

Although considerable flow can be lost next to the pipeline along Snake Creek when discharges exceed $3 \mathrm{ft}^{3} / \mathrm{s}$, this study focused on the connection between surface water and groundwater from about $1 \mathrm{mi}$ upstream of the eastern boundary of GBNP, near where Snake Creek crosses over the Eureka Quartzite, to the Nevada-Utah state line (fig. 42). A series of discharge measurements were done along this reach on July 19, 2009, September 10, 2009, and February 10, 2010, to augment discharge measurements on three dates reported by Elliot and others (2006). Together, the discharge measurements on all six dates showed persistent losses from Snake Creek in the lower part of the karst-limestone zone in GBNP and a gaining reach across the Tertiary fault and in the upperpiedmont zone (fig. 43).

\section{Streambed-Seepage Rates}

Net streambed-seepage rates were estimated by dividing the difference between selected discharge measurements with an estimate of the streambed area (table 12). On July 21, 2009, the net streambed seepage rate was about $-4 \mathrm{ft} / \mathrm{d}$ (negative values indicate losses through the streambed) for reach 1 , from upstream of where Snake Creek crosses the Eureka Quartzite to start of the fiber-optic cable downstream of piezometer PS1. The streamflow loss measured for this reach was similar to previous measurements (fig. 43). In reach 2, from the start of the fiber-optic cable downstream of piezometer PS1 to upstream of piezometer PS2, the net streambed-seepage rates on two days in 2009 were 14.8 and $20.5 \mathrm{ft} / \mathrm{d}$ (positive values indicate gains). The net rates excluded estimated flow from north Gruden Spring. In reach 3, from upstream of piezometer PS2 to upstream of piezometer PS4, the net streambedseepage rate was less than the uncertainty in the discharge measurement on the same two days in 2009 as for reach 2 . This indicates that more groundwater entered the creek along reach 2 than reach 3 , and much of the streamflow gain for the

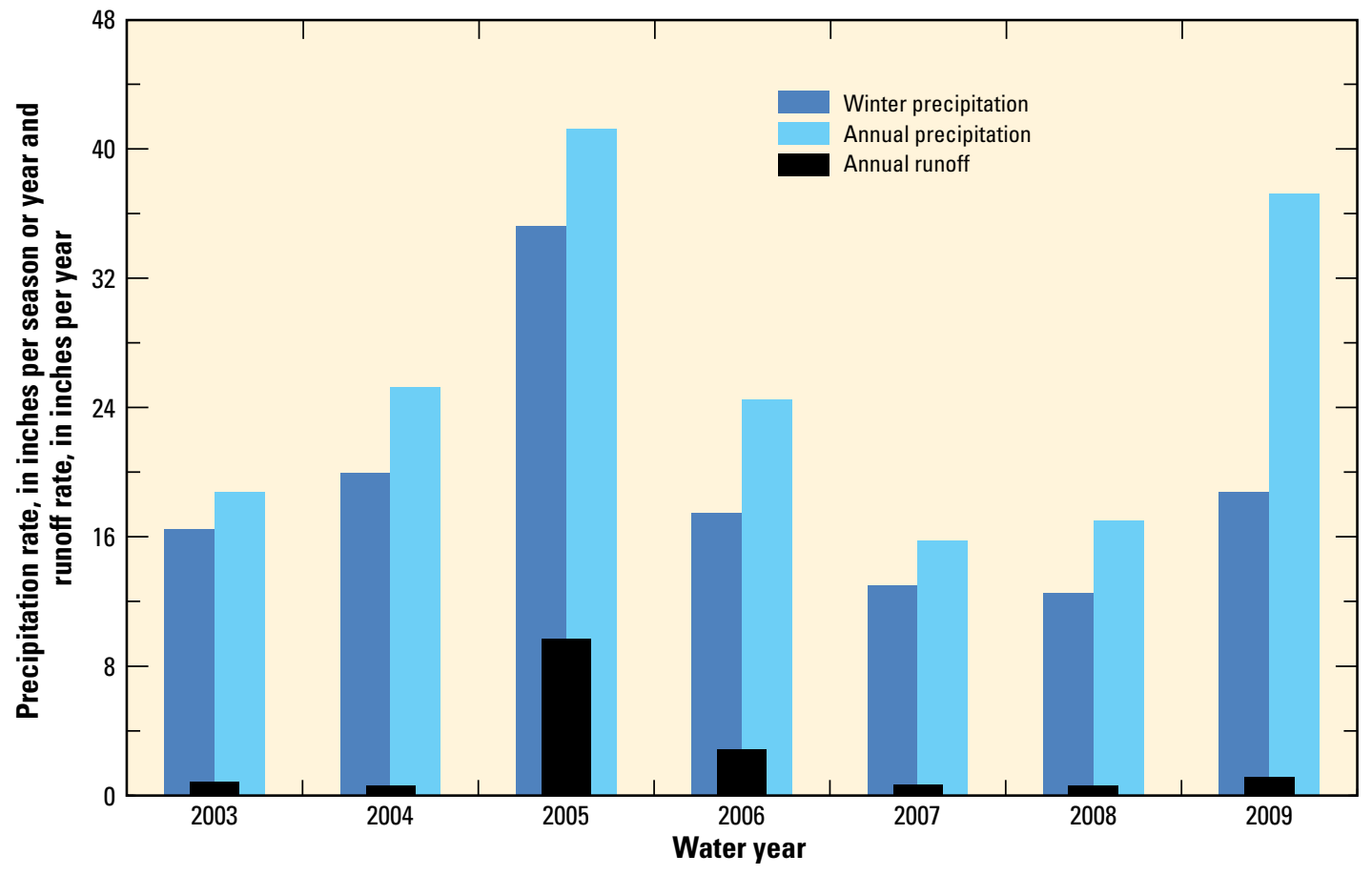

Figure 41. Discharge data from four gaging stations on Snake Creek from October 1, 2002, to September 30, 2004, Great Basin National Park, White Pine County, Nevada: $A$, daily mean discharge at each gaging station, and $B$, change in daily mean discharge between gaging stations. 

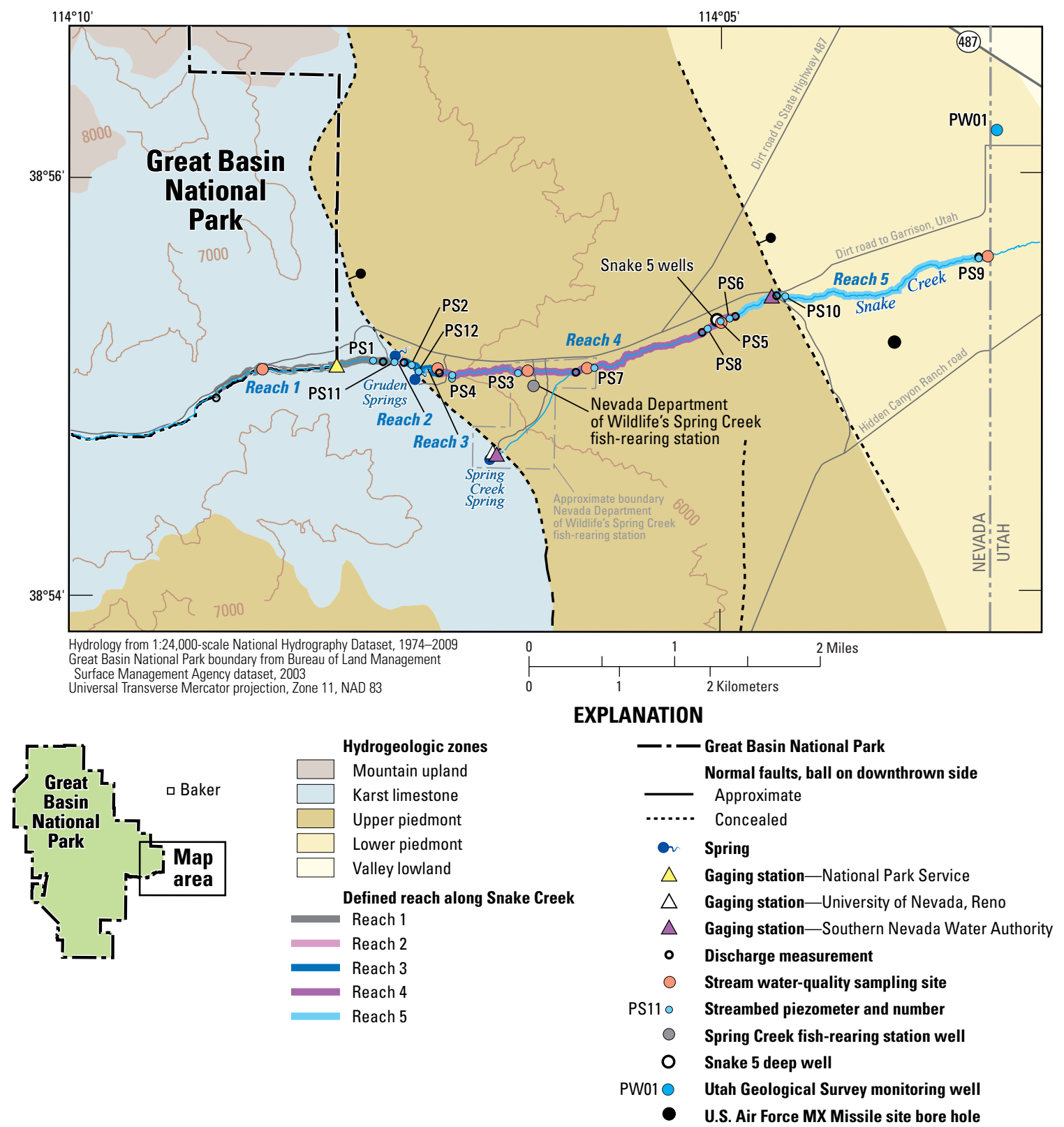

Figure 42. Monitoring locations in Snake Creek drainage basin from 1 mile inside Great Basin National Park to the Nevada-Utah state line, White Pine County, Nevada.

combined reaches on September 10, 2009, and February 25, 2010, was along reach 2 (table 12).

Two piezometers were installed in the lower part of the karst-limestone zone (PS1 and PS11). Piezometer PS1 was downstream of the gaging station at the GBNP boundary in reach 1; Piezometer PS11 was immediately upstream of flow from north Gruden Spring (fig. 42). The streambedseepage rate for piezometer PS1 was estimated by using the amplitude-ratio of temperatures in the creek compared with temperature recorded by the pressure transducer at the bottom of the piezometer. Temperatures at this site had consistent diurnal temperature fluctuations in mid-July, with lower amplitudes below the streambed than in the creek (fig. 44A).
By September 4, 2009, flow downstream of piezometer PS1, measured at the upstream site of reach 2 , had decreased to $0.22 \mathrm{ft}^{3} / \mathrm{s}$ and, then, became intermittent until September 24, 2009 , when flow ceased entirely (figs. $44 B, 45 A$ ). The streambed-seepage rate ranged from -0.7 to $-2.1 \mathrm{ft} / \mathrm{d}$, with a mean of $-1.1 \mathrm{ft} / \mathrm{d}$ (table 13), indicating the creek consistently lost flow during that period at the piezometer. The greatest rates of loss were during high flow in June and July 2009, and the least were during low flows in early September 2009.

Streambed temperatures were different at PS11, in a gaining reach of Snake Creek, from those at PS1. From July 22 to 27,2009 , the diurnal temperature fluctuations at a depth of $0.3 \mathrm{ft}$ in PS11 were much less than those at PS1; in PS11, 


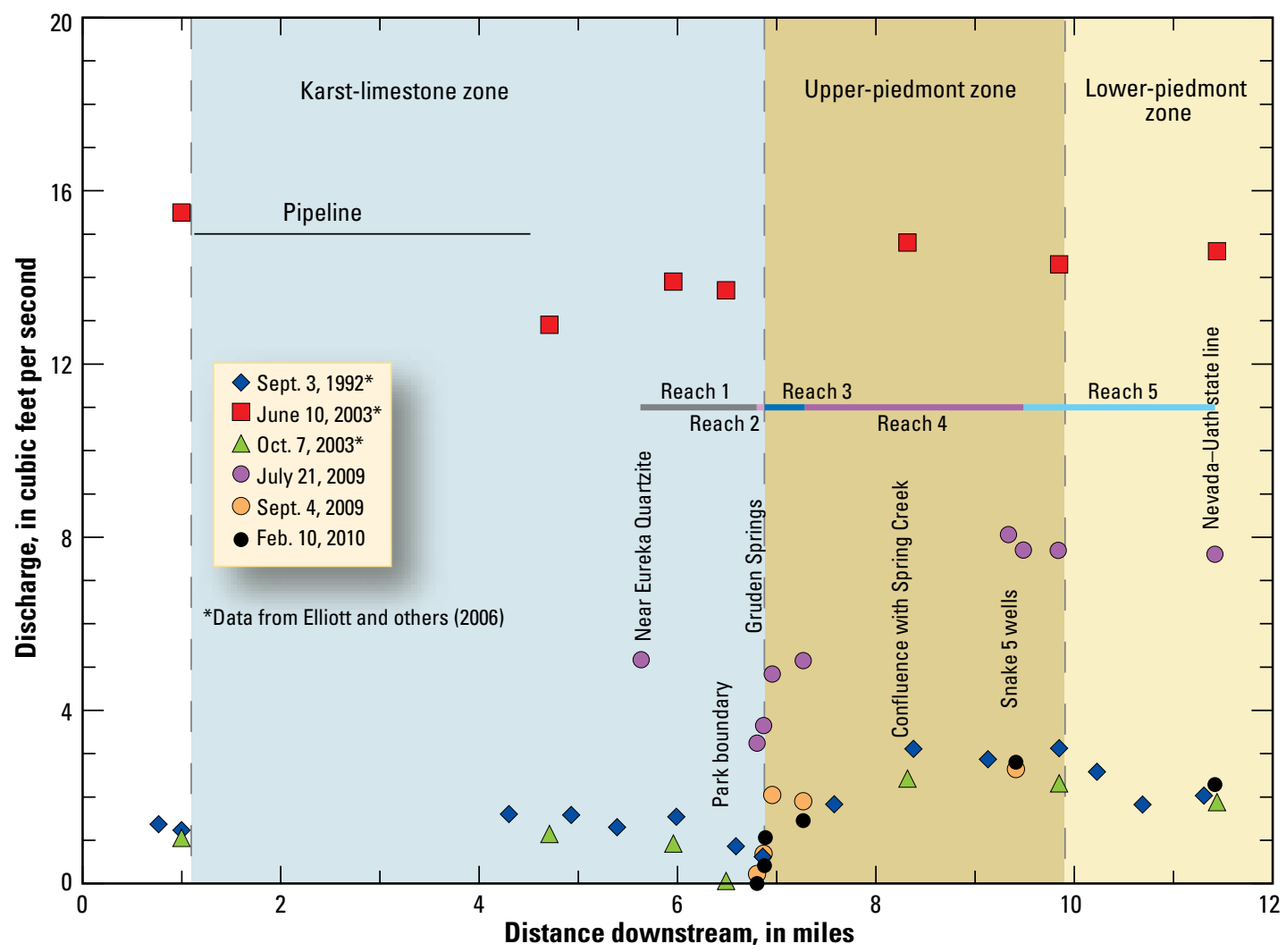

Figure 43. Discharge measurements in Snake Creek for six dates between September 1992 and February 2010, Great Basin National Park, White Pine County, Nevada.

Table 12. Net streambed-seepage rates from stream-discharge measurements along selected reaches on Snake Creek, Great Basin National Park, White Pine County, Nevada, July 2009 through February 2010.

[Reach1 is from discharge measurement upstream of park boundary to start of fiber-optic cable; reach 2 is from start of fiber-optic cable to upstream of piezometer PS2, reach 3 is from upstream of piezometer PS2 to upstream of piezometer PS4; reach 4 is from upstream of PS4 to near Snake 5 wells, and reach 5 is from Snake 5 wells to the Nevada-Utah state line. Reaches are shown in figure 42. Gain is positive; loss is negative. Discharge and gain or loss rounded to three significant figures; uncertainty and net streambed-seepage rate rounded to two significant figures. Abbreviation: $\mathrm{mm}$, two digit month; dd, two digit day; yyyy, four digit year. Symbol: - , net streambed-seepage rate less than uncertainty]

\begin{tabular}{|c|c|c|c|c|c|c|c|c|c|}
\hline $\begin{array}{c}\text { Date } \\
\mathrm{mm} / \mathrm{dd} / \mathrm{yyyy}\end{array}$ & $\begin{array}{c}\text { Reach } \\
\text { number }\end{array}$ & $\begin{array}{c}\text { Upstream } \\
\text { discharge } \\
\text { (cubic feet per } \\
\text { second) }\end{array}$ & $\begin{array}{l}\text { Downstream } \\
\text { discharge } \\
\text { (cubic feet per } \\
\text { second) }\end{array}$ & $\begin{array}{l}\text { Gain or loss } \\
\text { (cubic feet per } \\
\text { second) }\end{array}$ & Gain or loss & $\begin{array}{c}\text { Estimated } \\
\text { uncertainty } \\
\text { (cubic feet per } \\
\text { second) }\end{array}$ & $\begin{array}{c}\text { Estimated } \\
\text { stream length } \\
\text { (feet) }\end{array}$ & $\begin{array}{c}\text { Estimated } \\
\text { average stream } \\
\text { width (feet) }\end{array}$ & $\begin{array}{l}\text { Net streambed- } \\
\text { seepage rate } \\
\text { (feet per day) }\end{array}$ \\
\hline $07 / 21 / 2009$ & 1 & 5.16 & 3.25 & -1.91 & Loss & 0.52 & 6,200 & 7 & -3.8 \\
\hline $07 / 21 / 2009$ & 2 & 3.25 & ${ }^{1} 4.23$ & 0.98 & Gain & 0.65 & 820 & 7 & 14.8 \\
\hline 09/04/2009 & 2 & 0.22 & ${ }^{1} 1.39$ & 1.17 & Gain & 0.18 & 820 & 6 & 20.5 \\
\hline $07 / 21 / 2009$ & 3 & 4.83 & 5.14 & 0.31 & Neutral & 0.64 & 1,600 & 7 & - \\
\hline 09/04/2009 & 3 & 2.04 & 1.90 & -0.14 & Neutral & 0.32 & 1,600 & 7 & - \\
\hline 09/10/2009 & $2+3$ & 0.00 & ${ }^{1} 1.37$ & 1.37 & Gain & 0.20 & 2,420 & 5 & 9.8 \\
\hline $02 / 25 / 2010$ & $2+3$ & 0.00 & ${ }^{1} 0.80$ & 0.80 & Gain & 0.15 & 2,420 & 5 & 5.7 \\
\hline $07 / 21 / 2009$ & 4 & 5.14 & ${ }^{2} 5.50$ & 0.36 & Neutral & 1.3 & 11,300 & 7 & - \\
\hline 09/04/2009 & 4 & 1.90 & ${ }^{2} 0.64$ & -1.26 & Loss & 0.46 & 11,300 & 6 & -1.6 \\
\hline $02 / 25 / 2010$ & 4 & 1.45 & ${ }^{2} 1.90$ & 0.45 & Gain & 0.39 & 11,300 & 6 & 0.6 \\
\hline $07 / 21 / 2009$ & 5 & 7.99 & 7.50 & -0.49 & Neutral & 1.4 & 11,000 & 8 & - \\
\hline $02 / 25 / 2010$ & 5 & 2.80 & 2.28 & -0.52 & Loss & 0.41 & 11,000 & 6 & -0.7 \\
\hline
\end{tabular}

${ }^{1}$ Estimated flow of north Gruden Spring subtracted from downstream discharge.

${ }^{2}$ Flow of Spring Creek Spring subtracted from downstream discharge. 

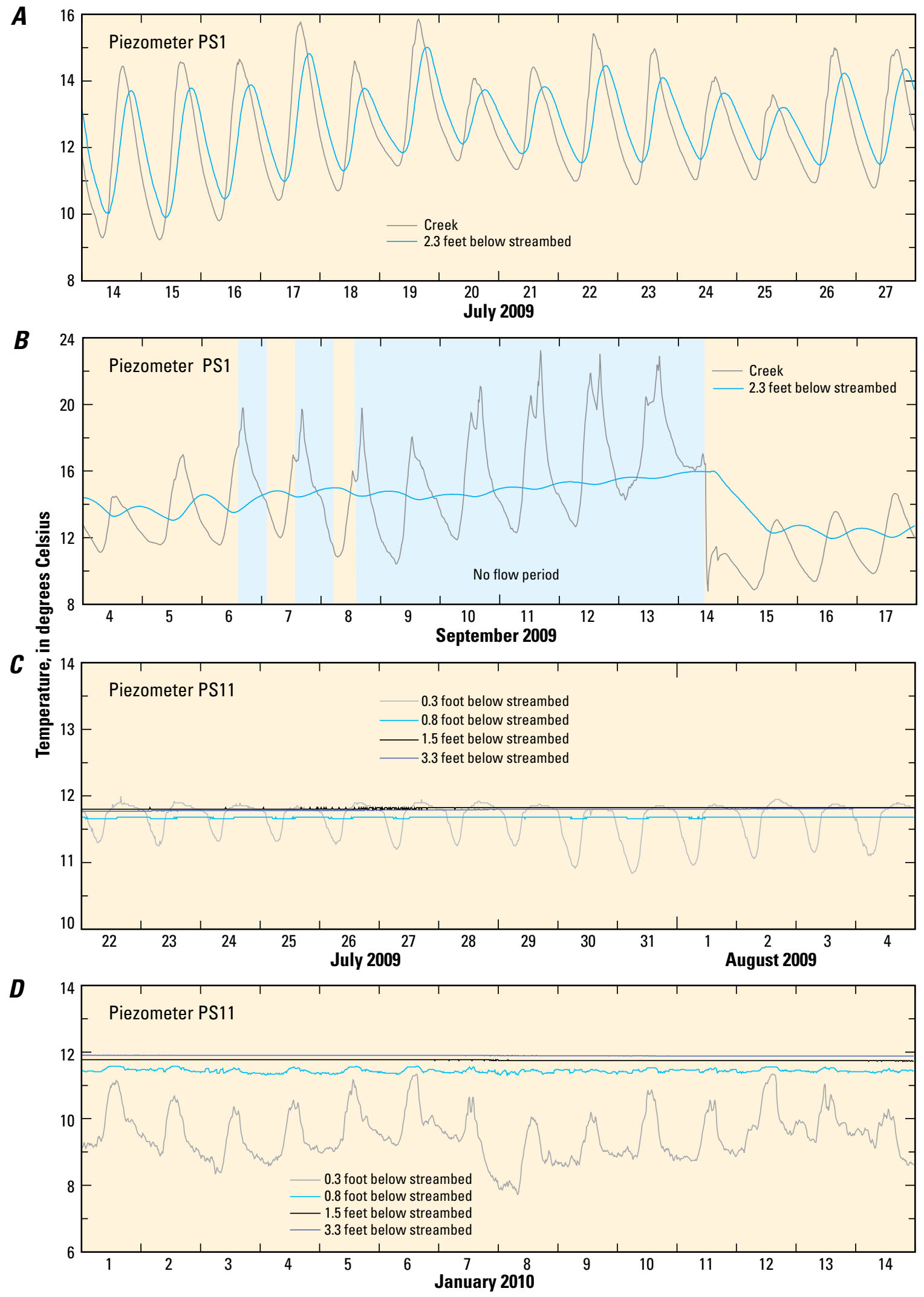

Figure 44. Creek and streambed temperatures in two piezometers in karst-limestone zone on Snake Creek for selected 2-week periods, Great Basin National Park, White Pine County, Nevada: A, July 14-27, 2009, piezometer PS1; B, September 4-17, 2009, piezometer PS1; $C$, July 22-August 4, 2009, piezometer PS11; $D$, January 1-14, 2010, piezometer PS11. 


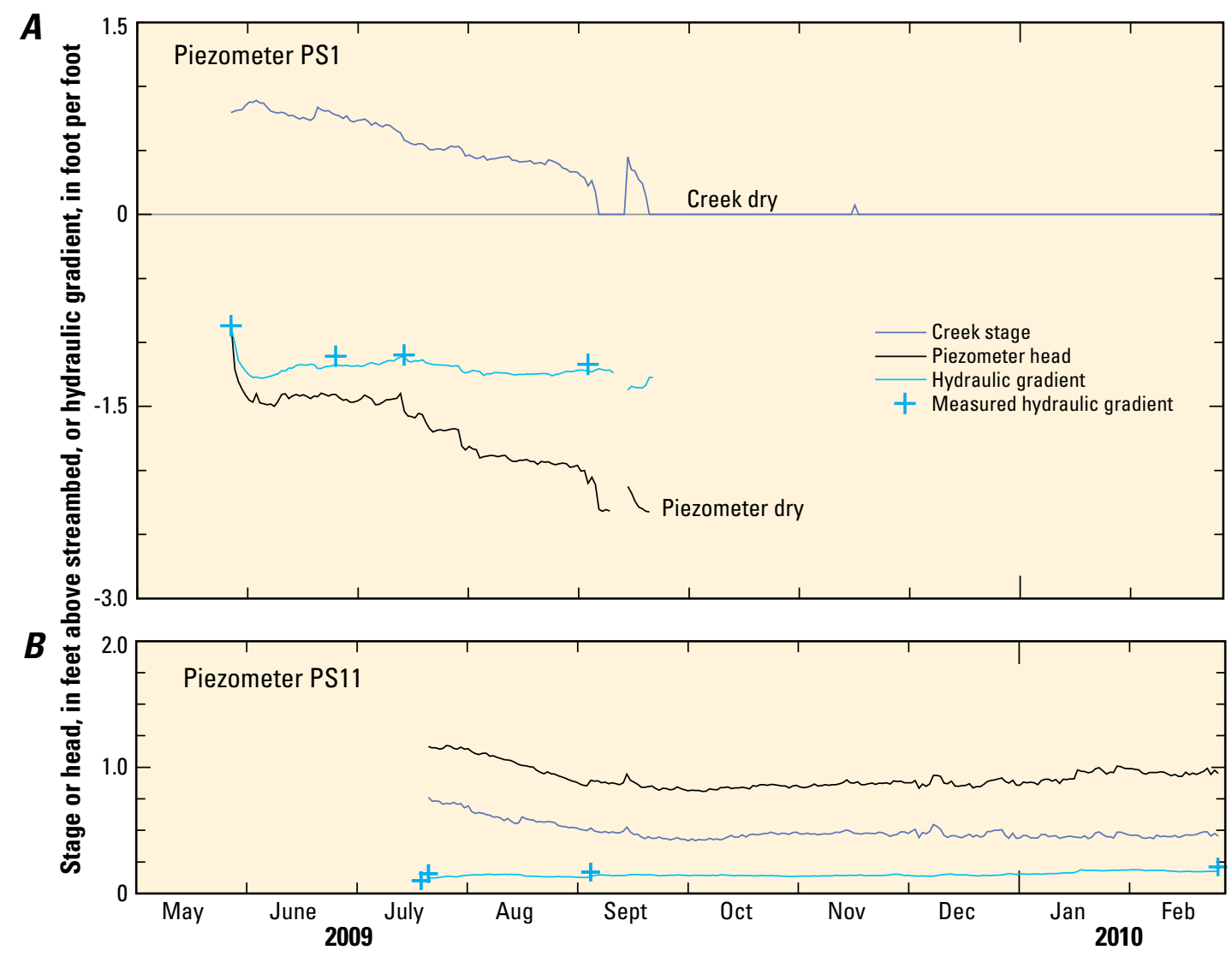

Figure 45. Daily mean stream stage, piezometer head above streambed, and daily mean and measured hydraulic gradient at piezometers in Snake Creek, at the lower end of karst-limestone zone, between May 2009 and February 2010, Great Basin National Park, White Pine County, Nevada: $A$, piezometer PS1, and $B$, piezometer PS11.

maximum temperatures at $0.3 \mathrm{ft}$ deep were at least $1{ }^{\circ} \mathrm{C}$ less than those at PS1 (fig. 44 A, C), and the minimum temperatures at the bottom of PS1 were similar to those at the bottom of the PS11, which were constant at $11.8^{\circ} \mathrm{C}$. During the first half of January 2010, the temperature at the bottom of PS11 was $11.9^{\circ} \mathrm{C}$, while the temperature at a depth of $0.3 \mathrm{ft}$ showed diurnal temperatures that ranged from about $8^{\circ} \mathrm{C}$ at night to $11^{\circ} \mathrm{C}$ during the day (fig. $44 D$ ). The conduction of heat from the creek to the streambed resulted in colder temperatures at intermediate depths compared with deeper ones (fig. 44D), even though the water level in the piezometer was higher than that in the creek (fig. 45B).

The streambed-seepage rate at piezometer PS11 was estimated by using the daily mean temperatures between depths of $0.3 \mathrm{ft}$ and $3.3 \mathrm{ft}$ and the daily mean hydraulic gradient between the creek and piezometer, as described in appendix 14. The daily streambed-seepage rate ranged from 1.9 to $3.1 \mathrm{ft} / \mathrm{d}$, with a mean gain of $2.4 \mathrm{ft} / \mathrm{d}$ (table 13), which was about an order of magnitude less than the net streambed-seepage rate estimated for reach $2 \mathrm{a}$ (table 12). Although the streambed-seepage rate at PS11 indicated groundwater continuously flowed to Snake Creek, the difference between it and the net seepage rate determined from a few discharge measurements indicated considerable spatial variability in streambed-seepage. The difference between these estimates could be caused by more groundwater inflow upstream of PS11, where shallow flow of water lost upstream returns to the creek, than near PS11, where deeper groundwater flow returns to the creek. The water temperature measured from July 21 to 24, 2009, at north Gruden Spring was $1{ }^{\circ} \mathrm{C}$ cooler than that at PS11. North Gruden Spring is about $40 \mathrm{ft}$ north of Snake Creek and $90 \mathrm{ft}$ upstream of PS11, but its flow enters Snake Creek downstream of PS11.

\section{Hydraulic Conductivity of Streambed}

Hydraulic conductivity was estimated for lateral and vertical flow. Lateral hydraulic conductivity of the streambed was estimated from multiple slug tests at PS1 and PS11 to be about $60 \mathrm{ft} / \mathrm{d}$ and $40 \mathrm{ft} / \mathrm{d}$, respectively (table 13). The $1 \mathrm{ft} / \mathrm{d}$ vertical hydraulic conductivity at PS1 was determined by dividing the streambed-seepage rate by the daily mean hydraulic gradient, whereas the $20 \mathrm{ft} / \mathrm{d}$ vertical hydraulic conductivity at PS11 was estimated through numerical modeling as described in appendix 14. The lower vertical hydraulic conductivity compared with lateral hydraulic conductivity at PS1 was consistent 
Table 13. Streambed-seepage rates and hydraulic conductivities of the streambed at 10 piezometers driven into Snake Creek, Great Basin National Park, White Pine County, Nevada, May 2009 through February 2010.

[Piezometer locations are shown in figure 42. Numbers following piezometer name are distances in miles downstream of gaging station at park boundary. Flow from creek to streambed is negative (losing stream); flow from streambed to creek is positive (gaining stream). Methods used to estimate vertical hydraulic conductivity discussed in appendix 14; land-surface altitude, depth, diameter, and screened interval for each piezometer and method used to estimate lateral hydraulic conductivity are presented in appendix 13 . Hydraulic conductivity reported to one significant figure. Abbreviation: mm, two digit month; dd, two digit day; yyyy, four digit year. Symbol: >, greater than; <, less than]

\begin{tabular}{|c|c|c|c|c|c|c|c|}
\hline \multirow{2}{*}{$\begin{array}{l}\text { Streambed } \\
\text { piezometer }\end{array}$} & \multirow{2}{*}{$\begin{array}{c}\text { Dates } \\
\mathrm{mm} / \mathrm{dd} / \mathrm{yyyy}\end{array}$} & \multicolumn{2}{|c|}{$\begin{array}{l}\text { Streambed-seepage rate } \\
\text { (feet per day) }\end{array}$} & \multicolumn{2}{|c|}{$\begin{array}{l}\text { Hydraulic gradient } \\
\text { (foot per foot) }\end{array}$} & \multicolumn{2}{|c|}{$\begin{array}{l}\text { Hydraulic conductivity } \\
\text { (feet per day) }\end{array}$} \\
\hline & & Mean & Range & Mean & Range & Vertical & Lateral \\
\hline \multicolumn{8}{|c|}{ Karst-limestone zone } \\
\hline PS $1-0.26$ & $05 / 27 / 2009$ to $09 / 05 / 2009$ & -1.1 & -2.0 to -0.7 & -1.21 & -1.37 to -0.88 & 1 & 60 \\
\hline PS11-0.39 & $07 / 22 / 2009$ to $02 / 24 / 2010$ & 2.4 & 1.9 to 3.1 & 0.15 & 0.12 to 0.19 & 20 & 40 \\
\hline \multicolumn{8}{|c|}{ Upper-piedmont zone } \\
\hline PS2-0.5 & $07 / 04 / 2009$ to $02 / 24 / 2010$ & -0.3 & -0.4 to -0.2 & -0.06 & -0.10 to -0.03 & 6 & 30 \\
\hline PS12-0.71 & $08 / 10 / 2009$ to $02 / 24 / 2010$ & -0.007 & -0.01 to 0.0 & -0.19 & -0.27 to -0.06 & 0.03 & 0.03 \\
\hline PS4-0.81 & $06 / 25 / 2009$ to $02 / 24 / 2010$ & -0.006 & -0.01 to 0.0 & 0.00 & -0.01 to 0.01 & $<1$ & 50 \\
\hline PS3-1.39 & $05 / 31 / 2009$ to $09 / 10 / 2009$ & -3.2 & -4.1 to -2.4 & -0.07 & -0.09 to -0.06 & 40 & $>100$ \\
\hline PS7-1.88 & $06 / 25 / 2009$ to $02 / 24 / 2010$ & -0.6 & -0.8 to -0.4 & -0.10 & -0.14 to -0.05 & 1 & 1 \\
\hline PS5-2.91 & $06 / 25 / 2009$ to $02 / 24 / 2010$ & -1.2 & -2.9 to -0.6 & -0.91 & -0.10 to -0.66 & 1 & 20 \\
\hline \multicolumn{8}{|c|}{ Lower-piedmont zone } \\
\hline PS10-3.38 & $07 / 22 / 2009$ to $09 / 03 / 2009$ & -0.6 & -0.8 to -0.6 & -0.89 & -1.32 to -0.53 & 0.7 & 100 \\
\hline PS9-4.93 & $06 / 25 / 2009$ to $02 / 24 / 2010$ & -0.8 & -1.6 to -0.4 & -0.83 & -0.97 to -0.39 & 1 & 10 \\
\hline
\end{tabular}

with piezometers, where water from the creek flowed downward through the streambed. The lower vertical hydraulic conductivity indicated fine-grained sediments filtered into the streambed, thereby reducing porosity and vertical flow. The vertical hydraulic conductivity estimated at PS11 was 20 times greater than that at PS1, even though the lateral hydraulic conductivity at PS1 was similar to that at PS11 (table 13). This indicated the streambed was not clogged with fine-grained sediments in its gaining reach, which was consistent with Rosenberry and Pitlick (2009) reporting greater streambed vertical hydraulic conductivities in gaining stream reaches compared with losing stream reaches.

\section{Aquifers}

Aquifers in the karst-limestone zone consist of thin alluvial deposits associated with Snake Creek that overlie complexly faulted Paleozoic limestone and dolomite rocks (figs. 36, 37). Unlike the karst-limestone zone in the Baker and Lehman Creek drainage basins, where the shallowly dipping southern Snake Range detachment fault marks the surface contact between older basin-fill deposits and the Pole Canyon Limestone, younger Paleozoic limestone and dolomites overlie the detachment fault higher in the southern Snake Range (fig. 37). The large faulted blocks on top of the detachment fault in much of the karst-limestone zone feature abrupt changes in stratigraphy and stratal dip, resulting in the formation of many relatively shallow and localized groundwater-flow systems (fig. 38).

The exception to this general pattern of relatively shallow compartments of groundwater flow is the outcrop of Pole Canyon Limestone along Snake Creek at the uppermost end of the karst-limestone zone (figs. 36, 37). Considerable streamflow can be lost across the limestone when streamflow at the end of the mountain-upland zone exceeds the carrying capacity of the pipeline used to convey water across the limestone and detachment fault (Elliott and others, 2006, p. 37). Springs next to Prospect Mountain Quartzite in the dry channel of Snake Creek, at the end of the pipeline, are too small to account for the water lost in the section of the Pole Canyon Limestone during snowmelt.

An impediment to groundwater flow through carbonate rocks above the detachment fault and downstream of the pipeline is the dense, tightly cemented, Eureka Quartzite that outcrops on both sides of the creek in GBNP (Elliott and others, 2006, p. 39). The quartzite is depicted in the geologic cross section (fig. 37). The quartzite results in shallow groundwater flow upstream of the outcrop through alluvial deposits and tilted carbonate rocks on top of the detachment fault. Springs are present just upstream of the quartzite, and Snake Creek is perennial from the end of the pipeline (because of the pipeline) to downstream from where the creek crosses the quartzite. Downstream from the quartzite, streamflow is lost in carbonate rocks (fig. 38), and Snake Creek is intermittent at the GBNP boundary (fig. 39). Water lost from along reach 1 (fig. 42) is likely to be the first groundwater that returns to the surface at the end of the karst-limestone zone, where a Tertiary fault has placed westward-dipping older alluvial deposits against the limestone (figs. 36-38). The hydraulic properties of the carbonate-rock aquifers in this zone are unknown, and the lateral hydraulic conductivity of the shallow alluvial deposits are probably similar to the estimates determined at piezometers PS1 and PS11 (60 and $40 \mathrm{ft} / \mathrm{d}$, respectively; table 13). 


\section{Water Budget}

Inflow to the karst-limestone zone includes runoff and groundwater from the mountain-upland zone and precipitation that falls in the zone (table 11). Additional groundwater flow from the Big Wash drainage basin could account for the flow of Spring Creek Spring. More water flows from this spring than can be explained by the water budget for the karst-limestone zone. The estimate of mean annual precipitation in the karst-limestone zone included areas with outcrops of lowpermeable rocks (fig. 35), and the mean annual precipitation was more than that in the mountain-upland zone because the drainage basin area was 1.7 times larger (table 11).

Mean annual outflow from the karst-limestone zone was dominated by evapotranspiration, which was estimated to be 12,000 acre-ft (table 11). Evapotranspiration was estimated by subtracting the mean annual precipitation from the mean annual water yield derived from the average of equations 1 and 2 (mean annual water yield for equation 1 was 640 acre$\mathrm{ft}$ and for equation 2 was 1,320 acre-ft) and rounded to the nearest 1,000 acre-ft. The calculation assumed no change in soil-water or groundwater storage. The mean annual runoff out of the zone was estimated to be about 2,900 acre-ft (table 11), which indicated a net annual loss of 100 acre-ft compared with runoff that entered the zone. This differs from the 1,100 acre$\mathrm{ft} / \mathrm{yr}$ measured as a net streamflow loss between the gaging stations upstream of the pipeline and at the GBNP boundary during water years 2003-04, which were years with average to below-average precipitation and runoff. The reason for the difference is that considerable flow is added to Snake Creek in the karst-limestone zone during above-average precipitation years, such as water year 2005. About 2,200 acre-ft of groundwater exited the zone through springs, in addition to about 700 acre-ft as groundwater flow through alluvial deposits and fractured limestone (includes 300-acre-ft of flow through the Pole Canyon Limestone in the area of the pipeline). The estimated total mean annual inflow to groundwater in the karst-limestone zone was 2,900 acre- $\mathrm{ft}$ and included (1) streamflow losses along Snake Creek (1,100 acre-ft—about 1,000 acre-ft of mean annual water yield generated in the zone was assumed to enter Snake Creek upstream from the Eureka Quartzite); (2) groundwater flow from the mountainupland zone (100 acre-ft); and (3) groundwater flow from the Big Wash drainage basin to the Snake Creek drainage basin between south of the park boundary and south of Spring Creek Spring (1,700 acre-ft), which was used to balance the water budget (table 11). Precipitation on the carbonate-rock outcrop in the hills to the south of Spring Creek Spring and to the south of Gruden Springs is insufficient to account for the mean annual flow of the springs. Estimated mean annual water yield in these hills is between 50 and 200 acre- $\mathrm{ft}$ when equations 1 and 2 are used. Thus, the most likely source of groundwater flow to these springs is from the Big Wash drainage basin.

Some of the streamflow in Snake Creek was lost in the channel next to the pipeline when discharges exceeded $3 \mathrm{ft}^{3} / \mathrm{s}$, and much of the loss was in the section of the creek underlain by Pole Canyon Limestone. Streamflow loss to the Pole
Canyon Limestone was estimated by first determining when daily mean discharge exceeded $3 \mathrm{ft}^{3} / \mathrm{s}$ at the upstream gaging station during water years 2003-04. More than 80 percent of the time, the daily mean discharge was less than $3 \mathrm{ft}^{3} / \mathrm{s}$, and streamflow losses between the two gaging stations averaged $1.2 \mathrm{ft}^{3} / \mathrm{s}$. This mean streamflow loss was assumed to represent losses downstream of the outcrop of Eureka Quartzite along the lower reach and was similar to the measured loss from discharge measurements (fig. 43). The mean loss from this lower reach was subtracted from the total loss for days when the daily mean discharge at the upper gaging station (upstream of the pipeline and the Pole Canyon Limestone) exceeded $3 \mathrm{ft}^{3} / \mathrm{s}$. The daily streamflow loss along the pipeline ranged from 0 to $27 \mathrm{ft}^{3} / \mathrm{s}$, and the mean was $2 \mathrm{ft}^{3} / \mathrm{s}$. The measured loss on June 10, 2003, was $2.6 \mathrm{ft}^{3} / \mathrm{s}$, whereas the estimated daily loss for that day was $1.9 \mathrm{ft}^{3} / \mathrm{s}$. The estimated annual runoff lost to the Pole Canyon Limestone during water years 2003-04 was 300 acre-ft. This indicated a mean annual loss of about 800 acre-ft downstream of the Eureka Quartzite during 2003-04. An estimate of the mean annual runoff lost to the reach along the pipeline, assuming no pipeline and a mean streamflow loss of $2 \mathrm{ft}^{3} / \mathrm{s}$ for the entire year, was 1,400 acre-ft. Thus, the pipeline could add 1,100 acre-ft of mean annual runoff in the creek at the Eureka Quartzite, of which much is lost along the creek downstream of the Eureka Quartzite and then returned to springs downstream of the park boundary.

Water lost in the channel crossing the western-most section of Pole Canyon Limestone has little chance to return to Snake Creek because of a large intervening section of Prospect Mountain Quartzite and the detachment fault. The direction of groundwater flow in the Pole Canyon Limestone is unknown, but it could recharge a deep regional groundwater flow system (fig. 38). Because the limestone dips to the southeast, Elliott and others $(2006$, p. 37) postulated that water exited the Snake Creek drainage basin to the south into the North Fork of Big Wash drainage basin, where the Pole Canyon Limestone outcrops along its channel (fig. 36). The channel of North Fork is normally dry, however, and no springs were evident where the Pole Canyon Limestone outcrops. The detachment fault intersects the channel of Big Wash upstream from the confluence of the two forks. Small springs are present along Big Wash downstream from the confluence of the two forks at the end of the Sevy Dolomite, which is a tilted block above the detachment fault (fig. 36). The source of these springs is most likely groundwater locally recharged in the tilted blocks of carbonate rocks above the detachment fault. Groundwater that exited Snake Creek drainage basin to Big Wash drainage basin through the Pole Canyon probably continues southeast or east beneath the overlying Lincoln Peak Limestone and the detachment fault, unless younger faults allow pathways for flow to return back to the rocks above the detachment fault somewhere.

The mean annual streamflow loss of 800 acre-ft downstream from the Eureka Quartzite was returned to Snake Creek at the end of the karst-limestone zone at north Gruden Spring and upstream of PS11, where springs along Snake 
Creek accounted for an annual gain of about 1,000 acre-ft. Thus, 200 acre- $\mathrm{ft}$ of groundwater in the karst-limestone zone could flow back to Snake Creek, in addition to the streamflow lost downstream of the Eureka Quartzite. The remaining 1,200 acre-ft of spring flow listed in table 11 was from Spring Creek Spring.

Some groundwater is likely to exit the karst-limestone zone through the shallow alluvium and the underlying karstlimestone zone; otherwise Snake Creek would not gain flow downstream of north Gruden Spring, and Snake Creek would become a losing stream after crossing over the Tertiary fault. The estimated mean annual groundwater flow through the shallow alluvium at that end of the karst-limestone zone was only 20 acre-ft (listed as minor in table 11), assuming a hydraulic conductivity of $50 \mathrm{ft} / \mathrm{d}$, the average of lateral hydraulic conductivities from slug tests at piezometers PS1 and PS11; a thickness of $20 \mathrm{ft}$; a width of $50 \mathrm{ft}$; and a hydraulic gradient equal to the streambed slope of $0.05 \mathrm{ft} / \mathrm{ft}$. Similarly, the mean annual groundwater flow through carbonate rocks out of the zone was estimated to be 400 acre-ft on the basis of the transmissivity estimated from three slug tests at the Snake 5 deep well (Prudic, 2012b), a width of flow of $5,000 \mathrm{ft}$, and a hydraulic gradient of 0.025 (half the streambed slope).

Calculations of chloride mass in the karst-limestone zone, assuming all chloride in the creek and in groundwater was from atmospheric deposition, differed from chloride concentrations in the creek and springs measured in February 2009 and January 2010. Assuming a mean chloride concentration of $0.6 \mathrm{mg} / \mathrm{L}$ in precipitation, the chloride concentration in the 640 to $1,300 \mathrm{acre}-\mathrm{ft} / \mathrm{yr}$ of water yield estimated after evapotranspiration, would be between 11 and $6 \mathrm{mg} / \mathrm{L}$, respectively. Mixing this mass of chloride and assuming this water enters the creek upstream of the Eureka Quartzite with the estimated chloride mass entering from the mountain-upland zone, minus the mean annual streamflow loss along the creek where it flows over Pole Canyon Limestone (2.4 mg/L times 2,700 acre-ft/yr), yielded a mean chloride concentration of between 3.6 (mean annual water yield of 1,300 acre-ft) and $4.3 \mathrm{mg} / \mathrm{L}$ (mean water yield of 640 acre-ft) in Snake Creek at the Eureka Quartzite. Chloride concentrations in Snake Creek were $1.1 \mathrm{mg} / \mathrm{L}$ at the end of the pipeline and $6 \mathrm{mg} / \mathrm{L}$ near the Eureka Quartzite in February 2009 (Paul and others, 2014; appendix table 16-3). During the same time, chloride concentrations at selected springs were $20 \mathrm{mg} / \mathrm{L}$ at Squirrel Spring Cave midway along the pipeline, $10 \mathrm{mg} / \mathrm{L}$ at the middle Outlet Spring at the end of the pipeline, and $4.8 \mathrm{mg} / \mathrm{L}$ at Outhouse Spring upstream of the Eureka Quartzite (Paul and others, 2014; appendix table 16-8). The chloride concentration of $11 \mathrm{mg} / \mathrm{L}$ at PS11 in January 2010 was within the range of chloride concentrations from springs upstream of the Eureka Quartzite in February 2009 and was slightly more than the chloride concentrations of 9.3 and $9.7 \mathrm{mg} / \mathrm{L}$ measured in February 2009 and January 2010, respectively, at Spring Creek Spring. A second sample was collected from Outlet Spring in May 2010, and that sample had a chloride concentration of $16 \mathrm{mg} / \mathrm{L}$, or 1.6 times that of the sample collected in February 2009.

For groundwater in the karst-limestone zone to have chloride concentrations similar to those observed in springs and at piezometer PS11, the mean annual water yield for the zone would need to be about 700 acre-ft or about the same as that estimated from equation 1 assuming that the mean chloride concentration in precipitation was $0.6 \mathrm{mg} / \mathrm{L}$ and all the water yield became groundwater recharge. However, the water samples were collected during years of below-average snowpack and the samples potentially did not represent the mean chloride concentration accurately. Another possibility is that the chloride in precipitation and in runoff from the mountain-upland zone were not the only sources of chloride in the karst-limestone zone. Chloride concentrations of rocks were only available for the different granites, Prospect Mountain Quartzite, Pioche Shale, and Pole Canyon Limestone in the southern Snake Range (Lee and Van Loenen, 1971). A rock outcrop at the Squirrel Spring Cave had a distinct sulfurous odor when freshly exposed with a rock hammer. Chloride and sulfate concentrations in springs and caves were generally greater in the Snake Creek drainage basin than in springs and caves in the Baker and Lehman Creek drainage basins (Paul and others, 2014; appendix table 16-8), which could reflect dissolution from some the carbonate rocks in the Snake Creek drainage basin.

\section{Upper-Piedmont Zone}

The upper-piedmont zone makes up a similar fraction of the Snake Creek drainage basin as it does in the Baker and Lehman Creek drainage basins. The upper-piedmont zone is separated from the karst-limestone zone by the Tertiary fault. The detachment fault is deeply buried beneath older alluvial deposits and rotated blocks of carbonate rocks (fig. 38). Groundwater flow in the upper-piedmont zone is conceptualized as shallow flow through young alluvial deposits associated with Snake Creek and deeper flow through older, consolidated alluvial deposits tilted westward along older faults and carbonate rocks (fig. 46). Carbonate rocks are exposed north and south of Snake Creek, near the downstream end of the upper-piedmont zone (fig. 36), and were encountered in two wells drilled in this zone. The Snake 5 wells encountered limestone at a depth of $80 \mathrm{ft}$, after drilling through $40 \mathrm{ft}$ of alluvium, followed by $38 \mathrm{ft}$ of clay. A second well drilled on private land, west of the NDOW Spring Creek fish-rearing station in 2011, encountered limestone at a depth of $104 \mathrm{ft}$ (George Douglass, Jr., Nevada Department of Wildlife, Baker, Nev., oral commun, 2011). 


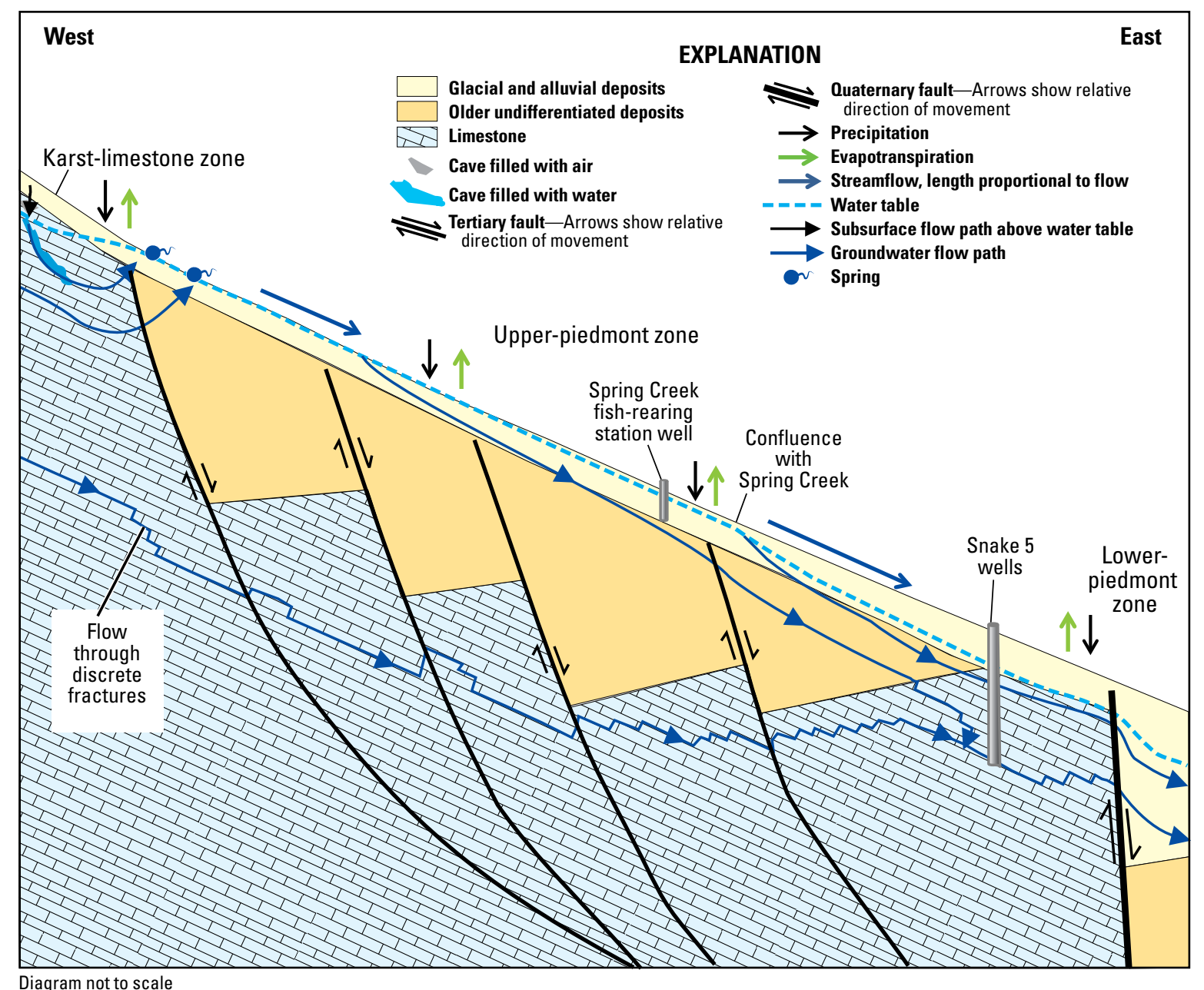

Figure 46. Idealized cross section showing flow along Snake Creek in the upper-piedmont zone, downstream of Great Basin National Park, White Pine County, Nevada.

\section{Streamflow}

Snake Creek primarily gains streamflow in the first $0.5 \mathrm{mi}$ downstream from the Tertiary fault (figs. 36, 43). Additional water is added to Snake Creek from Spring Creek, after it and some water from Snake Creek is circulated through the NDOW Spring Creek fish-rearing station. Gruden and Spring Creek Springs contribute much of the gain to Snake Creek in the upper-piedmont zone (fig. 43).

Snake Creek, between the gaging stations at the GBNP boundary and downstream of the confluence with Spring Creek, had an average gain of $2.7 \mathrm{ft}^{3} / \mathrm{s}$, or about 2,000 acre-ft/yr, during a 21-month period from January 9 , 2003, to September 30, 2004 (fig. 41). This gain was relatively constant, regardless of streamflow at the GBNP boundary. The streamflow gain included inflows from Gruden Springs, Spring Creek after passing through ponds at the NDOW Spring Creek fish-rearing station, and several smaller springs. The mean annual runoff at Spring Creek Spring was estimated to be 1,200 acre-ft (table 1) and indicated that the spring could contribute about half the streamflow gain to Snake Creek between the GBNP boundary and the confluence with Spring Creek.
The character of streamflow in Snake Creek changes downstream of its confluence with Spring Creek; during the 21-month period from January 9, 2003, to September 30, 2004, the average streamflow loss was $0.7 \mathrm{ft}^{3} / \mathrm{s}$, or about $500 \mathrm{acre}-\mathrm{ft} / \mathrm{yr}$, between gaging stations downstream from the confluence with Spring Creek and at the Nevada-Utah state line (fig. 41). This included streamflow losses from the lower reach in the upper-piedmont zone as well as along the lowerpiedmont zone to the Nevada-Utah state-line (fig. 42).

\section{Streambed-Seepage Rates}

Net streambed-seepage rates from discharge measurements were divided into two reaches in the upper-piedmont zonereaches 3 and 4 (fig. 42; table 12). Reach 3 , at the beginning of the upper-piedmont zone, was short and extended from upstream of piezometer PS2 to the upstream side of a culvert beneath a private road crossing the creek near piezometer PS4. Reach 4 was long and extended from upstream of the culvert near PS4 to near the Snake 5 wells. The net streambed-seepage rate for reach 3 on 2 days in July and September 2009 could not be estimated because the streamflow gain or loss was 
less than the uncertainty in the discharge measurements. The net streambed-seepage rate along reach 4 varied from losing to gaining after flow of Spring Creek Spring was subtracted from the downstream discharge measurement near the Snake 5 wells. This variation in net streambed-seepage rates could be a result of transient storage in the fish-rearing ponds, but, overall, the reach was neither gaining or losing. These results indicated that, downstream of GBNP, much of the measured streamflow gain was in reach 2 (table 12), where Snake Creek crosses over the Tertiary fault, and from Spring Creek Spring, after flowing through ponds at the NDOW Spring Creek fishrearing station.

A fiber-optic cable was placed in Snake Creek on July 18,2009 , in the area where Snake Creek gains flow from Gruden Springs and shallow groundwater flow to the creek at the transition from the karst-limestone zone to the upperpiedmont zone (fig. 47A; appendix 15). Water temperatures measured at 3.3-ft intervals (1-m interval) along the cable were averaged during the coolest (early morning) and warmest (late afternoon) hours on July 22, 2009, and September 6, 2009 (figs. 47B, C). During the coolest hour on July 22, 2009, temperatures were nearly constant upstream of north Gruden Spring, increased slightly where flow from north Gruden Spring entered Snake Creek, cooled slightly and remained constant for another $500 \mathrm{ft}$ downstream of PS11, before slowly warming to the end of the cable. The slight warming could be from warmer water entering the creek from the meadow south of the creek, or it could be caused by no additional inflow and air temperature warmer than that of the water in the creek. During the warmest hour of the day on July 22, 2009, stream temperatures decreased where the cable entered the creek to north Gruden Spring and decreased again where water from north Gruden Spring entered the creek downstream of PS11 (fig. 47B). This colder water mixed rapidly with the warmer creek water, and water temperatures increased for about $100 \mathrm{ft}$ downstream, then remained nearly constant for another $400 \mathrm{ft}$ before temperatures began to increase slowly, most likely because the air temperature was much warmer than the water in the creek and because warming from solar radiation. These results were consistent with discharge measurements on July 21, 2009, that showed reach 2 had the most net streamflow gain, and reach 3 had little to no net gain (table 12).

Averaged water temperatures along the cable for the coolest and warmest hours on September 6, 2009, showed a similar pattern to the measurements from July 22, except that the creek was dry for the first $100 \mathrm{ft}$, and a large part of the cable upstream of north Gruden Spring was out of the water before groundwater flow to the creek provided sufficient stream depth to cover the cable (fig. 47C). During the coolest hour of the day, the temperature at north Gruden Spring increased from $11^{\circ} \mathrm{C}$ on July 22,2009 , to $11.5^{\circ} \mathrm{C}$ on September 6, 2009, whereas, during the warmest hour, the average temperature was cooler on September 6, 2009, than on July 22, 2009. Again, increasing temperatures about $500 \mathrm{ft}$ downstream of PS11 were consistent with no net increase in streamflow along reach 3 on September 4, 2009. The measured gain between where the fiber-optic cable entered the creek to immediately upstream of north Gruden Spring was $0.47 \mathrm{ft}^{3} / \mathrm{s}$ on September 4, 2009, and $0.51 \mathrm{ft}^{3} / \mathrm{s}$ on September 10, 2009. Streamflow gains of 0.40 and $0.41 \mathrm{ft}^{3} / \mathrm{s}$ were measured on July 21, 2009, and February 25, 2010, respectively, indicating a nearly constant gain at the beginning of reach 2 from July 2009 to February 2010 (appendix table 3-4).

Six piezometers were driven into Snake Creek in the upper-piedmont zone (fig. 43). Piezometers PS2 and PS12 were installed in reach 3 , where the fiber-optic cable had been placed. Piezometers PS4 and PS3 were installed in the upper part of reach 4, downstream of the fiber-optic cable and upstream of the pond used to divert Snake Creek to the NDOW Spring Creek fish-rearing station. Piezometers PS7 and PS5 were installed in the lower part of reach 4, downstream from the confluence with Spring Creek (fig. 42). Streambed-seepage rates are summarized in table 13. Streambed-seepage rates for piezometer PS2 and PS5 were estimated by using the amplitude-ratio method described in appendix 14, whereas rates for the other piezometers (PS3, PS4, PS7, and PS12) were estimated by using a numerical model for each piezometer that is also described in appendix 14.

Mean streambed-seepage rates indicated flow from the creek into the streambed at all six piezometers; the highest mean rate was at PS3, and the lowest was at PS12. During September 2-15, 2009, temperatures at the bottom of piezometers PS2, PS12, and PS4 were nearly constant; the temperature at PS2 was almost $13{ }^{\circ} \mathrm{C}$, and temperatures at PS12 and PS4 were slightly cooler (fig. 48). The daily diurnal temperature fluctuations in Snake Creek were about $2{ }^{\circ} \mathrm{C}$, except on September 14, 2009, when a thunderstorm increased streamflow in the creek and decreased the temperature of the creek. These lower temperatures propagated downward at PS2, but had little effect on temperatures at the bottom of PS12 and PS4. The greatest diurnal temperature fluctuations in the creek and in the streambed were measured at PS3. This piezometer was driven into loose sand and gravel, where the stream was deeper than normal because of the diversion dam downstream and had the highest estimated lateral hydraulic conductivity (table 13).

The ranges in streambed-seepage rates and hydraulic gradients at PS7, downstream from the confluence with Spring Creek, were similar to those at PS2, whereas the range in streambed-seepage rates and hydraulic gradients at PS5 more closely approximated those at PS1 in the karst-limestone zone (table 13). Creek water temperatures at PS7 were generally warmer than the temperature at the bottom of the piezometer from September 2 to 15, 2009, except following the thunderstorm on September 14, 2009 (fig. 49A). Diurnal temperature fluctuations in the creek were about $1{ }^{\circ} \mathrm{C}$, and the water temperature at the bottom of the piezometer was nearly constant. In January 2010 , creek water was colder and continued to show a greater diurnal temperature fluctuation than at the bottom of the piezometer. Temperature fluctuations at PS5 showed a different pattern compared with the other piezometers (fig. 49). Diurnal temperature fluctuations in the 

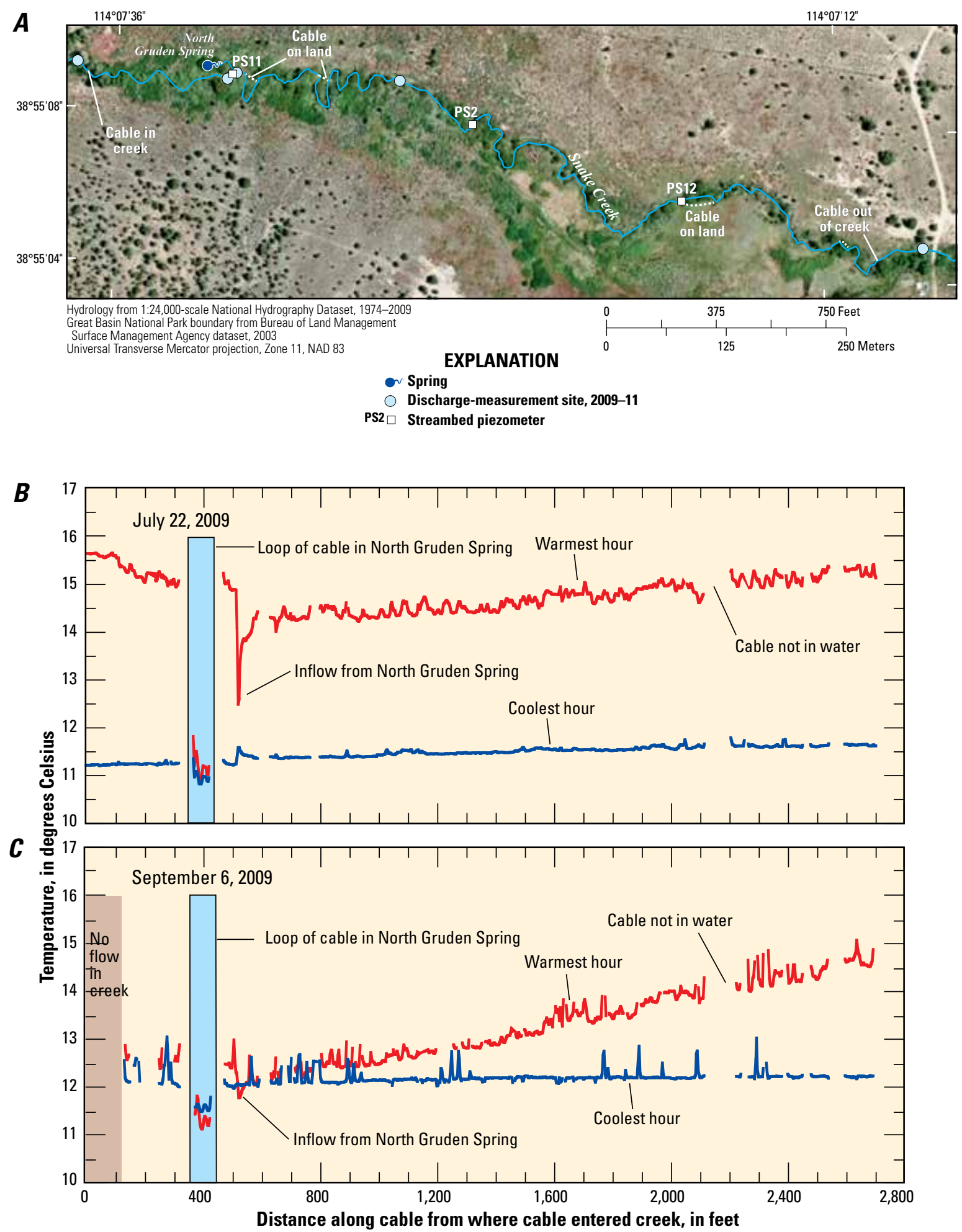

Figure 47. Distributed-temperature sensing measurements every 3.28 feet (1 meter), Great Basin National Park, White Pine County, Nevada: $A$, location of fiber-optic cable placed in Snake Creek at the Tertiary fault marking the transition from the karst-limestone zone to the upper-piedmont zone; $B$, averaged stream temperatures for the coolest and warmest hour on July 22, 2009; and $C$, averaged stream temperatures for the coolest and warmest hour on September 6, 2009. 

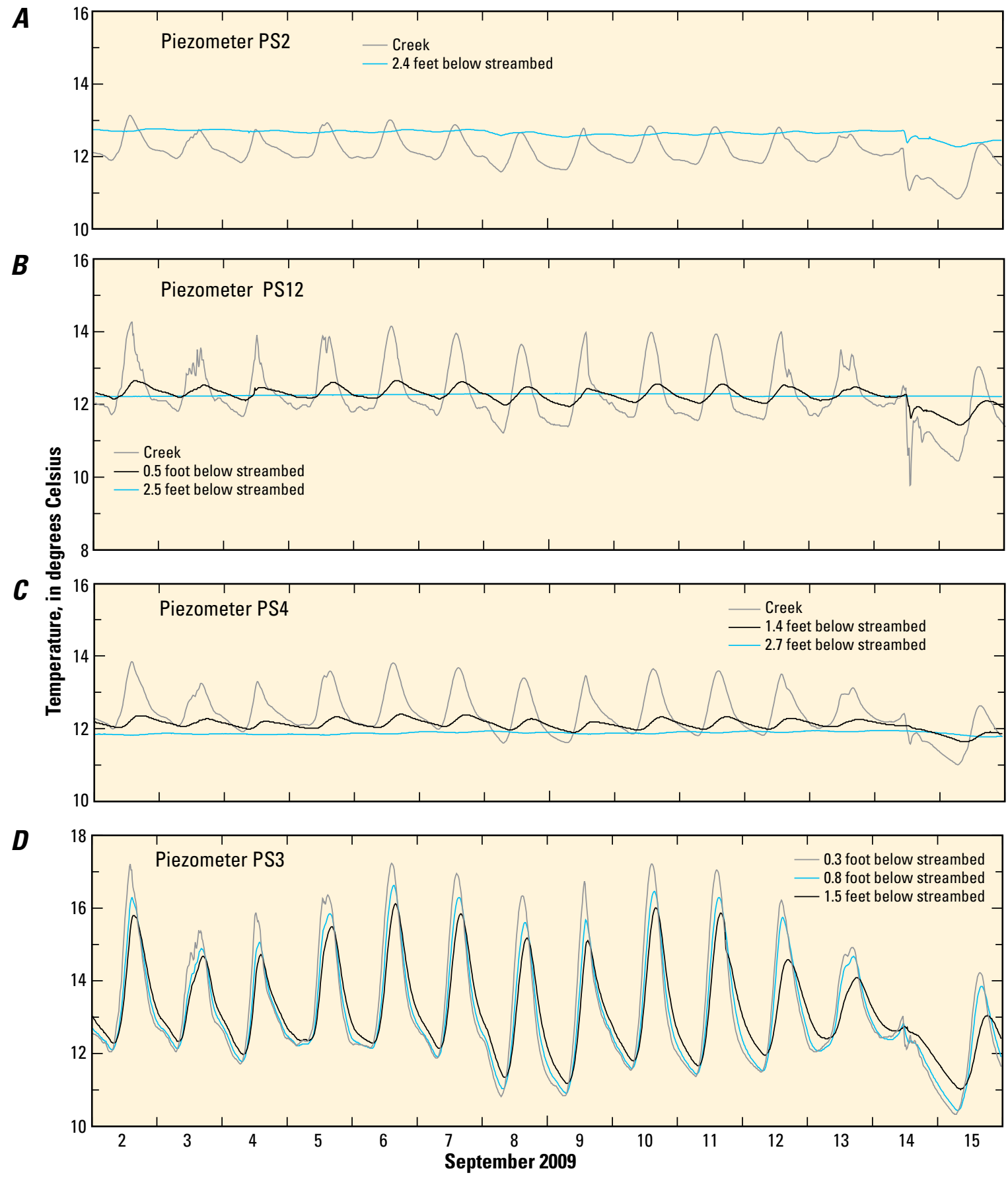

Figure 48. Streambed temperatures in four piezometers in the upper-piedmont zone of Snake Creek for September 2-15, 2009, Great Basin National Park, White Pine County, Nevada: $A$, PS2; $B$, PS12; C, PS4; and D, PS3. 

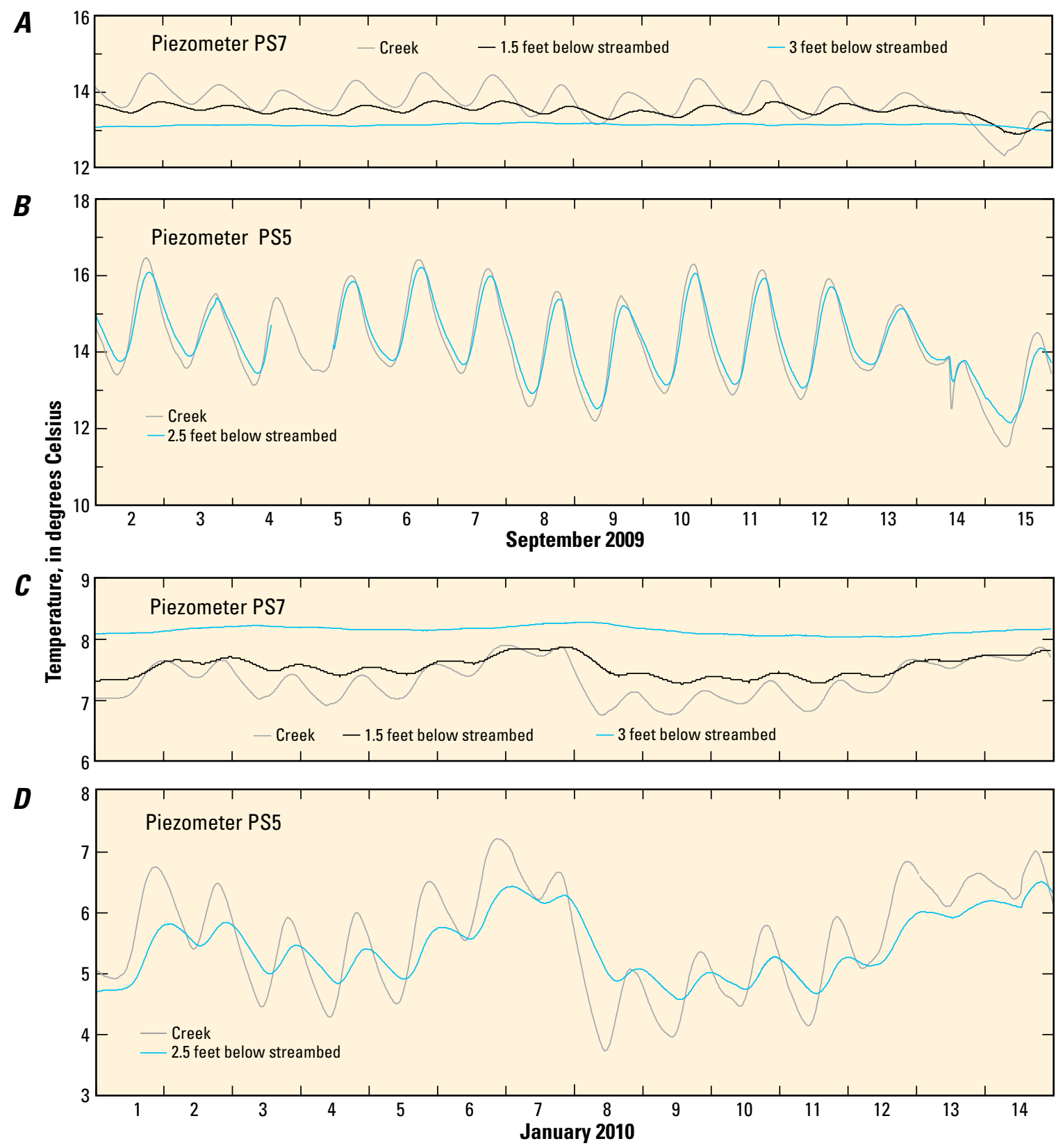

Figure 49. Streambed temperatures at two piezometers PS7 and PS5 during two selected 2-week periods in upper-piedmont zone of Snake Creek downstream from Great Basin National Park, White Pine County, Nevada: $A$, September 2 to 15, 2009, at PS7; B, September 2 to 15,2009 , at PS5; $C$, January 1 to 14,2010 , at PS7; and $D$, January 1 to 14,2010 , at PS5.

creek and bottom of piezometer were greater than $2{ }^{\circ} \mathrm{C}$ during September 2-15, 2009, indicating little attenuation in the fluctuation with increasing depth. The thunderstorm on September 14, 2009, had a much greater effect at PS5 than that at PS7. Perhaps, water from Spring Creek had a stabilizing effect on the creek temperature, or considerable overland flow from the thunderstorm entered the creek between PS7 and PS5. The diurnal temperature fluctuations decreased between September 2009 and February 25, 2010, when the data loggers were removed. A decrease in the diurnal temperature fluctuation at the bottom of the piezometer relative to the creek was evident in early January (fig. 49D). The change in the character of the diurnal temperature fluctuations between the creek and piezometer indicated a continual decrease in the streambedseepage rate at PS5, from -2.9 to $-0.6 \mathrm{ft} / \mathrm{d}$.

The mean vertical hydraulic gradients at all piezometers, except PS5, were slightly negative (mean between 0.0 and $-0.2 \mathrm{ft} / \mathrm{ft}$; table 13 ). The daily mean hydraulic gradients were generally consistent from July 2009 to February 2010 (fig. 50), except at piezometer PS12, where $1 \mathrm{ft}$ of scour in early August resulted in a change in the stream stage and groundwater level relative to the streambed. The stream stage and water level in piezometer PS4 were nearly identical and resulted in a daily mean vertical hydraulic gradient that ranged from -0.01 to 
$\boldsymbol{A}$

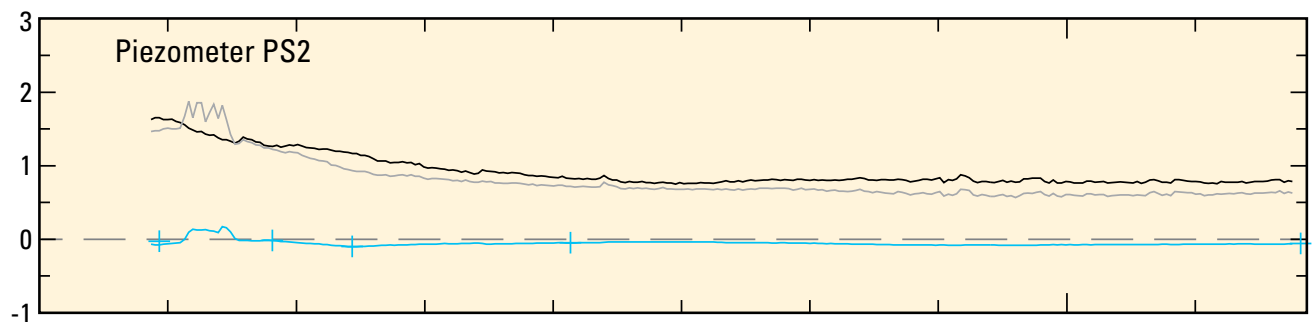

$\boldsymbol{B}$

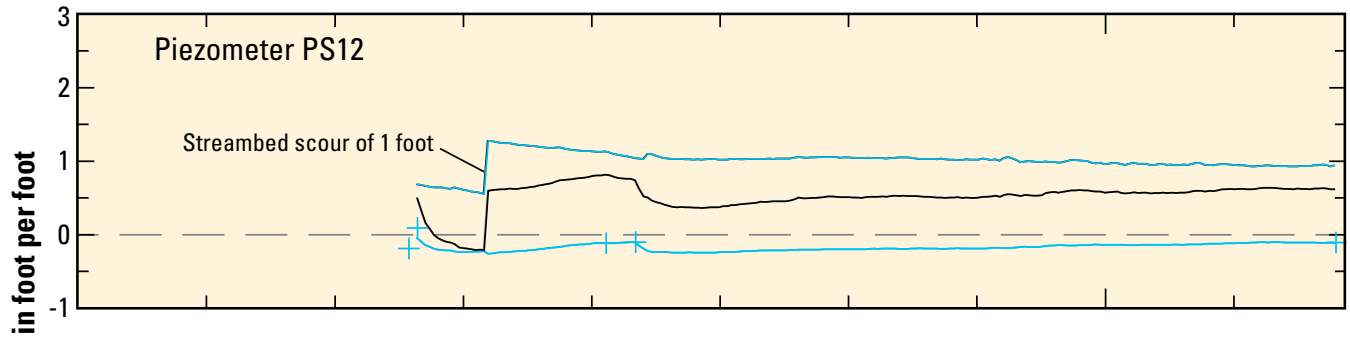

C

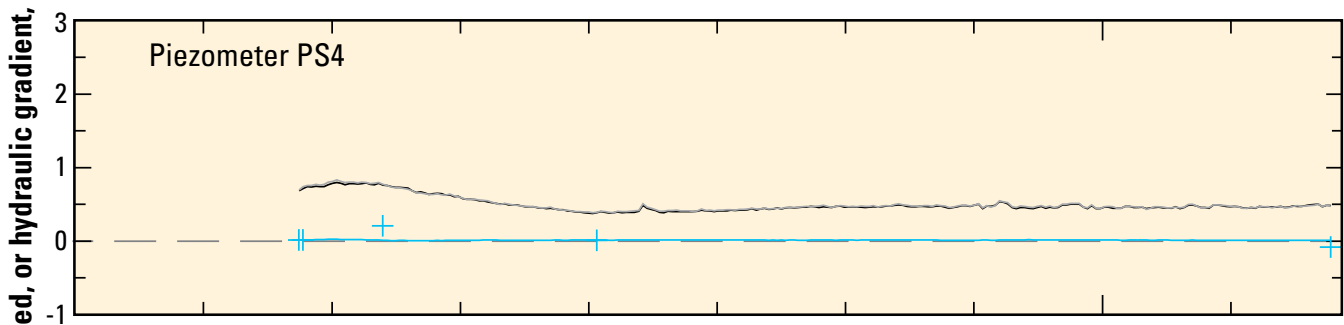

D

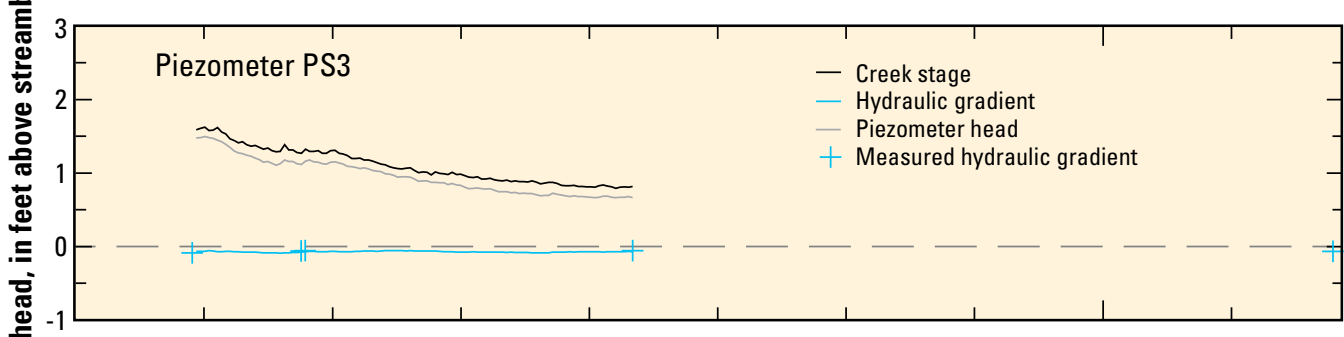

$\boldsymbol{E}$

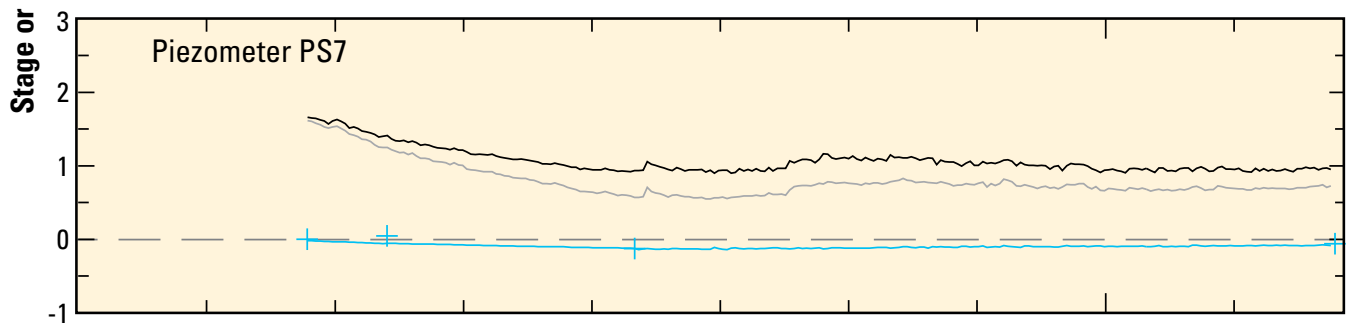

F

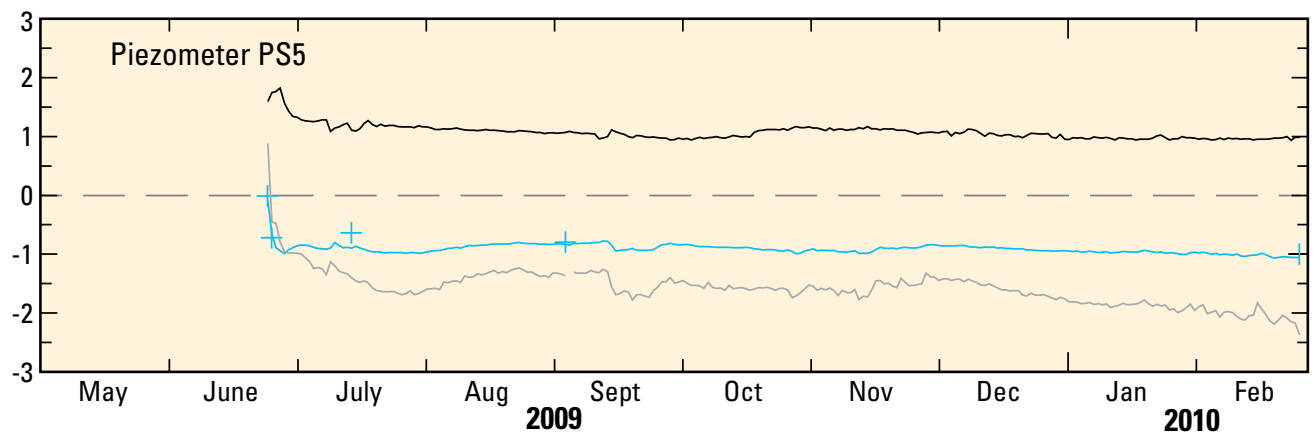

Figure 50. Daily mean stream stage and piezometer head above streambed and daily mean and measured hydraulic gradient at piezometers in Snake Creek in the upper-piedmont zone between May 2009 and February 2010, downstream from Great Basin National Park, White Pine County, Nevada: $A$, piezometer PS2; $B$, piezometer PS12; $C$, piezometer PS4; $D$, piezometer PS3; $E$, piezometer PS7; and $F$, piezometer PS5. 
$0.01 \mathrm{ft} / \mathrm{ft}$. The mean vertical hydraulic gradient at PS5 was $-0.91 \mathrm{ft} / \mathrm{ft}$, which gradually became more negative as the water level in the piezometer gradually decreased, while the stream stage remained nearly constant (fig. 50F). Both the decreasing streambed-seepage rate and the gradually greater depth to water in the piezometer indicated that the streambed was disturbed when it was installed. Although the streambed became partly sealed by fine-sediments next to the piezometer, the streambed continued to seal with time. Similar observations were made at piezometers PS6, PS8, PS9, and PS10.

Two stream-bank piezometers were placed along a transect south of piezometer PS4 to evaluate the potential for groundwater flow to the creek in an area where the bank was water logged during June 2009 (fig. 51). Piezometer PS4_sb1was driven into a wet area about $14 \mathrm{ft}$ south of PS4. The south bank of Snake Creek was midway between these piezometers. The surface materials of the bank were gray silt and fine sand that were saturated to land surface. A second piezometer, PS4_sb2, was driven $31 \mathrm{ft}$ south of piezometer PS4-sb1 and $45 \mathrm{ft}$ south of PS4. This piezometer encountered a gravel layer at a depth of about $3.9 \mathrm{ft}$, and the piezometer was driven until the midpoint of the piezometer was $4.2 \mathrm{ft}$ below land surface (fig. 51). Piezometer PS4_sb2 was flowing at the time it was installed. Piezometer PS4_sb1 was in the fine sediments and responded slowly to water being removed from the piezometer; its hydraulic conductivity was estimated from a slug test in October 2013 at $0.1 \mathrm{ft} / \mathrm{d}$ (appendix table 13-22). Piezometer PS4_sb2 was pumped, and the resulting recovery indicated an estimated hydraulic conductivity of $1 \mathrm{ft} / \mathrm{d}$; a later slug test in October 2013 produced an estimate of $2 \mathrm{ft} / \mathrm{d}$ (appendix table 13-22). Although the water levels in both stream-bank piezometers were above the stream stage at PS4, the hydraulic conductivity of the near surface deposits south of Snake Creek was insufficient to support much groundwater flow to the creek. The low permeability of the near surface deposits was consistent with discharge measurements that indicated little groundwater contribution to Snake Creek downstream of reach 2, except for the inflow from Spring Creek.

\section{Hydraulic Conductivity of Streambed}

Lateral hydraulic conductivities estimated from slug tests immediately after the piezometers were installed in the streambed ranged from about $0.03 \mathrm{ft} / \mathrm{d}$ at PS12 to greater than $100 \mathrm{ft} / \mathrm{d}$ at PS3 (table 13). Slug tests at piezometers PS5, PS6, and PS8 near the Snake 5 wells repeated 2 months after installation showed lateral hydraulic conductivities decreased an order of magnitude at PS5, whereas the estimates for piezometers PS6 and PS8 decreased less than a factor of 2 (appendix table 13-22). Nevertheless, these tests provided additional evidence that driving piezometers into the streambed can cause preferential flow along the pipe until that pathway becomes sealed by fine-grained sediments. The highest estimated vertical hydraulic conductivity was $40 \mathrm{ft} / \mathrm{d}$ at piezometer PS3, just upstream of the pond used to divert Snake Creek water to the NDOW Spring Creek fish-rearing station; this was consistent with the large diurnal temperature fluctuations at depth and a mean hydraulic gradient of $-0.07 \mathrm{ft} / \mathrm{ft}$ (table 13). Vertical hydraulic conductivities were considerably less than the lateral hydraulic conductivity, except at PS12, where thermal conduction controlled the movement of heat because the hydraulic gradient was near zero. Piezometer PS12 was driven into fine-grained sediments at the south edge of Snake Creek near a large marshy area, similar to the conditions by piezometer PS4_sb1.

\section{Calcite Precipitation as a Mechanism for Clogging Streambed}

While attempting to move cobbles in the streambed next to the Snake 5 wells, it became evident that calcite could be cementing the streambed in Snake Creek downstream of where springs supply all the flow to the creek during low flow. The sand and silt surrounding the cobbles had a strong reaction to 5-percent hydrochloric acid solution. This cement was thought to be the hard, resistive layer encountered while driving piezometers into the streambed at sites downstream of the confluence with Spring Creek. Calcite also was deposited on piezometer standpipes during streamflow recession. These physical observations, combined with vertical hydraulic gradients that became more negative with time and streambedseepage rates that decreased with time, indicated that calcite deposition could be an important process in the lower reaches of Snake Creek. Subsequently, a geochemical analysis of the water in Snake Creek from GBNP to the Nevada-Utah state line was done in January 2010 to investigate the primary mechanisms that were causing the formation of calcite cement in the streambed (Dotson, 2010).

Six water samples were collected from Snake Creek from about $0.5 \mathrm{mi}$ upstream of the GBNP boundary to the NevadaUtah state line during January 16-17, 2010, and were analyzed for major-ion chemistry and for stable isotopes of water. Water samples also were collected from Spring Creek Spring (January 16, 2010) piezometer PS11 (January 17, 2010), a domestic well used to supply residents at the NDOW Spring Creek fish-rearing station (January 16, 2010), and the Snake 5 deep well (January 18, 2010). Selected dissolved constituents and the ratio of ${ }^{18} \mathrm{O}$ to ${ }^{16} \mathrm{O}$ for these samples are compared with dissolved-chloride concentrations in figure 52.

The general water-quality trend in Snake Creek was for chloride and other dissolved constituents to increase (except calcium) downstream of the first sampling site in GBNP (fig. 42; Dotson, 2010, p. 36). At the time of sampling, the estimated discharge in Snake Creek at the uppermost site was $1 \mathrm{ft}^{3} / \mathrm{s}$, and all the flow in the creek was lost before reaching the eastern boundary of GBNP. Flow did not begin again until about $300 \mathrm{ft}$ upstream of piezometer PS11, where groundwater flow to the creek resulted in a measured discharge of about $0.5 \mathrm{ft}^{3} / \mathrm{s}$ just upstream of where north Gruden Spring entered the creek. Concentrations of sodium, magnesium, and chloride nearly doubled between the first two sampling sites, whereas calcium only increased by 15 percent (fig. 52). The other 


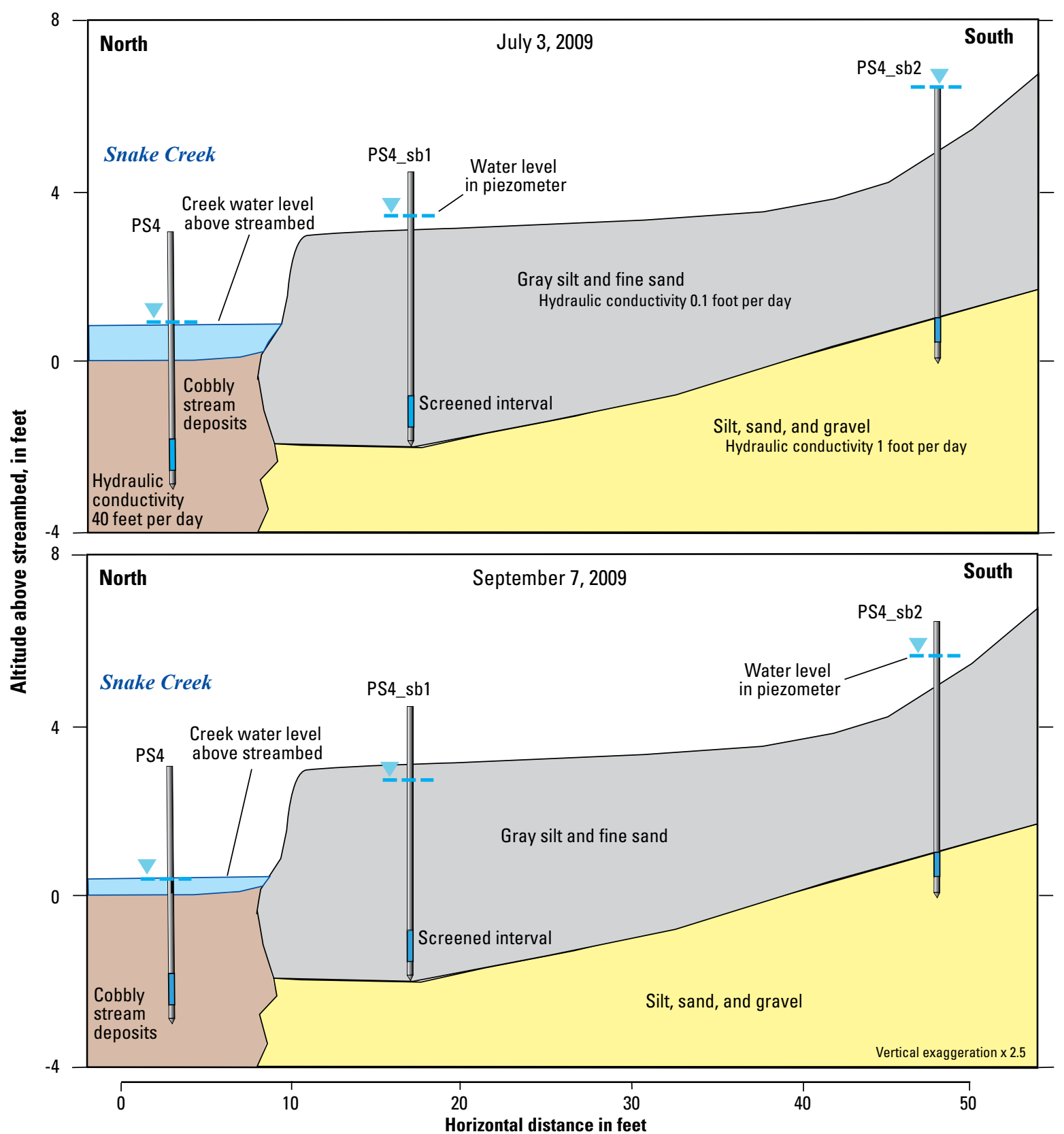

Figure 51. Diagrams showing water levels in near-surface deposits next to Snake Creek on July 3, 2009, and September 7, 2009, downstream from Great Basin National Park, White Pine County, Nevada.

constituents generally increased about 25 percent, except the ratio of ${ }^{18} \mathrm{O}$ to ${ }^{16} \mathrm{O}$, reported in units of delta ${ }^{18} \mathrm{O}$ permil relative to the ratio in sea water (Craig, 1961b; Giofiantini, 1978), which did not change. Water was sampled from piezometer PS11 (fig. 42) instead of north Gruden Spring because it was easier to access. Water in the creek, the spring, and the piezometer were assumed to be the same because of their proximity to the start of streamflow in Snake Creek.

Water from Spring Creek Spring had less sodium, chloride, and fluoride than water in piezometer PS11, but more calcium, magnesium, potassium, and sulfate (fig. 52). Concentrations of dissolved constituents in Snake Creek between piezometer PS11 and the confluence with Spring Creek (sampling site 6) showed a slight increase in dissolved chloride and other constituents, but a large decrease in manganese and iron (appendix tables $16-3,16-4)$. The delta ${ }^{18} \mathrm{O}$ ratios shown on figure 52 indicated some possible enrichment (less negative), but all samples were within the 2 standard deviation uncertainty of \pm 0.2 permil. The delta ${ }^{18} \mathrm{O}$ ratios differed slightly from those presented by Dotson (2010) because the analytical results were revised following recalibration of the instrument at the University of Nevada, Reno (UNR) stable-isotope laboratory (Simon 


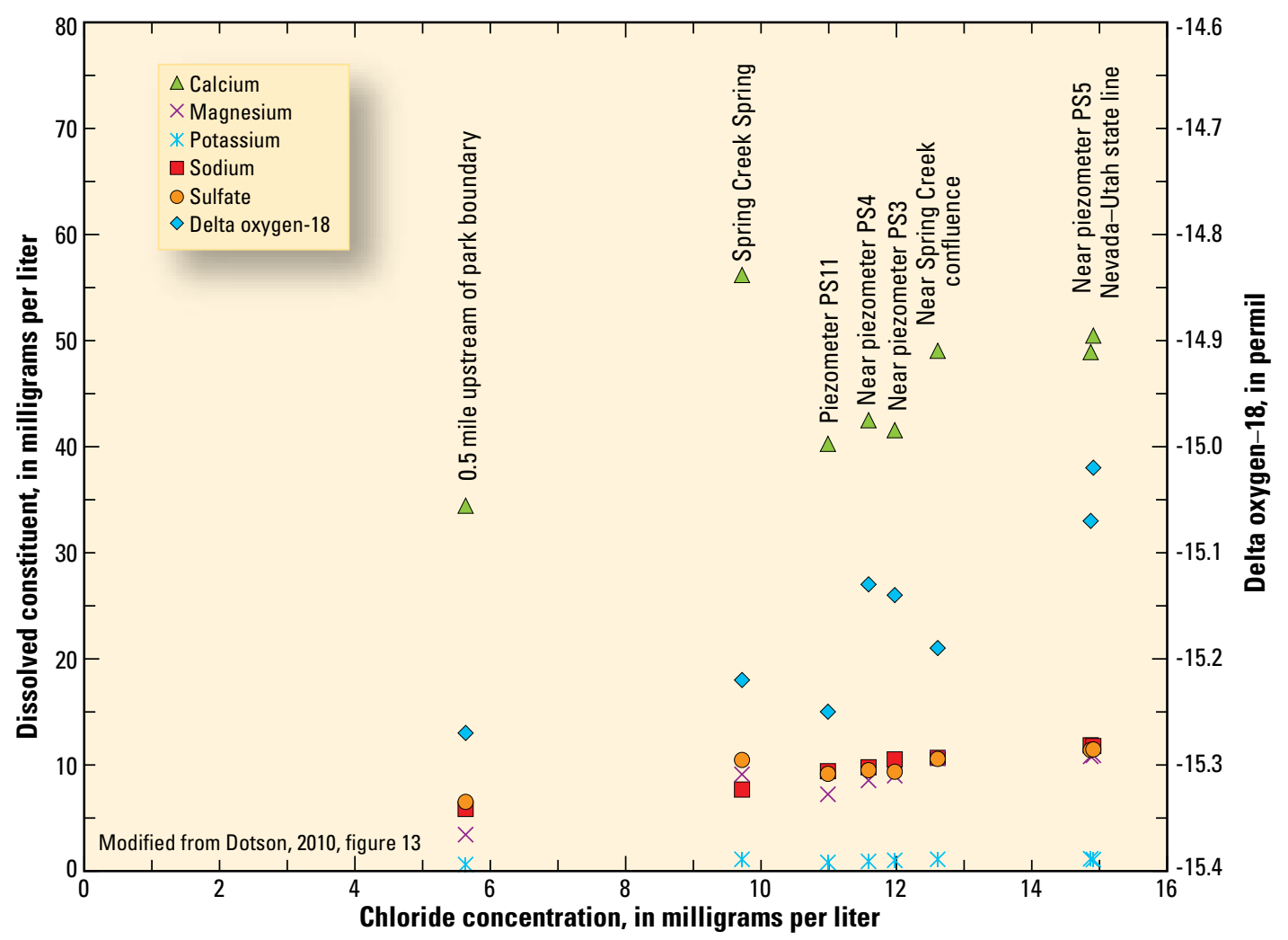

Figure 52. Selected dissolved constituents and ratio of oxygen-18 to oxygen-16 relative to dissolved-chloride concentration in Snake Creek, piezometer PS11 and Spring Creek Spring downstream from Great Basin National Park, White Pine County, Nevada, during January 16-17, 2010.

Paulson, University of Nevada, Reno, Reno, Nev., written commun., 2011). The potentially slight enrichment of delta ${ }^{18} \mathrm{O}$ ratios and the increase in chloride downstream of the confluence with Spring Creek indicated some evaporation of water in the creek, because water levels in piezometers in this reach indicated downward flow from the creek to the streambed.

Simple mixing of Spring Creek Spring water with Snake Creek water did not fully explain the dissolved concentrations downstream of their confluence (Dotson, 2010, p. 36). Although no discharge measurements were done while sampling, about 60 percent of the flow downstream of the confluence was estimated to be from Snake Creek (discharge measurements on February 25, 2010; appendix table 3-5), and 40 percent was from Spring Creek Spring (daily mean discharge between January 17 and 18, 2010; appendix table 4-5). Even so, variations in the percentage of flow could not explain the higher concentrations downstream from the confluence with Spring Creek for sodium, magnesium, fluoride, chloride, and sulfate (appendix table 16-3). During January 2010, nearly all the flow in Snake Creek was diverted to the fish-rearing ponds, where water from Snake Creek and Spring Creek Spring mixed before being released back to Snake Creek. Evaporation of water in the fish-rearing ponds or increased salts from fish food or waste could explain measured concentrations greater than can be explained by simple mixing (Dotson, 2010).
Speciation calculations to determine the likelihood of calcite precipitation along Snake Creek were done by Dotson (2010) using PHREEQC, a geochemical modeling program (Parkhurst and Appelo, 1999). Dotson (2010) divided the geochemical modeling into two types of calculations-batch reaction and inverse (Parkhurst and Appelo, 1999). Batch-reaction calculations were used to determine the importance of mixing Spring Creek Spring with Snake Creek, of carbon dioxide $\left(\mathrm{CO}_{2}\right)$ off-gassing, and of temperature on calcite precipitation on and in the streambed. Inverse calculations were used to evaluate geochemical reactions that accounted for the change in chemical composition of water in Snake Creek.

The saturation indices of calcite $\left(\mathrm{CaCO}_{3}\right)$ and the partial pressure of carbon dioxide gas $\left(\mathrm{P}_{\mathrm{CO} 2}\right)$ were calculated in the modeling (Dotson, 2010, p. 42). Calcite has a greater capacity to dissolve in systems exposed to the atmosphere (known as open systems) because carbon-dioxide $\left(\mathrm{CO}_{2}\right)$ gas from the atmosphere maintains a nearly constant $\mathrm{P}_{\mathrm{CO} 2}$ across the airwater interface (Drever, 1988, p. 68). In contrast, the $\mathrm{P}_{\mathrm{CO} 2}$ in a closed system is not constant because the reactions for calcite dissolution consume the aqueous $\mathrm{CO}_{2}$, and it is not replenished by the atmosphere. Water in limestone aquifers is generally close to equilibrium with calcite, and its $\mathrm{P}_{\mathrm{CO} 2}$ is almost always greater than atmospheric, indicating dissolution of calcite in open systems (Drever, 1988, p. 69). Water in Snake Creek is open to the atmosphere. In January, however, the creek was 
fed by springs and groundwater flow to the streambed from limestone aquifers that had a $\mathrm{P}_{\mathrm{CO} 2}$ much greater than atmospheric (table 14). Although the $\mathrm{P}_{\mathrm{CO} 2}$ values in Snake Creek $\left(10^{-3.23}\right.$ to $\left.10^{-3.01}\right)$ were less than those from the springs and in groundwater $\left(10^{-2.41}\right.$ to $\left.10^{-1.78}\right)$, the values were consistently greater than the atmospheric $\mathrm{P}_{\mathrm{CO} 2}$ of about $10^{-3.5}$ (Dotson, 2010, p. 41). If the majority of water in Snake Creek was not from springs flowing from limestone aquifers, the $\mathrm{P}_{\mathrm{CO} 2}$ in the stream would have remained nearly the same as the water sampled about $0.5 \mathrm{mi}$ upstream from the eastern boundary of GBNP (Dotson, 2010).

The speciation for each water sample was calculated for the batch reaction modeling, and a calcite solubility curve for the system was created by using a stepwise reaction of water chemistry at the uppermost sampling site $(0.5 \mathrm{mi}$ upstream of the GBNP boundary) that assumed calcite equilibrium with carbon dioxide in the atmosphere (Dotson, 2010, p. 40). Water samples collected from Snake Creek downstream of piezometer PS11 to the Nevada-Utah state line were supersaturated with respect to calcite (fig. 53). Samples from piezometer PS11 in the streambed, Spring Creek Spring, the domestic well at the NDOW Spring Creek fish-rearing station, and the Snake 5 deep well were undersaturated with respect to calcite (Dotson, 2010, p. 40).

Batch-reaction mixing calculations were developed by using the water sample collected from Snake Creek just upstream from the diversion for the NDOW Spring Creek fish-rearing station and from Spring Creek Spring to evaluate the importance of mixing on calcite precipitation downstream of the confluence with Spring Creek (Dotson, 2010, p. 42). The water chemistries of the two sampling sites were mixed at ratios that were incrementally increased by 10 percent, beginning with all water from Snake Creek upstream of the diversion and ending with all water from Spring Creek Spring. The mixed solution became saturated with respect to calcite when about 60 percent of water from Snake Creek upstream of the diversion pond was mixed with about 40 percent of Spring Creek. When more than 70 percent of the water was from Snake Creek, the mixture became supersaturated. The daily mean discharge at Spring Creek Spring was nearly constant between mid-January and the last part of February 2010 (appendix table 4-5), when discharge was measured on two dates in Snake Creek (appendix table 3-5). Assuming nearly constant streamflow in Snake Creek and flow through the fishrearing ponds on the two dates, about two-thirds of the streamflow downstream of the confluence with Spring Creek was from Snake Creek upstream from the diversion and one-third was from Spring Creek Spring. The mixed water downstream of the confluence was expected to be near saturation with respect to calcite. All samples downstream of the confluence, however, were supersaturated with respect to calcite, indicating other processes were affecting the water chemistry at and downstream of the NDOW Spring Creek fish-rearing station (Dotson, 2010, p. 43).

Batch-reaction calculations also were used to evaluate the relation between temperature and calcite precipitation because calcite precipitation increases with increasing temperatures (Dotson, 2010, p. 44). All the surface-water samples collected from Snake Creek were supersaturated with respect to calcite between temperatures of 0 and $25^{\circ} \mathrm{C}$ (fig. 54). Groundwater from Spring Creek Spring and from the deep well at Snake 5 were undersaturated with respect to calcite at temperatures less than $15^{\circ} \mathrm{C}$ and were supersaturated at temperatures greater than $15^{\circ} \mathrm{C}$, whereas groundwater samples from piezometer PS11 and from the domestic well at the NDOW Spring Creek fish-rearing station were always undersaturated with respect to calcite (fig. 54). Surface-water temperatures ranged from 1.5 to $9.5^{\circ} \mathrm{C}$ and were largely dependent on the time of sampling. The temperature of groundwater samples ranged from 10.0 to $13.4^{\circ} \mathrm{C}$, and Spring Creek Spring was the warmest (Dotson, 2010, p. 44). These analyses indicated that temperature was less important for calcite precipitation than the off-gassing of excess carbon dioxide gas dissolved in the water.

Table 14. Saturation indices of calcite and the partial pressure of carbon dioxide for water samples collected January 16-18, 2010, from Snake Creek, springs, and wells, Great Basin National Park, White Pine County, Nevada.

[Modified from Dotson, 2010, table 2]

\begin{tabular}{|c|c|c|c|c|}
\hline Sample location & $\begin{array}{l}\text { Date sampled in } \\
\text { January } 2010\end{array}$ & $\begin{array}{c}\text { Time sampled } \\
\text { (Pacific Standard) }\end{array}$ & $\begin{array}{l}\text { Saturation index for } \\
\text { calcite }\end{array}$ & $\begin{array}{l}\text { Log partial pressure } \\
\text { of carbon dioxide }\end{array}$ \\
\hline $\begin{array}{l}\text { Snake Creek about } 0.5 \text { mile upstream from Great Basin National } \\
\text { Park boundary }\end{array}$ & 17 & $13: 45$ & 0.072 & -3.16 \\
\hline Piezometer PS11 (groundwater) & 17 & $12: 20$ & -0.295 & -2.41 \\
\hline Snake Creek near piezometer PS4 & 17 & $11: 10$ & 0.583 & -3.23 \\
\hline Snake Creek near piezometer PS3 and upstream from diversion & 16 & $13: 00$ & 0.573 & -3.21 \\
\hline Spring Creek Spring (groundwater) & 16 & $15: 15$ & -0.005 & -2.29 \\
\hline Snake Creek downstream of confluence with Spring Creek & 17 & 09:50 & 0.548 & -3.06 \\
\hline Snake Creek near piezometer PS5 and Snake 5 wells & 17 & $15: 30$ & 0.491 & -3.01 \\
\hline Snake Creek near piezometer PS9 and Nevada-Utah state line & 17 & $08: 15$ & 0.641 & -3.23 \\
\hline Snake 5 deep well (groundwater) & 18 & $09: 30$ & -0.034 & -2.10 \\
\hline Spring Creek fish-rearing station well (groundwater) & 16 & $10: 35$ & -0.386 & -1.78 \\
\hline
\end{tabular}




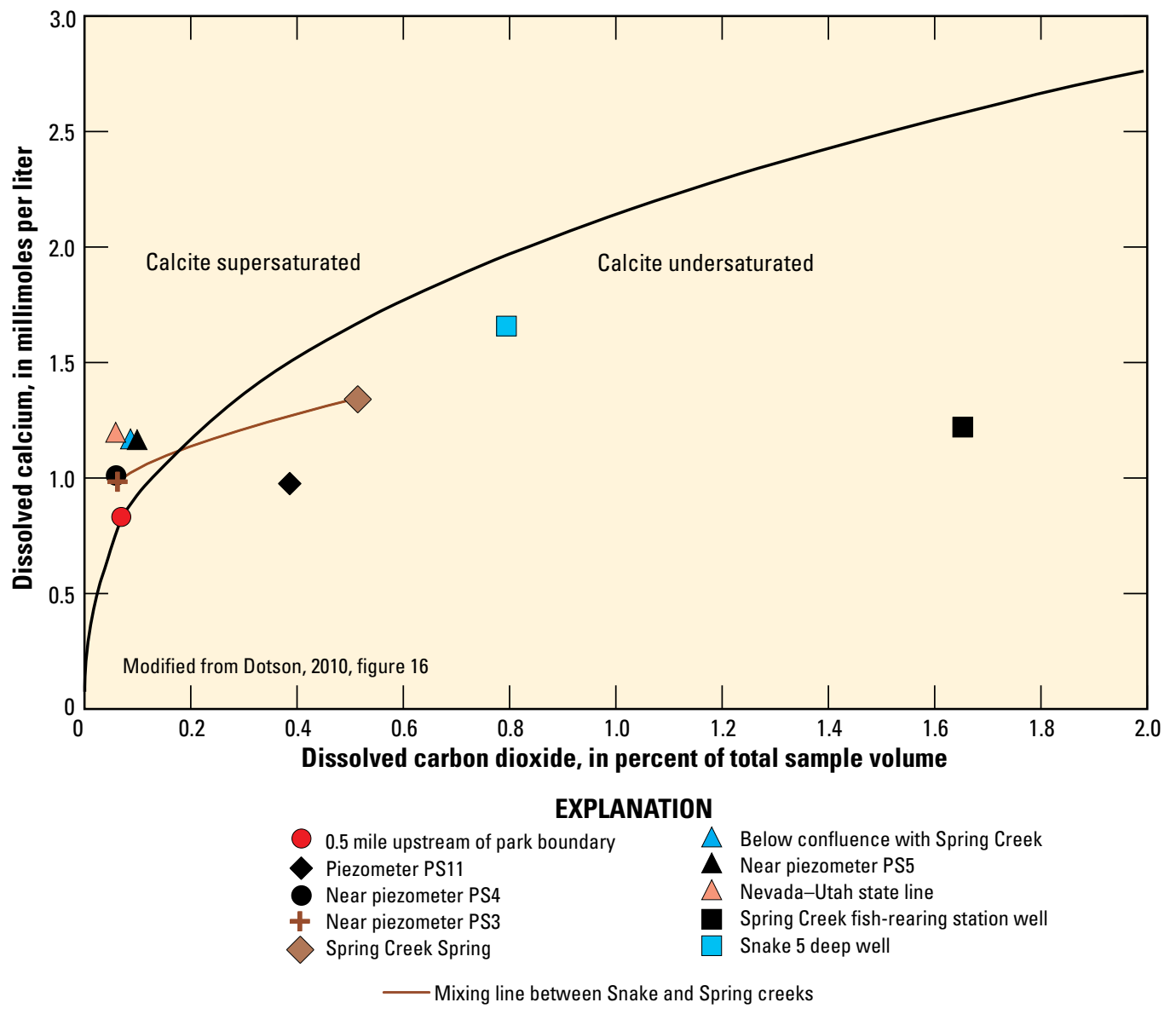

Figure 53. Calcium concentrations relative to the percentage of dissolved carbon dioxide volume in water samples collected along Snake Creek, Nevada, during January 16-18, 2010.

Inverse geochemical calculations were used to evaluate the chemical evolution along Snake Creek, including the effects of mixing Spring Creek Spring water with Snake Creek water (Dotson, 2010, p. 46). Constraints for the models included the elements calcium, carbon, chlorine, fluorine, iron $\left(\mathrm{Fe}^{2+}\right.$ and $\left.\mathrm{Fe}^{3+}\right)$, magnesium, manganese, oxygen, potassium, silica, strontium, and sulfur. Mineral phases included calcite, chalcedony, dolomite, fluorite, halite, iron sulfide, plagioclase, potassium mica, pyrolusite, and strontianite. The mineral phases were chosen on the basis of speciation reactions and the types of rocks that outcrop in the Snake Creek drainage basin (Dotson, 2010, p. 46). Halite was included because a source of chloride was needed in the calculations, and evaporite deposits have been found in the older basin-fill deposits (Sweetkind and others, 2007). The gradual increase in chloride and slightly enriched ratios of delta ${ }^{18} \mathrm{O}$ downstream along Snake Creek (fig. 52) indicated evaporation changed water chemistry. Evaporation was calculated by using water vapor content (Dotson, 2010, p. 46). All the normal mole-balance equations in PHREEQC were included, with the exception of soil organic carbon $\left(\mathrm{CH}_{2} \mathrm{O}\right)$ and plagioclase. The mole-balance equations for these reactions were specified, as follows, from Dotson (2010, p. 46):

$$
\begin{gathered}
\mathrm{CH}_{2} \mathrm{O}+\mathrm{H}_{2} \mathrm{O}=\mathrm{CO}_{2}+2 \mathrm{H}^{+}+4 e^{-} \text {and } \\
\left.\mathrm{Na}_{0.62} \mathrm{Ca}_{0.38} \mathrm{Al}_{1.38} \mathrm{Si}_{2.62} \mathrm{O}_{8}\right)+\mathrm{H}_{2} \mathrm{O}=0.62 \mathrm{Na}^{+}+ \\
0.38 \mathrm{Ca}^{2+}+1.38 \mathrm{Al}^{3+}+2.62 \mathrm{H}_{4} \mathrm{SiO}_{4}
\end{gathered}
$$

Snake Creek was divided into four segments for the inverse geochemical calculations. The first segment was from 0.5 mi upstream of the GBNP boundary to piezometer PS11. The second segment was from piezometer PS11 to just upstream of the diversion for the fish-rearing ponds. The third segment was from upstream of the fish-rearing ponds diversion to the confluence with Spring Creek downstream from the ponds and included water from upstream of the diversion mixed with water from Spring Creek Spring. The last segment was downstream from the confluence with Spring Creek to the Nevada-Utah state line. The first segment had an uncertainty of 3 percent, and 11 results that could explain the changes in water chemistry; the second segment had an uncertainty of 5 percent, and 3 results; the third segment had an uncertainty of 3 percent, and 11 results; and the fourth segment had an uncertainty of 3 percent, and more than 100 results (Dotson, 2010 , p. 47-50). The most probable model for each reach is listed in table 15 . 


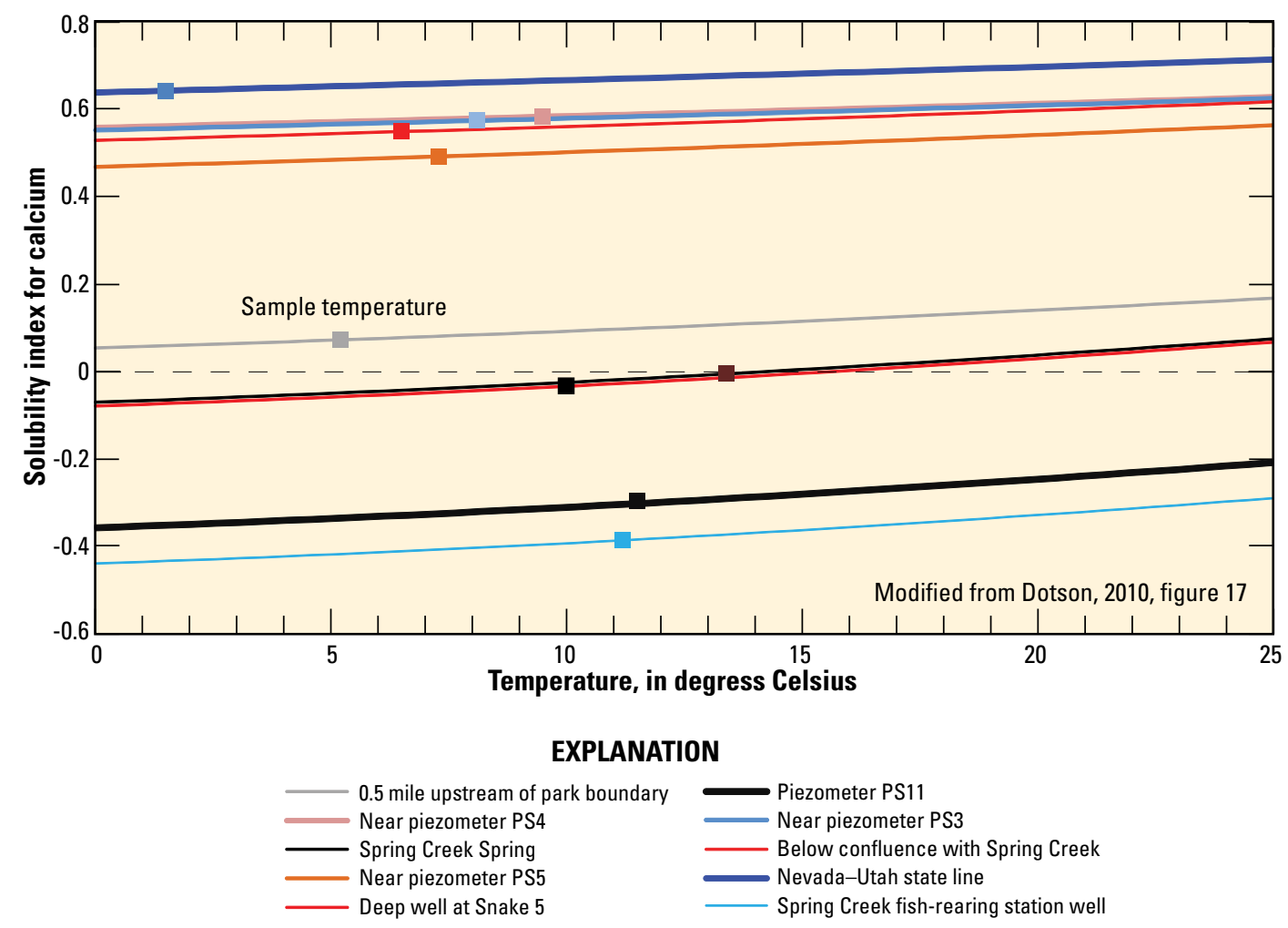

Figure 54. Saturation index for calcium relative to temperature for surface-water and groundwater samples collected along Snake Creek, Nevada, during January 16-18, 2010.

Results from geochemical modeling indicated that evaporation is important along Snake Creek (table 15). Off-gassing of carbon dioxide gas was important in segments downstream of north Gruden Spring. Dissolution of dolomite and precipitation of calcite and strontianite (dedolomitization) were simulated along the first three segments (table 15), and precipitation of dolomite, calcite, and strontianite was simulated along segment 4, downstream of the confluence with Spring Creek. Although no physical evidence exists for dedolomitization, the presence of dolomite in the drainage basin, as well as an increase in magnesium concentrations downstream, supports the theoretical model results (Dotson, 2010, p. 47). Calcite precipitates were found on cobbles downstream of north Gruden Spring (segments 2-4) as well as evidence of dissolution (pits in carbonate cobbles). Chalcedony (amorphous $\mathrm{SiO}_{2}$ ) precipitation was simulated in all segments, and iron-sulfide precipitation was simulated for segments downstream of north Gruden Spring (table 15). Consequently, the model results supported the observations indicating calcite precipitation in the streambed is effectively reducing streambed-seepage rates by cementing the streambed and decreasing the vertical hydraulic conductivity. Precipitation of all carbonate minerals (calcite, dolomite, and strontianite) downstream of the confluence of Spring Creek is primarily caused by the mixing of Spring Creek Spring water and Snake Creek water, either in the ponds or in the creek, as well as evaporation and off-gassing of carbon-dioxide gas. Stream-water temperature was not important when streamflow in Snake Creek was dominated by spring flow along the Tertiary fault. Clogging of the streambed with calcite downstream of the confluence with Spring Creek was furthered by large negative vertical hydraulic gradients causing downward flow of creek water to the streambed. These results indicated that groundwater flow from limestone to streams in eastern Nevada, where streamflow is dominated by groundwater inflow, could result in the clogging of streambeds from calcite precipitates that can reduce pore sizes and streamflow loss rates on the alluvial fans.

\section{Aquifers}

The main aquifers underlying the upper-piedmont zone are the shallow, younger alluvial deposits along Snake Creek and open fractures in carbonate rocks that underlie older alluvial deposits (fig. 46). The older alluvial deposits (Miocene) are generally a consolidated mixture of cobbles, sand, silt, and clay that dip west. The contact between the west-dipping, older basin-fill deposits and the underlying carbonate rocks is uncertain and is depicted as a series of faulted and tilted blocks in the idealized cross section along Snake Creek (fig. 46).

Only nine wells or test borings have been drilled in the upper-piedmont zone: seven were at the NDOW Spring Creek fish-rearing station, one was a test boring on private land immediately west of it, and the last were the Snake 5 wells drilled for this study (appendix 1) next to Snake Creek about 
Table 15. Geochemical modeling results of mineral-phase mass transfer for each of four segments along Snake Creek from water samples collected January 16-17, 2010, Great Basin National Park, White Pine County, Nevada.

[Modified from Dotson, 2010, tables 3-6. Segment 1 is between samples collected 0.5 mile upstream of park boundary and at piezometer PS11. Segment 2 is between samples collected at piezometer PS11 to immediately upstream of diversion to fish-rearing ponds. Segment 3 is between samples collected immediately upstream of diversion to fish-rearing ponds and immediately downstream of confluence with Spring Creek and includes mixing of water from Spring Creek and ponds. Segment 4 is between samples collected immediately downstream of confluence with Spring Creek and at the Nevada-Utah state line. Positive values represent mineral dissolution and negative values mineral precipitation. Loss of carbon dioxide to off-gassing and loss to evaporation is represented by a negative value. Symbol: - , no mineral phase or process transfer simulated]

\begin{tabular}{|c|c|c|c|c|c|}
\hline \multirow{3}{*}{ Mineral phase or process } & \multirow{3}{*}{ Chemical formula } & \multicolumn{4}{|c|}{ Stream segments } \\
\hline & & 1 & 2 & 3 & 4 \\
\hline & & \multicolumn{4}{|c|}{ (moles per liter) } \\
\hline Carbon dioxide gas, dissolved & $\mathrm{CO}_{2(\mathrm{aq})}$ & - & $-1.76 \mathrm{E}-04$ & $-1.29 \mathrm{E}-04$ & $-7.34 \mathrm{E}-05$ \\
\hline Chalcedony & $\mathrm{SiO}_{2}$ & $-7.10 \mathrm{E}-05$ & $-2.09 \mathrm{E}-05$ & $-2.67 \mathrm{E}-05$ & $-2.54 \mathrm{E}-05$ \\
\hline Fluorite & $\mathrm{CaF}_{2}$ & $2.30 \mathrm{E}-07$ & $-4.14 \mathrm{E}-07$ & $1.34 \mathrm{E}-07$ & - \\
\hline Halite & $\mathrm{NaCl}$ & $9.05 \mathrm{E}-05$ & $-1.12 \mathrm{E}-05$ & $1.08 \mathrm{E}-05$ & $2.51 \mathrm{E}-05$ \\
\hline Iron sulfide, precipitate & $\mathrm{FeS}$ & - & $-4.96 \mathrm{E}-06$ & $-4.73 \mathrm{E}-06$ & $-6.25 \mathrm{E}-07$ \\
\hline Plagioclase & $\mathrm{Na}_{0.62} \mathrm{Ca}_{0.38} \mathrm{Al}_{1.38} \mathrm{Si}_{2.62} \mathrm{O}_{8}$ & - & - & - & $6.34 \mathrm{E}-06$ \\
\hline Strontianite & $\mathrm{SrCO}_{3}$ & $-1.26 \mathrm{E}-07$ & $-1.39 \mathrm{E}-07$ & $-1.25 \mathrm{E}-07$ & $-7.20 \mathrm{E}-08$ \\
\hline
\end{tabular}

$0.5 \mathrm{mi}$ upstream of the Quaternary fault (fig. 36). Two wells at the fish-rearing station were drilled for domestic supply; one was drilled in 1955, and a second test boring that was intended to replace the 1955 well was drilled in 1987 to west of the first well. The 1987 well was filled with concrete after the boring reportedly encountered granite at a depth of $20 \mathrm{ft}$ that continued to a depth of $163 \mathrm{ft}$ (Nevada Division of Water Resources Well Drillers' Log 29074). The other five wells at the fishrearing station were shallow monitoring wells (9-12 ft deep) near the ponds and were abandoned in 2002.

The contact between the west-dipping older basin-fill deposits and the underlying Paleozoic limestone is irregular and is depicted in figure 46 as resulting from a series of faults that offset and tilt the limestone blocks and the lower part of the older basin-deposits. Limestone was encountered at the Snake 5 wells at a depth of $80 \mathrm{ft}$ after drilling through about $40 \mathrm{ft}$ of alluvial deposits and an underlying $38 \mathrm{ft}$ of clay. The test boring drilled on private land west of the fish-rearing station and north of the Tertiary fault encountered fractured limestone at a depth of $104 \mathrm{ft}$ (George Douglass, Jr., Nevada Department of Wildlife, Baker, Nev., oral commun., 2011). The description of granite encountered in the test boring at the fish-rearing station was unusual; if the rock was described correctly by the driller, it could be a large megablock in the older basin-fill deposits or simply cemented cobbles that are primarily granite. The irregular nature of this contact is evident in the Big Wash drainage basin south of Snake Creek, where, apparently, one well was completed in the older basin-fill deposits and a nearby well was completed in fractured limestone.

\section{Hydraulic Properties of Deposits and Rocks}

The hydraulic properties of the younger basin-fill deposits in Snake Creek were evaluated from a 5-hr single-well aquifer test at the domestic well for the NDOW Spring Creek fishrearing station (Jackson, 2010, p. 77). A description of the test and results also are available at http://nevada.usgs.gov/water/ AquiferTests/Snake_Valley_NDOW.cfm? studyname=Snake Valley_NDOW. Transmissivity of the younger basin-fill deposits at the well was estimated at $300 \mathrm{ft}^{2} / \mathrm{d}$ and was nearly the same as that estimated from specific capacity when the storage coefficient was 0.1 (table 16).

The hydraulic properties of Miocene basin-fill deposits are unknown in the upper-piedmont zone of Snake Creek drainage basin because no wells have been completed in these deposits. A well was drilled in the Big Wash drainage basin to the south, however, and the drillers' log (Nevada Division of Water Resources well drillers' log 49244) indicated mostly consolidated (sedimentary) gravel and clay in the screened interval of the well. Transmissivities estimated from specificcapacity data for this well ranged from 1 to $2 \mathrm{ft}^{2} / \mathrm{d}$ (table 16). The estimated hydraulic conductivity for the older basin-fill deposits encountered in the Big Wash drainage basin was about $0.01 \mathrm{ft} / \mathrm{d}$, which was similar to the value estimated for older basin-fill deposits from an aquifer test along Baker Creek (Jackson, 2010). The hydraulic properties of the older basin-fill deposits are probably more variable than indicated by these results.

The hydraulic properties of fractured limestone were estimated from three slug tests in the Snake 5 deep well (Prudic, 
Table 16. Summary of transmissivity estimates from specific capacities reported in well-drillers' logs and from two aquifer tests for wells in the Snake Creek and Big Wash drainage basins, vicinity of Great Basin National Park, White Pine County, Nevada.

[Nevada well-log number and data obtained from Nevada Division of Water Resources. Utah well-log number and data obtained from Utah State Engineer. Transmissivity rounded to one significant figure. Symbol: - , not applicable]

\begin{tabular}{|c|c|c|c|c|c|c|c|c|}
\hline $\begin{array}{l}\text { Well name/ } \\
\text { Nevada well-log } \\
\text { number/Utah } \\
\text { well-log number }\end{array}$ & $\begin{array}{c}\text { Hole } \\
\text { diameter } \\
\text { (inches) }\end{array}$ & $\begin{array}{c}\text { Screened } \\
\text { interval } \\
\text { (feet below land } \\
\text { surface) }\end{array}$ & Geologic unit & $\begin{array}{c}\text { Pump rate } \\
\text { (gallons per } \\
\text { minute) }\end{array}$ & $\begin{array}{l}\text { Drawdown } \\
\text { (feet) }\end{array}$ & $\begin{array}{l}\text { Hours well } \\
\text { pumped }\end{array}$ & $\begin{array}{c}\text { Range in storage } \\
\text { coefficient }\end{array}$ & $\begin{array}{c}\text { Estimated } \\
\text { transmissivity } \\
\text { (feet squared per day) }\end{array}$ \\
\hline \multicolumn{9}{|c|}{ Upper-piedmont zone_-Snake Creek drainage } \\
\hline $\begin{array}{l}\text { Fish-rearing } \\
\text { station well }\end{array}$ & 6 & $16-32$ & Sand and gravel & 18 & 10 & 5 & $1 E-1-2 E-5$ & $300-500$ \\
\hline Snake 5 deep & 7 & $290-310$ & Fractured limestone & - & - & - & $2 \mathrm{E}-6-2 \mathrm{E}-9$ & $300-500$ \\
\hline \multicolumn{9}{|c|}{ Upper-piedmont zone_Big Wash drainage } \\
\hline 49244 & 10 & $109-289$ & Consolidated gravel and clay & 3 & 253 & 3 & $5 E-2-2 E-4$ & $1-2$ \\
\hline 67897 & 8 & $104-109$ & Fractured limestone & 21 & 10.5 & 6 & $1 E-4-5 E-6$ & $500-600$ \\
\hline \multicolumn{9}{|c|}{ Lower-piedmont zone } \\
\hline 21273 & 14 & $80-300$ & Cobbles and gravel & 1,500 & 100 & 10 & $1 E-1-2 E-4$ & $3,000-4,000$ \\
\hline \multicolumn{9}{|c|}{ Valley-lowland zone } \\
\hline 21277 & 10 & $35-95$ & Cobbles, clay and gravel & 26 & 46 & 6 & $2 \mathrm{E}-1-5 \mathrm{E}-5$ & $70-100$ \\
\hline 21287 & 16 & $163-270$ & Cobbles, clay and gravel & 1,500 & 97 & 24 & $1 E-2-1 E-4$ & $3,000-5,000$ \\
\hline 21313 & 16 & $60-250$ & Gravel, clay and sand & 600 & 100 & 72 & $1 E-1-2 E-4$ & $1,000-2,000$ \\
\hline 21314 & 6 & $126-146$ & Clay, sand and gravel & 32 & 44 & 4 & $1 E-1-6 E-5$ & $100-200$ \\
\hline 22541 & 6 & $130-160$ & Sand and gravel & 20 & $<1$ & 2 & $1 E-1-3 E-5$ & $4,000-6,000$ \\
\hline 22542 & 10 & $130-160$ & Sand and gravel & 40 & $<1$ & 2 & $2 E-1-5 E-5$ & $7,000-12,000$ \\
\hline
\end{tabular}

2012b; appendix tables 11-1, 11-2, 11-3). Transmissivity for the fractured limestone ranged from 300 to $500 \mathrm{ft}^{2} / \mathrm{d}$ and was dependent on estimated storage coefficients that ranged from $5 \times 10^{-6}$ to $2 \times 10^{-9}$ (table 16 ). The range in storage coefficients was estimated on the basis of fracture porosity ranging from 1 to 10 percent. Dividing the estimated transmissivity of fractured limestone by the screened interval of $20 \mathrm{ft}$ yielded an estimated hydraulic conductivity from 15 to $25 \mathrm{ft} / \mathrm{d}$. The well drilled in the Big Wash drainage basin south of the NDOW Spring Creek fish-rearing station encountered unfractured limestone at a depth of $69 \mathrm{ft}$ before intersecting a fracture at a depth of $105 \mathrm{ft}$. The estimated transmissivity from specificcapacity data ranged from 300 to $500 \mathrm{ft}^{2} / \mathrm{d}$, assuming storage coefficients ranging from $1 \times 10^{-4}$ to $5 \times 10^{-6}$ (table 16). Both wells had similar transmissivity estimates, and considerable thickness of unfractured limestone was encountered prior to intersecting a fracture. These limited tests indicated a small storage coefficient for the limestone because of infrequent open fractures in relatively thick intervals of unfractured or calcite-filled fractured limestone. The result was hydraulic diffusivity (transmissivity divided by storage coefficient) that ranged from $5 \times 10^{6}$ to $2 \times 10^{11} \mathrm{ft}^{2} / \mathrm{d}$, which allows for rapid propagation of head changes through the fractures.

\section{Geochemical Evidence for Flow through Carbonate Rocks}

Dotson (2010) used PHREEQC (Parkhurst and Appelo, 1999) to do inverse geochemical calculations to evaluate the possible sources of water in the Snake 5 deep well, including water from Snake Creek downstream of the confluence with Spring Creek and shallow groundwater in the younger basin-fill deposits indicated by the water chemistry from the domestic well at the NDOW Spring Creek fish-rearing station. Constraints for the inverse calculations included the elements calcium, carbon, chlorine, fluorine, iron $\left(\mathrm{Fe}^{2+}\right.$ and $\left.\mathrm{Fe}^{3+}\right)$, magnesium, manganese, oxygen, potassium, silica, strontium, and sulfur. Mineral phases included anhydrite, calcite, dolomite, fluorite, halite, iron sulfide, kaolinite, plagioclase, potassium mica, pyrolusite, rhodochrosite, and strontianite; dissolved carbon dioxide was included in the gas phase. The molebalance equations were the same as those used for inverse calculations along Snake Creek.

Results indicated that the water chemistry of Snake Creek downstream of its confluence with Spring Creek or next to the Snake 5 wells could not explain the water chemistry in the Snake 5 deep well (Dotson, 2010, p. 51); however, the water chemistry of Spring Creek Spring and water from piezometer PS11 could explain water chemistry in the well (table 17). The uncertainty of these simulations was 2 percent for both models (Dotson, 2010, p. 51). A total of 12 results were found to explain the chemistry at the Snake 5 deep well by using water from Spring Creek Spring, and 1 result was found by using water from piezometer PS11. Calcite and dolomite were dissolved, carbon dioxide increased, and kaolinite was chemically precipitated in all models (table 17). Many attempts were made to include water from shallow groundwater in the basin-fill deposits near the domestic well at the NDOW Spring Creek fish-rearing station. Inverse geochemical calculations could only reproduce the water chemistry in the Snake 5 deep well to within 5 percent uncertainty when less than 10 percent 
of the water was from the domestic well at the NDOW Spring Creek fish-rearing station and more than 90 percent was either from Spring Creek Spring or piezometer PS11 (Dotson, 2010, p. 53; table 17). This indicated that much of the water in the Snake 5 deep well was from flow through fractures in limestone that underlie the older basin-fill deposits. Finally, the water chemistry at the domestic well at the NDOW Spring Creek fish-rearing station could be explained by using water from either piezometer PS11 or from Spring Creek Spring, indicating the source of water in the shallow alluvial deposits was from limestone aquifers upstream of the older normal fault (Dotson, 2010, p. 54-56).

\section{Water-Level Trend in Fractured Limestone}

The water level in the Snake 5 deep well was monitored hourly starting January 18, 2010. The initial pressure transducer could monitor a recordable range in water level of about $45 \mathrm{ft}$ (Schlumberger Diver with a reported 10-meter range). The transducer was placed $9.4 \mathrm{ft}$ below the water level measured on January 18, 2010. The water level remained at a depth of about $210 \mathrm{ft}$ until mid-February 2010, when it began to rise slowly (fig. 55). The water level rose $26 \mathrm{ft}$ between June 3 and June 8, 2010, at an average rate of about $4 \mathrm{ft} / \mathrm{d}$. On June 8, the water level rose above depths the transducer recorded and did not fall within the pressure transducer range until July 2, 2010. No water was detected in the shallow well screened in sand and gravel from 30 to $35 \mathrm{ft}$ below land surface during the recorded rise in the fractured limestone in the deep well. A 40-ft section of clay residuum and another $210 \mathrm{ft}$ of calcite-filled fractured limestone separate the two wells.
Two additional pressure transducers were placed in the deep well above the bottom transducer on April 20, 2011, to record water-level rises above its range, and a pressure transducer with a recordable range of $165 \mathrm{ft}$ was installed on June 1, 2011, at a depth of $215 \mathrm{ft}$ along with pressure transducer with a range of about 45 feet at a depth of $65 \mathrm{ft}$. At the same time, a temperature logger was installed at a depth of 300 feet near the mid-point of the screened interval. A pressure transducer also was installed at the bottom of the screened interval in the shallow well on June 1, 2010, because $0.3 \mathrm{ft}$ of water was measured at the bottom of the well below the screened interval. No evidence was found to indicate that water on the surface entered through the top of the well casing. Snake Creek was bank full on June 1, 2011, and soon after overflowed its banks upstream and downstream of the Snake 5 wells, but no flow was observed at the wells.

The water level in the deep well rose from $198 \mathrm{ft}$ below land surface on April 1, 2011, to a maximum of $58 \mathrm{ft}$ below land surface on June 25, 2011 (fig. 55). During this period, the maximum daily rise was $6 \mathrm{ft}$, and the average daily rise was $1.6 \mathrm{ft}$. A rapid water-level rise also was recorded in the shallow well in June. The water level in this well rose to a maximum of $21 \mathrm{ft}$ below land surface on June 25, 2011, the same day that the water level in the deep well peaked. The peak water level in the shallow well was about $15 \mathrm{ft}$ below the streambed of nearby Snake Creek. The rapid water-level response of the deep well was consistent with a confined aquifer, where flow is through discrete fractures in the limestone, which generally has a low storage coefficient.

Table 17. Geochemical modeling results of mineral-phase mass transfer for flow paths to the Snake 5 deep well from spring and wellwater samples collected January 16-18, 2010, Great Basin National Park, White Pine County, Nevada.

[Modified from Dotson, 2010, tables 7-10. Water chemistry of north Gruden Spring is represented by water from streambed piezometer PS11 driven beneath Snake Creek next to spring. Positive values represent mineral dissolution and negative values mineral precipitation. Increase in carbon dioxide from the atmosphere is represented by a positive value. Abbreviation: NDOW, Nevada Department of Wildlife. Symbol: —, no mineral phase or process transfer simulated]

\begin{tabular}{|c|c|c|c|c|c|}
\hline \multirow{3}{*}{ Mineral phase or process } & \multirow{3}{*}{ Chemical formula } & \multirow[b]{2}{*}{$\begin{array}{l}\text { Spring Creek } \\
\text { Springs }\end{array}$} & \multirow[b]{2}{*}{$\begin{array}{l}\text { North Gruden } \\
\text { Spring }\end{array}$} & \multicolumn{2}{|c|}{$\begin{array}{l}\text { Mixing } 10 \text { percent of NDOW fish-rearing } \\
\text { station well water with } 90 \text { percent }\end{array}$} \\
\hline & & & & $\begin{array}{l}\text { Spring Creek } \\
\text { Spring }\end{array}$ & $\begin{array}{l}\text { North Gruden } \\
\text { Spring }\end{array}$ \\
\hline & & \multicolumn{4}{|c|}{ (moles per liter) } \\
\hline Anhydrite & $\mathrm{CaSO}_{4}$ & - & $2.41 \mathrm{E}-05$ & $-1.24 \mathrm{E}-05$ & $1.10 \mathrm{E}-05$ \\
\hline Calcite & $\mathrm{CaCO}_{3}$ & $2.07 \mathrm{E}-04$ & $4.99 \mathrm{E}-04$ & $2.88 \mathrm{E}-04$ & $4.99 \mathrm{E}-04$ \\
\hline Carbon dioxide, dissolved & $\mathrm{CO}_{2(\mathrm{aq})}$ & $5.87 \mathrm{E}-04$ & $1.01 \mathrm{E}-03$ & $4.07 \mathrm{E}-04$ & $8.22 \mathrm{E}-04$ \\
\hline Dolomite & $\mathrm{CaMg}\left(\mathrm{CO}_{3}\right)_{2}$ & $8.27 \mathrm{E}-05$ & $1.51 \mathrm{E}-04$ & - & $8.94 \mathrm{E}-05$ \\
\hline Fluorite & $\mathrm{CaF}_{2}$ & $1.58 \mathrm{E}-07$ & $-1.58 \mathrm{E}-07$ & $-1.39 \mathrm{E}-07$ & $-4.24 \mathrm{E}-07$ \\
\hline Halite & $\mathrm{NaCl}$ & $1.01 \mathrm{E}-04$ & $5.67 \mathrm{E}-05$ & $5.09 \mathrm{E}-05$ & $-1.48 \mathrm{E}-05$ \\
\hline Iron sulfide, precipitate & $\mathrm{FeS}$ & $1.24 \mathrm{E}-06$ & $-1.12 \mathrm{E}-05$ & $1.08 \mathrm{E}-06$ & $-1.01 \mathrm{E}-05$ \\
\hline Kaolinite & $\mathrm{Al}_{4} \mathrm{Si}_{4} \mathrm{O}_{10}(\mathrm{OH})_{8}$ & $-9.92 \mathrm{E}-06$ & $-1.45 \mathrm{E}-05$ & - & $-1.53 \mathrm{E}-05$ \\
\hline Plagioclase & $\mathrm{Na}_{0.62} \mathrm{Ca}_{0.38} \mathrm{Al}_{1.38} \mathrm{Si}_{2.62} \mathrm{O}_{8}$ & $2.22 \mathrm{E}-05$ & $1.16 \mathrm{E}-05$ & - & $1.14 \mathrm{E}-05$ \\
\hline Potassium-mica & $\mathrm{KAl}_{3} \mathrm{Si}_{3} \mathrm{O}_{10}(\mathrm{OH})_{2}$ & $-3.58 \mathrm{E}-06$ & $4.35 \mathrm{E}-06$ & - & $4.94 \mathrm{E}-06$ \\
\hline Pyrolusite & $\mathrm{MnO}_{2}$ & - & $-6.05 \mathrm{E}-05$ & $-6.35 \mathrm{E}-10$ & $-5.59 \mathrm{E}-05$ \\
\hline Rhodochrosite & $\mathrm{MnCO}_{3}$ & $-1.66 \mathrm{E}-09$ & $6.04 \mathrm{E}-05$ & - & $5.58 \mathrm{E}-05$ \\
\hline Strontianite & $\mathrm{SrCO}_{3}$ & - & $7.83 \mathrm{E}-07$ & - & $6.94 \mathrm{E}-07$ \\
\hline
\end{tabular}




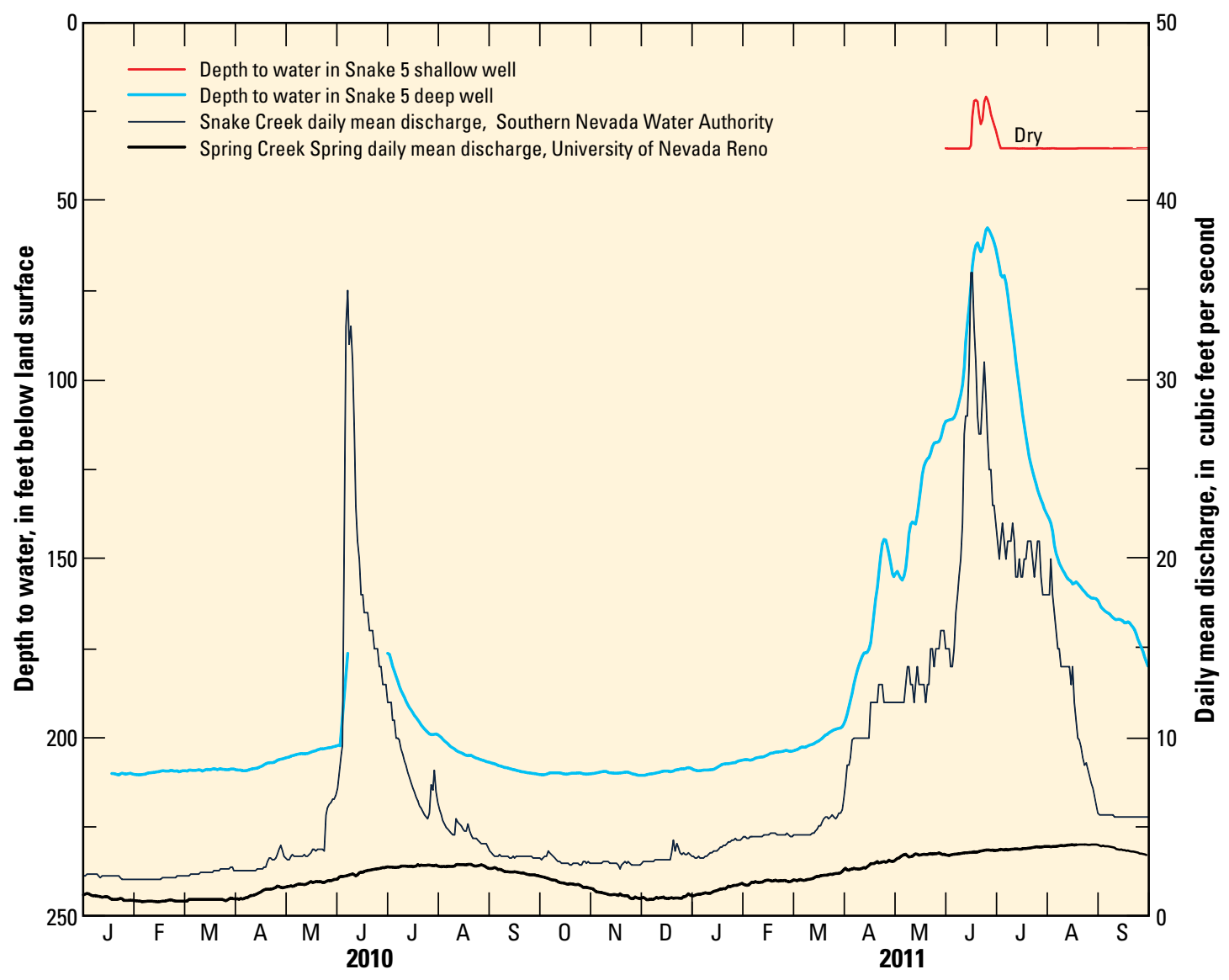

Figure 55. Daily mean depth to water in the Snake 5 wells in relation to daily mean discharge of Snake Creek near the boundary between the upper-piedmont and lower-piedmont zones and Spring Creek Spring, January 2010-September 2011, White Pine County, Nevada.

The water level in the Snake 5 deep well followed the same trend as the daily mean discharge in Snake Creek at the SNWA gaging station, except that the peak daily mean discharge in Snake Creek preceded the peak water level in the deep well by 8 days (fig. 55; daily mean discharge provided by Gavin Kistinger, Southern Nevada Water Authority, Las Vegas, Nev., written commun., 2011 and 2012). The gaging station is about $0.5 \mathrm{mi}$ downstream of the Snake 5 wells and just upstream of piezometer PS10 (fig. 42). In contrast, the peak daily mean discharge at Spring Creek Spring lagged considerably from Snake Creek and in the Snake 5 deep well, indicating that the water-level response in the fractured limestone was related to snowmelt in the karst-limestone zone of the Snake Creek drainage basin more than to pressure changes at Spring Creek Spring. The slow response of Spring Creek Spring to snowmelt indicated a longer flow path with greater storage than in the fractured limestone at the deep well.

Although the water level in the deep well responded quickly to snowmelt during the summer of 2010 , temperature in the middle of the screened interval remained a constant $10.9^{\circ} \mathrm{C}$ from June 1,2011 , to June 2, 2012, indicating that the rapid water-level response was pressure controlled and not caused by rapid groundwater flow from spring snowmelt through large fractures in the limestone between areas of outcrop and the well or from stream leakage in neighboring Snake Creek.

The tritium concentration in a water sample collected June 3, 2010, from the Snake 5 deep well was $22 \mathrm{pCi} / \mathrm{L}$ (Phillip Gardner, U.S. Geological Survey, Salt Lake City, Utah, written commun., 2011). Assuming the mean atmospheric concentration of tritium is between $27 \mathrm{pCi} / \mathrm{L}$ (estimated from tritium analysis of Lehman Creek; table 5) and $32 \mathrm{pCi} / \mathrm{L}$ (Clark and Fritz, 1997, p. 182) and has a half-life of 12.3 years, the mean age of water in the Snake 5 deep well was 4 to 7 years old based on the equation from Clark and Fritz (p. 181). This was consistent with geochemical modeling that indicated most of the water in the fractured limestone at the deep well traveled through limestone beneath the older basin-fill deposits.

An estimate of the mean hydraulic conductivity for the fractured limestone between the areas of outcrop and the Snake 5 deep well was approximated from the mean age of water in the well, assuming water traveled between 3 and $5 \mathrm{mi}$ (the distance from the well to lower and upper ends of karstlimestone zone in the Snake Creek drainage basin) from the karst-limestone zone beneath Snake Creek, a fractured porosity for the limestone from 1 to 10 percent (Prudic, 2012b), and 
a hydraulic gradient of $0.03 \mathrm{ft} / \mathrm{ft}$ (half the streambed slope). The mean hydraulic conductivity of the fractured limestone equals the mean velocity of the water (travel distance divided by time) multiplied by the fractured porosity, divided by the hydraulic gradient; therefore, the mean hydraulic conductivity ranged from 2 to $60 \mathrm{ft} / \mathrm{d}$. The range was consistent with an estimated hydraulic conductivity of $15-25 \mathrm{ft} / \mathrm{d}$ from three slug tests at Snake 5 deep well (Prudic, 2012b). Thus, the mean age of water in the fractured limestone in the deep well provided additional evidence for a hydraulic diffusivity that can produce rapid water-level changes in the fractured limestone in the upper-piedmont zone. Discrete fractures in the limestone allow for relatively rapid transport of water (4-7 years) from the karst-limestone zone through the upper-piedmont zone and to the lower-piedmont zone, even though groundwater flow through the limestone is only a fraction of streamflow that exits the upper-piedmont zone (table 11).

\section{Water Budget}

Inflow to the upper-piedmont zone consists of precipitation, runoff in Snake Creek from the karst-limestone zone, springs along the Tertiary fault, and groundwater flow through the younger basin-fill deposits along Snake Creek and through fractures in the limestone across the fault. Total mean annual inflow was about 8,100 acre-ft/yr (table 11). Mean annual precipitation accounted for about 32 percent of the total inflow, runoff in Snake Creek accounted for 36 percent, springs along the fault accounted for another 27 percent, and the remaining 5 percent was groundwater inflow.

Outflow consisted of evapotranspiration, runoff to the lower-piedmont zone, and groundwater flow through fractured limestone. The majority of the outflow from the zone was runoff, accounting for 54 percent of the total (table 11). Evapotranspiration was assumed to be the difference between all estimated inflows and estimates of all other outflows and accounted for 41 percent of total outflows. The remaining 5 percent was groundwater that flows through fractured limestone and subsequently enters a thicker section of younger basin-fill deposits on the downthrown side of the Quaternary fault. The estimate of groundwater outflow to the lower-piedmont zone through fractured limestone was based on a transmissivity of $300-500 \mathrm{ft}^{2} / \mathrm{d}$ of fractured limestone, an effective width of 5,000-3,000 ft, and a hydraulic gradient of $0.03 \mathrm{ft} / \mathrm{ft}$ (the estimated mean gradient between the Snake 5 deep well and the shallowest well at UGS site PW01). The estimated groundwater flow from the upper-piedmont was a fraction of the mean annual runoff.

A set of water-quality samples was collected in January 2010, when all the flow in Snake Creek was from groundwater flow to springs, and none was from snowmelt. A simple mixing model was used to estimate the mean chloride concentration of runoff leaving the upper-piedmont zone, assuming mean chloride concentrations of $3.4 \mathrm{mg} / \mathrm{L}$ in Snake Creek water and $12 \mathrm{mg} / \mathrm{L}$ in groundwater entering the zone, and that about 700 acre-ft/yr of runoff and groundwater flow in the zone was lost to evapotranspiration. The estimated mean chloride concentration in runoff leaving the zone was about $8 \mathrm{mg} / \mathrm{L}$ and was $5-7 \mathrm{mg} / \mathrm{L}$ less than the chloride concentration for Snake Creek water in January 2010 downstream of the confluence with Spring Creek. Using the estimate of mean chloride concentrations and summing chloride mass for all water budget components in the upper-piedmont zone, assuming that the mean chloride concentration of precipitation was $0.6 \mathrm{mg} / \mathrm{L}$, the estimated groundwater flow leaving the zone was $200 \mathrm{acre}-\mathrm{ft} / \mathrm{yr}$, about half that estimated for table 11, but within the uncertainty of that estimate.

\section{Lower-Piedmont and Valley-Lowland Zones}

The lower-piedmont zone is similar in characteristics to that of Baker and Lehman Creek drainage basins. The zone extends from the Quaternary fault downstream of the Snake 5 wells to east of the Nevada-Utah state line (fig. 35). The valley-lowland zone includes only a small part of the Snake Creek drainage basin, near Garrison, Utah. Snake Creek is diverted for irrigation, along with groundwater pumping in basin-fill deposits, on the Utah side of the lower-piedmont zone and in the valley-lowland zone. The combined younger and older basin-fill deposits were at least 1,600 ft thick at the UGS site PW01 (fig. 42).

Most of the water passing through the lower-piedmont and valley-lowland zones is in Snake Creek. Groundwater flow is primarily through basin-fill deposits, except near the eastern edge, where limestone in the Burbank Hills could allow water in the basin-fill deposits to flow into carbonate rocks (fig. 56). The Quaternary fault caused the limestone on the upthrown side to be placed against coarse-grained sand and gravel in the younger basin-fill deposits. As groundwater flows from discrete fractures in the limestone across the fault to the porous sand and gravel, the increased transmissivity and greater storage capacity in the sand and gravel causes a downward deflection of groundwater flow and a drop in the water table (fig. 56). Groundwater flow along Snake Creek in the valleylowland zone merges with northward-moving groundwater flow beneath Lake Creek. Much of this flow is through fractured limestone rocks that underlie the alluvial deposits at a relatively shallow depth or are in contact with alluvial deposits to the east along the Burbank Hills.

Little, if any, water from precipitation contributed to flow in Snake Creek or recharged groundwater in the lowerpiedmont and valley-lowland zones. Streambed seepage from Snake Creek added some water to groundwater beneath the creek but was limited by the low vertical hydraulic conductivity of the streambed. Some groundwater could move downward to the underlying limestone or move laterally in limestone near the base of the Burbank Hills (fig. 56), which could be the principal reason for the lower groundwater levels in the valley-lowland zone compared with those in the Lehman and Baker Creek drainage basin. No water budget was developed for the lower-piedmont and valley-lowland zones because streamflow losses and groundwater pumping were not estimated in Utah. 


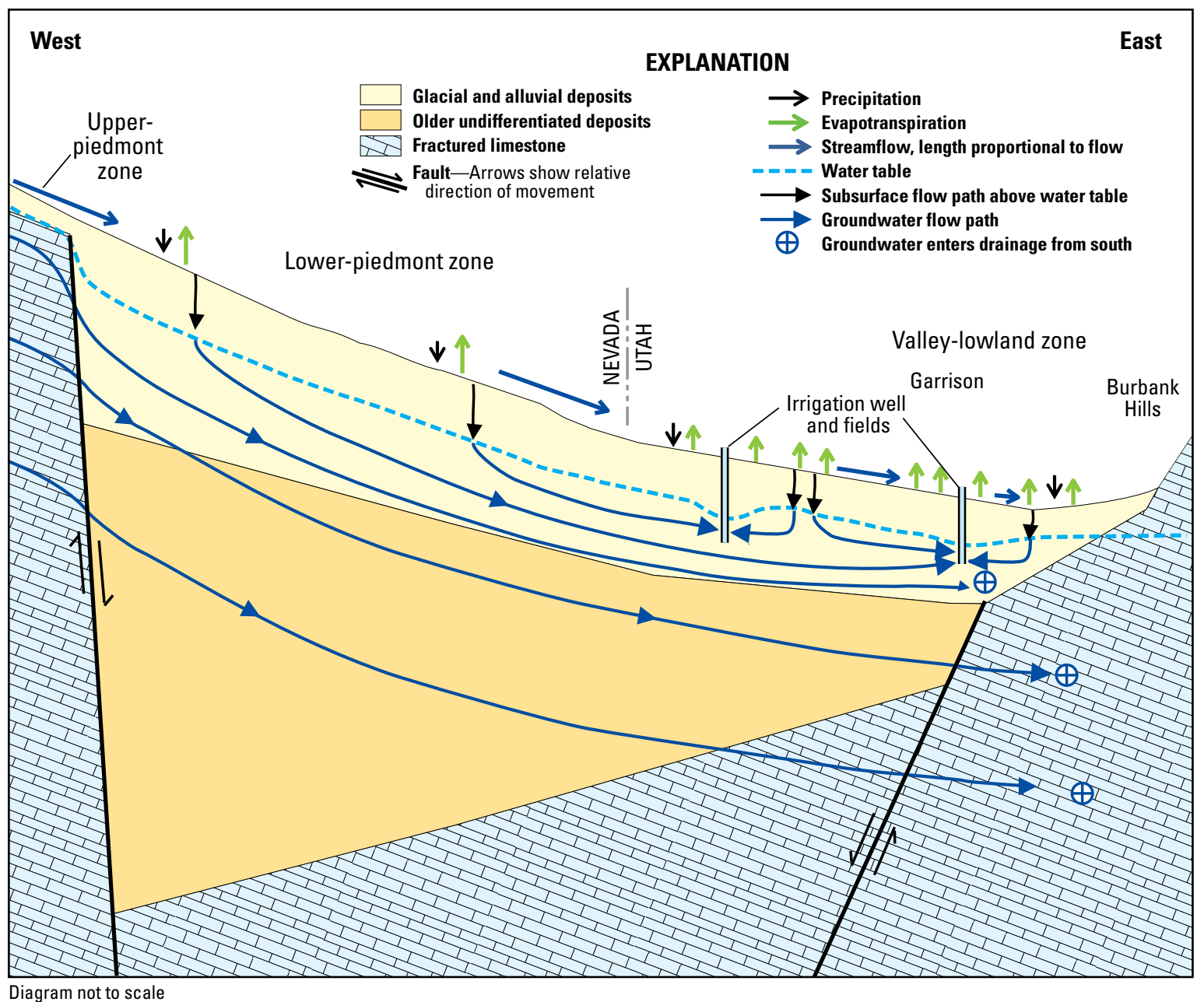

Figure 56. Idealized cross section showing flow along Snake Creek in the lower-piedmont and valley-lowland zones, White Pine County, Nevada and Millard County, Utah.

\section{Streambed-Seepage Rates}

The streambed-seepage rate along reach 5 estimated from discharge measured on February 25, 2010, from near the Snake 5 wells to the Nevada-Utah state line, was $-0.7 \mathrm{ft} / \mathrm{d}$ (table 12). Although the estimated streamflow loss for the reach on July 21, 2009, was the same as the loss on February 25,2010 , the uncertainty for the discharge measurements precluded an estimate of the streambed-seepage rate. The mean streamflow loss between the gaging stations at the confluence with Spring Creek and at the Nevada-Utah state line, operated from January 9, 2003, to September 30, 2004 (fig. 41), was $-0.7 \mathrm{ft}^{3} / \mathrm{s}$. Assuming a mean streambed area between the two gaging stations of $115,000 \mathrm{ft}^{2}$, an average streambed-seepage rate for the 3.1-mi long reach was $-0.5 \mathrm{ft} / \mathrm{d}$.

The net streambed-seepage rates estimated from streamflow losses were similar to streambed-seepage rates at piezometers PS10 and PS9 (table 13) estimated by using the temperature-amplitude ratio method described in appendix 14. Diurnal temperature fluctuations were greatest in the creek and decreased and lagged at the bottom of the piezometers from the end of August to mid-September 2009 (fig. 57). Although diurnal temperature fluctuations in the creek at PS9 from January 1 to 14,2010 , were about half the range of those during September 2009, fluctuations in the piezometer were even more attenuated, which resulted in a streambed-seepage rate that was half that calculated for September 2009. The gradual decrease in streambed-seepage rates at PS9 shown in fig. 57 indicated that the streambed was disturbed by pounding the piezometer into the streambed, which slowly resealed.

\section{Hydraulic Conductivity of Streambed}

The lateral hydraulic conductivity at piezometers PS10 and PS9 differed by an order of magnitude (table 13). Vertical hydraulic conductivities at PS10 and PS9 were estimated by dividing the daily streambed-seepage rate estimated from diurnal temperature fluctuations by the daily mean hydraulic gradient between the creek and the mid-point of the screened interval of the piezometers. The hydraulic gradient through 

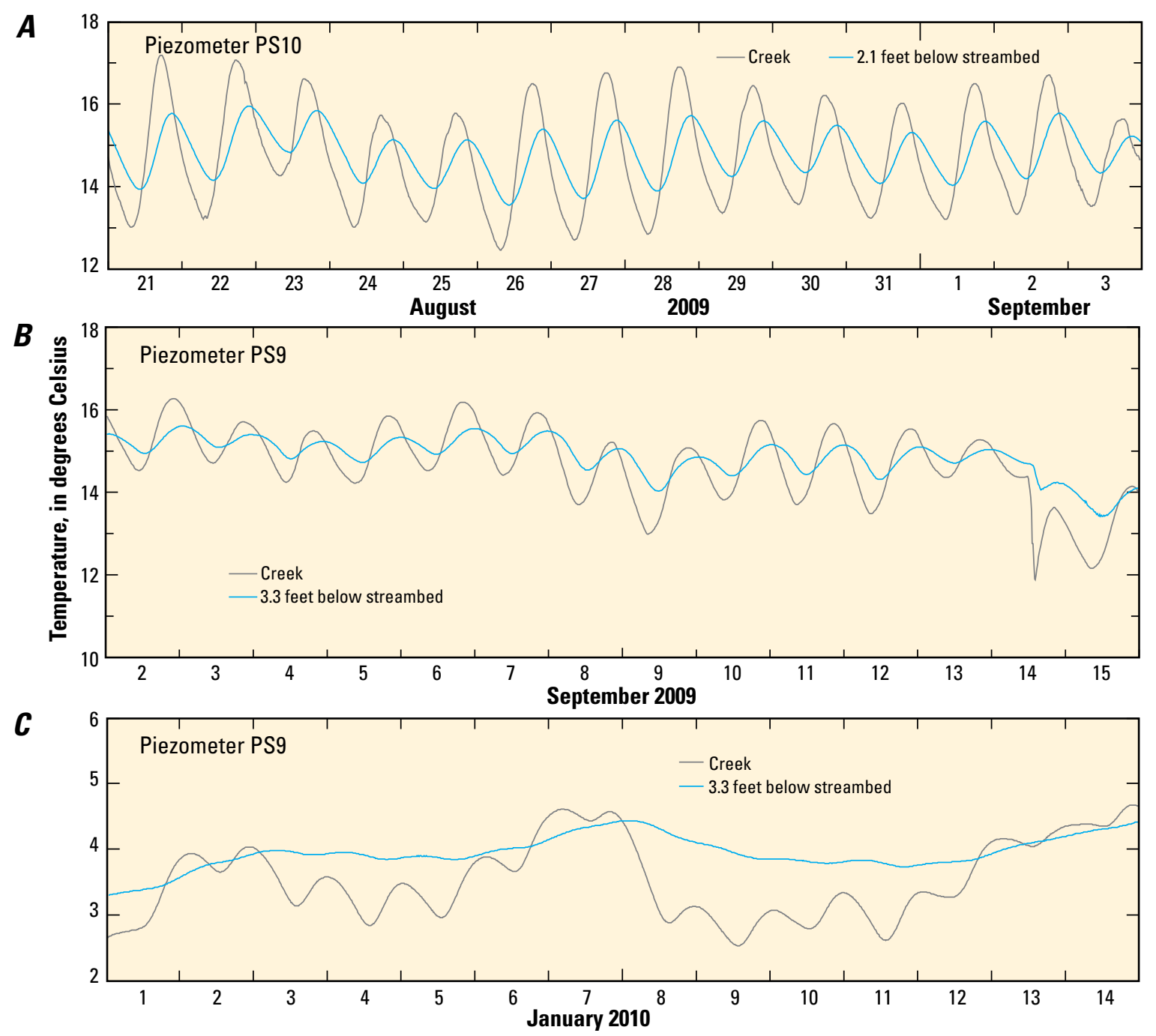

Figure 57. Streambed temperatures at piezometers PS10 and PS9 in upper-piedmont zone of Snake Creek, downstream of Great Basin National Park, White Pine County, Nevada, for selected 2-week periods: $A$, PS10 from August 21, 2009, to September 3, 2009; $B$, PS9 from September 2 to 15, 2009; and C, PS9 from January 1 to 14, 2010.

the streambed at PS10 and PS9 was negative, indicating downward flow through the streambed (fig. 58). The pressure transducer in the creek at PS10 was removed on September 4, 2009, and, from September 4, 2009, until February 25, 2010, the daily mean stage was estimated by using the stage at PS9 corrected to manual measurements. The hydraulic gradient at PS9 rapidly became more negative after the piezometer was driven into the streambed in June 2009, then gradually continued becoming more negative. It was $-1 \mathrm{ft} / \mathrm{ft}$ in January and February 2010. This was caused by a greater decrease in the water level in the piezometer than in the stream stage (fig. 58). The gradual increase in the hydraulic gradient was consistent with a gradual sealing of the streambed following the installation of the piezometer causing a corresponding decrease in the streambed-seepage rate, as estimated from diurnal temperature fluctuations. The hydraulic gradient at PS10 was measured through September 4, 2009, and estimated afterwards. The increase in the piezometer water levels, starting in September 2009 and peaking in November 2009, was unexplained, but could be caused by a reduction in evapotranspiration losses along the creek facilitating an increase in lateral groundwater flow in the streambed beneath the creek.

The mean vertical hydraulic conductivity at PS10 was $0.6 \mathrm{ft} / \mathrm{d}$ between July 22, 2009, and September 3, 2009. The mean vertical hydraulic conductivity at PS9 was $0.9 \mathrm{ft} / \mathrm{d}$ between June 25, 2009, and February 24, 2010. The values at both piezometers were nearly the same as the mean vertical hydraulic conductivity estimated from streambed-seepage rates derived from discharge measurements (see previous section) assuming gravity drainage beneath the streambed and a vertical hydraulic gradient of $-1 \mathrm{ft} / \mathrm{ft}$. Thus, the vertical hydraulic conductivity of the streambed along Snake Creek in the lower-piedmont zone was much less than the lateral hydraulic conductivity estimated from slug tests, which further 


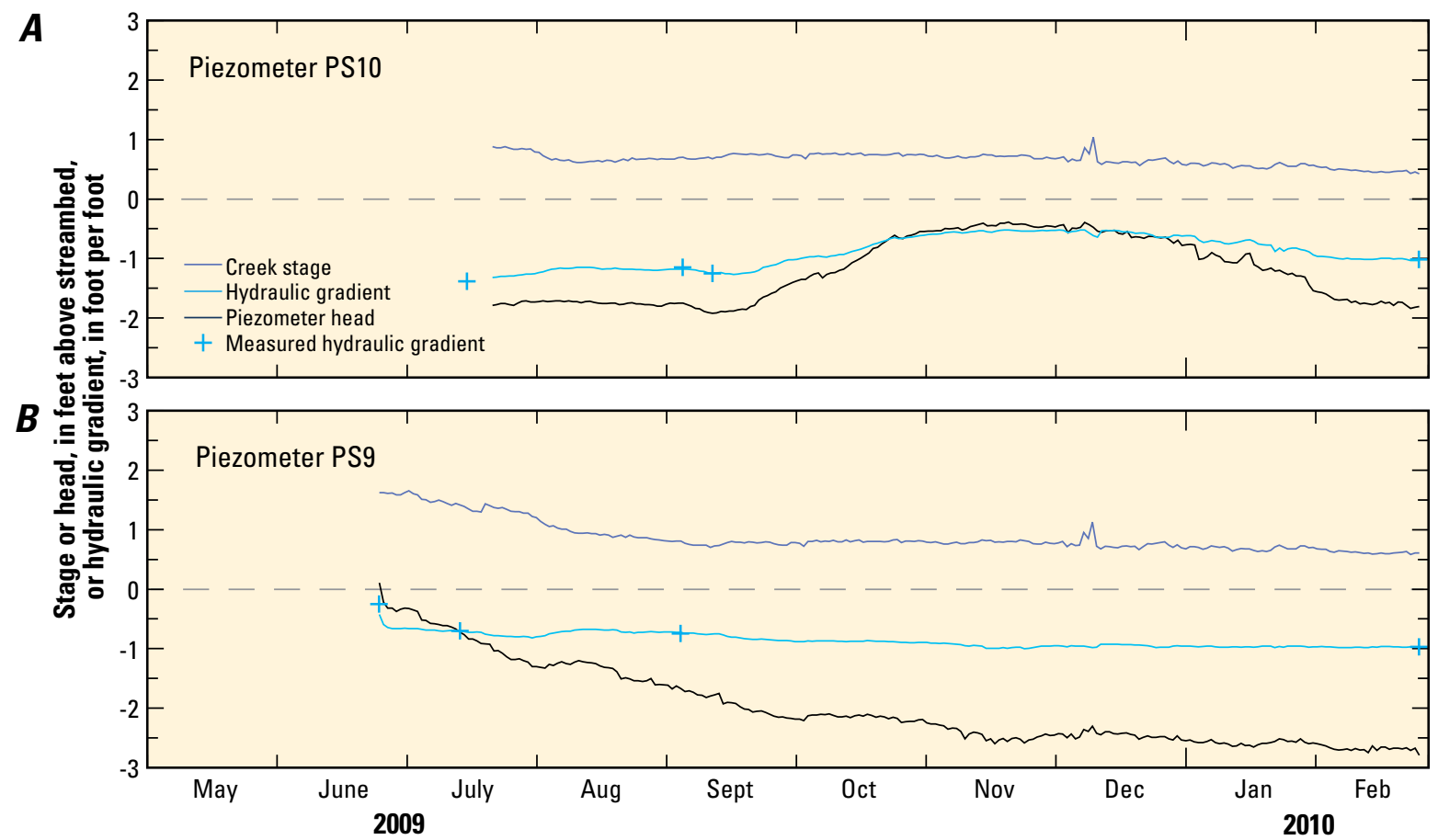

Figure 58. Daily mean stream stage, piezometer head above streambed, and daily mean and measured hydraulic gradient at piezometers in Snake Creek in the lower-piedmont zone, downstream of Great Basin National Park, White Pine County, Nevada, between May 2009 and February 2010: $A$, piezometer PS10; and B, piezometer PS9.

indicated clogging of the streambed from infiltration of fine sediments and chemical precipitation of calcite in the streambed (Dotson, 2010).

\section{Aquifers}

No information about groundwater is available in the lower-piedmont zone of Nevada. One test boring was drilled to a depth of $200 \mathrm{ft}$, as part of the U.S. Air Force's MX missile-siting investigation in the early 1980s, near the drainage divide between Snake Creek and Big Wash midway between the Quaternary fault and the Nevada-Utah state line (Tumbusch and Schaefer, 1996; fig. 42). The test boring did not encounter groundwater, so no well was installed.

The UGS installed three nested wells in a hole drilled just east of the Nevada-Utah State line and about $0.75 \mathrm{mi}$ north of Snake Creek (site PW01, fig. 42; well location and data were obtained from UGS, http://apps.geology.utah.gov/groundwater/map.php?proj_id=1, accessed July 20, 2012). The three nested wells range in depth from 250 to $1,617 \mathrm{ft}$, and each has a 20 -ft long screen. The near-surface deposits are mostly sand and gravel, as indicated from the lithologic log at PW01 The deposits become finer-grained with increasing depth and grade to mixtures of sand, silt, and clay.

Mean annual seepage from the streambed to the basin-fill between the Quaternary fault and the Nevada-Utah state line was estimated to be about 400 acre- $\mathrm{ft}$ from the difference in estimated mean annual discharge at the SNWA gaging station near the Quaternary fault and the gaging station at the
Nevada-Utah state line (table 1). Much of this loss recharged the underlying groundwater because the estimated mean annual evapotranspiration is only about 20 acre-ft. Evapotranspiration was estimated for the 1.6-mi reach by assuming an annual water loss of $6 \mathrm{ft}$ (72 in.) and a 10-ft swath of riparian vegetation on both banks of the creek, for a total width of $20 \mathrm{ft}$. Combining the estimate of groundwater flow from the upper-piedmont zone (table 11) and recharge from seepage through the streambed of Snake Creek produced an estimated mean annual groundwater flow from Nevada to Utah of about $800 \mathrm{acre}-\mathrm{ft}$, or about $1 \mathrm{ft}^{3} / \mathrm{s}$. Therefore, the total annual water yield in the Snake Creek drainage basin across the NevadaUtah state line was about 4,800 acre-ft, of which more than 80 percent was streamflow.

\section{Water-Level Trends in Basin-Fill Deposits}

Water-levels in the nested wells at site PW01, about 0.75 mi north of Snake Creek, showed similar trends, and the depth to water below land surface in a well $250 \mathrm{ft}$ deep and in another $995 \mathrm{ft}$ deep were nearly the same (fig. 59A). The water level in the deepest well (depth of 1,617 ft) was lower than the shallower wells, and measurements indicated slow recovery after pumping the well. Although no tests of transmissivity for the three nested wells at PW01 have been published, the deepest well had a low transmissivity on the basis of this slow recovery. In part, the slow recovery could result from inadequate purging of drilling mud following completion of the well (Hurlow, 2014), but the sediments next to the well screen 
had a large fraction of clay as well. The rapid rise in water levels from mid-June to mid-July (fig. 59A) corresponded to a rapid rise in water levels in the fractured limestone in the Snake 5 deep well (fig. 55). Similar trends in peak water levels indicated that groundwater was able to move from the fractured limestone across the Quaternary fault to the basin-fill deposits relatively quickly. The lesser water-level rise in the basin-fill deposits reflected the greater storage capacity of the basin-fill deposits.

Water levels rose gradually in all three nested wells at site AG13 from November 2009 to April 2010 (fig. 59B), but the water-level rises in the two deeper wells were greater (Data for wells at site AG13 were accessed from UGS, http://apps. geology.utah.gov/groundwater/map.php?proj_id=1). accessed July 20, 2012 The reason for this is the deeper wells were confined. The shallow well was screened at the water table; the screened interval was 65 to $85 \mathrm{ft}$ below land surface, and the water level rose from about $70 \mathrm{ft}$ below land surface in November 2009 to $65 \mathrm{ft}$ in April 2010. Sharp water-level rises were measured from the end of May to mid-June, during mid-July, and again in mid-August 2011. These rises took place during a period of generally declining water levels and indicated that nearby groundwater pumping ceased, perhaps, for cutting of alfalfa (Gretchen Baker, Great Basin National Park, Baker, Nev., written commun., 2013).

The greater-than-normal depth to water in wells in the valley-lowland zone indicated (1) little infiltration of water from Snake and Lake Creeks and from irrigated fields, (2) groundwater pumping for irrigation lowered groundwater levels, (3) downward or lateral water movement from the basinfill deposits to fractured limestone that crops out in the nearby Burbank Hills, or (4) a combination of these possibilities.

Water-level altitudes in wells from fractured limestone in the lower end of the upper-piedmont zone (Snake 5 deep

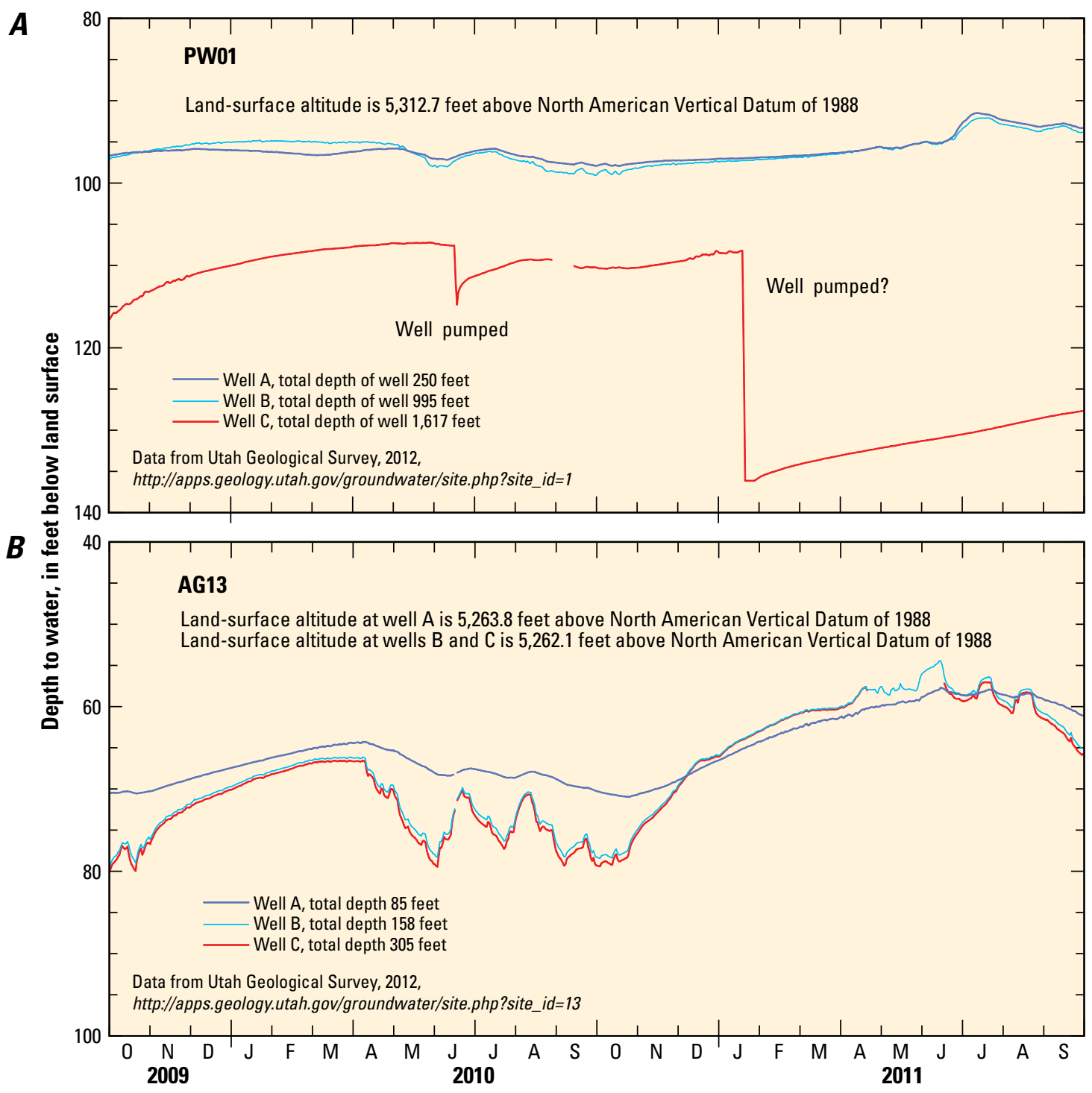

Figure 59. Daily mean depth to water in Utah Geological Survey monitoring wells in lower-piedmont and valley-lowland zones of Snake Creek drainage basin near Garrison, Millard County, Utah, 2009-11: A, PW01; and B, AG13. 
well) through the basin-fill deposits in the lower-piedmont and valley-floor zones indicated that groundwater flow beneath Snake Creek is parallel to the slope of the creek (fig. 60A). The daily mean hydraulic gradient was calculated between wells at four monitored sites from October 1, 2009, to September 30, 2011 (fig. 60A). The mean hydraulic gradient between the Snake 5 deep well and the shallow well at PW01 was $0.03 \mathrm{ft} / \mathrm{ft}$. The maximum hydraulic gradient was estimated during the peak water level at the Snake 5 deep well, which was on June 26, 2011. The peak water level in the shallow well at PW01 lagged 17 days and was reached on July 13, 2011. The mean hydraulic gradient between the Snake 5 deep well and the shallowest well at PW01 was more than those between shallow wells at PW01 and AG13 and AG13 and PW03, where the mean hydraulic gradient was 0.007 and $0.008 \mathrm{ft} / \mathrm{ft}$, respectively. Water-level data for wells PW01, AG13, and
PW03 were obtained from the UGS, http://apps.geology.utah. gov/groundwater/map.php?proj_id=1; accessed July 20, 2012.

\section{Hydraulic Properties of Deposits and Rocks}

Data about the hydraulic properties of the basin-fill deposits in the lower-piedmont and valley-lowland zones were limited to wells drilled in Utah (table 16). Only one well in the lower-piedmont zone had a specific capacity estimate. In 2007, the UGS drilled a well into fractured limestone near the base of the Burbank Hills encountered considerable water, but no specific-capacity estimate was available (Utah Geological Survey, http://files.geology.utah.gov/esp/snake_valley_project/ logs/lithologic/UGS-PW03AB-lithlog.pdf, accessed July 20, 2012). All other well-drillers' logs that had specific-capacity estimates were in the valley-lowland zone. The estimated

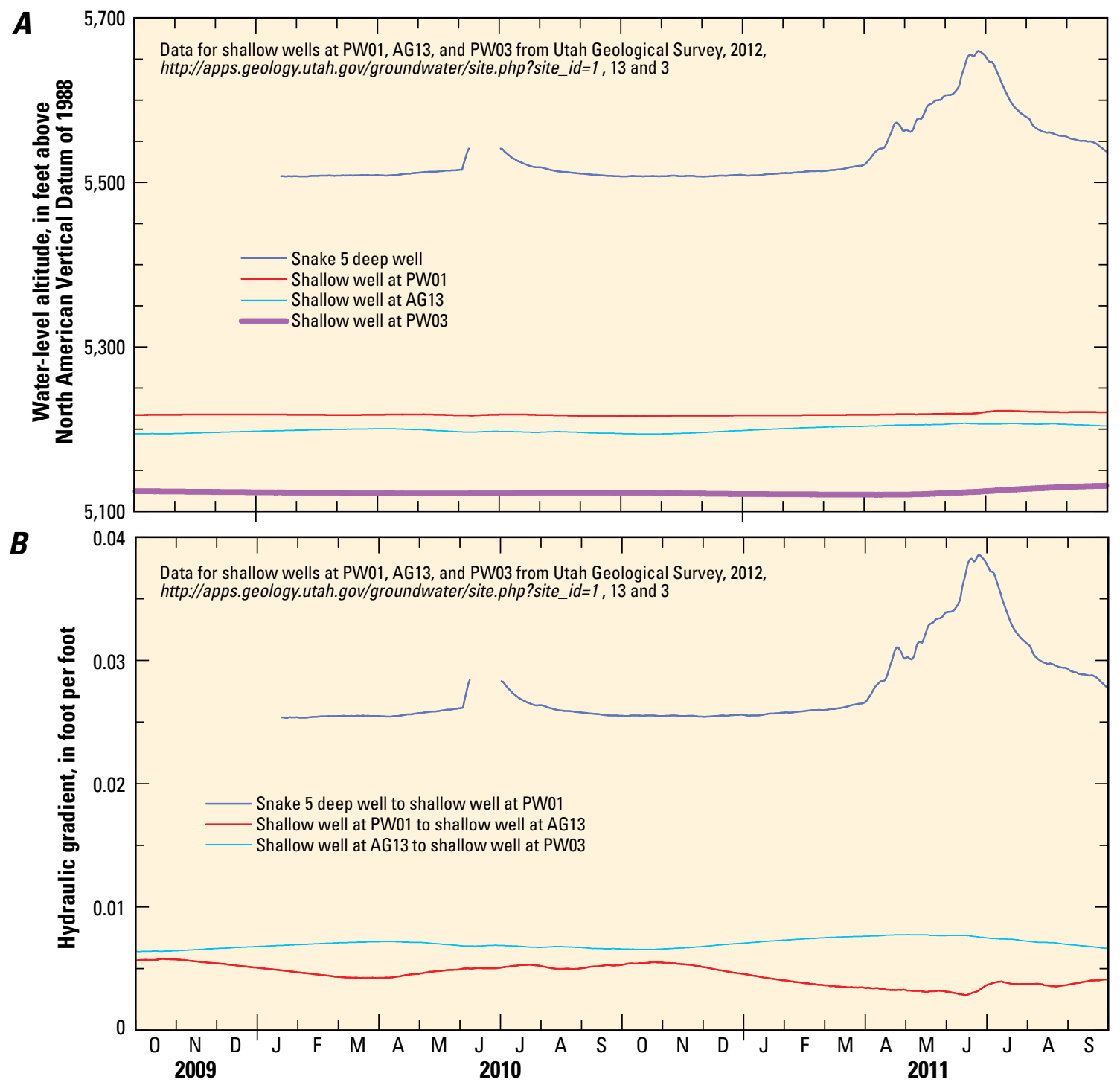

Figure 60. Well data from fractured limestone in upper-piedmont zone through basin-fill deposits in lower-piedmont and valley-lowland zones in the Snake Creek drainage to fractured limestone in the Burbank Hills, White Pine County, Nevada and Millard County, Utah, October 1, 2009, to September 30, 2011: $A$, water-level altitude; and B, hydraulic gradient. 
transmissivity for the well in the lower-piedmont zone ranged from 3,000 to $4,000 \mathrm{ft}^{2} / \mathrm{d}$, assuming the storage coefficient ranged from 0.01 to 0.0002 . The transmissivities for six wells in the valley-lowland zone for which specific capacities were estimated ranged from 70 to $12,000 \mathrm{ft}^{2} / \mathrm{d}$. No aquifer tests were available to evaluate the effect of well loss on the transmissivity estimates. Consequently, transmissivity could be greater than reported in table 16. An order of magnitude increase in transmissivity from the fractured limestone in the upper-piedmont zone to the basin-fill deposits in the lowerpiedmont and valley-lowland zones was supported by a similar decrease in the hydraulic gradient, indicating that much of the change in the hydraulic gradient between zones was the result of an increase in transmissivity in the basin-fill deposits on the downthrown side of the Quaternary fault.

\section{Summary}

The drainage basin was divided into five zones to help understand the nature of the groundwater connection between the mountain and valley in the Snake Creek drainage basin and its relation to surface water: mountain upland, karst limestone, upper piedmont, lower piedmont, and valley lowland. The primary hydrologic connection between the wet mountain-upland zone and the dry valley-lowland zone is runoff from Snake Creek, which composed nearly 80 percent of the mean annual water yield (runoff and groundwater flow) across the NevadaUtah state line from the Snake Creek drainage basin.

In the mountain-upland zone, granite and quartzite are covered by thin soil or by thin glacial and alluvial deposits, which limit groundwater flow. The only inflow to the mountain-upland zone is precipitation, and outflows are evapotranspiration and runoff to the karst-limestone zone.

Groundwater flow increased in the karst-limestone zone, primarily, because of increased permeability of the karst and fractured limestone. The increased permeability resulted in a net mean annual streamflow loss of about 100 acre- $\mathrm{ft}$, even though more precipitation fell in this zone than in the mountain-upland zone. Groundwater flow in the karst-limestone zone was through tilted and faulted blocks of Paleozoic rock that overlie the southern Snake Range detachment fault. The juxtaposition of varying stratigraphic units in these faulted blocks resulted in alternating losing and gaining reaches along Snake Creek. The estimated outflow from the karst-limestone was not in balance with the inflow, indicating that much of the flow at Spring Creek Spring on the south end of the drainage basin was groundwater flow from the Big Wash drainage basin.

In the upper-piedmont zone, a shallow unconfined aquifer in the younger basin-fill deposits associated with Snake Creek was separated from a confined aquifer in the fractured limestone by less permeable older basin-fill deposits. The water table in the younger deposits was higher than or near the stage in Snake Creek for a distance of at least $500 \mathrm{ft}$ downstream of the Tertiary fault because of streamflow gains. The water level in the shallow alluvial deposits remained near the stream stage until downstream from the confluence with Spring Creek, where water levels in piezometers were lower, and the vertical hydraulic gradient of the streambed was about $-1 \mathrm{ft} / \mathrm{ft}$. These negative gradients did not result in greater streambed-seepage rates. The mean streambed-seepage rate was between -0.5 and $-0.7 \mathrm{ft} / \mathrm{d}\left(\mathrm{ft}^{3} / \mathrm{d} / \mathrm{ft}^{2}\right)$.

Results from a geochemical investigation of water in Snake Creek and of the streambed sediments indicated the streambed was cemented by calcite precipitated after off-gassing of excess carbon dioxide gas downstream of springs at the Tertiary fault (Dotson, 2010). This takes place from late summer to winter, when all the streamflow in Snake Creek comes from groundwater flow to springs along the fault.

Comparison of water chemistry from samples at the Snake 5 deep well with that of other water samples in the drainage basin indicated that most of the water in the deep well was from flow through fractured limestone beneath younger and older basin-fill deposits (Dodson, 2010). The chemistry of water from Snake Creek downstream of its confluence with Spring Creek and from a domestic well in younger basin-fill at the NDOW Spring Creek fish-rearing station collected in January 2010 differed sufficiently from the water chemistry at the Snake 5 deep well that they were not its likely sources, nor were mixtures of water from these sites with water from Spring Creek Spring or from groundwater where it enters Snake Creek near the Tertiary fault. The tritium concentration in water from the Snake 5 deep well indicated a mean age of 4 to 7 years and relatively rapid transport through open fractures in limestone in the upper-piedmont zone, even though this flow was a fraction of the streamflow in Snake Creek.

The lower-piedmont zone is separated from the upperpiedmont zone by a Quaternary fault associated with a rapid thickening of the younger basin-fill deposits. The fault resulted in fractured limestone lying next to younger basin-fill deposits. The greater transmissivity and higher storage capacity of the basin-fill deposits relative to the limestone resulted in a lowering of the water table across the fault. An order of magnitude increase in transmissivity in the younger basin-fill deposits compared to the limestone was supported by a corresponding decrease in the lateral hydraulic gradient in the younger basinfill deposits.

Depth to water in the valley-lowland zone was more than $50 \mathrm{ft}$ below land surface, which precluded much groundwater loss to evapotranspiration. Fractured limestone underlies the basin-fill deposits in the valley-lowland zone, but is next to the basin-fill deposits along the Burbank Hills to the east. Water levels in monitoring wells in the fractured limestone next to the Burbank Hills were lower than water levels in basin-fill deposits beneath the valley-lowland zone, indicating groundwater flows across the valley-lowland zone to the fractured limestone in the Burbank Hills east of Garrison, Utah. Thus, groundwater flows from the karst-limestone zone in the Snake Range to the valley-lowland and to the fractured limestone in the Burbank Hills, where it merges with northward-flowing groundwater. Groundwater flow from the karst-limestone 
zone in GBNP to the valley-lowland zone in Utah is limited by the relatively low transmissivity of the fractured limestone beneath the upper-piedmont zone. The low transmissivity reflects the small percentage of open fractures and the concomitant small confined storage coefficients (on the order of $\left.10^{-6}-10^{-9}\right)$. These small confined storage coefficients result in large aquifer diffusivity, however, which allows for rapid head changes to propagate quickly in the fractured limestone beneath the upper-piedmont zone.

\section{Big Springs}

\section{Physical Characteristics}

The southern study area focused on Big Springs at the south end of Snake Valley and included potential source areas to the springs from the south end of the Snake Range and from southern Spring Valley as groundwater flow beneath the Limestone Hills to the south and across northern Hamlin Valley (fig. 61). Northern Hamlin Valley merges with southern Snake Valley.

All mountain drainage basins along the southern Snake Range south of Lexington Creek are ephemeral. The largest of these ephemeral drainage basins is Big Spring Wash, which drains to northern Hamlin Valley before turning northeast and joining northward-trending Hamlin Valley Wash near southern Snake Valley (fig. 61). Hamlin Valley Wash is a long, northnortheast trending ephemeral channel that drains northward along the topographic axis of Hamlin Valley. Big Spring Wash forms a large alluvial fan where the toe extends from Big Springs southeast at least $3 \mathrm{mi}$ to the middle of northern Hamlin Valley. Big Spring Wash is deeply incised in the upper part of the fan, indicating it had major periods of flow in the past. During 2002-04, a gaging station was operated on Decathon Canyon, a tributary to Big Spring Wash (fig. 61), where flow was recorded only on 2 days during that period; the daily mean discharge for those days was $0.1 \mathrm{ft}^{3} / \mathrm{s}$ (Elliott and others, 2006, p. 15).

The group of springs known as Big Springs was called "Big Spring" from the late 1800s to the 1960s (Wheeler and Lockwood, 1875; Meinzer, 1911; Hood and Rush, 1965). Big Springs has the most flow of all springs on the east side of the southern Snake Range (fig. 61). Two groups of spring orifices and smaller seeps form two main channels that are the headwaters of Big Springs Creek. The springs have been interpreted to be controlled by a series of north-northeast striking faults that have Quaternary displacement (Kistinger and others, 2009; Rowley and others, 2009). These faults form a prominent break in slope between the fans and lowlands in southwestern Snake Valley (Kistinger and others, 2009). The springs are near the convergence of the foot of a large alluvial fan formed by Big Spring Wash with steep alluvial fans formed by lesser drainage basins along the southeast front of the Snake Range.
Several springs are present near the toe of the alluvial fans in an area that extends north from Big Springs along the west side of Big Springs Creek to the Nevada-Utah state line (fig. 61). Additional springs also are present southeast of Big Springs at the foot of the alluvial fan formed by Big Spring Wash. Big Springs is about 5,570 ft above mean sea level. The springs north of Big Springs are nearly at this same altitude, whereas the springs to the southeast are 5 to $10 \mathrm{ft}$ lower. The springs roughly define the western and southern edge of an area of phreatophytes and meadows that are supported by springs and shallow groundwater.

Flow at Big Springs and from smaller nearby springs produces perennial flow down the water course that is called Big Springs Creek in Nevada and Lake Creek in Utah (fig. 61). Another group of springs near the Nevada-Utah state line, called Dearden Springs (Bunch and Harrill, 1984), and more recently called Stateline Springs (Southern Nevada Water Authority, 2012), are on both sides of the creek as well as in the creek channel. Discharge downstream of the springs was reported at $18 \mathrm{ft}^{3} / \mathrm{s}$ in the early 1900s (Meinzer, 1911, p. 129) and ranged from 15 to $19 \mathrm{ft}^{3} / \mathrm{s}$ between June and November 1972 (Walker, 1972). The mean discharge in the two main ditches (East and West middle) averaged $15.7 \mathrm{ft}^{3} / \mathrm{s}$ between October 1, 2009, and September 30, 2011 (table 1). Flow in Lake Creek continues northeastward to Pruess Lake, where, at high water levels, water is held behind a small dam and released during spring and summer for irrigation of fields at Garrison, Utah. Both Big Springs Creek in Nevada and Lake Creek in Utah, upstream of Pruess Lake, are diverted and used for irrigation of natural pasture, which affects streamflow along the creeks.

\section{Spring Flow}

Much of the flow of Big Springs Creek in its upper reaches originates at two main spring orifices about $50 \mathrm{ft}$ apart. Discharge from each of the orifices has been recorded since 2005 at USGS gaging stations named Big Springs Creek south channel and Big Springs Creek north channel (USGS site numbers 10243224 and 102432241, respectively). The gaging station in the south channel has been continuously recording discharge since May 2005, and its overall record is considered to be fair to good. The gaging station in the north channel has been continuously recording discharge since October 2005, and its overall record is considered to be poor to fair. The reason for the poor quality of record at the north channel gaging station is that aquatic vegetation frequently chokes the stream channel and interferes with the control. The two channels join to form the headwaters of Big Springs Creek about $50 \mathrm{ft}$ east of the two gaging stations.

Daily mean discharges in the south channel ranged from a maximum of $7.2 \mathrm{ft}^{3} / \mathrm{s}$ on December 6,2006 , to a minimum $5.1 \mathrm{ft}^{3} / \mathrm{s}$ during June 29-July 2, 2009 (fig. 62). The mean discharge from May 1, 2005, to September 30, 2011, was $6.1 \mathrm{ft}^{3} / \mathrm{s}$ (table 1). Daily mean discharge in the north channel ranged from a maximum of $5.9 \mathrm{ft}^{3} / \mathrm{s}$ on May 22, 2007, to a minimum 


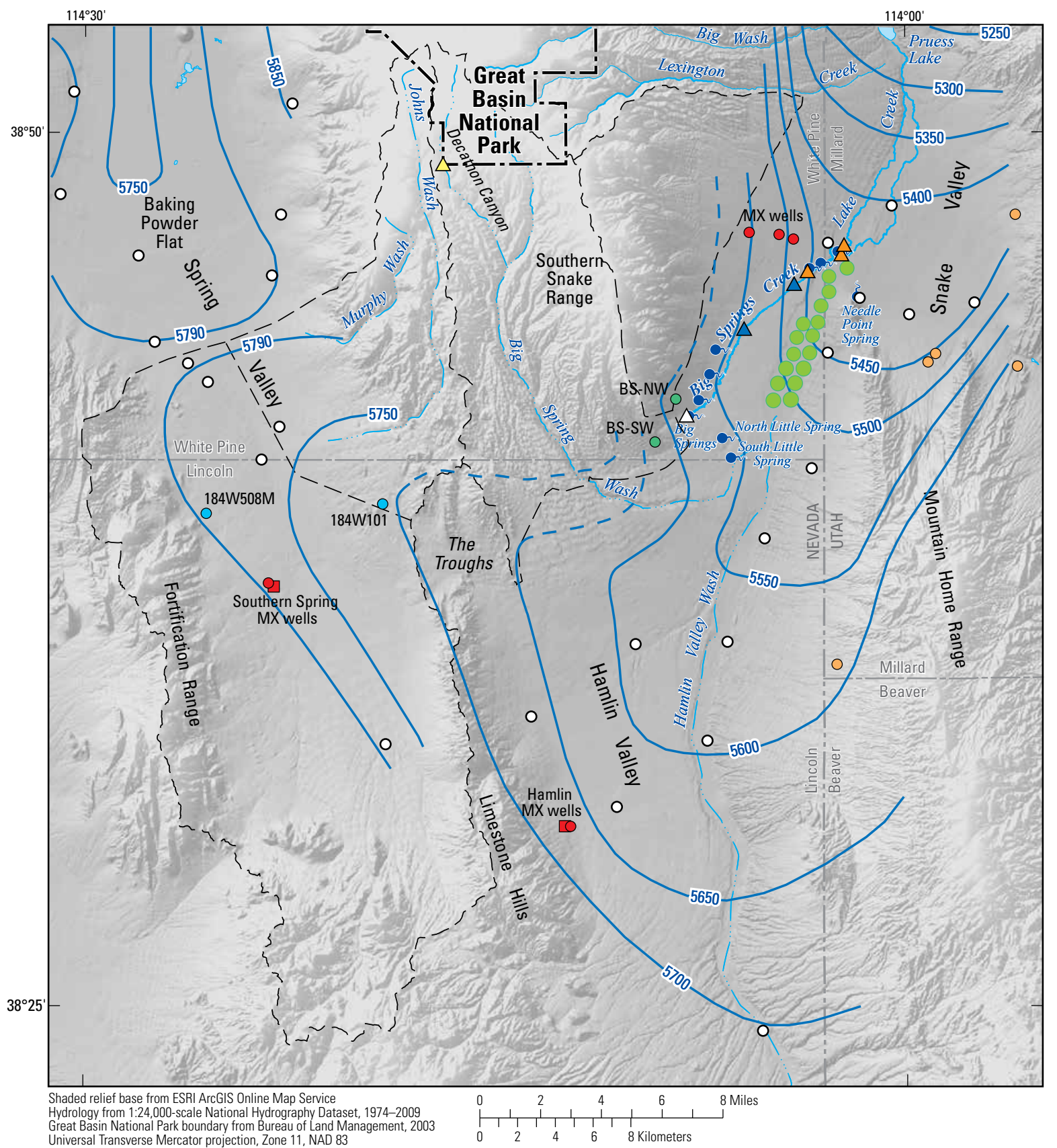

Great Basin National Park boundary from Bureau of Land Management, 2003
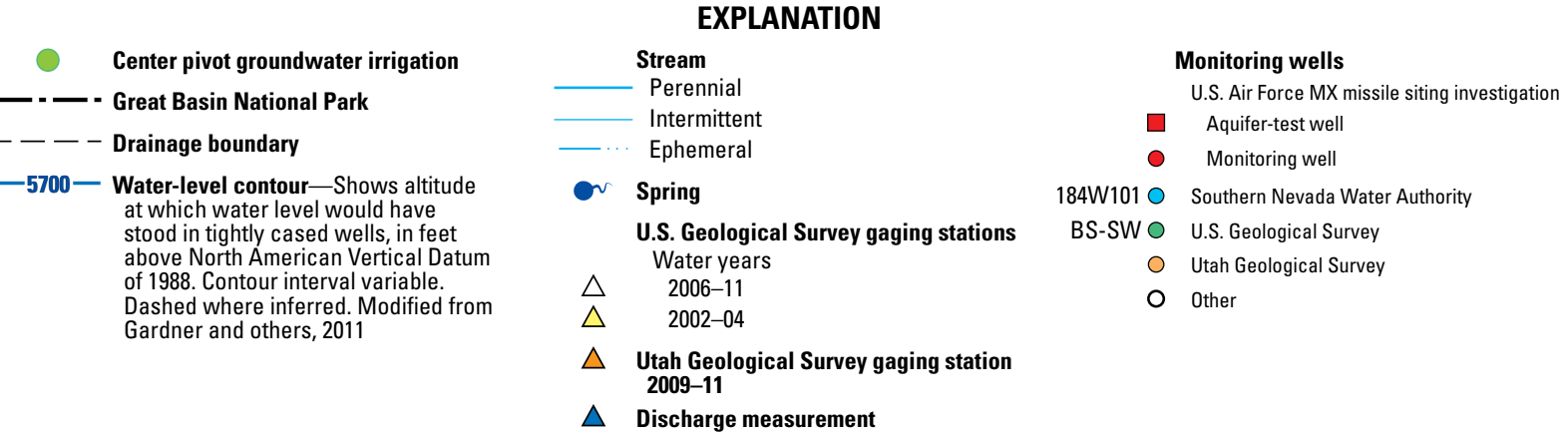

Figure 61. Location of Big Springs in southern Snake Valley, Big Spring Wash at the south end of the Snake Range in northern Hamlin Valley, Limestone Hills that divide southern Spring Valley from northern Hamlin Valley, and water level contours that depict a groundwater divide in southern Spring Valley, south of Baking Powder Flat, Lincoln and White Pine Counties, Nevada. 
of $2.8 \mathrm{ft}^{3} / \mathrm{s}$ on several days in October 2005 and March 2006 and on March 8, 2007. The mean discharge from October 1, 2005, to September 30, 2011, was $3.8 \mathrm{ft}^{3} / \mathrm{s}$ (table 1). The combined mean discharge of both channels was $9.9 \mathrm{ft}^{3} / \mathrm{s}$.

The combined annual mean discharge of the two channels decreased $0.9 \mathrm{ft}^{3} / \mathrm{s}$ from an annual mean of $10.3 \mathrm{ft}^{3} / \mathrm{s}$ in water year 2007 to $9.4 \mathrm{ft}^{3} / \mathrm{s}$ in water year 2011. The uncertainty in the annual mean from the quality of the records ranged from 5 to 10 percent for the south channel and from 10 to 15 percent for the north channel. Combining these uncertainties with the annual mean discharge of the two channels produced an uncertainty ranging between 0.6 and $1.2 \mathrm{ft}^{3} / \mathrm{s}$. Thus, the apparent decrease in annual discharge was within the uncertainty associated with the combined annual discharge. Daily mean discharge in the south channel was less variable and had less uncertainty (fig. 62), yet the annual mean discharge decreased $0.5 \mathrm{ft}^{3} / \mathrm{s}$ between water years 2007 and 2011, although the value was still in the uncertainty range of $0.3-0.6 \mathrm{ft}^{3} / \mathrm{s}$. A time bias in the combined annual discharge was required to explain the trend, however; otherwise, if the errors were unbiased, the variability in annual discharge would not have shown a trend.
If the trend of decreased discharge was not a bias resulting from the data collection, the apparent decrease in annual mean discharge could have been caused by groundwater pumping. An analysis of groundwater pumping in an area northeast of Big Springs (fig. 61) for 2001-03 was used to estimate the hydraulic properties of the basin-fill and carbonate-rock aquifers that resulted in an estimated a drawdown at Big Springs of about $0.5 \mathrm{ft}$ at the end of the 2003 irrigation season (Dong and others, 2012). The drawdown estimated by the analysis indicated that increased groundwater pumping could explain the decreased flow at Big Springs between water years 2006 and 2011. Whether or not groundwater pumping affected the combined flow at Big Springs is uncertain. Continued monitoring at the gaging stations, along with a few monitoring wells between Big Springs and the area of groundwater pumping, could help identify if the trend of decreasing discharge is related to groundwater pumping.

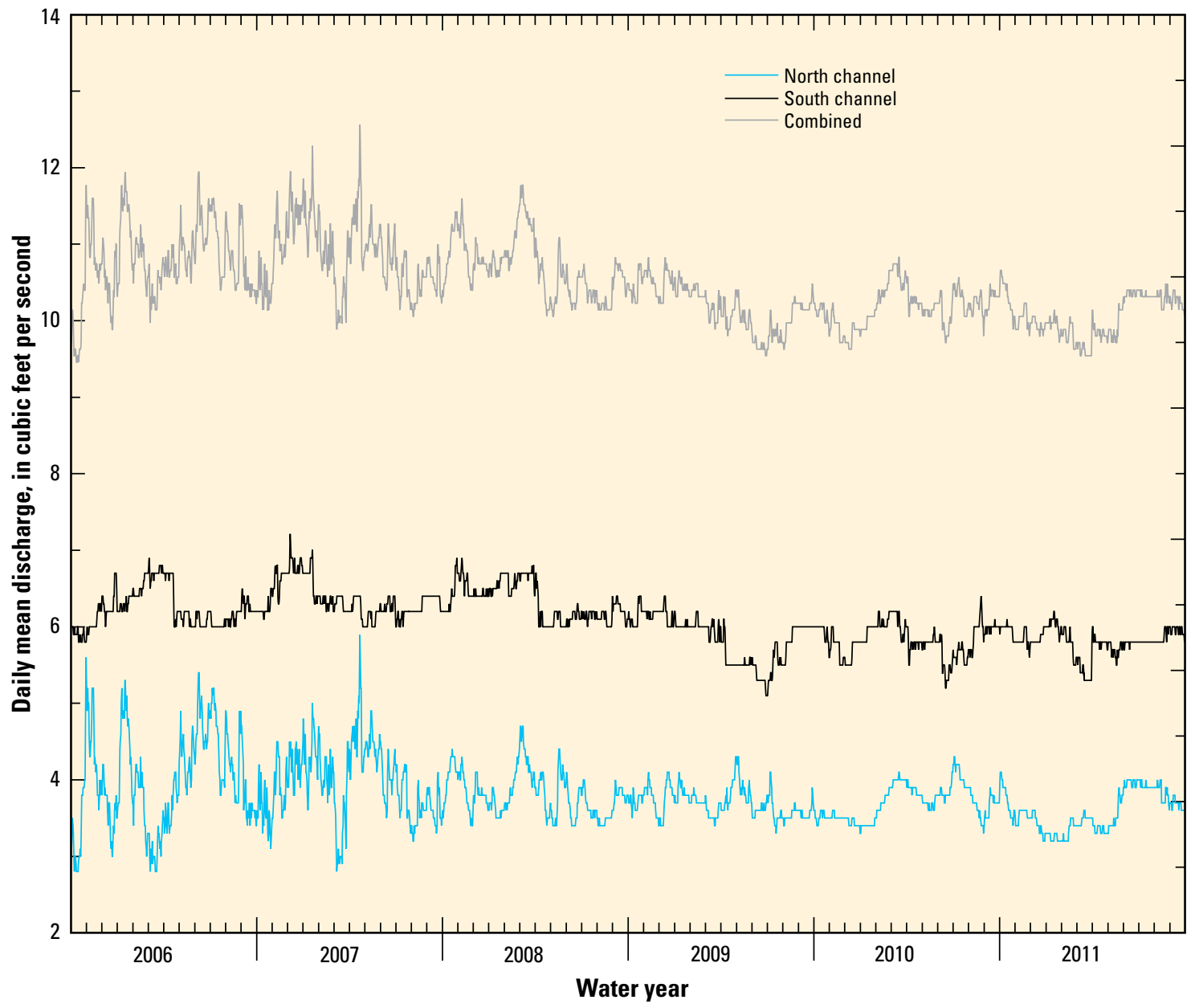

Figure 62. Daily mean discharge in the north and south channels and combined daily mean discharge of Big Springs for water years 2006-11, southern Snake Valley, White Pine County, Nevada. 


\section{Potential Source Area}

The size of the source area that contributes water to Big Springs is uncertain. Precipitation in small drainage basins immediately west of the springs is insufficient to explain flow at the springs. The spring flow could be from the Big Spring Wash drainage basin, which includes a large part of the south end of the Snake Range (fig. 61). Also, some of flow at Big Springs could come from southern Spring Valley (Hershey and others, 2007). Water levels in wells in northern Hamlin Valley were lower than water levels in southern Spring Valley. A groundwater divide (where the hydraulic gradient is zero) in the basin-fill deposits separates northwest-moving groundwater near Baking Powder Flat in southern Spring Valley from southeast-moving groundwater. This groundwater divide, coupled with depth to water in wells greater than $100 \mathrm{ft}$ below land surface, led Rush and Kazmi (1965) to hypothesize that groundwater flows from southern Spring Valley to northern Hamlin Valley because groundwater flow did not return to the surface at springs or was lost to evapotranspiration in southern Spring Valley. The approach in the present study was to evaluate a potential source area to Big Springs that included areas immediately west of the springs, Big Spring Wash drainage basin, and Spring Valley south of the groundwater divide.

\section{Geology}

\section{Distribution of Rocks}

The general geology of the southern study area and the vicinity of Big Springs is shown in figure 63, which was created by merging and modifying a 1:24,000-scale digital geologic map of the GBNP (Brown and Davila, 1995; National Park Service, 2007) with 1:100,000-scale map data in Utah (Hintze and Davis, 2002a, 2002b) and, where no more detailed digital data were available, with 1:500,000-scale geologic map data from Nevada (Stewart and Carlson, 1978; Raines and others, 2003) and Utah (Hintze and others, 2000). In contrast to the upland areas of the northern parts of the southern Snake Range, where granitic and siliciclastic rocks predominate (Whitebread, 1969; National Park Service, 2007), the bedrock geology at the south end of the Snake Range predominantly consists of lower Paleozoic carbonate rocks with minor siliciclastic layers and local faulted sections of Devonian and Mississippian carbonates and Tertiary volcanic rocks (Hose and Blake, 1976; Rowley and others, 2009; fig. 63). The Paleozoic sedimentary section is present in relatively intact east- and southeast-dipping tilt blocks that are bounded by high-angle normal faults. These carbonate-rock tilt blocks form prominent ridge crests to the north, but become lower in altitude toward the south end of the Snake Range, where a low-altitude pass, the Troughs, separates the Snake Range from the Limestone Hills (fig. 63).

The southern Snake Range detachment fault, instrumental in the structural setting of the northern parts of the southern Snake Range, is not exposed at the south end of the range (Miller and others, 1999; National Park Service, 2007; fig. 63).
Map relations and subsurface data indicated that the detachment fault plunges south into the subsurface at the south end of the range (Miller and others, 1999; Shah Alam and Pilger, 1991). Seismic and geologic data indicated that the normal faults along the east side of the southern Snake Range dip moderately to the east; offset on these faults increases southward (Hose and Blake, 1976; Shah Alam, 1990; Rowley and others, 2009).

To the south of the Snake Range, the Limestone Hills form a low bedrock ridge that separates southern Spring Valley from northern Hamlin Valley (fig. 63). The Limestone Hills are mostly Ordovician to Devonian carbonate rocks with gentle east tilts (Hose and Blake, 1976; Rowley and others, 2009). Geologic mapping (Hose and Blake, 1976; Rowley and others, 2009), gravity data (Watt and Ponce, 2007; Mankinen and McKee, 2009), AMT data (Dixon and others, 2007: McPhee and others, 2009), and seismic data (Shah Alam, 1990; Shah Alam and Pilger, 1991) indicated that the Limestone Hills are bounded by normal faults both on the eastern and western sides (fig. 63). The western side of the Limestone Hills is bounded by a young fault that is mapped as having Quaternary offset (Dohrenwend and others, 1996). The eastern side of the Limestone Hills appears to be older because the Hills are generally flanked by alluvial fans that head far into the hills, with no young fault scarps present. Thus, range-bounding faults on the eastern side of the Limestone Hills are either buried under young alluvium or extend far into the basin to the east of the range front (Rowley and others, 2009, plate 1). The Limestone Hills are internally faulted by both northwest- and north-striking faults. North-south striking faults offset the carbonate-rock section by tens to hundreds of feet. Field mapping indicated that some of these faults were, at one point in their history, dilatant and feature blocky, irregular fault breccias, typically cemented by banded calcite vein material. Relatively rare northwest-striking strike-slip faults in the Limestone Hills are tight, closed features with little fault gouge or attendant brecciation. Some of these faults could serve as connectors that transfer displacement between the tips of nearby normal faults.

South of the Limestone Hills, the Wilson Creek Range consists of mostly Oligocene volcanic rocks of the Indian Peak caldera complex (Best and others, 1989a, b). The caldera complex margin trends south-southeast between the Limestone Hills and the Wilson Creek Range (fig. 63); ore deposits of the Atlanta mining district are found at this boundary (Willis and others, 1987). At least four major calderas have been identified in this complex on the basis of the presence of thick, intracaldera tuff sequences and intracaldera collapse megabreccias; two other calderas were inferred from the presence of regionally extensive ash-flow sheets (Best and Grant, 1987; Best and others, 1989a, 2013). The intracaldera rocks south of the caldera margin belong mostly to the Needles Range Group, are probably many thousands of feet thick, and are likely underlain by a buried intrusion (Sweetkind and DuBray, 2008; Best and others, 2013). Volcanic rocks associated with this complex extend northwest to the Fortification Range (fig. 63); outflow tuff from this caldera complex caps the central part of the Mountain Home Range to the east of Hamlin Valley (fig. 63). 
The Mountain Home Range bounds the eastern side of the northern part of Hamlin Valley and consists mostly of folded, middle to upper Paleozoic carbonate rocks (Hintze and Davis, 2002a, 2003; fig. 63). The main bounding fault of the range is along its western side (Hintze and Davis, 2002a, 2003) and is mapped as having Quaternary offset (Dohrenwend and others, 1996). The internal structure of the range consists of a syncline-anticline pair and a local thrust fault that placed lower Paleozoic carbonate rocks over upper Paleozoic carbonate rocks (Hintze and Davis, 2002a, 2003). The north-trending Needle Point anticline at the north end of the range has been prospected for oil (Hintze and Davis, 2003). The anticline plunges northward beneath southern Snake Valley, where it creates a buried bedrock high evident in gravity and seismic data (Shah Alam, 1990; Watt and Ponce, 2007). The south end of the range mostly consists of east-dipping ash-flow tuffs from the Indian Peak caldera complex (Best and Grant, 1987). A well drilled in the western flank of the range by the UGS penetrated $800 \mathrm{ft}$ of volcanic rock and bottomed in volcanic rocks without hitting underlying Paleozoic rocks (Utah Geological Survey, accessed April 2012, at http://apps.geology. utah.gov/groundwater/site.php?site_id=4).

Paleozoic carbonate rocks are exposed at the south end of the Snake Range, in the Limestone Hills to the south, in the Mountain Home Range to the east of Hamlin Valley, and at the north end of the Fortification Range at the southwestern side of Spring Valley (fig. 63). Only a few wells were drilled deeply enough to penetrate Cenozoic volcanic rocks or Paleozoic rocks below the Cenozoic basin fill in Snake, Hamlin, and Spring Valleys. Some of the wells that intercept carbonate rocks at depth were drilled next to outcrops of the Paleozoic section; others were drilled on buried bedrock highs, such as the wells drilled on the buried part of the Needle Point anticline on the Nevada-Utah state line (fig. 63). These well intercepts, combined with the regional prevalence of carbonate bedrock in surrounding ranges, indicated that a relatively continuous carbonate-rock section could exist beneath the basin-fill deposits in southern Snake Valley, northern Hamlin Valley, and southern Spring Valley.

In contrast to the Sacramento Pass area and Snake Creek, older Tertiary sedimentary rocks do not commonly outcrop south of the Snake Range. The only major outcrop is in Big Spring Wash (fig. 63). These Tertiary sediments unconformably overlie faulted Devonian carbonate rocks at the south end of the Snake Range.

A broad, cemented piedmont surface of older alluvium slopes gently to the east and southeast, away from the mountain front, in the vicinity of the Big Wash and Lexington Creek drainage basins. Although it has the morphologic appearance of an alluvial fan, this surface is erosional in nature, and all younger alluvium has been removed to the level of a highly cemented, older alluvial layer, which caps the surface. This cemented surface can be traced southward and southeastward in the subsurface, where it is identified on seismic reflection profiles (Shah Alam, 1990) as a series of subhorizontal reflectors that unconformably overlie steeply dipping reflectors that are interpreted by Shah Alam (1990) to correspond to synextensional Miocene deposits. The highly cemented nature of the older alluvium in this area could be the result of the prevalence of carbonate rocks in the headwaters of the Big Wash and Lexington Creek drainage basins, which could have provided calcium and carbonate-rich water and, ultimately, produced the carbonate cement. Drainage basins to the north of Snake Creek have predominantly granite or quartzite in the headwaters; alluvial materials in these drainage basins are much less cemented.

Surficial deposits in southern Snake and northern Hamlin Valleys are mainly coalescing alluvial fans and channel alluvium along ephemeral stream courses. Spring Valley contains a playa called Baking Powder Flat to the northwest of the groundwater divide, but Spring Valley south of the divide or the parts of Snake and Hamlin Valleys in the southern study area have no playas.

\section{Subsurface Geology of Southern Snake and Northern Hamlin Valleys}

Gravity data, combined with seismic and drill-hole data, helped define the thickness and subsurface configuration of basin-fill deposits underlying southern Snake and northern Hamlin valleys (Watt and Ponce, 2007; Mankinen and McKee, 2009; fig. 64). Geologic sections, based on interpretation of seismic profiles (Shah Alam, 1990; Shah Alam and Pilger, 1991) across northern Hamlin Valley and southern Snake Valley, depict basin-fill deposits that range in thickness from $3,000 \mathrm{ft}$ thick in the northern part of the area to greater than $6,500 \mathrm{ft}$ thick in the south. Basin-fill deposits were interpreted to overlie Oligocene volcanic rocks and Paleozoic carbonate bedrock at depth.

Shah Alam (1990) subdivided the Quaternary and Tertiary basin-fill deposits into three unconformity-bounded sedimentary sequences on the basis of seismic-reflection character, including the presence of truncated seismic reflectors. The stratigraphy interpreted from the seismic profiles was tied to data from oil exploration holes in the center of Hamlin Valley to define the basin-fill stratigraphy from oldest to youngest. Tertiary volcanic rocks are the oldest and deepest basin-fill unit and underlie the three sedimentary basin-fill units. The volcanic rocks correlate with outcrops and drill hole intercepts of the 34-26 Ma volcanic rocks of the Needles Range Group on the eastern side of Hamlin Valley (Shah Alam and Pilger, 1991). The units are the thickest beneath the south-central part of Hamlin Valley and thin northward (fig. 64). No volcanic rocks were interpreted by Shah Alam (1990) to be present at depth beneath southern Snake Valley, an interpretation consistent with the absence of magnetic anomalies on published aeromagnetic data (Watt and Ponce, 2007).

The oldest sedimentary basin-fill unit forms a thick, localized depocenter in central Hamlin Valley (fig. 63). This section, likely $26-17 \mathrm{Ma}$ in age, consists of an upper $1,800-\mathrm{ft}$ thick section dominated by anhydrite interbedded with minor claystone and limestone, underlain by a 2,300-ft thick section 


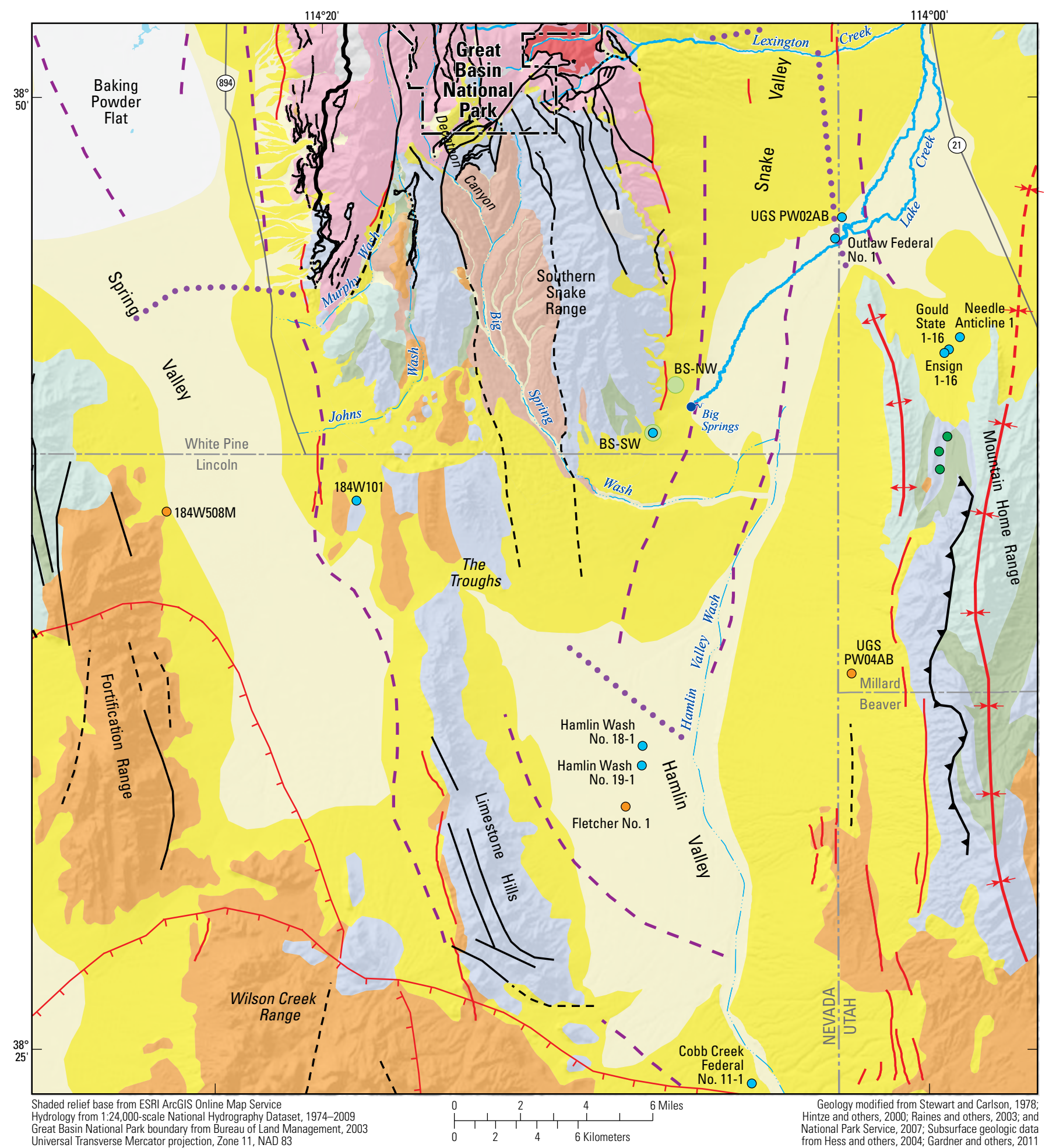

Figure 63. Geology of the Big Springs area in southern Snake Valley, including the south end of the Snake Range, northern Hamlin Valley, and southern Spring Valley in Lincoln and White Pine Counties, Nevada. 


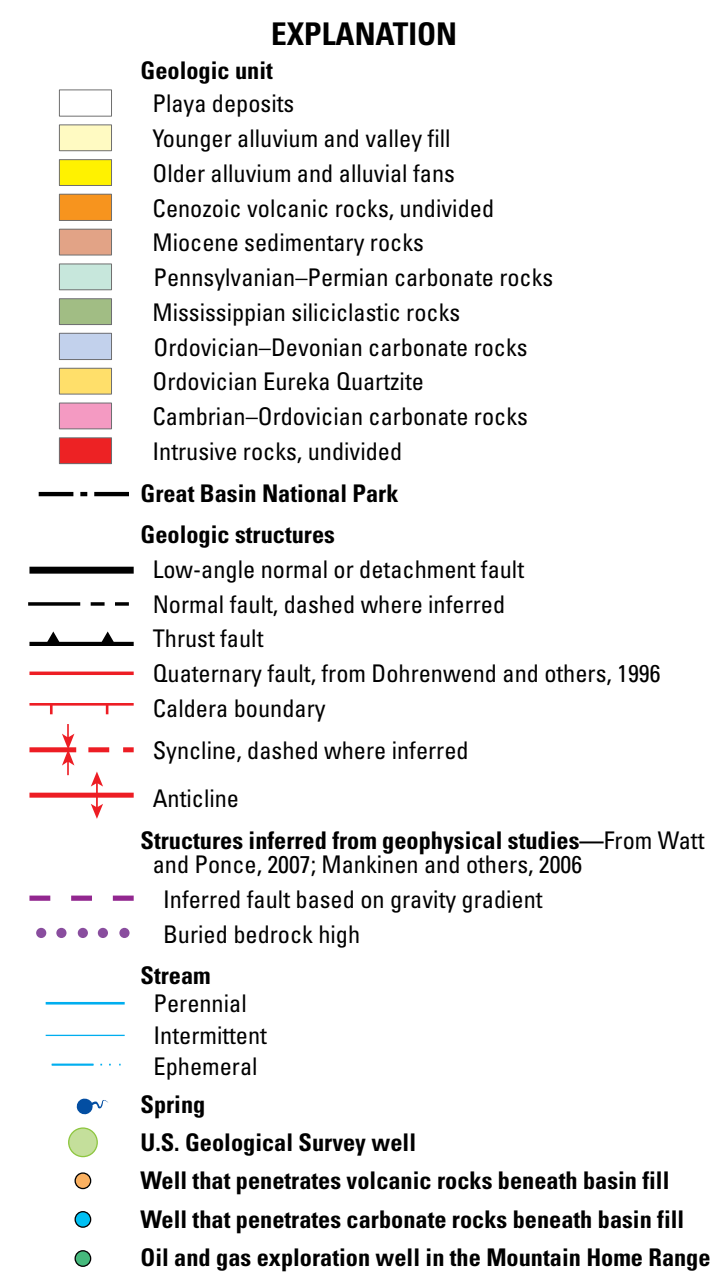

of interbedded claystone and limestone (Shah Alam, 1990; Shah Alam and Pilger, 1991). The generally fine-grained nature of the sediment and presence of thick anhydrite beds indicate a lacustrine depositional setting that was strongly evaporative at times. This west-dipping sequence is only present in Hamlin Valley; it is not present in southern Snake Valley.

An intermediate alluvial section, likely $17-10 \mathrm{Ma}$ (Shah Alam and Pilger, 1991), is widespread in the subsurface, based on a consistent reflection character for all of the seismic lines (fig. 64). This sequence is an 825 -ft thick section composed of poorly-sorted sands and gravels, with volcanic rocks as the predominant clasts. This sequence dips westward and thickens toward the bounding faults on the west side of Hamlin Valley and southern Snake Valley (fig. 64). Although truncated seismic reflectors show that this sequence is separated from the overlying section by an unconformity, this sequence is lithologically indistinguishable from the overlying sequence, where it is described from drill-hole cuttings. The youngest alluvial section evident from the seismic data was interpreted by Shah Alam and Pilger (1991) to be younger than $10 \mathrm{Ma}$ and to have been deposited following a regional change in extension direction. The young basin-fill deposits on the seismic sections consist of a 1,400-ft-thick section of poorly-sorted sands and gravels, with volcanic rocks as the predominant clast. This unit is subhorizontal, blankets the entire valley, and is interpreted to have been deposited in an alluvial fan setting. The youngest Quaternary sediments are too shallow to be imaged on the seismic sections (Shah Alam, 1990).

The southern part of Snake Valley is underlain by two basins that are separated by a buried ridge that is the northwest projection of the Needle Point anticline in the Mountain Home Range (Watt and Ponce, 2007; Mankinen and McKee, 2009; fig. 64). In the small basin to the east of the buried bedrock ridge, basin-fill deposits are generally less than $2,000 \mathrm{ft}$ thick. The basin that lies between the buried Needle Point bedrock ridge and the eastern flank of the southern Snake Range is a narrow, fault-bounded graben in which Cenozoic basin-fill deposits are greater than $4,000 \mathrm{ft}$ thick. The western bounding fault of this deep trough is the major normal fault that bounds the eastern front of the southern Snake Range (fig. 64). The location of the fault, as defined by gravity data, is based on the offset of consolidated Paleozoic rocks in the subsurface. Because the fault dips moderately to the east, the map-view location of the gravity-defined fault in the Paleozoic section is offset to the east from the surface-mapped fault trace, as defined by AMT studies (McPhee and others, 2009) or mapped Quaternary fault scarps at the base of the range (Dohrenwend and others, 1996).

The central part of Hamlin Valley, opposite the highest part of the Limestone Hills, is a west-dipping half graben (fig. 64), bounded on the west side by an east-dipping normal fault that is near the base of the Limestone Hills and partly buried by the youngest basin-filling deposits (Shah Alam, 1990). Seismic and gravity data are in agreement that this bounding fault is up to $1.5 \mathrm{mi}$ east of the northern Limestone Hills and is next to the eastern side of the southern Limestone Hills (Shah Alam, 1990; Watt and Ponce, 2007; Mankinen and McKee, 2009, fig. 4; Rowley and others, 2009, plate 1). The half graben beneath the northern part of Hamlin Valley contains a Cenozoic section that is greater than $4,000 \mathrm{ft}$ thick in its western part, but the basin shallows rapidly to the east to less than $1,500 \mathrm{ft}$ thick (fig. 64). Drilling data from wells in the northern part of Hamlin Valley showed Paleozoic rocks at depths of $3,060 \mathrm{ft}$ to more than $7,500 \mathrm{ft}$.

The differences in Cenozoic basin-fill stratigraphy indicated that Hamlin Valley is an older basin than southern Snake Valley (Shah Alam, 1990; Shah Alam and Pilger, 1991). Oligocene volcanic rocks and the oldest, fine-grained sedimentary basin-fill unit are present only in Hamlin Valley, whereas the Snake Valley sections are dominated by the younger units. The basin that underlies Hamlin Valley was apparently active during Oligocene and Miocene time and, thus, received more basin-fill deposits in middle Cenozoic time (Shah Alam, 1990; Shah Alam and Pilger, 1991). The basin underlying southern Snake Valley was apparently inactive during this early phase of basin development. 


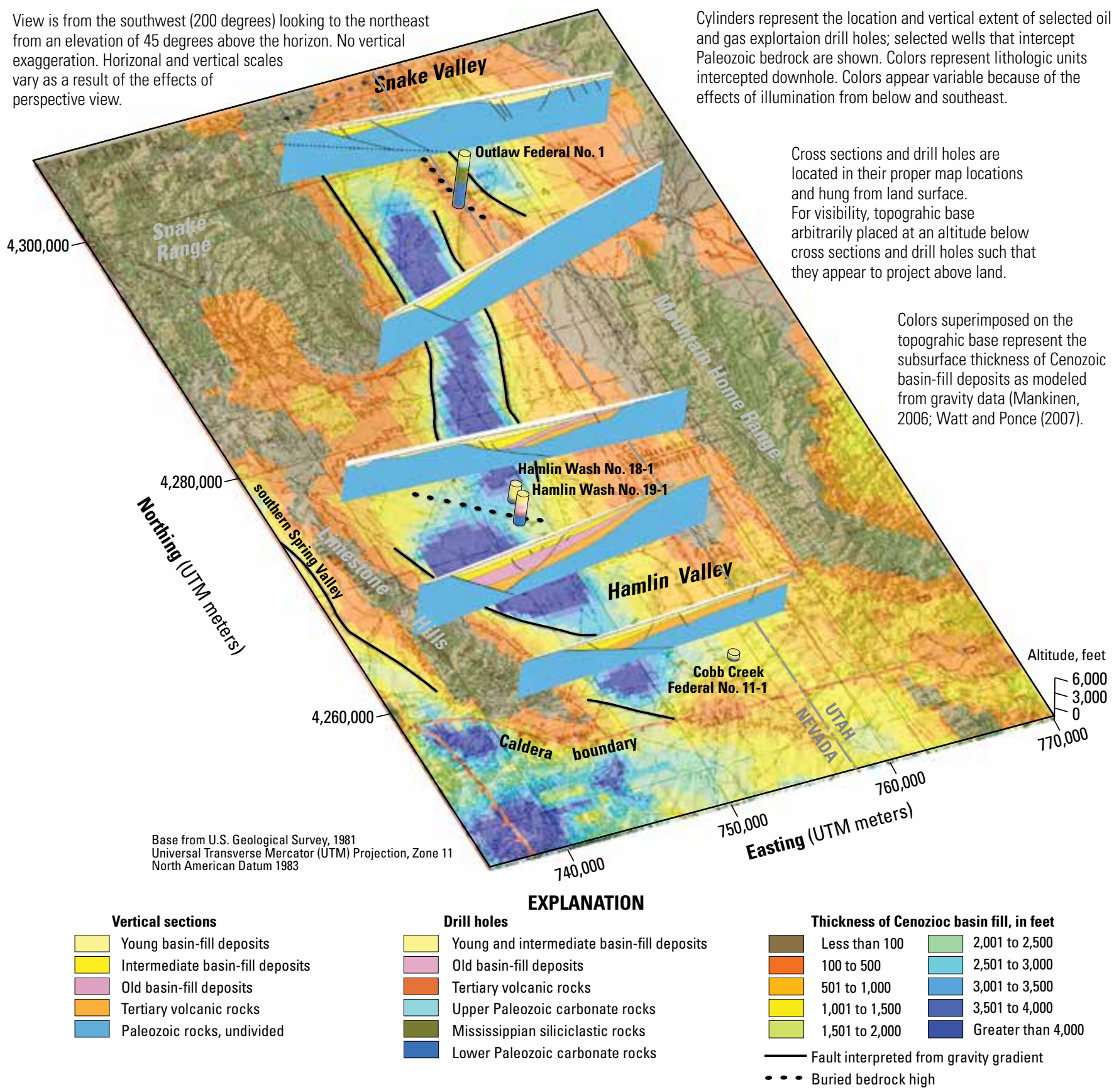

Figure 64. Perspective view showing the subsurface geology of southern Snake Valley, northern Hamlin Valley, and southern Spring Valley, as interpreted from well data, seismic-reflection profiles, and modeled gravity data.

During 2005 and 2006, the USGS collected and processed data from low frequency magnetotelluric (MT) sites along two east-west profiles in southern Spring Valley and Hamlin Valley (fig. 65). The MT method is a passive surface-geophysical technique that uses the Earth's natural electromagnetic fields to investigate the electrical resistivity of the subsurface from depths of tens of feet to several miles (Vozoff, 1991). The 2005-06 data were reprocessed for this study and two-dimensional MT models were constructed for each profile (fig. 65). Data collection and MT modeling methods were similar to those described by Williams and Rodriguez (2004). In the two transects from southern Spring Valley to Hamlin Valley, the carbonate bedrock of the Limestone Hills is electrically resistive, with resistivity greater than $250 \mathrm{ohm}$-meter (ohm-m), and the valley fill is electrically more conductive, with resistivity between $10-50 \mathrm{ohm}-\mathrm{m}$. The highly conductive layers could represent brines associated with anhydrite or high-conductivity welded tuffs. The faulted subsurface contacts between limestone bedrock and late Cenozoic basin-fill deposits appeared on the model profiles as abrupt, steeply-dipping transitions between high- and low-resistivity regions on either side of the Limestone Hills and in Hamlin Valley (fig. 65). 
The AMT data were collected and analyzed along four east-west profiles on the eastern flank of the southern Snake Range between Snake Creek and Big Springs (McPhee and others, 2009, p. 289). Similar to the MT profiles in Spring and Hamlin Valleys, the AMT profiles imaged a high-resistivity

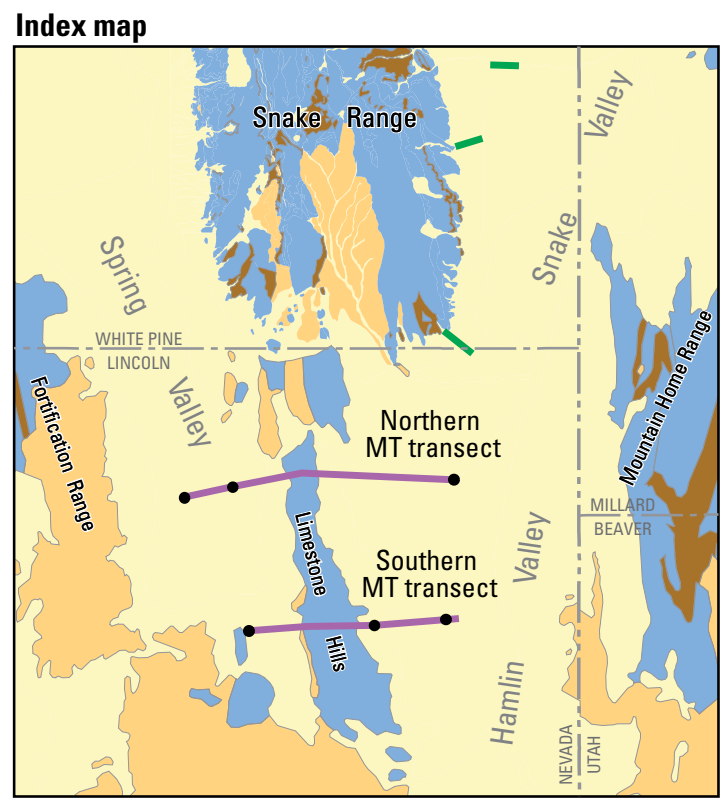

basement, most likely associated with carbonate bedrock as well as more conductive basin fill. Several faults were interpreted along the profiles on the basis of subsurface resistivity contrasts (McPhee and others, 2009).

\section{Aquifers}

Basin-fill deposits and carbonate rocks compose the principal aquifers in southern Spring Valley, northern Hamlin Valley, and southern Snake Valley, but hydraulic connections between the two types of aquifers are not well understood. Where basin-fill deposits and carbonate rocks are in fault or depositional contact, the two types of aquifers could be hydraulically connected and form a single aquifer system (Gardner and others, 2011). The interconnections can be poor or non-existent where older basin-fill deposits of Miocene age or volcanic
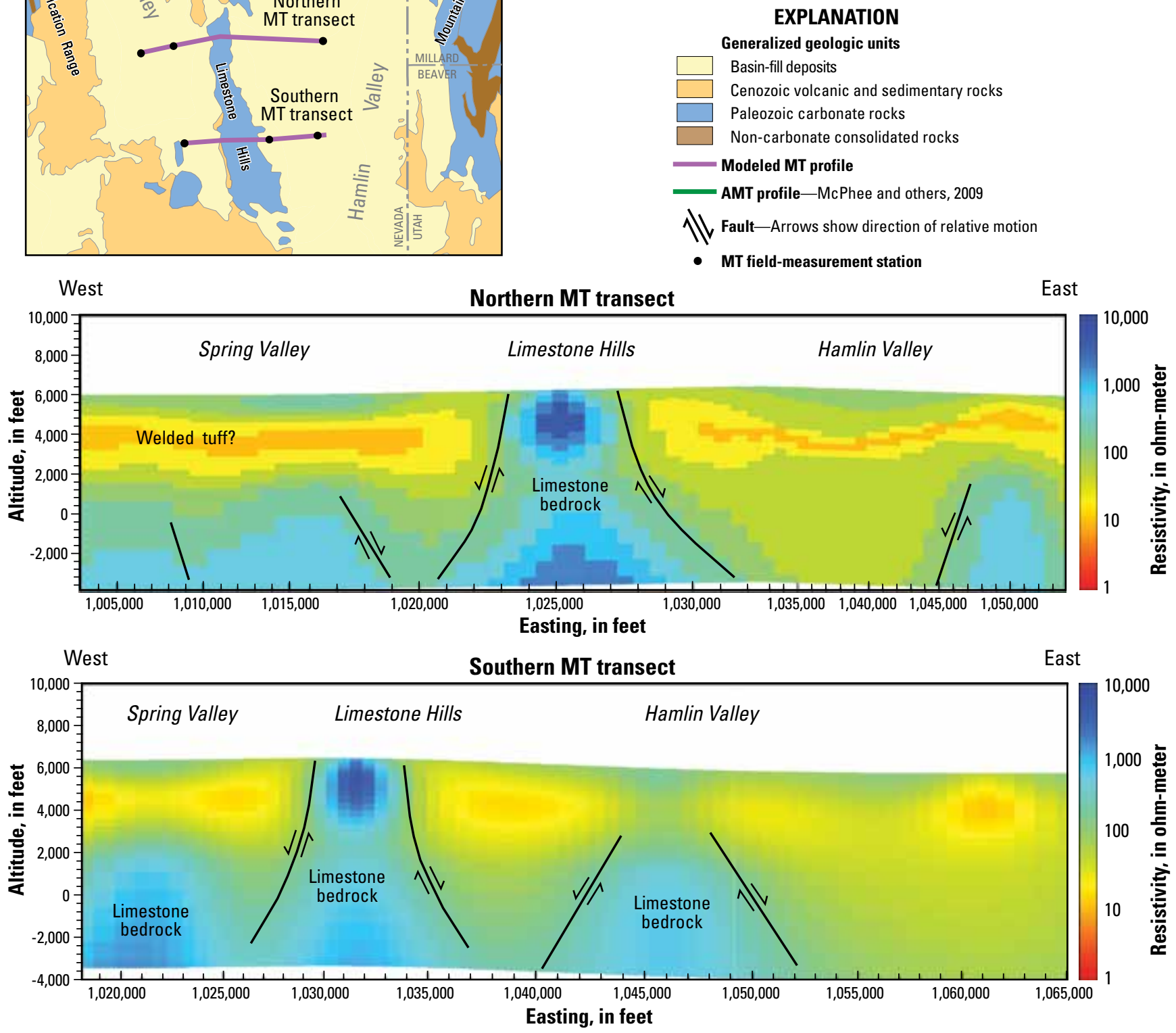

Figure 65. Location and two-dimensional resistivity profiles of low-frequency magnetotelluric (MT) data collected in the vicinity of the Limestone Hills in northern Hamlin Valley and southern Spring Valley, Lincoln County, Nevada. 
rocks underlie younger basin-fill deposits and overlie carbonate rocks, however.

\section{Distribution of Coarse- and Fine-Grained Deposits from Well-Drillers' Logs}

Water wells in the vicinity of Big Springs Creek and Lake Creek in southern Snake Valley are between $30 \mathrm{ft}$ and $805 \mathrm{ft}$ in depth. Many of the wells are near the Nevada-Utah state line on the western side of Needle Point, at the north end of the Mountain Home Range; only a few wells are on the alluvial fans flanking the valley (fig. 66). The wells penetrate different proportions of interbedded sand, gravel, fine sand, silt, and clay deposits, probably representing transitional facies between alluvial fan and basin-axis deposits. Drillers' descriptions of down-hole intervals from lithologic logs were obtained for wells in Nevada (Nevada Division of Water Resources, accessed March 2009, at http://water.nv.gov/data/ welllog/index.cfm) and Utah (Utah Division of Water Rights accessed March 2009, at http://www.waterrights.utah.gov/cgibin/wellview.exe?Startup). More detailed lithologic descriptions were obtained for monitoring wells drilled by the UGS (Utah Geological Survey, accessed April, 2012, at

http://apps.geology.utah.gov/groundwater/map.php?proj_id=1) and from the two wells drilled on the alluvial fans northwest and southwest of Big Springs as part of this study (fig. 61). Individually described down-hole intervals were interpreted as dominantly coarse-grained, medium-grained, or fine-grained, on the basis of the predominant grain size of the sediment and the presence or absence of a clay component. Intervals described as containing gravel or cobbles were classed as coarse-grained, provided the clay content was low. Sand-dominated intervals or mixtures of sand and gravel were classed as medium-grained deposits. Intervals in which the clay component was greater than one-third of the described lithologic types were classed as fine-grained, regardless of the size of the remaining clasts. This classification relied on the depth intervals and descriptions presented in the drillers' logs; it was not possible to subdivide an interval described as "clay, sand, and gravel" into thinner beds of a single clast type.

In an analysis of fluvial and alluvial materials in basins in north-central Nevada, Bredehoeft and Farvolden (1963) emphasized the importance of the total thickness of gravel in the alluvial section as the defining characteristic that controls the porosity and permeability characteristics of basin-fill aquifers. The present analysis modified that approach by giving some credit to sand-bearing intervals. In this approach, lithologic characteristics were generalized for the depth ranges less than or equal to $100 \mathrm{ft}$, greater than 100 to less than or equal to $250 \mathrm{ft}$, and greater than 250 to less than or equal to $500 \mathrm{ft}$. The total thickness of coarse-grained, medium-grained, and fine-grained intervals were determined for each of the three depth ranges, then a texture score was computed by using 100 percent of the coarse-grained thickness, 50 percent of the medium-grained thickness, and 5 percent of the fine-grained thickness. These values were added and normalized to the thickness of the depth range, as shown in the following equation:

$$
T S=\left(\frac{T_{C G}+\left(0.5 \times T_{M G}\right)+\left(0.05 \times T_{F G}\right)}{\left.\left(T_{C G}+T_{M G}\right)+T_{F G}\right)}\right) \times 100
$$

where

$T S$ is the texture score, in percent of total thickness of a specified depth interval:

$T_{C G}$ is the total thickness of coarse-grained sediments in the specified depth interval, in feet;

$T_{M G}$ is the total thickness of medium-grained sediments in the specified depth interval, in feet; and

$T_{F G}$ is the total thickness of fine-grained sediments in the specified depth interval, in feet.

The textural scores provide a numerical representation of the relative grain-size for the three depth intervals. A depth interval composed entirely of cobble and gravels would have a textural score of 100; an interval composed of 50 percent gravel and 50 percent sand would generate a textural score of 75; an interval composed entirely of clay would have a textural score of 5. Similar to the approach of the analysis of Bredehoeft and Farvolden (1963), the textural scores relied on the aggregate thickness of a grain-size class and did not specifically account for thin, coarse-grained beds that can be important local aquifers.

The depth interval from 0 to $100 \mathrm{ft}$ showed a crude spatial zonation of grain sizes, with coarse-grained deposits associated with the alluvial-fan piedmont, and grain size generally decreasing toward the valley floor (fig. 66A). Textural variations are especially complicated at the fan toe, where basinaxis and fan deposits appeared to be intimately interbedded as a result of varying episodes of fan progradation into the basin. Shallow-well 2335 exemplified this situation, with layers of alluvial fan gravels alternating with clay intervals (fig. 66A). Far fewer wells penetrated the depth intervals from greater than 100 to less than or equal to $250 \mathrm{ft}$ and from greater than 250 to less than or equal to $500 \mathrm{ft}$ (figs. 66B, 66C). Because of limited data and clustering of the wells at the north end of Hamlin Valley Wash, it was difficult to discern an overall pattern; in general the data were characterized by textural heterogeneity, where coarse-grained and fine-grained intervals are present in close proximity. The area to the northeast of the Needle Point anticline, represented by two wells in the depth interval from greater than $100 \mathrm{ft}$ to less than or equal to $250 \mathrm{ft}$ in the northeast corner of the map (fig. 66B), appeared to be uniformly fine-grained, perhaps as a result of a damming effect of the shallowly-buried bedrock high that traps coarsergrained particles upstream and allows only fines to continue along the stream course. In contrast to the conclusions presented by Bredehoeft and Farvolden (1963), none of the maps show a gravel-dominated fluvial channel along the valley axis. Instead, the system appeared to be dominated by the alluvial 
$\boldsymbol{A}$

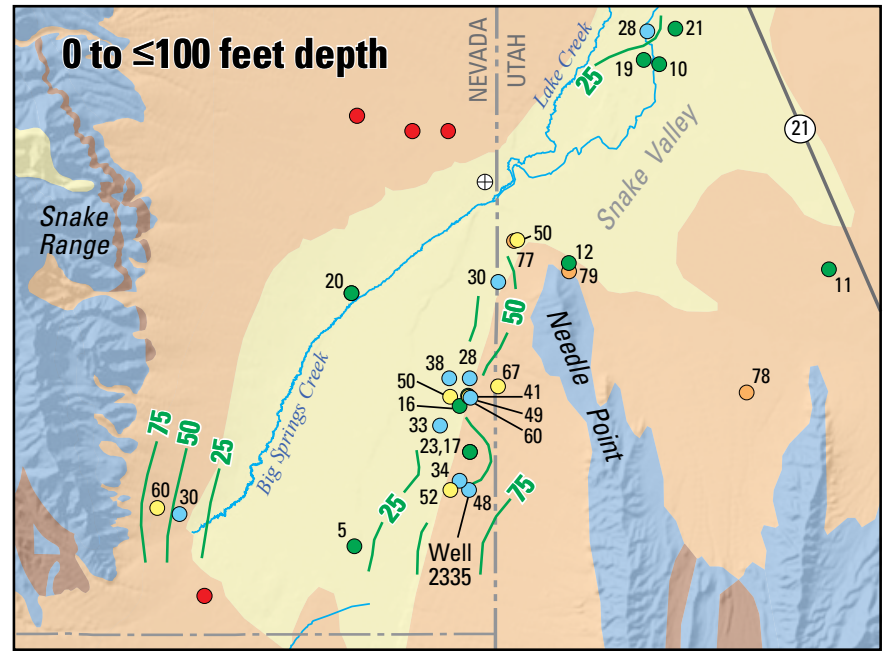

B

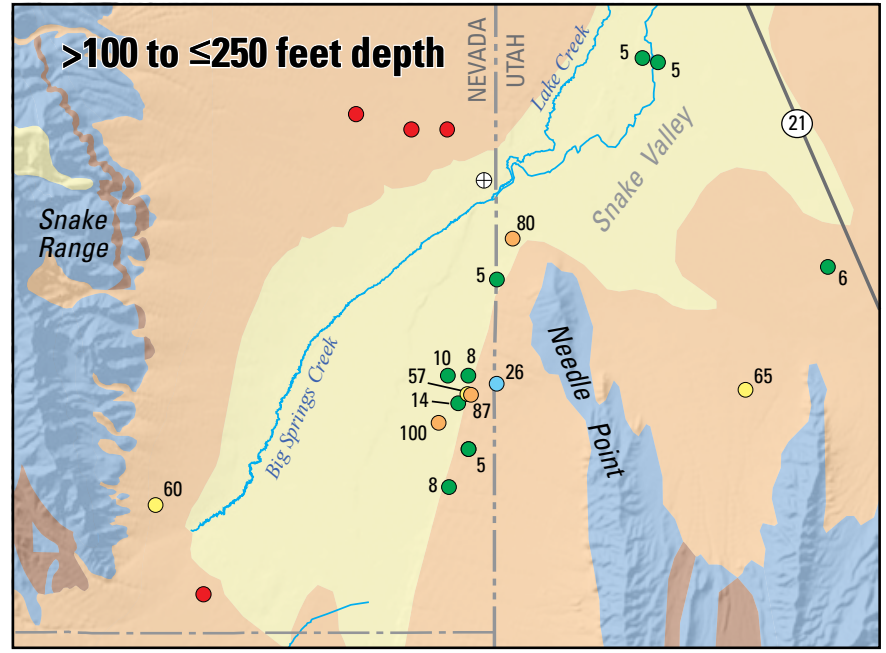

C

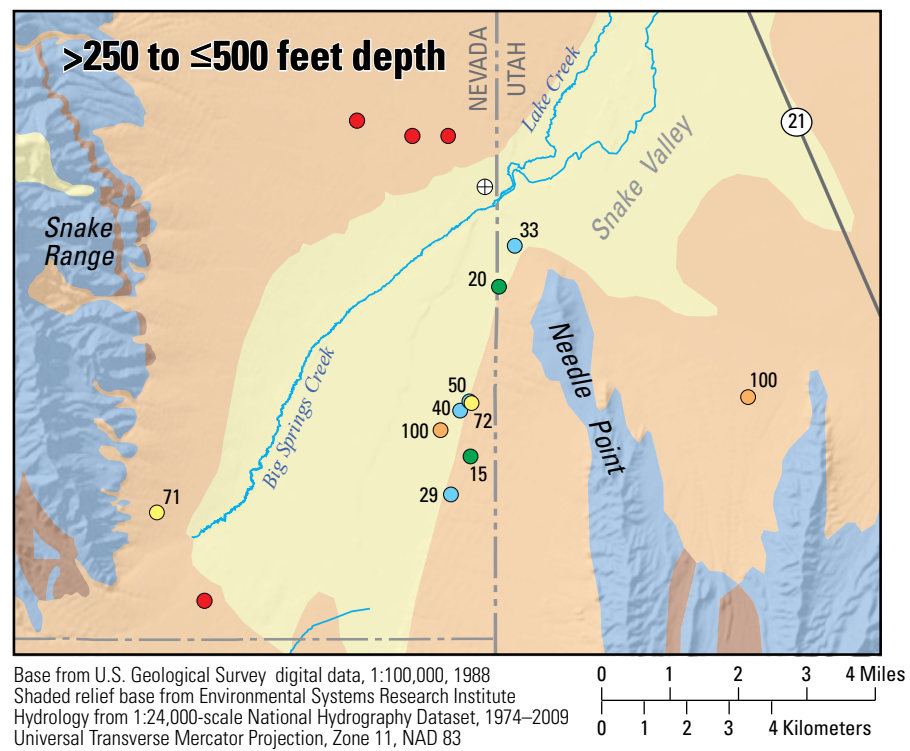

Example lithologic log, well 2335. Location shown on figure $66 \mathrm{~A}$ Nevada Department of Water Resources (NDWR)

U.S. Geological Survey (USGS)

NDWR log number 2335
USGS site-identification number 384236114042701

USGS site name 195 N10 E70 25D 1

\begin{tabular}{|c|c|c|}
\hline \multicolumn{2}{|c|}{ Depth, in feet } & \multirow{2}{*}{ Drillers' description } \\
\hline From & To & \\
\hline 0 & 5 & Clay \\
\hline 5 & 11 & Dry gravel \\
\hline 11 & 32 & Water gravel, main aquifer \\
\hline 32 & 40 & Clay \\
\hline 40 & 41 & Gravel, other aquifer \\
\hline 41 & 50 & Clay \\
\hline 50 & 54 & Gravel, other aquifer \\
\hline 54 & 70 & Clay \\
\hline
\end{tabular}

Topographic setting is valley lowland. Perforated intervals at $11-32,40-41$, and $50-54 \mathrm{ft}$. Static water level $8 \mathrm{ft}$. Aquifer at 11-32 ft may be water table and deeper ones confined

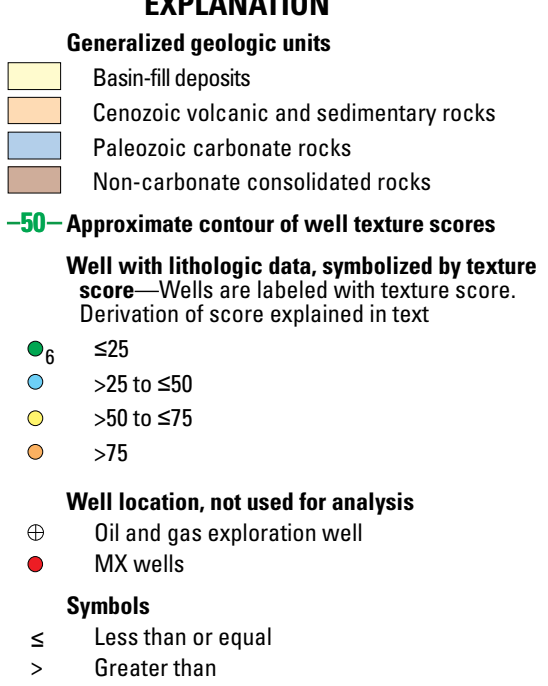

Figure 66. Location of wells with subsurface lithologic data in the vicinity of Big Springs, Lincoln and White Pine Counties, Nevada, and texture scores for the following depth intervals: $A$, between 0 and 100 feet; $B$, between 100 and 250 feet; and $C$, between 250 and 500 feet. 
fan complexes along the valley margins, with fines transported out farther into the valley axis. This difference could be the result of the streams in southern Snake Valley originating from springs rather than perennial streams that exit the mountains and flow across the valley. No wells penetrate deep in the valley-axis sediments, however, so little is known about the sedimentary character along the basin axis.

\section{Hydraulic Properties of Basin-Fill Deposits}

Estimates of transmissivity of the basin-fill deposits were limited. Specific-capacities from the well-drillers' logs were limited to five wells in the center-pivot irrigation area east of Big Springs Creek and near the Nevada-Utah state line and to three wells with aquifer tests - two from the U.S. Air Force's MX missile-siting investigation and one by this study on the fan northwest of Big Springs (fig. 61). Transmissivity was estimated by using the method by Theis and others (1963; see equation 4), and the results are summarized in table 18. This equation requires an estimate of the storage coefficients to obtain transmissivity. Estimates derived by this equation usually underestimate the actual transmissivity because the method does not consider turbulent losses in the pumped well (Fetter, 2001, p. 206). Empirical equations that relate specific capacity to transmissivity can be used, but, generally, these are limited to particular aquifers. Because of the limited number of specific-capacity estimates and aquifer tests in the study area, an empirical equation was not developed. Consequently, the estimates of transmissivity listed in table 18 probably underestimate the actual transmissivity, particularly for wells completed in coarse-grained basin-fill deposits or in fractured limestone rocks. Estimates of transmissivity from specific capacities in the center-pivot irrigation area ranged from about 100 to $3,000 \mathrm{ft}^{2} / \mathrm{d}$. These results were consistent with the estimated transmissivity of basin-fill deposits reported by Halford and Plume (2011) and (Dong and others, 2012).

The estimated transmissivity from specific-capacity data collected during a 48-hr aquifer test at the BS-NW well ranged from 2,000 to $3,000 \mathrm{ft}^{2} / \mathrm{d}$ (table 18 ), which was only $20-30$ percent of the $10,000 \mathrm{ft}^{2} / \mathrm{d}$ estimated from analysis of the aquifer test (table 19). The estimated transmissivity from specificcapacity data for the MX test well in northern Hamlin Valley was much less, ranging from 300 to $700 \mathrm{ft}^{2} / \mathrm{d}$ (table 18), but, again, was only 20 percent of that estimated from the analysis of water-level declines in a nearby observation well (table 19).

The greatest estimated transmissivity of the basin-fill deposits from specific-capacity data ranged from 10,000 to $13,000 \mathrm{ft}^{2} / \mathrm{d}$ from an aquifer test at the southern Spring Valley MX test well (table 18) south of the groundwater divide (fig. 61). Although attempts were made by contractors for the U.S. Air Force to analyze the aquifer-test data from the observation well, the results were reported as "not conclusive" (U.S. Air Force, 1983, p. 7; Bunch and Harrill, 1984) because of a pump malfunction (Ertec Western, Inc., 1981b). Data from a step test and two constant-rate tests during September 1980 were found and used to analyze the transmissivity and storage coefficient of the basin-fill deposits in the vicinity of the well. Results from the analysis are listed in table 19 and the measured drawdown in the pumped and observations wells were compared to drawdowns simulated from the Theis equation

Table 18. Summary of transmissivity estimates from specific capacities reported in well-drillers' logs and from aquifer tests for wells in southern Snake, northern Hamlin, and southern Spring Valleys, vicinity of Big Springs, White Pine and Lincoln Counties, Nevada.

[Location of wells is shown in figure 61. Well-log number and data obtained from Nevada Division of Water Resources. USGS, U.S. Geological Survey; SNWA, Southern Nevada Water Authority; BS-NW, Big Spring northwest well; BS-SW is Big Springs southwest well; Hamlin MX and southern Spring MX test wells were drilled for the U.S. Air Force's MX missile-siting investigation (Bunch and Harrill, 1984); and 184W508M and 184W101 are wells drilled for Southern Nevada Water Authority. Transmissivity rounded to one significant figure. Symbol: - , not determined]

\begin{tabular}{|c|c|c|c|c|c|c|c|c|c|}
\hline $\begin{array}{c}\text { Nevada well-log } \\
\text { number/USGS/ } \\
\text { SNWA well names }\end{array}$ & $\begin{array}{c}\text { Hole } \\
\text { diameter } \\
\text { (inches) }\end{array}$ & $\begin{array}{c}\text { Screened } \\
\text { interval } \\
\text { (feet below } \\
\text { land surface) }\end{array}$ & Geologic unit & $\begin{array}{c}\text { Texture } \\
\text { score }\end{array}$ & $\begin{array}{l}\text { Pump rate } \\
\text { (gallons per } \\
\text { minute) }\end{array}$ & $\begin{array}{c}\text { Drawdown } \\
\text { (feet) }\end{array}$ & $\begin{array}{c}\text { Hours } \\
\text { pumped }\end{array}$ & $\begin{array}{l}\text { Range in } \\
\text { storage } \\
\text { coefficient }\end{array}$ & $\begin{array}{c}\text { Estimated } \\
\text { transmissivity } \\
\text { (feet squared } \\
\text { per day) }\end{array}$ \\
\hline \multicolumn{10}{|c|}{ Center-pivot irrigation area in southern Snake Valley } \\
\hline 19237 & 12 & $12-345$ & Clay and gravel & 11 & 700 & 64 & 20 & $2 \mathrm{E}-1-2 \mathrm{E}-4$ & $2,000-3,000$ \\
\hline 64851 & 14 & $40-800$ & Clay, sand and gravel & 9 & 866 & 371 & 3 & $1 E-1-3 E-4$ & $300-500$ \\
\hline 67360 & 10 & $300-400$ & Clay & 5 & 200 & 352 & 1 & $1 E-2-3 E-4$ & $70-100$ \\
\hline 68651 & 14 & $100-605$ & Clay, sand and gravel & 12 & 950 & 200 & 20 & $1 E-1-3 E-4$ & $800-1,200$ \\
\hline \multicolumn{10}{|c|}{ Wells northwest and southwest of Big Springs } \\
\hline BS-NW & 12 & $300-460$ & Sand, gravel and cobbles & 71 & 260 & 24 & 42 & $2 E-1-2 E-4$ & $2,000-3,000$ \\
\hline BS-SW & 12 & $500-700$ & Fractured limestone & - & 170 & 39 & 48 & $1 E-4-1 E-6$ & $1,000-2,000$ \\
\hline \multicolumn{10}{|c|}{ MX missile-siting investigation test wells in Hamlin and southern Spring Valleys } \\
\hline Hamlin MX & 18 & $320-440$ & Clayey sand and sand & - & 110 & 83 & 120 & $1 E-1-2 E-4$ & $300-400$ \\
\hline southern Spring MX & 18 & $400-700$ & Sand & - & 600 & 14 & 120 & $1 E-1-3 E-4$ & $10,000-13,000$ \\
\hline \multicolumn{10}{|c|}{ Southern Nevada Water Authority test wells in southern Spring Valley } \\
\hline 184W508M & 15 & $376-1,140$ & Volcanic rock & - & 80 & 155 & 1 & $5 E-2-1 E-4$ & $50-100$ \\
\hline $184 \mathrm{~W} 101$ & 20 & $800-1,760$ & Fractured limestone & - & 2,520 & 225 & 72 & $3 E-2-5 E-5$ & $2,000-4,000$ \\
\hline
\end{tabular}


(Theis, 1935) for a confined aquifer (fig. 67). Data from the tests are listed in appendix 12. Again, the estimated transmissivity from specific-capacity data was only 20 percent of that estimated from analysis of the drawdown in the pumped and observation wells.

Well losses estimated from the step test were included in the analysis of transmissivity at the pumped well (fig. 67). The transmissivity of $60,000 \mathrm{ft}^{2} / \mathrm{d}$ (table 19) was much greater than could be justified from the sand lithology that was reported for the well, indicating that a confined aquifer analysis of the data overestimated the transmissivity. The reported pump malfunction (Ertec Western, Inc., 1981b) happened after 2.5 days of pumping during the first constant-rate test because the pump ran out of fuel (appendix table 12-2), and a second constantrate test began 33 hours later (fig. 67). The large transmissivity is based on the assumption of a confined aquifer without consideration of vertical leakage and that the reported pumping rate was about $600 \mathrm{gal} / \mathrm{min}$. Assuming the reported pumping rate was correct, the actual transmissivity of the basin-fill deposits in the vicinity of the MX test wells in southern Spring Valley is probably between 10,000 and $60,000 \mathrm{ft}^{2} / \mathrm{d}$. Another aquifer test could be done at the well because neither the pumped well nor the observation well have been destroyed.

\section{Hydraulic Properties of Carbonate Rocks}

Water and petroleum exploration wells drilled in the carbonate rocks in the Big Springs area provided information on the properties of carbonate rocks. Two water exploration wells were drilled in carbonate rocks at the south end of the Snake Range. One was drilled by SNWA in southern Spring Valley 1-2 mi west of the north end of the Limestone Hills (well 184W101; fig. 61); the other was drilled by the USGS as part of the present study (appendix 1) about $1.5 \mathrm{mi}$ southwest of Big Springs (BS-SW; fig. 61) and about 5.5 mi northeast of the north end of the Limestone Hills.
The SNWA well 184W101 penetrated fractured limestone and intervals of limestone and clay throughout its total depth of 1,760 ft (Prieur and others, 2010a). The saturated zone at this well is more than $1,300 \mathrm{ft}$ thick. The well was pumped at a rate of 2,520 gal/min during a 72-hour multiple-well aquifer test, and transmissivity was estimated at approximately $10,000 \mathrm{ft}^{2} / \mathrm{d}$ (table 19; Prieur and others, 2010a). This well was interpreted to intersect a high-angle fault and associated fracture zones in the tested interval (Prieur and others, 2010a), so the transmissivity computed for this well could be representative of fractured limestone in fault zones.

The BS-SW well (fig. 61) penetrated $215 \mathrm{ft}$ of basin-fill deposits consisting of sand, gravel, and cobbles and $485 \mathrm{ft}$ of limestone of probable Devonian age. There were severe drilling mud losses in the hole from 220 to $240 \mathrm{ft}$. A borehole televiewer log of the well revealed that the mud losses resulted from large open fractures in unsaturated limestone. Total depth of the well is $700 \mathrm{ft}$, with the bottom $200 \mathrm{ft}$ screened in fractured limestone. The well was pumped at a rate of $170 \mathrm{gal} / \mathrm{min}$ during a 47-hour single-well aquifer test, and the estimated transmissivity was approximately 4,000 $\mathrm{ft}^{2} / \mathrm{d}$ (table 19). Again, estimated transmissivity from specific-capacity data (table 18) was about 20 percent of that estimated from the aquifer test, indicating turbulent losses in the well.

Analysis of water-level fluctuations in the vicinity of the center-pivot irrigation area northeast of Big Springs and along the Nevada-Utah state line indicated an estimated transmissivity in the range of 7,000-16,000 $\mathrm{ft}^{2} / \mathrm{d}$ for the carbonate-rocks in the vicinity of Needle Point Spring (fig. 61; Dong and others, 2012). This range was comparable to that from the two aquifer tests in carbonate rocks listed in table 19 and from an aquifer test of a well drilled in carbonate rocks by the SNWA in Spring Valley west of the study area that showed a reported transmissivity of $11,000 \mathrm{ft}^{2 / \mathrm{d}}$ (Prieur and others, 2010b) and indicated that the carbonate rocks in this area are at least as transmissive as the basin-fill deposits.

Table 19. Summary of transmissivity from aquifer tests for wells in southern Snake, northern Hamlin, and southern Spring valleys, vicinity of Big Springs, White Pine and Lincoln Counties, Nevada.

[Location of wells is shown in figure 61. USGS, U.S. Geological Survey; SNWA, Southern Nevada Water Authority; USAF, U.S. Air Force; BS-NW, Big Spring-northwest well; BS-SW is Big Springs-southwest well; Hamlin MX and southern Spring MX test wells were drilled for the U.S. Air Force's MX missile-siting investigation (Bunch and Harrill, 1984); and 184W101 is a test well drilled for Southern Nevada Water Authority. Aquifer tests for BS-NW and BS-SW had no observation well, drawdown reported for pumped well. Drawdown rounded to two significant figures for values greater than 1 foot. Transmissivity rounded to one significant figure. Symbol: - , not applicable]

\begin{tabular}{|c|c|c|c|c|c|c|c|c|c|}
\hline \multirow{2}{*}{ Well name } & \multirow{2}{*}{$\begin{array}{c}\text { Observation } \\
\text { well from } \\
\text { pumped } \\
\text { well (feet) }\end{array}$} & \multicolumn{2}{|c|}{$\begin{array}{c}\text { Screened interval } \\
\text { (feet below land surface) }\end{array}$} & \multirow{2}{*}{$\begin{array}{l}\text { Pump rate } \\
\text { (gallons per } \\
\text { minute) }\end{array}$} & \multirow{2}{*}{$\begin{array}{c}\text { Drawdown in } \\
\text { observation or } \\
\text { pumped well } \\
\text { (feet) }\end{array}$} & \multirow{2}{*}{$\begin{array}{c}\text { Hours } \\
\text { pumped }\end{array}$} & \multirow{2}{*}{$\begin{array}{c}\text { Transmissivity } \\
\text { (feet squared } \\
\text { per day) }\end{array}$} & \multirow{2}{*}{$\begin{array}{l}\text { Storage } \\
\text { coefficient }\end{array}$} & \multirow{2}{*}{ Source } \\
\hline & & Pumped & Observation & & & & & & \\
\hline BS-NW & - & $300-460$ & - & 260 & 24 & 42 & 10,000 & - & USGS \\
\hline Hamlin MX & 500 & $320-440$ & $320-420$ & 110 & 1.6 & 120 & 2,000 & 0.01 & USAF \\
\hline \multicolumn{10}{|c|}{ Limestone } \\
\hline BS-SW & - & $500-700$ & - & 170 & 39 & 48 & 4,000 & - & USGS \\
\hline 184W101 & 175 & $800-1,780$ & $480-1,780$ & 2,520 & 21 & 72 & 10,000 & 0.02 & SNWA/USGS \\
\hline
\end{tabular}




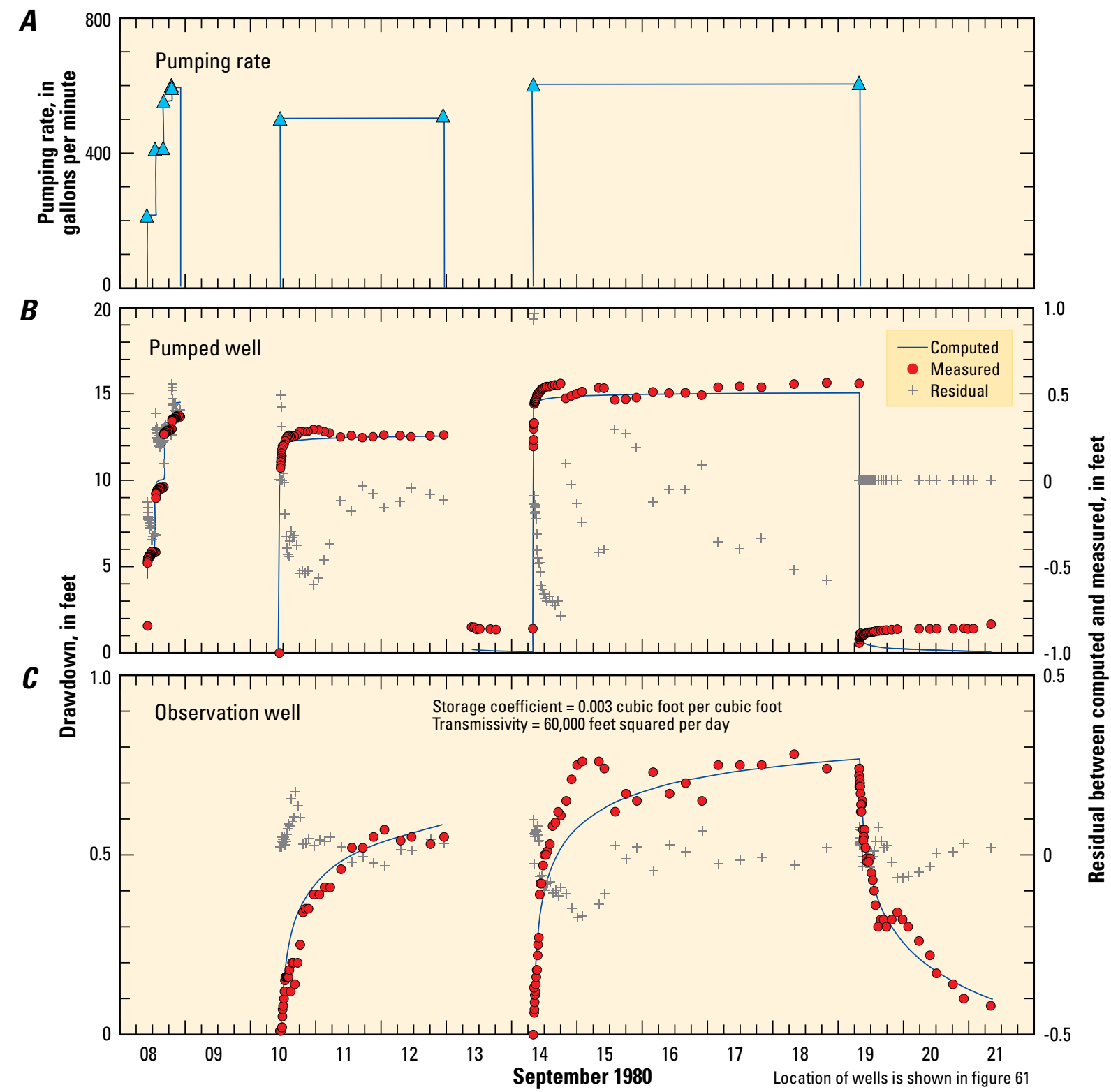

Figure 67. Distribution of groundwater pumping and comparison of measured and simulated drawdown during September 1980 for the MX test wells in southern Spring Valley, Lincoln County, Nevada, for a step test, and two constant-rate tests: $A$, pumping rate; $B$, pumped well; and $C$, observation well.

\section{Petroleum Exploration Wells in Carbonate Rocks}

Petroleum exploration companies have drilled a number of exploration wells in the Big Springs area since about 1980. Six wells were drilled in Nevada—one about $6.5 \mathrm{mi}$ northeast of Big Springs along the Nevada-Utah state line and five 11-25 mi to the south in Hamlin Valley. Eight wells were drilled about $8 \mathrm{mi}$ to the east, in Utah, at the north end of the Mountain Home Range (fig. 63). The most common exploration target was the Devonian Guilmette Formation, which ranges from land surface at the Utah wells to more than 3,000 ft below land surface in Hamlin Valley and more than $6,000 \mathrm{ft}$ below land surface at the hole in Nevada, $6.5 \mathrm{mi}$ northeast of Big Springs. Each of the petroleum test wells is referenced using its American Petroleum Institute (API) number $^{1}$. The records for these wells can be found online at the Nevada Bureau of Mines and Geology website at $h t t p: / / w w w$. nbmg.unr.edu/Oil\&Gas/NVWellInfo.html and at the Utah Division of Oil, Gas and Mining website at http://oilgas.ogm.utah. gov/Data_Center/LiveData_Search/well_information.htm.

\footnotetext{
${ }^{1}$ Whenever an oil exploration well is drilled, the American Petroleum Institute assigns it an API number denoting the state and county in which the well is located. Each API number consists of three numbers separated by dashes. The first number indicates the state-Nevada is 27 , and Utah is 43 . The second number indicates the county-White Pine County in Nevada is 033, Lincoln County in Nevada is 017, and Millard County in Utah is 027. The last number is assigned sequentially in each county.
} 
The deepest exploration well drilled in the Big Springs area is the one $6.5 \mathrm{mi}$ to the northeast of Big Springs, in Nevada (27-033-05245; Outlaw Federal No. 1, fig. 63). It penetrated $1,254 \mathrm{ft}$ of basin-fill deposits and then $11,746 \mathrm{ft}$ of Paleozoic rocks from the Ely Limestone to the Pogonip Group, for a total depth of 13,000 ft. The formation tops listed for this well indicated that the entire Paleozoic carbonate rock section is present in parts of the Big Springs area.

The eight wells drilled at the north end of the Mountain Home Range in Utah are 5-7 mi south of the exploration well (27-033-05245; fig. 63). The exploration target for all of these wells was the Devonian Guilmette Formation. Well-drillers' logs for three of these wells (43-027-20295, 43-027-30002, and 43-027-30004) indicated that drilling in the Guilmette Formation and overlying shale was complicated by zones of lost circulation, resulting in no cutting returns, and by zones that produced large quantities of water. Similar conditions were encountered in Hamlin Valley, where a hole (27-017-05217; Cobb Creek Federal No. 11-1, fig. 63) drilled in the Guilmette Formation was abandoned at a depth of $995 \mathrm{ft}$ below land surface because of lost circulation at $959 \mathrm{ft}$ and what the driller described as a large influx of fresh water at $995 \mathrm{ft}$. Although these well reports provided only qualitative information on the transmissivity of the carbonate rocks in the Big Springs area, they indicated that the carbonate rocks can be transmissive even at depths greater than $1,000 \mathrm{ft}$ below land surface.

\section{Groundwater Flow Beneath the Limestone Hills}

A groundwater divide in southern Spring Valley south of Baking Powder Flat separates groundwater flow to the flat from southeastward flow to northern Hamlin Valley (fig. 61), which was first described by Rush and Kazmi (1965, p. 19). The divide coincides with a buried bedrock high (fig. 63). North of the groundwater divide, water-level altitudes in wells decrease toward Baking Powder Flat, where depth to groundwater is less than $20 \mathrm{ft}$ below land surface (fig. 68). South of the divide, water-level altitudes decrease southeastward, and depth to groundwater exceeds $50 \mathrm{ft}$ throughout southern Spring Valley and northern Hamlin Valley, indicating little groundwater is lost to evapotranspiration until it reaches southern Snake Valley. Depth to groundwater east of the Limestone Hills was less than $20 \mathrm{ft}$ below land surface only near Big Springs and along Big Springs and Lake Creeks in southern Snake Valley. Thus, little groundwater flow is to springs or is lost to evapotranspiration in southern Spring Valley, south of the groundwater divide, where groundwater flow is southeastward toward the Limestone Hills.

Because of the lack of springs and areas where groundwater flow is lost to evapotranspiration in southern Spring Valley and northern Hamlin Valley, groundwater must flow from southern Spring Valley to northern Hamlin Valley and then to southern Snake Valley, which indicates that the carbonate rocks underlying the Limestone Hills are sufficiently permeable to allow flow (Rush and Kazmi, 1965, p. 19). Recently completed test wells in carbonate rocks in southern Spring Valley (SNWA well 184W101) and southwest of Big Springs (USGS well BS-SW) indicated that the fractured sections of carbonate rocks in the region are at least as transmissive as the basin-fill deposits. Although Gillespie and others (2012) reported lower water levels in northern Hamlin Valley compared with southern Spring Valley, they concluded that groundwater did not flow through the Limestone Hills on the basis of computer generated contours of delta deuterium and carbon-14 ages from sparse data, without regard to the hydrogeology or, more importantly, to the depth to groundwater, which indicated little groundwater was lost to evapotranspiration south of the groundwater divide, except in southern Snake Valley.

Groundwater flow from southern Spring Valley to northern Hamlin Valley is a potential source for Big Springs (Hershey and others, 2007). Groundwater flow from southern Spring Valley to northern Hamlin Valley was first estimated at 4,000 acre-ft/yr by Rush and Kazmi (1965, p. 24). This estimate was increased to 8,000-12,000 acre-ft/yr by Nichols (2000, p. C34) and was increased again to 33,000 acre-ft/yr by Laczniak and others (2007, p. 73). Recent estimates of groundwater flow through the Limestone Hills to northern Hamlin Valley have been reduced again to 5,600 acre-ft/yr (Halford and Plume, 2011) and 4,400 acre-ft/yr (Burns and Drici, 2011, p. 7-7).

The estimate of groundwater flow beneath the Limestone Hills in this report is based on a three-part approach. The first part of the approach included the measurement of the groundwater levels in wells during the spring of 2010 that provided data for a new water-level map of Spring, Hamlin, and Snake Valleys (fig. 61) as part of a regional analysis of groundwater levels in eastern Nevada and western Utah (Gardner and others, 2011). The second part was to estimate the total mean annual precipitation in southern Spring Valley, and the third part was to estimate groundwater recharge in southern Spring Valley southeast of the groundwater divide. The water-level map is described earlier in this section; descriptions of the other two approaches follow.

The estimate of groundwater flow from southern Spring Valley through the Limestone Hills was limited to the mean annual precipitation in the drainage area south of the groundwater divide (drainage areas used to calculate the mean annual precipitation and recharge is shown in fig. 61) and assumed the groundwater divide in the basin fill extends down to the underlying carbonate rocks. The drainage area for southern Spring Valley was divided into two parts along a line drawn from the center of the groundwater divide southeastward to SNWA well 184W101 (fig. 61). The northern part included Johns and Murphy Washes at the south end of the Snake Range, and the southern part included the eastern slope of the Fortification Range and western slope of the Limestone Hills. The total mean annual precipitation was estimated for the two parts by multiplying the area for each of the mean precipitation rates. 


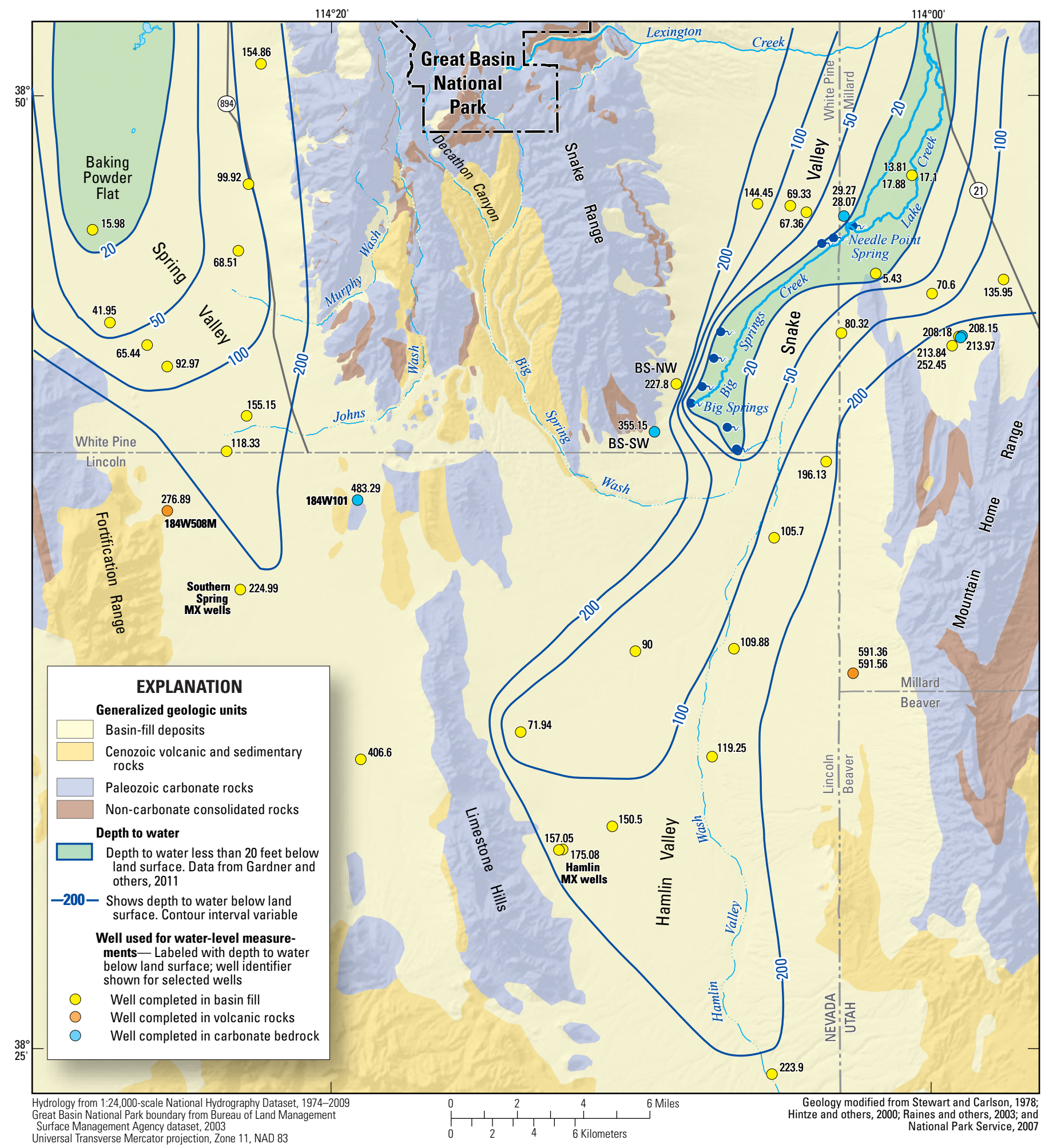

Figure 68. Distribution of basin-fill deposits and carbonate rocks and depth to groundwater in southern Spring Valley, northern Hamlin Valley, and southern Snake Valley, Lincoln and White Pine Counties, Nevada. 
A range for mean annual groundwater recharge from the total mean annual precipitation in southern Spring Valley was first estimated by using the water-yield equations developed for six drainage basins in the northern part of the southern Snake Range in Great Basin National Park, assuming that annual runoff in southern Spring Valley was minimal. The first equation (equation 1) portioned the total mean annual precipitation among four zones of precipitation rates, greater than 12 to $16 \mathrm{in} / \mathrm{yr}$, greater than 16 to $24 \mathrm{in} / \mathrm{yr}$, greater than 24 to $28 \mathrm{in} / \mathrm{yr}$, and greater than $28 \mathrm{in} / \mathrm{yr}$, with coefficients for each zone of $0.03,0.07,0.22$, and 0.79 , respectively. The second equation (equation 2) used only two zones, greater than 12 to $28 \mathrm{in} / \mathrm{yr}$ and greater than $28 \mathrm{in} / \mathrm{yr}$, with coefficients of 0.1 and 0.83 , respectively and produced somewhat greater recharge rates. The reason for the greater recharge rates from equation 2 is a greater fraction of precipitation became water yield for areas with less mean annual precipitation. Most the total mean annual precipitation in the two parts of southern Spring Valley fell in areas where the mean precipitation rates were less than $20 \mathrm{in} / \mathrm{yr}$ (table 20). No groundwater recharge from mean precipitation rates greater than 10 to $12 \mathrm{in} / \mathrm{yr}$ was used in the calculations because that zone was on the valley floor, where it was assumed to be lost to evapotranspiration, even though 3 percent was used as a coefficient for greater than 8 to $12 \mathrm{in}$. by Eakin and others (1951, p. 26-27).

Total mean annual groundwater recharge of the combined northern and southern parts in southern Spring Valley ranged from 6,000 to 11,000 acre- $\mathrm{ft}$ and, overall, was 4-7 percent of the total mean annual precipitation of the combined parts (table 20). The mean annual recharge from the northern part that included the southwestern end of the Snake Range was 40-50 percent of the total combined recharge estimate, even though the northern part accounted for only 25 percent of the total drainage area in southern Spring Valley south of the groundwater divide. The mean annual recharge for the northern part was 7-10 percent of the total mean annual precipitation in that part, whereas mean annual recharge for the southern part was 2-6 percent of the total mean annual precipitation in that part.
Dissolved chloride concentrations in wells in southern Spring Valley and northern Hamlin Valley were used to evaluate the percentage of groundwater recharge. This method uses the ratio of the chloride concentrations in precipitation from wet and dry fallout to the chloride concentration in a well or spring (table 21). The mean chloride concentration of $0.6 \mathrm{mg} / \mathrm{L}$ for wet and dry fallout estimated for the Baker Creek drainage basin was used for the south end of the Snake Range.

The chloride ratio method assumes no long-term storage of chloride in the drainage basin, no chloride is removed by runoff, and the only source of the chloride is from precipitation. The unsaturated zone in arid areas can store much of the chloride deposition from precipitation for thousands of years (Scanlon, 1991; Phillips, 1994; Prudic, 1994; Tyler and others, 1996; Stonestrom and others, 2004), but that usually happens in areas where the mean precipitation rates are less than 8 in.yr, where mean annual temperatures are warmer than they are in this study area, and where groundwater recharge is minimal. The chloride concentrations at the MX test wells in Hamlin Valley and southern Spring Valley were within $1 \mathrm{mg} / \mathrm{L}$ between analyses done for the U.S. Air Force in September 1980 (Bunch and Harrill, 1984, p. 51, 103) and those reported by SNWA for November 2010 and May 2011 (Southern Nevada Water Authority, 2012, p. F-4). The lack of variation in chloride concentrations at these sites indicated a nearly uniform movement of chloride through the unsaturated zone to groundwater.

The dissolved chloride concentration in water at SNWA well $184 \mathrm{~W} 101$ was $5.3 \mathrm{mg} / \mathrm{L}$, which indicated that about 11 percent of the mean annual precipitation in the northern part of southern Spring Valley, including the southwestern end of the Snake Range, becomes groundwater recharge (table 21). This was slightly greater than the groundwater recharge estimated by using the two water-yield equations (equations 1 and 2). The greater chloride ratios compared with recharge to precipitation ratios indicated slightly more precipitation could recharge groundwater in the more permeable carbonate rocks of the southern Snake Range than was indicated by the water-yield equations derived from areas of less permeable

Table 20. Mean annual precipitation volume and groundwater recharge in southern Spring Valley, Big Spring Wash drainage basin in northern Hamlin Valley, and eastern slope of southern Snake Range in southern Snake Valley, Lincoln and White Pine Counties, Nevada.

[Drainage areas are shown in figure 61. Mean precipitation rates from 1971-2000 (PRISM Climate Group, Oregon State University, http://prism.oregonstate.edu, created 7 Sept 2011). Recharge estimated from equations 1 and 2 assuming all water yield became groundwater recharge. Precipitation rounded to 3 significant figures; estimated mean annual recharge rounded to one significant figure. Symbol: $>$, greater than]

\begin{tabular}{|c|c|c|c|c|c|c|c|c|c|c|}
\hline \multirow{3}{*}{ Drainage basin } & \multirow{3}{*}{$\begin{array}{l}\text { Drainage } \\
\text { area } \\
\text { (square } \\
\text { miles) }\end{array}$} & \multirow{3}{*}{$\begin{array}{l}\text { Total mean } \\
\text { annual } \\
\text { precipitation } \\
\text { volume } \\
\text { (acre-feet) }\end{array}$} & \multirow{2}{*}{\multicolumn{6}{|c|}{$\begin{array}{c}\text { Mean annual precipitation volumes (acre-feet) } \\
\text { Range in mean precipitation rates (inches per year) }\end{array}$}} & \multirow{3}{*}{$\begin{array}{l}\text { Range in } \\
\text { estimated mean } \\
\text { annual recharge } \\
\text { (acre feet) }\end{array}$} & \multirow{3}{*}{$\begin{array}{l}\text { Percent of } \\
\text { mean annual } \\
\text { recharge to } \\
\text { precipitation }\end{array}$} \\
\hline & & & & & & & & & & \\
\hline & & & $>10-12$ & $>12-16$ & $>16-20$ & $>20-24$ & $>\mathbf{2 4 - 2 8}$ & $>\mathbf{2 8}$ & & \\
\hline southern Spring Valley_-Snake Range & 57.7 & 45,400 & 11,500 & 17,600 & 5,140 & 6,750 & 2,960 & 1,420 & $3,000-4,000$ & $7-10$ \\
\hline $\begin{array}{l}\text { southern Spring Valley-Fortification } \\
\text { Range and Limestone Hills } \\
\text { (southern part) }\end{array}$ & 174 & 118,000 & 46,300 & 57,900 & 14,200 & 0 & 0 & 0 & $3,000-7,000$ & $2-6$ \\
\hline Big Spring Wash & 69.1 & 61,900 & 5,290 & 19,100 & 16,100 & 12,800 & 7,310 & 1,320 & $5,000-7,000$ & $8-11$ \\
\hline southern Snake Valley_-Snake Range & 53.7 & 40,500 & 11,700 & 14,300 & 10,200 & 4,050 & 230 & 0 & $1,000-3,000$ & $4-7$ \\
\hline
\end{tabular}


Table 21. Selected water-quality constituents in water for wells and springs in southern Spring Valley, northern Hamlin Valley, and southern Snake Valley sampled between October 2010 and May 2011, Lincoln and White Pine Counties, Nevada.

[Location of wells and springs is shown in figure 61. USGS, U.S. Geological Survey; SNWA, Southern Nevada Water Authority; Hamlin MX and southern Spring MX test wells were drilled for the U.S. Air Force's MX missile-siting investigation (Bunch and Harrill, 1984). Abbreviations: mg/L, milligrams per liter; $\mu \mathrm{g} / \mathrm{L}$, micrograms per liter; PMC, percent modern carbon, rounded to two significant figures; Chloride concentrations rounded to two significant figures. Symbol: <, less than]

\begin{tabular}{|c|c|c|c|c|c|c|c|c|c|c|}
\hline \multirow{2}{*}{ Well/Spring } & \multirow{2}{*}{$\begin{array}{l}\text { Dissolved } \\
\text { solids } \\
\text { (mg/L) }\end{array}$} & \multicolumn{2}{|c|}{$\begin{array}{c}\text { Stable isotopes of water } \\
\text { (permil) }\end{array}$} & \multirow{2}{*}{$\begin{array}{c}\text { Tritium } \\
\text { (picocuries } \\
\text { per liter) }\end{array}$} & \multirow{2}{*}{$\begin{array}{l}\text { Carbon-14 } \\
\text { (PMC) }\end{array}$} & \multicolumn{2}{|c|}{ Strontium } & \multicolumn{2}{|c|}{ Chloride } & \multirow{2}{*}{ Source } \\
\hline & & $\begin{array}{c}\text { Delta } \\
\text { deuterium }\end{array}$ & $\begin{array}{c}\text { Delta } \\
\text { oxygen-18 }\end{array}$ & & & $(\mu \mathrm{g} / \mathrm{L})$ & $\begin{array}{c}\text { Ratio } \\
{ }^{87} \mathbf{S r} /{ }^{86} \mathbf{S r}\end{array}$ & $(\mathrm{mg} / \mathrm{L})$ & $\begin{array}{l}\text { Precipitation } \\
\text { ratio }\end{array}$ & \\
\hline \multicolumn{11}{|c|}{ Southern Spring Valley } \\
\hline SNWA 184W101 well & 215 & -114 & -15.2 & $<2.5$ & 4.2 & 185 & 0.71056 & 5.3 & 0.11 & SNWA \\
\hline SNWA 184W508M well & 218 & -109 & -14.4 & $<2.5$ & 60 & 130 & 0.71090 & 9.4 & 0.06 & SNWA \\
\hline southern Spring MX well & 185 & -107 & -13.9 & $<2.5$ & 32 & 310 & 0.71069 & 11 & 0.05 & SNWA \\
\hline \multicolumn{11}{|c|}{ Northern Hamlin Valley } \\
\hline Hamlin MX well & 253 & -114 & -15.0 & $<2.5$ & 6.8 & 391 & 0.71302 & 17 & 0.04 & SNWA \\
\hline \multicolumn{11}{|c|}{ Southern Snake Valley } \\
\hline Big Springs south channel & 202 & -111 & -15.0 & 4.9 & 31 & 121 & 0.71119 & 5.1 & 0.12 & $\begin{array}{l}\text { USGS/ } \\
\text { SNWA }\end{array}$ \\
\hline Big Springs-northwest well & 272 & -108 & -14.7 & $<0.7$ & 58 & 79 & 0.71006 & 12 & 0.05 & USGS \\
\hline Big Springs-southwest well & 199 & -111 & -15.1 & 2.0 & 34 & 118 & 0.71107 & 4.0 & 0.15 & USGS \\
\hline Stateline spring & 226 & -111 & -14.6 & $<2.5$ & 24 & 361 & 0.70960 & 23 & 0.03 & SNWA \\
\hline
\end{tabular}

rocks in the northern part of the southern Snake Range. In the northern part of southern Spring Valley, estimated total mean annual groundwater recharge was 4,000 acre-ft, which was derived by multiplying the chloride ratio of $5.3 \mathrm{mg} / \mathrm{L}$ from well $184 \mathrm{~W} 101$ by the total mean annual precipitation for the area of mean precipitation rates greater than $12 \mathrm{in} / \mathrm{yr}$. Dissolved chloride concentrations from two wells in the southern part of southern Spring Valley (SNWA 184W508M well and southern Spring Valley MX well) and one well in northern Hamlin Valley (Hamlin MX well) east of the Limestone Hills ranged from $9.4 \mathrm{mg} / \mathrm{L}$ to $17 \mathrm{mg} / \mathrm{L}$ (table 21). The ratio of chloride in water to chloride in precipitation for these three wells ranged from 0.04 to 0.06 ; when these ratios are multiplied with the total mean annual precipitation for rates greater than $12 \mathrm{in} / \mathrm{yr}$ in the southern part of southern Spring Valley, estimated mean annual groundwater recharge ranged from 2,000 to 4,000 acre-ft, a range that is about 50 percent less than the estimate of mean annual recharge for the southern part in southern Spring Valley listed in table 20. Thus, the range in total mean annual groundwater recharge of the combined two areas in southern Spring Valley estimated using chloride concentrations was 6,000 to 8,000 acre-ft, which was at the lower end of the range in mean annual groundwater recharge estimated from the two water-yield equations (equations 1,2).

Assuming a range in groundwater flow from 6,000 to $11,000 \mathrm{acre}-\mathrm{ft} / \mathrm{yr}$, a hydraulic gradient of $20 \mathrm{ft} / \mathrm{mi}$, and a width of flow of $18 \mathrm{mi}$, the transmissivity of saturated carbonate rocks beneath the Limestone Hills was 2,000 to 4,000 $\mathrm{ft}^{2} / \mathrm{d}$. This range was less than half of the transmissivity estimated from an aquifer test at SNWA well 184W101 (table 19). Much of the groundwater flow through the Limestone Hills could be limited to the northern part, however, which is east of the SNWA well 184W101 (fig. 61). Assuming the transmissivity for the northern part of the Limestone Hills was the same as at the SNWA well, or $10,000 \mathrm{ft}^{2} / \mathrm{d}$, the width of flow would be only $4 \mathrm{mi}$.

\section{Source of Water to Big Springs}

A geochemical study indicated that some of the flow at Big Springs could come from groundwater in southern Spring Valley (Hershey and others, 2007), whereas a more recent geochemical study indicated that flow to the springs was locally derived from the south end of the Snake Range (Gillespie and others, 2012). As a starting point in evaluating groundwaterflow direction, a simple three-point analysis was done using the water-level altitudes in BS-NW and BS-SW (fig. 61) along with the land-surface altitude at the main orifice of Big Springs south channel. Land-surface altitudes at the three locations were determined by using differential global positioning systems (GPS) to an accuracy of $\pm 0.08 \mathrm{ft}$ (Toby Welborn, U.S. Geological Survey, Carson City, Nev., written commun., 2011). The three-point analysis assumed the water surface forms a uniformly sloping surface, from which the magnitude and direction of the hydraulic gradient can be estimated and the direction of groundwater flow can be approximated. The result indicated a direction of groundwater flow that was north 57 degrees east, with a hydraulic gradient of $50 \mathrm{ft} / \mathrm{mi}$ $(0.01 \mathrm{ft} / \mathrm{ft})$. The direction of groundwater flow approximated the course of Big Springs Creek downstream of the springs (fig. 61). This analysis indicated that much of the flow at Big Springs was groundwater flow beneath alluvial fans at the south end of the Snake Range (fig. 63).

Big Springs and well BS-NW are located where groundwater flow direction changes from northeastward, south of Big Springs, to generally eastward, north of Big Springs 
(fig. 69). Groundwater flow beneath Hamlin Valley Wash is mostly northward, until it coincides with southward groundwater flow beneath Big Spring Wash in the southern Snake Range, eastward groundwater flow from southern Spring Valley, and eastward groundwater flow from the eastern slope of the Snake Range. Groundwater recharge was estimated for all the areas shown on figure 69, except for groundwater beneath Hamlin Valley Wash (table 20). The mean annual groundwater recharge estimated from the water-yield equations (equations 1 and 2) in the drainage basins north of Big Springs to the drainage basin south of Big Wash on the eastern slope of southern Snake Valley was from 1,000 to 3,000 acre-ft, or 4-7 percent of the total mean annual precipitation. The ratio of chloride in precipitation to chloride in the well northwest of Big Springs was 0.05 (table 21) or 5 percent of the total mean annual precipitation and was within the 4-7 percent of the total mean annual precipitation. Mean annual groundwater flow from recharge areas that included the east slope of the southern Snake Range north of Big Springs, Big Spring Wash, and southern Spring Valley ranged from about 12,000 to 21,000 acre- $\mathrm{ft}$; but the range derived by multiplying the chloride ratios for each area listed in table 21 to the total mean annual precipitation for rates greater than $12 \mathrm{in} / \mathrm{yr}$ (table 20) was 14,000-16,000 acre-ft. The change in direction of groundwater flow from these areas, as well as groundwater flow beneath Hamlin Valley Wash, was likely caused by a narrowing in width of groundwater flow in southern Snake Valley because of the upper Paleozoic siliciclastic unit (Mississippian Chainman Shale) that dips steeply at the north end of the Mountain Home Range and continues to the Burbank Hills (Gardner and others, 2011; fig. 3). The limited width of flow allowed by the steeply dipping confining unit also can explain the large area of groundwater lost to evapotranspiration from Big Springs in Nevada to Pruess Lake in Utah (fig. 69).

Chemical analyses were performed on groundwater samples collected from the Big Springs northwest and southwest wells and from the north spring orifice in the south channel of Big Springs. Analyses included the standard dissolved constituents and trace elements (appendix tables 16-8, 16-9) along with specific analyses to help identify the source of the spring water and to estimate its mean age. Radioactive isotopes of carbon (carbon-14) and hydrogen (tritium) were used for evaluating the mean age of water, whereas the stable isotopes of carbon, strontium, and uranium were used to evaluate the types of rocks that resulted in the dissolved constituents found in the spring water (tables 21, 22). Dissolved chlorofluorocarbon gases (CFC), introduced to the atmosphere after World War II, also can be used to estimate the mean age of relatively young water (Plummer and others, 1993). This analysis was included because previous studies that sampled water from Big Springs indicated some modern water was present (Hershey and others, 2007, p. 29; Gillispie, 2008, p. 30).

Water chemistry results (tables 21,22 ) indicated that most of the water in the south channel of Big Springs was groundwater from southwest of the springs, as represented by water from well BS-SW. The similar water chemistry in the south channel of Big Springs and in water from well BS-SW was consistent with the northeast-directed groundwater flow estimated from water-level altitudes in the two wells compared with the land-surface altitude at Big Springs

The water chemistry at well BS-NW indicated that water in this well was older than water from BS-SW and Big Springs because it lacked tritium (table 21) and had lower concentrations of dissolved CFC gases (table 22). The estimated mean age, assuming similar recharge altitudes and temperatures, was the mid-1950s for water in BS-NW and the mid to late 1960s for water in BS-SW. The mean age of water sampled from the two wells and Big Springs included much older and much younger water. If, for example, all the water in well BS-SW was recharged in the mid-1960s, during the peak atmospheric tritium concentration from thermonuclear bomb tests, the tritium concentration would be several hundred picocuries per liter. The trace, but detectable, concentration of tritium indicated that the water was a mixture of water with a range in ages.

Total dissolved solids and chloride concentrations in water from well BS-NW were higher than in water from the south channel of Big Springs and well BS-SW (table 21). The higher concentration of chloride at well BS-NW was consistent with enrichment of delta deuterium and delta oxygen-18; consequently, more precipitation in the catchment area of well BS-NW was lost to evapotranspiration compared with that of BS-SW. The carbon-14 concentration in water from well BS-NW was nearly twice that in water from the springs and well BS-SW, however. The higher carbon-14 concentration in water from well BS-NW, combined with lower concentrations

Table 22. Selected water-quality constituents in water from Big Springs and test wells northwest and southwest of the springs in southern Snake Valley sampled in October and November 2010, White Pine and Lincoln counties, Nevada.

[Location of wells and Big Springs is shown in figure 61. Spring orifice on south channel of Big Springs sampled November 2, 2010; Big Springs-northwest well sampled October 4, 2010; Big Springs-southwest well sampled November 3, 2010. Sample splits were collected at Big Springs and analyzed by the U.S. Geological Survey and Southern Nevada Water Authority separately; values listed are those stored in the U.S. Geological Survey National Water Information System database. Estimated year of recharge from dissolved chlorofluorocarbons (CFC) are based on an assumed recharge altitude of 8,000 feet above vertical datum and a mean annual temperature of 8 degrees Celsius. Abbreviation: mg/L, milligrams per liter; $\mu \mathrm{g} / \mathrm{L}$, micrograms per liter; ${ }^{234} \mathrm{U}$, uranium-234; ${ }^{238} \mathrm{U}$, uranium-238]

\begin{tabular}{|c|c|c|c|c|c|c|c|c|c|}
\hline \multirow[b]{2}{*}{ Well/spring } & \multicolumn{5}{|c|}{ Dissolved constituent (mg/L) } & \multirow{2}{*}{$\begin{array}{l}\text { Delta } \\
\text { Carbon-13 } \\
\text { permil }\end{array}$} & \multicolumn{2}{|c|}{ Uranium } & \multirow{2}{*}{$\begin{array}{l}\text { Estimated range in } \\
\text { year of recharge from } \\
\text { dissolved CFC }\end{array}$} \\
\hline & Bicarbonate & Calcium & Fluoride & Magnesium & Sodium & & $(\mu \mathrm{g} / \mathrm{L})$ & $\begin{array}{c}\text { Ratio } \\
{ }^{234} \mathbf{U} /{ }^{238} \mathbf{U}\end{array}$ & \\
\hline Big Springs south channel & 205 & 48 & 0.15 & 20 & 4 & -7.1 & 1.38 & 3.68 & $1965-69$ \\
\hline Big Springs-northwest well & 299 & 53 & 0.06 & 29 & 9 & -9.2 & 0.64 & 4.64 & $1953-57$ \\
\hline Big Springs-southwest well & 210 & 47 & 0.13 & 19 & 5 & -7.2 & 1.46 & 3.74 & $1965-69$ \\
\hline
\end{tabular}




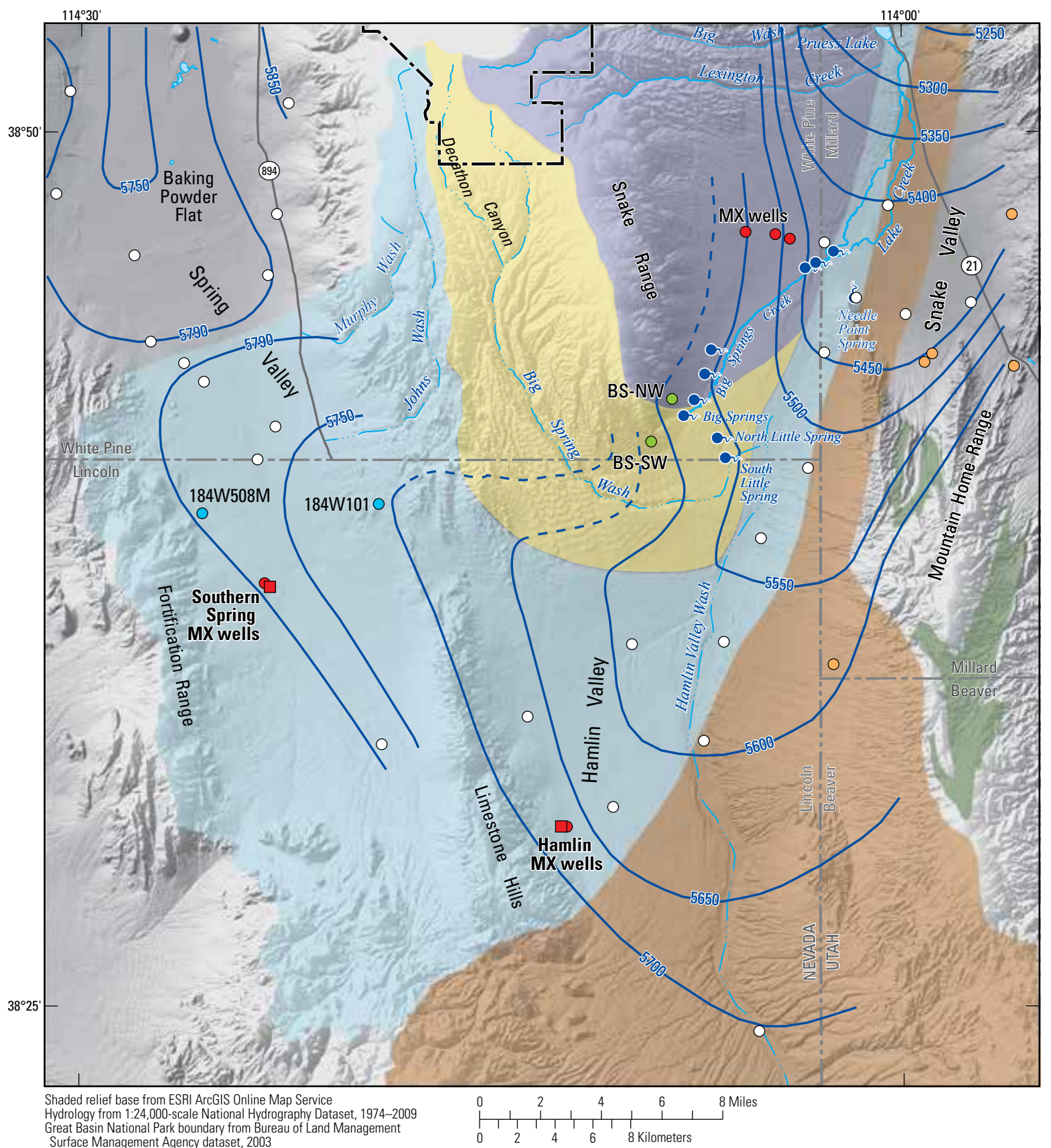
Great Basin National Park boundary from Bureau of Land Management Surface Managem Agency dataset, 2003

\section{EXPLANATION}

Outcrop of Chainman Shale Groundwater-flow areas Hamlin Valley Wash Southern Spring Valley Big Spring Wash Southeastern Snake Range

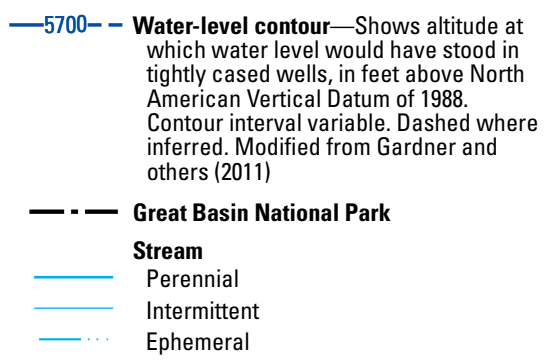

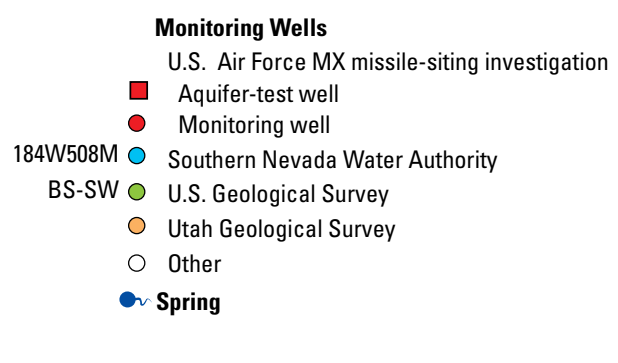

Monitoring Wells

U.S. Air Force MX missile-siting investigation

Aquifer-test well

Southern Nevada Water Authority

U.S. Geological Survey

Spring

Figure 69. Conceptualization of groundwater flow to southern Snake Valley from source areas in the south end of the Snake Range, southern Spring Valley, and northern Hamlin Valley, Lincoln and White Pine Counties, Nevada. 
of fluoride, strontium, and uranium, as well as differences in isotope ratios of strontium and uranium (tables 21, 22), indicated that water in well BS-NW had reacted with different rocks than water in well BS-SW and at Big Springs (Wiggly and Plummer, 1976). Thus, differences in water chemistry between wells BS-NW and BS-SW also indicated a northeast direction of groundwater flow from near the southwest well to Big Springs.

The mean annual groundwater recharge in the Big Spring Wash and and in local drainage basins between Big Spring Wash and Big Springs (drainage area for Big Spring Wash and local drainage basins is shown on fig. 61) estimated by using the two water-yield equations (equations 1 and 2) ranged from 5,000 to 7,000 acre-ft and was 8-11 percent of the total mean annual precipitation (table 20). These percentages were similar to those in the northern part of southern Spring Valley south of the groundwater divide that includes Murphy and Johns Washes. Groundwater recharge in the Big Spring Wash and nearby smaller drainage basins bound the estimate of the mean annual runoff of the two channels at Big Springs of 6,200 acre-ft (table 1). The chloride concentration and the ratio of chloride in precipitation to that in water from the north spring orifice of the south channel of Big Springs was nearly the same as those in water from SNWA well 184W101 (table 21). This ratio indicated that about 12 percent of the precipitation in the Big Spring Wash drainage basin could account for the flow at Big Springs, which was similar to that estimated from the water-yield equations (table 20). An additional calculation compared the total mean annual chloride mass at Big Springs to the total mean annual chloride mass in precipitation for mean precipitation rates exceeding $12 \mathrm{in} / \mathrm{yr}$ in the Big Spring Wash drainage basin and in smaller drainage basins between Big Spring Wash and Big Springs (drainage area for Big Spring Wash and local drainage basins is shown on fig. 61). The mean annual chloride mass that enters Big Spring Wash and nearby smaller drainage basins from precipitation was 46 tons, if the mean chloride concentration of precipitation and dry fallout was $0.6 \mathrm{mg} / \mathrm{L}$, and the total mean annual of precipitation for mean precipitation rates greater than $12 \mathrm{in} / \mathrm{yr}$ was 57,000 acre-ft (table 20). The mean annual chloride mass from the north and south channels of Big Springs also was 46 tons, assuming the mean chloride concentration of water from both channels was 5.5 $\mathrm{mg} / \mathrm{L}$ (average of five samples from Big Springs between 1983 and 2010 and available at http://waterdata.usgs.gov/nwis) and the mean annual runoff from both channels of Big Springs is 6,200 acre-ft (table 1). Thus, chloride mass in the Big Spring Wash and nearby smaller drainage basins can account for the mean annual runoff from Big Springs. Consequently, groundwater flow from southern Spring Valley was conceptualized as moving south of Big Springs between groundwater flow under Big Spring Wash to the north and flow under Hamlin Valley Wash to the south and east (fig. 69). Some of this flow could be lost to evapotranspiration on the eastern side of Big Springs Creek or could contribute to flow at springs near the NevadaUtah state line.
The temperature of water at the orifice of the south channel of Big Springs ranged from 17 to $19{ }^{\circ} \mathrm{C}$, which was warmer than the $9^{\circ} \mathrm{C}$ mean annual air temperature at the weather station near Lehman Caves Visitor Center. This difference in temperature can be explained by groundwater circulation to a depth of about $1,000 \mathrm{ft}$, assuming temperature in the ground increases about $1{ }^{\circ} \mathrm{C}$ every $100 \mathrm{ft}$ in depth (Nathenson and Guffanti, 1988). The water temperature from well BS-SW was $16{ }^{\circ} \mathrm{C}$ in November 2010 , where the screened interval was 500-700 ft below land surface, and the water temperature in well BS-NW was $13{ }^{\circ} \mathrm{C}$ in October 2010, where the screened interval was 300-460 ft below land surface, which is an increase of $3{ }^{\circ} \mathrm{C}$ over $220 \mathrm{ft}$ in depth between the midpoint of each screen or an increase of about $1.4{ }^{\circ} \mathrm{C}$ for every $100 \mathrm{ft}$ of depth. Such an increase in temperature indicated that water at Big Springs could originate from depths less than 1,000 ft.

\section{Summary}

The greatest spring flows in the study area were from Big Springs and springs on the valley floor of southern Snake Valley near the Nevada-Utah state line. Both spring areas are close to outcrops of Paleozoic carbonate rock and upland areas where streams are ephemeral. Water chemistry of water from the south channel of Big Springs was similar to that of water in a well southwest of Big Springs, indicating that groundwater flows northeast to Big Springs. All water flowing at Big Springs can be accounted for by precipitation in the Big Spring Wash drainage basin and smaller drainage basins between the wash and springs either by comparing the mean annual discharge at the springs with estimated groundwater recharge in the drainage basins or by comparing the mean annual chloride mass from precipitation with that from the springs. Much of the groundwater recharged in Big Spring Wash and nearby smaller drainage basins is likely the source to Big Springs.

A groundwater divide is present in basin-fill deposits in southern Spring Valley above a buried bedrock high. Two aquifer tests, one in basin-fill deposits and the other in carbonate rocks south of the divide, indicated transmissivities greater than $10,000 \mathrm{ft}^{2} / \mathrm{d}$. Depth to groundwater was greater than $100 \mathrm{ft}$ in southern Spring Valley and greater than $50 \mathrm{ft}$ in northern Hamlin Valley, indicating little if any groundwater flow is lost to evapotranspiration before reaching southern Snake Valley, where depth to groundwater was less than $20 \mathrm{ft}$. These observations indicated that groundwater in southern Spring Valley flows beneath the Limestone Hills and the north end of Hamlin Valley.

The mean annual groundwater flow beneath the Limestone Hills from southern Spring Valley was estimated to range from 6,000 to 11,000 acre-ft. The mean annual groundwater flow southward to northern Hamlin Valley from the Big Spring Wash drainage basin and nearby smaller drainage basins at the south end of the Snake Range was estimated to range from 5,000 to 7,000 acre-ft, and the mean annual groundwater flow 
in ephemeral drainage basins along the eastern slope of the southern Snake Range from north of Big Springs to south of Big Wash was estimated to range from 1,000 to 3,000 acre-ft. This eastward and southward groundwater flow converges with northward groundwater flow beneath Hamlin Valley Wash, which is constricted to a relatively narrow width in southern Snake Valley. The constriction is caused by the steeply dipping siliciclastic confining unit (Mississippian Chainman Shale) exposed along the eastern side of Snake Valley at the north end of the Mountain Home Range and in the Burbank Hills. Because the width of groundwater flow in this area narrows, considerable quantities of groundwater flows to springs or is lost to evapotranspiration between Big Springs in Nevada and Pruess Lake in Utah.

Groundwater flow from southern Spring Valley beneath the Limestone Hills is conceptualized to continue eastward south of Big Springs, where it turns in a northeast direction to accommodate northward flow beneath Hamlin Valley Wash. Although little if any groundwater from southern Spring Valley flows to Big Springs, some of the groundwater from southern Spring Valley is likely to be the source of flow to the springs near the Nevada-Utah state line or is lost to evapotranspiration along Big Springs Creek and Lake Creek. Any remaining groundwater from southern Spring Valley would continue as northeastward regional flow through carbonate rocks on the east side of Snake Valley.

\section{Limitations and Considerations}

The discussion of surface-water and groundwater flow presented in this report is supported by the integration of diverse data sets, but a full characterization of the connections of surface-water and groundwater in the southern Snake Range with groundwater in southern Snake and northern Hamlin Valleys was limited by geologic and hydrologic data deficiencies and the need for a better understanding of the local geologic framework that controls the connections. This study focused on two principal areas of importance to the National Park Service and the U.S. Bureau of Land Management: the drainage basins of Baker, Lehman, and Snake Creeks on the eastern slopes of the southern Snake Range and the area of groundwater connection between southern Spring Valley and southern Snake Valley. This section describes the limitations specific to these two areas and presents additional field investigations that could reduce uncertainty.

Five limitations and further investigations that bear on the conceptualization of the surface-water and groundwater systems in the Baker, Lehman, and Snake Creek drainage basins are discussed in the following paragraphs.

First, the principal range-front faults along the eastern side of the southern Snake Range north of Snake Creek either are interpreted as low-angle features that developed primarily in Miocene time (McGrew, 1993; Miller and others, 1999) or as high-angle features with primarily young offset (Dixon and others, 2007; Rowley and others, 2009). Understanding the location, continuity, and degree of offset along these faults is critical to hydrogeologic interpretation, especially where faults are in, or buried by, young alluvial sediments. Highangle and low-angle faults were interpreted from two AMT profiles in the vicinity of Baker Creek and Kious Spring (Asch and Sweetkind, 2010, 2011), but the hydraulic significance of these structures was not investigated. Additional studies of the range-front faults and their properties are needed to gain a better understanding of the potential for these faults to limit the effects of groundwater pumping in the lower-piedmont and valley-lowland zones on the water resources in Great Basin National Park.

Second, a water budget could not be calculated for the upper-piedmont zone in the Baker and Lehman Creek drainage basins because of uncertainties in estimates of mean annual runoff and groundwater flow from the zone. Information needed to develop a water budget for the upper-piedmont zone includes (1) determining the mean annual runoff in the natural channel of Baker Creek downstream from the diversion to Lehman Creek and the mean annual runoff of the combined Baker and Lehman Creeks upstream of the concrete ditch, (2) determining the hydraulic properties of the fractured limestone buried beneath younger and older basin-fill deposits, and (3) determining the flow and source of springs at the Home Farm north of the Lehman Creek drainage.

Third, the errors associated with the computation of wateryield in the mountain-upland zone are of an unknown magnitude as a result of (1) limited availability of precipitation and streamflow records, (2) the assumption that groundwater flow was a minor component of water yield, and (3) the assumption that water storage did not change. Additional precipitation and gaging stations are needed to improve estimates of water yield in the mountain-upland zone, particularly precipitation stations at altitudes above 11,000 ft. Furthermore, monitoring tritium and bulk chloride (wet and dry deposition) concentrations at the cooperative weather station at Lehman Caves Visitor Center can improve estimates of the mean age of water in the creeks and springs and provide additional information about the groundwater storage capacity in the mountain-upland zone.

Fourth, structural disruption in the karst-limestone zone in the Snake Creek drainage basin creates complex and incompletely understood connections between surface water and groundwater in this area. In particular, the groundwater connections with the Big Wash drainage basin to the south are poorly known and additional investigations are needed to evaluate the potential for groundwater flow beneath the drainage divide between the two basins. Streamflow losses to the Pole Canyon Limestone at the upper end of the karstlimestone zone in Snake Creek drainage basin do not reappear in the lower reaches of the Snake Creek drainage, and the path of these waters is poorly understood. Also, the local drainage area to Spring Creek Spring is insufficient to support its flow, indicating that groundwater from the Big Wash drainage basin could contribute to the spring. 
Fifth, water-yield estimates in the karst-zone limestone zone of the Snake Creek drainage determined from three methods produced different results. The method that used chloride concentrations in water produced an estimated water yield less than that of the computation of water yield developed for the mountain-upland zone or from annual runoff at two gaging stations and from flow at springs. The estimated water yield from chloride concentrations had greater uncertainty than the other two methods, which could be reduced by (1) measuring chloride concentration from atmospheric deposition, (2) analyzing the chloride concentrations of the younger carbonate rocks, and (3) measuring flow combined with chloride concentrations at selected locations in the Snake Creek drainage.

Three limitations and further investigations of the conceptualization of the groundwater connection between southern Spring Valley and southern Snake Valley are discussed in the following paragraphs.

First, although mean annual precipitation in Big Spring Wash is sufficient to explain the flow of Big Springs, the source area of water to Big Springs is incompletely understood. Only water sampled from the southern springs at Big Springs was analyzed for chemical constituents, and the chemistry of that water differed from the chemistry of water from the well northwest of Big Springs. The groundwater-flow direction north of Big Springs remains uncertain, and additional measurements of flow and water chemistry analyses at all the springs north of Big Springs could assist in the evaluation of groundwater flow.

Second, a groundwater divide in basin fill overlies a buried bedrock ridge in southern Spring Valley; however, the geologic nature and hydrologic importance of the bedrock ridge are not well understood. A buried ridge of carbonate rocks is consistent with the results of geophysical surveys, but this inference remains uncertain in the absence of test holes drilled into the bedrock ridge. Additional investigations could determine the type of bedrock, its hydraulic properties, and whether a groundwater divide in the underlying bedrock is different from the groundwater divide in the basin fill.

Third, estimates of groundwater flow from southern Spring Valley to northern Hamlin Valley still have considerable uncertainty. The completion of planned wells (United States Department of the Interior and Southern Nevada Water Authority, 2006; Southern Nevada Water Authority, 2008; appendix 1) near the drainage divide between the two valleys could provide information about where groundwater flows beneath the Limestone Hills. Drilling of the planned well at the south end of the Limestone Hills could improve understanding of the hydraulic properties of carbonate rocks near the contact with the Indian Peak caldera complex.

\section{Summary and Conclusions}

The desire by the Department of Interior (DOI) bureaus to understand the possibility and extent of adverse effects of groundwater pumping in the valleys on important water resources in federal lands led to this study. The purposes of this study were (1) to gain a better understanding of the aquifers controlling groundwater flow on the eastern side of the southern part of the Snake Range and their connection with aquifers in the valleys, (2) to evaluate the relation between surface water and groundwater along the piedmont slopes, (3) to evaluate sources for Big Springs and Rowland Spring, and (4) to assess groundwater flow from southern Spring Valley to northern Hamlin Valley. The study focused on two areasthe first included the drainage basins of Lehman, Baker, and Snake Creeks, and the second was the potential source area for Big Springs in the south end of Snake Valley that included the south end of the Snake Range, the Limestone Hills, the south end of Spring Valley, and the north end of Hamlin Valley.

A variety of data were compiled and collected for this study, including data from other federal and state (Nevada and Utah) agencies and the SNWA that routinely collect waterresource related data in the study area, as well as data collected for oil exploration and for local ranchers and homeowners. Data from other sources included precipitation; chemistry of precipitation, stream- and spring-water, and groundwater from wells; geology; previously drilled wells; streamflow and spring flow records; groundwater levels; and hydraulic properties from aquifer tests. Tasks performed specifically for this study included the following: (1) geologic field mapping in the Limestone Hills and the Baker, Lehman, Snake Creek, and Big Spring Wash drainage basins; (2) drilling test wells at specific sites to evaluate the geology, to monitor groundwater levels, to evaluate hydraulic properties through aquifer testing, and to assess the groundwater chemistry; (3) measuring streamflow and spring flow and sampling streams and springs for water chemistry; (4) installing shallow piezometers in the streambed of Baker, Lehman and Snake Creeks to determine streambed hydraulic gradients and seepage rates; and (5) monitoring temperature along selected reaches of Lehman and Snake Creeks to determine groundwater seepage through the streambed.

The southern Snake Range forms a fault-bounded uplift, where late Proterozoic and Cambrian siliciclastic rocks and intrusive rocks are present at or near the surface in the northern half of the range, and Paleozoic carbonate rocks outcrop in the southern half of the range. An Ordovician through Devonian section is present in fault-disrupted sections near Snake Creek and as an intact stratigraphic section at the south end of the range and in the Limestone Hills. The consolidated rocks of the Snake Range were intruded by plutons from Jurassic to Tertiary age. Intrusive rocks are most common in the northern half of the southern Snake Range, particularly in the area between the Lehman and Snake Creek drainage basins. The Prospect Mountain Quartzite, Pioche Shale, and Pole Canyon Limestone are all in intrusive contact with these plutons. 
Cenozoic rocks crop out locally and fill the basins that underlie Snake, Spring, and Hamlin Valleys. The oldest Cenozoic rocks are Oligocene volcanic rocks that were erupted from large volcanic calderas of the Indian Peak caldera complex. These volcanic rocks are exposed south of the Limestone Hills, in the Fortification Range southwest of the south end of the Snake Range, and in the Mountain Home Range to the southeast and are in the subsurface in southern Spring Valley and Hamlin Valley. Semi-consolidated Miocene strata are present along the eastern flank of the southern Snake Range in the vicinity of Sacramento Pass, by Snake Creek, and at the south end of the range in Big Spring Wash. Exposures of the Miocene section are rare elsewhere, but these rocks are known or inferred to exist in the subsurface on the eastern flank of the range. Miocene strata are highly heterogeneous and contain coarse conglomeratic facies and megabreccia deposits that record a major uplift of the Snake Range during Miocene time. Younger Tertiary and Quaternary sedimentary (basinfill) deposits overlie the older Cenozoic rocks and form the upper parts of basin-fill material in Snake, Spring, and Hamlin Valleys. These deposits consist of poorly-sorted stream and alluvial fan deposits of sand and gravel along the basin margins and of playa silts and clays along the basin axes. Glacial deposits are preserved locally in valleys in the northern part of the range.

Cenozoic deformation of the region is characterized by local extreme extension along a low-angle detachment fault, which is overprinted by generally younger Basin and Range extension along steeply dipping faults. The southern Snake Range detachment fault is the dominant structural feature along the east flank of the southern Snake Range from Snake Creek drainage basin northward to Sacramento Pass; the development of this fault affected the exposure and configuration of most of the consolidated and partly consolidated rocks in this area. The southern Snake Range detachment fault approximately parallels the northeastern boundary of GBNP from Strawberry Creek southward to Snake Creek and, then, trends southwest across the crest of the range. Rocks beneath the detachment are typically ductilely deformed and weakly metamorphosed Late Proterozoic to Middle Cambrian siliciclastic rocks, intrusive rocks, and some carbonate rocks. Above the detachment fault, Lower Paleozoic rocks are complexly faulted, particularly in the vicinity of Snake Creek and Big Wash. Thick, west-tilted, middle Miocene rocks, which were derived from the Snake Range during middle Miocene faulting and related uplift, are present locally. Displacement on the fault decreases southward; south of Snake Creek and Big Wash, it plunges far below the surface outcrops. The south end of the range features tilted panels of middle and upper Paleozoic carbonate rocks that are separated by high-angle normal faults; this structural pattern continues southward to the Limestone Hills. The eastern range front has been modified by post-Miocene to Quaternary-aged faults. Along the northern half of the range, this modification is minor; young faults were imaged by geophysical methods beneath some rangefront alluvial fans and in the deep basins east of the range. The southern Snake Range between Snake Creek and Big Springs shows the clearest evidence for recent fault offset.

Baker, Lehman, and Snake Creek drainage basins were divided into five hydrologic zones on the basis of distinct climatic, geologic, and topographic features. The five zones, from the mountain crest to the valley floor, are the mountainupland, karst-limestone, upper-piedmont, lower-piedmont, and valley-lowland zones. The primary source of water in the dry valley-lowland zone is streamflow generated in the precipitation-rich mountain-upland zone in the Baker, Lehman, and Snake Creek drainage basins. Much of the streamflow from the mountain-upland zone is generated at land-surface altitudes that exceed $11,000 \mathrm{ft}$ above mean sea level, where about 80 percent of the total mean annual precipitation was estimated to become annual runoff because poorly-permeable quartzite and intrusive rocks are covered by thin soil or by thin glacial and alluvial deposits that limit groundwater recharge, flow, and storage.

Groundwater flow increases in the karst-limestone zone of all three drainage basins, primarily, because of the presence of permeable carbonate-rock aquifers and increased permeability from dissolution of the limestone. This resulted in combined streamflow losses along the creeks of 3,300 acre- $\mathrm{ft} / \mathrm{yr}$ in the Baker and Lehman Creek drainage basins and 1,100 acre-ft/ $\mathrm{yr}$ in the Snake Creek drainage basin, although the mean net streamflow loss was only 100 acre-ft/yr in Snake Creek because of intermittent tributary and groundwater inflows to the creek following winters with above-average precipitation. Much of the groundwater flow in the karst-limestone zone is through large tubular openings to fault-controlled springs in the Baker, Lehman, and Snake Creek drainage basins. Outflow from the karst-limestone zone to the upper-piedmont zone is mostly by streamflow and spring flow along faults. The mean annual runoff and the flow of springs totaled 13,600 acre-ft in the Baker and Lehman Creek drainage basins and 5,100 acre-ft in the Snake Creek drainage basin.

In contrast to mean annual runoff and the flow of springs, the mean annual groundwater inflow to the upper-piedmont zone was 1,600 acre-ft for the Baker and Lehman Creek drainage basins, about half of which was through fractured limestone. Mean annual groundwater inflow to the upper-piedmont zone was 440 acre-ft in the Snake Creek drainage basin, mostly through fractured limestone. In the upper-piedmont zone, groundwater can be divided into an unconfined aquifer in the younger alluvial deposits associated with each creek and a confined aquifer in the fractured limestone, which are separated by less permeable older basin-fill deposits. The water table in the younger deposits was generally near the streambed, as indicated by little stream gain or loss and water levels in piezometers that were near the water level in the creeks. An exception was the lower reach of Snake Creek drainage basin, downstream from the confluence with Spring Creek, where hydraulic gradients indicated gravity drainage (hydraulic gradients near $-1 \mathrm{ft} / \mathrm{ft}$ ), which continued to the lower-piedmont zone to the Nevada-Utah state line. Streamflow in this 3.1-mi reach of Snake Creek was disconnected from the groundwater 
system. The net streamflow loss in this reach averaged only $0.7 \mathrm{ft}^{3} / \mathrm{s}$ between January 2002 and October 2004 and resulted in a net streambed-seepage rate of $0.5 \mathrm{ft} / \mathrm{d}$. This rate was consistent with estimates from three streambed piezometers and, because of gravity drainage, the vertical hydraulic conductivity was also about $0.5 \mathrm{ft} / \mathrm{d}$, an order of magnitude less than the vertical hydraulic conductivity estimated for the streambeds along Baker and Lehman Creeks. The reason for the low hydraulic conductivity was that the streambed sediments are cemented with calcite caused by off-gassing of carbon dioxide gas in water that came from springs at the end of the karstlimestone zone from late summer to winter, when all the flow in Snake Creek was from the springs.

Specific-capacity estimates and aquifer tests indicated that the transmissivity of the fractured limestone beneath the older basin-fill deposits in the upper-piedmont zone was less than that in the karst-limestone zone, likely because dissolution of the fractured limestone was limited by the availability of dissolved carbon dioxide gas that entered with groundwater leaving the karst-limestone zone. The estimated transmissivity of the fractured limestone from slug tests at the Snake 5 deep well next to Snake Creek was about $500 \mathrm{ft}^{2} / \mathrm{d}$. Geochemical modeling indicated that water from the Snake Creek 5 deep well traveled mostly through carbonate-rocks beneath the older basin-fill deposits. The mean age of water, estimated from tritium concentration in the well water, was 4-7 years. This indicated relatively rapid transport through fractures from the karst-limestone zone in Great Basin National Park to the well, even though groundwater flow through the fractured limestone was 9 percent of the estimated mean annual runoff in Snake Creek at the end of the upper-piedmont zone.

Much of the groundwater flow to the upper-piedmont zone in all three drainage basins becomes groundwater flow to the lower-piedmont zone, particularly in the Baker and Snake Creek drainage basins. The younger alluvial deposits thicken rapidly downslope of the Quaternary faults that separate the upper-piedmont zone from the lower-piedmont zone, which causes a corresponding increase in transmissivity and in depth to groundwater. Groundwater flow through the younger deposits in all three drainage basins was not always inhibited by the Quaternary faults; otherwise groundwater would flow to the surface along the creek in the upper-piedmont zone upstream of the fault, similar to the flow of groundwater to springs between the karst-limestone and upper-piedmont zones. An exception was the fault-controlled springs at the Home Farm, north of the Lehman Creek drainage basin, the source of which could be groundwater flow from stream losses in the karst-limestone zone by Lehman Creek.

In the lower-piedmont zone in the Snake Creek drainage basin, groundwater flow from the Quaternary fault to the Nevada-Utah state line included 400 acre-ft/yr from the fractured limestone beneath the upper-piedmont zone and another $400 \mathrm{acre}-\mathrm{ft} / \mathrm{yr}$ of streamflow loss. Most of this flow was through younger alluvial deposits above a relatively thick section of older basin-fill deposits that are mostly fine sand, silt, and clay. The depth to water in the valley-lowland zone of the Snake Creek drainage basin in Utah was about $50 \mathrm{ft}$ below land surface, which precluded much groundwater loss to evapotranspiration. Fractured limestone underlies the basin-fill deposits in the valley-lowland zone and abuts the deposits to the east. The relatively deep water table in the valley-lowland zone can be explained by the presence of relatively permeable limestone beneath the basin-fill deposits and in the Burbank Hills that acts as a drain for the younger and older basin-fill deposits. Finally, groundwater flow in the Snake Creek drainage basin is continuous between the karst-limestone zone in Great Basin National Park and the valley-lowland zone in Utah. Groundwater flow from the karst-limestone zone to the valley-lowland zone, however, was limited by the small percentage of open fractures in the limestone beneath the upperpiedmont zone.

Groundwater flow from southern Spring Valley through the Limestone Hills to northern Hamlin Valley previously was considered to be a potential source of Big Springs. A groundwater divide south of Baking Powder Flat in southern Spring Valley separates northward flow to the flat from southeast flow to northern Hamlin Valley. The mean hydraulic gradient between wells near the groundwater divide and in northern Hamlin Valley east of the Limestone Hills was $20 \mathrm{ft} / \mathrm{mi}$. The depth to water below land surface in these wells exceeded $50 \mathrm{ft}$, which precluded much groundwater loss to evapotranspiration in southern Spring Valley and northern Hamlin Valley. Because of the eastward flow in southern Spring Valley, and no place for groundwater to be lost to evapotranspiration until southern Snake Valley, groundwater flow is likely to be continuous from southern Spring Valley beneath the Limestone Hills and northern Hamlin Valley to southern Snake Valley.

Mean annual groundwater flow beneath the Limestone Hills was estimated to range from about 6,000 to 11,000 acre- $\mathrm{ft}$ on the basis of groundwater recharge estimated by using the water-yield equations from the mountain-upland zone and the total mean annual precipitation for mean precipitation rates greater than $12 \mathrm{in} / \mathrm{yr}$ in southern Spring Valley south of the groundwater divide. The ratio of chloride in precipitation to chloride in wells in southern Spring Valley, multiplied by the total mean annual precipitation for mean precipitation rates greater than $12 \mathrm{in} / \mathrm{yr}$, indicated a range in groundwater flow from southern Spring Valley of $6,000-8,000$ acre-ft, which was similar to that estimated by using the water-yield equations.

Groundwater flow to Big Springs in southern Snake Valley can be accounted for by precipitation in the Big Spring Wash drainage basin and smaller basins between the wash and the springs. This conclusion was based on (1) a simple three-point analysis of water levels in wells northwest and southwest of Big Springs and the land-surface altitude at the springs, (2) the chemistry of water from the wells and Big Springs, and (3) groundwater recharge in the Big Spring Wash and nearby smaller drainage basins estimated from the water-yield equations and from a calculation of total chloride mass in precipitation and spring flow. Except for one well at the northwest end of the Limestone Hills in southern Spring Valley and near 
the south end of the Snake Range, groundwater chemistry in southern Spring Valley and northern Hamlin Valley contained more dissolved salts than water at Big Springs, indicating that these waters did not flow to Big Springs.

Groundwater flow from southern Spring Valley beneath the Limestone Hills is conceptualized to continue eastward south of Big Springs, where it turns in a northeast direction to accommodate northward flow beneath Hamlin Valley Wash. Although little if any groundwater from southern Spring Valley flows to Big Springs, some of the groundwater from southern Spring Valley is likely to be the source of water at springs near the Nevada-Utah state line or is lost to evapotranspiration along Big Springs Creek and Lake Creek. Any remaining groundwater from southern Spring Valley would continue as northeastward regional flow through carbonate rocks on the east side of Snake Valley.

\section{References Cited}

Acheampong, S.Y., 1992, Isotope hydrology of Lehman and Baker Creek drainages, Great Basin National Park, Nevada: Las Vegas, Nev., University of Nevada, Las Vegas, unpublished M.S. Thesis, $105 \mathrm{p}$.

Acheampong, S.Y., Farnham, I.M., and Watrus, J.M., 2009, Geochemical characterization of ground water and surface water of Snake Valley and the surrounding areas in Utah, in Tripp, B.T., Krahulec, Ken, and Jordan, J.L., eds., Geology and Geologic Resources and Issues of Western Utah: Utah Geological Association Publication 38, p. 325-344.

Allander, K.K., and Berger, D.L., 2009, Seismic velocities and thicknesses of alluvial deposits along Baker Creek in the Great Basin National Park, east-central Nevada: U.S. Geological Survey Open-File Report 2009-1174, 14 p.

Allmendinger, R.W., Sharp, J.W., Von Tish, Douglas, Serpa, Laura, Brown, Larry, Kaufman, Sidney, Oliver, Jack, and Smith, R.B., 1983, Cenozoic and Mesozoic structure of the eastern Basin and Range Province, Utah, from COCORP seismic reflection data: Geology, v. 11, p. 532-536.

Armstrong, R.L., 1968, Sevier orogenic belt in Nevada and Utah: Geological Society of America Bulletin, v. 79, p. $429-458$.

Armstrong, R.L., 1982, Cordilleran metamorphic core complexes - from Arizona to southern Canada: Annual Review of Earth and Planetary Science, v. 10, p. 129-154.

Asch, T.H., and Sweetkind, D.S., 2010, Geophysical characterization of range-front faults, Snake Valley, Nevada: U.S. Geological Survey Open-File Report 2010-1016, 226 p., http://pubs.usgs.gov/of/2010/1016/.
Asch, T.H., and Sweetkind, D.S., 2011, Audiomagnetotelluric characterization of range-front faults, Snake Valley, Nevada: Geophysics, v. 78, no. 1, p. B1-B7, doi:10.1190/1.3511358.

Axen, G.J., Taylor, W.J., and Bartley, J.M., 1993, Space-time patterns and tectonic controls of Tertiary extension and magmatism in the Great Basin of the western United States: Geological Society of America Bulletin, v. 105, p. 56-76.

Bartley, J.M., and Wernicke, B.P., 1984, The Snake Range décollement interpreted as a major extensional shear zone: Tectonics, v. 3, p. 647-657.

Bedinger, M.S., Sargent, K.A., and Langer, W.H., 1990, Studies of geology and hydrology in the Basin and Range province, southwestern United States, for isolation of highlevel radioactive waste-Characterization of the Bonneville region, Utah and Nevada: U.S. Geological Survey Professional Paper 1370-G, 38 p.

Belcher, W.R., ed., 2004, Death Valley regional ground-water flow system, Nevada and California-Hydrogeologic framework and transient ground-water flow model: U.S. Geological Survey Scientific Investigations Report 20045205, 408 p.

Belcher, W.R., Elliot, P.E., and Geldon, A.L., 2001, Hydraulicproperty estimates for use with a transient ground-water flow model of the Death Valley regional ground-water flow system, Nevada and California: U.S. Geological Survey Water-Resources Investigations Report 01-4210, 28 p.

Best, M.G., and Grant, S.K., 1987, Stratigraphy of the volcanic Oligocene Needles Range Group in southwestern Utah and eastern Nevada: U.S. Geological Survey Professional Paper 1443-A, $28 \mathrm{p}$.

Best, M.G., Christiansen, E.H., and Blank, H.R., Jr., 1989a, Oligocene caldera complex and calc-alkaline rocks of the Indian Peak volcanic field, Nevada and Utah: Geological Society of America Bulletin, v. 101, p. 1076-1090.

Best, M.G., Christiansen, E.H., Deino, A.L., Grommé, C.S., McKee, E.H., and Noble, D.C., 1989b, Excursion 3A: Eocene through Miocene volcanism in the Great Basin of the western United States: New Mexico Bureau of Mines and Mineral Resources Memoir, v. 47, p. 91-133.

Best, M.G., Christiansen, E.H., Deino, A.L., Grommé, Sherman, Hart, G.L., and Tingley, D.G., 2013, The 36-18 Ma Indian Peak-Caliente ignimbrite field and calderas, southeastern Great Basin, USA: Multicyclic super-eruptions: Geosphere, v. 9, p. 864-950.

Blakely, R.J., and Ponce, D.A., 2001, Map showing depth to pre-Cenozoic basement in the Death Valley Ground-water model area, Nevada and California: U.S. Geological Survey Miscellaneous Field Studies Map MF-2381-E, 6 p., 1 plate. 
Blankennagel, R.K., and Weir, J.E., Jr., 1973, Geohydrology of the eastern part of Pahute Mesa, Nevada Test Site, Nye County, Nevada: U.S. Geological Survey Professional Paper 712-B, 35 p.

Bredehoeft, J.D., 1963, Hydrogeology of the lower Humboldt River basin, Nevada: Nevada Department of Conservation and Natural Resources, Water Resources Bulletin, 21, 50 p.

Bredehoeft, J.D., and Farvolden, R.N., 1963, Disposition of aquifers in intermountain basins of northern Nevada: International Association of Scientific Hydrology, Commission of Subterranean Waters Publication 64, p. 197-212.

Bridgemon, R.R., 1965, The caves of Baker Creek with reference to the Baker Creek cave system, White Pine County, Nevada: Tucson, Arizona, University of Arizona Association of Cavers Grotto of the National Speleological Society, Arizona Caver, v. 2, no. 4, p. 45-79.

Broadbent, R.C., Katzer, Terry, and Brothers, Kay, 1995, Mountain front runoff and groundwater recharge in eastcentral Nevada: Las Vegas Valley Water District, Cooperative Water Project, Series Report no. 17, 16 p.

Brooks, L.E., Masbruch, M.D., Sweetkind, D.S., and Buto, S.G., 2014, Steady-state numerical groundwater flow model of the Great Basin carbonate and alluvial aquifer system: U.S. Geological Survey Scientific Investigations Report 2014-5213, 124 p., 2 pl. http://dx.doi.org/10.3133/ $\operatorname{sir} 20145213$.

Brothers, Kay, Buqo, T.S., and Tracy, J.V., 1993, Hydrology and steady state ground-water model of Snake Valley, eastcentral Nevada, and west-central Utah: Las Vegas Valley Water District, Cooperative Water Project, Series Report no. 9, 66 p.

Brothers, Kay, Buqo, T.S., Bernholtz, A.J., and Tracy, J.V., 1994, Hydrology and steady state ground-water model of Spring Valley, Lincoln and White Pine Counties, Nevada: Las Vegas Valley Water District, Cooperative Water Project, Series Report no. 13, 69 p.

Brown, J.L., and Davila, Videl, Jr., 1995, Large-scale geologic mapping in Great Basin Nation Park, in van Riper, Charles, III, ed., Proceedings of the second biennial conference on research in Colorado Plateau National Parks: National Park Service Transactions and Proceedings Series NPS/ NRNAUINRTP-95/1 1, p. 55-66.

Bunch, R.L., and Harrill, J.R., 1984, Compilation of selected hydrologic data from the MX missile-siting investigation, east-central Nevada and western Utah: U.S. Geological Survey Open-File Report 84-702, 123 p.
Burns, A.G., and Drici, W., 2011, Hydrology and water resources of Spring, Cave, Dry Lake, and Delamar Valleys, Nevada and vicinity: Southern Nevada Water Authority, Las Vegas, Nev., presentation for Water Rights Hearing on Spring, Cave, Dry Lake, and Delamar Valleys, Nevada State Engineer's Office, Carson City, Nev., Exhibit 258, variously paged, http://water.nv.gov/hearings/past/springetal/browseabledocs/Exhibits/SNWA\%20Exhibits/SNWA_Exh_258 Burns\%20and\%20Drici\%20Report/SNWA_Exh_258_ Burns\%20and\%20Drici\%20Report.pdf.

Carlton, S.M., 1985, Fish Springs multi-basin flow system, Nevada and Utah: Reno, Nev., University of Nevada, Reno, Mackay School of Mines, unpubl. M.S. thesis, 103 p.

Clark, I.D., and Fritz, Peter, 1997, Environmental isotopes in hydrogeology: Boca Raton, Fla., CRC Press LLC, 328 p.

Cohen, Philip, and others, 1965, Water Resources of the Humboldt River Valley near Winnemucca, Nevada: U.S. Geological Survey Water-Supply Paper 1795, 143 p.

Coney, P.J., 1980, Cordilleran metamorphic core complexes; an overview, in Crittenden, M.D., Coney, P.J., and Davis, G.K., eds., Cordilleran Metamorphic Core Complexes, Geological Society of America Memoir 153, p. 7-34.

Cooper, F.J., 2008, Structural and thermobarometric constraints on the exhumation of the northern Snake Range metamorphic core complex, Nevada: Los Angeles, University of Southern California, Ph.D. dissertation, 200 p.

Cooper, F.J., Platt, J.P., Platzman, E.S., Grove, M.J., and Seward, Gareth, 2010, Opposing shear senses in a subdetachment mylonite zone: Implications for core complex mechanics: Tectonics, v. 28, p. 997-1,020.

Craig, Harmon, 1957, Isotopic standards for carbon and oxygen and correction factors for mass-spectrometric analysis of carbon dioxide: Geochimica et Cosmochimica Acta, v. 12, p. 133-149.

Craig, Harmon, 1961a, Isotopic variations in meteoric water: Science, v. 133, no. 3465, p. 1,702-1,703.

Craig, Harmon, 1961b, Standard for reporting concentrations of deuterium and oxygen-18 in natural waters: Science, v. 133 , no. 3467 , p. 1,833-1,834.

Davis, S.N., and DeWeist, R.J.M., 1966, Hydrogeology: New York, John Wiley and Sons, Inc., 463 p.

DeSaussure, Raymond, Mowat, G.D., and Lange, A.L., 1953, Report of the California-Nevada Speleological Survey: Western Speleological Institute Technical Report 2, 198 p.

Dettinger, M.D., 1989, Reconnaissance estimates of natural recharge to desert basins in Nevada, U.S.A., by using chloride-balance calculations: Journal of Hydrology, v. 106, p. $55-78$. 
Dettinger, M.D., Harrill, J.R., Schmidt, D.L., and Hess, J.W., 1995, Distribution of carbonate-rock aquifers and the potential for their development, southern Nevada and adjacent parts of California, Arizona, and Utah; 1995: U.S. Geological Survey Water Resources Investigations Report 91-4146, $100 \mathrm{p}$.

Dixon, G.L., Rowley, P.D., Burns, A.G., Watrus, J.M., Donovan, D.J., and Ekren, E.B., 2007, Geology of White Pine and Lincoln counties and adjacent areas, Nevada and Utah: The geologic framework of regional groundwater flow systems: Las Vegas, Nev., Southern Nevada Water Authority, Doc. No. HAM-ED-0001, 157 p.

Dohrenwend, J.C., Schell, B.A., Menges, C.M., Moring, B.C., and McKittrick, M.A., 1996, chap. 9, Reconnaissance photogeologic map of young (Quaternary and late Tertiary) faults in Nevada, in Singer, D.A., ed., An analysis of Nevada's metal-bearing mineral resources, Nevada Bureau of Mines and Geology Open-File Report 96-2, p. $9-1-9-12$.

Dong, Weiquan, Naranjo, R.C., and Halford, K.J., 2012, Analysis of water-level fluctuations from pumpage for irrigation during multiple drought years in Snake Valley, HA195, near Needle Point and south of Garrison, Utah: U.S. Geological Survey Aquifer Test, http://nevada.usgs.gov/water/AquiferTests/snake_valley_needlepoint.cfm?studyname $=$ snake_valley_needlepoint.

Dotson, K.L., 2010, Geochemical analysis of calcium carbonate cementation and its role in reducing loss rates along Snake Creek, southern Snake Valley, White Pine County, Nevada: Reno, Nev., University of Nevada, Reno, unpubl. M.S. thesis, $72 \mathrm{p}$.

Drever, J.I., 1988, The geochemistry of natural waters ( $2 \mathrm{~d}$ ed.): Englewood Cliffs, N.J., Prentice Hall, Inc., 437 p.

Eakin, T.E., Maxey, G.B., Robinson, T.W., Fredericks, J.C., and Loeltz, O.J., 1951, Contributions to the hydrology of eastern Nevada: Nevada State Engineer, Water Resources Bulletin 12, $171 \mathrm{p}$.

Eakin, T.E., Price, Don, and Harrill, J.R., 1976, Summary appraisals of the Nation's ground-water resources-Great Basin region: U.S. Geological Survey Professional Paper 813-G, 37 p., 1 plate.

Eastman, H.S., and Muller, D.C., 2009a, Geologic data analysis report for monitor well 184W506M and test well 184W105 in Spring Valley: Las Vegas, Nev., Southern Nevada Water Authority, Doc. No. RDS-ED-0011, 41 p.

Eastman, H.S., and Muller, D.C., 2009b, Geologic data analysis report for monitor well 184W508M in Spring Valley: Southern Nevada Water Authority, Las Vegas, Nevada, Doc. No. RDS-ED-0010, 34 p.
Eastman, H.S., and Muller, D.C., 2009c, Geologic data analysis report for monitor well 184W101 in Spring Valley: Southern Nevada Water Authority, Las Vegas, Nevada, Doc. No. RDS-ED-0009, 48 p.

Eastman, H.S., and Muller, D.C., 2009d, Geologic data analysis report for monitor well 184W504M and test well 184W103 in Spring Valley: Southern Nevada Water Authority, Las Vegas, Nevada, Doc. No. RDS-ED-0008, 49 p.

Eaton, A.D., Clesceri, L.S., Rice, E.W., and Greenberg, A.E., 2005, Standard methods for the examination of water and waste water: American Public Health Association, 1,368 p.

Elliott, P.E., Beck, D.A., and Prudic, D.E., 2006, Characterization of surface-water resources in the Great Basin National Park area and their susceptibility to ground-water withdrawals in adjacent valleys, White Pine County, Nevada: U.S. Geological Survey Scientific Investigations Report 2006-5099, 156 p.

Ertec Western, Inc., 1981a, MX Siting Investigation, Water Resources Program, Technical Summary Report Volume I, Report E-TR-52-I, prepared for the U.S. Department of the Air Force, Ballistic Missile Office, Norton Air Force Base, California, $97 \mathrm{p}$.

Ertec Western, Inc., 1981b, MX Siting Investigation, Water Resources Program, Technical Summary Report Volume II, Report E-TR-52-II, prepared for the U.S. Department of the Air Force, Ballistic Missile Office, Norton Air Force Base, California, $286 \mathrm{p}$.

Ertec Western, Inc., 1981c, MX Siting Investigation, Water Resources Program, Technical Summary Report Volume IIA, Report E-TR-52-II, prepared for the U.S. Department of the Air Force, Ballistic Missile Office, Norton Air Force Base, California, $41 \mathrm{p}$.

Ertec Western, Inc., 1981d, MX Siting Investigation, Water Resources Program, Technical Summary Report Volume IIB, Report E-TR-52-II, prepared for the U.S. Department of the Air Force, Ballistic Missile Office, Norton Air Force Base, California, $131 \mathrm{p}$.

Farmer, D.E., Glew, T.R., and Faller, S.H., 1998, Measurement of current tritium concentrations in winter and summer precipitation at Las Vegas, Nevada (USA): Transactions on the Ecology and the Environment, v. 23, p. 97-112.

Fetter, C. W. 2001, Applied Hydrogeology (4th ed.): Upper Saddle River, New Jersey, Prentice Hall, 598 p.

Freeze, R.A., and Cherry J.A., 1979, Groundwater: Englewood Cliffs, N.J., Prentice Hall, 604 p.

Friedman, Irving, Smith, G.I., Johnson, C.A., and Moscati, R.J., 2002, Stable isotope compositions of waters in the Great Basin, United States 2-Modern precipitation: Journal of Geophysical Research, v. 107, no. 4401, 22 p. 
Gans, P.B., and Miller, E.L., 1983, Styles of mid-Tertiary extension in east-central Nevada, in Gurgel, K.D., ed., Geologic excursions in the overthrust belt and metamorphic core complexes of the intermountain region, Nevada: Utah Geological and Mineral Survey Special Studies 59, p. 107-160.

Gans, P.B., Miller, E.L., McCarthy, Jill, and Ouldcott, M.L., 1985 Tertiary extensional faulting and evolving ductilebrittle transition zones in the northern Snake Range and vicinity: New insights from seismic data: Geology, v. 13, p. 189-193.

Gardner, P.M., Masbruch, M.D., Plume, R.W., and Buto, S.G., 2011, Regional potentiometric-surface map of the Great Basin carbonate and alluvial aquifer system in Snake Valley and surrounding areas, Juab, Millard, and Beaver Counties, Utah, and White Pine and Lincoln Counties, Nevada: U.S. Geological Survey Scientific Investigations Map 3193, 2 sheets.

Gates, J.S., 1984, Hydrogeology of northwestern Utah and adjacent parts of Idaho and Nevada: Utah Geological Association Publication 13, p. 239-248.

Gillespie, J. M., 2008, A conceptual model of groundwater flow in Spring Valley, NV, and Snake Valley, NV-UT: Provo, Utah, Brigham Young University, unpubl. M.S. thesis, $80 \mathrm{p}$.

Gillespie, J.M., Nelson, S.T., Mayo, A.L., and Tingey, D.G., 2012, Why conceptual groundwater flow models matter-a trans-boundary example from the arid Great Basin, western USA: Hydrogeology Journal, v. 20, p. 1,133-1,147.

Giofiantini, R., 1978, Standards for stable isotope measurements in natural compounds: Nature, v. 271, p. 534-536.

Goulden, M.L., Anderson, R.G., Bales, R.C., Kelly, A.E., Meadows, M., and Winston, G.C., 2012: Evapotranspiration along an elevation gradient in California's Sierra Nevada: Journal of Geophysical Research, v. 117, G03028, 13 p., doi:10.1029/2012JG002027.

Grier, S.P., 1984, Alluvial fan and lacustrine carbonate deposits in the Snake Range: A study of Tertiary sedimentation and associated tectonism: Stanford, Calif., Stanford University, unpubl. M.S. thesis, $61 \mathrm{p}$.

Halford, K.J., and Plume, R.W., 2011, Potential effects of groundwater pumping on water levels, phyreatophytes, and spring discharges in Spring and Snake Valleys, White Pine County, Nevada and adjacent areas in Nevada and Utah: U.S. Geological Survey Scientific Investigations Report 2011-5032, 50 p. and 8 appendices.
Harrill, J.R., and Prudic, D.E., 1998, Aquifer systems in the Great Basin region of Nevada, Utah, and adjacent StatesSummary report: U.S. Geological Survey Professional Paper 1409-A, 66 p.

Harrill, J.R., Gates, J.S., and Thomas, J.M., 1988, Major ground-water flow systems in the Great Basin region of Nevada, Utah, and adjacent states: U.S. Geological Survey Hydrologic Investigations Atlas HA-694-C, scale $1: 1,000,000,2$ sheets $\mathrm{p}$.

Heilweil, V.M., and Brooks, L.E., eds., 2011, Conceptual model of the Great Basin carbonate and alluvial aquifer system: U.S. Geological Survey Scientific Investigations Report 2010-5193, 191 p.

Hershey, R.L., Heilweil, V.M., Gardner, Philip, Lyles, B.F., Earman, Sam, Thomas, J.M., and Lundmark, K.W., 2007, Groundwater chemistry interpretations supporting the Basin and Range Regional Carbonate-rock Aquifer System (BARCAS) study, eastern Nevada and western Utah: Reno, Nev., Desert Research Institute DHS publication 41230, 86 p.

Hess, R.H., Fitch, S.P., and Warren, S.N., 2004, Nevada Oil and Gas Well Database (NVOILWEL): Nevada Bureau of Mines and Geology Open-File Report 04-1, 242 p.

Hintze, L.F., and Davis, F.D., 2002b, Geologic map of the Tule Valley 30' x 60' quadrangle and parts of the Ely, Fish Springs, and Kern Mountains 30' x 60' quadrangles, northwest Millard County, Utah: Utah Geological Survey Map 186 , scale 1:100,000.

Hintze, L.F., and Davis, F.D., 2002a, Geologic map of the Wah Wah Mountains North 30' x 60' quadrangle and part of the Garrison 30' x 60' quadrangle, southwest Millard County and part of Beaver County, Utah: Utah Geological Survey Map 207DM, scale 1:100,000, CD-ROM.

Hintze, L.F., and Davis, F.D., 2003, Geology of Millard County, Utah: Utah Geological Survey Bulletin 133, 305 p.

Hintze, L.F., and Kowallis, B.J., 2009, Geologic History of Utah: A Field Guide to Utah's Rocks: Brigham Young University Geology Studies Special Publication 17, 225 p.

Hintze, L.F., Willis, G.C., Laes, D.Y.M., Sprinkel, D.A., and Brown, K.D., 2000, Digital geologic map of Utah: Utah Geological Survey Map 179DM, CD-ROM, scale $1: 500,000$.

Hood, J.W., and Rush, F.E., 1965, Water-resources appraisal of the Snake Valley area, Utah and Nevada: Nevada Department of Conservation and Natural Resources, Water Resources-Reconnaissance Report 34, 43 p.

Hose, R.K., 1977, Structural geology of the Confusion Range, west-central Utah: U.S. Geological Survey Professional Paper 971, 9 p. 
Hose, R.K., and Blake, M.C., Jr., 1976, Geology and mineral resources of White Pine County, Nevada, Part I, Geology: Nevada Bureau of Mines and Geology Bulletin 85, 105 p.

Houghton, J.G., Sakamoto, C.M., and Gifford, R.O., 1975, Nevada's weather and climate: Nevada Bureau of Mines and Geology Special Publication 2, 78 p.

Hunsaker, C.T., Whitaker, T.W. and Bales, R.C., 2012: Snowmelt runoff and water yield along elevation and temperature gradients in California's southern Sierra Nevada: Journal of the American Water Resources Association, v. 48, no. 4, p. 667-678, doi: 10.1111/j.1752-1688.2012.00641.x

Hurlow, Hugh, ed., 2014, Hydrogeologic studies and groundwater monitoring in Snake Valley and adjacent hydrographic areas, west-central Utah and east-central Nevada: Utah Geological Survey Bulletin 135, 304 pages, 4 Plates, Appendices and data tables.

Jachens, R.C., and Moring, B.C., 1990, Maps of the thickness of Cenozoic deposits and the isostatic residual gravity over basement for Nevada, U.S. Geological Survey Open-File Report 90-404, 15 p.

Jackson, T.R., 2010, Evaluation of the hydraulic connection between streams and aquifers at Baker and Snake Creek near Great Basin National Park, Snake Valley, White Pine County, Nevada: Reno, Nev., University of Nevada, Reno, unpubl M.S. thesis, $236 \mathrm{p}$.

Jeton, A.E., Watkins, S.A., Lopes, T.J., and Huntington, Justin, 2005, Evaluation of precipitation estimates from PRISM for 1961-1990 and 1971-2000 data sets, Nevada: U.S. Geological Survey Scientific Investigations Report 2005-5291, $26 \mathrm{p}$.

Katzer, T., and Donovan, D.J., 2003, Surface-water resources and basin water budget for Spring Valley, White Pine and Lincoln Counties, Nevada, Report for the Las Vegas Valley Water District, $70 \mathrm{p}$.

Kellogg, H.E., 1963, Paleozoic stratigraphy of the southern Egan Range, Nevada: Geological Society of America Bulletin, v. 74, p. 685-708.

Kirby, Stefan, and Hurlow, Hugh, 2005, Hydrogeologic setting of the Snake Valley hydrologic basin, Millard County, Utah, and White Pine and Lincoln Counties, Nevada-Implications for possible effects of proposed water wells: Utah Geological Survey Report of Investigations 254, CD-ROM.

Kistinger, G.M., Prieur, J.P., Rowley, P.D., and Dixon, G.L., 2009, Characterization of streams and springs in the Snake Valley area, Utah and Nevada, in Tripp, B.T., Krahulec, Ken, and Jordan, J.L., eds., Geology and Geologic Resources and Issues of Western Utah: Utah Geological Association Publication 38, p. 299-323.
Kleinhampl, F.J., and Ziony, J.I., 1985, Mineral resources of northern Nye County, Nevada: Nevada Bureau of Mines and Geology Bulletin 99-B, 243 p.

Laczniak, R.J., Flint, A.L., Moreo, M.T., Knochenmus, L.A., Lundmark, K.W., Pohll, Greg, Carroll, R.W.H., Smith, J.L., Welborn, T.L., Heilweil1 V.M., Pavelko, M.T., Hershey, R.L., Thomas, J.M., Earman, Sam, and Lyles, B.F., 2007, Ground-water budgets, in Welch, A.H., Bright, D.J., and Knochenmus, L.A., eds., 2007, Water resources of the Basin and Range carbonate-rock aquifer system, White Pine County, Nevada, and adjacent areas in Nevada and Utah: U.S. Geological Survey Scientific Investigations Report 2007-5261, p. 43-82.

Lange, A.L., 1958, Stream piracy and cave development along Baker Creek, Nevada: Santa Barbara, Calif., Western Speleological Institute Bulletin 1, p. 1-24.

Langbein, W.B., and Iseri, K.T., 1995, Science in your watershed, general introduction and hydrologic definitions, Manual of Hydrology: Part 1. General Surface-Water Techniques: U.S. Geological Survey Water-Supply Paper 1541-A, http://water.usgs.gov/wsc/glossary.html.

Langenheim, R.L., Jr., and Larson, E.R., 1973, Correlation of Great Basin stratigraphic units: Nevada Bureau of Mines and Geology Bulletin 72, 36 p, 3 plates.

Lee, D.E., and Christiansen, E.H., 1983, The granite problem as exposed in the southern Snake Range, Nevada: Contributions to Mineralogy and Petrology, v. 83, p. 99-116.

Lee, D.E., and Van Loenen, R.E., 1971, Hybrid granitoid rocks of the Southern Snake Range, Nevada: U.S. Geological Survey Professional Paper 668, 48 p.

Lee, D.E., Kistler, R.W., Friedman, Irving, and Van Loenen, R.E., 1981, Two-mica granites of northeastern Nevada: Journal of Geophysical Research, v. 86, no. B11, p. 10,60710,616, doi:10.1029/JB086iB11p10607.

Lohman, S.W., 1972, Ground water hydraulic: U.S. Geological Survey Professional Paper 708, 70 p.

Loucks, M.D., Tingey, D.G., Best, M.G., Christiansen, E.H., and Hintze, L.F., 1989, Geologic map of the fortification Range, Lincoln and White Pine Counties, Nevada: U.S. Geological Survey Miscellaneous Investigations Series Map I-1866, scale 1:50,000.

Lucas, L.L., and Unterweger, M.P., 2000, Comprehensible reviews and critical of the half-life of tritium: Journal of Research of the National Institute of Standards and Technology, v. 105, no. 4, p. 541-549.

Mace, J.T., and Muller, D.C., 2010a, Geologic data analysis report for monitor well SPR7007M and test well SPR7007X in Spring Valley: Las Vegas, Nev., Southern Nevada Water Authority, Doc. No. RDS-ED-0019, 31 p. 
Mace, J.T., and Muller, D.C., 2010b, Geologic data analysis report for monitor well SPR7006M in Spring Valley: Las Vegas, Nev., Southern Nevada Water Authority, Doc. No. RDS-ED-0018, 23 p.

Mace, J.T., and Muller, D.C., 2010c, Geologic data analysis report for monitor well SPR7005M and test well SPR7005X in Spring Valley: Las Vegas, Nev., Southern Nevada Water Authority, Doc. No. RDS-ED-0017, 30 p.

Mace, J.T., and Muller, D.C., 2010d, Geologic data analysis report for monitor well SPR7008M and test well SPR7008X in Spring Valley: Las Vegas, Nev., Southern Nevada Water Authority, Doc. No. RDS-ED-0020, 30 p.

Mankinen, E.A., and McKee, E.H., 2009, Geophysical setting of western Utah and eastern Nevada between latitudes $37^{\circ} 45^{\prime}$ and $40^{\circ} \mathrm{N}$, in Tripp, B.T., Krahulec, Ken, and Jordan, J.L., eds., Geology and geologic resources and issues of western Utah: Utah Geologic Association Publication 38, p. 271-286.

Mankinen, E.A., Roberts, C.W., McKee, E.H., Chuchel, B.A., and Moring, B.C., 2006, Geophysical data from the Spring and Snake Valleys area, Nevada and Utah: U.S. Geological Survey Open-File Report 2006-1160, 39 p.

Masbruch, M.D., Gardner, P.M., and Brooks, L.E., 2014, Hydrology and numerical simulation of groundwater movement and heat transport in Snake Valley and surrounding areas, Juab, Millard, and Beaver Counties, Utah, and White Pine and Lincoln Counties, Nevada: U.S. Geological Survey Scientific Investigations Report 2014-5103, 108 p. http:// dx.doi.org/10.3133/sir20145103.

Mason, J.L., Atwood, John, Buettner, Priscilla, 1985, Selected test well data from the MX-missilesiting study, Tooele, Millard, Beaver, and Iron Counties, Utah: U.S. Geological Survey Open-File Report 85-347, 13 p., 1 pl.

Maurer, D.K., 1986, Geohydrology and simulated response to ground-water pumping in Carson Valley, a river dominated basin in Douglas County, Nevada, and Alpine County, California: U.S. Geological Survey Water-Resources Investigations Report 86-4328, 109 p.

Maurer, D.K., and Berger, D.L., 1997, Subsurface flow and water yield from watersheds tributary to Eagle Valley hydrographic area, West-Central Nevada: U.S. Geological Survey Water-Resources Investigations Report 97-4191, $56 \mathrm{p}$.

McCarthy, Jill, 1986, Reflection profiles from the Snake Range metamorphic core complex: A window into the mid-crust, in Barazangi, M., and Brown, L., eds., Reflection Seismology: The Continental Crust: American Geophysical Union Geodynamics Series, v. 14, p. 281-292.
McGrew, A.J., 1993, The origin and evolution of the southern Snake Range décollement, east central Nevada: Tectonics, v. 12 , no. 1 , p. 21-34.

McGrew, A.J., Miller, E.L., and Brown, J.L., compiler, 1995, Geologic map of Kious Spring and Garrison 7.5' quadrangles, White Pine County, Nevada and Millard County, Utah: U.S. Geological Survey Open-File Report 95-10, scale 1:24,000.

McPhee, D.K., Chuchel, B.A., and Pellerin, Louise, 2006, Audiomagnetotelluric data from Spring, Cave, and Coyote Spring Valleys, Nevada: U.S. Geological Survey Open-File Report 2006-1164, 41 p.

McPhee, D.K., Chuchel, B.A., and Pellerin, Louise, 2008, Audiomagnetotelluric data and preliminary two-dimensional models from Spring, Snake, and Three Lakes Valleys, Nevada: U.S. Geological Survey Open-File Report 20081301,59 p.

McPhee, D.K., Pari, Keith, and Baird, F.A., 2009, Audiomagnetotelluric investigation of Snake Valley, Eastern Nevada and Western Utah, in Tripp, B.T., Krahulec, Ken, Jordan, J.L., eds., 2009, Geology and Geologic Resources and Issues of Western Utah: Utah Geological Association Publication 38, p. 287-297.

Meinzer, O.E., 1911, Ground water in Juab, Millard, and Iron Counties, Utah: U.S. Geological Survey Water-Supply Paper 277, 162 p.

Mifflin, M.D., 1968, Delineation of ground-water flow systems in Nevada: University of Nevada Desert Research Institute Technical Report H-W no. 4, 112 p.

Miller, E.L., Gans, P.B., and Garing, J., 1983, The Snake Range décollement-An exhumed mid-Tertiary ductilebrittle transition: Tectonics, v. 2, p. 239-263.

Miller, E.L., Gans, P.B., Wright, J.E., and J.F. Sutter, 1989, Metamorphic history of the east-central Basin and Range province-Tectonic setting and relationship to magmatism, in Ernst, W.G., ed., Metamorphism and Crustal Evolution, Western Conterminous United States, Rubey Volume VII: Englewood Cliffs, New Jersey, Prentice-Hall, p. 649-682.

Miller, E.L., Miller, M.M., Stevens, C.H., Wright, J.E., and Madrid, R., 1992, Late Paleozoic paleogeography and tectonic evolution of the western U. S. Cordillera, in Burchfiel, B.C., Lipman, P.W., and Zoback, M.L., The Cordilleran Orogen: conterminous U. S.- The Geology of North America, Volume G-3, Decade of North American Geology: Boulder, Colo., Geological Society of America, p. 57-106.

Miller, E.L., Gans, P.B., Grier, S.P., and Brown, J.L., compiler, 1995a, Geologic map of Windy Peak 7.5' quadrangle, White Pine County, Nevada: U.S. Geological Survey Open-File Report 94-687, scale 1:24,000. 
Miller, E.L., Grier, S.P., and Brown, J.L, compiler, 1995b, Geologic map of the Lehman Caves quadrangle, White Pine County, Nevada: U.S. Geological Survey Geologic Quadrangle Map 1758, scale 1:24,000.

Miller, E.L., Dumitru, T.A., Brown, R.W., and Gans, P.B., 1999, Rapid Miocene slip on the Snake Range-Deep Creek Range fault system, east-central Nevada: Geological Society of America Bulletin, v. 111, no. 6, p. 886-905.

Moore, D.O., 1968, Estimating mean runoff in ungaged semiarid areas: Nevada Department of Conservation and Natural Resources Water Resources Bulletin no. 36 (reprinted from International Association of Scientific Hydrology XIII Annee No. 1, p. 29-39).

Morris, D.A., and Johnson, I.A., 1967, Summary of hydrologic and physical properties of rock and soil materials as analyzed by the Hydrologic Laboratory of the U.S. Geological Survey, 1948-60: U.S. Geological Survey Water-Supply Paper 1839-D, $41 \mathrm{p}$.

Muller, D.C., Eastman, H., Gurnee, T., and Mace, J., 2009, Borehole geophysics and geology of test and monitor wells in Eastern Nevada, in Tripp, B.T., Krahulec, Ken, and Jordan, J.L., eds., Geology and Geologic Resources and Issues of Western Utah: Utah Geological Association Publication 38 , p. $345-360$.

Nathenson, M., and Guffanti, M., 1988, Geothermal gradients in the conterminous United States: Journal of Geophysical Research, v. 93, no. 7, p. 6,437-6,450.

National Atmospheric Deposition Program, 2011, Monthly water chemistry of precipitation at Great Basin National Park from 1985-2011: National Atmospheric Deposition Program, accessed November 10, 2011, http://nadp.sws. uiuc.edu/.

National Park Service, 2007, Digital geologic map of Great Basin National Park and vicinity, Nevada: National Park Service, U.S. Department of the Interior, accessed October 27, 2009, http://science.nature.nps.gov/nrdata/datastore. cfm? ID $=44849$.

National Park Service, 2012b, Natural features and ecosystems: National Park Service, U.S. Department of the Interior, accessed August 17, 2012, http://www.nps.gov/grba/ naturescience/naturalfeaturesandecosystems.htm.

National Park Service, 2012a, Plants: National Park Service, U.S. Department of the Interior, accessed August 17, 2012 http://www.nps.gov/grba/naturescience/plants.htm.

Natural Resources Conservation Service, 2011, Snow course and monthly SNOTEL data tables: Natural Resources Conservation Service, U.S. Department of Agriculture, accessed December 23, 2011, http://www.wcc.nrcs.usda.gov/cgibin/ state-site.pl? state $=N V \&$ report $=$ snowcourse .
Nevada Demographer, 2011, Nevada's census population by incorporated city and census designated place for 2000 and 2010: Nevada State Demographer, University of Nevada, Reno, accessed May 5, 2011, http://nvdemography.org/wpcontent/uploads/2011/03/NV-Total-Census-Population-ByCity-and-Place.pdf.

Nevada Division of Water Resources, 2008, Well log database: Nevada Division of Water Resources, State of Nevada, accessed February 8, 2008, http://water.nv.gov/data/welllog/ index.cfm.

Nichols, W.D., 2000, Regional ground-water evapotranspiration and ground-water budgets, Great Basin, Nevada: U.S. Geological Survey Professional Paper 1628, 82 p.

Nolan, K.M, Shields, R.R., and Rehmel, R.S., 2000, Measurement of stream discharge by wading: U.S. Geological Survey Water Resources Investigations Report 00-4036, accessed May 10, 2011, http://training.usgs.gov/TEL/Nolan/ SWProcedures/Index.html.

Orndorff, R.L., Wieder, R.W., and Filkorn, H.F., 2001, Geology underfoot in Central Nevada: Missoula, Mountain Press Publishing, $294 \mathrm{p}$.

Osborn, Gerald, and Bevis, Ken, 2001, Glaciation in the Great Basin of the Western United States: Quaternary Science Reviews, v. 20, p. 1,377-1,410.

Parkhurst, D.L., and Appelo, C.A.J., 1999, Users guide to PHREEQC (version 2) - A computer program for speciation, batch-reaction, one-dimensional transport, and inverse geochemical calculations: U.S. Geological Survey Water Resources Investigations Report 99-4259, 312 p.

Paul, A.P., Thodal, C.E., Baker, G.M., Lico, M.S., and Prudic, D.E., 2014, Preliminary geochemical assessment of water in selected streams, springs, and caves in the Upper Baker and Snake Creek drainages in Great Basin National Park, Nevada, 2009: U.S. Geological Survey Scientific Investigations Report 2014-5108, 33 p. http://dx.doi.org/10.3133/ sir20145108.

Pease, Charles, Clark, Larry, Bridgemon, Ron, and Shuttles, Cameron, 1969, The Baker Creek cave system: National Speleological Society, NSS news, p. 36-138.

Phillips, F.M., 1994, Environmental tracers for water movement in desert soils of the American Southwest: Soil Science Society of America Journal, v. 58, p. 15-24.

Plume, R.W., 1996, Hydrogeologic framework of the Great Basin region of Nevada, Utah, and adjacent States: U.S. Geological Survey Professional Paper 1409-B, 64 p.

Plummer, L.N., Michel, R.L., Thurman, E.M. and Glynn, P.D., 1993, Environmental tracers for age dating young ground water, in Alley, W.M., ed., Regional Ground-Water Quality: New York, Van Nostrand Reinhold, p. 255-294. 
Plummer, L.N., Rupert, M.G., Busenberg, Eurybiades, and Schlosser, Peter, 2000, Age of irrigation water in ground water from the eastern Snake River Plain Aquifer, southcentral Idaho: Groundwater, v. 38, no. 2, p. 264-283.

Poole, F.G., and Sandberg, C.A., 1977, Mississippian paleogeography and Tectonics of the western United States, in Stewart, J.H., Stevens, C.H., and Fritsche, A.E., eds., Paleozoic paleogeography of the western United States: Pacific Section, Society Economic Paleontologists and Mineralogists, p. 67-85.

Poole, F.G., Stewart, J.H., Palmer, A.R., Sandberg, C.A., Madrid, R.J., Ross, R.J., Jr., Hintze, L.F., Miller, M.M., and Wrucke, C.T., 1992, Latest Precambrian to latest Devonian time; development of a continental margin, in Burchfiel, B.C., Lipman, P.W., and Zoback, M.L., eds., The Cordilleran Orogen - conterminous U.S.: Geological Society of America, The Geology of North America, v. G-3, p. 9-54.

Prieur, J.P., Farnham, I.M., and Fryer, W., 2009, Hydrologic data analysis report for Test Well 184W105 in Spring Valley: Las Vegas, Nev., Southern Nevada Water Authority, Doc. No. DAR-ED-0002, 81 p.

Prieur, J.P., Farnham, I.M., and Ashinhurst, C.S., 2010a, Hydrologic data analysis report for Test Well 184W101 in Spring Valley Hydrographic Area 184: Southern Nevada Water Authority, Las Vegas, Nevada, Doc. No. DARED-0003, 78 p.

Prieur, J. P., Farnham, I. M., and Ashinhurst, C.S., 2010b, Hydrologic Data Analysis Report for Test Well 184W103 in Spring Valley Hydrographic Area 184: Southern Nevada Water Authority, Las Vegas, Nevada, Doc. No. DARED-0004, 79 p.

Prudic, D.E., 1991, Estimates of hydraulic conductivity from aquifer-test analyses and specific-capacity data, Gulf Coast regional aquifer systems, south-central United States: U.S. Geological Survey Water Resources Investigations Report 90-4121, 38 p.

Prudic, D.E., 1994, Estimates of percolation rates and ages of water in unsaturated sediments at two Mojave Desert sites, California-Nevada: U.S. Geological Survey Water Resources Investigations Report 94-4160, 19 p.

Prudic, D.E., 2012b, Analysis of slug test for Snake5 deep well (site ID 385524114045601): Snake Valley, Nevada, June 1, 2011: U.S. Geological Survey, http://nevada.usgs. gov/water/AquiferTests/Snake5.cfm?studyname=Snake5.

Prudic, D.E., 2012a, Report on the drilling of monitoring wells near Lehman Caves, Great Basin National Park, White Pine County, Nevada, May-June 2012: University of Nevada, Reno, final report for National Park Service, August 30, 2012, National Park Service unpublished report 2198459 , 38 p., https://irma.nps.gov/App/Reference/Profile/2198459.
Prudic, D.E., and Glancy, P.A., 2009, Geochemical investigation of the source water to Cave Springs, Great Basin National Park, White Pine County, Nevada: U.S. Geological Survey Scientific Investigations Report 2009-5073, 28 p.

Prudic, D.E., Harrill, J.R., and Burbey, T.J., 1995, Conceptual evaluation of regional ground-water flow in the carbonaterock province of the Great Basin, Nevada, Utah, and adjacent states: U.S. Geological Survey Professional Paper 1409-D, 102 p.

Prudic, D.E., Niswonger, R.G., Harrill, J.R., and Wood, J.L., 2007, Streambed infiltration and ground-water flow from the Trout Creek drainage, an intermittent tributary to the Humboldt River, Chap. K in Stonestrom, D.A., Constantz, Jim, Ferre, T.P.A., and Leake, S.A., eds., 2007, Groundwater recharge in the arid and semiarid southwestern United States: U.S. Geological Survey Professional Paper 1703, p. 313-351, http://pubs.usgs.gov/pp/pp1703.

Raines, G.L., Connors, K.A., Moyer, L.A., and Miller, R.J., 2003, Spatial digital database for the geologic map of Nevada (ver. 3.0): U.S. Geological Survey Open-File Report 03-66, 33 p.

Rantz, S.E., and others, 1982, Measurement of stage and discharge by conventional current-meter method, Chap. 5 in Rantz, S.E., and others, eds., Volume 1: Measurement and computation of streamflow: U.S. Geological Survey WaterSupply Paper 2175, p. 79-183.

Reheis, Marith, 1999, Extent of Pleistocene lakes in the western Great Basin: U.S. Geological Survey Miscellaneous Field Studies Map MF-2323, scale 1:800,000.

Rehg, K.J., Packman, A.I., and Jianhong, R., 2005, Effects of suspended sediment characteristics and bed sediment transport on streambed clogging: Hydrological Processes, v. 19, p. 413-427, doi: 10.1002/hyp.5540.

Reinemann S.A., Patrick, N.A., Baker, G.M., Porinchu, D.F., Mark, B.G., and Box J.E., 2011, Climate change in Great Basin National Park - Lake sediment and sensor-based studies: National Park Service, Science Applications, Park Science, v. 28, no. 2, p. 31-35.

Riggs, H.C., and Moore, D.O., 1965, A method of estimating runoff from ungaged basins in mountainous regions: U.S. Geological Survey Professional Paper 525-D, p. D199D202.

Ronan, A.E., Prudic, D.E., Thodal, C.E., and Constantz, Jim, 1998, Field study and simulation of diurnal temperature effects on infiltration and variably saturated flow beneath an ephemeral stream: Water Resources Research, v. 34, no. 9, p. 2,137-2,154. 
Rosenberry, D.O., and Pitlick, John, 2009, Local-scale variability of seepage and hydraulic conductivity in a shallow gravel-bed river: Hydrological Processes, v. 23, issue 23, p. 3,306-3,348, doi:10.1002/hyp.7433.

Rowley, P.D., Dixon, G.L., Burns, A.G., Collins, C.A., 2009, Geology and hydrogeology of the Snake Valley area, Western Utah and Eastern Nevada in Tripp, B.T., Krahulec, Ken, and Jordan, J.L., eds., Geology and Geologic Resources and Issues of Western Utah: Utah Geological Association Publication 38, p. 251-270.

Rush, F.E., and Kazmi, S.A.T., 1965, Water resources appraisal of Spring Valley, White Pine and Lincoln Counties, Nevada: Nevada Department of Conservation and Natural Resources, Water Resources-Reconnaissance Report 33, 39 p.

Saltus, R.W., and Jachens, R.C., 1995, Gravity and basindepth maps of the Basin and Range Province, western United States: U.S. Geological Survey Geophysical Investigations Map 1012, scale 1:2,500,000.

Scanlon, B.R., 1991, Evaluation of moisture flux from chloride data in desert soils: Journal of Hydrology, v. 128, p. 137-156.

Schälchli, U., 1992, The clogging of coarse river beds by fine sediment: Hydrobiologia, v. 235/236, p. 189-197.

Selker, J., Thevanaz, L., Huwald, H., Mallet, A., Luxemburg, W., van de Giesen, N., Stejskal, M., Zeman, J., Westhoff, M., and Parlange, M.B., 2006, Distributed fiber-optic temperature sensing for hydrologic systems: Water Resources Research, v. 42, W12202, 8 p, doi:10.1029/2006WR005326.

Shah Alam, A.H.M., 1990, Crustal extension in the southern Snake Range and vicinity, Nevada-Utah: An integrated geological and geophysical study: Baton Rouge, Louisiana State University, Ph.D. dissertation, 126 p.

Shah Alam, A.H.M., and Pilger, R.H., Jr., 1991, An integrated geologic and geophysical study of the structure and stratigraphy of the Cenozoic extensional Hamlin Valley, Nevada-Utah, in Raines, G.L., Lisle, R.E., Schafer, R.W., and Wilkinson, W.H., eds., Geology and ore deposits of the Great Basin: Symposium Proceedings, Geological Society of Nevada, p. 93-100.

Southern Nevada Water Authority, 2008, Spring Valley stipulation agreement hydrologic monitoring plan status and data report: Las Vegas, Nev., Southern Nevada Water Authority, Doc. No. WRD-ED-0001, $76 \mathrm{p}$.

Southern Nevada Water Authority, 2009a, Water resource plan 09: Las Vegas, Nev., Southern Nevada Water Authority, 67 p., http://www.snwa.com/assets/pdf/wr_plan.pdf
Southern Nevada Water Authority, 2009b, 2008 Spring Valley hydrologic monitoring and mitigation plan status and data report: Las Vegas, Nev., Southern Nevada Water Authority, Doc. No. WRD-ED-0004, 109 p.

Southern Nevada Water Authority, 2010, 2009 Spring Valley hydrologic monitoring and mitigation plan status and data report: Las Vegas, Nev., Southern Nevada Water Authority, Doc. No. WRD-ED-0007, $120 \mathrm{p}$.

Southern Nevada Water Authority, 2011, 2010 Spring Valley hydrologic monitoring and mitigation plan status and data report: Las Vegas, Nev., Southern Nevada Water Authority, Doc. No. WRD-ED-0010, 126 p.

Southern Nevada Water Authority, 2012, 2011 Spring Valley hydrologic monitoring and mitigation plan status and data report: Las Vegas, Nev., Southern Nevada Water Authority, Doc. No. WRD-ED-0014, variously paginated.

Southern Nevada Water Authority and U.S. Bureau of Land Management, 2008, Baseline characterization report for Clark, Lincoln, and White Pine Counties groundwater development project: Las Vegas, Nev., Southern Nevada Water Authority, U.S. Bureau of Land Management, 1,156 p, accessed July 11, 2013, http://www.blm.gov/nv/st/ en/prog/planning/groundwater_projects/snwa_groundwater_project/documents_and_maps.html.

Stewart, J.H., 1980, Geology of Nevada: a discussion to accompany the geologic map of Nevada: Nevada Bureau of Mines and Geology Special Publication 4, $136 \mathrm{p}$.

Stewart, J.H., 1998, Regional characteristics, tilt domains, and extensional history of the late Cenozoic Basin and Range province, western North America, in Faulds, J.E., and Stewart, J.H., eds., Accommodation zones and transfer zones: The regional segmentation of the Basin and Range Province: Geological Society of America Special Paper 323, p. 47-74.

Stewart, J.H., and Carlson, J.E., compilers, 1978, Sources of data for the geologic map of Nevada: U.S. Geological Survey Miscellaneous Field Studies Map 930, 1 sheet.

Stewart, J.H., and Poole, F.G., 1974, Lower Paleozoic and uppermost Precambrian Cordilleran miogeocline, Great Basin, western United States, in Dickinson, W.R., ed., Tectonics and Sedimentation: Tulsa, Okla., Society of Economic Petrologists and Mineralogists, p. 27-57.

Stonestrom, D.A., Prudic, D.E., Laczniak, R.J., and Akstin, K.C., 2004, Tectonic, climatic, and land-use on groundwater recharge in an arid alluvial basin: Amargosa Desert, U.S.A., in Hogan, J.F., Phillips, F.M., and Scanlon, B.R., eds., Groundwater recharge in a desert environment-The southwestern United States: Washington D.C., American Geophysical Union, Water Science and Application 9, p. 29-48. 
Sweetkind, D.S. and du Bray, E.A., 2008, Compilation of Tertiary volcanic-rock stratigraphic thicknesses and caldera structures - east-central Nevada and west-central Utah: U.S. Geological Survey Digital Data Series DS-271, 40 p.

Sweetkind, D.S., Knochenmus, L.A., Ponce, D.A., Wallace, A.R., Scheirer, D.S., Watt, J.T., and Plume, R.W., 2007, Hydrogeologic framework, in Welch, A.H., Bright, D.J., Knochenmus, L.A., eds., Water resources of the Basin and Range carbonate-rock aquifer system, White Pine County, Nevada, and adjacent areas in Nevada and Utah: U.S. Geological Survey Scientific Investigations Report 2007-5261, p.11-17.

Theis, C.V., 1935, The relation between the lowering of the piezometric surface and the rate and duration of discharge of a well using groundwater storage: Transactions, American Geophysical Union, v. 16, no. 5, p. 519-524.

Theis, C.V., Brown, R.H., and Meyer, R.R., 1963, Estimating the transmissibility of aquifers from the specific capacity of wells, in Bentall, Ray, Methods of determining permeability, transmissibility and drawdown: U.S. Geological Survey Water-Supply Paper 1536-I, p. 331-341.

Thornbury, W.D., 1969, Principles of Geomorphology (2d ed.): New York, John Wiley \& Sons, Inc., 594 p.

Tumbusch, M.L., and Schaefer, D.H., 1996, Selected hydrologic data for and location of MX wells in east-central and southern Nevada, January 1980 through May 1996: U.S. Geological Survey Open-File Report 96-469, 37 p.

Tyler, S.W., Chapman, J.B., Conrad, S.H., Hammermeister, D.P., Blout, D.O, Miller, J.J., Sully M.J., and Ginanni, J.M., 1996, Soil-water flux in the southern Great Basin, United States-Temporal and spatial variations over the last 120,000 years: Water Resources Research, v. 32, p. $1,481-1,499$.

Tyler, S.W., Selker, J.S., Hausner, M.B., Hatch, C.E., Torgersen, T., Thodal, C.E., and Schladow, S.G., 2009, Environmental temperature sensing using Raman spectra DTS fiberoptic methods: Water Resources Research, v. 45, W00D23, doi:10.1029/2008WR007052.

U.S. Air Force, 1983, Air Force M-X multiple protective shelter water resources program - Nevada, A summary: Norton Air Force Base, Calif., Regional Civil Engineer-MX (AFESC), $18 \mathrm{p}$.

U.S. Department of the Interior, 1992, Great Basin National Park, Nevada - Final general management plan, development concept plans, environmental impact statement: Denver, Colo., U.S. Department of the Interior, National Park Service, $434 \mathrm{p}$.
U.S. Department of the Interior and Southern Nevada Water Authority, 2006, Stipulation for withdrawal of protests, September 8, 2006: Southern Nevada Water Authority, U.S. Bureau of Land Management, $18 \mathrm{p}$.

U.S. Geological Survey, 2008, A study of the connection among basin-fill aquifers, carbonate-rock aquifers, and surface-water resources in southern Snake Valley, Nevada: U.S. Geological Survey Fact Sheet 2008-3071, 2 p.

U.S. Geological Survey, 2011, Great Basin carbonate and alluvial aquifer system (GBCAAS) water availability: U.S. Geological Survey, accessed April 6, 2011, http://ut.water. usgs.gov/projects/greatbasin/index.html

U.S. Geological Survey and Nevada Bureau of Mines and Geology, 2006, Quaternary fault and fold database for the United States: U.S. Geological Survey, accessed October 27, 2009, http://earthquake.usgs.gov/hazards/qfaults/.

Utah Geological Survey, 2011, West desert groundwater monitoring network: Utah Geological Survey, accessed April 7, 2011 http://geology.utah.gov/esp/snake_valley_project/ overview.htm\#description.

Vozoff, K., 1991, The magnetotelluric method, in Nabighian, M.N., ed., Electromagnetic methods in applied geophysics: Tulsa, Okla., Society of Exploration Geophysicists, v. 2, part. B, p. 641-711.

Walker, W.R., 1972, Preliminary report on the results of investigation of the Big Springs Irrigation Company, June 10, 1972 to November 18, 1972: Delta, Utah, Office of Sevier River Commissioner, November 30, 1972, 4 p.

Ward, A.D., and Trimble, S.W., 2004, Environmental Hydrology ( $2 \mathrm{~d}$ ed.): Boca Raton, Florida, Lewis Publishers, CRC Press, $475 \mathrm{p}$.

Watt, J.T., and Ponce, D.A., 2007, Geophysical framework investigations influencing ground-water resources in eastcentral Nevada and west-central Utah, with a section on geologic and geophysical basin-by-basin descriptions by Wallace, A.R., Watt, J.T., and Ponce, D.A.: U.S. Geological Survey Open-File Report 2007-1163, 40 p. 2 plates, scale 1:750,000.

Welch, A.H., Bright, D.J., and Knochenmus, L.A., 2007, Water resources of the Basin and Range carbonate-rock aquifer system, White Pine County, Nevada, and adjacent areas in Nevada and Utah: U.S. Geological Survey Scientific Investigations Report 2007-5261, 96 p.

Wernicke, Brian, 1992, Cenozoic extensional tectonics of the U.S. Cordillera, in Burchfiel, B.C., Lipman, P.W., and Zoback, M.D., eds., The Cordilleran Orogen; conterminous U.S: Boulder, Colo., Geological Society of America, Geology of North America, p. 553-581. 
Wernicke, Brian, 2013, The detachment era (1977-1982) and its role in revolutionizing continental tectonics, in Ring, Uwe, and Wernicke, Brian, eds., Extending a continent: Architecture, rheology and heat budget: London, Geological Society, Special Publications, v. 321, p. 1-8.

Western Regional Climate Center, 2011, Garrison, Utah, period of record monthly climate summary, 1903-1990: Desert Research Institute, Western Regional Climate Center, accessed March 24, 2011, http://www.wrcc.dri.edu/cgi-bin/ cliMAIN.pl?ut3138.

Western Regional Climate Center, 2012a, Great Basin National Park, Nevada, period of record monthly climate summary: Desert Research Institute, Western Regional Climate Center, accessed August 18, 2012, http://www.wrcc. dri.edu/cgi-bin/cliMAIN.pl?nv3340.

Western Regional Climate Center, 2012b, Eskdale, Utah, period of record monthly climate summary: Desert Research Institute, Western Regional Climate Center, accessed August 18, 2012, http://www.wrcc.dri.edu/cgi-bin/ cliMAIN.pl?ut2607.

Wheeler, G.M., 1875, Report upon geographical and geological explorations and surveys west of the one hundredth meridian: U.S. Army, Engineer Department, 681 p.

Wheeler, G.M., and Lockwood, D.W., 1875, Preliminary report upon the reconnaissance through southern and southeastern Nevada made in 1869: Government Printing Office, Washington D.C., U.S. U.S. Army, Engineer Department, $72 \mathrm{p}$.

Whitebread, D.H., 1969, Geologic map of the Wheeler Peak and Garrison quadrangles, Nevada and Utah: U.S. Geological Survey Miscellaneous Geologic Investigations Map I-578, scale 1:48,000.

Wiggly, T.M.L., and Plummer, L.N., 1976, Mixing of carbonate waters: Geochimica et Cosmochimica Acta, v. 42, p. 1,117-1,139.

Williams, J.M., and Rodriguez, B.D., 2004, Magnetotelluric survey to locate the Archean/Proterozoic suture zone in northeastern Nevada: U.S. Geological Survey Open-File Report 2004-1215, 212 p.

Williams, M.R., and Melack, J.M., 1997, Atmospheric deposition, mass balances, and processes regulating streamwater solute concentrations in mixed-conifer catchments of the Sierra Nevada, California: Biogeochemistry, v. 37, p. 111-144.

Williams, V.S., Best, M.G., and Keith, J.D., 1997, Geologic map of the Ursine-Panaca Summit-Deer Lodge area, Lincoln County, Nevada, and Iron County, Utah: U.S. Geological Survey Miscellaneous Investigations Series Map I-2479, scale 1:50,000.
Willis, J.B., Best, M.G., Kowallis, B.J., and Best, V.C., 1987, Preliminary geologic map of the northern Wilson Creek Range, Lincoln County, Nevada: U.S. Geological Survey Miscellaneous Field Studies Map MF-1971, scale 1:50,000.

Winograd, I.J., and Thordarson, William, 1975, Hydrogeologic and hydrochemical framework south-central Great Basin, Nevada-California, with special reference to the Nevada Test Site: U.S. Geological Survey Professional Paper 712-C, $126 \mathrm{p}$.

Zoback, M.L., Anderson, R.E., and Thompson, G.A., 1981, Cenozoic evolution of the state of stress and style of tectonism of the Basin and Range province, of the western United States, in Vine, F.J., and Smith, A.D., eds., Extensional Tectonics Associated with Convergent Plate Boundaries: London, The Royal Society, p. 189-216.

Zones, C.P., 1961, Ground-water potentialities in Crescent Valley, Eureka and Lander Counties, Nevada: U.S. Geological Survey Water-Supply Paper 1581, 50 p. 


\section{Glossary}

Annual runoff is the total water discharged at a particular location on a stream, canal, ditch, or at a spring during a year. Units of the annual quantity of runoff used in this report are acre-feet.

Aquifer is a rock or sediment in a formation, group of formations, or part of a formation that is saturated and sufficiently permeable to transmit economic quantities of water to wells and springs.

Confining unit is a rock or sediment that has a low hydraulic conductivity.

Daily mean discharge is the daily averaged volumetric flow rate determined from records at a gaging station on a stream, ditch, canal, spring or pipe.

Discharge is the volumetric flow rate of water in a stream, ditch, canal, spring or through an aquifer past a specific location. Units used in this report are cubic feet per second or gallons per minute.

Drainage area is the surface area of a stream that is delineated by a continuous topographic divide in which all runoff joins a single stream and extends downstream to where the stream crosses the divide.

Drainage basin is a part of the earth's surface that is occupied by a drainage system, which consists of a surface stream or a body of impounded surface water together with all tributary surface streams and bodies of impounded surface water.

Evapotranspiration is water withdrawn from a land area by evaporation of water and by plant transpiration. Units of the annual quantity of evapotranspiration used in this report are acre-feet.

Evapotranspiration rate is the quantity of water that is withdrawn from a land area by evaporation of water and by plant transpiration, expressed as a volume per unit area for a given period. Units used in this report are cubic inches per square inch per season or year or as a depth in inches per season or year.

Formation is a body of rock identifiable by lithologic characteristics and stratigraphic position that is mappable at the Earth's surface or traceable in the subsurface.

Gaging station is a particular site on a stream, canal, spring, lake, or reservoir where systematic observations of gage height, discharge, or other hydrologic data are obtained.

Groundwater divide is a boundary between two adjacent groundwater basins and is represented by a high in the water table.

Groundwater flow is the movement of water through openings in a rock or sediment.

Hydraulic conductivity is the coefficient of proportionality describing the rate at which water can move through a fractured rock or porous sediment and includes the density and viscosity of the water.

Hydraulic diffusivity is a property of an aquifer defined as the transmissivity divided by the storage coefficient, or the lateral hydraulic conductivity divided by the specific storage, where the aquifer is confined, and as the transmissivity divided by the specific yield for an unconfined aquifer.

Hydraulic gradient is the change in hydraulic head with a change in distance in a given direction.

Hydraulic head is the sum of the altitude head and the pressure head at a given location in an aquifer, when the velocity head is neglected.

Hydrostratigraphic unit is a rock or sediment in a formation, group of formations, or part of a formation that has similar physical characteristics with respect to the capacity to store and transmit water.

Lateral is parallel to land surface or streambed slope.

Precipitation is water that is precipitated from the atmosphere onto the earth's surface over a specified area. Precipitation includes rainfall, snow, hail, and sleet. Units of the annual quantity of precipitation used in this report are acre-feet.

Precipitation rate is the quantity of water that is precipitated from the atmosphere onto the earth's surface, expressed as a volume per unit area or depth for a given period. Units used in this report are cubic inches per square inch per season or year or as a depth of inches per season or year.

Runoff is the same as annual runoff.

Runoff rate is the quantity of runoff divided by the drainage area for a given period. Units used in this report are cubic inches per square inch per year or as a depth of inches per year.

Snow-water equivalent is water that would be obtained if the snow should be completely melted. Units of the quantity of snow-water equivalent used in this report are cubic inches per square inch or as a depth in inches.

Specific capacity is the volumetric rate of water discharging from a well divided by the water-level decline in the well over a particular interval of time.

Specific storage is the volume of water that is added to or released from a unit volume of aquifer due to a unit change in pressure head.

Specific yield is the ratio of the unit volume of water drained by gravity from a unit volume of rock or sediment.

Storage coefficient is the volume of water an aquifer releases from or takes into storage per unit surface area of aquifer per unit change in total hydraulic head.

Streambed is the material over which water in a stream channel flows.

Streambed seepage is water that flows through a streambed. Units of the annual quantity of streambed seepage used in this report are acre-feet. 
Streambed-seepage rate is the volumetric rate of water flowing through a unit area of streambed. Units used in this report are cubic feet per square foot per day or as a depth of feet per day.

Streamflow is used in this report to describe the flow of water down a natural channel.

Streamflow gain or gaining stream is a reach of a stream where flow is increased by groundwater inflow.

Streamflow loss or losing stream is a reach of a stream where flow is lost through the streambed.

Surface water is water found on the surface of the earth.

Water budget is the evaluation of all inflows and outflows with respect to an aquifer or drainage basin.

Water table is the surface in an aquifer or confining unit at which the pore-water pressure is atmospheric.

Water year is the 12-month period, October 1 to September 30 . The water year is designated by the calendar year in which it ends and includes 9 of the 12 months.

Water yield is the runoff from a drainage basin plus groundwater outflow that bypasses the stream and leaves the basin underground, expressed as a volume during a year. Water yield is the annual precipitation minus the annual evapotranspiration. Units of the annual quantity of water yield used in this report are acre-feet.

Additional definitions of hydrologic terms can be found (1) in glossary of terms for U.S. Geological Survey Water-Data Reports (http://water.usgs.gov/ADR_Defs_2004.pdf); (2) in Langbein and Iseri, 1995 (http://water.usgs.gov/glossaries. $h t m l)$; and in Fetter, 2001. 


\section{Appendix 1. Geologic and Geophysical Data for Test Wells Drilled September 2009-0ctober 2010.}

Geologic and geophysical data were summarized for test wells drilled by the U.S. Geological Survey between September 2009 and October 2010. Three shallow boreholes were drilled along Baker Creek at the Baker Creek 4 aquifer-test site; a deep borehole was drilled next to Snake Creek at the Snake 5 site; and two deep boreholes were drilled northwest and southwest of Big Springs at the south end of the Snake Range (BS NW and SW wells). Two of the boreholes drilled along Baker Creek and the deep borehole next to Snake Creek had two wells installed in each hole (nested wells). One well was installed in the other boreholes. The location and depth of each well (including nested wells) are listed in table 1-1; site locations are shown in figure $1-1$.

Table 1-1. Monitoring wells drilled near Great Basin National Park, White Pine County, Nevada, as part of this study, $2009-2010$.

[U.S. Geological Survey site-identification number can be used to obtain data from the National Water Information System. Horizontal coordinate information is referenced to the North American Datum of 1983. Land-surface altitude is referenced to the North American Vertical Datum of 1988. NDWR, Nevada Division of Water Resources. Abbreviation: $\mathrm{mm}$, two digit month; dd, two digit day; yyyy, four digit year]

\begin{tabular}{|c|c|c|c|c|c|c|c|c|c|}
\hline \multirow[b]{2}{*}{ Name } & \multirow{2}{*}{$\begin{array}{c}\text { U.S. Geological Survey } \\
\text { site-identification } \\
\text { number }\end{array}$} & Latitude & Longitude & \multirow{2}{*}{$\begin{array}{l}\text { Land- } \\
\text { surface } \\
\text { altitude } \\
\text { (feet) }\end{array}$} & \multirow{2}{*}{$\begin{array}{c}\text { Well } \\
\text { diameter } \\
\text { (inches) }\end{array}$} & \multirow{2}{*}{$\begin{array}{c}\text { Date well } \\
\text { completed } \\
\text { (mm/dd/yyyy) }\end{array}$} & \multirow{2}{*}{$\begin{array}{l}\text { Well } \\
\text { depth } \\
\text { (feet) }\end{array}$} & \multirow{2}{*}{$\begin{array}{l}\text { NDWR } \\
\text { log } \\
\text { number }\end{array}$} & \multirow[b]{2}{*}{$\begin{array}{c}\text { Geophysical } \\
\text { logs }\end{array}$} \\
\hline & & \multicolumn{2}{|c|}{ Decimal degrees } & & & & & & \\
\hline Baker 4: 6-inch well & 385947114113201 & 38.996 & 114.192 & 6,390 & 6 & $09 / 18 / 2009$ & 40.7 & 108854 & no \\
\hline Baker 4: upstream shallow & 385946114113201 & 38.996 & 114.192 & 6,387 & 2 & $09 / 10 / 2009$ & 20.5 & 108857 & no \\
\hline Baker 4: upstream deep & 385946114113202 & 38.996 & 114.192 & 6,387 & 2 & 09/10/2009 & 60.5 & 108858 & no \\
\hline Baker 4: downstream shallow & 385946114113101 & 38.996 & 114.192 & 6,389 & 2 & $09 / 14 / 2009$ & 17.5 & 108855 & no \\
\hline Baker 4: downstream deep & 385946114113102 & 38.996 & 114.192 & 6,389 & 2 & $09 / 14 / 2009$ & 34.5 & 108856 & no \\
\hline Snake 5 shallow & 385524114045601 & 38.923 & 114.082 & 5,617 & 2 & $09 / 08 / 2009$ & 35.0 & 108852 & yes \\
\hline Snake 5 deep & 385524114045602 & 38.923 & 114.082 & 5,617 & 2 & $09 / 08 / 2009$ & 309.5 & 108853 & yes \\
\hline Big Springs-northwest well & 384227114082701 & 38.708 & 114.141 & 5,815 & 8 & $10 / 13 / 2009$ & 460.0 & 116598 & yes \\
\hline Big Springs-southwest well & 384112114091101 & 38.687 & 114.153 & 6,020 & 8 & $08 / 31 / 2010$ & 700.0 & 112248 & yes \\
\hline
\end{tabular}

Permission for drilling three sites in the Great Basin National Park, near Lehman Caves, was not obtained during this study. One of these wells, SLE (fig. 1-1), was completed in May and June 2012, and the results are described in a University of Nevada-Reno report (Prudic, 2012a). A well at the south end of the Limestone Hills was planned, but was not drilled because costs for the other wells exceeded the estimates. The planned locations of five monitoring wells that were to be drilled by the Southern Nevada Water Authority as part of the systematic monitoring plan in Spring Valley, northern Hamlin Valley, and southern Snake Valley also are shown in figure $1-1$.

\section{Baker Creek 4 Aquifer-Test Site}

The Baker Creek 4 aquifer-test site (fig. 1-2) consists of a 6-inch (in.) diameter monitoring well 54 feet (ft) north of Baker Creek along a four-wheel drive trail and near dualcompletion monitoring wells drilled closer to the creek both upstream and downstream of the 6-in. well. The three holes were drilled by using an asymmetric air-percussion hammer bit (under-reaming bit) that pulled steel casing as the hole was deepened (Dewey and Miller, 1996). The steel casing was removed as the hole was backfilled following the placement of 6-in. schedule 80 polyvinyl chloride (PVC) casing for the 6-in. diameter monitoring well or 2-in. diameter schedule 80 PVC casing for the nested monitoring wells. A 20-ft long screen with 0.020 -in. machine slots was placed at the bottom of the 6-in. diameter well, and 5-ft screens with the same size openings were placed at the bottom of the nested wells, except in the deep well at the upstream site, which had a 10-ft long screen. Fine gravel to very-coarse sand was placed around each well screen; bentonite was used to seal the annulus between nested monitoring wells; and cement grout was used to seal the borehole near land surface. The 6-in. diameter monitoring borehole penetrated quartzite gravel and boulders with sand and little to no silt and clay to a depth of $30 \mathrm{ft}$ and mostly quartzite gravel and sand with minor quantities of silt and clay between a depth of 30 and $40.7 \mathrm{ft}$.

The upstream hole penetrated coarse quartzite gravel and boulders, with lesser quantities of sand and silt, to a depth of $32 \mathrm{ft}$. The hole penetrated clay starting at $32 \mathrm{ft}$ and, at a depth of $35 \mathrm{ft}$, alternating thin layers of calcareous shale and siltstone. The hole was deepened to $62 \mathrm{ft}$ without casing by using a 7-in. air-percussion hammer bit, and the hole remained in shale to its total depth. The deeper monitoring well in the upstream hole was placed at a depth of $60.5 \mathrm{ft}$ because some materials fell to the bottom of the hole as the drill bit was removed. The downstream hole penetrated coarse sand, gravel, cobbles, and boulders to a depth of $35 \mathrm{ft}$. The depth of each monitoring well is listed in table 1-1. 


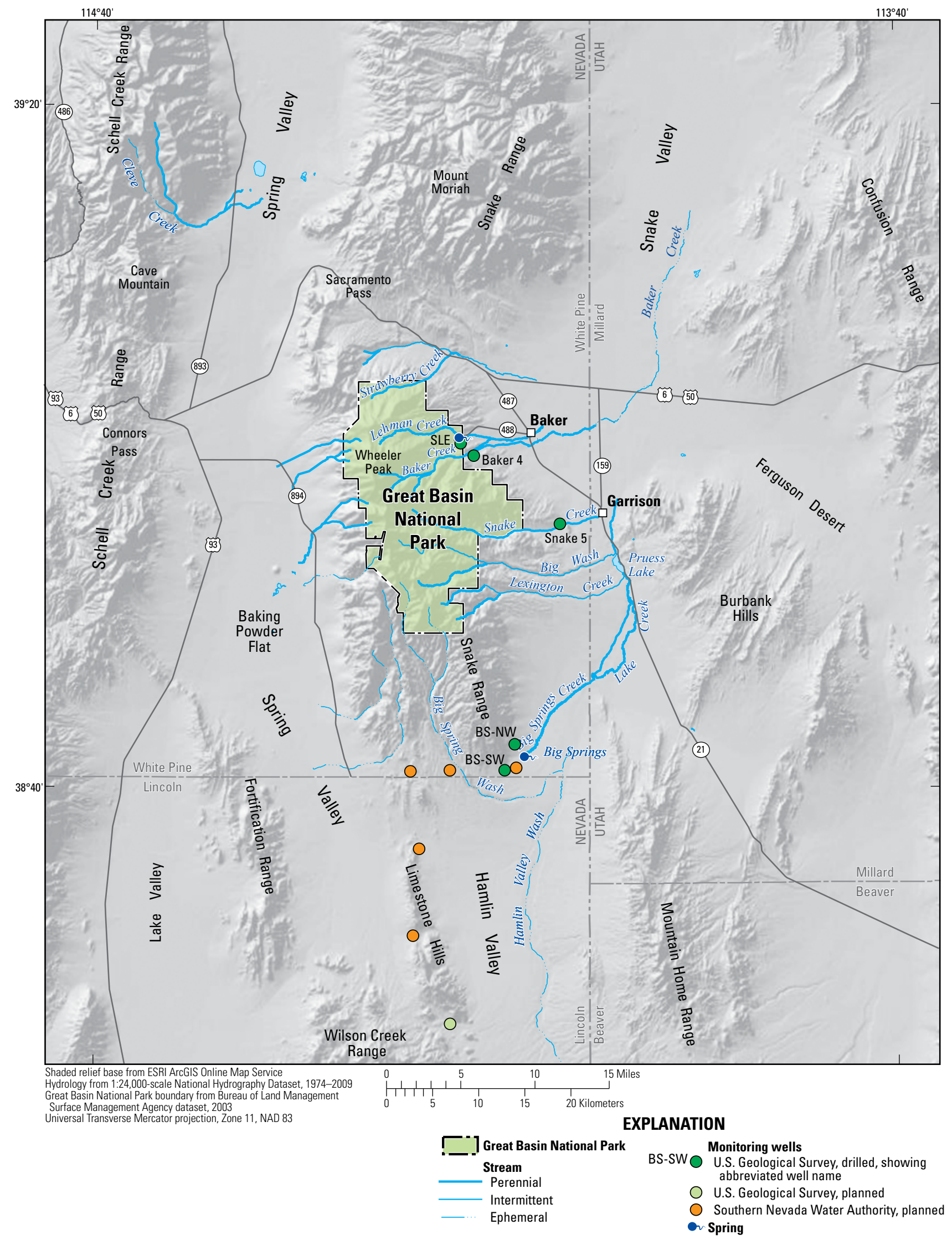

Figure 1-1. Location of completed and planned wells near Great Basin National Park, White Pine County, Nevada. 


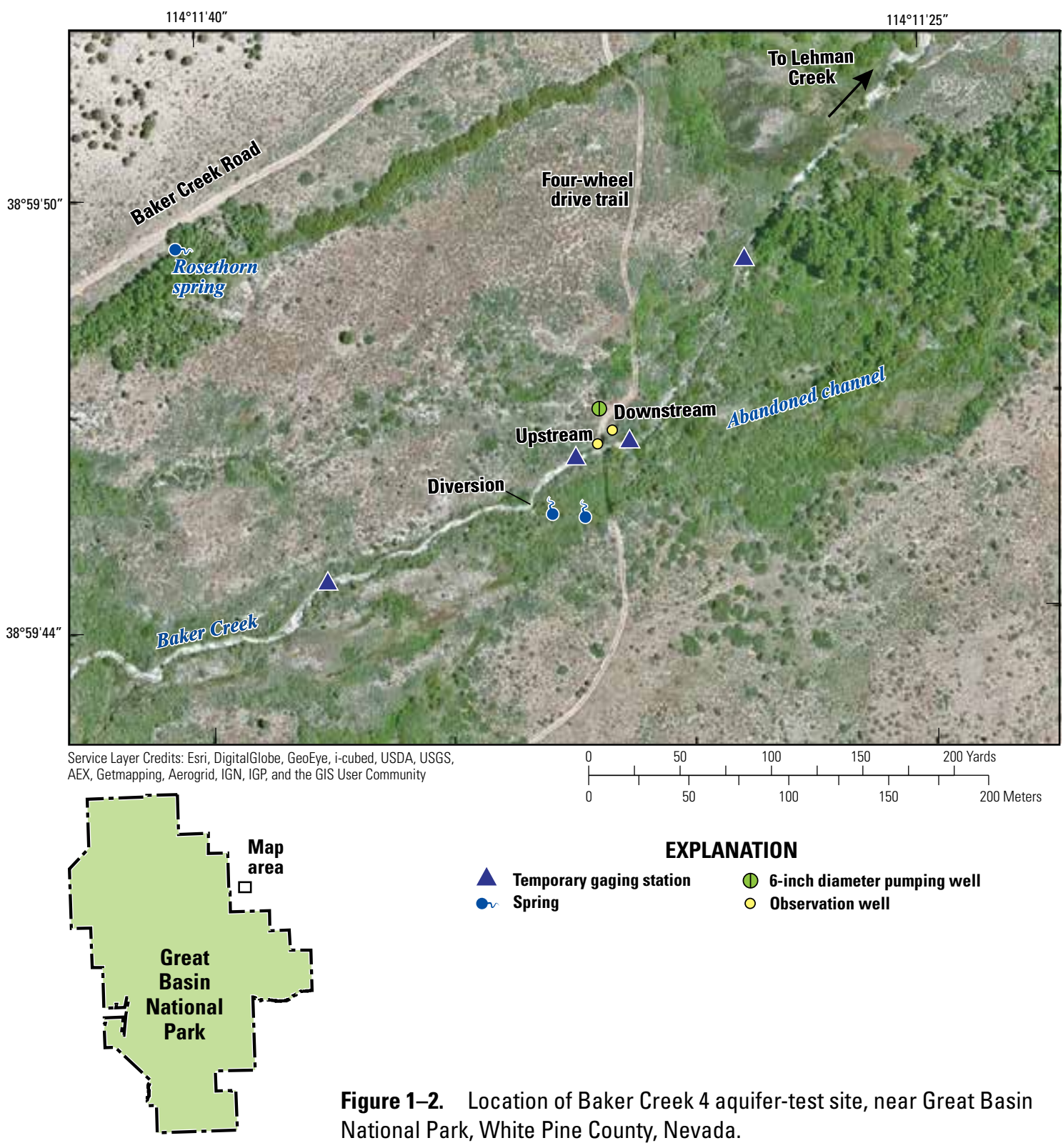

No geophysical logs were run on any of the Baker Creek wells because they were relatively shallow and because they needed to be cased while drilling, because the unconsolidated deposits were unstable.

\section{Snake 5 Wells}

Drilling and construction of the Snake 5 wells (fig. 1-1) were done during September 3-8, 2009. The same method was used to drill the first $80 \mathrm{ft}$ as was used to drill the Baker Creek wells. The first $80 \mathrm{ft}$ of the hole penetrated mostly noncalcareous quartzite cobbles and gravel, with slightly calcareous sand and silt from 0 to $30 \mathrm{ft}$; non-calcareous gravel, sand, and silt from 30 to $40 \mathrm{ft}$; a moderate brown, plastic clay from 40 to $60 \mathrm{ft}$; a moderate brown clay with increasing percentages of carbonate rock chips from 60 to $73 \mathrm{ft}$; and mostly carbonate rock chips from a depth of 73 to $80 \mathrm{ft}$. The drilling method was changed at a depth of $80 \mathrm{ft}$, and the hole was deepened by using a 7-in. air-percussion hammer bit without casing to a depth of 310-ft below land surface. From $80 \mathrm{ft}$ to $295 \mathrm{ft}$, the hole penetrated extensively fractured, sulfurous limestone of the Guilmette Formation, but all fractures were filled with secondary calcite and small quantities of Snake Creek water were injected to help circulate cuttings. The cuttings began exhibiting iron staining at a depth of $290 \mathrm{ft}$, and water entered the hole at a depth of $300 \mathrm{ft}$, so injection of water from the creek was stopped. The hole was deepened to a depth of $310 \mathrm{ft}$ when drilling stopped because water from the hole began to overwhelm the cyclone separator used to separate fine cuttings (silt and clay size) from coarse cuttings (sand and gravel size). 
A suite of geophysical logs was run in the hole (fig. 1-3), as was a downhole televiewer log that provided information about the distribution of fractures in the test hole. The televiewer logs showed that, from a depth of 80 to $295 \mathrm{ft}$, the limestone had fractures that were filled with calcite veins and, thus, had low porosity and permeability. Solution-widened fractures appeared at a depth of $295 \mathrm{ft}$ and extended to the bottom of the hole at a depth of $310 \mathrm{ft}$.

The hole was completed by installing two 2 -in. schedule 80 PVC monitoring wells. The deeper well was screened from a depth of 289.5 to $309.5 \mathrm{ft}$ below land surface in the zone of fractured limestone. Coarse sand was poured through a tremie pipe to fill to a depth of $280 \mathrm{ft}$. From 280 to $40 \mathrm{ft}$, the hole was backfilled with a liquid bentonite grout (American Colloid Pure Gold Grout) that was pumped through a tremie pipe. The steel casing was removed from 80 to $40 \mathrm{ft}$ depth while the hole was filled with grout. A gamma log was used in the cased part of the hole to identify a logical depth to place the shallow monitoring well. The log indicated the coarsest alluvial deposits were between a depth of 30 and $35 \mathrm{ft}$, and, consequently, the screened interval of the shallow well was placed there. First, coarse sand was poured in the hole to fill it from a depth of 40 to $35 \mathrm{ft}$. The well screen and casing were placed in the hole, and coarse sand was added to fill it to a depth of $25 \mathrm{ft}$. The remainder of the hole was grouted with bentonite to within $3 \mathrm{ft}$ of land surface, and the uppermost part of the hole was filled with concrete. The last of the steel casing was removed as the hole was backfilled.

\section{Big Springs Northwest Well}

The hole at Big Springs Northwest well was drilled to a depth of $460 \mathrm{ft}$ by using mud rotary (Driscoll, 1986, p. 286-289; fig. 1-1). The hole penetrated mostly sand, gravel, and cobbles composed of carbonate rocks throughout the entire depth. Small balls of clay in the cuttings indicated thin clay beds at depths of 160-180 ft, 298-300 ft, $405-425 \mathrm{ft}$, and 440-460 ft. Geophysical logs, including natural gamma, spontaneous potential, caliper, resistivity, and sonic, were run in the hole on September 30, 2009, prior to installing a 8-in. diameter steel casing (fig. 1-4). The bottom $160 \mathrm{ft}$ of hole was screened with 0.03 -in. machine slotted-steel casing. The annulus around the well screen was filled with coarse sand poured through a tremie pipe to a depth of $230 \mathrm{ft}$. From $230 \mathrm{ft}$ to within $5 \mathrm{ft}$ of land surface, the annulus was filled with bentonite, and the remaining $5 \mathrm{ft}$ was filled with concrete. A 5-ft long piece of 12 -in. casing was embedded $2.5 \mathrm{ft}$ in the concrete to protect the monitoring well.

\section{Big Springs Southwest Well}

The hole at Big Springs Southwest well (fig. 1-1) was drilled to a depth of $220 \mathrm{ft}$ by using mud rotary, after which the hole was deepened by using a combination of casing pulled down the hole with an under-reaming air-percussion hammer bit and by an air-percussion hammer bit without casing. Geophysical logs were run on August 17, 2010 (fig. 1-5). Difficulties were encountered during drilling because highly fractured limestone was encountered above the water table. The hole penetrated sand, gravel, and cobbles composed of carbonate rocks from a depth of 0 to $213 \mathrm{ft}$ below land surface; fractured, fairly competent limestone re-cemented by calcite from 213 to $236 \mathrm{ft}$; less competent limestone, with numerous solution-widened and open fractures, from 236 to $305 \mathrm{ft}$; fractured limestone re-cemented by white calcite from 305 to $515 \mathrm{ft}$; limestone with solution-widened fractures from 515 to $575 \mathrm{ft}$; and fractured limestone re-cemented by white calcite with occasional open fractures from 575 to $700 \mathrm{ft}$. Below a depth of $235 \mathrm{ft}$, the drill bit tended to follow the open fractures in the limestone, resulting in a borehole deviating from vertical. The bottom of the hole is offset $55 \mathrm{ft}$ east and $18 \mathrm{ft}$ north of the well collar location.

Lithologic descriptions for the Snake 5 and the two wells near Big Springs have been compiled in tables (tables 1-2, $1-3$, and 1-4). These tables list the following information for Snake 5, Big Springs NW, and Big Spring SW wells:

- Top of interval, in feet.

- Base of interval, in feet.

- Lithologic unit.

- Lithologic description.

\section{References Cited}

Dewey, C.H., and Miller, G.C., 1996, Drilling and under reaming simultaneously: A cost-effective option: Denver, Colo., Society of Petroleum Engineers Annual Technical Conference and Exhibition, October 6-9, 1996. doi 10.2118/36462-MS

Driscoll, F.G., 1986, Groundwater and Wells (2d ed.): St. Paul, Minn., Johnson Division, 1,089 p.

Prudic, D.E., 2012, Report on the drilling of monitoring wells near Lehman Caves, Great Basin National Park, White Pine County, Nevada, May-June 2012: University of Nevada, Reno, final report for National Park Service, August 30, 2012, National Park Service unpublished report 2198459, 38 p., https://irma.nps.gov/App/Reference/Profile/2198459. 


\section{Snake Creek well}

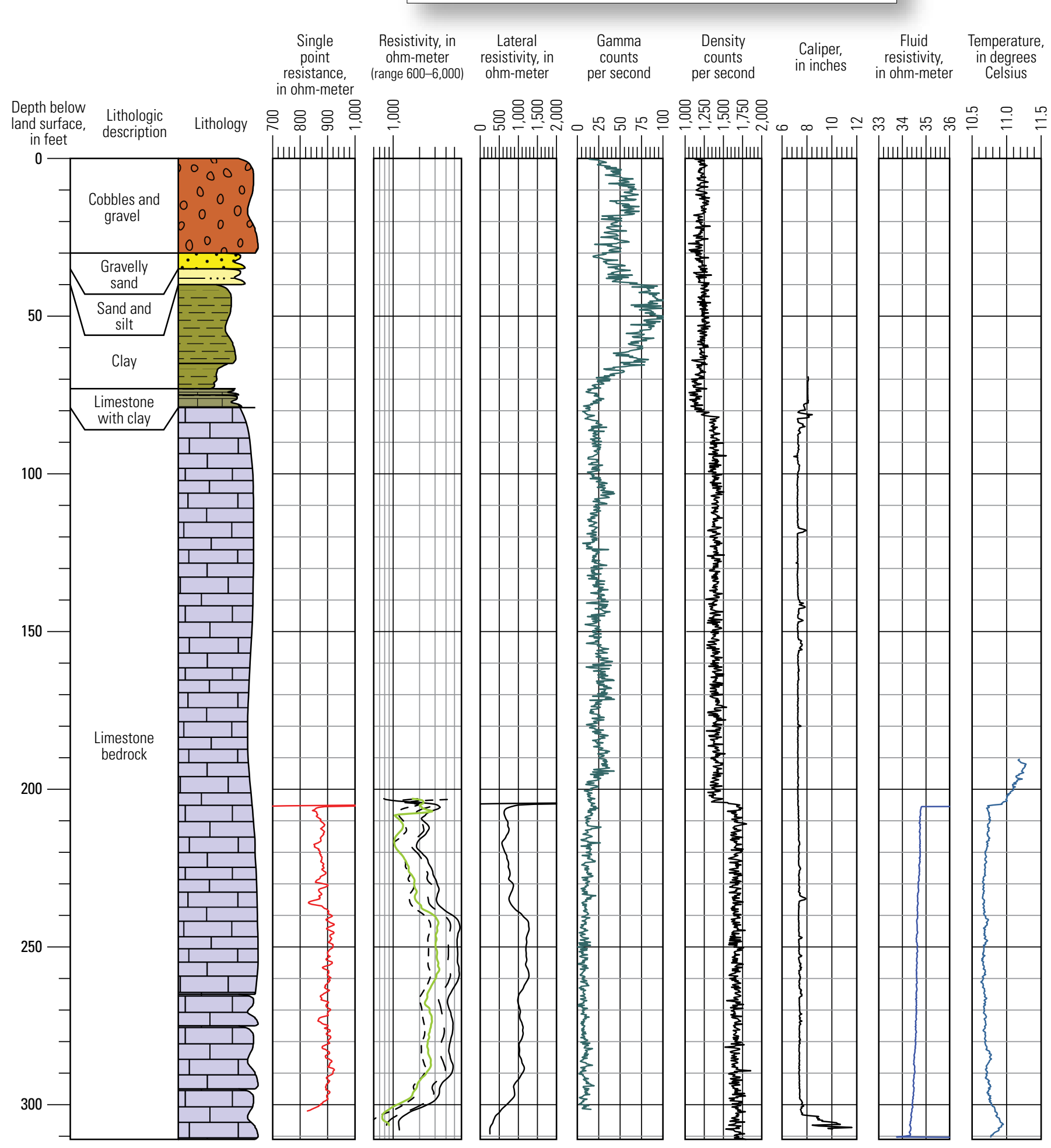

Explanation of Resistivity Curves

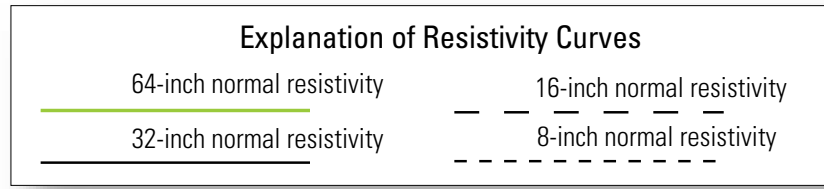

Figure 1-3. Lithologic and geophysical logs for the Snake 5 well. 


\section{Big Springs Northwest well}

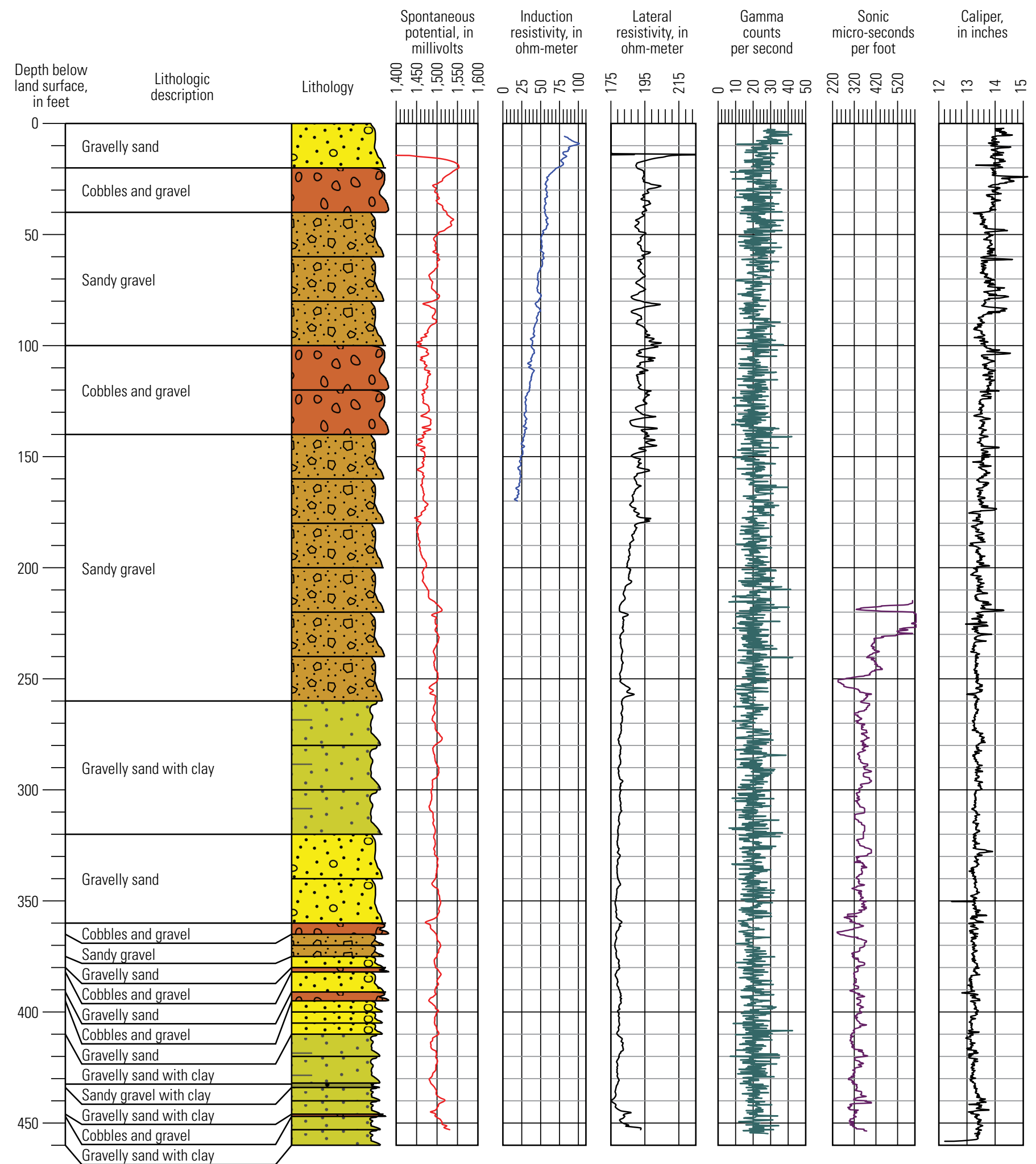

Figure 1-4. Lithologic and geophysical logs for the Big Springs northwest well. 


\section{Big Springs
Southwest well \\ Big Springs
Southwest well}
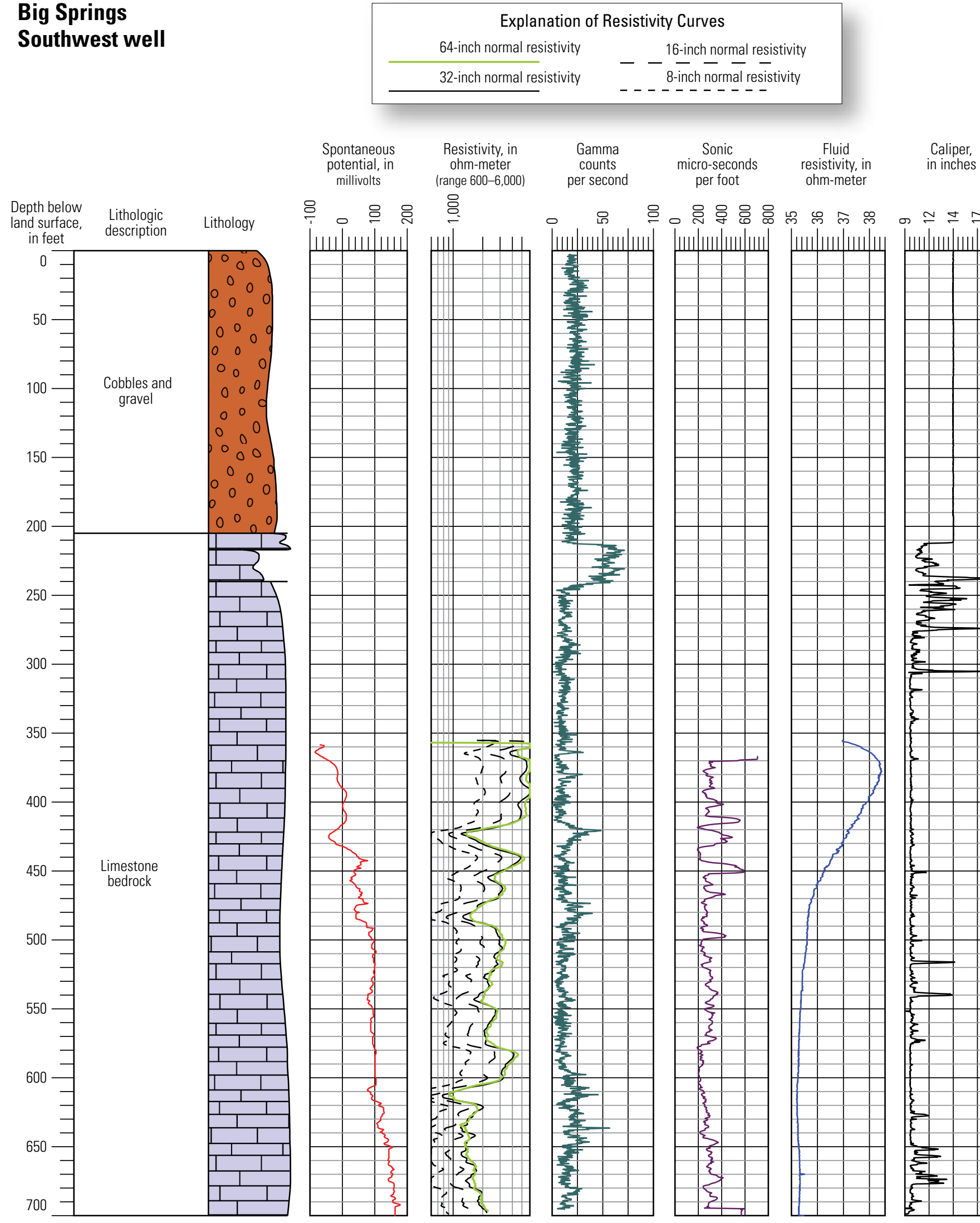

(range 600-6,000)

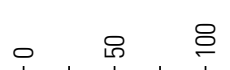

$\simeq \approx$ |ய山Ш山Ш|
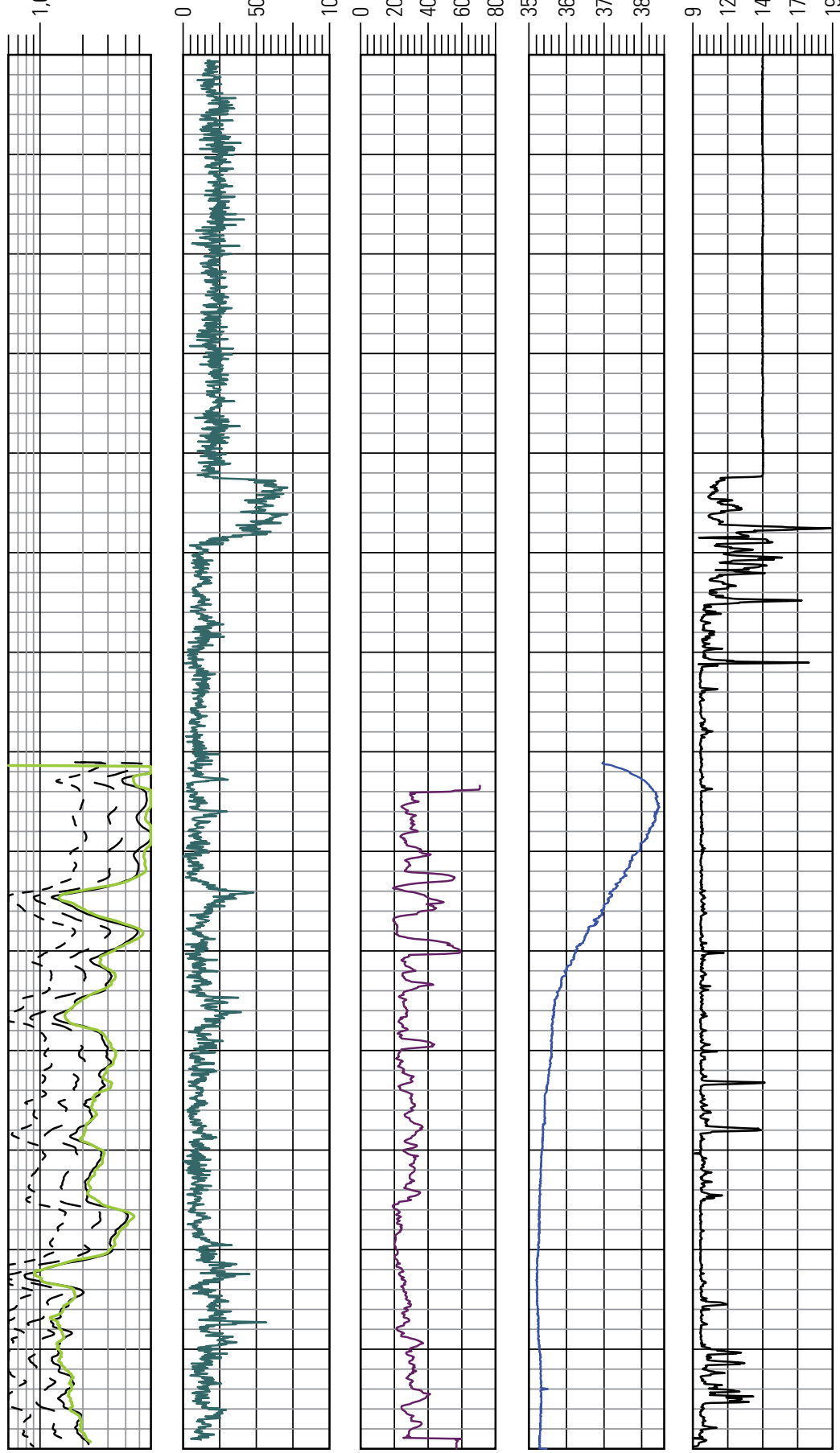

Figure 1-5. Lithologic and geophysical logs for the Big Springs southwest well. 
The following tables are distributed as part of this report in Microsoft ${ }^{\circledR}$ Excel 2010 format and is available for download at http://dx.doi.org/10.3133/pp1819.

Table 1-2. Lithologic description of down hole intervals, Snake Creek 5 monitoring wells, Great Basin National Park, White Pine County, Nevada.

Table 1-3. Lithologic description of down hole intervals, Big Springs Northwest well, southern part of the Snake Range, White Pine County, Nevada.

Table 1-4. Lithologic description of down hole intervals, Big Springs Southwest well, south end of the Snake Range, White Pine County, Nevada. 


\section{Appendix 2. Records at Bulk-Precipitation Stations on Mount Washington, Unnamed Peak Northwest of Mount Mariah, and Cave Mountain, White Pine County, Nevada for Water Years 1984-2011.}

Site descriptions of the three bulk-precipitation stations are summarized in table 2-1. Precipitation recorded at the station on the west slope of Mount Washington in the southern part of the Snake Range is listed in table 2-2. Precipitation recorded at the station on an unnamed peak northwest of Mount Moriah in the northern part of the Snake Range is listed in table 2-3. Precipitation at the station on Cave Mountain in the Schell Creek Range west of Spring Valley is listed in table 2-4. All three stations are at altitudes in excess of 9,000 feet above mean sea level. Data for each bulk-precipitation station have been published routinely in the annual water-data reports for Nevada by the U.S. Geological Survey since 1985. Precipitation reported between October 1984 and October 2003 at these gaging stations is only available through printed annual waterdata reports for each water year (references for these reports are listed in the "Reports with Bulk-Precipitation at Stations in Nevada" section). Since October 2003, the reported values are available online and can be accessed at $h t t p: / / w d r$ water.usgs. gov/.

Table 2-1. Description of bulk-precipitation stations in and near Great Basin National Park, White Pine County, Nevada.

[Latitude and longitude are referenced to North American Datum of 1927 (NAD27). Land-surface altitude is referenced to National Geodetic Vertical Datum of 1929 (NGVD 29). Data for each station can be obtained by using the U.S. Geological Survey siteidentification number as the site-selection criteria at: http://waterdata.usgs.gov/nv/nwis/]

\begin{tabular}{|c|c|c|c|c|}
\hline \multirow[b]{2}{*}{ Station name } & \multirow{2}{*}{$\begin{array}{l}\text { U.S. Geological Survey } \\
\text { site-identification } \\
\text { number }\end{array}$} & Latitude & Longitude & \multirow{2}{*}{$\begin{array}{l}\text { Land- } \\
\text { surface } \\
\text { altitude } \\
\text { (feet) }\end{array}$} \\
\hline & & \multicolumn{2}{|c|}{ Decimal degrees } & \\
\hline Mount Washington & 385409114185401 & 38.902 & 114.315 & 10,440 \\
\hline $\begin{array}{l}\text { Unnamed peak north- } \\
\text { west of Mount Moriah }\end{array}$ & 391913114143101 & 39.32 & 114.242 & 9,300 \\
\hline Cave Mountain & 390946114364901 & 39.163 & 114.614 & 10,650 \\
\hline
\end{tabular}

Tables 2-2, 2-3, and 2-4 list the following information for each bulk-precipitation station:

- Date data collection began.

- Date data collection ended.

- Depth of precipitation, in cubic inches per square inch.

- Season (winter or summer).

- Water-year total precipitation.

- Remarks.

- Source of data.
The following tables are distributed as part of this report in Microsoft ${ }^{\circledR}$ Excel 2010 format and is available for download at http://dx.doi.org/10.3133/pp1819.

Table 2-2. Record of bulk precipitation at station on Mount Washington, southern part of the Snake Range, Great Basin National Park, White Pine County, Nevada, 1984-2011.

Table 2-3. Record of bulk precipitation at station on unnamed peak northwest of Mount Moriah, northern part of the Snake Range, White Pine County, Nevada, 1984-2011.

Table 2-4. Record of bulk precipitation at station on Cave Mountain, Schell Creek Range, White Pine County, Nevada, 1985-2011.

\section{Reports with Bulk Precipitation at Stations in Nevada}

Allander, K.K., Gortsema, G.G., Hutchinson, D.D., and Schwertzenberger, J.T., 2001, Water resources data, Nevada, water year 2001: U.S. Geological Survey Water-Data Report NV-00-1, $561 \mathrm{p}$.

Bauer, D.J., Foster, B.J., Joyner, J.D., and Swanson, R.A., 1996, Water resources data, Nevada, water year 1995: U.S. Geological Survey Water-Data Report NV-95-1, 734 p.

Berris, S.N., Crompton, E.J., Joyner, J.D., and Ryan, Roslyn, 2003, Water resources data, Nevada, water year 2002: U.S. Geological Survey Water-Data Report NV-02-1, 592 p.

Bonner, L.J., Elliott, P.E., Etchemendy, L.R., and Swartwood, J.R., 1998, Water resources data, Nevada, water year 1997: U.S. Geological Survey Water-Data Report NV-97-1, $636 \mathrm{p}$.

Bonner, L.J., Evetts, D.M., Swartwood, J.R., and Wilson, J.W., 2005, Water resources data, Nevada, water year 2004: U.S. Geological Survey Water-Data Report NV-04-1, 606 p., http://wdr.water.usgs.gov/.

Bostic, R.E., Hitch, Daniel, Van Gordon, Lloyd, and Swanson, Robert, 1991, Water resources data, Nevada, water year 1990: U.S. Geological Survey Water-Data Report NV-90-1, 358 p.

Bostic, R.E., Kane, R.L., Kipfer, K.M., and Johnson, A.W., 1997, Water resources data, Nevada, water year 1996: U.S. Geological Survey Water-Data Report NV-96-1, 611 p. 
Clary, S.L., McClary, D.R., Whitney, Rita, and Reeves, D.D., 1995, Water resources data, Nevada, water year 1994: U.S. Geological Survey Water-Data Report NV-94-1, 768 p.

Emett, D.C., Hutchinson, D.D., Jonson, N.A., and O'Hair, K.L., 1994, Water resources data, Nevada, water year 1993: U.S. Geological Survey Water-Data Report NV-93-1, $596 \mathrm{p}$.

Frisbie, J.R., La Camera, R.J., Riek, M.M., and Wood, D.B., 1984, Water resources data, Nevada, water year 1984: U.S. Geological Survey Water-Data Report NV-84-1, 247 p.

Frisbie, J.R., La Camera, R.J., Riek, M.M., and Wood, D.B., 1985, Water resources data, Nevada, water year 1985: U.S. Geological Survey Water-Data Report NV-85-1, 255 p.

Garcia, K.T., Gortsema, G.C., Pennington, R.N., and Priessler, A.M., 1992, Water resources data, Nevada, water year 1991: U.S. Geological Survey Water-Data Report NV-91-1, $481 \mathrm{p}$.

Garcia, K.T., Munson, R.H., Spauling, R.J., and Vasquez, S.L., 2002, Water resources data, Nevada, water year 2001: U.S. Geological Survey Water-Data Report NV-01-1, 562 p.

Hess, D.L., Mello, K.A., Sexton, R.J., and Young, R.L., 1992, Water resources data, Nevada, water year 1992: U.S. Geological Survey Water-Data Report NV-92-1, 511 p.

Jones, C.Z., Rowe, T.G., Sexton, R.J., and Tanko, D.J., 2000, Water resources data, Nevada, water year 2000: U.S. Geological Survey Water-Data Report NV-00-1, 600 p.
Preissler, A.M., Roach, G.A., Thomas, K.A., and Wilson, J.W., 1999, Water resources data, Nevada, water year 1998: U.S. Geological Survey Water-Data Report NV-98-1, 598 p.

Pupacko, Alex, La Camera, R.J., Riek, M.M., and Swartwood, J.R., 1986, Water resources data, Nevada, water year 1986: U.S. Geological Survey Water-Data Report NV-86-1, $263 \mathrm{p}$.

Pupacko, Alex, La Camera, R.J., Riek, M.M., and Swartwood, J.R., 1989a, Water resources data, Nevada, water year 1987: U.S. Geological Survey Water-Data Report NV-87-1, $256 \mathrm{p}$.

Pupacko, Alex, La Camera, R.J., Riek, M.M., and Swartwood, J.R., 1989b, Water resources data, Nevada, water year 1988: U.S. Geological Survey Water-Data Report NV-88-1, $271 \mathrm{p}$.

Pupacko, Alex, Van Gordon, L.G., Swartwood, J.R., and Collins, R.P., 1990, Water resources data, Nevada, water year 1989: U.S. Geological Survey Water-Data Report NV-89-1, 342 p.

Stockton, E.L., Jones, C.Z., Rowland, R.C., and Medina, R.L., 2003, Water resources data, Nevada, water year 2003: U.S. Geological Survey Water-Data Report NV-03-1, 707 p.

U.S. Geological Survey, 2006-12, Water resources data, Nevada, water years 2005-2010: U.S. Geological Survey Water-Data Reports NV-05-1 to NV-11-1 (published annually), http://wdr.water.usgs.gov/. 


\section{Appendix 3. Discharge Measurements in and near Great Basin National Park, White Pine County, Nevada, Water Years 2009-11.}

More than 200 discharge measurements, along with less frequent measurements of specific conductance and temperature, were taken among all sites in the Baker Creek, Lehman Creek, and Snake Creek drainage basins and at three sites along Big Springs Creek in and near Great Basin National Park. Measurements were taken by personnel from the National Park Service, the U.S. Geological Survey, and the University of Nevada, Reno. Because of the infrequency of these measurements, they were not compiled by water year, and no monthly averages are reported; this appendix simply lists every measurement taken at each location during water years $2009-11$.

The measurements have been compiled in six tables in this appendix. Table 3-1 includes the location and description of each discharge-measurement site.

Tables 3-2 to 3-5 lists the following information at each discharge measurement site:

- Site name following the naming convention of sites by Elliott and others (2006).

- Date.

- Time span referenced to Pacific Daylight Time.

- Discharge, in cubic feet per second.

- Discharge measurement accuracy, as defined by Sauer and Meyer (1992).

- Area of flow, in square feet.

- Width of flow, in feet.

- Specific conductance of water, in microsiemens per centimeter at 25 degrees Celsius.

- Water temperature, in degrees Celsius.

- Remarks.

- Agency that took the measurement.
The following tables are distributed as part of this report in Microsoft ${ }^{\circledR}$ Excel 2010 format and is available for download at http://dx.doi.org/10.3133/pp1819.

Table 3-2. Discharge measurements at selected sites in the Baker Creek drainage basin, Great Basin National Park, White Pine County, Nevada, water years 2009-11.

Table 3-3. Discharge measurements at selected sites in the Lehman Creek drainage basin, Great Basin National Park, White Pine County, Nevada, water years 2009-11.

Table 3-4. Discharge measurements at selected sites in the Snake Creek drainage basin, Great Basin National Park, White Pine County, Nevada, water years 2009-11.

Table 3-5. Discharge measurements at selected sites on Big Springs Creek, Great Basin National Park, White Pine County, Nevada, water years 2009-11.

\section{References Cited}

Elliott, P.E., Beck, D.A., and Prudic, D.E., 2006, Characterization of surface-water resources in the Great Basin National Park area and their susceptibility to ground-water withdrawals in adjacent valleys, White Pine County, Nevada: U.S. Geological Survey Scientific Investigations Report 2006-5099, 156 p.

Sauer, V.B., and Meyer, R.W., 1992, Determination of error in individual discharge measurements: U.S. Geological Survey Open-File Report 92-144, 21 p. 
Table 3-1. Location and description of discharge measurements at selected sites in the Baker, Lehman, and Snake Creek drainage basins, Great Basin National Park, White Pine County, Nevada, water years 2009-11.

[Site name is based on Elliott and others, 2006. Horizontal coordinate information is referenced to the North American Datum of 1983. Land-surface altitude is referenced to the North American Vertical Datum of 1988]

\begin{tabular}{|c|c|c|c|c|}
\hline \multirow{2}{*}{ Site name } & Latitude & Longitude & \multirow{2}{*}{$\begin{array}{l}\text { Land-surface } \\
\text { altitude } \\
\text { (feet) }\end{array}$} & \multirow{2}{*}{ Site description } \\
\hline & \multicolumn{2}{|c|}{ Decimal degrees } & & \\
\hline \multicolumn{5}{|r|}{ Baker Creek } \\
\hline $\mathrm{B} 2 \mathrm{~A}$ & 38.991 & 114.224 & 7,160 & At Grey Cliffs group campground 30 feet downstream of B-loop culvert \\
\hline B3 & 38.990 & 114.218 & 7,030 & In the Narrows upstream of Dynamite Cave and Sink Cave \\
\hline B5 & 39.010 & 114.207 & 6,560 & At gaging station at Great Basin National Park boundary \\
\hline B5A & 38.996 & 114.194 & 6,417 & About 400 feet upstream of Baker 4 aquifer-test site \\
\hline B5B & 38.997 & 114.191 & 6,358 & Diverted Baker Creek about 400 feet downstream of Baker 4 aquifer-test site \\
\hline B5C & 38.997 & 114.195 & 6,480 & Rosethorn spring \\
\hline B5D & 39.002 & 114.184 & 6,220 & Ditch near its confluence with diverted Baker Creek \\
\hline $\mathrm{PC} 1$ & 38.983 & 114.222 & 7,160 & At trail crossing upstream of Pioche Shale outcrop \\
\hline PC2 & 38.989 & 114.214 & 6,920 & About 50 feet upstream of confluence with Baker Creek \\
\hline \multicolumn{5}{|r|}{ Lehman Creek } \\
\hline L1 & 39.033 & 114.239 & 6,700 & At lower Lehman campground; camp site 5 \\
\hline L2 & 39.012 & 114.214 & 6,560 & About 50 feet downstream of gaging station \\
\hline L2A & 39.010 & 114.209 & 6,220 & About 100 feet downstream of main park road \\
\hline L2B & 39.010 & 114.207 & 6,560 & About 100 feet upstream of Joe's Way \\
\hline L3 & 39.009 & 114.208 & 6,580 & Rowland Spring \\
\hline L3A & 39.009 & 114.207 & 6,540 & Rowland Spring creek about 400 feet downstream of Rowland Spring \\
\hline L3B & 39.010 & 114.199 & 6,420 & Rowland Spring creek about 200 feet downstream of Sage Way \\
\hline Sn4A & 38.919 & 114.127 & 6,130 & About 1,600 feet downstream of park boundary \\
\hline Sn4B & 38.919 & 114.126 & 6,120 & About 70 feet upstream of confluence with north Gruden Spring \\
\hline $\mathrm{Sn} 4 \mathrm{C}$ & 38.919 & 114.126 & 6,115 & About 20 feet upstream of confluence with north Gruden Spring \\
\hline Sn4D & 38.919 & 114.124 & 6,110 & About 40 feet downstream of confluence with north Gruden Spring \\
\hline $\mathrm{Sn} 4 \mathrm{E}$ & 38.919 & 114.124 & 6,100 & About 400 feet downstream of confluence with north Gruden Spring \\
\hline $\mathrm{Sn} 4 \mathrm{~F}$ & 38.918 & 114.119 & 6,030 & About 50 feet upstream of culvert on Duff property \\
\hline Sn5 & 38.909 & 114.113 & 6,125 & Spring Creek Spring about 3 feet upstream of 9-inch Parshall flume \\
\hline Sn6A & 38.923 & 114.084 & 5,630 & About 360 feet upstream of Snake 5 wells \\
\hline Sn6B & 38.923 & 114.083 & 5,620 & Next to Snake 5 wells \\
\hline $\mathrm{Sn} 6 \mathrm{C}$ & 38.924 & 114.083 & 5,610 & About 390 feet downstream of Snake 5 wells \\
\hline $\operatorname{Sn} 7$ & 38.926 & 114.077 & 5,576 & At Southern Nevada Water Authority gaging station \\
\hline Sn8 & 38.926 & 114.049 & 5,350 & At Nevada-Utah state line \\
\hline \multicolumn{5}{|r|}{ Big Springs Creek } \\
\hline BS1 & 38.738 & 114.100 & 5,476 & Big Springs Creek below Big Springs Ranch near Baker, Nevada \\
\hline BS2 & 38.760 & 114.068 & 5,450 & Big Springs Creek below transmission line near Baker, Nevada \\
\hline BS3 & 38.760 & 114.071 & 5,449 & Big Springs Creek diversion below transmission line near Baker, Nevada \\
\hline
\end{tabular}




\section{Appendix 4. Daily-Mean Discharge at Temporary Gaging Stations in and near Great Basin National Park, White Pine County, Nevada, Water Years 2005-11.}

Daily mean discharges were computed for gaging stations maintained by the National Park Service on Baker Creek at Narrows (water years 2005-10), on Rowland Spring at Great Basin National Park boundary (water years 2005-10), and on Snake Creek at Great Basin National Park boundary (water years 2005-09). Additionally, the following temporary gaging stations were established and operated by the University of Nevada, Reno, at selected sites in and near the park: (1) Pole Canyon inside Great Basin National Park, where the creek crosses over Pioche Shale (June 2011-September 2011); (2) Pole Canyon near its confluence with Baker Creek (June 2011-September 2011); (3) Model Cave resurgent spring in the Narrows of Baker Creek (June 2011-September 2011); (4) Rosethorn spring in the Baker Creek drainage basin (March 2010-September 2011); and (5) Spring Creek Spring at NDOW Spring Creek fish-rearing station near Garrison, Utah (June 2009-September 2011). Daily mean discharge was estimated for each of these sites from 15-minute readings of stream stage, which was then related to discharge through rating curves, except for the gaging station on Spring Creek Spring. Stage at this site was recorded at a 9-inch (in.) Parshall Flume, and discharge was estimated from a standard rating equation. Daily mean temperatures were compiled at the five temporary gaging stations. Table $4-1$ summarizes the location and description of gaging stations operated by the National Park Service and the University of Nevada, Reno.
Tables 4-2 to 4-9 list daily mean discharge, by month and day, for each water year of record in a similar format as that used for reporting daily mean discharge at gaging stations listed in the annual water-data reports by the U.S. Geological Survey.

The following tables are distributed as part of this report in Microsoft ${ }^{\mathbb{R}}$ Excel 2010 format and is available for download at http://dx.doi.org/10.3133/pp1819.

Table 4-2. Daily mean discharge at National Park Service gaging station on Baker Creek at Narrows near Baker, Nevada (station 10243240), water years 2005-10.

Table 4-3. Daily mean discharge at National Park Service gaging station on Rowland Spring at Great Basin National Park boundary near Baker, Nevada (station 10243265), water years 2005-10.

Table 4-4. Daily mean discharge at National Park Service gaging station on Snake Creek at Great Basin National Park boundary near Baker, Nevada (station 10243232), water years 2005-09.

Table 4-5. Daily mean discharge at University of Nevada, Reno, temporary gaging station on Pole Canyon upstream of Pioche Shale outcrop near Baker, Nevada (site-identification number 385858114131901), water year 2011.

Table 4-1. Location and description of National Park Service and University of Nevada, Reno, gaging stations in the Baker, Lehman, and Snake Creek drainage basins in and near Great Basin National Park, White Pine County, Nevada, water years $2005-11$.

[A water year is defined as beginning on October 1 of the prior calendar year and ending on September 30 of the designated year. Latitude and longitude are referenced to the North American Datum of 1983. Land-surface altitude is referenced to the North American Vertical Datum of 1988. Abbreviation: mm, two digit month; dd, two digit day; yyyy, four digit year]

\begin{tabular}{|c|c|c|c|c|c|c|}
\hline \multirow[b]{2}{*}{ Site name } & \multirow{2}{*}{$\begin{array}{l}\text { U.S. Geological Survey } \\
\text { site-identification } \\
\text { number }\end{array}$} & \multirow{2}{*}{$\begin{array}{r}\text { Latitude } \\
\text { Decim }\end{array}$} & \multirow{2}{*}{$\begin{array}{l}\text { Longitude } \\
\text { degrees }\end{array}$} & \multirow{2}{*}{$\begin{array}{l}\text { Land- } \\
\text { surface } \\
\text { altitude } \\
\text { (feet) }\end{array}$} & \multicolumn{2}{|c|}{ Daily mean gaging station records } \\
\hline & & & & & Type of record & $\begin{array}{l}\text { Period of record } \\
\text { (mm/dd/yyyy) }\end{array}$ \\
\hline \multicolumn{7}{|c|}{ Gaging stations operated by National Park Service } \\
\hline Baker Creek at Narrows near Baker, Nevada & 10243240 & 38.991 & 114.207 & 6,730 & Discharge & $10 / 01 / 2005-09 / 30 / 2010$ \\
\hline $\begin{array}{l}\text { Rowland Spring at Great Basin National Park near } \\
\text { Baker, Nevada }\end{array}$ & 10243265 & 39.010 & 114.208 & 6,580 & Discharge & $10 / 01 / 2005-09 / 30 / 2010$ \\
\hline $\begin{array}{l}\text { Snake Creek at Great Basin National Park bound- } \\
\text { ary near Baker, Nevada }\end{array}$ & 10243232 & 38.919 & 114.133 & 6,190 & Discharge & $10 / 01 / 2005-09 / 30 / 2009$ \\
\hline \multicolumn{7}{|c|}{ Temporary gaging stations operated by University of Nevada, Reno } \\
\hline $\begin{array}{l}\text { Pole Canyon at trail crossing upstream of Pioche } \\
\text { Shale near Baker, Nevada }\end{array}$ & 385858114131901 & 38.983 & 114.222 & 7,160 & $\begin{array}{l}\text { Discharge and } \\
\text { temperature }\end{array}$ & $06 / 01 / 2011-09 / 30 / 2011$ \\
\hline $\begin{array}{l}\text { Pole Canyon near confluence with Baker Creek } \\
\text { near Baker, Nevada }\end{array}$ & 385922114125101 & 38.989 & 114.214 & 6,920 & $\begin{array}{l}\text { Discharge and } \\
\text { temperature }\end{array}$ & $06 / 01 / 2011-09 / 30 / 2011$ \\
\hline $\begin{array}{l}\text { Model Cave resurgent spring in Baker Creek } \\
\text { drainage basin near Baker, Nevada }\end{array}$ & 385922114123701 & 38.989 & 114.210 & 6,820 & $\begin{array}{l}\text { Discharge and } \\
\text { temperature }\end{array}$ & $06 / 01 / 2011-09 / 30 / 2011$ \\
\hline $\begin{array}{l}\text { Rosethorn spring in Baker Creek drainage basin } \\
\text { near Baker, Nevada }\end{array}$ & 385948114114401 & 38.997 & 114.196 & 6,460 & $\begin{array}{l}\text { Discharge and } \\
\text { temperature }\end{array}$ & $03 / 25 / 2010-09 / 30 / 2011$ \\
\hline $\begin{array}{l}\text { Spring Creek Spring at Nevada Department of } \\
\text { Wildlife fish-rearing station near Garrison, Utah }\end{array}$ & 385433114064501 & 38.909 & 114.113 & 6,125 & $\begin{array}{l}\text { Discharge and } \\
\text { temperature }\end{array}$ & 06/24/2009-09/30/2011 \\
\hline
\end{tabular}


Table 4-6. Daily mean discharge at University of Nevada, Reno, temporary gaging station on Pole Canyon near confluence with Baker Creek near Baker, Nevada (site-identification number 3859221141251), water year 2011.

Table 4-7. Daily mean discharge at University of Nevada, Reno, temporary gaging station on Model Cave resurgent spring near Baker, Nevada (site-identification number 385922114123701), water year 2011.

Table 4-8. Daily mean discharge at University of Nevada, Reno temporary gaging station on Rosethorn spring near Baker, Nevada (site-identification number 385948114114401), water years 2010-11.

Table 4-9. Daily mean discharge at University of Nevada, Reno, temporary gaging station on Spring Creek Spring, Nevada Department of Wildlife Spring Creek fish-rearing station, near Garrison, Utah (site-identification number 385434114063901), water years 2009-11.

Daily mean temperatures at temporary gaging stations at the two sites on Pole Canyon, the site on Model Cave resurgent spring, and the site on Rosethorn spring in the Baker Creek drainage basin and Spring Creek Spring in the Snake Creek drainage basin are listed in tables 4-10 to 4-14. These tables list daily mean temperature, by month and day, for each water year of record in a similar format as that used for reporting daily mean temperature at gaging stations listed in the annual water-data reports by the U.S. Geological Survey.
Table 4-10. Daily mean water temperature at University of Nevada, Reno, temporary gaging station on Pole Canyon upstream of Pioche Shale outcrop near Baker, Nevada (site-identification number 385858114131901), water year 2011.

Table 4-11. Daily mean water temperature at University of Nevada, Reno, temporary gaging station on Pole Canyon near confluence with Baker Creek near Baker, Nevada (siteidentification number 3859221141251), water year 2011.

Table 4-12. Daily mean water temperature at University of Nevada, Reno, temporary gaging station on Model Cave resurgent spring near Baker, Nevada (site-identification number 385922114123701), water year 2011.

Table 4-13. Daily mean water temperature at University of Nevada, Reno, temporary gaging station on Rosethorn spring near Baker, Nevada (site-identification number 385948114114401 ), water years 2010-11.

Table 4-14. Daily mean temperature at University of Nevada, Reno, temporary gaging station on Spring Creek Spring, Nevada Department of Wildlife Spring Creek fish-rearing station, near Garrison, Utah (site-identification 385434114063901$)$, water years 2009-11. 


\section{Appendix 5. Daily Mean Water Level and Temperature in Monitoring Wells at Baker 4 Aquifer-Test Site and Stage in Baker Creek, near Great Basin National Park, White Pine County, Nevada, Water Years 2009-11.}

Three holes were drilled at the Baker 4 aquifer-test site along Baker Creek about 0.8 miles (mi) east of the Great Basin National Park boundary along a four-wheel drive trail during September 9-18, 2009. The Baker 4 aquifer-test site consisted of a 6-inch (in.) diameter monitoring well that was drilled about 54 feet (ft) north of Baker Creek to a depth of $40.7 \mathrm{ft}$ below land surface and two dual-completion 2-in. monitoring wells that were drilled near the edge of Baker Creek at an upstream and downstream location. These wells were constructed as part of an aquifer test designed to characterize the hydraulic connection between the groundwater and surface water along Baker Creek by estimating the streambed and underlying aquifer hydraulic properties for a $1,200-\mathrm{ft}$ stream section. Additionally, these wells provided seasonal trends in groundwater levels near Baker Creek from October 2009 through September 2011.

Water levels and temperatures in the monitoring wells and in Baker Creek were monitored hourly by using absolute pressure transducers (Schlumberger mini-diver, $h t t p: / / w w w$. swstechnology.com/groundwater-monitoring/groundwaterdataloggers/mini-diver accessed September 18, 2012), except during 4 weeks that began with a 94-hour aquifer test on October 9, 2009, when water levels were monitored every 5 minutes. Daily mean water levels and temperatures from when the pressure transducers were installed to September 2011 are listed in 12 tables (tables 5-1 to 5-12).

The following tables are distributed as part of this report in Microsoft ${ }^{\circledR}$ Excel 2010 format and is available for download at http://dx.doi.org/10.3133/pp1819.

Table 5-1. Daily mean depth to water in 6-inch diameter monitoring well at Baker 4 aquifer-test site next to Baker Creek near Baker, Nevada (site-identification number 385947114113201), water years 2009-11.

Table 5-2. Daily mean depth to water in shallow monitoring well at Baker 4 aquifer-test site about 37 feet southeast of 6 -inch well next to Baker Creek near Baker, Nevada (site-identification number 385947114113202), water years 2009-11.

Table 5-3. Daily mean depth to water in deeper monitoring well at Baker 4 aquifer-test site about 37 feet southeast of 6 -inch well next to Baker Creek near Baker, Nevada (site-identification number 385947114113203), water years 2009-11.

Table 5-4. Daily mean depth to water in shallow monitoring well at Baker 4 aquifer-test site about 50 feet south of 6 -inch well next to Baker Creek near Baker, Nevada (site-identification number 385947114113204), water years 2009-11.
Table 5-5. Daily mean depth to water in deeper monitoring well at Baker 4 aquifer-test site about 50 feet south of 6 -inch well next to Baker Creek near Baker, Nevada (site-identification number 385947114113205), water years 2009-11.

Table 5-6. Daily mean stage in Baker Creek at site 2 near upstream monitoring wells at Baker 4 aquifer-test site (siteidentification number 385946114113301), water years 2009-11.

Table 5-7. Daily mean water temperature in 6-inch diameter monitoring well at Baker 4 aquifer-test site next to Baker Creek near Baker, Nevada (site-identification number 385947114113201), water years 2009-11.

Table 5-8. Daily mean water temperature in shallow monitoring well at Baker 4 aquifer-test site about 37 feet southeast of 6 -inch well next to Baker Creek near Baker, Nevada (site-identification number 385947114113202), water years 2009-11.

Table 5-9. Daily mean water temperature in deeper monitoring well at Baker 4 aquifer-test site about 37 feet southeast of 6 -inch well next to Baker Creek near Baker, Nevada (site-identification number 385947114113203), water years 2009-11.

Table 5-10. Daily mean water temperature in shallow monitoring well at Baker 4 aquifer-test site about 50 feet south of 6 -inch well next to Baker Creek near Baker, Nevada (site-identification number 385947114113204), water years 2009-11.

Table 5-11. Daily mean water temperature in deeper monitoring well at Baker 4 aquifer-test site about 50 feet south of 6 -inch well next to Baker Creek near Baker, Nevada (site-identification number 385947114113205), water years 2009-11.

Table 5-12. Daily mean temperature in Baker Creek at site 2 near upstream monitoring wells at Baker 4 aquifer-test site (siteidentification number 385946114113301), water years 2009-11.

The six tables reporting water levels list daily mean water levels, by month and day, for each water year of record in a similar format as that used for reporting daily mean water levels in wells listed in the annual water-data reports by the U.S. Geological Survey; the six tables reporting temperature list daily mean temperatures, by month and day, for each water year of record in a similar format as that used for reporting daily mean temperatures in wells listed in the annual waterdata reports by the U.S. Geological Survey. 


\section{Appendix 6. Daily Mean Water Levels in the Shallow and Deep Wells at Snake 5, near Great Basin National Park, White Pine County, Nevada, Water Years 2010-11.}

The Snake 5 wells included a deep well, screened from a depth of 289.5-309.5 feet (ft) below land surface (bls), and a shallow well, screened from 30-35 ft bls. Daily mean water levels and temperatures were computed by using hourly measurements from absolute pressure transducers in both wells. An absolute pressure transducer was placed in the deep well on January 18,2010 . The pressure transducer was capable of monitoring a water-level change as great as $40 \mathrm{ft}$, but during June and July 2010, the water level rose more than $40 \mathrm{ft}$ and over-pressured the transducer. Subsequently, the transducer was replaced in June 2011 with one that had a range of $165 \mathrm{ft}$, and a shallower transducer was added to ensure a complete hydrograph of the well. Also, in June 2011, a temperature logger was placed at a depth of $300 \mathrm{ft}$, near the middle of the screened interval. No water was detected in the shallow well until June 1, 2011, when water was measured, but was below the bottom of the screen. A pressure transducer was added to this well and recorded a water-level rise of about $15 \mathrm{ft}$ between June 1 and June 25, 2011. The water level dropped below the bottom of the screen on July 4, 2011, and remained below the bottom of the screen through June 2012. Recorded water levels from the pressure transducers were within a few hundredths of a foot compared with measurements taken with a calibrated tape.
Tables 6-1 and 6-2 list daily mean water levels, by month and day, for each water year of record in a similar format as that used for reporting daily mean water levels in wells listed in the annual water-data reports by the U.S. Geological Survey. No water temperature data are given for the Snake 5 wells because water temperature in the deep well from a temperature logger next to the well screen was consistently 10.9 degrees Celsius between June 2011 and June 2012, and the shallow well only briefly had water above the bottom of the screen.

The following tables are distributed as part of this report in Microsoft ${ }^{\circledR}$ Excel 2010 format and is available for download at http://dx.doi.org/10.3133/pp1819.

Table 6-1. Daily mean depth to water in Snake 5 shallow well next to Snake Creek near Garrison, Utah (site-identification number 385524114045602), water years 2010-11.

Table 6-2. Daily mean depth to water in Snake 5 deep well next to Snake Creek near Garrison, Utah (site-identification number 385524114045601), water years 2010-11. 


\section{Appendix 7. Daily Mean Depth to Water in Wells Northwest and Southwest of Big Springs, Southern Part of Snake Valley, White Pine County, Nevada, Water Years 2010-12.}

The Big Springs northwest (BS-NW) and Big Springs southwest (BS-SW) wells are at the south end of the Snake Range in southwestern Snake Valley in White Pine County, Nevada. Daily mean water levels measured in the two wells were compiled from water levels recorded hourly, except during aquifer tests of the wells, when water levels were recorded at 1-minute intervals. Mean, maximum, and minimum water levels were computed on a monthly basis from the daily means. The data logger for the BS-SW failed in early July 2011; consequently, no water-level data are reported for that well after June 30, 2011. Recorded water levels at the wells were within a few hundredths of a foot compared with water levels periodically measured by hand using a calibrated tape. The data for these two wells are compiled in two tables (tables $7-1$ and 7-2). The two tables list daily mean water level, by month and day, for each water year of record in a similar format to that used for reporting daily mean water levels of wells listed in the annual water-data reports by the U.S. Geological Survey.
The following tables are distributed as part of this report in Microsoft ${ }^{\circledR}$ Excel 2010 format and is available for download at http://dx.doi.org/10.3133/pp1819.

Table 7-1. Daily mean depth to water in northwest Big Springs well before, during, and after 48-hour aquifer test at well (siteidentification number 384227114082701), south end of Snake Valley, White Pine County, Nevada, water years 2010-12.

Table 7-2. Daily mean depth to water in southwest Big Springs well before, during and after 48-hour aquifer test at well (siteidentification number 384112114091101), south end of Snake Valley, White Pine County, Nevada, water years 2010-11. 


\section{Appendix 8. Baker Creek Stage, Groundwater Levels, Water Temperatures, and Pumping Rates Measured before, during, and after a 92-Hour Aquifer Test at Baker 4 Aquifer-Test Site, near Great Basin National Park, White Pine County, Nevada, October 2009.}

The 6-inch (in.) diameter well at the Baker 4 aquifer-test site was pumped at an average rate of 26 gallons per minute (gal/min) for 94 hours starting October 7, 2009, at 14:39 and ending October 11, 2009, at 12:31. The 6-in. diameter well was drilled to a depth of 40.7 feet (ft) below land surface about $54 \mathrm{ft}$ north of Baker Creek and screened from 20-40 ft below land surface. One 8 -in. diameter hole was drilled near the edge of Baker Creek both upstream and downstream of the 6-in. well. The upstream hole was drilled $50 \mathrm{ft}$ south of the 6-in. diameter well and next to the creek. The downstream hole was drilled about $37 \mathrm{ft}$ southeast of the 6-in. diameter well and was $25 \mathrm{ft}$ downstream from the upstream hole. Both the upstream and downstream holes were completed with two 2 -in. diameter schedule 80 polyvinyl chloride (PVC) wells in the deep and shallow parts of each hole.

Water levels and temperature were recorded in the 6-in. diameter monitoring well, in the four nearby 2 -in. diameter PVC wells, and at four selected sites along Baker Creek.

Pressure transducers measured water levels simultaneously at 3-minute intervals between September 12, 2009, and November 1, 2009, a period that spanned from 2 weeks before the test to 2 weeks after the test. The measurement interval was increased to hourly in the months following the aquifer test. A report describing the configuration of the monitoring wells, the aquifer test, and results is available online:
http://nevada.usgs.gov/water/AquiferTests/snake_valley_baker. cfm? studyname=snake_valley_baker.

Data collected at the Baker 4 aquifer-test site are compiled in seven tables (tables $8-1$ to $8-7$ ). Table $8-1$ lists the name and locations of the monitoring wells used in the aquifer tests and the name and locations of four temporary gaging stations on Baker Creek upstream and downstream of the aquifer-test site.

Table-8-2 summarizes data collected at the pumped well before, during, and after a 94-hour aquifer test. The listed data were selected from temperature and water-level data collected every three minutes. The table lists the following information:

- Date and time.

- Temperature.

- Depth to water.

- Time since pumping began.

- Drawdown.

- Total gallons pumped.

- Pumping rate.

- Remarks.

Table 8-1. Names and locations of monitoring wells at Baker Creek 4 aquifer-test site and temporary gaging stations in Baker Creek near Great Basin National Park, White Pine County, Nevada.

[U.S. Geological Survey site-identification number can be used to obtain data from the National Water Information database. Latitude and longitude are referenced to North American Datum of 1983. Altitude is referenced to North American Vertical Datum of 1988. Altitude is at land surface for wells and at pressure transducer for temporary gaging stations on Baker Creek. Temporary gaging stations numbered from upstream to downstream. Symbol: -, not applicable]

\begin{tabular}{|c|c|c|c|c|c|c|c|}
\hline \multirow[b]{2}{*}{ Site name } & \multirow{2}{*}{$\begin{array}{c}\text { U.S. Geological Survey site- } \\
\text { identification } \\
\text { number }\end{array}$} & Latitude & Longitude & \multirow{2}{*}{$\begin{array}{c}\text { Altitude } \\
\text { (feet) }\end{array}$} & \multirow{2}{*}{$\begin{array}{c}\text { Well } \\
\text { diam- } \\
\text { eter, nominal } \\
\text { (inches) }\end{array}$} & \multicolumn{2}{|c|}{ Depth below land surface (feet) } \\
\hline & & \multicolumn{2}{|c|}{ Decimal degrees } & & & Well bottom & Top of screen \\
\hline \multicolumn{8}{|c|}{ Well next to Baker Creek } \\
\hline Six-inch pump well & 385947114113201 & 38.9964 & 114.1922 & $6,384.51$ & 6 & 40.7 & 20.2 \\
\hline Downstream shallow & 385947114113202 & 38.9963 & 114.1921 & $6,383.30$ & 2 & 18.2 & 13.0 \\
\hline Downstream deep & 385947114113203 & 38.9963 & 114.1921 & $6,383.30$ & 2 & 35.1 & 29.7 \\
\hline Upstream shallow & 385947114113204 & 38.9962 & 114.1922 & $6,382.56$ & 2 & 20.6 & 15.2 \\
\hline Upstream deep & 385947114113205 & 38.9962 & 114.1922 & $6,358.02$ & 2 & 60.5 & 50.2 \\
\hline \multicolumn{8}{|c|}{ Temporary gaging station on Baker Creek } \\
\hline Baker Creek 1 & - & 38.9956 & 114.1939 & $6,417.15$ & - & - & - \\
\hline Baker Creek 2 & - & 38.9961 & 114.1924 & $6,382.33$ & - & - & - \\
\hline Baker Creek 3 & - & 38.9962 & 114.1920 & $6,376.52$ & - & - & - \\
\hline Baker Creek 4 & - & 38.9971 & 114.1913 & $6,358.02$ & - & - & - \\
\hline
\end{tabular}


The following tables are distributed as part of this report in Microsoft ${ }^{\circledR}$ Excel 2010 format and is available for download at http://dx.doi.org/10.3133/pp1819.

Table 8-2. Temperature, depth to water, drawdown, and pumping rate in 6-inch diameter well at Baker 4 aquifer-test site (site-identification number 385947114113201), October 2009.

Tables 8-3 to 8-6 summarize data collected at the four nearby monitoring wells before, during, and after a 94-hours aquifer test. These data were selected from temperature and water-level data collected every 3 minutes. The tables list the following information for each of the four monitoring wells:

- Date and time.

- Temperature.

- Depth to water.

- Time since pumping began.

- Drawdown.

Table 8-3. Temperature, depth to water, and drawdown in shallow 2-inch monitoring well about 37 feet southeast (downstream) of pumped well at Baker 4 aquifer-test site (siteidentification number 385947114113202), October 2009.

Table 8-4. Temperature, depth to water, and drawdown in deeper 2-inch monitoring well about 37 feet southeast (downstream) of pumped well at Baker 4 aquifer-test site (siteidentification number 385947114113203), October 2009.

Table 8-5. Temperature, depth to water, and drawdown in shallow 2-inch monitoring well about 50 feet south (upstream) of pumped well at Baker 4 aquifer-test site (site-identification number 385947114113204), October 2009.

Table 8-6. Temperature, depth to water, and drawdown in deeper 2-inch monitoring well about 50 feet south (upstream) of 6 -inch pumped well at Baker 4 aquifer-test site (site-identification number 385947114113205), October 2009

Hourly means of temperature and stage measured by the four pressure transducers in Baker Creek are listed in table 8-7. Data from the four pressure transducers in Baker Creek were collected between noon on September 5, 2009, and noon on October 24, 2009. Table 8-7 lists the following information for each of the four pressure transducers:

- Date and time.

- Temperature.

- Stage above the pressure transducer.

Table 8-7. Hourly mean temperature and stage for pressure transducers in Baker Creek near Baker 4 aquifer-test site, October 2009. 


\section{Appendix 9. Temperature, Depth to Water, and Drawdown in Nevada Department of Wildlife Well next to Snake Creek during and following a 5-Hour Aquifer Test on June 23, 2009, White Pine County, Nevada.}

A single-well aquifer test was done in the Snake Creek drainage basin, east of Great Basin National Park, utilizing a preexisting Nevada Department of Wildlife (NDOW) well next to Snake Creek at the Spring Creek fish-rearing station. The NDOW well was pumped for 5 hours at 17 gallons per minute on June 23, 2009. During the test, water levels were measured at 3-minute intervals with a pressure transducer and periodically measured with an electric tape. A report discussing test results is available online:

http://nevada.usgs.gov/water/AquiferTests/snake_valley_ndow. cfm?studyname=snake_valley_ndow.

The data from this test are compiled in table 9-1, which lists the following information:

- Time.

- Temperature.

- Depth to water below land surface.

- Time since pumping began.

- Drawdown.

- Remarks.
Table 9-1. Temperature, depth to water, and drawdown in Nevada Department of Wildlife well next to Snake Creek during and following 5-hour aquifer test on June 23, and June 24, 2009, Spring Creek fish-rearing station, White Pine County, Nevada.

This table is distributed as part of this report in Microsoft ${ }^{\circledR}$ Excel 2010 format and is available for download at http://dx.doi.org/10.3133/pp1819. 


\section{Appendix 10. Depth to Water and Drawdown in Northwest and Southwest Big Springs Well before, during, and after Aquifer Tests, South End of Snake Valley, White Pine County, Nevada, October and November 2010.}

The Big Springs northwest well (BS-NW) was pumped for 42 hours at 260 gallons per minute between 12:19 on October 4,2010 , and $06: 35$ on October 6, 2010. The pumping rate was determined by using a totalizing flow meter. Starting water level was 227.53 feet (ft) below land surface. Water levels were recorded every minute by using a pressure transducer. The well is about three quarters of a mile northwest of Big Springs on an alluvial fan between the Snake Range and Snake Valley in White Pine County, Nevada, and is identified by the U.S. Geological Survey site-identification number 384227114082701 . Its altitude is $5,815.18 \mathrm{ft}$ above the North American Vertical Datum of 1988. The well is $460 \mathrm{ft}$ deep and perforated from 360 to $400 \mathrm{ft}$. The aquifer consists of sand, gravel, and cobbles.

The Big Springs southwest well (BS-SW) was pumped for 47.25 hours at 170 gallons per minute between 14:28 on November 2, 2010, and 13:48 on November 4, 2010. The pumping rate was determined by using a totalizing flow meter. The starting water level was 355.55 feet (ft) below land surface. Water levels were recorded every minute by using a pressure transducer. The well is about 1.5 miles southwest of Big Springs and was completed in carbonate rocks of Devonian age at the south end of the Snake Range in White Pine County, Nevada. The U.S. Geological Survey site-identification number is 384112114091101 , and its altitude is $6,019.53 \mathrm{ft}$ above the North American Vertical Datum of 1988 (NAVD88). The well is $700 \mathrm{ft}$ deep and perforated from 500 to $700 \mathrm{ft}$.
Water levels were monitored a couple of weeks prior to each aquifer test and a few weeks after pumping ceased. A report discussing test results at BS-NW is available online: http://nevada.usgs.gov/water/AquiferTests/snake_valley_bsnw.cfm?studyname $=$ snake_valley_bsnw. A report discussing test results at BS-SW is available online: $h t t p: / /$ nevada.usgs.gov/water/AquiferTests/snake_valley_bssw. cfm? studyname $=$ snake_valley_bssw.

The data from each test have been compiled in tables 10-1 and 10-2, which list the following information:

- Date and time.

- Depth to water below land surface.

- Time since pumping began.

- Drawdown.

- Remarks.

The following tables are distributed as part of this report in Microsoft ${ }^{\circledR}$ Excel 2010 format and is available for download at http://dx.doi.org/10.3133/pp1819.

Table 10-1. Depth to water and drawdown in northwest Big Springs well before, during, and after 42-hour aquifer test at well (site-identification number 384227114082701), south end of Snake Valley, White Pine County, Nevada, October 4-10, 2010.

Table 10-2. Depth to water and drawdown in southwest Big Springs well before, during, and after 47.25 -hour aquifer test at well (site-identification number 384112114091101 ), south end of Snake Valley, White Pine County, Nevada, November 2-4, 2010. 


\section{Appendix 11. Slug-Test Data at Snake 5 Deep Well, Southern Part of Snake Range, White Pine County, Nevada, June 2011.}

Three slug tests were done in the Snake 5 deep well on June 3, 2011, by using an air injection method (Greene and Shapiro, 1995). Results of the slug tests are available online: http://nevada.usgs.gov/water/AquiferTests/Snake5. cfm? studyname $=$ Snake5. Air was injected into a sealed well to a gaged pressure of 120 inches of water (10 feet of water). Two absolute pressure transducers were installed inside the sealed well. One was 20 feet below the water level in the well and had a 30 foot range in pressure above atmospheric, and the other was in air near the top of the well and had a 3 foot range in pressure above atmospheric. Both pressure transducer were set to read absolute pressure every 0.5 second, and an average offset between the two pressure transducers was determined by setting them next to each other before and after the tests. In the two subsequent tests, the well was pressurized to a gage pressure of 240 inches of water or 20 feet of water. The latter two tests over pressured the transducer in the air, however, so the maximum displacement and the first data collected after air was released from the well were inaccurate because of the time needed for air to return back to atmospheric pressure. The maximum displacement for the last two tests was estimated at 20 feet, equal to the gaged pressure while injecting air into the well.

Data from the three slug tests (one table per test) are in tables 11-1, 11-2, and 11-3, which include the following information:

- Date and time.

- Absolute pressure of water plus air above pressure transducer in water.

- Absolute pressure of air near top of well.

- Average air offset between pressure transducers.

- Water head above transducer.

- Time since maximum water displacement.

- Head displacement.

- Ratio of head displacement to maximum head displacement.

- Remarks.
The following tables are distributed as part of this report in Microsoft ${ }^{\circledR}$ Excel 2010 format and is available for download at http://dx.doi.org/10.3133/pp1819.

Table 11-1. Slug-test data for test 1 at Snake 5 deep well on June 1, 2011, Great Basin National Park, White Pine County, Nevada.

Table 11-2. Slug-test data for test 2 at Snake 5 deep well on June 1, 2011, Great Basin National Park, White Pine County, Nevada.

Table 11-3. Slug-test data for test 3 at Snake 5 deep well on June 1, 2011, Great Basin National Park, White Pine County, Nevada.

\section{References Cited}

Greene, E.A. and Shapiro, A.M., 1995, Methods of conducting air-pressurized slug tests and computation of type curves for estimating transmissivity and storage: U.S. Geological Survey Open-File Report 95-424, 43 p. 


\section{Appendix 12. Depth to Groundwater in Southern Spring Valley MX Wells and Pumping Rates before, during, and after a Step-Drawdown and Two Constant- Rate Tests, South End of Spring Valley, Lincoln County, Nevada, September 1980.}

A step-drawdown test and two constant-rate tests were done in September 1980 to determine the hydraulic properties of the basin-fill deposits in southern Spring Valley, Lincoln County, Nevada, as part of the U.S. Air Force's MX missile-siting investigation in eastern Nevada and western Utah. The 10-inch (in.) test well was pumped for 120 hours at 600 gallons per minute and had 16 feet (ft) of drawdown during the second constant-rate test. A 2-in. diameter observation well is $1,020 \mathrm{ft}$ north and west of the 10 -in. well (Tumbusch and Schaefer, 1996). Detailed lithologic logs of the pumped and observation well indicated sand was the aquifer material.

The test data included a step drawdown test, an aborted constant-rate test (the pump ran out of gasoline during the night), and a second constant-rate test that lasted 120 hours. The pumping rate was not constant because the drawdown in the pumped well rose $1 \mathrm{ft}$ between measurements and then slowly declined during the rest of the test. The observation well showed the same drawdown pattern, but it had a time lag.

The data for the wells at this site are in three tables (tables $12-1$ to $12-3$ ).
The following tables are distributed as part of this report in Microsoft ${ }^{\circledR}$ Excel 2010 format and is available for download at http://dx.doi.org/10.3133/pp1819.

Table 12-2. Depth to water and drawdown in the 10-inch diameter pumped well before, during, and after one stepdrawdown and two constant-rate aquifer tests as part of U.S. Air Force MX missile-siting investigation (site-identification number 383704114225001), south end of Spring Valley, White Pine County, Nevada, September 1-21, 1980.

Table 12-3. Depth to water and drawdown in the 2-inch diameter observation well before, during, and after the two constant-rate aquifer tests as part of U.S. Air Force Missile siting program (site-identification number 385947114113203 ), south end of Spring Valley, White Pine County, Nevada, September 10-21, 1980

\section{References Cited}

Tumbusch, M.L., and Schaefer, D.H., 1996, Selected hydrologic data for and location of MX wells in east-central and southern Nevada, January 1980 through May 1996: U.S. Geological Survey Open-File Report 96-469, 37 p.

Table 12-1. Site-identification number, location, well diameter, casing depth, and depth to top and bottom of screened interval of pumped and observation wells in southern Spring Valley used for aquifer tests as part of U.S. Air Force MX missile-siting investigation, White Pine County, Nevada, September 1-21, 1980.

[Latitude and longitude are referenced to North American Datum of 1983. Land-surface altitude is referenced to North American Vertical Datum of 1988 . Wells drilled August 1980 for U.S. Air Force MX missile-siting investigation. Aquifer-test data obtained from U.S. Geological Survey, Carson City, Nevada, April 2012. Land-surface altitude for 10-inch diameter well obtained from Southern Nevada Water Authority, Document Number WRD-ED-0014, March 2012, p. A-3. Altitude for 2-inch well from 10-meter Digital Elevation Model (DEM) data determined by Toby Welborn, U.S. Geological Survey, Carson City, Nevada, April 2012, written communication]

\begin{tabular}{|c|c|c|c|c|c|c|c|c|}
\hline \multirow{2}{*}{$\begin{array}{l}\text { U.S. Geological Survey } \\
\text { local well name }\end{array}$} & \multirow{2}{*}{$\begin{array}{c}\text { U.S. Geological Survey site- } \\
\text { identification } \\
\text { number }\end{array}$} & Latitude & Longitude & \multirow{2}{*}{$\begin{array}{l}\text { Land- } \\
\text { surface } \\
\text { altitude } \\
\text { (feet) }\end{array}$} & \multirow{2}{*}{$\begin{array}{c}\text { Well } \\
\text { diameter, } \\
\text { nominal } \\
\text { (inches) }\end{array}$} & \multirow{2}{*}{$\begin{array}{l}\text { Casing depth } \\
\text { below land } \\
\text { surface } \\
\text { (feet) }\end{array}$} & \multicolumn{2}{|c|}{$\begin{array}{l}\text { Depth below land } \\
\text { surface (feet) }\end{array}$} \\
\hline & & Dec & rees & & & & $\begin{array}{l}\text { Well bot- } \\
\text { tom }\end{array}$ & $\begin{array}{l}\text { Top of } \\
\text { screen }\end{array}$ \\
\hline 184 N09 E68 30AAAB1 & 383704114225001 & 38.6177 & 114.3841 & $6,000.52$ & 10 & 699 & 679 & 559 \\
\hline 185 N09 E68 30AB3 & 385947114113203 & 38.6186 & 114.3867 & 6,016 & 2 & 700 & 700 & 553 \\
\hline
\end{tabular}




\section{Appendix 13. Description of Piezometer Installation, Stream Stage, and Water Levels in Shallow Piezometers and Hydraulic Gradients at Selected Sites on Baker, Lehman, and Snake Creeks, near Great Basin National Park, White Pine County, Nevada.}

Shallow piezometers were hand driven into the streambed of Baker, Lehman, and Snake Creeks at selected locations. All but one of the piezometers were driven into the streambed outside of Great Basin National Park. The piezometers were made of a nominal 1.25-inch (in.) diameter, 1-foot (ft) long, stainless-steel pipe. Approximately 0.25 -in. diameter holes were drilled every 0.75 in. over a 6 -in. interval and were wrapped with 0.01 -in. stainless-steel gauze covered with 0.05 -in. stainless-steel mesh. The end of the pipe was threaded onto a hardened-steel point. A coupling was used to attach a 5 - $\mathrm{ft}$ long piece of 1.254-in. diameter galvanized pipe threaded at both ends, except for two piezometers for which nominal 1.254-in. diameter schedule 80 polyvinyl chloride (PVC) was used. A drive cap was screwed onto the top of the galvanized pipe, and either a 25-pound (lb) or 50-lb fence-post driver was used to pound the well point and pipe 2-3 ft into the streambed. Piezometers with schedule 80 PVC pipe were driven into the streambed by placing a piece of nominal 0.75 -in. diameter pipe into the piezometer that protruded from the top of the $\mathrm{PVC}$ pipe and then pounding the piezometer by using either the $25-1 \mathrm{~b}$ or $50-1 \mathrm{~b}$ fence-post driver.

A total of 12 piezometers were driven into the streambed of Snake Creek from Great Basin National Park boundary to the Nevada-Utah state line (table 13-1). Additional

Table 13-1. Location, land-surface altitude, depths, screen length, and dates of installation and removal of piezometers driven into the streambed or near streambed of Baker, Lehman, and Snake Creeks, Great Basin National Park, White Pine County, Nevada.

[Numbers following piezometer name are distances in miles downstream of gaging station at or near park boundary. Latitude and longitude are referenced to North American Datum of 1983. Land-surface altitude is referenced to North American Vertical Datum of 1988. Hydrogeological zones: karst, karst-limestone zone; upper, upper-piedmont zone; lower, lowerpiedmont zone. All piezometers used nominal 1-1/4-inch pipe. Piezometers PS4sb1 and PS4sb2 were driven into ground 14 and 45 feet south of piezometer PS4, respectively. Depth below streambed to screen midpoint corrected for pipe angle. Abbreviation: PVC, polyvinyl chloride; mm, two digit month; dd, two digit day; yyyy; four digit year]

\begin{tabular}{|c|c|c|c|c|c|c|c|c|c|c|}
\hline \multirow{2}{*}{$\begin{array}{l}\text { Streambed } \\
\text { piezometer }\end{array}$} & \multirow{2}{*}{$\begin{array}{l}\text { Latitude } \\
\text { Decim }\end{array}$} & \multirow{2}{*}{$\begin{array}{l}\text { Longitude } \\
\text { legrees }\end{array}$} & \multirow{2}{*}{$\begin{array}{l}\text { Land- } \\
\text { surface } \\
\text { altitude } \\
\text { (feet) }\end{array}$} & \multirow{2}{*}{$\begin{array}{l}\text { Hydro- } \\
\text { geologic } \\
\text { zones }\end{array}$} & \multirow{2}{*}{$\begin{array}{c}\text { Type of pipe } \\
\text { above well } \\
\text { point }\end{array}$} & \multirow{2}{*}{$\begin{array}{l}\text { Total inside } \\
\text { length } \\
\text { (feet) }\end{array}$} & \multirow{2}{*}{$\begin{array}{l}\text { Depth below } \\
\text { streambed } \\
\text { to screen } \\
\text { midpoint } \\
\text { (feet) }\end{array}$} & \multirow{2}{*}{$\begin{array}{l}\text { Screen } \\
\text { length } \\
\text { (feet) }\end{array}$} & \multicolumn{2}{|c|}{ Date (mm/dd/yyyy) } \\
\hline & & & & & & & & & Installed & Removed \\
\hline \multicolumn{11}{|c|}{ Baker Creek } \\
\hline PB2-1.48 & 39.002 & 114.184 & 6,220 & Upper & Steel & 6.3 & 2.66 & 0.59 & $07 / 16 / 2009$ & $11 / 04 / 2010$ \\
\hline PB1-2.29 & 39.008 & 114.172 & 5,970 & Upper & Steel & 6.2 & 1.45 & 0.53 & $07 / 15 / 2009$ & $11 / 04 / 2010$ \\
\hline \multicolumn{11}{|c|}{ Lehman Creek } \\
\hline PL1-0 & 39.012 & 114.214 & 6,700 & Karst & Steel & 6.4 & 1.96 & 0.56 & $05 / 29 / 2009$ & $11 / 04 / 2010$ \\
\hline PL4-0.44 & 39.010 & 114.207 & 6,560 & Karst & Steel & 6.2 & 2.05 & 0.54 & $07 / 16 / 2009$ & $11 / 04 / 2010$ \\
\hline PL3-1.60 & 39.010 & 114.187 & 6,220 & Upper & Steel & 6.3 & 2.83 & 0.66 & $07 / 16 / 2009$ & $11 / 04 / 2010$ \\
\hline PL2-2.42 & 39.008 & 114.172 & 5,970 & Upper & Steel & 6.3 & 2.42 & 0.58 & $07 / 15 / 2009$ & $11 / 04 / 2010$ \\
\hline \multicolumn{11}{|c|}{ Snake Creek } \\
\hline PS1-0.26 & 38.919 & 114.128 & 6,160 & Karst & PVC & 6.2 & 1.80 & 0.51 & 05/27/2009 & $11 / 03 / 2010$ \\
\hline PS11-0.39 & 38.919 & 114.126 & 6,110 & Karst & Steel & 6.3 & 3.51 & 0.54 & 07/19/2009 & $11 / 03 / 2010$ \\
\hline PS2-0.50 & 38.919 & 114.123 & 6,090 & Upper & PVC & 6.2 & 2.21 & 0.56 & 05/29/2009 & not removed \\
\hline PS12-0.71 & 38.918 & 114.120 & 6,040 & Upper & Steel & 6.5 & 3.44 & 0.63 & 07/19/2009 & not removed \\
\hline PS4-0.81 & 38.918 & 114.118 & 6,025 & Upper & Steel & 6.3 & 2.45 & 0.63 & $06 / 24 / 2009$ & not removed \\
\hline PS4sb1-0.81 & 38.918 & 114.118 & 6,028 & Upper & Steel & 6.4 & 4.32 & 0.47 & $06 / 24 / 2009$ & not removed \\
\hline PS4sb2-0.81 & 38.918 & 114.118 & 6,030 & Upper & Steel & 6.5 & 4.19 & 0.50 & $06 / 24 / 2009$ & not removed \\
\hline PS3-1.39 & 38.918 & 114.109 & 5,890 & Upper & Steel & 6.6 & 1.95 & 0.52 & 05/29/2009 & $11 / 03 / 2010$ \\
\hline PS7-1.88 & 38.919 & 114.100 & 5,800 & Upper & Steel & 6.2 & 2.91 & 0.57 & $06 / 25 / 2009$ & $11 / 03 / 2010$ \\
\hline PS8-2.90 & 38.923 & 114.084 & 5,623 & Upper & Steel & 6.1 & 2.01 & 0.58 & $06 / 25 / 2009$ & $11 / 03 / 2010$ \\
\hline PS5-2.91 & 38.923 & 114.084 & 5,620 & Upper & Steel & 6.4 & 2.85 & 0.60 & $06 / 24 / 2009$ & $11 / 03 / 2010$ \\
\hline PS6-2.92 & 38.923 & 114.083 & 5,619 & Upper & Steel & 6.3 & 2.75 & 0.52 & $06 / 24 / 2009$ & $11 / 03 / 2010$ \\
\hline PS10-3.38 & 38.926 & 114.076 & 5,540 & Lower & Steel & 6.3 & 2.72 & 0.54 & 07/15/2009 & $11 / 03 / 2010$ \\
\hline PS9-4.93 & 38.929 & 114.049 & 5,360 & Lower & Steel & 6.2 & 3.10 & 0.54 & $06 / 25 / 2009$ & $11 / 03 / 2010$ \\
\hline
\end{tabular}


piezometers were driven into the ground about 7 and $38 \mathrm{ft}$ south of Snake Creek on private land in a meadow area, where groundwater was at shallow depth (piezometers PS4sb1 and PS4sb2, respectively, in table 13-1). Four piezometers were driven into Lehman Creek between the Lehman Creek gaging station (U.S. Geological Survey gaging-station number 10243260) and the confluence with Baker Creek (table 13-1). Only two piezometers could be driven into the streambed of Baker Creek (table 13-1), despite several attempts, because the presence of quartzite boulders greater than $2 \mathrm{ft}$ in diameter prevented it. One piezometer driven into Baker Creek near the confluence with Lehman Creek was damaged when a boulder rolled onto the pipe. Another piezometer, farther upstream and closer to the aquifer-test site, was destroyed during peak flow in June 2010 after a boulder rolled over it.

Following installation of the piezometers, usually 1 liter (about 1 quart) of water was rapidly poured into each piezometer, and its response to the added water was measured by using a pressure transducer that recorded changes in water level every 0.5 seconds. The process was repeated at least twice, except at piezometers PS7, PS12 and PS4_sb2. Data collected from the response of water added or removed were analyzed to estimate hydraulic conductivity in the vicinity of the screened interval by using the method described by and Bouwer and Rice (1976). Results from the slug tests represented the most permeable materials near the well screen and were assumed to represent the lateral hydraulic conductivity of sediments that parallel the streambed. The following equation from Bouwer and Rice (1976) was used to estimate hydraulic conductivity:

$$
K=\frac{r_{c}^{2} \log _{e}\left(R_{e} / R\right)}{2 L_{e} t} \log _{e}\left(\frac{H_{o}}{H_{t}}\right)
$$

where

$K$ is the hydraulic conductivity,

$r_{c}$ is the radius of the well casing,

$R$ is the radius of the well screen or gravel envelope,

$R_{e}$ is the effective radial distance over which head is dissipated,

$L_{e}$ is the length of the well screen through which water can enter,

$H_{O}$ is the drawdown at start of test,

$H_{t}$ is the drawdown at time $t$, and

$t$ is the time since equalled.

The natural log of the ratio of the effective radial distance, divided by the radius of the well screen, can be estimated, assuming the aquifer thickness was equal to the distance from the static water level in the piezometer to the bottom of the screened interval, by using the following equation:

$$
\log _{e}\left(\frac{R_{e}}{R}\right)=\left[\frac{1.1}{\log _{e}\left(\frac{L w}{R}\right)}+\frac{C}{\frac{L_{e}}{R}}\right]^{-1}
$$

where

$C$ is a dimensionless number dependent on the ratio of the well screen length, divided by the radius of the well screen or gravel envelope; and

$L_{w} \quad$ is the distance from the bottom of the well screen to the top of the water level in the piezometer prior to adding or removing water from the well.

Piezometer PS4sb2, about $38 \mathrm{ft}$ south of Snake Creek, was flowing at the time it was driven into the ground. Consequently, water in the well was evacuated by using a peristaltic pump, and the water level recovery was used to estimate the hydraulic conductivity at that piezometer. After completion of the slug tests, an absolute pressure transducer with a range in head of $3 \mathrm{ft}$ (Schlumberger baro-diver, http://www.swstechnology.com/groundwater-monitoring/groundwater-dataloggers/ baro-diver accessed September 18, 2012) was installed in the bottom of selected piezometers, and the water level in the piezometer was recorded every 15 minutes. A second pressure transducer was placed in a well point next to the piezometer with its screen in the creek to measure stream stage at the same time that a water level was measured in the piezometer. Water-levels in the piezometers and stream stage were measured periodically during the study.

Daily mean head (water level) and temperature in the streambed piezometers, daily mean stream stage and temperature in the creek, and daily mean hydraulic gradient are listed in tables 13-2 to 13-19; one table is used for each piezometer in Baker Creek, Lehman Creek, and Snake Creek. These tables list the following information:

- Date (month, day, year).

- Daily mean stream stage, in feet above streambed.

- Daily mean piezometer head, in feet above streambed.

- Daily mean hydraulic gradient, in foot per foot.

- Daily mean stream temperature, in degrees Celsius.

- Daily mean piezometer temperature, in degrees Celsius.

- Time of manual measurement, if any, for a particular date.

- Manual measurement of stream stage, in feet above streambed.

- Manual measurement of piezometer head, in feet above streambed.

- Manual measurement of hydraulic gradient, in foot per foot.

- Remarks. 
The following tables are distributed as part of this report in Microsoft ${ }^{\circledR}$ Excel 2010 format and is available for download at http://dx.doi.org/10.3133/pp1819.

Table 13-2. Daily mean stream stage, groundwater head relative to streambed, and hydraulic gradient from pressure-transducer data and manual measurements in piezometer PB1 driven into the streambed of Baker Creek, Great Basin National Park, White Pine County, Nevada, 2009-10.

Table 13-3. Daily mean stream stage, groundwater head relative to streambed, and hydraulic gradient from pressure-transducer data and manual measurements in piezometer PB2 driven into the streambed of Baker Creek, Great Basin National Park, White Pine County, Nevada, 2009-10.

Table 13-4. Daily mean stream stage, groundwater head relative to streambed, and hydraulic gradient from pressure-transducer data and manual measurements in piezometer PL1 driven into the streambed of Lehman Creek, Great Basin National Park, White Pine County, Nevada, 2009-10.

Table 13-5. Daily mean stream stage, groundwater head relative to streambed, and hydraulic gradient from pressure-transducer data and manual measurements piezometer PL2 driven into the streambed of Lehman Creek, Great Basin National Park, White Pine County, Nevada, 2009-10.

Table 13-6. Daily mean stream stage, groundwater head relative to streambed, and hydraulic gradient from pressure-transducer data and manual measurements piezometer PL3 driven into the streambed of Lehman Creek, Great Basin National Park, White Pine County, Nevada, 2009-10.

Table 13-7. Daily mean stream stage, groundwater head relative to streambed, and hydraulic gradient from pressure-transducer data and manual measurements piezometer PL4 driven into the streambed of Lehman Creek, Great Basin National Park, White Pine County, Nevada, 2009-10.

Table 13-8. Daily mean stream stage, groundwater head relative to streambed, and hydraulic gradient from pressure-transducer data and manual measurements in piezometer PS1 driven into the streambed of Snake Creek, Great Basin National Park, White Pine County, Nevada, 2009-10.

Table 13-9. Daily mean stream stage, groundwater head relative to streambed, and hydraulic gradient from pressure-transducer data and manual measurements in piezometer PS2 driven into the streambed of Snake Creek, Great Basin National Park, White Pine County, Nevada, 2009-13.

Table 13-10. Daily mean stream stage, groundwater head relative to streambed, and hydraulic gradient from pressuretransducer data and manual measurements in piezometer PS3 driven into the streambed of Snake Creek, Great Basin National Park, White Pine County, Nevada, 2009-10.

Table 13-11. Daily mean stream stage, groundwater head relative to streambed, and hydraulic gradient from pressuretransducer data and manual measurements in piezometer PS4 driven into the streambed of Snake Creek, Great Basin National Park, White Pine County, Nevada, 2009-13.
Table 13-12. Daily mean stream stage, groundwater head relative to streambed, and hydraulic gradient from pressuretransducer data and manual measurements in piezometer PS5 driven into the streambed of Snake Creek, Great Basin National Park, White Pine County, Nevada, 2009-10.

Table 13-13. Daily mean stream stage, groundwater head relative to streambed, and hydraulic gradient from pressuretransducer data and manual measurements in piezometer PS6 driven into the streambed of Snake Creek, Great Basin National Park, White Pine County, Nevada, 2009-10.

Table 13-14. Daily mean stream stage, groundwater head relative to streambed, and hydraulic gradient from pressuretransducer data and manual measurements in piezometer PS7 driven into the streambed of Snake Creek, Great Basin National Park, White Pine County, Nevada, 2009-10.

Table 13-15. Daily mean stream stage, groundwater head relative to streambed, and hydraulic gradient from pressuretransducer data and manual measurements in piezometer PS8 driven into the streambed of Snake Creek, Great Basin National Park, White Pine County, Nevada, 2009-10.

Table 13-16. Daily mean stream stage, groundwater head relative to streambed, and hydraulic gradient from pressuretransducer data and manual measurements in piezometer PS9 driven into the streambed of Snake Creek, Great Basin National Park, White Pine County, Nevada, 2009-10.

Table 13-17. Daily mean stream stage, groundwater water head relative to streambed, and hydraulic gradient from pressuretransducer data and manual measurements in piezometer PS10 driven into the streambed of Snake Creek, Great Basin National Park, White Pine County, Nevada, 2009-10.

Table 13-18. Daily mean stream stage, groundwater head relative to streambed, and hydraulic gradient from pressuretransducer data and manual measurements in piezometer PS11 driven into the streambed of Snake Creek, Great Basin National Park, White Pine County, Nevada, 2009-10.

Table 13-19. Daily mean stream stage, groundwater head relative to streambed, and hydraulic gradient from pressuretransducer data and manual measurements in piezometer PS12 driven into the streambed of Snake Creek, Great Basin National Park, White Pine County, Nevada, 2009-13.

Data from the piezometers driven into the stream bank south of Snake Creek and next to piezometer PS4 are listed in tables 13-20 and 13-21, which list the following information:

- Date (month, day, year).

- Daily mean piezometer head, in feet below land surface.

- Daily mean piezometer temperature, in degrees Celsius.

- Time of manual measurement, if any, for a particular date.

- Manual measurement of piezometer head, in feet below land surface.

- Remarks. 
Table 13-20. Daily mean groundwater head relative to land surface and temperature from pressure-transducer data and manual measurements in piezometer PS4_sb1 driven into ground 14 feet south of piezometer PS4 in Snake Creek, Great Basin National Park, White Pine County, Nevada, 2009-13.

Table 13-21. Daily mean groundwater head relative to land surface and temperature from pressure-transducer data and manual measurements in piezometer PS4_sb2 driven into ground 45 feet south of piezometer PS4 in Snake Creek, Great Basin National Park, White Pine County, Nevada, 2009-13.

Table 13-22 contains information regarding slug tests at the piezometers and lists the following information:

- Piezometer name.

- Date (month, day, year).

- Time at start of test (Pacific Daylight Time).

- Inside radius of casing ( $\mathrm{rc}$ ), in centimeters.

- Inside radius of well screen (R), in centimeters.

- Screen length (Le), in centimeters.

- Distance from bottom of screen to static water level $(\mathrm{Lw})$, in centimeters.

- Volume of water added to or removed from piezometer, in cubic centimeters.

- Time taken to add water, in seconds.

- Computed initial displacement, assuming instantaneous slug, in centimeters.

- Measured maximum displacement, in centimeters.

- Computed volume using maximum displacement, in cubic centimeters.

- Time for water level to rise or fall to 37 percent of the initial displacement, in seconds.

- Estimate of hydraulic conductivity, in centimeters per second.

- Estimate of hydraulic conductivity, converted to feet per day.
Table 13-22. Estimates of lateral hydraulic conductivity from slug tests in piezometers driven into the streambed of Baker, Lehman, and Snake Creeks, Great Basin National Park, White Pine County, Nevada, 2009-2013.

This table is distributed as part of this report in Microsoft ${ }^{\mathbb{B}}$ Excel 2010 format and is available for download at http://dx.doi.org/10.3133/pp1819.

\section{References Cited}

Bouwer, Herman, and Rice, R.C., 1976, A slug test for determining hydraulic conductivity of unconfined aquifers with completely or partially penetrating wells: Water Resources Research, v. 12, no. 3, p 423-428. 


\section{Appendix 14. Description of Water-Temperatures in Streambed Piezometers Used for Determining Streambed-Seepage Rates and Vertical Hydraulic Conductivity at Selected Sites on Baker, Lehman, and Snake Creeks, near Great Basin National Park, White Pine County, Nevada.}

One to three Onset Computer Corporation Water Temp Pro $2^{\circledR}$ temperature loggers were hung on a nylon cord in many of the streambed piezometers at depths ranging from 0.3 to 1.5 feet $(\mathrm{ft})$ below the streambed (description of each streambed piezometer is given appendix 13, table 13-1). These temperature loggers, along with temperatures measured by pressure transducers in the creek and near the bottom of the piezometers, were used to measure the vertical temperature gradient through the streambed. The data from the temperature loggers were collected at the same 15-minute interval as the data from the pressure transducers. Temperature profiles were used to quantify the seepage rate and vertical hydraulic conductivity between a stream and shallow groundwater beneath the stream (Stonestrom and Constantz, 2003).

Because water has a greater heat capacity than most streambed sediments, temperature measurements can effectively quantify streambed-seepage rates (Anderson, 2005).

Two different methods were used to estimate the streambed-seepage rate and vertical hydraulic conductivity. A graphical software program for simulating fluid flow and solute or energy transport in variably saturated porous media, named VS2DI (Hsieh and others, 1999), was used in conjunction with the computer program VS2DH to simulate flow and energy transport (Healy and Ronan, 1996). Version 1.3 was obtained from http://wwwbrr.cr.usgs.gov/projects/ GW_Unsat/vs2di1.3/index.html. The computer program was used to simulate temperature and head changes between the creek and the screened interval of the piezometer by using either hourly or daily mean values.

Model simulations from data collected at the piezometers were calibrated to one or two intermediate temperatures from temperature loggers placed inside the piezometer. Calibration was done by adjusting the vertical hydraulic conductivity by using the procedure described by Niswonger and Prudic (2003). Daily mean temperatures and water levels were used for piezometers PB1, PB2, PS11, and PS12, whereas the daily mean stream stage and hourly temperatures and water levels were used for piezometers PL1, PL2, PS4, PS5, and PS7, where stream stage was measured. Porosity of the streambed was at the low end of the range reported by Niswonger and Prudic (2003, p. 86), because the streambed contained large stones (boulders and cobbles), and the void space was filled with silt and sand, which reduced pore space relative to the total volume (Fetter, 2001, p. 71). The values listed in table 14-1 are for saturated sand with a porosity of 31 percent (Tottori sand; Stonestrom and Blasch, 2003, p. 76). The models were calibrated by minimizing the square root of the sum of the squared difference between measured and simulated temperature at a selected depth between the creek and bottom of the piezometer.

The two most sensitive variables during model calibration were vertical hydraulic conductivity and thermal conductivity at saturation. Thermal conductivity was less sensitive than vertical hydraulic conductivity, except when the vertical hydraulic gradient of the streambed was near zero (greater than -0.01 and less than 0.01) or when the vertical hydraulic conductivity was less than 1 foot per day, which made thermal conductivity (thermal diffusivity) the primary mechanism by which heat propagated vertically through the streambed. Thermal conductivity was assumed to be constant in all calculations, because of a lack of information about variations in porosity or in the chemical composition of the minerals (assumed to be quartz) in the streambed, both vertically and laterally. Longitudinal dispersivity was generally insensitive and was set to 0.1 meter for all model analyses. Because the models only assumed vertical flow and heat transport, transverse dispersivity was not used in the VS2DH calculations, but was required as input to the model. The value was always set to one tenth of the longitudinal dispersivity (0.01), although a value of zero produced the same results.

The amplitude ratio of the analytical time-series method (Hatch and others, 2006) was used to estimate the streambedseepage rates for piezometers where only temperatures of the creek water and at the bottom of the piezometer were measured, because water in the piezometer was near its bottom or because the inside diameter of the stand pipe was too small for the temperature loggers (piezometers PL3, PS1, PS3, PS5, PS9, and PS10). The time-series method was well suited for these piezometers because flow was in the same direction as the diurnal thermal pulse, and the daily mean temperatures in the creek and at the bottom of the piezometer were nearly the same. The equation for one-dimensional heat and fluid flow (known as the one-dimensional conduction-advection dispersion equation, Stallman, 1965) is as follows:

$$
\frac{\partial T}{\partial t}=K_{e} \frac{\partial^{2} T}{\partial z^{2}}-\frac{v}{n \gamma} \frac{\partial T}{\partial z}
$$

where

$T$ is temperature, in degrees Celsius (varies with time, $t$, and depth, $z$ ),

$K_{e} \quad$ is effective thermal diffusivity ( 0.073 meter squared per day was used),

$\gamma \quad$ is the ratio of volumetric heat capacity of the saturated sediments in the streambed to that of water ( 0.62 was used), 
$v$ is the thermal-front velocity in meters per day, and

$n$ is the porosity, dimensionless.

Assuming the top of the streambed is zero, a positive thermal-front velocity indicates creek water flows to the streambed (losing stream), and a negative value indicates flow from shallow groundwater to the creek (gaining stream). The thermal-front velocity was a function of the daily amplitude ratio between two selected depths (a positive value). The amplitude ratio was used because it could be easily computed. The following equation was used for the amplitude ratio method (Hatch and others, 2006):

$$
V_{A r}=\frac{2 K_{e}}{\Delta z} \log _{e} A_{r}+\sqrt{\frac{\alpha+v^{2}}{2}}
$$

where

$V_{A r}$ and $v \quad$ are the thermal-front velocity on the left and right sides of the equation, in meters per day, respectively;

$\Delta z \quad$ is the vertical distance between two points beneath the streambed, in meters;

$A_{r} \quad$ is the daily amplitude ratio of the deeper temperature logger to the shallower temperature logger, where the amplitude was computed as half of the sum of the maximum and minimum temperatures during a day, and $\alpha=\sqrt{\mathrm{v}^{4}+}\left(8 \pi \frac{K_{e}}{p}\right)$

where

$P \quad$ is the period used to compute the amplitude ratio (1 day).

Because the thermal-front velocity is on both sides of the equation, the equation was solved iteratively in Excel by using the "Solver" function until the thermal-front velocity was the same on both sides of the equation. The vertical streambedseepage rate, in meters per day, was calculated as follows:

$$
q_{s t r b d}=\frac{v}{n \gamma}
$$

where

$$
\begin{aligned}
& \frac{v}{n y} \text { is the average linear-pore-water velocity, in meters } \\
& \text { per day. }
\end{aligned}
$$

A negative streambed-seepage rate indicates downward movement of water from the creek through the streambed (losing stream), and a positive streambed-seepage rate indicates groundwater moving upward to the creek (gaining stream); this convention was used to be consistent with the hydraulic gradients computed for the piezometers.

Model simulations using VS2DH are more robust than the time-series method because the model considers temperature and pressure-head changes simultaneously between the creek and the screened interval in the piezometer and accounts

Table 14-1. Hydraulic and thermal properties used to estimate streambed-seepage rates and vertical hydraulic conductivity at piezometers driven into the streambeds at selected locations along Baker, Lehman, and Snake Creeks near Great Basin National Park, White Pine County, Nevada.

\begin{tabular}{|c|c|c|}
\hline Hydraulic or thermal property & Value & Standard international units \\
\hline \multicolumn{3}{|c|}{$\begin{array}{l}\text { Properties used for variably saturated two-dimensional heat transport model } \\
\text { (VS2DH: Healy and Ronan 1996) }\end{array}$} \\
\hline Porosity & 0.3 & Cubic meter per cubic meter \\
\hline Specific storage & $3 \times 10^{-6}$ & Cubic meter per square meter \\
\hline Residual water content & 0.1 & Cubic meter per cubic meter \\
\hline \multicolumn{3}{|l|}{ van Genuchten retention model } \\
\hline Alpha & 1 & Cubic meter per square meter \\
\hline Beta & 5 & Dimensionless exponent \\
\hline Heat capacity of dry sediment (quartz) & $1.9 \times 10^{6}$ & Joules per cubic meter per degree Celsius \\
\hline Heat capacity of water & $4.2 \times 10^{6}$ & Joules per cubic meter per degree Celsius \\
\hline Thermal conductivity of saturated sediment & $1.9 \times 10^{5}$ & Joules per meter per day per degree Celsius \\
\hline Thermal conductivity at residual water content & 650 & Joules per meter per day per degree Celsius \\
\hline Longitudinal dispersivity & 0.2 & Meter \\
\hline \multicolumn{3}{|c|}{ Properties used for analytical time-series method (Hatch and others, 2006) } \\
\hline Heat capacity of saturated sediment (quartz) & $2.6 \times 10^{6}$ & Joules per cubic meter per degree Celsius \\
\hline Thermal dispersivity of saturated sediment & 0.073 & Meter squared per day \\
\hline Gamma & 0.62 & $\begin{array}{l}\text { Ratio of volumetric heat capacity of saturated sediment to volumetric heat capacity of } \\
\text { water }\end{array}$ \\
\hline
\end{tabular}

[Time units for hydraulic conductivity and thermal conductivity for saturated sediment and for sediment at residual water content converted to hours by dividing values listed by 24 hours per day] 
for changes in storage of water and heat in the profile. Both methods assume vertical flow of water through the streambed, however, and the analytical method also assumes the same mean temperature throughout the profile (that is, no change in heat storage; Hatch and others, 2006). Lateral flow parallel to the creek can affect the streambed-seepage rates, particularly when lateral flow is dominate. This can happen when the piezometer is near the edge of the creek and the streambed is deeper in the center or when lateral hydraulic gradients of the channel are greater than the vertical ones. Furthermore, the times-series method does not consider changes in the direction of flow and storage through the profile as a result of changes in the hydraulic gradient between the creek and the bottom of the piezometer. Neither method can accurately determine the streambed-seepage rate when the hydraulic gradient approaches zero because conduction (thermal conductivity or thermal diffusivity) becomes the dominant driver of changes in temperature in the profile. Thus, vertical hydraulic conductivities are only reported to one significant figure.

The time-series method determined the vertical hydraulic conductivity of the streambed $\left(K_{v}\right)$ at the piezometers by dividing the mean streambed-seepage rate $\left(q_{\text {stribd }}\right)$ by the mean hydraulic gradient, or $\frac{\Delta h}{\Delta z}$ according to Darcy's Law and assuming vertical flow $\left(K_{v}=-q_{\text {strbd }} d\left[\frac{\Delta h}{\Delta z}\right]\right)$. The term is the head in the piezometer minus the head in the creek. Hydraulic gradients less than -1 feet per foot $(\mathrm{ft} / \mathrm{ft})$, indicating gravity drainage, were assigned a value of $-1 \mathrm{ft} / \mathrm{ft}$ in calculations of vertical hydraulic conductivity.

Hourly temperatures and water levels used to estimate streambed-seepage rates and vertical hydraulic conductivity for the streambed piezometers are listed in tables for piezometers in Baker, Lehman, and Snake Creeks (tables 14-2 to 14-17).

The following tables are distributed as part of this report in Microsoft ${ }^{\circledR}$ Excel 2010 format and is available for download at http://dx.doi.org/10.3133/pp1819.

Table 14-2. Hourly temperature and water level at selected depths in piezometer PB1, driven into the streambed of Baker Creek, Great Basin National Park, White Pine County, Nevada, 2010.

Table 14-3. Hourly temperature and water level at selected depths in piezometer PB2, driven into the streambed of Baker Creek, Great Basin National Park, White Pine County, Nevada, 2009-10.

Table 14-4. Hourly temperatures and water levels in creek and at selected depths in piezometer PL1, driven into the streambed of Lehman Creek, Great Basin National Park, White Pine County, Nevada, 2009-10.

Table 14-5. Hourly temperatures and water levels in creek and at selected depths in piezometer PL2, driven into the streambed of Lehman Creek, Great Basin National Park, White Pine County, Nevada, 2010.
Table 14-6. Hourly temperatures and water levels in creek and at selected depths in piezometer PL3, driven into the streambed of Lehman Creek, Great Basin National Park, White Pine County, Nevada, 2010.

Table 14-7. Hourly temperatures and water levels in creek and at selected depths in piezometer PL4, driven into the streambed of Lehman Creek, Great Basin National Park, White Pine County, Nevada, 2009-10.

Table 14-8. Hourly temperatures and water levels in creek and at bottom of piezometer PS1, driven into the streambed of Snake Creek, Great Basin National Park, White Pine County, Nevada, 2009.

Table 14-9. Hourly temperatures and water levels in creek and at bottom of piezometer PS2, driven into the streambed of Snake Creek, Great Basin National Park, White Pine County, Nevada, 2009.

Table 14-10. Hourly temperatures and water levels in creek and at selected depths in piezometer PS3, driven into the streambed of Snake Creek, Great Basin National Park, White Pine County, Nevada, 2009.

Table 14-11. Hourly temperatures and water levels in creek and at selected depths in piezometer PS4, driven into the streambed of Snake Creek, Great Basin National Park, White Pine County, Nevada, 2009-10.

Table 14-12. Hourly temperatures and water levels in creek and at bottom of piezometer PS5, driven into the streambed of Snake Creek, Great Basin National Park, White Pine County, Nevada, 2009-10.

Table 14-13. Hourly temperatures and water levels in creek and at selected depths in piezometer PS7, driven into the streambed of Snake Creek, Great Basin National Park, White Pine County, Nevada, 2009-10.

Table 14-14. Hourly temperatures and water levels in creek and at selected depths in piezometer PS9, driven into the streambed of Snake Creek, Great Basin National Park, White Pine County, Nevada, 2009-10.

Table 14-15. Hourly temperatures and water levels in creek and near bottom of piezometer PS10, driven into the streambed of Snake Creek, Great Basin National Park, White Pine County, Nevada, 2009.

Table 14-16. Hourly temperatures at selected depths in piezometer PS11, driven into the streambed of Snake Creek, Great Basin National Park, White Pine County, Nevada, 2009-10.

Table 14-17. Hourly temperature and water level at selected depths in piezometer PS12, driven into the streambed of Snake Creek, Great Basin National Park, White Pine County, Nevada, 2009-10. 


\section{References Cited}

Anderson, M.P., 2005, Heat as a ground water tracer: Ground Water, v. 46, no. 6, p. 951-968, doi: $10.1111 /$ j. $1745-$ 6584.2005.00052. Fetter, C.W., 2001, Applied hydrogeology (4th ed.): Upper Saddle River, New Jersey, Prentice Hall, $598 \mathrm{p}$.

Hatch, C.E., Fisher, A.T., Revenaugh, J.S., Constantz, Jim, and Ruehl, Chris, 2006, Quantifying surface water-groundwater interactions using time series analysis of streambed thermal records - methods development: Water Resources Research, v. 42, W10410, 14 p, doi:10.1029/2005WR004787.

Healy, R.W., and Ronan, A.D., 1996, Documentation of computer program VS2DH for simulation of energy transport in variably saturated porous media-modification of the U.S. Geological Survey's computer program VS2DT: U.S. Geological Survey Water-Resources Investigations Report 96-4230, 36 p., http://pubs.er.usgs.gov/pubs/wri/wri964230.

Hsieh, P.A., Wingle, William, and Healy, R.W., 1999, VS2DI-a graphical software package for simulating fluid flow and solute or energy transport in variably saturated porous media: U.S. Geological Survey Water-Resources Investigations Report 99-4130, 16 p., http://pubs.er.usgs. gov/pubs/wri/wri994130.

Niswonger, R.G., and Prudic, D.E., 2003, Modeling heat as a tracer to estimate streambed seepage and hydraulic conductivity, Appendix B in Stonestrom, D.A., and Constantz, Jim, eds., Heat as a tool for studying the movement of groundwater near streams: U.S. Geological Survey Circular 1260, p. $81-89$.

Stallman, R.W., 1965, Steady one-dimensional fluid flow in a semi-infinite porous medium with sinusoidal surface temperature: Journal of Geophysical Research, v. 70, p. $2,821-2,827$.

Stonestrom, D.A., and Blasch, K.W., 2003, Determining temperature and thermal properties for heat-based studies of surface-water ground-water interactions, Appendix A in Stonestrom, D.A., and Constantz, Jim, eds., Heat as a tool for studying the movement of groundwater near streams: U.S. Geological Survey Circular 1260, p. 73-80.

Stonestrom, D.A., and Constantz, Jim, eds., 2003, Heat as a tool for studying the movement of groundwater near streams: U.S. Geological Survey Circular 1260, 96 p. 


\section{Appendix 15. Description of Placement and Measurement of Stream Water Temperature Using Fiber-0ptic Cables and a Distributed Temperature Sensing Method near Great Basin National Park, White Pine County, Nevada.}

Groundwater flow to Snake and Lehman Creeks was evaluated by using distributed temperature sensing (DTS). The fiber-optic cable was first installed along Snake Creek just downstream of the Great Basin National Park on July 18,2009 . The cable was custom-made with a white plastic outer protective casing to limit solar heating (Neilson and others, 2010). The uppermost part of the reach was intermittent, but the lower part of the reach was perennial, indicating groundwater discharge to the creek (Elliot and others, 2006, p. 36-40). The fiber-optic cable entered the upstream end of the reach from a Bureau of Land Management (BLM) access road (lat 38 $55^{\prime} 09^{\prime \prime} \mathrm{N}$., long $114^{\circ} 07^{\prime} 36^{\prime \prime} \mathrm{W}$., North American Datum of 1983, or NAD83) at an altitude of about 6,120 feet (ft) above mean sea level (msl) and left the reach just upstream of a culvert (lat $38^{\circ} 55^{\prime} 06^{\prime \prime}$., long $114^{\circ} 06^{\prime} 51^{\prime \prime} \mathrm{W}, \mathrm{NAD} 83$ ) at an altitude of about 5,970 ft above msl. The fiber-optic cable was secured to the streambed by cobbles, which were common in the reach. The total length of cable in the stream was $2,824 \mathrm{ft}$. About $65 \mathrm{ft}$ of the fiber-optic cable was placed in north Gruden Spring (lat $38^{\circ} 55^{\prime} 09^{\prime \prime} \mathrm{N}$., long $114^{\circ} 07^{\prime} 36^{\prime \prime} \mathrm{W}$, NAD83). The spring was approximately $40 \mathrm{ft}$ north of the creek and $4 \mathrm{ft}$ higher in altitude. Extra cable was coiled at the upstream and downstream ends for temperature calibration during deployments at all sites.

The cable was connected to a Sensornet Limited ${ }^{\circledR}$ Sentinel ${ }^{\mathrm{TM}}$ DTS and 4-channel Multiplexer (Hertfordshire, United Kingdom), which provides temperature data at 3.28feet (1-meter) spatial resolution on four channels up to $3.2 \mathrm{mi}$ or 5 kilometers $(\mathrm{km})$ in length and can sample as often as every 10 seconds. Measurements along fiber-optic cable can be made either in one direction (single-ended) or both directions (double-ended). Fiber-optic cables used in study were 0.2 by 0.3 inch All Dielectric Self-Supporting (ADSS) Flat Drop ${ }^{\mathrm{TM}}$ cable (AFL Telecommunications, LLC ${ }^{\text {TM }}$ is a subsidiary of Fujikura Ltd., Japan) 3,280 ft (1,000 meters) long that contained two optical fibers. If these fibers are spliced together at one end of the cable and are both connected to the DTS unit at the other, double-ended measurement configurations can be used; if not, only single-ended configurations are possible. Independent temperature measurements for calibration of DTS data were made in portable coolers that were either filled with stream water or an ice-and-water mixture. The water and ice-and-water baths were continually mixed with an aquarium bubbler. Temperatures of the calibration baths were measured continuously when the DTS was in operation by using a combination of Onset Computer Corporation (Bourne, Mass.) WaterTemp Pro ${ }^{\circledR}$ (ceramic thermistor) temperature loggers, with a resolution of 0.02 degrees Celsius $\left({ }^{\circ} \mathrm{C}\right)$ and accuracy of $0.15^{\circ} \mathrm{C}$ between -4 and $37{ }^{\circ} \mathrm{C}$, ThermoWorks Logmaster (Alpine, Utah) RTDTemp $101^{\circledR}$ (100 ohms platinum resistance thermocouple, PT100) temperature loggers, with a resolution of $0.01{ }^{\circ} \mathrm{C}$ and accuracy of $0.05{ }^{\circ} \mathrm{C}$ between -40 and $80{ }^{\circ} \mathrm{C}$, and PT100 temperature loggers incorporated into the Sentinel DTS unit.

The DTS was connected to the cable in Snake Creek three times between July and October 2009 (table 15-1): 5 days, from July 19 to 24, 2009; 7 days, from September 3 to 10, 2009; and 2 days, from October 7 to 9, 2009.

Table 15-1. Distributed temperature sensing measurements from selected reaches of Lehman and Snake Creeks in and near Great Basin National Park, White Pine County, Nevada, 2009-10.

[Longitude and latitude are referenced to the North American Datum of 1983. Land-surface altitude is referenced to the North American Vertical Datum of 1988. Abbreviation: mm, two digit month; dd, two digit day; yyyy; four digit year; hh, two digit hour; mn, two digit minute]

\begin{tabular}{|c|c|c|c|c|c|c|c|}
\hline \multirow{3}{*}{ Stream } & \multirow{2}{*}{\multicolumn{2}{|c|}{$\begin{array}{c}\text { Measurement date/time } \\
\text { (mm/dd/yyyy hh:mn) } \\
\text { Pacific Daylight Time }\end{array}$}} & \multirow{3}{*}{$\begin{array}{l}\text { Measurement } \\
\text { type }\end{array}$} & \multicolumn{3}{|c|}{ Cable location at upstream end } & \multirow{3}{*}{$\begin{array}{l}\text { Length of } \\
\text { cable in } \\
\text { stream } \\
\text { (feet) }\end{array}$} \\
\hline & & & & Latitude & Longitude & Land-surface & \\
\hline & Begin & End & & \multicolumn{2}{|c|}{ Decimal degrees } & (feet) & \\
\hline Lehman Creek, upstream cable & $10 / 09 / 200918: 34$ & 10/10/2009 08:55 & Single ended & 39.012 & 114.214 & 6,700 & 2,544 \\
\hline Lehman Creek, upstream cable & 10/10/2009 09:10 & 10/11/2009 11:41 & Double ended & 39.012 & 114.214 & 6,700 & 2,544 \\
\hline Lehman Creek, upstream cable & $11 / 03 / 200917: 43$ & 11/05/2009 16:49 & Single ended & 39.012 & 114.214 & 6,700 & 2,544 \\
\hline Lehman Creek, upstream cable & $11 / 05 / 200917: 59$ & 11/08/2009 09:59 & Single ended & 39.012 & 114.214 & 6,700 & 2,544 \\
\hline Lehman Creek, downstream cable & $11 / 05 / 200917: 01$ & 11/08/2009 09:59 & Single ended & 39.010 & 114.207 & 6,560 & 2,739 \\
\hline Lehman Creek, upstream cable & $02 / 24 / 201016: 20$ & 02/26/2010 13:36 & Single ended & 39.012 & 114.214 & 6,700 & 2,544 \\
\hline Lehman Creek, downstream cable & $02 / 24 / 201016: 20$ & $02 / 26 / 201013: 36$ & Single ended & 39.010 & 114.207 & 6,560 & 2,739 \\
\hline Snake Creek & 07/19/2009 11:56 & 07/24/2009 08:37 & Double ended & 38.919 & 114.127 & 6,120 & 2,824 \\
\hline Snake Creek & 09/03/2009 10:50 & 09/10/2009 07:39 & Double ended & 38.919 & 114.127 & 6,120 & 2,824 \\
\hline Snake Creek & $10 / 07 / 2009$ 15:00 & 10/09/2009 07:49 & Double ended & 38.919 & 114.127 & 6,120 & 2,824 \\
\hline
\end{tabular}


During each deployment, the Sentinel DTS was powered by a generator and contained in a temperature-controlled trailer. Two calibration baths were used - an ice and water bath upstream and stream water downstream - and were logged independently with PT100 thermistors. The July and September deployments were accompanied by measurements of stream temperature at one upstream and one downstream location by using PT100 temperature loggers.

During October and November 2009, two fiber-optic cables were placed in Lehman Creek. The upstream cable was installed on October 8, 2009. The cable entered the creek next to the gaging station inside Great Basin National Park (U.S. Geological Survey station number 10243260 : lat $39^{\circ} 00^{\prime} 42^{\prime \prime} \mathrm{N}$., long $114^{\circ} 12^{\prime} 52^{\prime \prime}$ W., NAD83) at an altitude of about 6,700 $\mathrm{ft} \mathrm{msl}$ and exited the creek outside Great Basin National Park and upstream of Joe's Way (lat $39^{\circ} 00^{\prime} 35.1^{\prime \prime} \mathrm{N}$., long $114^{\circ} 12^{\prime} 25.6^{\prime \prime} \mathrm{W} ., \mathrm{NAD}^{2}$ ) at an altitude of about 6,540 ft msl. The upstream and downstream cables both were secured with cobbles. The length of cable in the creek was 2,297 ft, 2,231 ft, and 2,667 ft in October, November, and February, respectively (length differences reflect different lengths of cable used for calibration at cable ends). The downstream cable was installed on November 7, 2009. This cable entered the creek about $120 \mathrm{ft}$ downstream from the first cable and $20 \mathrm{ft}$ upstream from the culvert beneath Joe's Way; (lat $39^{\circ} 00^{\prime} 40^{\prime \prime} \mathrm{N}$., long $114^{\circ} 12^{\prime} 00^{\prime \prime}$ W., NAD83) at an altitude of about $6,430 \mathrm{ft} \mathrm{msl}$; the downstream end of this cable was about $260 \mathrm{ft}$ downstream from where Sage Way crosses Lehman Creek, and it was looped back upstream to Sage Way. The length of cable in the creek was 2,985 ft in November and 2,999 ft in February. Both cables were removed in May 2010. The total distance of both cables downstream of the gaging station was $1.06 \mathrm{mi}$. This distance did not include the excess cable left at the beginning and end of each cable to connect with the DTS instrument and for use in temperature calibration baths nor the repeating 260-ft section downstream from Sage Way. Additionally, lengths of cable were placed next to the channel to avoid sharp meanders and places where vegetation made wading difficult. The distance downstream from the gaging station on Lehman Creek was used to denote the location of the cable in the creek relative to the gaging station and included where the cable was placed on ground next to the creek.
In Lehman Creek, the DTS was connected to the upstream cable on Lehman Creek and operated three times prior to the installation of the downstream cable: 1 day, from October 9 to 10, 2009 (single-ended); 1 day, from October 10 to 11, 2009 (double-ended); and 2 days, from November 3 to 5, 2009 (table 15-1). Two calibration baths were logged by using PT100 temperature loggers; the upstream bath contained stream water, and the downstream bath had an ice-and-water mixture. Upstream temperatures also were monitored at the site where the cable entered the creek. Temperature measurements were collected during three periods (October 9-11, 2009; November 3-8, 2009; and February 24-26, 2010), and temperatures were monitored at several key locations along the cable, to evaluate where Lehman Creek gained flow from shallow groundwater. Flow was continuous through the reach during all three measurement periods.

Once the lower reach cable was installed on Lehman Creek, subsequent DTS measurements of the two cables were synchronous. The first combined measurements were for 3 days from November 5to 8, 2009, and the second were for 2 days from February 24 to 26, 2010 (table 15-1). Six calibration baths were used and included stream water, heated water, snow, and ice-and-water baths. Upstream, midstream, and downstream temperatures, along with calibration bath temperatures, were monitored during the DTS measurements with a combination of PT100 and WaterTemp Pro temperature loggers.

\section{References Cited}

Elliott, P.E., Beck, D.A., and Prudic, D.E., 2006, Characterization of surface-water resources in the Great Basin National Park area and their susceptibility to ground-water withdrawals in adjacent valleys, White Pine County, Nevada: U.S. Geological Survey Scientific Investigations Report 2006-5099, 156 p.

Neilson, B.T., Hatch, C.E., Ban, H., and Tyler, S.W., 2010, Solar radiative heating of fiber-optic cables used to monitor temperatures in water: Water Resources Research, v. 46, W08540, doi:10.1029/2009WR008354. 


\section{Appendix 16. Summary of Water-Quality Data at Selected Stream Sites, Springs, and Wells, Great Basin National Park and Vicinity, White Pine County, Nevada, September 2007-January 2010.}

Chemical analyses of water samples collected from selected stream locations, springs, and wells during the study (table 16-1) were used to evaluate the connection of streams with aquifers and to evaluate source areas to Rowland Spring and Big Springs. Because water in the creeks is well-mixed, a sample of the centroid of the stream was taken at each stream sampling location. Samples from springs were obtained by driving a $3 / 8$-inch (in.) stainless-steel well point with a 2 -in. long screen placed about 3 in. up from a machined point into the spring, then using a peristaltic pump to remove water from

Table 16-1. Sampling locations for water chemistry from creeks, springs, caves, and wells in and near Great Basin National Park, southern Snake Valley, Nevada.

[U.S. Geological Survey site-identification number can be used to obtain data from the National Water Information System database. Longitude and latitude are referenced to the North American Datum of 1983. Land-surface altitude is referenced to the North American Vertical Datum of 1988. Abbreviation: NDOW, Nevada Department of Wildlife]

\begin{tabular}{|c|c|c|c|c|c|}
\hline \multirow{2}{*}{ Site name } & \multirow{2}{*}{$\begin{array}{c}\text { U.S. Geological Survey } \\
\text { site-identification } \\
\text { number }\end{array}$} & Latitude & Longitude & \multirow{2}{*}{$\begin{array}{l}\text { Land-surface } \\
\text { altitude } \\
\text { (feet) }\end{array}$} & \multirow{2}{*}{ Sample type } \\
\hline & & \multicolumn{2}{|c|}{ Decimal degrees } & & \\
\hline \multicolumn{6}{|c|}{ Lehman Creek drainage basin } \\
\hline Rowland Spring & 10243265 & 39.010 & 114.208 & 6,580 & Spring \\
\hline \multicolumn{6}{|c|}{ Baker Creek drainage basin } \\
\hline Baker Creek at Grey Cliffs B-loop road crossing near Narrows & 385928114144201 & 38.991 & 114.245 & 7,160 & Surface water \\
\hline Wheelers Deep Cave in Narrows of Baker Creek & 385921114130401 & 38.989 & 114.218 & 6,970 & Cave water \\
\hline Pole Canyon at trail crossing upstream of Pioche Shale & 385858114131901 & 38.983 & 114.222 & 7,170 & Surface water \\
\hline Model Cave & 385918114124001 & 38.988 & 114.211 & 7,000 & Cave water \\
\hline \multicolumn{6}{|c|}{ Snake Creek drainage basin } \\
\hline Squirrel Spring Cave in Snake Creek drainage & 385510114114401 & 38.919 & 114.196 & 7,200 & Cave water \\
\hline Outlet Spring near end of pipeline on Snake Creek & 385445114102601 & 38.913 & 114.174 & 6,755 & Spring \\
\hline Snake Creek at end of pipeline & 385445114102301 & 38.913 & 114.173 & 6,750 & Surface water \\
\hline Outhouse Spring north side of Snake Creek & 385456114085501 & 38.916 & 114.149 & 6,395 & Spring \\
\hline Snake Creek at Outhouse Spring & 385456114085501 & 38.916 & 114.149 & 6,390 & Surface water \\
\hline Snake Creek 0.4 mile upstream of Cave Canyon Creek & 385506114083201 & 38.918 & 114.142 & 6,310 & Surface water \\
\hline Piezometer 11 in Snake Creek near north Gruden Spring & 385509114073301 & 38.919 & 114.126 & 6,120 & Groundwater \\
\hline Snake Creek about 50 feet upstream of culvert on Duff property & 385505114070801 & 38.918 & 114.119 & 6,030 & Surface water \\
\hline Snake Creek at Nevada-Utah state line & 10243234 & 38.928 & 114.042 & 5,350 & Surface water \\
\hline \multicolumn{6}{|c|}{ Big Springs area } \\
\hline Big Springs, north orifice of south channel & 384158114075201 & 38.699 & 114.132 & 5,570 & Spring \\
\hline Big Springs northwest well & 384227114082701 & 38.708 & 114.141 & 5,815 & Groundwater \\
\hline Big Springs southwest well & 384112114091101 & 38.687 & 114.153 & 6,020 & Groundwater \\
\hline
\end{tabular}


the well point. Well samples were collected by pumping each well. Two samples were collected from the Nevada Department of Wildlife's domestic well, which has a dedicated pump at the Spring Creek fish-rearing station. The first sample was collected in June 2009 during an aquifer test, and the second sample was collected in January 2010, when water samples were collected at selected sites in and near Snake Creek. Water from the domestic well was collected from an outlet prior to entering a pressurized storage tank after many pore volumes were pumped from the well. Water samples from monitoring wells drilled during this study required a pump. Pumps capable of withdrawing more than 250 gallons per minute (gal/min) were lowered into the two wells drilled northwest and southwest of Big Springs, and samples were collected during aquifer tests after many pore volumes were removed from the wells. A 4-in. diameter well was lowered into the 6-in. diameter well next to Baker Creek and used for a 92-hour aquifer test. The well was pumped at a rate of $26 \mathrm{gal} / \mathrm{min}$, and many pore volumes were removed before collecting a water sample. A small-diameter Bennett ${ }^{\mathbb{B}}$ pump capable of pumping up to $2 \mathrm{gal} / \mathrm{min}$ was lowered into Snake 5 deep well. The pump produced only $0.75 \mathrm{gal} / \mathrm{min}$ because the depth to water in the well exceeded $200 \mathrm{ft}$ in January 2010. The well was pumped for 2 hours prior to collecting a sample. A battery operated peristaltic pump was used to sample water from streambed piezometer PS11 near north Gruden Spring. The piezometer was pumped at a rate of $0.1 \mathrm{gal} / \mathrm{min}$ for 30 minutes prior to collecting a sample.

Water from each sampling location was measured for temperature, specific electrical conductance, $\mathrm{pH}$, dissolved oxygen, and alkalinity by using procedures described by Radke and others (2005), Lewis (2006), Rounds (2006), Ritz and Collins (2008), and Wilde (2006, 2008). Specific electrical conductance and $\mathrm{pH}$ were calibrated to standards at the time of sampling. Dissolved oxygen was calibrated at each sampling location. Alkalinity was determined by titration of a 50 milliliter $(\mathrm{mL})$ sample of filtered water by using an inflection-point method with 0.16 Normal (N) sulfuric acid. Bicarbonate concentrations were calculated from alkalinity (Rounds, 2006).

All sample bottles were rinsed three times with filtered or unfiltered water prior to collecting the sample. Duplicate samples were collected at each site. A portable battery-operated peristaltic pump equipped with C-flex tubing was used to filter water through a high volume, 0.45 micron filter. The tubing was rinsed with deionized water prior to each sample collection (Wilde, 2004). Water was pumped through the peristaltic pump at a rate of $0.1 \mathrm{gal} / \mathrm{min}$. Filtered water was poured into amber bottles, whereas unfiltered water was poured into plain bottles. Water in the amber bottles was untreated, whereas water in the plain bottles was acidified to a $\mathrm{pH}$ of less than 1 with $1 \mathrm{~mL}$ of $4.5 \mathrm{~N}$ sulfuric acid. Filtered water for dissolved-cation and trace-element analysis was collected in acid-rinsed $500-\mathrm{mL}$ polyethylene bottles. These samples were preserved with $7.7 \mathrm{~N}$ Ultrex nitric acid to a $\mathrm{pH}$ of less than 2 . Filtered water for dissolved anion analysis was collected in $250-\mathrm{mL}$ polyethylene bottles. Additionally, unfiltered water was collected in $250-\mathrm{mL}$ polyethylene bottles. Water for lowlevel nutrient analysis was collected in $125-\mathrm{mL}$ polyethylene bottles; these samples were kept at or below 4 degrees Celsius $\left({ }^{\circ} \mathrm{C}\right)$ prior to analysis.

Unfiltered water for analysis of stable isotopes of hydrogen and oxygen was collected in $60-\mathrm{mL}$ or $20-\mathrm{mL}$ clear-glass bottles with polyseal caps. The $60-\mathrm{mL}$ bottles were sent to the U.S. Geological Survey Isotope Laboratory or to the Yucca Mountain Laboratory, and the $20-\mathrm{mL}$ bottles were sent to the Geological Sciences Department Isotope Laboratory at the University of Nevada, Reno. Unfiltered water for analysis of radioactive tritium (hydrogen-3 or ${ }^{3} \mathrm{H}$ ) was collected in 1-liter (L) polyethylene bottles. Filtered water for analysis of stable isotopes of carbon (carbon-13/carbon-12 or ${ }^{13} \mathrm{C} /{ }^{12} \mathrm{C}$ ) and for radioactive carbon (carbon- 14 or ${ }^{14} \mathrm{C}$ ) was collected in $500-\mathrm{mL}$ amber-glass bottles and sealed with Teflon-lined caps. Unfiltered water for analysis of strontium and uranium isotopes was collected in acid-rinsed $500-\mathrm{mL}$ polyethylene bottles.

Water for analysis of dissolved gases was collected in $150-\mathrm{mL}$ clear-glass serum bottles by placing the serum bottle upside down at the bottom of the pool at a spring, then slowly turning it toward the direction of flow or, when pumped, by filling a stainless-steel container from the bottom up and allowing excess water to pour over its top. After all air bubbles were removed from the sample, a rubber stopper with a needle to remove excess water was inserted in the open end of the bottle while the bottle was at the bottom of the pool or container. The needle was removed under water after the rubber stopper was in place.

Five chlorofluorocarbon samples were collected at each sampling site. Neither dissolved gases nor chlorofluorocarbon samples were collected from the creeks. Although spring pools can be considered surface-water sites, water samples collected from the bottom of each spring (pools less than 2 feet deep) and from well points driven into the springs were classified as groundwater sites. Chlorofluorocarbon samples were collected in $125 \mathrm{~mL}$ Boston round, clear-glass bottles and sealed with white-plastic caps lined with aluminum foil. The dip-and-fill method was used to collect samples from the bottom of each spring when it was more than 1 foot deep, and samples were collected from the well point when the spring was less than a foot deep by using the same method as was used to fill stainless-steel containers for dissolved gas samples described previously. The foil-lined cap was tightened on the bottle while it was at the bottom of the pool or stainless-steel container after the bottle had completely filled with water. The caps on all the water samples were sealed with black-plastic electrical tape to prevent loosening during storage and shipment.

Water samples were shipped to several different U.S. Geological Survey (USGS) laboratories and to the stable-isotope laboratory at the University of Nevada, Reno (UNR). Water samples collected for major dissolved ions, selected trace elements, and low-level nutrients were sent the USGS National Water Quality Laboratory (NWQL) in Lakewood, Colorado. Water samples collected for stable isotopes of hydrogen and oxygen were sent to the USGS Reston Stable Isotope 
Laboratory (RSIL) in Reston, Virginia, or to the stable isotope laboratory at UNR. Water samples collected for dissolved gases and chlorofluorocarbons were sent to the USGS Chlorofluorocarbon (CFC) Laboratory in Reston, Virginia. Water samples for strontium isotope ratio $\left({ }^{87} \mathrm{Sr} /{ }^{86} \mathrm{Sr}\right)$, uranium isotopes $\left({ }^{234} \mathrm{U} /{ }^{235} \mathrm{U}\right)$, and a few samples for stable carbon isotopes $\left({ }^{13} \mathrm{C}\right.$ and $\left.{ }^{12} \mathrm{C}\right)$ and stable isotopes of water $\left({ }^{18} \mathrm{O} /{ }^{16} \mathrm{O}\right.$ and $\left.{ }^{2} \mathrm{H} /{ }^{1} \mathrm{H}\right)$ were sent to the Yucca Mountain Project Environmental Laboratory in Lakewood, Colorado. Samples for stable carbon isotopes and radioactive carbon collected from the two wells near Big Springs were sent to the research laboratory at Woods Hole Oceanographic Institution in Woods Hole, Massachusetts. Lastly, backup water samples initially collected between August 2010 and August 2011 for analysis of stable isotopes of water from (1) Lehman Creek at lower Lehman Campground, (2) either site on Baker Creek at Grey Cliffs (either near C-loop campground or B-loop road crossing) upstream from the Narrows, and (3) Rowland Spring (table 16-1) were analyzed at a research laboratory in Menlo Park, California, by using an ion chromatograph.

Results of all of the analyses by the different laboratories are stored in the U.S. Geological Survey NWIS database (http://waterdata.usgs.gov/nv/nwis/nwis). The analytical procedures used by the NWQL can be found at $h t t p: / / n w q l$. usgs.gov/OFR-00-212.shtml. Analytical procedures used by the RSIL can be found at http://isotopes.usgs.gov/lab/methods. $\mathrm{html}$, and those used by the CFC Laboratory can be found at http://water.usgs.gov/lab. Sampling and analytical procedures used by the Yucca Mountain Project Environmental Laboratory for strontium concentrations and ratios in water and rock are described in Paces and others (2007). Procedures for analyzing stable carbon isotopes in water are listed in a Technical Procedures of the Yucca Mountain Project as part of the U.S. Department of Energy's requirements for quality assurance and quality control (R.L. Moscati, U.S. Geological Survey, Lakewood, Colorado, written commun., 2007).

All laboratories used to analyze the water samples were quality assured. Standard laboratory procedures for quality assurance at the NQWL are documented by Pirkey and Glodt (1998) and Maloney (2005). Standard procedures for quality assurance for the stable isotopes of deuterium and oxygen-18 at the RSIL are documented at http://isotopes.usgs.gov/lab/ services/RSIL_SOP_1700.pdf. Duplicate samples (two for dissolved gases and five for chlorofluorocarbon analyses) were sent to the CFC Laboratory as part of their quality-assurance procedure. Multiple tests were done on the samples sent to the CFC laboratory.

Chemical analysis of water samples are listed in separate files. The files include water chemistry collected at sites listed in table 16-1 as a part of other U.S. Geological Survey studies in the study area during 2009-11. The surface-water chemistry are in five tables (tables 16-2 to 16-6), and the groundwater chemistry are in six tables (tables 16-7 to 16-12). Table 16-12 lists concentrations of chlorofluorocarbons and dissolved gases collected from selected groundwater sites.
The following tables are distributed as part of this report in Microsoft ${ }^{\circledR}$ Excel 2010 format and is available for download at http://dx.doi.org/10.3133/pp1819.

Table 16-2. Field parameters at selected surface-water sites for water chemistry in and near Great Basin National Park, White Pine County, Nevada, 2009-11.

Table 16-3. Dissolved major-ion concentrations at selected surface-water sites in and near Great Basin National Park, White Pine County, Nevada, 2009-11.

Table 16-4. Dissolved trace-element concentrations at selected surface-water sites in and near Great Basin National Park, White Pine County, Nevada, 2009-11.

Table 16-5. Nutrient concentrations at selected surface-water sites in and near Great Basin National Park, White Pine County, Nevada, 2009-11.

Table 16-6. Stable- and radioactive-isotope chemistry at selected surface-water sites in and near Great Basin National Park, White Pine County, Nevada, 2009-11.

Table 16-7. Field parameters at selected caves, springs, and groundwater sites for water chemistry in and near Great Basin National Park, White Pine County, Nevada, 2009-11.

Table 16-8. Dissolved major-ion concentrations at selected caves, springs, and groundwater sites in and near Great Basin National Park, White Pine County, Nevada, 2009-11.

Table 16-9. Dissolved trace-element concentrations at selected caves, springs, and groundwater sites in and near Great Basin National Park, White Pine County, Nevada, 2009-11.

Table 16-10. Nutrient concentrations at selected caves, springs, and groundwater sites in and near Great Basin National Park, White Pine County, Nevada, 2009-11.

Table 16-11. Stable- and radioactive-isotope chemistry at selected caves, springs, and groundwater sites in and near Great Basin National Park, White Pine County, Nevada, 2009-11.

Table 16-12. Dissolved chlorofluorocarbon and gas concentrations at groundwater sites in and near Great Basin National Park, White Pine County, Nevada, 2009-11.

The tables of field parameters list field measurements of discharge or pumping rate, water temperature, specific conductance, $\mathrm{pH}$, dissolved oxygen concentration, and alkalinity. The tables of dissolved major-ion concentrations list calcium, magnesium, sodium, potassium, bicarbonate, bromide, chloride, fluoride, nitrate, sulfate, silica, and organic carbon, as well as dissolved solids. The tables of trace-element concentrations list dissolved ions that are typically less than 1 milligram per liter; it includes arsenic, boron, iron, lead, manganese, strontium, and uranium, among other elements. The tables of nutrient concentrations list different species of nitrogen and phosphorus. The tables of stable and radioactive isotope chemistry list concentrations or ratios of concentrations of the stable or radioactive isotopes of water, carbon, strontium, sulfur, and uranium. The table of dissolved chlorofluorocarbon and gases in groundwater samples lists concentrations of the chlorofluorocarbons - trichlorofluoromethane (CFC11), 
dichlorodifluoromethane (CFC12), and trichlorotrifluoromethane (CFC113) - for samples collected from Wheelers Deep Cave and selected springs and wells. Concentrations of gases dissolved in the water include argon, carbon dioxide, methane, nitrogen, and oxygen. The dissolved chlorofluorocarbons and gases were used to estimate the mean age of groundwater, which is also listed for each sample.

\section{References Cited}

Lewis, M.E., 2006, Dissolved oxygen (ver. 2.1): U.S. Geological Survey Techniques of Water-Resources Investigations, book 9, chap. A6, section 6.2, June, accessed June 9, 2009, http://pubs.water.usgs.gov/twri9A6/.

Maloney, T.J., ed., 2005, Quality management system, U.S. Geological Survey National Water Quality Laboratory: U.S. Geological Survey Open-File Report 3005-1263, version 1.3, 9 November 2005, chapters and appendixes variously paged.

Paces, J.B., Peterman, Z.E., Futo, Kiyoto, Oliver, T.A., and Marshall, B.D., 2007, Strontium isotopic composition of Paleozoic carbonate rocks in the Nevada Test Site vicinity, Clark, Lincoln, and Nye Counties, Nevada, Inyo County, California: U.S. Geological Survey Data Series Report 280, $42 \mathrm{p}$.

Pirkey, K.D., and Glodt, S.R., 1998, Quality control at the U.S. Geological Survey National Water Quality Laboratory: U.S. Geological Survey Fact Sheet FS-026-98, 4 p.
Radke, S.A., Davis, J.V., and Wilde, F.D., 2005, Specific electrical conductance (ver. 1.2): U.S. Geological Survey Techniques of Water-Resources Investigations, book 9, chap. A6, section 6.3, August, accessed June 9, 2009, http://pubs.water.usgs.gov/twri9A6/.

Ritz, G.F., and Collins, J.A., 2008, pH (version 2.0): U.S. Geological Survey Techniques of Water-Resources Investigations, book 9, chap. A6, section 6.4, October, accessed June 9, 2009, http://pubs.water.usgs.gov/twri9A6/.

Rounds, S.A., 2006, Alkalinity and acid neutralizing capacity (version 3.0): U.S. Geological Survey Techniques of Water-Resources Investigations, book 9, chap. A6, section 6.6, July, accessed June 9, 2009, http://pubs.water.usgs.gov/ twri9A6/.

Wilde, F.D., ed., 2004, Cleaning of equipment for water sampling (ver. 2.0): U.S. Geological Survey Techniques of Water-Resources Investigations, book 9, chap. A3, April, accessed June 9, 2009 at http://pubs.water.usgs.gov/ twri9A3/.

Wilde, F.D., 2006, Temperature (ver. 2.0): U.S. Geological Survey Techniques of Water-Resources Investigations, book 9, chap. A6, section 6.1, March, accessed June 9, 2009, http://pubs.water.usgs.gov/twri9A6/.

Wilde, F.D., 2008, Guidelines for field-measured water quality properties: (ver. 2.0): U.S. Geological Survey Techniques of Water-Resources Investigations, book 9, chap. A6, section 6.0, October, accessed June 9, 2009, http://pubs.water.usgs. gov/twri9A6/. 



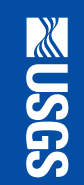

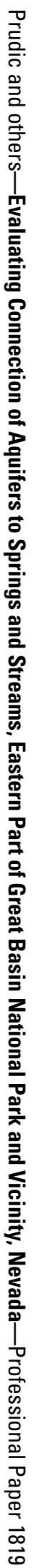

